m.

m.

m.

|.

m.

m.

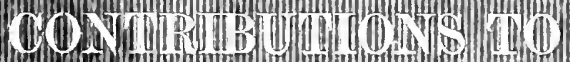

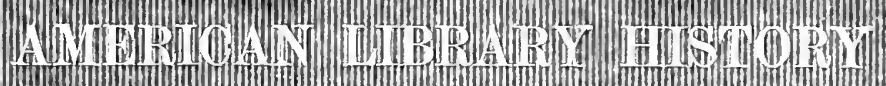

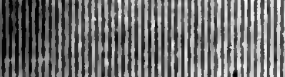

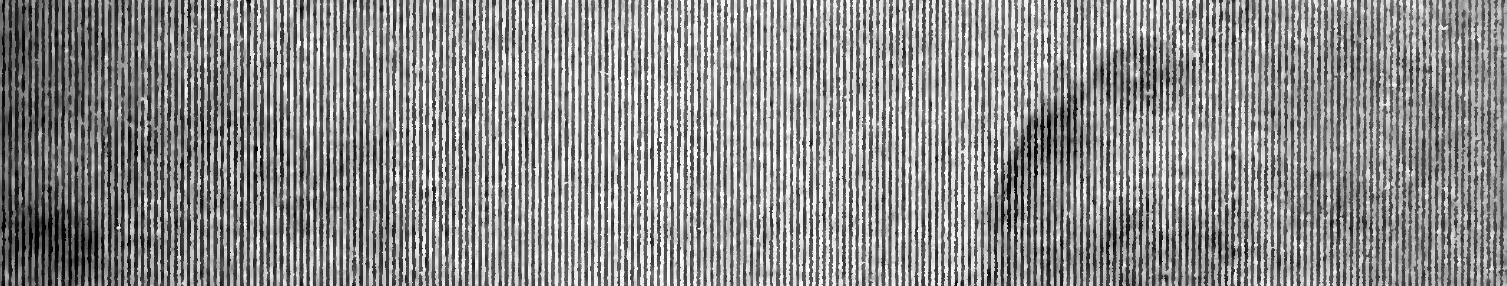

m.

m.

m.



|. m. 





Gontxidnutions to

Amexican giluxaxy ftistoxy 




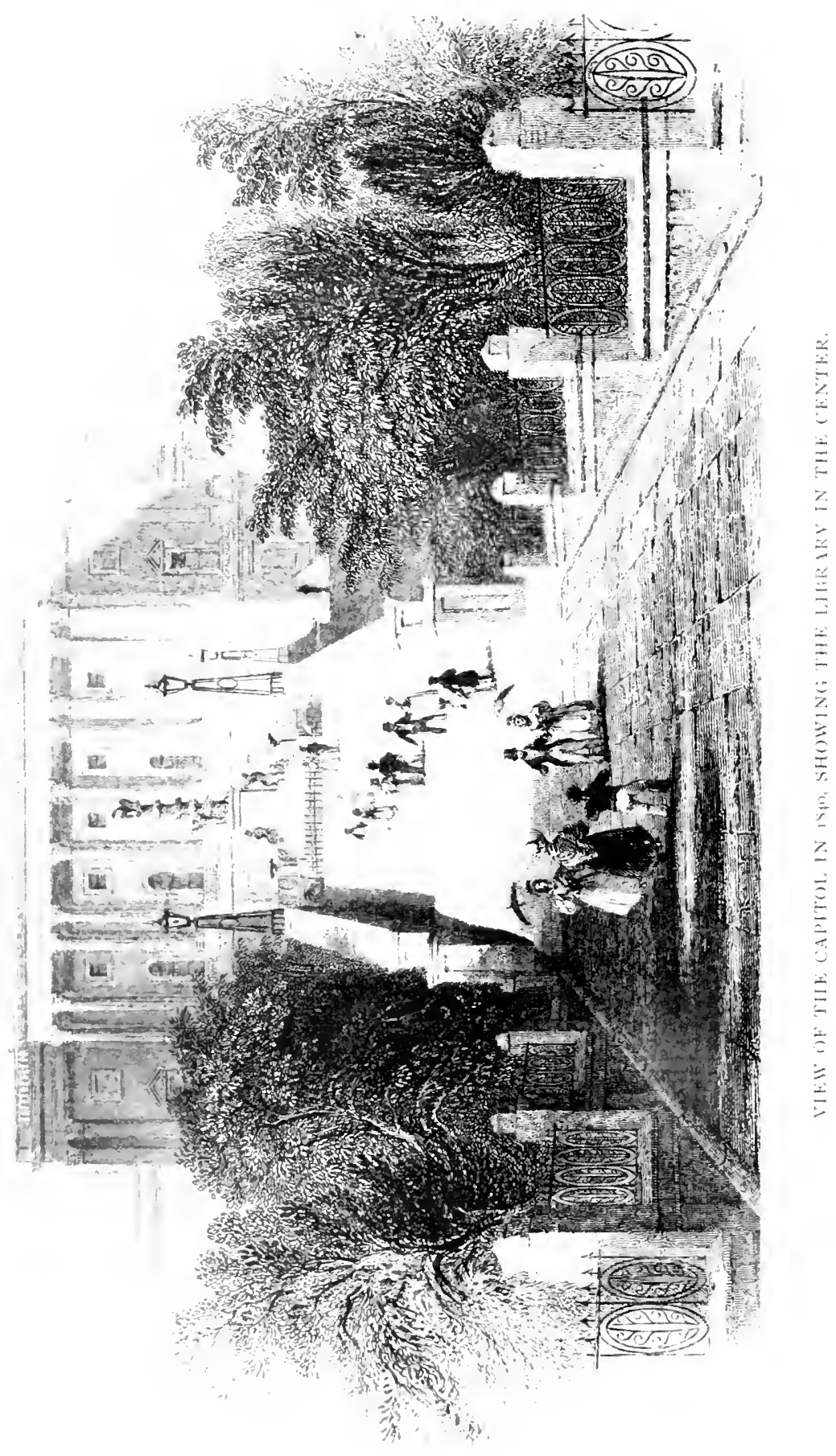




\title{
HISTORY OF THE
}

\section{LIBRARY OF CONGRESS}

\author{
VOLUME I \\ I800-1864
}

BY

WILLIAM DAWSON JOHNSTON

OF THE LIBRARY OF CONGRESS

WASHINGTON

GOVERNMENT PRINTING OFFICE

1904 



\section{UNIVERSITY OF CAJIFOKNIA \\ MANTA BARBAKa CULLEGE LIBRAM}

\section{LETTER OF TRANSMITTAL}

SIR: This volume is the first of the series of Contributions to American Library History, the preparation of which has been undertaken by librarians representing the several States, the editing and publishing of which has been assumed by this Library.

In conformity with the plan of that series all documents of importance which relate to the history of the national library are reproduced here in full or in extenso. Many picturesque incidents, many antiquarian details, many expressions of contemporary opinion, which in the history of another library might be of merely local interest, are presented. The development not only of the institution but of opinion regarding it is discussed.

The history of the Jefferson collection, now written for the first time, the references to the literary habits and prepossessions of statesmen of the first half of the century, and the material illustrative of the political and literary conditions of that period may be of general interest. The records of the Library administration, its bibliographical policy, its routine and method, its achievements and its plans, the account of the early policy of the Government with regard to the collection of manuscripts and of Americana, will appeal more especially to librarians and historians. The descriptions of the library rooms, the career of George Watterston, and perhaps other matters will be of local value.

The completion of this investigation, which has occupied my unofficial time for the past three years, has involved the examination of local archives and newspapers, of legislative records and documents, and of the representative literary and 
scientific periodicals of the country. It has been made possible by the richness and accessibility of the material in the national collection, and by the encouragement which the work has received from you, from the chief assistant librarian, Mr. Spofford, from my learned associates, and from officers of the other departments of the Government, particularly the clerk of the Joint Committee on the Library, Mr. H. A. Vale, the Chief Clerk in the Office of the Secretary of the Senate, Mr. H. M. Rose, and the Chief of the Bureau of Rolls in the Department of State, Mr. A. H. Allen.

I must also acknowledge my indebtedness to Mr. J. Henley Smith, Mr. Henry Adams, Miss Laura Meehan, and to the late Mr. David Watterston, of this city; to the Hon. William Everett, of Quincy, Mass.; to the Hon. J. A. Pearce, of Annapolis; to the late Mrs. Caroline Crane Marsh, of Scarsdale, N. Y.; to Mr. Elbridge T. Gerry, of Newport; to Mrs. Charles W. Allen, of Boston; to the Rev. Edward Everett Hale; to Mr. Robert H. Kelby, of the New York Historical Society; Mr. William Nelson, of the New Jersey Historical Society; Mr. John W. Jordan, of the Pennsylvania Historical Society; Mr. R. A. Brock, of the Southern Historical Society; Mr. William Beer, of the Howard Memorial Library, New Orleans; and to her who from first to last has shared with me the joy and labor of this work of research.

In order that the records of the national library may be as complete and accessible as possible, it is hoped to supplement this volume by a second, describing the history of the Library since I864, and a third describing the history of the other libraries of the Government.

Respectfully submitted.

Herbert Putnam

$$
\text { W. DAwson Johnston. }
$$

Librarian of Congress

Washington, D. C., April 20, 1904 


\section{CONTENTS.}

Letter of transmittal, 5; Contents, 7; I, ist of plates. Ir: Chronology, 13.

\section{CHAPTER ONE.}

CONDITIONS BEFORE, THF, YFAR 1800 .

Use of libraries in New York and Pliladelphia, i 7; Gerry's plan for a library, I 8 .

\section{CHAPTER TWO.}

FSTABLISHMENT OF THF IIBRARY, I8OO-I805.

The first purchase of books, 24; Report of committee on library organization, 26; Legislative debate, 29; Organic act, January 26, I 802, 32; Library room and officers, 1802-1805, 33; President Jefferson and the collection of books, I802-1805, 35 .

\section{CHAP'TER THREE.}

GROWTH OF THF, IIBRARY, I $805-18 I 4$.

The library room, I805-18I4, 4I; Library administration-the librarian, 44; The library committee, 45; John Quincy Adams's memoirs, 47; Character of the library in I8I 4,48 ; Neglect to secure Tatham's collection of American topography, 50; The collection of documents, 54; Privileges of the library extended to the agent of the library conmittee and justices of the Supreme Court, 55; Chief Justice Marshall, 57; Rules of the library, $5^{8}$.

\section{CHAPTER FOUR.}

DESTRUCTION OF THE OLD IAIRAKY ANI I'TRCHASF OF THF JFFHERSON I.IBRARY.

Burning of the Capitol, 65; Offer of the Jefferson library to Congress, 68; The question of purchase in Congress, 72; Public opinion regarding the purchase, 78 ; Evaluation of the library, 8o; Purchase of the library, 84; Value of the library, 90; Removal of the library to Wasl1ington, 97 . 


\section{CHAPTER FIVE.}

THE DEVELOPMENT OF THE LIBRARY, ISI4-I829.

Librarian Watterston, I07; His literary work, I09; Library room in Blodget's lotel, I20; A library building suggested, I23; Removal to the north wing of the Capitol, I8 18, I25; Completion of the library room in the center building, 1824, I28; Fire of December 22, 1825, I32; Question of a fireproof room, I35; Need of a national library, I 38; Classification of the library, I4I; Jefferson on classification, I42; Cataloguing of the library, I47; Administrative measures, I8 I5-I8 I 7 , I50; Development of the library, I8 17-1824, I58; Development of the library, I824-I829-renewed interest in the library, I60; Edward Everett's work, I64; Collections and departments in I829, I68; manuscripts, I69; law, I7I; documents, I73; Library staff and service, I78; Privileges of the library, 183; Use of the library, I 85.

\section{CHAPTER SIX.}

THE LIBRARY IN POLITICS.

The removal of Librarian Watterston by President Jackson, I89; Journalistic controversy regarding the legality of the removal, I90; Partisan attacks upon the library, I99; Speech of Senator Holmes, I99; The ex-librarian compares the Democratic with the Whig administration, 2OI; His attempts to secure reinstatement in office, letters to J. M. Clayton, 203; to Henry Clay, 205; to President Fillmore, 207.

\section{CHAPTER SEVEN.}

THE DEVELOPMENT OF THE LIBRARY, I $829-\mathrm{I} 85 \mathrm{I}$.

Librarian Meeha11, 213; The Library rooms, I829-1851, 215; The constitution of the Library committee, 222; Their bibliographical plans, 226; Ideas of Francis Lieber, 227, of Lewis Cass, 228; Offer of the Buturlin library, 229; Remarks of the North American Review, 23I; Senator Preston's report, 239; Offer of the Durazzo library, 243; Americana, 246; The law department, 248; The document collection, 25I; Inter11ational exchange, Alexandre Vattemare, 254; Distribution of public documents, 266; Character of the library in $1851,269$.

\section{CHAP'TER EIGH'T}

DEVFLOPMFNT OF THE LIBRARY, I 852-I864.

The fire of 1851, 275; Question in House regarding cause of fire and repairs, 278; Official and other opinion regarding cause of fire and new fire proof structure, 280; Prorision in Senate for books and for 
temporary rooms, 285; Discussed in the House, 285; Passed, 286; Plans for a new library room, 287; An appropriation of $\$ 72,500,29 \mathrm{I}$; A deficiency appropriation, 293; The room completed, 298; Purchase of books, 301 ; Definition of the bibliographical policy of the library, 302; Collections and departments, I852-1864, 310; Manuscripts, 312; proposition for the calendaring of manuscripts in British archives relating to American colonies, $3 \mathrm{I} 4$; Policy in regard to the purchasing of manuscripts of Madison, Jefferson, Hamilton, 32 I; Of the manuscript of Washington's farewell address, 326; Maps, 340; Lieutenant Hunt's plan for a geographical department of the library, 340; Newspapers, 346; Library staff and agents, 347; The Library service, 352; cataloguing, 354; Professor Jewett's experiment, 358; Assistant Librarian Spofford's reforms, 364; Indexing of Congressional documents, 368; Privileges of the library, 373; Evening opening agitated, 376; Use of the library, 379; Librarian Steplenson, 383 .

\section{CHAPTER NINE.}

OTHER IIBRARIES OF CONGRESS AND OF THE GOVERNMENT.

The House library, 387 ; The library rooms, 388 ; "Providing a library for the Southern Confederacy," 389 ; The investigation, 389; Senate library proposed, 392; Plans for the library, 393; Relations of the library of Congress with other libraries of the Government and of the city, 400 .

\section{CHAPTER TEN.}

THE SMITHSONIAN INSTITLTION AND PIANS FOR A NATIONAI, IIBRARY.

Senator Choate's speech on national library, 405; His first amendment to Tappan bill, 4IO; His second amendment, 4I2; A new bill, 4I 4; Question of relation to National Institute, 4I5; Buchanan's speech, 415; In the House of Representatives, Owen bill introduced, 417 ; Speech by Robert Dale Owen, 417; Reply by George P. Marsh, 421; Passage of the Marsh amendment and triumph of the library plan, 428; Plan of organization of the Smithsonian library, 443; Librarian Jewett's plans, 43I; The compromise resolutions of December I I, I 847,433 ; Early collections of the Smithsonian Library, 436;-Bibliograplical, 436; Publications of learned societies, 438 ; Copyright deposit, 439 ; Bibliographical undertakings-general catalogue of American libraries, 450; Cooperative cataloguing, 454; Other bibliographical enterprisesStevens's Bibliographia Americana, etc., 467; Defeat of the library plan; Librarian Jewett's reports upon a national library, 473; Resolutions of the library convention, $48_{2}$; North American Review, $4^{8} 3$; Secretary Henry's programme, 486; Criticised by Professor Jewett, 487; 
Supported by special committee, 489; A minority report, 490; Defeat of the library plan and removal of Librarian Jewett, 496; Defense of the policy of the Regents in the Senate, 496; Criticism of it in the House, 499; Opinions of the press, 504.

\section{APPFNDIXES.}

I. Officers of the library, I802-I 864, 509.

II. Members of the library committee, 509.

III. Number of volumes in the library, 5I5.

IV. Legislative appropriations for the library, $5^{1} 5$.

V. Catalogues of the library, I80I-I864, 516.

VI. Classification of the library, $52 \mathrm{I}$. 


\section{LIST OF PLATES}

I. View of the Capitol in 1840 , showing the Library in the center. From Nathaniel P. Willis American scenery. Drawings by W. H. Bartlett, vol. I, title-page.

FRONTISPIECE Opposite

2. Elbridge Gerry. From an engraving by Koevoets after a drawing by Vanderlyn. . . . . . . . . . . . . I8

3. Plan of principal story of Capitol in 1800 . From Glenn Brown. History of the United States Capitol ( 1900 ), vol. I, plate $36 . \quad$. 34

4. Facsimile of Catalogue of $\mathrm{rSO}$, showing early method of classification.

5. Plan of the principal story of the Capitol, I806. From original in the Library of Congress. . . . . . . . . . . . . 42

6. Thomas Jefferson. From a lithograph after a painting for Messrs. Doggett, by Gilbert Stuart. . . . . . . . . 68

7. George Watterston. From a water color in the custody of the Library of Congress.

8. Plan of attic story of north wing of Capitol, 1817 , showing location of apartments for the temporary accommodation of the Library. From original in the Library of Congress. . . . I 26

9. West front of the Capitol, showing Library in center. From a drawing by C. Bulfinch in Force's National calendar for I821, front.

IO. Plan of the principal floor of the Capitol. From Robert Mills's Guide to the Capitol, i $847-48$, p. r2. . . . . . I30

II. Facsimile of Jefferson's scheme of classification. From the catalogue of the Library, i8 15, p. vi-vii. . . . . . . 446

I2. Facsimile of letter from Edward Everett to Librarian Watterston, October $3 \mathrm{I}, \mathrm{I} 826$. . . . . . . . . . . . . . . . I64

I 3. Facsimile of record book showing charging system in use. . I82

14. Commission appointing John Silva Meehan Librarian of Congress. . . . . . . . . . . . . . . . . . I96

I5. John Silva Meehan. From a daguerreotype in the possession of Miss Laura G. Meehan. . . . . . . . . . . 214

I6. Library of Congress, as rebuilt after the fire of 1851 . Thomas U. Walter, architect. After water color in the Library of Congress. . . . . . . . . . . . . . . 216 
I7. Bookplates of the Library. . . . . . . . . . . . . $23 \mathrm{~s}$

IS. Portrait of Alexandre Vattemare. From a drawing by William

Walcutt in the possession of the New York Public Library. . 254

19. Detail of iron work in Library. From Glenn Brown. History of the Capitol, vol. 2, plate 253. . . . . . . . . . . 288

20. Entrance to Congressional Library. From Glenn Brown. History of the Capitol, vol. I, plate ro4. . . . . . . . 294

21. Drawing of console in Library. From Glenn Brown. History of the Capitol, vol. 2, plate 2 Io. . . . . . . . . 300

22. Library stamps and book labels. . . . . . . . . . 338

23. Facsimile of the Library of Congress Catalogue of 1849 and the Catalogue of i $S_{54}$ prepared upon Professor Jewett's plan. . 360

24. Library of Congress. Interior, I 856 . From United States Magazine, vol. 3, p. ro6. . . . . . . . . . . . 380

25. Rufus Choate. From an engraving by H. B. Hall after a photograph by Southworth \& Hawes. . . . . . . . 404

26. George P. Marsh. From a portrait by G. P. A. Healy in the possession of Dartmouth College. . . . . . . . . . 422

27. Charles C. Jewett. From a photograph in possession of his daughter, Mrs. Charles W. Allen. . . . . . . . . 448

28. Henry Sterens. From his Recollections of James Lenox, front. . . . . . . . . . . . . . . . 470

29. Table showing classification of the Library. . . . . . . 522 


\section{CHRONOLOGICAL TABLE}

I $800-$ Apr. 24. Act establishing the Library.

I $802-J a n$. 26. Act organizing the Library.

29. John Beckley appointed Librarian.

I 807-Nov. 7. Patrick Magruder appointed Librarian.

I8I 2-Mar. 2. Privileges of the Library extended to Justices of the Supreme Court.

I 8 1 4-Aug. 24. Destruction of the Library by British troops.

Sept. 2 I. Jefferson library offered to Congress; purchased January 30,1815 .

ISI5-Mar. 2I. George Watterston appointed Librarian.

I816-Apr. I6. Privileges of the Library extended to diplomatic corps.

I 824

Completion of Library room in the west center of the Capitol.

I 825-Dec. 22. The second fire.

I829-May 28. John Silva Meehan appointed Librarian.

I830-Jan. I3. Privileges of the Library extended to heads of Departments.

I832-July I4. Law Library established.

I840-July 20. Resolution authorizing international exchange.

I846-Aug. Io. Establishment of a national library on the Smithsonian foundation.

185I-Dec. 24. Fire destroying about 35,000 rolumes.

I86I-May 24. John G. Stephenson appointed Librarian.

I864-Dec. 3I. Ainsworth Rand Spofford appointed Librarian. 

(Thaptex (B)e

CONDITIONS BEFORE THE YEAR I8OO 



\section{Chapter One.}

\section{CONDITIONS BEFORE THE YEAR I8OO.}

Before the establishment of the Library of Congress, April 24, I 800 , the Houses of Congress had used the libraries of New York and Philadelphia.

At the opening of the sessions of the Continental Congress in Philadelphia, September 6, I774, an extract was read from the minutes of the directors of the Library Company of Philadelphia, dated August 3I, I774, ordering, "That the Library furnish the Gentlemen, who are to meet in Congress, with the Use of such Books as they may have Occasion for, during their Sitting, taking a Receipt for them. Signed by Order of the Directors, William Attmore, Secretary;" and it was ordered that the thanks of the Congress be returned to the Directors of the Library Company of Philadelphia for their obliging order. ${ }^{\mathrm{I}}$

The sessions of the First Congress of the United States were held in the city hall in New York City, and the City Library, or New York Society Library, as it was officially known, at that time deposited in the city hall, was nsed by Congress. ${ }^{2}$ After the removal of Congress to Philadelphia the directors of the Library Company of Philadelphia tendered to the President and Congress the free use of the books in their library in as full and ample a manner as if they were members of the company; and President Washington, through his secretary, Tobias Lear, returned thanks for the attention in the following note: ${ }^{3}$

THursday, Jan. 20, 1791 .

SIR: In obedience to the commands of the President of the United States I have the honor to communicate to you, to be presented to the

${ }^{1}$ Annals of Congress, I: Io.

"Catalogue of the New York Society Library, New York, 1850, Int.

${ }^{3}$ J. T. Scharf and T. Westcott, "History of Philadelphia," v. 2, IISI. 23399-04-2 
directors of the Library Company of Philadelphia, his best thanks for the polite manner in which they have offered him the use of the books in the Library, and he begs that they will be assured that this mark of attention has made a proper impression on him.

I have the honor to be, very respectfully, sir,

TOBIAS LEAR, Secretary to the President of the United States.

William RaWle, Esq.

Secretary to the Directors of the Library Company of Philadelphia.

There were some, however, who felt that Congress should possess a library of its own, who recognized that a democratic assembly representative of popular opinion should be informed of the condition and progress of popular opinion, and that as a means to that end the books, the pamphlets, and the journals of the day should be collected and rendered accessible to every member of Congress. The most earnest advocate of these views and the author of the first measure to establish a library for Congress was Elbridge Gerry, Representative from Massachusetts. ${ }^{\text {. }}$

On Thursday, the 6th of August, I789, Representative Gerry presented a motion that a committee be appointed to report a catalogue of books necessary for the use of Congress, with an estimate of the expense, and the best mode of procuring them, ${ }^{2}$ and, on April 30, I790, was appointed with Messrs. Burke, of South Carolina, and White, of Virginia, to form that committee. ${ }^{3}$ On the 23d of June, Mr. Gerry, on behalf of the committee, submitted the following report:

That, as far as the nature of the case will admit, they have in the schedule annexed complied with the order of the House, having due regard to the state of the Treasury. That the committee have confined themselves in great measure to books necessary for the use of the legislative and executive departments, and not often to be found in private or in circulating libraries. That, nevertheless, without further provision of books on laws and government, to which reference is often nec-

\footnotetext{
I The life of Gerry, by James T. Austin (Boston, 1828-29, 2 v.), and the letters of Gerry, $17 S_{4}-1804$, edited by W. C. Ford (printed in the New England Historic and Genealogical Register, vol. 49, pp. 430-44I, October, I895, and vol. 5o, pp. 21-30, January, 1896, reprinted by the Historical Printing Club, Brooklyn, iS96), contain nothing illustrating this cpisode, nor has his grandson, Elbridge T. Gerry, of Newport, any papers or data casting light upon it.

'Annals I: 679 .

3.nulals 2: 1550 .
} 

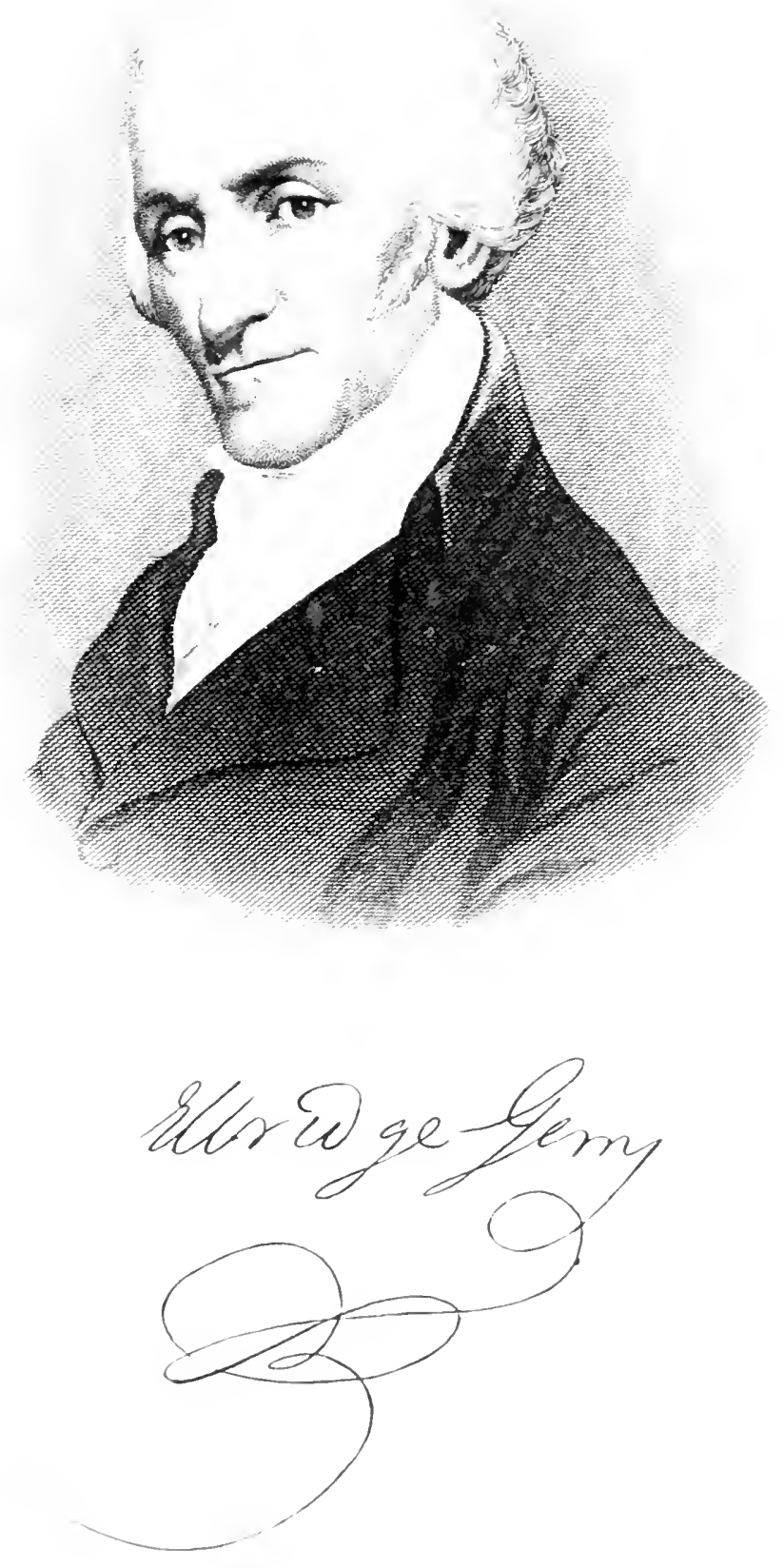

essary, members of the legislature and other offices of the Government may be either deprived of the use of such books when necessary, or be obliged at every session to transport to the seat of the General Government a considerable part of their libraries, it seldom happening that they can otherwise command such books when requisite, without trespassing too much on the indulgence of their friends. The committee are therefore of the opinion that a sum, not exceeding $\mathrm{I}$, ooo dollars, be appropriated in the present session, and that the sum of 500 dollars be hereafter annually appropriated to the purchase of books for a public library, and be applied to the purpose by the Vice-President, Chief Justice, and Secretary of State of the United States, without confining them to the catalogue reported, until, in the opinion of Congress, the books provided shall be adequate to the purpose.

The books reported were of the following description, viz: Laws of the several States, laws relating to the trade and navigation of the several nations of Europe with whom the United States may have treaties, laws of Ireland and Scotland, laws of Canada, British statutes at large, militia system of Switzerland, the Russian and Frederician codes, sundry authors on the laws of nature and nations, sundry authors on the privilege and duties of diplomatic bodies, a collection of treaties and alliances from the earliest periods, a collection of parliamentary books, sundry books on the civil and common law, etc., etc. ${ }^{5}$

This report was laid on the table, ${ }^{2}$ and no further attempt was made to revive the plan or devise other plans for a library for Congress until a permanent seat of Government had been selected and the Houses of Congress removed to Washingtoll.

Without pursuing any definite bibliographical programme, however, the two Houses of Congress did acquire, before their removal to Washington or immediately after, as shown by the catalogue of $1802,{ }^{3} 45$ folio volumes, 68 quartos, and I 30 octavos; that is, 243 volumes in all. Among these were the Bibliotheca Americana, 2 I volumes of the Statutes at Large, I 8 volumes of the Journals of the House of Commons, Hatsell's Precedents; Luders, Heywood, and Fraser on elections;

\footnotetext{
${ }^{1}$ Gazette of the United States, New York, June 26, I790. 'Annals 2: I647.

3 There, under the caption "additional from the respective library of the Senate and the House of Representatives," are set down the names of such books as were acquired for the two Houses of Congress, before and immerliately after the rennoval to Washington. The act of January 26, I 802 , provided that these books or libraries, heretofore kept separately by each House, should be placed in the newly constituted Library of Congress, with the books purchased under the act of April 24, ISoo.
} 
I4 volumes of the State Trials, together with Hogan's State 'Trials; Dallas's and Robinson's Reports; Blackstone, ${ }^{\mathrm{I}}$ Reeves, and Wooddeson on English Law; John Adams's Defense of the American Constitution, Swift's system of laws of Connecticut, Cooke's Bankrupt laws, Chalmers's collection of treaties, Vattel's law of nations, and Staunton's Embassy to China. Among books of reference were 36 volumes of the Encyclopædia, Chambers's and Mortimer's Dictionaries. Anong geographical works: Paine's and Morse's geographies, Guthrie's geography and atlas, the Maritime Atlas in 5 volumes, the Gazetteer of France, Wendeborn's View of England, Moreau de St. Méry's St. Domingo, and the collection of voyages known as the World Displayed. Among historical works: Hume's History of England, Hazard's Collections for American History, Belknap's American Biography, Belknap's History of New Hampshire, and Ramsay's History of South Carolina. Among works on economics: Anderson's Commerce, Sheffield and Coxe on American Commerce, Necker's Finances of France, Millar on Insurance, and Varlo's Husbandry. Among periodicals: The New Annual Register, the American Musenm, and the Monthly Review. Other works were Thomas Paine's Miscellanies, Rush on Yellow Fever, and Burns's Poems.

\footnotetext{
'March IO, I794, the Senate ordered, That the Secretary purchase Blackstone's
} Commentaries and Vattel's I aw of Nature and Nations, for the use of the Senate. 


\section{(UKa)tex}

ESTABLISHMENT OF THE LIBRARY, I8O0-I805 
- 


\section{Chapter TWO.}

ESTABLISHMENT OF THE LIBRARY, $1800-1805$.

With the removal of the capital to Washington, a Congressional library, which had hitherto been merely desirable, became a necessity. So on motion of Samuel Livermore, a graduate of Princeton, then Senator for New Hampshire, a fifth section was added to the "Act to make provision for the removal and accommodation of the Government of the United States," approved April 24, I800. This read as follows:

And be it further cnacted, That for the purchase of such books as may be necessary for the use of Congress at the said city of Washington, and for fitting up a suitable apartment for containing them and for placing them therein the sum of five thousand dollars shall be, and hereby is, appropriated; and that the said purchase shall be made by the Secretary of the Senate and Clerk of the House of Representatives, pursuant to such directions as shall be given, and such catalogue as shall be furnished by a joint committee of both Houses of Congress to be appointed for that purpose; and that the said books shall be placed in one suitable apartment in the Capitol in the said city, for the use of both Houses of Congress and the members thereof, according to such regulations as the committee aforesaid shall devise and establish. ${ }^{x}$

On the next day, in order to carry the provisions of this law into execution, Mr. Dennis moved in the House of Representatives the following resolution: "Resolved, That — be a committee, jointly with such committee as may be appointed on the part of the Senate, for the purpose of making out a catalogue of books and adopting the best mode of procuring a library at the city of Washington; and for adopting a system of rules and regulations relative thereto;" which motion was agreed to, and Robert Waln, of Pennsylvania, Thomas Evans and Leven Powell, both of Virginia, appointed members of the committee on the part of the House, ${ }^{2}$ and on Monday, April 28, the Senate having adopted the resolution, 
Samuel Dexter, of Massachusetts, William Bingham, of Pennsylvania, and William Cary Nicholas, of Virginia, were appointed members of the committee on the part of the Senate.

The chairnan of this joint committee, and the only member thereof who has left behind him any trace of a fondness for or an acquaintance with books, "was Samuel Dexter, a graduate of Harvard, and a lawyer of some eminence. Under his direction the measures recommended by the law of I 800 were carried into execution, and the nucleus of the new library ordered from the London booksellers Cadell \& Davies. The following letter to Messrs. W. Bingham and Robert Waln, dated London, December II, ISoo, with bill for $£ 489 \mathrm{7s}$, list of books sent, and books to the number of 740 were received in response and forwarded to the new metropolis in the trunks in which they had been imported:

GENTLEMEN: We were favored with your joint letter of June 20, inclosing a list of books for the intended library at Washington, and we instantly set about executing the order in the best manner we were able.

Inclosed we transmit you the invoice and bill of lading, and we earnestly hope the books will arrive perfectly safe, great care having been taken in packing them. We judged it best to send trunks rather than boxes, which after their arrival would have been of little or no value.

Several of the books sent were only to be procured second-handed, and some of them, from their extreme scarcity, at very advanced prices.

We have in all cases sent the best copies we could obtain and charged the lowest prices possible. We annex a list of a few articles that we have not been able to procure, but, as we firmly trust that the execution of the present order will meet your approbation, and that, in that case, we may hope to be favored with your further commands, we shall continue our search for these articles and send them out with the next parcel. $^{2} * * *$

When this letter had been received Samuel Otis, Secretary of the Senate, wrote to President Jefferson:

WASHington, May' 2, r8or.

SiR: I do myself the honor to inclose you a copy of the invoice of books for the public library. The package being perfectly dry, I shall

'Harper's Magazine 46: 4r.

${ }^{2}$ List of books purchased by Cadell \& Davies for the Library of Congress, in a volume in the Library of Congress, lettered "State Papers, ISoI, Decem., I8o2, Jan." 
onit opening them until further orders. Whenever they are opened some person should be made answerable for them or in my opinion the volumes will be immediately dispersed and lost. ${ }^{\mathrm{x}} * * *$

On the Ioth of May Willian Duane, editor of the Aurora, wrote from Philadelphia to Madison, Secretary of State: "Permit me also to suggest that as provision has been made for furnishing a library for the use of Congress, I should be glad to undertake the provision of such books as may be required, and as I have had some experience, having resided in England for five years, and am acquainted not only with the first booksellers but numbers of the first literary characters in that country, I could undertake the importation of the books for the public library under advantages that few others possess."

And on the 8th of December, ISor, the petition of John McDonald, recently a broker and keeper of a circulating library at I4 Soutl Fourth street, Philadelphia, was presented to the Honse of Representatives and read, praying that he might be employed to superintend the arrangement and safekeeping of the books intended for the Library of the two Houses of Congress; and that he might receive such compensation for his services, in that capacity, as to the wisdom of Congress should seem meet. Referred to the Joint Committee on the Library of Congress. ${ }^{3}$ Before professional assistance could be engaged in the development and custody of the Library, however, an act of organization was necessary,

On the first day of the next session of Congress, Monday, December 7, I80I, President Jefferson, who was from its inception an ardent friend of the Library, called upon Mr. Otis, the Secretary of the Senate, to make a statement respecting the books purchased. This showed that $\$ 2,200$ of the $\$ 5,000$ appropriated had been expended, for which there had been received 740 volumes. On the same day, accordingly, the Senate passed the following resolution: "That a committee be appointed to join such gentlemen as shall be appointed by the House of Representatives to take into consideration a statement made this day by the Secretary of the Senate,

${ }^{3}$ Jefferson Papers, series 2, vol. 64, No. 32 .

${ }^{2}$ Madison MSS., Library of Congress.

3 Annals II: 3 I 2. 
respecting books and maps purchased in consequence of an act of Congress passed the 24th of April, ISoo, and to make a report of their opinion respecting the future arrangement of said books and maps; and that Messrs. Tracy and Nicholas be the committee on the part of the Senate." And a message from the Senate having informed the House of the passage of this resolution, the House appointed a committee on their part, to consist of Messrs. Nicholson, Bayard, and Randolph.

\section{REPORT OF COMMITTEE ON LIBRARY ORGANIZATION.}

The chairman of the new joint committee was Senator Nicholas, of Virginia. Of his associates, Senator Uriah Tracy was from Connecticut and a graduate of Yale, Representative James A. Bayard, from Delaware and a graduate of Princeton, Representative Joseph Hopper Nicholson, from Maryland, and representative John Randolph, from Virginia. This committee reported on the following week through Senator Tracy (December IS) and Representative Randolph (December 2r). The author of their report was John Randolph, of Roanoke, author also of the phrase "a good library is a statesman's workshop." " He was one of the earliest friends and supporters of the Library, always took pains to secure liberal appropriations for it, had a good deal to do with the selection of its books, and now had prepared a report which like the report of Representative Gerry, June 23, 1790, is one of the most notable documents relating to the early history of the Library, but unlike the former led to legislative action, and became the basis, after some discussion in the House of Representatives, of the act concerning the Library for the

'There is a letter in the Southern Literary Messenger, February, i 854 (vol. 2o, pp. 76-79), describing his library at Roanoke. Nathan Sargent said that Randolph would not have in his possession an American book, not even an Anerican Bible. (Public men and events, ISI7-IS53, vol. r, p. I25.)

Josiah Quincy has the following reminiscence: (Figures of the past, Boston, $188_{3}$, p. 2I4.) "Randolph had recited to me a certain passage from Burke, which I told him I did not remember and asked where I could find it. 'Go to the Congressional Library,' was Mr. Randolph's reply, 'look in the third alcove, on the right-hand side, third shelf from floor, fifth volume on the shelf, page 336 , about halfway down.' I marle a memorandum of the direction, went to the Library and found the passage exactly where he had placed it." 
use of both Houses of Congress, approved January 26, I802. The report of the committee drawn up by this man and leading to these important consequences was as follows: ${ }^{x}$

That in their opinion the following resolutions contain the proper regulations upon the subject committed to them; they therefore present them for consideration.

I. Resolved by the Senate and House of Representatives of the United States of America in Congress assembled, That the books and maps purchased by direction of the act of Congress passed the 24th day of April, I 800 , be placed in the Capitol in the room which was occupied by the House of Representatives during the last session of the 6th Congress, and that the books shall be numbered, labelled, and set up in portable cases with handles to them for the purpose of easy removal, with wire netting, doors, and locks. And that the books or libraries which have heretofore been kept separately by each House sliall be removed and set up with those lately purchased, and be numbered and labelled with them, making one library of the whole.

II. And it is further resolved, That the Secretary of the Senate and the Clerk of the House of Representatives for the time being be, and they are hereby authorized to take charge of the room, books, and maps aforesaid, and they are hereby authorized and directed to make suitable arrangements in said room for the library and maps, to procure proper furniture for the room, to procure the cases, number and label the books, and set them up in their places; to procure for their own use and the use of both Houses of Congress printed catalogues of all books with the label number of each and of the maps, to place on each book some proper mark or marks to designate it as belonging to the Congressional Library; to procure printed blank receipts for members to sign them when they take books from the room; and to arrange and hang up the maps; all to be done under the inspection and direction of the President of the Senate and Speaker of the House of Representatives for the time being.

III. And it is further resolved, That the Secretary of the Senate and the Clerk of the House of Representatives shall be responsible for the safe-keeping of the room, furniture, books, and maps aforesaid, and shall not permit any map to be taken out of said room by any person nor any book except by members of the Senate and House of Representatives for the time being, and no member shall be permitted to take any book out

"This is printed as "Report of the joint committee appointed to take into cousideration the arrangement of books and maps belonging to Congress, December 18, ISor. Printed by order of the Senate of the United States." 6 p. $8^{\circ}$. Also as "Report on the Congressional Library. Representative J. Randolph, December 21, ISOI" in Annals of Congress I2: 1292-1294, and in American State Papers, Miscellaneous, I: 253-254. 
of said room until he shall sign a receipt for the same, the form of which follows, viz:

Received this - day of - of the keepers of the Congressional Library (here the book and its number is to be described), which I promise to return within — days from this date or forfeit the sum of _- dollars to be paid to said keepers or either of them or to their successors or either of them. Witness my hand.

IV. And it is further resolved, That no member shall have at any one time more than three books out of said Library, and a folio volume shall be returned within _ days, a quarto within — days, an octavo within _- days, a duodecimo within _ days after the date of the receipt respectively; and in case of such return the receipt shall be cancelled, but in case of forfeiture the keepers shall immediately collect the penalty.

V. And it is further resolved, That the keepers of said Library shall one of them attend or shall cause some proper person for whose conduct they shall be responsible, to attend in said room from the hour of eleven in the morning until three in the afternoon of each day, Sundays excepted, during each session of Congress, for the purpose of delivering and receiring said books; and the keepers of said Library shall receive for their services, including the safe-keeping of the room, furniture, books, and maps, delivering and receiving the books and collecting the forfeitures - dollars annually, to be paid out of the fund annually appropriated for the contingent expenses of both Houses of Congress.

VI. And it is further resolved, That the keepers of said Library shall at the commencement of every session of Congress exhibit a statement to each House of the condition of said room, furniture, books, and maps, with information of the sum of forfeitures, if any, which they have collected, and of the necessary expenses for fuel, etc., in said room during the period next preceding each statement which then remains unsettled, that their accounts may be liquidated and approved by Congress, and the balance shall be paid out of the fund appopriated for the contingent expenses of both Houses of Congress.

VII. And it is further resolved, That the keepers of said Library shall cause a printed copy of the third, fourth, and fifth of the foregoing resolutions to be pasted up in some conspicuous place in said room, which shall be there at all times for the information of the members; and the committee further report for the consideration of Congress the following resolutions:

Resolved, That the Secretary of the Senate be, and he is hereby, directed to make sale of the trunks in which the books lately purcliased were imported; that he exhibit to both Houses of Congress an account of the proceeds, including a statement of the actual expenditures incurred under the act of the 24th of April, I 800 , as well by the purchase of books and maps and incidental expenses as for the expense of fitting up 
the room, procuring furniture, cases, etc., as mentioned in the second of the foregoing resolutions, and the residue of the $\$ 5,000$ appropriated by said act shall be laid out by the Secretary of the Senate aud the Clerk of the House of Representatives for books and maps, or books alone, under the direction of the joint committee to be appointed for that purpose, to consist of members from the Senate and - members from the House of Representatives.

Resolved, That Congress will by law annually appropriate the sum of - dollars, to be laid out for books and maps, or books alone, by the Secretary of the Senate and the Clerk of the House of Representatives, under the direction of the joint committee to be appointed by them for that purpose. ${ }^{2}$

\section{HOUSE DEBATE UPON THE REPORT.}

This report gave rise to considerable debate in both Houses of Congress, the Senate desiring to establish a library for Congress alone, supported by liberal annual appropriations and under executive control, the House desiring to extend the use of the Library to other departments of the Government, but wishing to minimize expenditure for books and to keep the Library from becoming an executive department or bureau. On Monday, December 2I, the bill was brought up for consideration in the Senate and adopted with amendments providing for an annual appropriation and the appointment of a librarian by the President of the United States. ${ }^{2}$ On the $23 \mathrm{~d}$ it was debated in Committee of the Whole in the House of Representatives, and amended so as to give the right of taking books from the Congressional Library to the Attorney-General, the judges of the Supreme Court, while that court was in session, and to foreign ministers. The appropriation clause occasioned more debate. Rev. John Bacon, of Massachusetts, was in favor of \$10,000 annual appropriation for the Library, holding that it was a moderate and a necessary sum. He had not made a calculation, he said, but he believed the House expended as much in deliberating as the sum about which they were contending would amount to. Mr. James A. Bayard, of Delaware, advocated the annual appropriation of $\$ I, \infty \circ$ for ten years. But the Republicans opposed any considerable appropriation for what would evidently become a national 
library, Mr. Randolph thinking it better, he said, to save money than to spend it. Finally Mr. Calvin Goddard, of Connecticut, spoke in favor of $\$ I, 000$ annually, and Mr. Ebenezer Elmer, of New Jersey, against. So it was resolved to appropriate $\$ I, \infty 00$, but only for one year. As for the other provisions of the report, Mr. Bayard moved that instead of the Secretary of the Senate and Clerk of the House of Representatives there be a librarian appointed by the President, but this motion was lost. ${ }^{\mathrm{T}}$ Then the resolutions as amended in Committee of the Whole were recommitted to a select committee consisting of Messrs. Randolph, Bayard, Eustis, Dana, and Elmer.

The aid of President Jefferson was now sought by the Federalists and friends of the Library, and through his influence the Republicans were induced to support a bill drawn up by John Randolph, of the select committee to whom the amended Senate resolutions had been committed on the $23 \mathrm{~d}$ of December. ${ }^{2}$ On the 29th Mr. Randolph reported from the committee on the resolutions of the Senate a resolution, "That the House disagree to the said resolutions;" in which the House concurred. He then reported a new bill, entitled "A bill concerning the Library for the use of both Houses of Congress," the provisions of which were as follows:

I. That the Library, consisting of all the books of the tro Houses, be kept in the room last session occupied by the House of Representatives. 2 and 3. That the President of the Senate and Speaker of the House of Representatives appoint a librarian; and that the President and Speaker have the superintendence of the Library subject to the provisions of the act; the librarian to be allowed $\$ 2$ a day. 4. No map to be taken out of the Library, and the books to be taken out by the President and Vice-President of the United States, and the members of the two Houses, by the heads of Departments and Attorney-General, during the sitting of the legislature, and by the judges of the Supreme Court during its sittings. ${ }^{3}$

'Annals II: 349; National Intelligencer; House Journal.

'Harper's Magazine 46: 42.

${ }^{3}$ Some observations were made as to the time which the Library was to remain open. Mr. Griswold moved to confine it to the time of the session of Congress. It was carried, with an exception, moved by Mr. Southard, in favor of the judges of the Supreme Court, whose sessions did not accord with those of Congress. - Benton's Abridgment of the Debates of Congress, 2: 578 . 
For the last section, the impression being that the unexpended balance was sufficient for the present, ${ }^{\mathrm{I}}$ it was provided simply that the unexpended balance of sums heretofore appropriated, viz, $\$ 2,800$, be applied to the purchase of books under the direction of a joint committee of three members of each House. The bill as thus drawn up differed from that amended by the Senate in providing for a librarian to be appointed not by the President but by the President of the Senate and the Speaker of the House of Representatives. It differed from both the original bill and that amended in the Senate in extending the use of the Library to the President and the Vice-President of the United States, heads of Departments, and as recommended in the Committee of the Whole on the 23d, to the Attorney-General, judges of the Supreme Court, and foreign ministers.

This bill being twice read was accordingly committed to a committee of the whole, where in the debate on the use of the Library Mr. Sprigg moved to add the judges of the District of Columbia, and was supported in argument by Mr. Dennis, upon the ground of the importance of the causes which this especial district would represent, and the great expense and extreme scarcity of some most valuable and necessary law books. But Mr. Bayard objected. He could discover no reason for distinguishing the judges of the District from others; but judges of the Supreme Court, being far from their libraries, required such references. He hoped the Congressional Library would never be subjected to the abuse to which books used in courts of justice were too liable. ${ }^{2}$ The motion was not agreed to. After due consideration the committee rose and reported their agreement to the resolutions contained in the report, and several amendments to the bill. But the inconsistency between a small appropriation and an extended use of the Library being made apparent, Mr. Randolph moved on the following day (December 30) to strike ont that part which gave permission to the heads of Departments, judges of the Supreme Court, and foreign ministers to take out books, which was agreed to, ${ }^{3}$ and on

$\times$ National Intelligencer, December 3 .

'Annals II: 352

${ }_{3}$ National Intelligencer, January 4, I802; Annals I I: 353. 
the 3 Ist of December, I80I, the engrossed bill being read the third time was passed: "Resolved, That the said bill do pass, and that the title be "An act concerning the Library for the use of both Houses of Congress.'" I

On the same day (December $3 \mathrm{I}$ ), a message from the House having informed the Senate that the House disagreed to the resolutions of the Senate, and had passed a bill concerning the Library in which they desired the concurrence of the Senate, the bill was twice read and referred to a committee consisting of Messrs. Tracy, Logan, and Dayton. On the following week Mr. Tracy, from this committee, reported ${ }^{2}$ certain amendments, which were read and laid on the table, but finally, on Monday, January i $\mathrm{r}$, taken up for consideration, and, with further amendments, adopted, and the bill read the third time and passed, as amended. ${ }^{3}$

The difference between the Senate and the House regarding the appointment of a Librarian by the President and regarding an annual appropriation of $\$ \mathrm{I}, \mathrm{OOO}$ was still unresolved. After nearly a month's further consideration and debate, ${ }^{4}$ however, the bill was passed, the main difference between the original Randolph bill and this being that the latter provided for the appointment of a Librarian by the President of the United States, the Senate having receded from their demand for an annual appropriation, the House from their demand that the Librarian be a Congressional employee.

AN ACT Concerning the Library for the use of both Houses of Congress.

Be it enacted, $\mathcal{F}^{\circ} \mathrm{c}$., That the books and maps purchased by direction of the act of Congress, passed the twenty-fourth of April, one thousand eight hundred, together with the books or libraries which have heretofore been kept separately by each House, shall be placed in the Capitol,

Annals II: 354 .

${ }^{2}$ U. S. Seventh Congress, first session, Senate Report. Report of the committee to whom was referred the bill, passed by the House of Representatives, concerning the Library for the use of both Houses of Congress. Printed by order of the Senate of the United States, January 7, I802. Washington, I8o2. 4 pp. $8^{\circ}$.

3 Annals II: 42.

${ }^{4}$ The record of the amendments and motions recorded in the journals of the two Houses in the course of this debate is not intelligible because of the loss of the texts of the bills amended. 
in the room which was occupied by the House of Representatives, during the last session of the Sixth Congress.

SEc. 2. And be it furthcr cnacted, That the President of the Senate and Speaker of the House of Representatives, for the time being, be, and they hereby are, empowered to establish sucl regulations and restrictions in relation to the said library, as to them shall seen proper, and, from time to time, to alter or amend the same: Providcd, That no regulation shall be made repugnant to any provision contained in this act.

SEC. 3. And be it further enacted, That a librarian, to be appointed by the President of the United States solely, shall take charge of the said library; who, previous to his entering upon the duties of his office, shall give bond, payable to the United States, in such a sum, and with such security, as the President of the Senate and Speaker of the House of Representatives, for the time being, may deem sufficient, for the safe keeping of such books, maps, and furniture as may be confided to his care, and the faithful discharge of his trust, according to such regulations as may be, from time to time, established for the government of the said library; which said bond sliall be deposited in the office of the Secretary of the Senate.

SEC. 4. And be it further enacted, That no map shall be permitted to be taken out of the said library by any person; nor any book, except by the President and Vice President of the United States, and members of the Senate and House of Representatives, for the time being.

SEC. 5. And be it further enacted, That the keeper of the said library shall receive for his services, a sum not exceeding two dollars per dien for every day of necessary attendance; the amount whereof, together with the necessary expenses incident to the said library, after being ascertained by the President of the Senate and Speaker of the House of Representatives, for the time being, shall be paid out of the fund annually appropriated for the contingent expenses of both Houses of Congress.

SEC. 6. And be it further cnacted, That the unexpended balance of the sum of five thousand dollars appropriated by the act of Congress aforesaid, for the purchase of books and maps for the use of the two Houses of Congress, together with such sums as may hereafter be appropriated to the same purpose, shall be laid ont under the direction of a joint committee, to consist of three members of the Senate and three nembers of the House of Representatives.

Approved, January 26, 1802.

\section{THE LIBRARY ROOM AND OFFICERS.}

Until I 825 the question of a room for the Library was uppermost. In I 800 only the north wing of the Capitol was finished. The east side of this structure was occupied by the Senate; the west side by the House of Representatives. The books bronght $23399-04-3$ 
by Congress from Philadelphia and the books acquired in consequence of the act of April 24, I80o, were placed in the office of the Clerk of the Senate, a room 22 by 34 feet, and 2I feet high, sonth of the Senate Chamber. This arrangement was preserved during the second session of the Sixth Congress (November I 7, I800, to March 3, I801).

During the year I8OI, however, a temporary structure was erected on the south for the use of the House of Representatives. Accordingly the room which had hitherto been occupied by that body - a room 86 by 35 feet, and 36 feet high, lighted by two ranges of windows and furnished with galleries-r was, by the act of January 26, I802, devoted to the use of the Library, and the Secretary of the Senate having been instructed to sell the trunks in which the books lately purchased had been imported, these books and maps, together with the books or libraries which had been heretofore collected by the two Houses, were removed to their new quarters. Here the library remained until December, I8O5.

In accordance with the law of January 26, ISO2, providing for the appointment of a Librarian by the President of the United States, at a salary not exceeding $\$ 2$ per diem for every day of necessary attendance, President Jefferson on the 29th of Jannary, I802, appointed as Librarian his friend John Beckley, a Virginian, the Clerk of the House of Representatives. Samuel Otis, the Secretary of the Senate, the Federalist candidate, and John McDonald, keeper of a circulating library in Philadelphia, were the unsuccessful applicants for the position. Beckley was Librarian of Congress during the period before its first removal from the library room (December 2, I805). Before its restoration to the library room he died. ${ }^{3}$

\footnotetext{
${ }^{1}$ Report of James Moban, Superintendent of the Capitol, of the state of that building on the 18 th of November, I799. No. 9, in "Letter from the Secretary of the Treasury, transmitting copies of letters from the Commissioners of the city of Washington, witl sundry documents, marked from No. I to Io, inclusively, exhibiting a view of the receipts and expenditures of all monies entrusted to them, and of the progress and state of the business and funcls under their administration, from the ISth of Noventber, I798, to the ISth of November, I799, 5th of December, I799," in State Papers 1799-1800.

${ }^{2}$ There is a notice of Beckley in Awrora, March I4, I8oo, and a biographical note in the Virginia Historical Society Collections n. s. 9: 64.

${ }^{3}$ April 8, I8o7.
} 


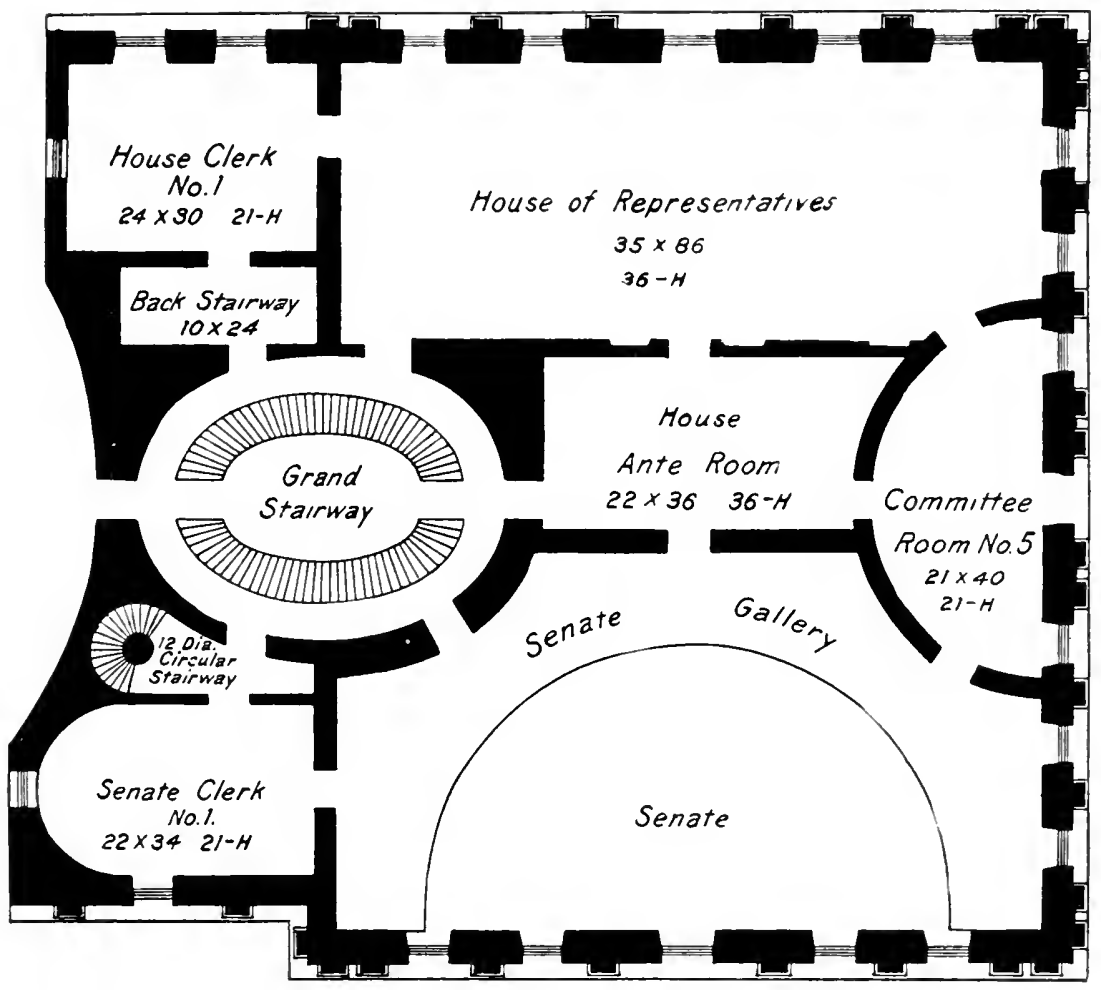

PLAN OF PRINCIPAL, STORY OF CAPITOI, IN ISOO. 

Though Beckley was appointed Librarian, the duties of that office seem to have been performed by Josias Wilson King, engrossing clerk in the office of the Clerk of the House from I 797 to December 3I, ISO5. This is shown by the following memorial from King presented in the Honse by Mr. Nicholson, of Maryland, February i8, i So6: "That at the first session of the Seventh Congress, immediately after the passage of the act concerning the Library for the use of both Honses of Congress, your memorialist was appointed assistant librarian to label, arrange, and take charge of the books of the said Library; that the memorialist accordingly performed the said duty, and also executed the trust reposed in him as a clerk in the office of the Clerk to the House at the same time. That the present Clerk of your honorable body, who was appointed Librarian by the President of the United States, agreed to divide equally the compensation with your memorialist allowed by the said act, during the time he continued to serve in the Library, but the memorialist has not hitherto received the said compensation, as he had a right to expect, although repeated applications have in vain been made therefor, from the year 1802 to the present time." $* * *$ The Committee of Accounts, to whon the memorial was referred, reported unfavorably, and King was obliged to content himself with his salary as engrossing clerk $(\$ I, 000$ per annum). ${ }^{\mathrm{I}}$

PRESIDENT JEFFERSON AND THE PURCHASE OF BOOKS, I802-1805.

Consequent upon the act of Jannary 26, ISO2, a new Library Committee had been appointed ${ }^{2}$ consisting of Messrs. Baldwin, Clinton, and Logan, on the part of the Senate, and Messrs. Nicholson, Bayard, and Randolph, on the part of the House. It was their duty to complete the task begun by the committee appointed in April, I80o, which had, under the direction of Samuel Dexter, made the first purchase of books for the Library of Congress. The cliaiman of the new committee seems to have been Abraham Baldwin, Senator from

\footnotetext{
'Library of Congress Accession Book, I800-1802. Library of Congress MiSS. ac.: 484.

'In the House, March 5, 1So2, and in the Senate, March 11 .
} 
Georgia and brother-in-law of Joel Barlow, at this time the possessor of one of the finest private libraries in America and projector of the scheme for a national university. Senator Baldwin was a graduate of Yale College, had been for four years instructor in that institution, and was considered one of the foremost classical and mathematical scholars of the age. ${ }^{I}$ Under his direction the balance of $\$ 2,800$, appropriated by the act of 1800 , was expended; by what methods and in what manner the following letters from President Jefferson to Abraham Baldwin and the report of the Treasurer of the United States, January IO, I806, published in the report of the Library Committee, January 20, I806, will indicate:

\section{Jefferson to Baldwin, April I7, I802.}

I have prepared a catalogue for the Library of Congress in conformity with your ideas that books of entertainment are not within the scope of it, and that books in other languages, where there are not translations of them, are not to be admitted freely. I have confined the catalogue to those branches of science which belong to the deliberations of the members as statesmen, and in these have omitted those classical books, ancient and modern, which gentlemen generally have in their private libraries, but which can not properly claim a place in a collection made merely for the purpose of reference. In history, I have confined the list to the chronological works which give facts and dates with a minuteness not to be found in narratives composed for agreeable reading. Under the law of nature and nations, I have put down everything I know of worth possessing, because this is a branch of science often under the discussion of Congress, and the books written in it not to be found in private libraries. In law I have set down only general treatises for the purpose of reference. The discussions under this head in Congress are really so minute as to require and admit that reports and special treatises shonld be introduced. The parliamentary section I have imagined should be complete. It is only by having a law of proceedings and by every member having the means of understanding it for himself, and appealing to it, that he can be protected against caprice and despotism in the Chair. The two great encyclopedias form a compleat supplement for the sciences omitted in the present collection, slould occasion happen to arrive for recurring to them. I have added a set of dictionaries in the different languages which nay be often wanting. This catalogue combined with that you may approve in those offered by others, will enable you to form your general plan and to select from it every year, to the amount of the annual

'There is a sketcli of his career, with portrait, in the National Gallery of Portraits IV: I 7 I. 
fund, of those most wanting. In estimating the anount of an annual selection, folios may be slated as costing 1 1/2 guineas, quarto a guinea, octaros 8 shillings, duodecimos 4 shillings, in England, and in France three-fourths of those prices, in neat but not splendid bindings. ${ }^{*}$

This bibliographical programme and the accompanying list of desiderata undoubtedly formed the basis of the purchases for the Library until rSo6, for Albert Gallatin in his report as 'Treasurer, January, I So6, speaks of an unexpended balance for which the English agent, "Mr. Erving, is accountable and which it is understood is to be applied from time to time in the purchase of several scarce books, agreeable to a catalogue prepared, I believe, by the President of the United States."

President Jefferson again showed his interest in the Library, in the following letter to Senator Baldwin, February 4, ISo3:

Mr. Dufief, a bookseller of Philadelphia, who possesses Doctor Franklin's library, has inclosed me the catalogue, with a desire that I should put it into the hands of the conmittee charged with procuring a library for Congress, with an offer of the whole or any part of it at what he says shall be moderate prices. My dealings with him ${ }^{2}$ give me confidence that his prices would be moderate. Without presuming on the answer of the committee to this proposition, I have ventured to mark with a pencil a few particular books, which I imagine are worthy of their acquisition if they are not already in the Library. A return of the catalogue is asked when you have made of it the use which you may desire. $^{3}$

The report ${ }^{4}$ from the Treasurer of the United States, Jannary I0, I806, showed that disbursements on the Library account had been made as follows: First, in payment of the first purchase made by Messrs. Binghan and Walı, $\$ 2,174.89$; to Robert Gilmor, for freight charges and duties, $\$ 296.95$; second, on account of subsequent purchases directed to be made in London, viz, to Jonathan Burrall, for the cost of a bill of $f_{220}$ IIs. 9d. sterling remitted for that object

'Jefferson Papers, series I, vol. 8, No. 322. The accompanying letter-press copy of the catalogue is quite illegible.

2 There are two series of letters from Dufief to Jefferson relating to the purchase of books among the Jefferson Papers, series 2, vol. 28, Nos. 1-34, and vol. 3I, Nos. 3-37.

${ }^{3}$ Jefferson Papers, series 2, vol. 7, No. 17d.

4 Printed in the Senate report, January 20, ISO6, of the "committee to whom was referred the order of the Senate of the 5 th of December last, that inquiry be made whether a further appropriation ouglit not to be made for the amgnentation of the Congressional Library." 
to George W. Erving, consul at London, $\$ \mathrm{I}, \mathrm{OOO}$; to R. Purviance, for freight and duty on a box of books sent by Erving, \$45.24; third, on account of a purchase directed to be made in Paris, viz, to Jonathan Burrall, for cost of a bill of 2,439 guilders remitted to the bankers of the United States at Amsterdam, the proceeds to be at the disposal of Robert $\mathrm{R}$. Livingston, minister of the United States at Paris, \$I,OOO, leaving in the Treasury an unexpended balance of $\$ 482.92$ of the appropriation of $\$ 5,000$. In consequence of these orders and disbursements, four shipments of books had been received, three from London-the second and third from George W. Erving, consul at London, via Alexandria and Baltimore--and one from Robert R. Livingston, minister of the United States at Paris. A catalogue of the new accessions was published in 1802 , with supplement in 1803 ; and a new catalogue was published in ISO4. Both of these catalognes were classified by size-folios, quartos, octavos, and duodecimos - and show the number of volumes and the estimated value of each.

A newspaper notice in the National Intelligencer, February I 3, I 804 , indicates the place which the Library had gained in popular esteem during this period. It says:

\section{CONGRESSIONAL, LIBRARY.}

This collection already embraces near 1,500 volumes of the most rare and valuable works in different languages. We observe with pleasure that authors and editors of books, maps, and charts begin to find that, by placing a copy of their works on the shelves of this institution they do more to diffuse a knowledge of them than is generally accomplished by catalogues and advertisements. 


\begin{tabular}{|c|c|c|c|c|}
\hline No. & FOLIO's. & $\left|\begin{array}{c}\text { No. of } \\
\text { Vols. }\end{array}\right|$ & \multicolumn{2}{|c|}{$\begin{array}{l}\text { Value, as near as } \\
\text { can be estimated. }\end{array}$} \\
\hline & & & $\begin{array}{c}\text { WHOLE } \\
\text { SET. }\end{array}$ & $\begin{array}{c}\text { EACH } \\
\text { BOOK. }\end{array}$ \\
\hline & & & Dollars. & Dollars. \\
\hline 48 & $\begin{array}{l}\text { Biographia Britannica, - } \\
\text { Cove's Travels in Switzerland, }\end{array}$ & 5 & $\begin{array}{l}60 \\
40\end{array}$ & $\begin{array}{l}12 \\
20\end{array}$ \\
\hline $\begin{array}{l}33 \\
55\end{array}$ & $\begin{array}{l}\text { Cose's Travels in Switzerland, } \\
\text { State Trials, }\end{array}$ & 2 & $\begin{array}{r}40 \\
111\end{array}$ & 20 \\
\hline 61 & Atlas to Crutwell's Gazetteer, & 17 & & \\
\hline 62 & $\begin{array}{l}\text { Atlas to Guthrie's System of Geogra- } \\
\text { phi: }\end{array}$ & & & \\
\hline 63 & American Atlas, $\therefore \cdots$ & $1 \zeta$ & & \\
\hline$E+1$ & Plates to Cook's third Voyage, & $1=$ & & \\
\hline 65 & Plates to Macartney's Emabssy to & दे & & \\
\hline 66 & $\begin{array}{l}\text { Journals of the Lords and Commons, } \\
\text { with the rolls and reports complete, }\end{array}$ & 102 & 300 & 3 \\
\hline & $\begin{array}{l}\text { Acititional from the respective Library } \\
\text { of the Senate and House of Represen- } \\
\text { tations. }\end{array}$ & & & \\
\hline 168 & Journal; House Comnions, - - & 18 & 54 & 3 \\
\hline 185 & State Trials, ${ }^{-}+\cdots$ & 14 & 112 & 8 \\
\hline$\approx 00$ & Coke upon Littleton, $\cdots$ & -1 & 10 & \\
\hline$\Sigma 0 !$ & Mortimer's Dictionary, - . - • & 1 & 10 & \\
\hline 202 & Chambers' Dictionary, - - • & 4 & 36 & 9 \\
\hline 206 & Index to Chambers' Dictionary, & 1 & 9 & \\
\hline 207 & Maritime Atlas, $-\overline{-}^{-} \cdot \cdots$ & 5 & 35 & 7 \\
\hline 212 & Atlas to Guthrie's Geography, - - & 1 & 10 & \\
\hline & QUARTO's. & & & \\
\hline 1 & Smith's Thucydides, - . - - & 2 & 10 & 5 \\
\hline 3 & $\cdot \cdot \cdot \cdot \cdot$ & 2 & 14 & 7 \\
\hline 5 & Spellman's Dionysius, = - - - - & 4 & 28 & 7 \\
\hline 9 & Mlurphey's Tacitus, $:-$ & 4 & 30 & 750 \\
\hline 13 & (iil)bon's Roman Empire, & 6 & 54 & $\theta$ \\
\hline 19 & Divilli, History of France by Farne- & & & \\
\hline 21 & Medici, • • & $\ddot{2}$ & 24 & 12 \\
\hline 23 & of Mexico, - & 2 & 24 & 12 \\
\hline 25 & 's Cliarles, - - - - & 3 & 18 & 6 \\
\hline 28 & Robertson's America, - & 2 & 24 & 12 \\
\hline
\end{tabular}





\section{(Thaptex dixne}

GROWTH OF THE LIBRARY, 1805-1814 



\section{CHAPTER THREE}

\section{GROWTH OF THE LIBRARY, 1805-1814}

The Library Committee had recommended (December I8, I80r) that the books, the larger number of which, recently imported, had been hitherto stored in trunks, be set up in portable cases with handles to them for the purpose of easy removal. The wisdom of this advice soon became evident, for in the year 1805 it was found necessary to replace the temporary structure erected for the House of Representatives, popularly known, because of its shape, as the "Oven or Elliptic Room," by a permanent structure which should form the south wing of the Capitol, and, during the progress of the alterations, to accommodate the House in its old quarters in the Library room. For this purpose the civil-appropriations act, approved March I, I805, provided $\$ 700$ for dismantling the Library room and fitting it up for the accommodation of the House at the ensuing session, and $\$ 900$ for the removal of the Library, all other contingent expenses of the same, and Librarian's allowance for the year I805. In consequence of this, the Library was removed to the committee room adjoining on the south. ${ }^{\mathrm{T}}$ Here it appears to have remained until the beginning of I8Io, for after the completion of the south wing, October 6,1807 , the north wing required rebuilding. While the Senate side was undergoing repair, the old Library room just vacated by the House was occupied first by the Supreme Court (October 6, I807, to March 3, I809), and then by the Senate (May 22, I809, to May I, I810). ${ }^{2}$

${ }^{1}$ Report of the committee to whom was referred on the $22 \mathrm{~d}$ ultimo the message of the President of the United States, communicating a report (February 28, 1804) of the surveyor of the public buildings at the city of Washington, March 6, I804.

${ }^{2}$ Message from the President of the United States communicating a report (November 25, r806) of the surveyor of public buildings at the city of Washington, on the subject of the said building. Read December I5, I806. In Ninth Congress, second session, reports I: II. Report of the committee appointed to confer with the surveyor of public buildings relative to the accommodation of the Senate at the next meeting of Congress, February $18,1809$. 
The Library side of the north wing now required attention. The decay of the timber of the roof and of the floor was such as to prevent any effectual security against leakage and render partial repair impossible. Moreover the room in which the Library had been located had become too small for the books already purchased, which were obliged to be piled about in heaps. Accordingly the surveyor of the public buildings asked for an appropriation of $\$ 25,000$ with which to carry up the Library side of the building solidly, and promised that if the appropriation were made the Library would be fitted up and ready for the reception of the books before the session of I8IO-II. The Library would consist of a main library room calculated to contain not less than 40,000 books shelved against its walls in three stages or galleries, a private reading room for members of the Legislature, and two storerooms for unbound books, pamphlets, and deposited copies of the laws, etc. ${ }^{\mathrm{T}}$

The only response was the insertion of a clause in the civilappropriations act, approved March 3, I809, providing for "temporary and adequate accommodations for the Library, in the room now used for that purpose and in the one in which the Senate now sits," the sum of $\$ 5,000 .^{2}$

Again, on December II, I809, the surveyor of the public buildings called the attention of Congress to this subject, saying:

I again beg leave to call your attention to the west side of this wing. It is intended to contain the Library, and is in such a state of decay throughout as to render it dangerous to postpone the work proposed. It is now the only part of the Capitol that remains to be solidly rebuilt. But independently of this consideration, the increasing extent of the Library of Congress induces me to represent to you the necessity of constructing rooms intended permanently to contain it. Should the work

\footnotetext{
${ }^{2}$ Message from the President of the United States transmitting a report of the surveyor of the public buildings of the United States in the city of Washington, December I, 1808. Read December 2, 1808, and ordered to lie on the table. In Tenth Congress, second session, reports, p. II.

'David B. Warden, a visitor in Washington before his appointment as consul at Paris, March 3, 181 I, speaks of the Library as being located under the Senate Chamber. Chorographical and statistical description of the District of Columbia, Paris, I816, p. 35. The Senate occupied the basement below the Library room from October 6, 1807, to March 3, 1 Sug.
} 


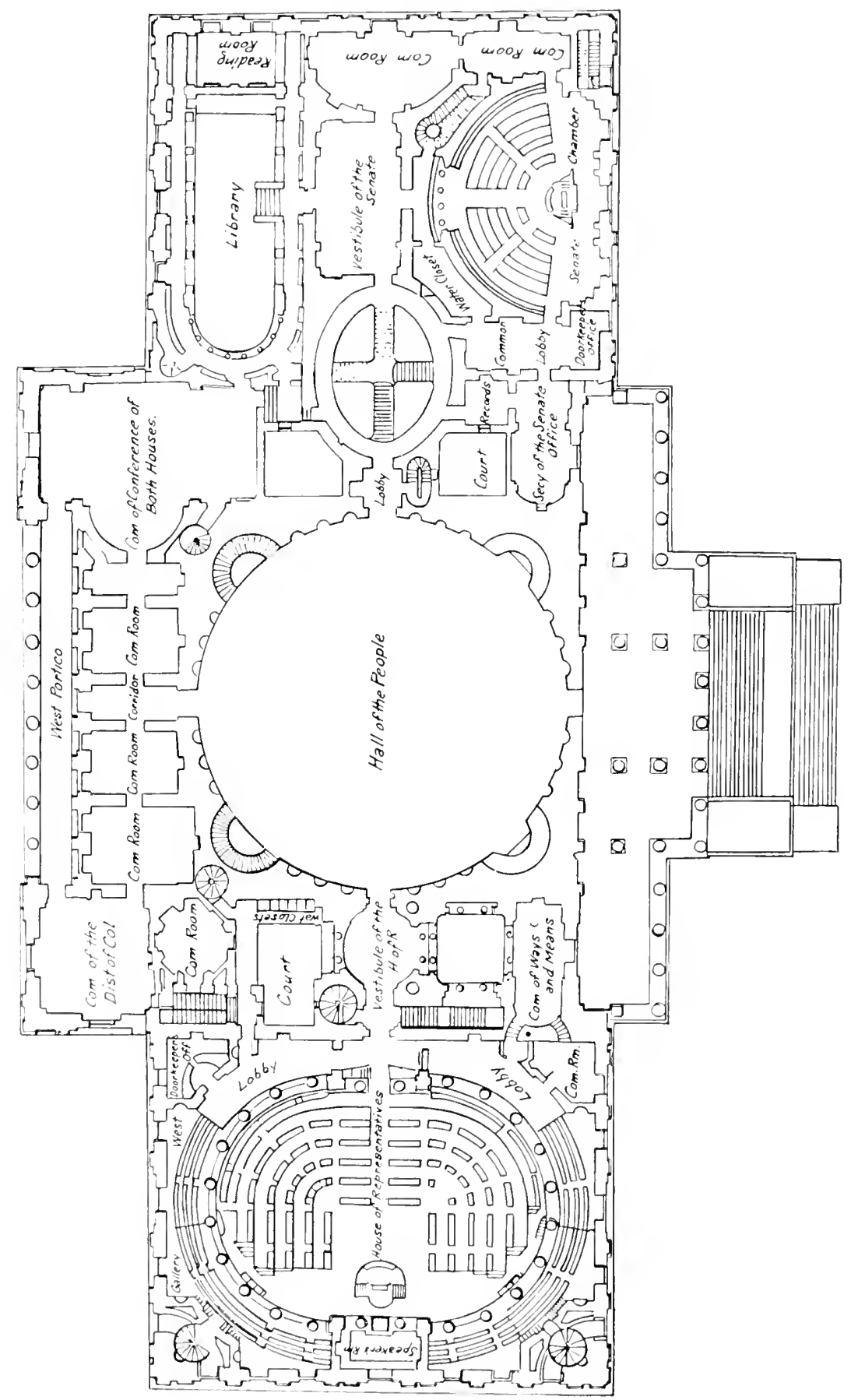

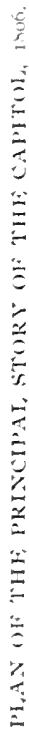



be commenced in the approaching season, the books may be removed, and the Library and reading rooms be fitted up for use by the session after next. ${ }^{\mathrm{x}}$

These appeals were without further effect until January 5 , I8II, when, on motion of Mr. Seybert in the House of Representatives, a committee was appointed to provide for the safekeeping of the books which belonged to the Library of Congress, and Mr. Seybert, Mr. Quincy, and Mr. Macon appointed the committee. On the Sth of January the President communicated a letter to the Senate, signed Adam Seybert, in behalf of the above committee, stating that the books in the Library were in great danger of being ruined in consequence of leaks in the roof of the building, and asking permission to place them for a time in one of the committee rooms belonging to the Senate; and the letter being read, it was "Resolved, That the Senate comply with the request contained therein, and assign their largest committee room for the purpose."

On January I7, on motion of Mr. Seybert in the House of Representatives, and on the 2Ist, on motion of Mr. Leib in the Senate, it was "Resolved, That the joint committee appointed by the Senate and the House of Representatives of the United States, respecting the Library belonging thereto, be directed to inquire into the expediency of making provision for the permanent safe-keeping of the books." In consequence of these efforts the civil-appropriations act, approved February 20, I8I I, provided for repairing the roof and fitting up the room on the west side of the 11orth wing of the Capitol the sum of $\$ 600$, in addition to $\$ 800$ for all contingent expenses of the Library and for the Librarian's allowance. The war of I 8 I 2 now threatened, and Congress ceased to make any appropriations for public buildings.

On the 24th of August, I8I4, the Library was destroyed by the British troops, the wooden interior and shingled roof making of the Library rooms a mere tinder box. ${ }^{2}$

\footnotetext{
${ }^{2}$ Message from the President of the United States, transmitting a report of the surveyor of the public buildings (December II, I809). Read December 21, I809. In Eleventh Congress, second session, reports I809-IO, I: II.

${ }^{2}$ Rev. George R. Gleig, a chaplain in the British army, gives a confused account of the Capitol, including the Library rooms, in his Narrative of the Campaigns of the British army at Washington, Phila., IS21, p. I38.
} 
ADMINISTRATION OF THE LIBRARY, I805-I8I4.

The death of John Beckley, April 8, I807, left the office of Librarian of Congress vacant. With respect to this vacancy President Jefferson wrote to the Secretary of War, Henry Dearborn, April 21, I807: "With respect to the office of Librarian, I have thought it best generally to give it to the Clerk of the House of Representatives, who being dependent on the House is, of course, bound to be complaisant to the nembers. In the present case I am strongly disposed to depart from the rule in favor of William Mayne Duncanson. He was in the very worst days of terror one of the four or five who alone stood their ground as Republicans in Washington and Georgetown. He is, I think, a very honest man, came here a very wealthy one, has been swindled out of his whole property, and now is in real distress. $\mathrm{He}$ is warm in his temper, and on acconnt of some communications with Colonel Smith in Miranda's affair and perhaps some acquaintance with Burr might, I fear, be rather unpopular with the members. But my confidence is that he would be and has been an honest man in all his purposes. I am a little puzzled, therefore, between doubt and inclination." I

It was, however, decided not to separate the two offices of Librarian of Congress and Clerk of the House of Representatives as yet, and Patrick Magruder, appointed Beckley's successor as Clerk of the House of Representatives, October 26, I807, received also the appointment of Librarian of Congress, November 7 , I807. ${ }^{2}$ During the sessions of Congress Magruder appears to have employed one James Kearney as assistant librarian, for a letter from him, dated Library of Congress, April 8, 1808, addressed to the Hon. S. L. Mitchill, chairman of the Joint Conmittee of the Library of Congress, beginning "the following donations to the Library have been received since the last report of the Library Committee" (February II, I807), is printed in the report of the Com-

\footnotetext{
'Jefferson MSS., series I, vol. I2, No. I32. I am indebted to Mr. Henry Adams, the historian, for reference to this letter.

2 December 12, 1808, J. P. Reibelt, formerly of Baltimore, wrote from New Orleans to Jefferson, asking to be appointed Librarian. Jefferson Papers, series 2, vol. 7 I, Nos. I 25-1 26.
} 
mittee, dated April I I, ISoS. At the time of the invasion of Washington, in ISr4, J. T. Frost was acting as assistant librarian.

While the custody of the Library was thus conferred upon a Librarian, the most important duties of the office as now conceived, i. e., the bibliographical, devolved upon the Library Committee.

At the beginning of the second session of the Ninth Congress, December 6, ISo5, the Senate "Resolved, That a committee be appointed to inquire into the expediency of appropriating a further sum of money to purchase maps and books for the Library," and "Ordered, That Messrs. Mitchill, Baldwin, and Tracy be the committee."

The chairman of this committee was Dr. Samuel Latham Mitchill, celebrated as the Nestor of American science, called by President Jefferson "the Congressional dictionary" and by John Randolph "the Congressional Library." There is a legend which runs as follows: One day Mr. Dana, of Connecticut, who was also distinguished for learning, wishing to confer with Doctor Mitchill on committee business, was looking for him at the door of the House when he met Mr. Randolph. "I am looking," said Mr. Dana, "for our 'stalking library.", "Are you?" said Randolph; "I have just heard him inquiring for his "index.'" I

A report was at once drawn up by this committee under the direction of Doctor Mitchill and presented to the Senate on the 2oth of January, I 806 . After narrating the legislative history of the Library and presenting a statement from Albert Gallatin, Treasurer of the United States, describing the manner in which the appropriation made in the year I Soo had been expended, ${ }^{2}$ this report referred to the need for a further appropriation for the Library in the following words:

Every member knows that the inquiries of standing and select committees cau not here be aided by large public libraries, as in New York,

'John W. Francis, "Reminiscences of Samuel Latham Mitchill," New York, 1859; Harper's Magazine 58: 740; Historical Magazine I: 358 .

2January 3, 1806, Gallatin wrote to Jefferson, saying that the Library Committee desired information as to expenditures, observing that Firving and Livingston had not accounted to the Treasury, and inquiring whether they had rendered their accounts to the President. Jefferson Papers, series 3, vol. 6, No. I. 
Baltimore, and Philadelphia. Nor has it hitherto appeared that so much benefit is to be derived from private collections at the present seat of Government as in those large cities. Every week of the session causes additional regret that the volumes of literature and science within the reach of the National Legislature are not more rich and ample. The want of geographical illustration is truly distressing; and the deficiency of historical and political works is scarcely less severely felt. There is, however, no danger of realizing the story of a parliamentum indoctum in this country, especially if steps be seasonably taken to furnish the Library with such materials as will enable statesmen to be correct in their investigations, and, by a becoming display of erudition and research, give a higher dignity and a brighter luster to truth. ${ }^{x}$

In consequence of this report a bill making a further appropriation for the support of the Library was at once drawn up, discussed in Committee of the Whole, and amended on the 28th; on the 3 Ist read the third time and passed; ${ }^{2}$ and on February 3d read in the Honse of Representatives for the third time and passed. ${ }^{3}$ This act was as follows:

AN ACT Making further appropriation for the support of a Library.

$B e$ it enacted, $\mathcal{E}_{c}$., That in addition to the unexpended balance of the former appropriation made to purchase books for the use of Congress, which is hereby revived and continued, there shall be appropriated the sum of one thousand dollars yearly, for the term of five years; to be paid out of any moneys in the Treasury not otherwise appropriated, and expended under the direction of a joint committee, to consist of three members of the Senate, and three members of the House of Representatives, to be appointed every session of Congress, during the continuance of this appropriation. ${ }^{4}$

Approved, February 21, I806.

The Joint Library Committee appointed in accordance with this law consisted of Senators Mitchill, Baldwin, and Adams, appointed February 25, I806, and of Representatives Joseph Clay, Thomas M. Randolph, and Dana, appointed February 27.

'Annals I5: 54-55; Ninth Congress, first session, Reports. State Papers, Miscellaneous, I: 437. In his Economica (p. 21), published in Washington in ISo6, Samuel Blodget suggested to Congress the desirability of passing "a law to augment the National Library, for the benefit of the Legislature."

${ }^{2}$ Annals 15: 74, So.

${ }^{3}$ Annals 15: 416, 462 .

4 Annals I5: 1227. This act was continued by the act of December 6, I8ri, for five years more. Annals 22: 957, 965; 23: 24, 25, 397 . 
Its work is illustrated in an interesting manner by the Memoirs of John Quincy Adanns. In these he writes, March I 2, I 806: "Met the Joint Committee on the Library-Mr. Mitchill, Mr. Baldwin, and myself, of the Senate; Mr. J. Clay, Mr. T. M. Randolph, and Mr. Dana, of the House. All present. We passed two or three votes and are to meet again. We sat late, and when I went into the Senate I fonnd that the South Carolina tomnage bill had passed to a third reading while I was absent."

March 3I, I806: "Met the Joint Committee on the Library, and we made some further progress in our business. We agreed that the principal part of the fund appropriated this year should be expended by Doctor Mitchill, Mr. Clay, and myself during the recess in collecting books in Boston, New York, and Philadelphia, as the occasion may offer. We are to meet again."

An extract from the minutes of the committee, signed by the members of the committee, and preserved among the archives of the Library, evidently refers to the business of this meeting. It reads:

"Ordered, That Samuel L. Mitchill, John Quincy Adams, and Joseph Clay be each authorized to draw on Joseph Nourse, agent for the joint committee, for any sum not exceeding $\$ 494$, to be accounted for to the said agent, at the ensuing session of Congress."

On the IIth of February, I807, the Library Committee made the following report upon its work of the preceding year. It said:

The committee were successful in procuring the consent of Joseph Nourse, esq., to be their agent to hold the money, and drew upon the Treasury in his favor for the amount appropriated. Messrs. Mitchill, Adams, and Clay were then nominated agents to expend the money conformably to the directions of the law. To each of them was allotted a specific sum, with an understanding that books should be purchased in Boston, New York, and Philadelphia; the articles bought in pursuance of this authority have been placed in the Library, except one box of books, which lias been unfortunately lost on its passage from Boston to Washington, by the foundering at sea of the vessel on board of which it had been shipped. **** 
In conclusion, it added:

The members of the two Houses are respectfully requested to furnish lists of good and proper books, and to suggest hints for the improvement of the Library. All communications on these subjects may be addressed to the Librarian, who will transmit them to the committee.

Mr. Adams's diary continues: "February 28, 1807.-Met Doctor Mitchill and Mr. Dana, of the Library Committee, in the Library. Mr. Baldwin and Mr. T. M. Randolph are both unwell and were not able to attend. Mr. J. Clay is absent, and being appointed cashier of a new bank in Philadelphia will probably resign his seat in Congress. We conld not form a majority of the committee, but directed an order to be drawn on the Treasurer for the amount of the annual appropriation, and agreed to meet again Monday morning."

"November 20, 1807.-The Library Committee of last session were to meet at ro this morning, but only three members, Doctor Mitchill, Mr. Dana, and myself attended. Mr. Clay, though notified, did not come, and we have lost two membersMr. Baldwin by death, and Mr. T. M. Randolph, who is not a member of the present Congress. We agreed, however, that Doctor Mitchill, the chairman, should prepare a report to be made to the two Houses; that Mr. Dana should superintend the making and printing of a new list of the books, and that Doctor Mitchill and myself should confer with the President respecting the place for keeping the Library." I

CHARACTER OF THE LIBRARY IN ISI4.

In consequence of this activity of the Library Committee, there was expended for books between March 25, iso7, and March II, ISOS, the sum of $\$ I, I 49.20$, and between June $S$ and December $S$, ISOS, the sum of $\$ I, I 33.01 .{ }^{2}$ During the same period 3 I donations, mostly from Senators and authors, were made to the Library. Complete lists of the books in the Library, including these acquisitions, were published in the catalogues of I 808 and I8I2. In the second of these catalogues short titles of some 3,000 volnmes are entered. The old system of classification by size only is abandoned and the

'Memoirs, edited by C. F. Adams, Philadelphia, IS74, I: 420, 42.4, 463, 478.

=Reports of the Library Committee, April I1, 1SoS, and January 27, ISog. 
books are arranged by size under the following captions: Sacred history; ecclesiastical history; civil history, including chronology, biography, antiquities, etc.; geography and topography; voyages and travels; law; ethics, or the moral system in general; theology and mythology; logic, rhetoric, and criticism; dictionaries, grammars and treatises on education; general and local politics; political economy, etc.; trade and commerce; military and naval tactics; agriculture rural economy, etc.; natural history; natural and experimental philosophy, etc.; medicine, surgery, and chemistry; poetry and the drama; works of fiction, wit, etc.; arts and sciences, and miscellaneous literature; gazettes, maps, charts, and plans.

Samuel Knapp ${ }^{1}$ observed that journals, laws, and state papers were about all the Representatives of the United States could have access to in their public reading room until the Jefferson library was purchased. An examination of the early catalogues does not, however, bear out such a conclusion. On the other hand, the collection may be said to have represented general literature better than it did political literature. ${ }^{2}$ There were several reasons for this. The legislators of that time were without academic training in politics, they found their precedents in the poetry, not in the legislation of the past, their political arguments in the verses of Greek and Roman writers, not in the principles of political economy, or of constitutional or international law. This being true, it was natural that members of Congress should require a collection of books of the most general character. Another important reason for the general character of the collection lay in the fact that there was at this time no public library in the city. It was because there were no other sonrces of amusement that the Library, before $18 \mathrm{I} 4$, and indeed later, was much resorted to as a place of relaxation.

'Sketches of Public Characters, 1830, p. I17.

'Walsh's American Register, copied by the Washington City Weekly Gazette, July 12, 18I7, and by the Intelligencer, July 14, said that the Library consisted of the best English works on history, politics, and polite literature.

$23399-04-4$ 
OPPORTUNITIES FOR THE DEVELOPMENT OF A NATIONAL LIBRARY.

An account of the acquisitions of the Library before IS I 4 would be incomplete without some reference to the collections which it failed to acquire. It was partly the inexperience of the Library Committee and partly, as a later committee reported, ${ }^{1}$ the inconsiderable sums put from time to time at their disposal that rendered them unable to avail themselves of the many opportunities which were offered, on account of the political revolutions in Europe, of purchasing large collections of very valuable books at the lowest prices. In the same way may be explained their failure to secure and thus preserve the invaluable collection of American topography made by Col. William Tatham. Colonel Tatham was the first to define the functions of a national library of the United States. In a letter to the Speaker of the House of Representatives, dated Jefferson street, Georgetown, February IO, ISo6, he recommended that all ancient works, tracts, etc., as well as all new materials relating to American history, should be carefully collected, classed, and arranged; and in addition, books and proceedings of foreign agricultural boards and societies, books on commerce, particularly those relative to roads, river and canal navigation. In this same letter he offered to sell his library to the Government of the United States. This collection, accumulated during thirty years of public service in America and in Europe, embraced manuscripts relating to the history, topography, commercial, agricultural, and liydraulic improvements of this country; surveys comprehending nearly all the surveys known to have been made in North America by the topographical engineers of England, France, and Spain, prior to the American Revolution, describing adjacent countries about the Lakes, Canada, the St. Lawrence, Nova Scotia, and Labrador to the northward and westward, and in the Floridas and Louisiana, including the Mississippi and the Mobile, to the sonthward and westward, besides a very extensive collection made within the United States, including the documents for completing Tatham's large 
and smaller maps of the Southern States, his James River navigation, and State of Virginia, his divisions of the Sonthern and Western States, his Northern States and United States, and his proposed American atlas on Ioo plates; also plans and drawings of perliaps nearly all the towns, suburbs, liarbors, environs of fortified places, etc., topographically delineated, together with the plans, sections, and elevations of the barracks, fortifications, etc., of each; among them many of the original documents of General Wolfe and of others who served under and succeeded him in Canada, on the Lakes, on the Mississippi, etc., with plans, sections, and the elevations of blockhouses and other works; also all the similar documents of the operations in Florida, together with most part of the collection of the late British engineer General Montresor, with many of the originals of General Howe's campaigns in the Jerseys, with a few landscapes of interesting parts of the country-aqueducts, engineering and architectural drawings, etc. Of engravings there was a considerable collection on both large and small scales, in portfolios and on separate sheets, of various port improvements, containing all those recently made in London from the actual surveys of the city, parliamentary surveys and reports, the surveys of eminent engineers, their reports, estimates, etc.; a large collection on the subject of bridge building, all the late designs for bridges, docks, quays, etc., collected and engraved at parliamentary expense on very large and highly finished plates; many other bridges, aqueducts, mill works, waterworks, etc., with many machines and contrivances for saving and abridging animal labor in various agricultural, commercial, and mechanical employments, together with an extensive assortment of locks, basins, canals, river and road plans of varions descriptions, and examples from other parts of Europe, etc., with many interesting descriptions of the most suitable instruments, tools, utensils, and apparatus in these pursuits. Of his books Tatham wrote:

This small library (allowed by many men of science to be the completest of its kind) has been selected from the great mass in London and other places, by many years of research, industry, perseverance, and sacrifice of time and expense by the proposer in person. It consists of a few hundred volumes, perhaps most of which are not to be had else- 
where, as they are chiefly books out of print, and others the result of of actual operations, facts, and experience, brought forward by professional men of superior talents at the public expense, or at the charge of incorporate companies, societies, wealthy proprietors, etc. These have been carefully collected together, classed, arranged, and bound in rolnumes suitable to the respective topics on which they treat, and suitable tables of contents added to each collective volume in manuscript. They are wholly scientific and useful, it having been an invariable rule with the selector to reject plays, farces, novels, romances, fabulous stories, and all that trash and fashionable nonsense which tends to give a contaminated tone to the popular morals and habits; to disseminate indolence, dissipation, immorality, vice, artificial wants, false luxury, envy, hatred, ambition, mental inquietude, individnal strife, and the more lamentable mania of foreign wars, bloodshed, and contention, too often about a mere definition of words and terms which both parties would construe alike under the governance of reason.

The subjects treated of, and relative, are agriculture, horticulture, irrigation, drainage and embankments, commerce, finance, internal economy, domestic and rural economy, architecture in general, rural, hydraulic, military, and maritime architecture, arithmetic, mathematics, surveying, leveling, mechanics, hydraulics, hydrostatics, pnenmatics, natural and experimental philosophy, and those sciences in particular which relate to civil engineering, chemistry of nature and art, the use of instruments, apparatus, and machines for saving labor, canal navigation, river navigation, and roads, parliamentary proceedings and reports in these respects, the works of governments, incorporated companies, and engineers throughout the world, the more detailed knowledge of water works, mill works, engines, etc., the knowledge of tides and land floods, with the means of converting their mechanical powers to useful purposes, and of counteracting their evils by efficient means. The whole deduced from the results of practice and actual experience. In general and local history and topography, the collection has been chiefly confined to domestic matter (more peculiarly applicable to our public economy), and to that which is immediately relative on either our Atlantic or Pacific coasts, or in the interior. In the latter, Canada, Hudson's Bay, the Russian confines, California, Mexico, South America, Louisiana, and the Floridas have been attended to, and will be found copious and instructive. On the subject of public institutions, useful societies, public boards, charities, useful economical improvements, the economy of public roads, the general and local jurisdiction of the public sewers and estuaries, and metropolitan police, there has been a careful selection, as there has been also a tolerably complete one of contemporary facts during the revolution of America, brought into a few chronological volumes. ${ }^{x}$

\footnotetext{
${ }^{2}$ Report from the committee appointed on the Ioth of February last, on the letter of William Tatham to the Speaker, April I, ISo6. Read and ordered to lie on the table. Washington, A. \& G. Way, 1806. Ninth Congress, first session. 23 pp. $8^{\circ}$.
} 
The committee to whom this letter was referred, feeling that in affairs of war the experience of their predecessors was peculiarly valuable, and considering the value of the Tatham collection, recommended the following resolution: "That in addition to the appropriation already made by law, a sum not exceeding _- dollars be appropriated as a part of the fund for the purchase of books, maps, and charts for the Department of War, to enable the Secretary of War to purchase from Willian Tatham such parts of his collection as may be, in the judgment of the Secretary, of public use, to be paid out of any money in the Treasury not otherwise appropriated." The report was, however, laid upon the table.

There are further notices of the collection, at that time stored in Tatham's house near the Treasury, in the Nationat Intelligencer, November 6, I8I3, and March 25, ISI4. On the Ioth of February, ISI7, a committee recommended in the House the appropriation of the sum of $\$ 5,000$ for the purchase of the collection. This recommendation, too, failed. On the $22 \mathrm{~d}$ of February, rSrg, the unfortunate genius, then a resident of Richmond, committed stricide. The Enquirer, February 25, ISI9, speaking of the event, observed: "He left a valuable stock of maps, plates, charts, and explanatory manuscripts, filling six rooms of his house, which it is hoped will be carefully preserved." "

We have named those who held the office of librarian before I8I4, and we have described the bibliographical activity of the Library Committee; it remains for us to speak of the development of the functions of the Library and of the rules and regulations governing its administration during the first period of its existence.

\footnotetext{
s There is an obituary of Tatham in the Georgetown Messenger, February 26, ISI9; an autobiographical sketch in the Richmond Enquirer, March 2, ISI9, reprinted in the City of Washington Gazelte, March 4 . There is a good biographical sketch in Pubic Characters, 180 r-2, 2d ed., London, isu. 4 pp. 424-450. There are letters from Tatham to Madison regarding this collection, March 16 , June 26, December 7 , is 12 , April I8, I8I4, April 1, 1815 , among the Madison MSS. It is possible that a part of this collection was acquired by leter Force and transferred with his library to the Lilurary of Congress in 1967.
} 
DETELOPMENT OF THE COLLECTION OF DOCUMENTS.

Before ISO5 the collection of public documents, local and national, of the United States and of foreign countries had been left to the caprice of the irresponsible individual. On the $2 \mathrm{~d}$ of January, I805, however, the following act for the disposal of certain copies of the journals and of the laws of the United States was approved:

Be it enacted by' the Senate and House of Representatives of the United States of America, in Congress assembled, That three hundred copies of the laws of the United States, which have been procured by the Secretary of State, in obedience to the law passed for that purpose, and three hundred copies of the journals of Congress, which have been procured in pursuance of the resolution of the second of March, one thousand seven hundred and ninety-nine, shall be placed in the Library of Congress.

SEc. 2. And be it further enacted, That the Secretary of the Senate, for the time being, be, and he is hereby, authorized to receive three hu1dred copies of the laws of the United States, out of the thousand copies reserved by law for the disposal of Congress, as soon as the same shall be printed after each session; which lie shall cause to be placed in the library, and assorted respectively with the sets of copies mentioned in the first section of this act; excepting only, that at the close of the present session, which will complete the eighth Congress, and in like manner after each particular session in future, which shall complete a Congress, he shall cause the several copies, reserved by hill as aforesaid, for all the sessions for each respective Congress, to be bound in one rolume, making three hundred volumes for each Congress, as aforesaid; which he shall cause to be placed in the library, assorted with the respective sets of copies mentioned in the first section of this act. And the several copies of the laws and journals of Congress, mentioned in this act shall not be taken out of the library, except by the President and Vice President of the United States, and nembers of the Senate and House of Representatives for the time being. And the expense of binding shall be paid, fron time to time, out of the fund appropriated to defray the contingent expenses of both Houses of Congress.

SEc. 3. And be it furtherenacted, That the President of the Senate and Speaker of the House of Representatives, for the time being, be, and they are hereby, empowered to establislı such regulations and restrictions in relation to the copies of the laws and journals of Congress, directed by this act to be placed in the library, as to them shall seem proper, and from time to time to alter and amend the same: Provided, That 1to regulation nor restriction shall be valid, which is repugnant to the provisions contained in this act. 
In ISog this provision for the preservation of the laws of the United States and journals of the two Houses of Congress was supplemented by a measure providing for the preservation of all documents laid before Congress. On Febrnary I, Mr. Burwell in the House of Representatives moved the following resolution: "That the Clerk of this House be instructed to furnish the Librarian of Congress with two complete sets of all documents laid before Congress at each session," which was laid on the table. On the following day, on motion of Mr. Burwell, the House proceeded to consider the resolution, and the same was amended on the several motions of $\mathrm{Mr}$. Macon and Mr. Marion, to read as follows: "Resolved, That the Clerk of this House be instructed to furnish the Librarian of Congress with two complete sets of the journals and all documents and reports laid before Congress at each session." Then a motion was made by Mr. Durell further to amend the said resolntions by adding to the end thereof the words following: "and to transmit to the secretary of each of the States in the Union, and of the Territories thereof, one such set for the use of said States and Territories, respectively." But this was lost, and on motion of Mr. Stanford the resolntion, as amended, was referred to a select committee to consider and report upon to the House. On the 6th of February, the committee consisting of Messrs. Burwell, Stanford, and Ely reported, and it was "Resolied, That the Clerk of this House be directed to furnish the Library of Congress with two sers of the journals and of all printed reports and public documents laid before Congress, or either House, at each session." "

FX'THNSION OF THE, PRIVILEGES OF' THF IIBRARY.

The House of Representatives was the leader in enlarging the functions of the Library in another direction. From the first the Senate had stood for appropriations large enough to enable the Library to fulfill its functions as a Congressional Library. On the other hand, the Honse of Representatives had stood for an enlargement of the sphere of service of the Library-for the extension of the privileges of the Library, 
not only to the President and Vice-President of the United States, but also to the heads of Departments, the AttorneyGeneral, judges of the Supreme Court and of the district conrt of the District of Columbia, and foreign ministers, and, by inference, the development of the Library along the wider lines dictated by the extension of the privileges of the Library to readers of wider interests. The first step in this direction subsequent to the act of 1802 was taken in the House, February 19, r806. On that day it was "Resolved, That a committee be appointed to consider the propriety of amending the fourth section of the Act of $\mathrm{ISO}_{2}$ so as to extend the privilege of taking books out of the Library to the Secretary of State, the Secretary of the Treasury, the Secretary of War, the Secretary of the Navy, and the Attorney-General of the United States; and that the committee have leave to report by bill, or otherwise. Ordered, That Messrs. Joseph Clay, Nicholson, and John C. Smith be appointed a committee, pursuant to the said resolution."

On the following day this committee reported by bill, which, after several amendments in Committee of the Whole, was read the third time and passed, February 25. ${ }^{\mathrm{T}}$

On the same day a message from the House informed the Senate of the passage of this bill, in which they desired the concurrence of the Senate. On the following day, ${ }^{2}$ accordingly, the Senate referred the bill to a committee consisting of Messrs. Anderson, Baldwin, and Mitchill to consider and report upon, which, on the $7^{\text {th }}$ of March, they did, without amendment. But after consideration in Committee of the Whole, ${ }^{3}$ the measure was lost on the third reading. ${ }^{4}$

On the $27^{\text {th }}$ of April, I8Io, however, on motion of Mr. Lloyd in the Senate, a bill to amend the fourtl section of the act of I 802 passed the Senate, and on the 3oth of April the Honse, yeas 53 , nays 32 , as follows: ${ }^{5}$

AN AC'T In addition to an act entitled "An act concerning tle Library for the use of both Houses of Congress."

Be it enacted, Esc., That the President of the Senate and Speaker of the House of Representatives, for the time being, be, and they are hereby, authorized to grant the use of the books in the I,ibrary of Congress, to

'Annals 15: 4 So, 482, 497 . 'February 26.

4 March 14. Anuals 15: 140-141, I65, I82, I84.

3 March II.

${ }^{5}$ Anuals 21: 1997, 2017. 
the Agent of the Joint Committee of Congress, appointed in relation to the Library, on the same terms, conditions, and restrictions as members of Congress are allowed to use said books, anything contained in any former law to the contrary, notwithstanding.

Approved, May I, I8IO. ${ }^{\text {. }}$

On the 26th of February, is 8 2, the following resolution, in the form of a joint resolution of the two Houses of Congress, was submitted by Mr. Seybert in the House of Representatives:

Resolved by the Senate and House of Representatives of the United Statcs of Amcrica, in Congress asscmbled, That the President of the Senate and the Speaker of the House of Representatives, for the time being, be, and they are hereby, authorized to grant the use of the books in the Library of Congress to the Judges of the Supreme Court of the United States, at the time and on the same terms, conditions and restrictions, as members of Congress are allowed to use said books.

On the following day, the 27th of February, the resolution was read the third time in the House and passed. ${ }^{2}$ On the same day a message from the House informed the Senate of the passage of the resolution, and requested the concurrence of the Senate. On motion of Mr. Lloyd, accordingly, the resolution was read three times by unanimous consent, and was concurred in, ${ }^{3}$ and on March 2, ISI2, approved, ${ }^{4}$ in the form in which it had been introduced.

On the same day, March 2, the Speaker laid before the House a letter from the Chief Justice of the United States, in behalf of the justices of the Supreme Court, acknowledging the favor which Congress had conferred upon them. ${ }^{5}$ It was a favor, Ben: Perley Poore says in his Reminiscences, ${ }^{6}$ which Chief Justice Marshall prized very highly. "He liked to wait upon himself, rather than to be served by the Librarian, and one day in taking a law book from the upper shelf of an alcove, he pulled down a dozen ponderous tomes, one of which struck him on the forehead with such force that he fell prostrate. An assistant librarian, who hastened to the old gentleman's assistance, found hin slightly stumed by the fall but he soon recovered and declined to be aided to his feet, saying with a merry twinkle in his eye, 'I've laid down the law ont of the law books many a time in my long life, but this is the

\footnotetext{
Annals 21: 2587 .

${ }^{3}$ Annals 23: 130.

2Anuals 23: 1105-1107, 1116.

A Anuls 24: 2362.

5 Annals 23: 1116.

- Page 43.
} 
first time they have laid me down.' And he remained seated upon the floor, surrounded by the books which he had pulled down, until he found what he sought and made a note thereof."

RULES OF THE LIBRARY BEFORE I814.

In the catalogue of the Library published in I 808 the following Rules and Regulations to be observed in the Library of Congress are to be found:

I. The Library shall be open every day cluring the session of Congress, and for one week preceding and subsequent thereto, Sundays excepted, from 9 o'clock in the morning to 3 in the afternoon, and from 5 o'clock to 7 in the erening.

II. In the recess of Congress, it shall be opened three days in every week, during the hours aforesaid, to wit, on Tuesday, Thursday, and Saturday.

III. It shall be the duty of the Librarian to label and number the books, place them on the shelves, and preserve due lists and catalogues of the same. He shall also keep due account and register of all issues and returns of books as the same shall be made, together with regular accounts of all expenses incident to the said Library and which are authorized by law.

IV. Books, to be issued by the Librarian pursuant to law, shall be returned as follows: A folio within three weeks, a quarto within two weeks, an octavo or duodecimo within one week, and no member shall receive more than one folio, one quarto, or two octavos or duodecimos within the terms aforesaid, unless where so connected as to be otherwise useless.

$V$. For all books issued ${ }^{2}$ a receipt or note shall be given, of clouble the value thereof as near as can be estimated, conditioned to return the same undefaced within the term above mentioned or to forfeit the amount of such note; at the expiration of which, unless application has been made by another person for the same book and the Librarian requested to take memorandum thereof, the said Librarian, upon the books being produced to him, may renew the issue of the same for the time and on the conditions aforesaid: Provided, That every receipt or note shall contain a further forfeiture or penalty for every day's detention of a book beyond the specified term-that is to say, for a folio, $\$ 3$ per day; a quarto, \$2 per day; an octaro, \$I per day, ${ }^{2}$ which forfeiture or penalty may, for good cause, be renitted by the President of the Senate and Speaker of the House of Representatives, for the time being, in whole or in part, as the case nilay require.

"Rules of 1SI 2: "to any person, except a member of Congress."

2Rules of 1812: Folio, $\$ \mathrm{r}$; quarto, 50 cents; octavo, 25 cents per day. Rules of ISI6: Folio, 20 cents; quarto, Io cents; octavo, 5 cents. 
VI. When a member shall prefer to take a book for the limited time without removing it from the Library, he sliall be allowed to do so without giving a receipt or note for the same, and to preserve his priority for the use of sucli book for the time linited, in like manner as if he had withdrawn the book from the Library and given a receipt or note therefor. And the Librarian shall keep due account and entry of all such cases.

VII. Books returned shall be delivered to the Librarian to be examined whether damaged or not.

VIII. If a book be returned damaged, the party returning it shall not be entitled to receive another until the damage for the first shall be satisfied.

IX. No book shall be issued within one week ${ }^{\mathrm{x}}$ of the termination of any session of Congress.

$\mathrm{X}$. All books shall be returned three days ${ }^{2}$ before the close of the session, whether the time allowed for the use thereof be expired or not.

Rules and regulations to be observed in the Library of Congress for issuing, disposing, and safe-keeping of the tau's and journals of Congress, deposited in the said Library, pursuant to the act of Congress of the ad of January, 1805 .

I. During a session of Congress the Secretary of the Senate and Clerk of the House of Representatives shall, on their respective responsibility, be entitled to receive for the use of their respective Houses, that is to say, the Secretary of the Senate six sets of the said laws and journals and the Clerk of the House of Representatives eight sets; those for the Senate to be distributed, one set for the President's table, two sets for the Secretary's table, and the other three sets for committees of the Senate; those for the House of Representatives, one set for the Speaker's table, two sets for the Clerk's table, and one set for each of the standing committees of the House; which sets of laws and journals shall be duly returned to the I,ibrary by the said Secretary and Clerk within three days after the close of the session for which they shall be drawn.

II. Whenever any persoll authorized thereto by law (except the President of the United States), ${ }^{3}$ shall receive from the Library a set of the said laws and jonrnals, he shall give receipt therefor to the Librarian, conditioned to return the same undefaced to the Library three days ${ }^{2}$ before the close of that session of Congress for which they shall be drawn, under a penalty of double the value of each volume of the laws or journals received, that is to say, for eacl volume of the laws and journals valued at $\$ 2.50$ per volume, in a penalty of $\$ 5$ per volume.

III. One set of the said law's and journals sliall be delivered by the Librarian to the President of the United States for his own use and for the use of his sticcessors in office, the Presiclent filing with the Iibrarian a written acknowledgment of the receipt of the same.

\footnotetext{
"Rules of ISI 2: "ten days." 3 Rules of ISI2: "and members of Congress."
}

"Rules of 1812: "five rlays." 
IV. It shall be the duty of the Librarian to provide, at public expense, a nuuber of suitable boxes, equal to the number of individuals hereby authorized to receive from the Library sets of the said laws and journals, each box to be provided with a lock and key, and delivered on application for the use of such persons as may draw in the manner aforesaid, in which to deposit and safely keep the books so by them respectively received, which boxes shall be returued to the Library together with the books at the time and in the manner limited by the rules aforesaid. ${ }^{r}$

In addition to these 14 rules the following are added in the Catalogue of the Library published in ISI2:

$X V$. There shall be retained in the Library all charts (the case of maps being specified in the act of January 26, 1802), plans of fortifications, buildings, or other designs in manuscript; volumes of plates or engravings; books accompanying the charts, plates or engravings; tables of chronology; rolumes of newspapers; one set of the volumes of any encyclopedia or dictionary of the arts; one set of the rolumes of any geographical work, gazetteers, dictionaries of languages. Of the above none shall be taken from the Library, by any person, without special permission in writing from the President of the Senate and Speaker of the House of Representatives, except in cases where the presiding officer of either House may require any of them for the immediate use of the House.

XVI. The previous approbation of the President of the Senate and Speaker of the House of Representatives shall be obtained for the purchase of articles for the use of the Library, to be charged upon the contingent fund of the two Houses.

XVII. It shall be the duty of the Librarian, four days before the termination of every session of Congress, to present to any member of Congress a list of the books which he has received from the Library and not returned.

XVIII. The Librarian shall, three days before the termination of every session of Congress, furnish the Speaker of the House of Representatives and the Secretary of the Senate with a list of the names of such members of Congress as shall not have returned the books received from the Library, together with a description and value of such books, and also of the value of the set to which they belong, and of the amount of fines with which they stand charged; and it shall be the duty of the Speaker in settling the accounts of any stich Representative, and of the Secretary of the Senate in settling the accounts of any such Senator, to retain a sum equal to double the value of the books retained, and if they shall form a part of a set, then double the value of the whole set; and also a stun equal to the fines with which such member nay stand charged.

${ }^{1}$ The last rule was rescinded by the rules of January 1, 1816. 
XIX. Whenever any Senator or Representative shall obtain leave of absence for the remainder of any session of Congress, it shall be the duty of the Speaker of the House of Representatives, or of the Secretary of the Senate, as the case may be, to ascertain of the Librarian whether such Senator or Representative shall have returned the books which he may have received from the Library and have paid the fines which may have been incurred by him; and in case of failure the same deduction shall be made in the settlement of the accounts of such Senator or Representative as are directed in the eighteenth rule.

$\mathrm{XX}$. The Librarian shall collect all fines and forfeitures accruing upon notes given for books taken from the Library.

XXI. All moneys arising from fines and forfeitures shall constitute a part of the Library fund and shall be paid, when required, to the joint committee of the two Houses of Congress who are charged with the disposition of that fund.

XXII. The Librarian shall, during the first week of every session, present to the joint committee of the two Houses of Congress charged with the disposition of the Library fund an accurate statement of all moneys received during the preceding year arising from fines and forfeitures under the foregoing rules.

Upon considering the subject of rules proper to be observed in the Library of Congress, and examining and revising those heretofore adopted, we do order and direct that the foregoing be observed.

(Signed)

DECEMBER 4, I8I2.
WII. H. CRAWFORD, President of the Senate pro tempore.

$\mathrm{H}$. $\mathrm{CI}_{\mathrm{A}} \mathrm{Y}$, Speaker of the House of Representatizes. 


\section{(Etraptex $\mathfrak{d o w x}$}

THE DESTRUCTION OF THE OLD LIBRARY AND THE PURCHASE OF THE JEFFERSON LIBRARY 



\section{CHAPTER FOUR.}

THE DESTRUCTION OF THE OLD LIBRARY AND THE PURCHASE OF THE JEFFERSON LIBRARY.

In the latter part of July, I $8 \mathrm{I}_{4}$, being compelled by an indisposition to seek recreation, Librarian Magruder left Washington for the Virginia Springs. The newly appointed assistant librarian, J. T. Frost, remained in charge of the Library for the purpose of opening and airing the books. About the middle of August the British army appeared in the Chesapeake, and on the igth the whole body of the militia of the District of Columbia was called out, under which call every clerk in the office of the Clerk of the House of Representatives was taken into the field. Assistant Librarian Frost was not, however, comprehended in this order, being over the age prescribed by law for militia service. On the 19 th, 2oth, 2 Ist, and $22 \mathrm{~d}$ the removal of the papers belonging to the other departments was effected, but not until the afternoon of the last day was anything done toward the removal of the Library of Congress. On the afternoon of the 2ist Mr. Burch, of the office of the Clerk of the House, was furloughed by Brigadier-General Smith, at the request of the chief clerk of the office of the Clerk of the House, Col. George Magruder, and on the night of the same day returned to the city to take care of and assist in saving such parts of the books in the Library of Congress and papers in the office of the Clerk of the House as he could, in case the enemy should get possession of the place. His orders from Colonel Magruder were not to begin packing up until it was ascertained that the clerks at the War Department were doing so. It was not until I2 o'clock on Monday, the 22d, that Burch and Frost were informed that the clerks at the War Office had begun to move the effects of that office, although they were subsequently told that the moving had commenced the day before. The two men immediately began packing up, and 
Mr. Burch went out in search of wagons or other carriages for the transportation of the books and papers. Every wagon and almost every cart in the city had been previously impressed into the service of the United States for the transportation of the baggage of the Army. The few he was able to find were loaded with the private effects of individuals who were noving without the city. These he attempted to hire; not succeeding, he claimed a right to impress them, but having 110 legal anthority or military force to aid him he failed. He then sent off three messengers into the country, one of whom obtained from Mr. John Wilson, whose residence was six miles from the city, the use of a cart with four oxen. This did not arrive at the Capitol until after dark, but was immediately loaded with the most valuable records and papers and driven nine miles the same night to a safe and secret place in the country. He continued to remove as many of the more valuable books and papers as he was able to with one cart until Wednesday morning, the day of the battle of Bladensburg, after which he was unable to take away anything further. ${ }^{\mathrm{I}}$

That same evening the enemy entered Washington and set fire to the Capitol. In the conflagration which followed the interior of the west room was practically destroyed. As the surveyor of the Capitol said: "The whole of the interior of the west side liaving been constructed of timber, and the old shingle roof still remaining over the greatest part of the wing, an intensity of heat was produced, which burned the walls most exposed to it, and being driven by the wind into the Senate Chamber burned the marble columms to lime, cracked everything that was of freestone, and finding vent through the windows and up the private stairs damaged the exterior of the wing very materially."

\footnotetext{
"Letter from Patrick Magruder, detailing the facts in relation to the destruction of the office of the House.-September 22, I 814 , Thirteenth Congress, third session. House Document No. 2.

${ }^{2}$ Report of the surveyor of the Capitol, Fourteenth Congress, second session. Senate report No. IOI, Nebruary I4, I817. National Intelligencer, Narch 12, I8I8, on the destruction of the printed journals of Congress; see also Sixteenth Congress, first session, Senate report No. I19, April 25, I820, on the destruction of the printed journals of the Senate in the conflagration of 1814 ; and a letter to a gentleman in Philadelphia on the condition of the Capitol after the fire, printed in the Philadelphia Aurora, December 12, I814.
} 
According to tradition the Library was entirely consumed in this conflagration. As we have seen, however, several loads of books were saved by having been removed to a place of safety before the capture of the city, and with regard to the Library as a whole Burch and Frost made the following statement: "A number of the printed books were consumed, but they were all duplicates of those which have been preserved." This would seem to indicate that all of the Library which was of value was this saved. On the other hand the committee to whom was referred the communication of Patrick Magruder relative to the destruction of the Library, reported through Mr. Joseph Pearson, December I2, ISI4, "that they have satisfactory evidence that the Library of Congress, consisting of volnmes agreeably to the catalogue herewith submitted, was destroyed by the enemy on the 24th of August last." In answer to this, Magruder, on the igth of December, communicated to the House the following letter from the assistant librarian:

DECEMBER I 7, I8I4.

SIR: On examining the report of the committee appointed on the subject of your conmunication to the House of the 2oth of September last, I find that the committee admit that, after the 2 ist of August, the difficulty of procuring teams for the removal of the books, papers, etc., from your office was so great as to justify a belief that all was done after that period which could (with the means we possessed) have been expected. But the committee states that measures preparatory for a removal had not been taken. On that head I can only say that, on Monday, the $22 \mathrm{~d}$ of August last, if carriages for the conveyance of the books, etc., could have been obtained, they were in a situation to be immediately removed; the several loads which were saved were taken from the shelves on which they were placed and deposited in the carts by which they were taken away; they have suffered no injury, and to have procured boxes or trunks to pack them in, if that plan had been preferred, would have been utterly impossible.

Your obedient servant,

J. T. FROST.

In conclusion the committee replied: "The error or negligence consisted not so much in delaying to pack up the effects of the office till the 22d of Angust as the neglect to provide the means of transportation, which night have been done by 
the clerk who remained in the office, or any agent employed for that purpose." " On the 2Sth of January, I 8 I 5 , Mr. Magruder communicated to the House his resignation as Clerk of that body. ${ }^{2}$

The indignation felt by Congress at the destruction of the Library, and vented by that body upon the unfortunate Librarian, was shared by all lovers of literature and learning. Not since the burning of the Alexandrian library by the Mohammedans, it was said, had such a deed been perpetrated. English newspapers, too, condemued the act, among them the editor of a newspaper published at Nottingham, who, in speaking of the burning of the Library, said that it was "an act without example in modern wars or in any other wars since the inroads of the barbarians who conflagrated Rome and overthrew the Roman Empire." ${ }^{3}$ And General Ross himself is said to have lamented the destruction of the Library. "Had I known it in time," said he, "the books most certainly should have been saved." ${ }_{4}$

\section{OFFER OF THF JEFFERSON LIBRARY TO CONGRESS.}

On the 29th of September, I8I4, the President of the Senate presented a letter from the President of the Washington Library, with a resolution of the directors, offering the use of that library to the members of Congress. On the zoth he communicated a letter from Richards \& Mallory, booksellers of Georgetown, offering the use of their books to the members of the Senate. ${ }^{5}$ On the 7 th of October, I8 I4, the Joint Library Committee, through Mr. Goldsborough, presented to the Senate an offer from Thomas Jefferson of the whole of his library for Congress upon such terms as they might choose.

Thomas Jefferson had made donations to the old Library

'Thirteenth Congress, third session, House report No. 45, January 16, I815.

'American State Papers, Miscellaneous, 2: 267, 268.

${ }^{3}$ 'This incident is noticed in the Philadelplia Aurora, October 18 , IS15, with this additional observation: "The printer was proscribed for this as a libel and has been condenned to such punishment as is usually inflicted on the most abandoned villains. The English Government is determined to maintain its character." 'This was copied by the Fissex Register, Salem, October 28.

${ }^{4}$ Ingersoll, Historical sketcli of the second war between the United States and Great Britain, I'hiladelphia, $1849,2: 190$.

5 Annals 28: IS, 20. 


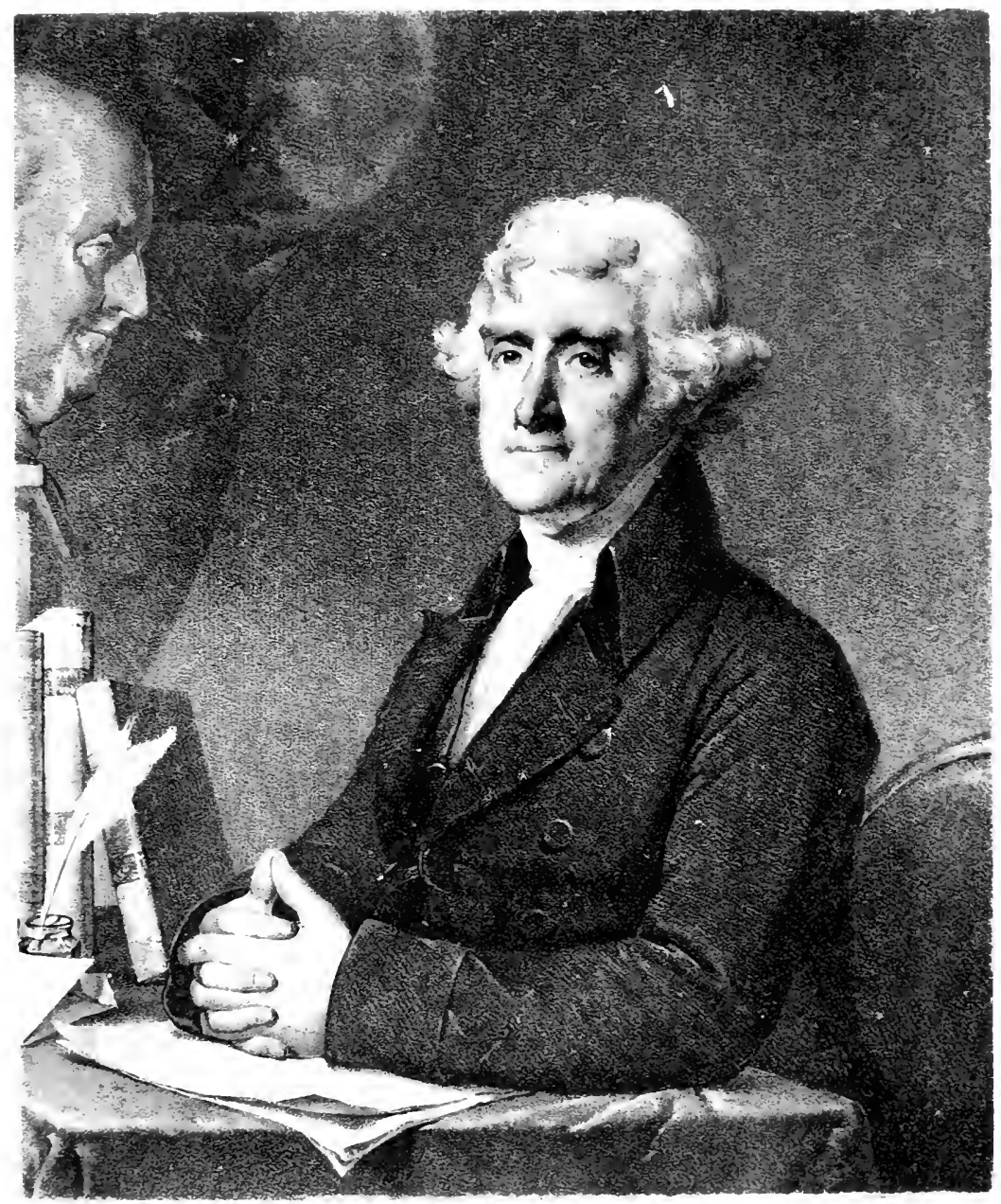

THO.MAS JHFFRGQS 


$$
\cdot
$$


of Congress, and he had drawn up the list of desiderata which had formed the basis for the earlier purchases of the Library. At the same time he was collecting a library of his own. This, in a letter to Dr. Thomas Cooper, dated January r6, ISI4, he described as probably the best chosen collection of its size in America, and at the same time expressed the hope that it might finally become the library of the projected University of Virginia ${ }^{\mathrm{I}}$ as he had before expressed the hope to Madison that it might become the library of the National University if the plans for such an establishment should ever be realized. ${ }^{2}$

The loss of the old Library of Congress, however, presented a better opportunity for the disposition of his library than either of those which he had suggested. Upon hearing of the disaster, accordingly, he tendered the offer of his library to Congress through his friend Samuel Harrison Smith, September 2I, ISI4.

His letter to Mr. Smith was as follows: "I am imposing a task on your friendship which needs much apology and will be explained in the letter accompanying this. It is to offer my library to the Library Committee of Congress. I would not have trespassed on your time so much but that I hope it will give you little trouble. The delivery of the accompanying letter (which is written separately with that view) and the catalogue will enable them to give you their yea or nay. As the subject, however, can not but be interesting, and I shall feel anxiety until I know their inclinations, you would greatly oblige me by informing me of them as soon as youl can form a probable conjecture what they are likely to decide." 3

The communication submitted to Congress which accompanied this letter was as follows:

DEAR SIR: I learn from the newspapers that the vandalism of our enemy has triumphed at Washington over science as well as the arts by the destruction of the public library with the noble edifice in which it was deposited. Of this transaction, as of that of Copenhagen, the world will entertain but one sentiment. They will see a nation suddenly withdrawn from a great war, full armed and full handed, taking advantage

${ }^{2}$ Writings of Thomas Jefferson, 1854, 6: 294.

${ }^{2}$ Jefferson to Madison, October 6, I809, Madison MSS.

${ }^{3} \mathrm{~J}$. Henley Sinith MISS. 
of another whom they had recently forced into it, unarmed and unprepared to indulge themselves in acts of barbarism which do not belong to a cirilized age. When Van Ghent destroyed their shipping at Cliatham, and De Ruyter rode trimmphantly up the Thames, he might in like namner, by the acknowledgment of their own historians, have forced all their ships up to London bridge, and there have burned them, the tower, the city, had these examples been then set. London, when thus menaced, was near a thousand years old; Washington is but in its teens.

I presume it will be among the early objects of Congress to recommence their collection. This will be difficult while the war continues, and interconrse with Europe is attended with so much risk. You know my collection, its condition and extent. I have been fifty years making it, and have spared no pains, opportunity or expense, to make it what it is. Wlile residing in Paris, I devoted every afternoon I was disengaged, for a summer or two in examining all the principal bookstores, turning over every book with my own hand, and putting by everything which related to America, and indeed whatever was rare and valuable in every science. Besides this, I had standing orders during the whole time I was in Europe, on its principal book-marts, particularly Amsterdam, Frankfort, Madrid, and London, for such works relating to America as could not be found in Paris. So that, in that department particularly, such a collection was made as probably can never again be effected, because it is hardly probable that the same opportunities, the same time, industry, perseverance and expense, with the same knowledge of the bibliography of the subject would again happen to be in concurrence. During the same period, and after my return to America, I was led to procure, also, whatever related to the cluties of those in the high concerns of the nation. So that the collection, which I suppose is of between nine and ten thousand volumes, while it includes what is chiefly valuable in science and literature generally, extends more particularly to whatever belongs to the American statesman. In the diplomatic and parliamentary branches, it is particularly full. It is long since I liave been sensible it ought not to continue private property, and had provided that at my deatli, Congress should have the refusal of it at their own price. The loss they have now incurred, makes the present the proper moment for their accommodation, without regard to the small remnant of time and the barren use of my enjoying it. I ask of your friendship, therefore, to make for me the tender of it to the Library Committee of Congress, not knowing myself of whom the committee consists. I enclose you the catalogue, which will enable them to judge of its contents. Nearly the whole are well bound, abundance of them elegantly: and of the choicest editions existing. They may be valued by persons named by themselves, and the payment made convenient to the public. It may be, for instance, in snch amunal installments as the law of Congress has left at their disposal, or in stock of any of their late loans, or 
of any loan they may institute at this session, so as to spare the present calls of our country and await its days of peace and prosperity. They may enter, nevertheless, into immediate use of it, as eighteen or twenty wagons would place it in Washington in a single trip of a fortnight.

I should be willing, indeed, to retain a few of the books, to amuse the time I have yet to pass, which might be valued with the rest, but not included in the sum of valuation until they should be restored at my death, which I would carefully provide for, so that the whole library as it stands in the catalogue at this moment should be theirs without any garbling. Those I should like to retain wonld be chiefly classical and mathematical. Some few in other branches, and particularly one of the five encyclopedias in the catalogue. But this, if not acceptable, would not be urged. I must add, that I have not revised the library since I came home to live, so that it is probable some of the books may be missing, except in the chapters of Law and Divinity, which have been revised and stand exactly as in the catalogue. The return of the catalogue will of course be needed, whether the tender be accepted or not.

I do not know that it contains any branch of science which Congress would wish to exclude from their collection; there is, in fact, no subject to which a member of Congress may not have occasion to refer. But such a wish would not correspond with ny views of preventing its dismemberment. My desire is either to place it in their hands entire, or to preserve it so here. I an engaged in making an alphabetical index of the authors' names, to be annexed to the catalogue, which I will forward to you as soon as completed. Any agreement you shall be so good as to take the trouble of entering into with the committee, I hereby confirm. ${ }^{x}$

On the 24th of September he wrote to President Madison ${ }^{2}$ and to James Monroe ${ }^{3}$ also, acquainting them with his offer, and asking for their support.

In response Mr. Smith wrote to Jefferson October 7, I $814:{ }^{4}$

It gives me great pleasure to acknowledge the receipt of your favor of the $2 x$ st ultimo, which from some casualty did not reach me until the 2 instant. * * * The Library that is lost, was valuable and was the commencement of an institution fitted in its nativity to be the pride and ornament of our country. But valuable as it was, if replaced by your collection, the loss will be more than supplied. Being somewhat of an enthusiast as to the benefits that arise from such institutions, I conld

'J. Henley Smith MSS., printed in the Writings of Thomas Jefferson, edited by P. L. Ford, 9: 485-488, and numerous other places.

"Writings of 'Thomas Jefferson, $1854,6: 3^{8} 7$.

${ }^{3}$ Jefferson MSS., series 2, vol. 58, No. 91. See also Jefferson to David B. Warden, February 27, I8I5, Jefferson MSS., series 2, vol. 87, No. I49.

${ }^{4}$ Jefferson MSS., series 2, vol. 78 , No. 28. 
only hail the prospect of seeing so broad a foundation laid for a national one on a scale of expanding grandeur.

I submitted, without delay, your letter and catalogue to the Iibrary Committee of the two Houses of Congress. That of the Senate consists of Messrs. Goldsborough, Tait, and Fromentin, and that of the Representatives of Messrs. Seybert, Lowndes, and Gaston. The tender was respectfully received by both committees, with the assurance that no time should be lost in acting upon it. They each expressed the opinion that the committee could not go further than to recommend to their Houses such steps as they should on consultation consider advisable, and promised to inform me of the conrse determined on. I have made several other members acquainted with the offer made by you, and have been happy to find that it is highly appreciated by them and will receive their warm support.

I perceive no obstacle to its acceptance, but the pending proposition to remove the seat of Govermment. I fear that many of those who are interested in this measure, will consider the possession of such a library as depriving them of a strong argument in favor of removal and hence will be apt by delay or evasion, to keep back its consideration. Should this prove to be the case, I submit to you the policy of permitting a publication of your letters. $* * *$

P. S. I an just advised by Mr. Goldsborough that the joint committee have reported a resolution empowering them to contract for the purchase of the library.

Madison replied to Jefferson's letter, October ro: "Your favor of the 24th ultino came duly to hand. I learn that the Library Conmittee will report favorably on your proposition to supply the loss of books by Congress. It will prove a gain to them if they have the wisdonn to replace it by such a collection as yours." I

And Monroe likewise responded, October Io, promising to use his influence in pronnoting the negotiation. ${ }^{2}$

\section{THE, QUESTTON OF PURCHASF, IN CONGRESS.}

On the 7 th of October the Joint Committee reported in the Senate (by Mr. Goldsborough), as follows:

That they have received from Mr. Samuel H. Smith an offer from Mr. Jefferson, late President of the United States, of the whole of his library for Congress, on snch terms as they consider highly advantageous to the nation, and worthy the distinguished gentleman who tenders it.

'Writings of Madison, I865, 2: 588.

2 Writings of James Monroe, edited by S. Mi. Mamilton, Igor, 5: 299. 
But the means placed at the disposal of the committee being very limited, and totally inadequate to the purchase of such a library as that now offered, the committee must have recourse to Congress either to extend their powers, or adopt stch other as they may think most proper.

Should it be the sense of Congress to confide this matter to the committee, they respectfully submit the following resolution:

Resolied, by the Senate and the House of Representatizes of the United States of America in Congress assembled, That the Joint Library Committee of the two Houses of Congress be, and they are hereby, authorized and empowered to contract, on their part, for the purchase of the library of Mr. Jefferson, late President of the United States, for the use of both Houses of Congress. ${ }^{\mathrm{x}}$

On October Io Mr. Goldsborough, chairman of the Joint Library Committee, communicated a letter from Samuel H. Smith, esq., inclosing Mr. Jefferson's letter tendering the disposition of his library to Congress. Then the resolution reported by the committee, authorizing the Library Committee to contract for the purchase of the library of $\mathrm{Mr}$. Jefferson, was discussed, as in Committee of the Whole, and, no amendment having been proposed, reported and passed.

On the same day a message informed the House of the passage of the resolution in the Senate, and desired the concurrence of the House therein. On the IIth, accordingly, the discussion of the resolution was taken up in the House, as in Committee of the Whole. ${ }^{2}$ After much desultory conversation, according to the records, as to the value of the library, the nature of the selection, etc., the committee rose (in order, apparently, to give further time to the nembers to examine the catalogue), and obtained leave to sit again. A week later (Monday, October I7) the debate was resumed as in Committee of the Whole, Joseph Lewis, of Virginia, in the chair. The ensuing debate betrayed the English prepossessions of some, the narrow parsimony of others, the party prejudices of nearly all. Mr. Oakley, of New York, moved so to amend the resolution as to leave it open to the Library Committee to contract for the purchase of a library for the use of Congress. O11 this motion considerable desultory debate took place, the purchase of Mr. Jefferson's library being opposed by Messrs.

x Thirteenth Congress, third session, Senate report, October 7,1814 .

2Annals 28: 394 . 
Oakley, Jolnn Reed, and Grosvenor, and advocated by Messrs. Wright, Seybert, Bolling Robertson, Joseph Hawkins, and John Forsytl. The objections to the purchase were generally its cost, its extent, the nature of the selection, and the number of the works in foreign languages, particularly French, many of them the writings of Voltaire, Roussean, and other literary apostles of the French Revolution; nor did English works of progress and speculative freedom, such as Locke's, escape animadversion. Other works were said to be of too philosophical a character, and some, as Callender's Prospect before ı1s, were otherwise objectionable.

On the other hand, those who advocated the proposed purchase contended that so valuable a library, one so admirably calculated for the substratum of a great National Library, was not to be obtained in the United States; and that although there were possibly some works to which gentlemen might take exception, there were others of a very opposite character; that besides, this was no reason against the purchase, because in every library of value some books might be found to which exceptions would be taken, according to the feelings or prejudices of those who examined them. Mr. Oakley's motion was negatived by the following vote: For the amendment, 33; against it, 87 .

The Speaker now resumed the chair, and Mr. Lewis reported that the committee had had the resolution under consideration and had made no amendment thereto. The House then proceeded to consider the said resolution, and despite the fact that Mr. Jefferson had declined to dispose of a part only of the library, a motion was made by Mr. King, of Massachusetts, to amend the resolntion by inserting after the word "purchase," in the third line, the words "of such part;" and at the end of the resolution to add the words "as they may judge suitable for that purpose." This measure was designed to exclude French progressive and philosophical works, and was supported by John Reed, Timothy Pickering, Timothy Pitkin, Richard Stockton, and Daniel Webster, while William Gaston, Moss Kent (brother of Chancellor Kent), and other Federalists opposed it. After 
some discussion the question on this anendment was decided by yeas and nays by the following vote: For the amendment, 47 ; against it, 9I, as follows:

Yeas.-Messrs. Baylies of Massachusetts, Bigelow, Boyd, Bradbury, Brigham, Champion, Cilley, Cooper, Cox, Culpeper, Davenport, Ely, Farrow, Geddes, Goldsborough1, Grosvenor, Hanson, Jackson of Rhode Island, King of Massachusetts, Law, Lewis, Lovett, Markell, Miller, Moffitt, Moseley, Oakley, Pearson, Pickering, Pitkin, Post, Potter, John Reed, Ruggles, Schureman, Sherwood, Shipherd, Smith of New York, Stockton, Sturges, Vose, Ward of Massachusetts, Webster, Wheaton, Wilcox, Wilson of Massachusetts, and Winter.

Nays.-Messrs. Alexander, Alston, Archer, Avery, Barbour, Bard, Bowen, Bradley, Brown, Butler, Camnon, Chappell, Clark, Clopton, Condict, Conard, Crawford, Creighton, Crouch, Cuthbert, Dana, Denoyelles, Desha, Duvall, Farle, Findley, Fisk of Vermont, Fisk of New York, Forney, Forsyth, Franklin, Gaston, Gholson, Glasgow, Goodwyn, Gourdin, Griffin, Hall, Harris, Hasbrouck, Hawes, Hopkins of Kentucky, Hubbard, Humphreys, Hungerford, Hulbert, Irving, Irwin, Jackson of Virginia, Johnson of Virginia, Johnson of Kentucky, Kennedy, Kent of New York, Kent of Maryland, Kerr, Kershaw, King of North Carolina, Lefferts, Lowndes, Lyle, McCoy, McKim, McLean, Moore, Nelson, Newton, Ornısby, Parker, Pickens, Piper, Pleasants, Rhea of 'Tennessee, Rich, Ringgold, Roane, Robertson, Sage, Seybert, Sharp, Smith of Pennsylvania, Smith of Virginia, Stanford, Strong, Tamnehill, Taylor, Telfair, Ward of New Jersey, Wilson of Pennsylvania, Wright, and Yancey.

Mr. John Reed, of Massachusetts, then made an appeal to the well-known parsimony of many Republicans by moving to amend the resolution by adding at the end of the same the following proviso: "Provided, That the amount thereof shall not exceed twenty-five thousand dollars." Upon this a motion was made by Mr. Stanford that the further consideration of the resolution be postponed until the first Monday in Decen1ber. This was negatived. ${ }^{\mathrm{r}}$

On the r 8th the debate upon the Reed amendment continued with considerable vivacity. The anendment was supported by Messrs. Oakley, of New York, and Pickering, of Massachusetts, and was opposed by Mr. Forsyth and Mr. Joln C. Hulbert, a young Federalist of the Massachusetts delegation,

\footnotetext{
'See in addition to the Journals Cliarles J. Ingersoll's History of the second war between the United States and Great Britain, 2d series, 2: 27 I-273.
} 
who, in a maiden speech of much force, advocated the purchase of the library. The debate before its conclusion became rather too animated, and being checked by the Speaker, the question was permitted to be taken. For the amendment, 37; against it, I03, as follows:

Yeas.-Messrs. Baylies of Massachusetts, Bigelow, Boyd, Bradbury, Brigham, Cannon, Champion, Cilley, Culpeper, Davenport, Ely, Geddes, Grosvenor, Jackson of Rhode Island, Lewis, Macon, Markell, Moffit, Montgomery, Pearson, Pitkin, Post, Potter, John Reed, William Reed, Sherwood, Shipherd, Smith of New York, Stockton, Taggart, Thompson, Vose, Ward of Massachusetts, Ward of New Jersey, Wheaton, Wilcox, and Wilson of Massachusetts.

Nay's.-Messrs. Alexander, Alston, Archer, Avery, Bard, Barnett, Bayly of Virginia, Bowen, Burwell, Bradley, Brown, Butler, Chappell, Clark, Clopton, Condict, Conard, Cooper, Cox, Crawford, Creighton, Crouch, Cuthbert, Dana, Davis of Pennsylvania, Denoyelles, Desha, Duvall, Earle, Evans, Farrow, Findley, Fisk of New York, Forney, Forsyth, Franklin, Gaston, Gholson, Goodwyn, Gourdin, Hall, Hanson, Harris, Hasbrouck, Hawes, Hawkins, Hopkins of Kentucky, Hubbard, Humphreys, Hungerford, Hulbert, Ingersoll, Irving, Jackson of Virginia, Johnson of Virginia, Kennedy, Kent of New York, Kent of Maryland, Kerr, Kershaw, King of Massachusetts, King of North Carolina, Law, Lefferts, Lovett, Lyle, McCoy, McKim, McLean, Moore, Moseley, Nelson, Newton, Oakley, Ormsby, Parker, Pickering, Piper, Pleasants, Rhea of 'Tennessee, Rich, Ringgold, Roane, Ruggles, Sage, Schureman, Seybert, Sharp, Skinner, Smith of Pennsylvania, Stanford, Strong, Sturges, Tannehill, Taylor, Telfair, Troup, Udree, Webster, Wilson of Pennsylvania, Winter, Wright, and Yancey.

Among those who thus voted to reduce the price of the library was Nathaniel Macon, who, observes Ingersoll, "never failed to demonstrate his always peculiar, often eccentric, and sometimes extravagant economy." On the other hand, Mr. Hanson, Mr. Webster, even Cyrus King, Mr. Oakley, Mr. Pickering, Mr. Sturges, and Mr. Law, who had voted for the King amendment, on this money vote sided with those who favored the purchase of the Jefferson library.

A motion was then made by Mr. Pickering to amend the said resolution by striking out from the words "purchase of" in the third line to the end thereof, and to insert "such of the books in the library of Mr. Jefferson, late President of the United States, as in their opinion will at this time be 
proper to be received and deposited at the seat of Government for the use of the two Houses of Congress." This amendment was in substance the sane as that moved on the day before by Mr. King. This motion was supported by several of the library party-Macon and a few more-and by most of the Federalists, including Mr. Webster, but Mr. Gaston, Mr. Hulbert, and Mr. Kent to the last adhered to the original motion and the amendment was decided in the negative-yeas 52 , nays 96 . Those who voted in the affirmative were:

Messrs. Baylies of Massachusetts, Bayly of Virginia, Bigelow, Boyd, Bradbury, Brigham, Cannon, Champion, Cilley, Cooper, Cox, Culpeper, Davenport, Davis of Pennsylvania, Geddes, Goldsborough, Grosvenor, Hanson, Jackson of Rhode Island, King of Massachusetts, Law, Lewis, Lovett, Macon, Moffitt, Montgomery, Moseley, Markell, Oakley, Pearson, Pickering, Pitkin, Post, John Reed, William Reed, Ruggles, Schureman, Sherwood, Shipherd, Smith of New York, Stockton, Stuart, Sturges, Taggart, Thompson, Vose, Ward of Massachusetts, Webster, Wheaton, White, Wilcox, Wilson of Massachusetts.

Those who voted in the negative were:

Messrs. Alexander, Alston, Archer, Avery, Barbour, Bard, Barnett, Bowen, Bradley, Brown, Burwell, Butler, Caldwell, Chappell, Clark, Clopton, Condict, Conard, Crawford, Creighton, Crouch, Cuthbert, Dana, Denoyelles, Desha, Duvall, Earle, Evans, Farrow, Findley, Fisk of New York, Forney, Forsyth, Franklin, Gaston, Gholson, Goodwyn, Gourdin, Griffin, Hall, Harris, Hasbrouck, Hawes, Hawkins, Hopkins of Kentucky, Hubbard, Humphreys, Hungerford, Hulbert, Ingersoll, Irving, Jackson of Virginia, Johnson of Virginia, Johnson of Kentucky, Kennedy, Kent of New York, Kent of Maryland, Kerr, Kershaw, King of North Carolina, Lefferts, Lowndes, Lyle, McCoy, McKim, McLean, Miller, Moore, Nelson, Newton, Ormsby, Parker, Pickens, Piper, Pleasants, Rhea of Tennessee, Rich, Ringgold, Roane, Sage, Seybert, Sharp, Skinner, Smith of Pennsylvania, Snith of Virginia, Stanford, Strong, Tannehill, Taylor, Telfair, Troup, Udree, Ward of New Jersey, Wilson of Pennsylvania, Wright, and Yancey.

Finally, on motion of Mr. Oakley, the resolntion was amended by adding to the end thereof the following: "and that the committee lay the terms of said contract before Congress for their ratification." On the following day, the rath, the resolution thus amended was passed. 
On the same day a message from the House informed the Senate that the House had passed the resolution, which originated in the Senate, empowering the Joint Library Committee of Congress to contract for the purchase of Mr. Jefferson's library, with an amendment, in which they request the concurrence of the Senate. ${ }^{I}$ On the 2oth the Senate proceeded to consider the Honse amendment. Mr. Mason noved that the further consideration thereof be postponed to the first Monday in April next. This was determined in the negative-yeas 7 , nays $2 \mathrm{I}$, as follows: ${ }^{2}$

Yeas.-Messrs. Daggett, German, Gore, Horsey, King, Mason, and Thompson.

Nays.-Messrs. Anderson, Bibb, Bledsoe, Brown, Chace, Condit, Fromentin, Gaillard, Giles, Goldsborough, Lacock, Morrow, Roberts, Robinson, Tait, Taylor, Turner, Varnum, Walker, Wharton, and Worthington.

Whereupon, "Resolved, That they concur therein."

On October 20 the Washington correspondent of the Boston Gazette wrote: "The grand library of Mr. Jefferson will undoubtedly be purchased with all its finery and philosophical nonsense. ${ }^{3}$

On the 2ist the measure passed:

RESOLUTION empowering the Joint Library Committee of Congress to contract for the purchase of Mr. Jefferson's library.

Resolicd, by the Senate and House of Representatives of the United States of America in Congress assembled, That the Joint Library Con1mittee of the two Houses of Congress be, and they are hereby, authorized and empowered to contract on their part for the purchase of the library of Mr. Jefferson, late President of the United States, for the use of both Houses of Congress; and that the Committee lay the terms of said contract before Congress, for their ratification.

PUBLIC OPINION REGARDING THE PURCHASE OF THE LIBRARY.

Joseph Milligan, a Georgetown bookseller, who had for years been collecting books for Jefferson, and was, perhaps, the first to be informed of Jefferson's offer of his library to Congress, wrote, September 24: "Your truly magnanimous offer of the Monticello library to Congress will be very accept-

Annals 28: 29. $\quad$ Annals 28: 30. $\quad{ }^{3}$ Boston Gazette, October 27, isi4. 
able. If Congress should purchase it, to literary men it would be a great privilege to be permitted at all times of the year to have free access, not to take away the books, but to read in the Library and make extracts. Therefore the place of Librarian would be well to be a distinct office from the Clerk of the House of Representatives. If they do take it everything that I can do in arranging it shall be done, and I will keep the library for this session free of cost. By this I would have it clearly understood that it is not my wish to fish for it as a permanent thing, for I would not accept a place of profit under any Government.

"You will please communicate with the Secretary of State on the subject, and inclose the catalogue to him. I will immediately, on receipt of it, arrange to have it printed."

In like fashion William Thornton, Commissioner of Patents, wrote to Jefferson December II, ISI4: "What dreadful scenes we have witnessed liere! But all may be repaired, and in some respects we shall be benefited, for if the buildings should be repaired, we shall never hear any more of the removal of Congress: and I have congratulated the members on the loss of their library since you have offered yours on such generous terms. I advised them to offer you $\$ 50,000$ at once, for I had seen the books and knew them to be very valuable; that they ought not to value them as books in a common library, for, besides the learning and ability it would require to select the books, they were not to be obtained but at very great trouble, great expense, great risk, and many of them not to be had at all, but I fear they will not give half the value."

And William Short, of Philadelphia, to whom Jefferson was indebted to the amount of $\$ 10,500$, writing March II, I $\delta$ I 5 , congratulated Jefferson on the sale of his library to Congress, on the ground that it wonld preserve it from the fate of the

\footnotetext{
${ }^{2} \mathrm{James}$ Monroe.

${ }^{2}$ Jefferson MISS., series 2, vol. 6I, No. 80.

${ }^{3}$ Jefferson MISS., series 2, vol. 8I, No. 34. In reply to this Jefferson wrote, Monticello, December 24, "The loss of the library will be more than repaired should they conclude to take mine. The rarity of many of the books and choice of editions of the greater part render the collection really valuable." Jefferson MSS., series 2, vol. 8I, No. 48.
} 
Westover Library, which, after the death of Col. William Byrd, the third of that name, in I 777 , had been dispersed by sale. ${ }^{\text {. }}$

Even the newspapers were interested in the purchase of the library. One of these, the Petersburg Courier, expressed itself in the following words: ${ }^{2}$

The objections made by the Federal members of Congress, to the purchase of Mr. Jefferson's library, are certainly not only extraordinary and illiberal, but they reflect the greatest discredit upon the national character of this country. What can be a greater stigma upon the members of our National Legislature than to assert that books of a philosophical description are improper for their perusal? Were Mr. Oakley, Mr. Reed, and Mr. Grostenor, the literary censors of the United States, the works of Newton, Locke, Simpson, Stewart and all others of equal merit, would doubtless be committed to the flames, and their places supplied perhaps by The Tales of IVonder, the Tales of Horror, and the Arabian Nights' Entertainnent.

Another great objection is, that Mr. Jefierson's library contains the works of Voltaire-what a pitiful observation! Will it be said that the works of an author, which hold the first rank on the shelves of all the libraries of Europe, and which may be found in the libraries of Oxford and Cambridge, and in those of the four Scotch universities, for the express purpose to be perused by students, should be prohibited or forbidden a place in the Library of Congress? Will the force of Federal prejudice and superstition be so powerful as to effect this?

Jefferson thus had the good wishes of friends, creditors, and editors-Virginia and Republican editors-but before the sale of the library could be effected it was necessary to answer the question raised by the Oakley amendment of October 19, as to the value of the library.

\section{EVALUATION OF' THE LIBRARY.}

This question was presented to Jefferson in the following letter from Samuel Harrison Smith, October 2 I, IS I 4:

I was this day invited by the Library Committee to a conference with them. They represented that in consequence of the amendment to their report, it becane necessary to ascertain the value of the library and to

${ }^{2}$ Jefferson Papers, in collections of the Massacbusetts Historical Society, series 7, vol. I, p. 229. There is a catalogue of the books in the library at Westover belonging to William Byrd, esq., in the "Writings of Col. William Byril," edited by J. S. Bassctt, New York, I9or, pp. 4r3-444.

${ }^{2}$ This article was reprinted in the Nationa! Intelligencer, October 25, I8I4. 
obtain an authority from the two Houses to pay it, to enable them to do which they enquired of me, whether I could specify what would be recaived for it. I replied that I was unable to state its value, and that I was certain that it would be much more agreeable to you that this should be done either by the committee themselves, or by disinterested persons; that I was persuaded that you feel some delicacy, if not repugnance, to setting a value on your own property, and that you might, in forming the estimate, from obvious motives, be driven to the alternative of either depreciating its value, or of laying yourself open to the imputation of extravagance. I, therefore, proposed another course; that the library should be estimated by some one sent for that purpose, or, which I consider most advisable, that it should be brought to this place without delay, valued by the committee, or by persons named by the committee, or by the committee and myself, that this valuation should be submitted to the committee, and if agreed to by them, that a correspondent report and contract should be made to Congress, of whose approbation I did not entertain a doubt; that should, however, a different result ensue, I would take the responsibility on myself.

To this the committee answered that they did not consicler themselves authorized to take the proposed steps, and having agreed to receive the library, even provisionally, Congress might be considered as committed in regard to the definitive agreement. They added that in ascertaining its value they did not wish any estimate as made by you, to be submitted to them, that the information I might obtain would be entirely private and confidential, and that any proposition, that a certain sum would be received for it, which sum they did not mean should be computed with close precision, would be accepted as the basis of a contract.

Our conversation conclusively exhibited their purpose not to proceed without a proposition analogous to that desired. Upon the whole, although not insensible to the delicacy of the step, I would recommend that you authorize me to state that a sum not exceeding a specified amount will be received, and that to guard against any unjust imputiotion, such sum within that amonnt will be taken as shall be the result of a valuation to be made after the library is on the spot.

In response to this letter, Jefferson wrote to Joseph Milligan, October 29: ${ }^{2}$

The Library Committee requires a proposition on my part as to the price of my library, and as a ground of negotiation in making such a proposition, I conld take no ground but from the number of volumes, their sizes and average value. But having sent them my catalogue, I have no means of coming at the numbers, for the conjecture I had for-

${ }^{1} \mathrm{~J}$. Henley Smith MSS.

${ }^{2}$ Jefferson MSS., series 2, vol. 6r, No. 125.

$23399-04-6$ 
merly made was on counting a few pages only, taking an average of them, and nultiplying by the number of pages. In this way, I guessed the whole number to be about 9,00o. But more accuracy is now requisite. I have ventured to say in a letter to Mr. Smith, that I thought you would be so good as to take the trouble of actually counting the numbers of every page of the catalogue, distinguishing separately the folios, quartos, octavos, and duodecinos, so as to inform him how many there are of each format, which would enable him to set a value on the whole, and to propose it to the Committee. And this favor I have still to solicit from you, further, that you will be so good as to call on hisi and to inform him as to the character of the bindings generally, and state of preservation in which you saw them here. I have tried a rough method of coming at their numbers, by taking the running measure of each format as they stand on their shelves, and counting a few shelves for an average. Then estimating these conjectural numbers at what I thought a moderate price, the average price of the whole per volume came out almost exactly what you had conjectured when here, to wit, three dollars a volume. I imagine Mr. Smith will adopt some such method of estimate, by the sizes and numbers you will be so good as to furnish him. This mode of guessing at the number of volumes made it less than the former estimate. When this proposition of a sum shall have been made, I have asked the favor of the return of the catalogue, and as soon as I can correct that by an actual review of the library, which will be the work of a week or ten days, I will begin to send you sheets of the catalogue for printing.

To Mr. Smith, he made the following answer, October 29: -

Your favors of the $19^{\text {th }}$ and 2 ist were received by one mail, yesterday. Presuming that the proposition in my letter of September 2 Ist, was not sufficiently explained I will state more particularly the course I had supposed the transaction would have taken. The proposition was that the books should be valued by persons named by the Committee themselves, and the payment made in whatever form, and at such distant time as they might think accommodated to the circumstances of the times. I supposed that they would send one or two persons here, acquainted with the subject, perhaps booksellers, to value the books either singly, or by an average deduced from their sizes and numbers; this valuation I expected to be binding on me, while I had and have no objection to a right of rejection either in the Committee or in Congress. If the valuation were accepted by them, I supposed they would send on some person to see to the exact delivery of the books, and to their safe conveyance. They are arranged at present in plain pine cases, closed in the back, but open in front, and so compact that they might go as they stand on their shelves, the fronts only being nailed up, and be ready to set up in any

${ }^{2} J$. Henley Smith MISS., copy in Jefferson MSS., series 2, vol. 7S, No. 35. 
room in perfect order. Having no anxiety abont the sum or mode of valuation, but wishing the collection secured to the public and at the moment of the recent loss rather than any other, I supposed a valuation by persons of their own choice the most mexceptionable gromind I could propose to the committee; but persevering in the same object, I will acquiesce in any other which they shall prefer, except that of proposing a value myself, for which I really an not qualified by a sufficient familiarity with prices, nor willing to trust myself in a case where motives of interest might subject me to bias, and certainly to the suspicion of it. I can not propose to you the tronble of making an estimate, of which no one would be more capable; but the labor of counting in every page of the catalogne the number of folios, quartos, octavos, and duodecimos, and summing all these, might be performed by another, and might furnish you ground by an average of numbers and size, to name to the committee a sum which you would deem reasonable, and whatever sum you should name, shall be binding on me, as a maximum, subject to be reduced, but not enlarged by actual valuation by any persons the committee shall think proper to appoint. In all this I wish myself to be entirely passive, and to abide absolutely by the estimate thus found. As the condition of the books must enter, of conrse, as an element into their valuation, Mr. Milligan, bookseller of Georgetown, who has lately had an opportunity of seeing them, can give you information on that head; and I have written to ask the favor of him to take the trouble of numbering them in the catalogue, and of reporting the sizes and numbers to you, from which you could readily deduce an estimate of the total, to be proposed as a maximum. Mr. Milligan has asked permission of me to print the catalogue on his own account, as a book of sale. You must still be aware that some of the books entered in the catalogue will doubtless be missing. The collection has not been revised since my return from Europe. During my absence from home, it has been open to limited uses, and I have occasionally found books missing. Some of these may be only misplaced, but some are probably lost. I should mention also, that there are two entered on the catalogue which I did not possess, but meaning to import them immediately, I entered them while writing the catalogue; the war, however, supervening, prevented my importing them. These are the "Geoponica," and an English translation of them lately published.

I had expressed in my letter a wish to keep some of the books during my life, not to be paid for, of course, nutil delivered; but that I should retire from the wish if at all unacceptable. I must, of course, replace many by new purcliases, but anong my classics particularly, there are some special editions which could not now be replaced, and some mathematical books wlich I should unwillingly be without, until peace shall open the means of getting them from Europe. The number I might wish to retain, for a while at least, wonld be between one and two hun- 
dred rolumes, but I report my willingness to let all go at once, if preferred by the committee.

I shall set out tomorrow on a journey which will occasion an absence of about a fortnight; the return of the catalogue by that time, if the committee shall have no further use for it, would be desirable; because I would then begin the general review of the library, the restoring to their proper places the rolumes which have been misplaced, and the ascertaining such as may have been lost. This would be a work of several days, and it would only be after that operation that the valuation could take place, if that idea be accepted by the comnittee.

PURCHASE OF THE L,IBRARY.

As a result of this correspondence Milligan wrote to Jefferson, Norember I6, I8I4: ${ }^{\text {I }}$

I have run through the catalogue and find that the amount of volumes, if we include the Edinburgh Review, will amount to say 6500, which agreeable to the rule which I have laid down, viz:- for a folio ten dollars, for a quarto six dollars, for an octaro three dollars, for a duodecimo one dollar, - will amount to a trifle over $\$ 24000$. $* * *$

This information appears to have been sent to Mr. Smith and by him communinicated to the Library Committee. The following unsigned note anong the J. Henley Smith Papers, dated November 25, undoubtedly refers to this. It reads: "The recent engagements of the Senate have prevented an earlier meeting of the Library Committee, than tomorrow morning (Saturday), Io o'clock. At which time they beg the favour of your company." In this meeting a valuation of the library, based upon the estimates of Mr. Milligan, was determined upon, and on the 28 th of November the following report of the Library Committee was presented in the Senate by Mr. Goldsborough: "In pursuance of the resolution of Congress, passed oil the 2ist day of October last, your committee have received from Mr. Samuel Harrison Snith, agent for Mr. Jefferson, precise terms of sale of his library, in which the number of volmmes is stated to be $64 S_{7}$, and the estimated price $\$ 23,950$. To these terms your committee have conditionally acceded, and they have contracted with the agent of Mr. Jefferson, for the purchase of his library according to the 
catalogue and number of volumes stated, at the price beforementioned, subject to the ratification of Congress. They therefore present the bill to anthorize the purchase of the library of Thomas Jefferson, late President of the United States." .

On the $3 \mathrm{~d}$ of December this bill passed the Senate, without amendment. On the same day a message from the Senate informed the House of the passage of the bill in the Senate and desired the concurrence of the Honse therein. On the

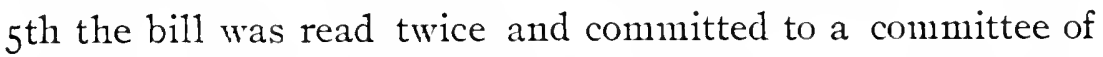
the whole. There the matter rested until January 26, I8I5, when a motion was made by Mr. Lewis that the consideration of the bill be postponed indefinitely. For the motion 69, against it 73. A motion was then made by Mr. Cooper, of Delaware, to postpone the further consideration of the bill to the 4th day of March next. For the motion 68, against it $74 .^{\mathrm{I}}$

A motion was then made by Mr. King, of Massachusetts, that the bill be committed to a select committee, with instructions to report as an amendment thereto the following section:

SEc. 2. And be it further enacted, That as soon as said library shall be received at Washington, the Joint Library Committee be, and they are hereby authorized and directed to select therefrom, all such books as, in their opinion, are not useful or necessary for Congress, and to cause the same to be sold, and the proceeds thereof invested in other books for the use of Congress.

This motion received $5^{6}$ affirmative votes, but was determined in the negative. Then Mr. King moved to recommit the bill, with instructions to report a section "authorizing the Library Committee, as soon as said library shall be received at Washington, to select therefrom all books of an atheistical, irreligions, and immoral tendency, if any such there be, and send the same back to Mr. Jefferson withont any expense to him." This motion Mr. King thought proper afterwards to withdraw.

This subject, and the various motions relative thereto, say the Annals, ${ }^{2}$ gave rise to a debate which lasted to the hour of

'The yeas and nays are given in the Journal.

annals 28: 1 105-1106. 
adjonrnment; which, though it afforded much amusement to the auditors, would not interest the feelings or judgment of any reader. Those who supported the bill in debate were Messrs. Wright, Fish, of Vermont, Rhea, of Tennessee, and Hulbert, and those who opposed it were Messrs. King, of Massachusetts, Farrow, Cannon, Hanson, Grosvenor, Pickering, and Webster. The speech of Cyrus King, a sincere and not uninformed gentleman, may be taken as an example of the eloquenee of the opposition: "It might be inferred," he said, "from the character of the man who collected it, and France, where the collection was made, that the library contained irreligious and immoral books, works of the French philosophers, who caused and influenced the volcano of the French Revolution, which had desolated Europe and extended to this conntry. He was opposed to a general dissemination of that infidel philosophy, and of the principles of a man [Jefferson] who had inflicted greater injury on our country than any other, except Mr. Madison. The bill would put $\$ 23,900$ into Jefferson's pocket for abont 6 ,ooo books, good, bad, and indifferent, old, new, and worthless, in languages which many can not read, and most ought not; which is true Jeffersonian, Madisonian philosophy, to bankrupt the Treasury, beggar the people, and disgrace the nation." Others, among whom were a number of the political and personal friends of Mr. Jefferson, opposed the bill on the ground of the scarcity of money, and the necessity of appropriating it to purposes more indispensable than the purchase of a library; the probable insecurity of such a library placed here; the high price to be given for this collection; its miscellaneons and almost exclusively literary (instead of legal and historical) character, etc. To those arguments, enforced with zeal and vehemence, the friends of the bill replied with fact, wit, and argument, to show that the purchase, to be made on terms of long credit, conld not affect the present resources of the United States; that the price was moderate, the library more valuable from the scarcity of many of its books, and altogether a most admirable substratum for a national library. So the Intelligencer reported the debate. 
But the Washington correspondent of the New York Evening Post was also present, and wrote to the Post January $3 \mathrm{I}$, as follows:

Shonld Mr. Gales ${ }^{x}$ ever comply with his promise and give a faithful report of the debate upon the bill to purchase Mr. Jefferson's library, we venture to say, it will make but one impression upon the honest portion of his readers. In the place of a fair report of the debate, Gales contents himself with saying, that "the arguments enforced with zeal and vehemence", against the bill, were answered "with fact, wit, and argument,' by Messrs. Wright, Rhea, Fish, and Hulbert. The latter gentleman was undoubtedly plausible, and reasoned with ingenuity, but where to find the wit, or what are the facts alluded to, we know not, although we were present, and heard all that was said. It is true as Mr. Gales says, the amount of what was said by the friends of the bill, was, that the price, - $\$ 23,900)$, was moderate, that the library was valuable from the scarcity of the books, and that it could not injure materially the national resources, because it was to be paid for in Treasury bills, the depreciation of which was alluded to as a proof of the soundness of the bargain. This was the amount of the wit, facts, and arguments on the part of the friends of the bill.

On the other hand it was urged by those who opposed it, (Messrs. Lewis, Cannon, Hanson, Grosvenor, Pickering, King, Webster, and Farrow), that the price was exorbitant, and the library was not such as Congress wanted, being almost entirely literary, containing comparatively little of law or history, that it abounded with productions of an atheistical, irreligious and immoral character, - a fourth of the books were in foreign languages, and many in the dead languages, such as romances, tracts on architecture, farriery, cookery and the like. Upon the latter subject, it was mentioned as a fair example of the books, there were no less than ten different works, nine being in foreign languages. The necessity of husbanding the resonrces, retrencling the expenses of government, and commencing a systen of economy was strongly urged. Although it was admitted for argument sake, that the nation was under great obligations to Mr. Jefferson for the great benefits conferred upon the country, the numerous blessings which were likely to flow from the system of politics he had introduced, yet the report of the Secretary of the Treasury was referred to as proof that the present was not a time to reward him ont of his "overflowing treasury" by settling upon him a pension of more than a thousand dollars per annum to him and to his heirs forever. It was contended, in addition to the high price and unsuitableness of the library, which might be bought in any of the large cities for lalf the money, that it became Congress to act in this transaction as if they were making a bargain with any other 
individual than Mr. Jefferson, - that it behoved them to be just before they were generons, - that if there was money in the Treasury unappropriated, the interest of the public debt should be first paid,- - the militia, who liad been spilling their blood in defense of the country, should be paid,- the army should be clothed and fed, to whom the Government was in arrears nine millions of dollars, - that shoes should be purchased for the suffering soldiers who might be tracked on the northern frontier by the blood of their feet. The sum proposed to be given Mr. Jefferson for his books was said to exceed the quota of direct tax for nineteentwentieths of the districts represented in Congress, - to be equal to the enlistment of two hundred and ten men for the regular army, and the purchase of two thousand stands of arms. Reference was made to the last Treasury report to show the necessity of frugality and the distressing effect of the profusion in the public expenditures. It was asked whether the people would consent to pay a tax of one dollar upon every barrel of flour, to pay an income tax, etc., if their money was to be thus squandered. Arguments were drawn from the state of the country, the finances, and the bloody struggle in which we were engaged, to show the necessity of economy. The debate was closed with a short, but as eloquent an appeal to the justice, public spirit and patriotism of the house, as we recollect ever to have heard. But the bill passed by a majority of ten votes, and the Pensioner Jefferson has wrung from our beggared exchequer its very sweepings.

The final question on the passage of the bill was decided in the affirmative: For the passage of the bill, $S_{I}$; against it, $7 \mathrm{I}$, as follows:

Yeas.-Messrs. Alexander, Alston, Anderson, Barbour, Bines, Bowen, Brow11, Butler, Calhoun, Chappell, Conard, Crawford, Creighton, Crouch, Cuthbert, Desha, Duvall, Earle, Evans, Findley, Fisk of Vermont, Fisk of New York, Forney, Forsyth, Franklin, Gholson, Goodwyn, Gourdin, Griffin, Hall, Harris, Hasbronck, Hawes, Hawkins, Hopkins of Kentucky, Hubbard, Hulbert, Ingersoll, Ingham, Irving, Jackson of Virginia, Johnson of Kentucky, Kennedy, Kent of Maryland, Kerr, Kershaw, Kibbourı, Lefferts, Lowndes, Lyle, McCoy, McKim, McLean, Murfree, Nelson, Newton, Ormsby, Pickens, Piper, Pleasants, Rea of Pennsylvania, Rhea of Tennessee, Ricl, Ringgold, Roane, Robertson, Sage, Sevier, Seybert, Sharp, Smith of Pennsylvania, Smith of Virginia, Taylor, Telfair, Troup, Udree, Ward of New York, Williams, Wilson of Pennsylvania, Wright, and Yancey.

Nay's.-Messrs. Archer, Avery, Baylies of Massachusetts, Bayly of Virginia, Bigelow, Boyd, Bradbury, Breckenridge, Brighan, Caldwell, Cannon, Champion, Cilley, Clendenen, Connstock, Cooper, Cox, Culpeper, Davenport, Davis of Massachusetts, Davis of Pennsylvania, Ely, 
Farrow, Geddes, Goldsborough, Grosvenor, Hale, Hanson, Henderson, Howell, Hungerford, Jackson of Rhode Island, Kent of New York, King of Massachusetts, Law, Lewis, Lovett, Macon, Markell, Montgomery, Moseley, Oakley, Pearson, Pickering, Pitkin, Potter, John Reed, William Reed, Ridgely, Ruggles, Schureman, Sheffey, Sherwood, Shipherd, Slaymaker, Stanford, Stockton, Strong, Stuart, Sturges, Taggart, Tannehill, Thompson, Vose, IVard of Massachusetts, Webster, Wheaton, White, Wilcox, Winter, and Wood. ${ }^{\text {. }}$

AN ACT to authorize the purchase of the library of Thomas Jefferson, late President of the United States.

Be it enacted, $\mathcal{F}^{\circ}$. , That the Secretary of the Treasury be, and he is hereby, authorized and directed to cause to be paid to the Joint I,ibrary Committee of Congress, or their order, the sum of $\$ 23,950$, in Treasury notes of the issue ordered by the law of the 4 th of March, I814; to be by them applied to the purchase of the library of Thomas Jefferson, late President of the United States, for the use of Congress.

Approved, January 30, I8I5.

\section{VALUE OF THE LIBRARY.}

Of the value of the library thus acquired by Congress there was as much difference of opinion outside the two Honses of Congress as within. Niles's Weekly Register, December 3I, I8I 4, , on the one hand, observed, "It is strange that the rancor of party should penetrate even the temple of science, and that an opposition was made to the purchase of a collection that any monarch in Europe would be proud to own. For such a library the British Parliament would have given $£ 50,000 . "$

The editor of Walsh's American Register was much more voluble. He said: ${ }^{3}$

There would have been something more satisfactory in this transaction, had the Legislature of Virginia been the purchaser and bestowed it as a gift on the Federal Government. However this may be, it was an inestimable acquisition. $* * *$ The collection is exuberant in the ancient classics, richly stocked with the best classical history, ancient and modern, in the principal languages of Europe. The Titles History, Ancient and Modern, Politics, Geography and Criticism, of the catalogue, are particularly full and select. The head of Criticism presents

\footnotetext{
${ }^{x}$ Annals 28: r Io5-r ro6. $\quad$ 2Vol. 7, p. 285.

${ }^{3}$ Copied by the Washington City Weekly Gazette, July I2, 1817 , and by the
} National Intelligencer, July I4, I8I 7 . 
a number of precious works relating to the Anglo-Saxon and old British languages, and when we advert to the condition of the Fine Arts in the United States, - whatever may be the pretentions advanced,-we cannot attach too much importance to the contents of the chapters under that title in Mr. Jefferson's catalogue. There is, in the most attractive and splendid form, all that could be desired,-especially in architecture, where we are most lame,- - for the diffusion of teclnnical knowledge and the improvement of the public taste. And most of the great works and celebrated elementary treatises in the mathematical and physical sciences, are included in the collection. Three-fourths, indeed, of the whole number of volumes are of the highest reputation and of acknowledged authority. $* * *$

The next generation will, we confidently predict, blush at the objections made in Congress to the purchase of Mr. Jefferson's library. Party-spirit, darkling and chafing, spoke the language of an auctioneer or a chapman, and erred egregiously even in its huckstering calculations; for Mr. Jefferson's library was worth, and would, in all likelihood, have brought in the market, at least double the sum allotted by Congress to the purchase. We should be at a loss to fix the proportion between the price and the acquisition, if we took into the account the value of the latter in other points of view. This will be one day duly appreciated, without looking to the time when the Bibliomania may rage in the United States; a period which may be descried, although at the end of a long vista.

From this it was evident that the main objection to the purchase from the Republican point of view was the expense to the Government. But even this objection might be removed by showing that the library at the price at which it was bought was a bargain. So the Essex Register, Salem, November S, I 8I 5, copied by the National Intelligencer, November I4, said:

A writer in the Richmond Daily' Compiler has attempted to remove the objections to the purchase of Mr. Jefferson's library, upon the consideration of interest.

It is not believed that any objections have been made from pure conviction of error in the purchase, but many will be silent if they know the country has made a good bargain. This writer adduces the Loudon prices, and the prices paid by Congress, and having specified each, that any man might satisfy himself, discovers at the foot of the account that in thirty-seven rolumes the sterling cost would amount to upwards of $\$ 1,500$, when Congress did not pay $\$ 300$, gives the country, in these volumes only, the advantage of upwards of $\$ \mathrm{r}, 200$. Surely no man will pronounce that a Government which could purchase at such a rate ought to refuse the purchase. 
Upon which a correspondent of the Intelligencer, November 16 , remarked:

In your paper of yesterday, I discovered an attempt to calculate the value of the United States library. I believe no one can form any adequate estimate of this purchase. The library is such as to render all valuation absurd and impossible, if valuation were admitted into literature. It is such a library as cannot be bought in the ordinary mode in which books are purchased, because many of the books that are inestimable are wholly out of print, and many in manuscript that, of course, conld not be procured. I have had an opportunity, from the privilege of frequent examination, imperfectly to discover that it is unique-a library which, for its selection, rarity, and intrinsic value, is beyond all price. For the satisfaction of calculators, however, I will barely mention the value marked in English catalogues, of a few books which this library contains:-De Bry's Collection of Voyages, 3 rolumes, £400 sterling; Purchas' Pilgrimes, I volume, $\mathcal{L}_{56}$ sterling; Smith's History of Virginia, I volume folio, $£_{42}$ sterling, etc.; while the Government paid but $\$ 3$ per volume. It contains Buffon's Birds, ro volumes, quarto, 5 volumes of colored plates; Catesby's Natural History of Carolina, 2 volumes, folio; King James's works; Cliaucer's Poems, in black letter; all the Greek and Latin classics extant; Martyr's History of the West Indies; the best authors in the French, Spanish and English languages, with a variety of other works it would be difficult to enumerate.

Of the wit and argument of the Federal press, on the other hand, there is a good specimen in the Georgetown Daily Federal Republican, October IS, ISI 4 :

\section{To Thomas Jefferson, esquire, late President of the United States-}

DEAR SIR:-I have a library of books which I should be glad to sell. It consists of about 5000 rolumes, selected with care and caution. Various projects had occurred to me to effect this object, but none had appeared free of objection. One feels awkwardly to be hawking his commodities about the streets, and to send such a quantity of books to auction and hire a master of the arts, which there succeed to puff them off with the prevalent common-place slang, seems not quite consistent with those delicate feelings which should govern liigh-minded men. At the same time, the object is interesting, and if an old man can turn his books into cash, just as he has done with them and the world, at a good price, and especially if a great portion of them were presents to him, (which, inter nos, you know is the fact with yours and mine), it would be quite a handsome speculation, and save his executors much trouble.

Observing that you have, in one of your lucky moments, (and I never knew a man who had more such moments), hit upon a project entirely 
new, and seeing that it is very popular, I wish to know if you cannot, in a second application to Congress, through some Republican friend, aid me. My grandfather, my father, and myself, have employed much time in the last century and in this, in making the collection, so that it may be considered as the acquisition of nearly one hundred years labour. Many of my books are rare, most of them elegant and all inestimable. A considerable part of the works are in Sanscrit, Coptic, Celtic, and Arabic tongues. These can be translated, if it is thought proper, at little expense, though I should prefer that they should remain as written, and would respectfully recommend that Congress should immediately employ a competent number of professors to teach the members of that honorable body those languages. I am aware that there is not now so much "surplus revenue" as there was under your glorious administration (owing to the war which the "vandalism" of Great Britain has produced), yet stock may be created sufficient for their salaries and contingent funds. I hope I shall not be thought, by this, to wish to see the "undefined field of contingencies" opened again, if they have ever been closed.

My grandfather was a Dutch merchant, and spent all his time, while resident in Amsterdam, except what was employed in smoaking, in the " principal book marts," laying aside all the works of genius and taste which that country produced. The treatises there obtained are cliefly devoted to music, painting and poetry. My father and I have passed much time in both the Indies, and have occasionally visited almost all the enlightened parts of each. Our intercourse was not confined to those regions, but has been extended from Kamschatka to Buenos Ayres. A propensity for curious books, in every science, being incident to the family, it will not be thought vain in me to declare that this library is exceeded only by yours.

Being now nearly eighty years of age, and having no children, to whom my estate can descend, and not finding much time for reading, I should be much pleased to turn these books into cash. A few of them, however, I wish to retain for my own use after they shall be sold, taking care to see, after I am dead, that they may be safely transmitted to Washington. Those of this description are Vanderhuyden's poetical works, in sixteen volumes, with notes, critical and explanatory, by Mynheer Van Tromp, dedicated to Admiral Ruyter, who went up the English channel, as mentioned in your letter. Also a new edition, greatly enlarged, of Robinson Crusoe, in seven volumes, bound in calf, containing full-length portraits of that great traveller and his man Friday, with exact drawings of their working tools and other implements, with facsimiles of their hand-writing. Also, the whole works of Thomas Paine, your old friend, "who has already received his reward in the thankfulness of nations," consisting of his invaluable discoveries in moral, political and theological science. These copies, (I believe I have only thirty 
different editions), with those included in your proposals, and the various editions of Hobbes and Spinosa, those learned and virtuous men, will be sufficient, in that peculiarly charming part of theology, for the Congressional Library.

As to the price, I shall leave it entirely with the liberality of Congress, not wishing to be my own judge, and believing, inter nos, that by thus reposing on their generosity, the books will sell at from fifty to one hundred per cent, higher than in any other conceivable mode. To promote the bargain, I wish you to suggest, at the outset of your letter, that I hate, abhor, and detest with all my soul, strength and understanding, the whole British nation; that I consider every Englishman, except those who have been naturalized here, (and them, I sincerely love), a thief, liar, poltroon, robber, murderer, assassin, traitor, and that every man, woman and child ought to be hung, imbowelled, impaled, or broken on a wheel. In fine, that the character of that people is justly pourtrayed in a late Washington City Gazette, a paper which is second only to the National Intelligencer, and Binns's Democratic Press, for truth and wisdom; I am aware that such an introduction to a letter, proposing merely to sell books, is rather unusual, but I see you have resorted to it, and I think very wisely. People are to be treated according to their prejudices and partialities, and I have witnessed your success with them, by those means, in your splendid career from your inaugural address, through dry-docks, gunboats, and salt mountains down to that most august measure, the embargo.

I intended to have furnished you with an elegant catalogue of my library, that it might have been open to inspection; but am now wholly occupied in furnishing a drawing of the Capitol and President's House, while on fire, with Mr. M. mounted on a fleet charger, and in full speed flying to a place of safety, from the "vandalism" of the enemy, and Captain Jones, with a boatswain's whistle, calling all hands to burn the Navy Yard, and the frigate on the stocks to prevent them from being carried away by the Cossacks. I will, however, mention a few of the great number of books, and give you a sketch of the character of the whole.

There are entire sets of all the works of all the atheistical writers in every age and nation and tongue, superbly bound and lettered. Forty different editions of the Bible, thirty-nine of which are in the Arabic, and one in the Hebrew idiom; these are as good as when they came from the hands of the book-binder. A very learned treatise in ten volumes quarto, on the nature, properties, and uses of the animal called tad-pole, stiled vulgarly, Polly-wangs, with an appendix, in three volumes; on the toad of Caffraria. The whole of these, I have caused to be translated into six different languages. There is also, an elaborate and voluminous account of the terrapin, sometimes called nud-turtle, written by the author of sundry ingenius disquisitions on gun-boats and dry-docks, in 
modern French. An essay on "free-trade and sailors' rights," by a citizen of Algiers, bonnd in morocco with a copious appendix on allegiance. In this will be found a great part of the instructions given to the American ministers at Petersburgh and at Ghent. It is embellished with striking likenesses of John Henry and the Duke de Crillon. Also, a new edition in several volumes folio, on the Russian climate, and its effects on Frenchmen, French horses and American politics, with very learned notes by his Excellency Jonathan Russell, late charge de affaires at the Court of St. James, now minister Plenipotentiary at London, Envoy Extraordinary at Gottenburgh and Ghent, otherwise called Jonathan Russell, esquire of Providence, Trader. This book is dedicated to Napoleon Bonaparte living at Elba; it went through six editions at Ghent in four months. A treatise on Treasury notes, Banks and paper money, bound in calf, with a splendid title page, by Jacob Barker, Superintendent General of the Finances of the United States and first lord of the Treasury. A work of great worth, written in Persian, on the grass-hopper of the east, delineating, with entire accuracy, the size of his legs in different regions of that extensive country, with a copious appendix, containing the whole learning on the subject of that highly curious animal called the weasel. A complete system of ornithology, giving an account of every flying creature, from the insect of a day to the whippoor-will, the night-hawk and the crane, in blank verse, by Inchiquin, translated from the Italian into the Sclavonic, by a learned foreigner, comprized in thirteen volumes folio.

Of the whole collection, I take the liberty of saying, that it has been made with a particular view to the promotion of genuine republicanism, and the true orthodoxy in matters of faith of regenerated France, as set forth by those great apostles, Diderot, De Lambert, Paine and Godwin. The books are in excellent order, many of them truly elegant. Not a syllable could be taken from them without prejudice to the rest, as all the arts and sciences have a certain natural connection. I cannot consent to see my library gerry-mandered, for though such procedures are proper to promote democracy, which you know is the "chief end of man," yet they are not admissible in cases like the present. I must sell the whole or none. Ten wagons would carry the whole from my residence, which is only two hundred miles up the Missouri, in the vicinity of our red brethren, the allies of England, to Washington, in a short space of time.

If it should be objected, that four-fifths of this library are in foreign languages, and of course, unintelligible by nine-tenths of the members of Congress, I wonld reply that such an objection can come only from short-sighted men. The enlightened philosoplier looks to the present war, which we have so wisely and righteously waged, as terminating not only in the everlasting establishment upon an eternal basis of "freetrade and sailors' rights," (and if it should not so issue, we can make 
another war at any time), but also in the conquest of immeasurable regions to the north, west and south, and to the day when the representatives of this country will be composed "of all people, nations and languages under the whole Heavens."

Accept the assurance of my high consideration.

Missouri, October Ist, I8I4.

JOHANNES VONDERPUFF.

Among those, however, who judged the library with a more impartial mind, it was felt that while the collection lacked in the mathematical and physical branches, for which Jefferson for the past forty years had had no time, ${ }^{1}$ and was deficient in the historical and political literature of the past ten years, and that the books which Jefferson had received as an homage to his character and taste were, for the most part, of no value, still it was recognized that opportunities for the collection of material illustrative of American history, such as Jefferson had enjoyed while in Europe, would never come again. It was believed, too, that his subsequent collection made in America, of speeches, pamplilets, and books relating to the history of the Revolution, showing the arguments urged to bring on the contest, the reasoning required to keep the revolutionary spirit alive, to induce the people to form and accept a form of government, and to secure the liberty they had achieved, was greater than that of any other individual in the country. ${ }^{2}$ And it was understood that the books relating to foreign affairs and institutions selected by a statesman of Jefferson's ability would be of greater value to the statesman who succeeded him in power than those which might be chosen by persons either dunces or novices in the science of politics.

Jared Sparks, ${ }^{3}$ who saw the collection in 1826 , considered it valuable, or at least more valuable than the rest of the library, which contained about the same number of volumes and had cost, not connting the expenditure of service, about the same amount of money. George Ticknor, another of

\footnotetext{
${ }^{\mathrm{I}}$ Jefferson MSS., series 2, vol. 83, No. I25. Jefferson to John Vaughan, March I, I 8 I 5 .

${ }^{2}$ S. I. Knapp, Sketches of public characters, I830, p. II8.

${ }^{3}$ H. I3. Adams, Life of Sparks 1: 462 .
} 
those bookmen who made New England the center of learning in the carly part of the century, saw the library before it was removed to Washington and wrote of it, February 4, ISI 5: "In so short a time I could not, of course, estinnate its value, even if $I$ had been competent to do so. Perhaps the most curious single specimen-or, at least, the most characteristic of the man and expressive of his hatred of royaltywas a collection which he had bound up in six volumes, and lettered the 'Book of Kings,' consisting of the Mémoires de la Princesse de Bareith, 2 volumes; Les Mémoires de la Comtesse de la Motte, 2 volumes; the Trial of the Duke of York, I volume; and The Book, I volume. These documents of regal scandal seemed to be favorites with the philosopher, who pointed them out to me with a satisfaction somewhat inconsistent with the measured gravity he claims in relation to such subjects generally."

The English traveler Frances Wright D'Arusmont said in I82I: "These volumes marked with the name of America's President and philosopher, ${ }^{2}$ will always constitute the most interesting portion of the National Library." 3 Other travelers were interested in other books. One, in a copy of Professor Dalzel's Collectanea Græca Majora, which bore the following inscription in the autograph of the editor:

Ad virum honoratissimum et doctissimum

Thomas Jefferson, S. R. S., Edin. affoederatis Americae civitatibus ad Regiam majestatem Christianissimam cum plena potestate legatum hunc librum observationis causa misit Andreas Dalzel. ${ }^{4}$

And another in a copy of Dugald Stewart's Philosophy of the human mind, on the fly-leaf of which was pasted the

${ }^{2}$ Life, letters, and journals of George Ticknor I: 35 .

"Wherever the printer's signature occurs at the bottom of the page as an I or J, he has made a $T$ before it, and where $T$ occurs, a $J$ after it. This private mark constituted the initials of his name.

${ }^{3}$ Views of society and mamers in America, New York, 1821, p. 37 .

${ }^{4}$ J. M. Duncan, Travels through the United States and Canada, Glassrow, 1823, I: 260 . 
following original letter from its illustrious author to Mr. Jefferso11:

DEAR SIR: The book which accompanies this letter is the only performance which I have yet ventured to publish. I hope you will do me the honour to give it a place in your library, and that you will accept of it as a mark of my grateful recollection of the attentions which I have received from you at Paris.

I am, Dear Sir, Your most obedient and faithful servant,

DUgald STEWART.

College of Edinburgh, ist October, $1792 .^{1}$

REMOVAL OF THE LIBRARY TO WASHINGTON.

On the 3 oth of January, I8I5, the same day on which the act authorizing the purchase of the Jefferson collection was passed, Mr. Jefferson wrote to Mr. Smith, complaining that he had not heard from him since October 2I, asking to be informed how the negotiation stood, and requesting the return of the catalogue of his library. ${ }^{2}$

On the i4th of February, I8I5, the following note was received by Mr. Smith from the Library Committee. ${ }^{3}$

Mr. Goldsborongh of the Senate presents his compliments to Mr. Smith and if he will not be otherwise engaged at I I o'clock tomorrow morning, begs the favor to see him at that hour at the Senate for the purpose of concluding the negotiations for Mr. Jefferson's library. ${ }^{3}$

As the result of this meeting Mr. Smith wrote, February I 5, IS I 5, to Mr. Jefferson, in reply to his letter of Jannary 30 :

* * * Agreeably to the law lately passed, the Library Committee have desired the Secretary of the Treasury to issue, payable to your order, Treasury notes to the amount of $\$ 23,950$, this being the exact amount at which the library was valued by Mr. Milligan. Will you advise me how these notes should be filled? If with your name, they must be sent to you for your endorsement before they can be transferred to another. If you wish to appropriate them here or elsewhere to any immediate purpose, a letter from you desiring them to be filled with the name of any one, will be a sufficient warrant to the Secretary. I have requested that they be not made out until your answer is received.

The chairman of the committee has promised a return of the catalogue. $* * * 3$

\footnotetext{
${ }^{2}$ James Stuart, Three years in North America, Edinburgh, i $S_{33}, 2: S_{4}$.

${ }^{2}$ Jefferson MSS., series 2, vol. 78 , No. 36 .

3 J. Henley Smith MISS.

$23399-04-7$
} 
The letter concludes with the remark that the committee would seek legislation regarding the transportation of the library.

On the $27^{\text {th }}$ of February Jefferson answered Mr. Smith's letter regarding the method of payment for the library and made some suggestions regarding the transportation of the library. ${ }^{\mathrm{I}}$

With respect to the Treasury notes they, of course, should not be made until the library is delivered, or ready to be delivered. When this takes place, I will take the liberty of specifying my wishes as to the notes. As soon as I receive the catalogue, I will set about revising and arranging the books. This can be done only by myself, and admits of no help; in doing it I must be constantly on my legs, and I must ask indulgence, therefore, to proceed only as my strength will admit. I count on its taking me many days, perhaps a fortnight. As soon as all are in their places and numbered, I will give you notice. I am now calling in all which have been lent out as far as noted, ${ }^{2}$ but there will doubtless be many irrecoverably lost. As these must be struck off the catalogue, and deductions accordingly made from the amount of compensation, it would be not only very desirable to me, but entirely proper to have some agent of the committee here to see what are delivered, and adjust the deductions, as well as to superintend the packing, and perhaps the transportation. It would be a great pity to have the finer bindings destroyed for want of this small additional expense. Mr. Milligan in a former letter to me, expressed his willingness to come and see to the packing, and whatever else might be necessary, and no one could be more competent to the whole business. However, he, or any other person, whom the committee shall appoint will be acceptable to me. I send you on the next leaf some notes which may be useful towards arranging the transportation. The compensation embracing the whole of the catalogue, I shall not retain a single one, the only modification to be made being a deduction from the compensation in proportion to the size and number of the books which on the review shall appear to have been lost.

${ }^{\mathrm{I}}$ Jefferson's letter to the Secretary of the Treasury, Alexander J. Dallas, giving directions for the payment, is dated April IS, ISI5. It is printed in the Writings of Thomas Jefferson, edited ly P. L. Ford, vol. 9, pp. 514-515. The letters from Dallas to Jefferson, inclosing notes in payment for the library, are dated February $2 \mathrm{I}, 18 \mathrm{I} 5$, and April 28, ISr5. They are in the Jefferson MISS., series 2, vol. 29, Nos. 6o-6r.

${ }^{2}$ See letters to George Hay, February 26; W. W. Hening, March if and 25, April 8; I. H. Girardi11, IIarch 27; series 2, vol. 45, Nos. 130, 173, 174; series I, vol. 14, No. 29. And tlose to Watterston, June 3, isi6, June 20, ISi6, and October $2 \mathrm{O}$, ISIS. 
OBSERVATIONS ON THE, TRANSIORTATION OF THE MONTICHLLO

I.IBRARY.

The books stand at present in pine cases with backs and shelves without fronts. The cases are generally of three tier, one npon another, about 9 feet high in the whole. The lowest case is generally 13 inches deep, the second $63 / 4$ inches and the uppermost $5 \frac{3}{4}$, averaging $8 \frac{1}{2}$ inches, to that add $3 / 4$ inch for the front of boards to be nailed on, and it makes $9 \frac{1}{4}$ inches depth. I have measured the surface of wall which these cases cover and find it to be 855.39 feet, which divided into the depth of $9 \frac{1}{2}$ inches equals 676 cubic feet; of this 232 cubic feet would be the wood of the cases and $4+4$ cubic feet the books. I find a cubical foot of books to weigh 40 pounds, and as this is the weight of dry pine also, we need not distinguish between the weight of the wood and the books, but say the whole 676 cubic feet at 40 pounds makes 27046 pounds, or eleven waggon loads of $245^{8}$ pounds each.

It is said that waggon hire at Washington is eight dollars a clay, finding themselves here it is exactly half that price, or a half clozen waggons can be got here at four lollars, who will undertake to carry 2500 pounds. I think it would be better, therefore, to employ the waggons of this neigliborhood, and let them make two trips, but as the interstices between the books and shelves (which, however, are very small), will require a certain quantity of book binder's paper-parings; a great many elegant bindings will require to be wrapped in waste paper, and all should have slips of paper between then, which cannot be had here. Would it not be necessary to send on a waggon load from Washington to be deposited liere before the books are packed? It night take a return load of the books. And the books should go in their cases, every one in its station, so that the cases on their arrival need only be set up on end, and they will be arranged exactly as they stand in the catalogue. I will have the fronts elosed with boards for the journey; which, being taken off on their arrival at Washington, sash doors may be made there at little expense. But the books will require careful and skilful packing, to prevent their being rubbed in so long and rough a journey, by the jolting of the waggons.

The best road, by far, for waggons at this season, is from Monticello by Orange Court House, Culpeper Court House, Fauquier Court House, Emil's mill, Sorgater Lanes, and George T. ferry, because it is along cross roads nearly the whole way, which are very little travelled by waggons. The road by Fredericksburg is considerably further, and deeply cut through the whole. That by Stephensburg is the shortest and levellest of all, but being generally a deep living clay is absolutely unpassable from November to May. The worst circumstance of the road by the Court Honses is that two branches of the Rappahannock and three of the Occoquam are to be forded, and they are liable to sud- 
den swells. ${ }^{x}$ I presume a waggon will go loaded in seven days, and return empty in six, and allowing one for loading and accidents, the trip will be of a fortnight and come to $\$ 56$. I will have the waggons engaged if it is desired, to attend on any day which may be named. ${ }^{2}$

In Mr. Smith's letter to Jefferson of the I $5^{\text {th }}$ of February, he had observed that the Library Committee would introduce a bill in Congress providing for the transportation of the Jefferson library to Washington. The committee had also to provide a room for its reception. Accordingly a report was made by the committee in the Senate, February $20,{ }^{3}$ as follows:

That in pursuance of the act of Congress passed at the present session, they have lodged an order with the Secretary of the Treasury in favor of Thomas Jefferson, Esquire, late President of the United States, for the sum of $\$ 23,950$ in Treasury notes, as the purchase money for his library, for the use of Congress.

As the authority of the Committee, under the act of December, I8 I , by which they are created does not extend beyond the expenditure of the annual fund of one thousand dollars, and such balances as may have remained on hand for the purpose of making additions to the library, they respectfully submit to Congress the propriety of providing a library room, and for transporting the library lately purchased, to the City of Washington.

With this in view the committee presented a bill anthorizing the President of the Senate and the Speaker of the House of Representatives to select a proper apartment for a library room and provide for the transportation of the library. On the $22 \mathrm{~d}$ the bill was considered in Committee of the Whole. On motion by Mr. Roberts, the bill having been amended, the President reported it to the Senate accordingly, and on the $23 \mathrm{~d}$ the bill was read the third time and passed.

On the same day a message from the Senate informed the House that the Senate had passed the bill entitled "An act to

\footnotetext{
"Watterston suggested in a letter to President Madison, March 25, that the books be brought to Washington by water, a safer and less expensive route, he thouglit.Madison MSS.

${ }^{2} J$. Ilenley Smith MSS., copy in Jefferson MSS., series 2, vol. 78 , No. $3 S$. Note Madison's letter to Jefferson, March 1I, I8I5, Writings of Madison, Congressional edition, I865, 3: 602 .

${ }^{3}$ Thirteenth Congress, third session, Senate. Report of the Library Committee on the expediency of providing a library room, and for transporting the library lately purchased of Thomas Jefferson, esquire, to the city of Washington, February 20, ISI5. Washington, Roger C. Weightman, 18 I $_{5}$. 1 1. $8^{\circ}$.
} 
provide a library room, and for transporting the library lately purchased," and on March 3 the bill passed the House.

AN ACT to provide a library room, and for transporting the library lately purchased.

Be it enacted, $\mathcal{F}^{\circ} \mathrm{c}$. That the President of the United States be, and he is hereby, authorized to cause a proper apartment to be immediately selected and prepared for a library room, and to canse the library, lately purchased from Thomas Jefferson, to be placed therein during the ensuing recess of Congress.

SEC. 2. And be it further enacted, That the accounting officers of the Treasury be, and they are hereby, authorized and directed to settle the account of the expenditures incurred under this act; and that the account so settled shall be paid out of any moneys in the Treasury, not otherwise appropriated.

Approved, March 3, I8I5.

On the I th of March, I8I5, Mr. Smith wrote to Jefferson: "Congress having on the last day of this sitting, modified the pending bill for the transportation of the library, so as to leave the necessary disposition to the President of the United States, I yesterday conferred with him on the subject. He considers it advisable to postpone its transportation until some time in May, and that it be transported by land in such a way as shall be most agreeable to you. For this purpose, it is contemplated to employ Joseph Dougherty. I forward to you in a distinct packet the catalogue." 2

Already Jefferson had written to Joseph Dongherty, his old coachman at the White House: ${ }^{3}$

Monticello, February 27.

* * * Your letter of the $15^{\text {th }}$ was eight days on the road, and I answer it by the first return of our mail. I had prepared for Mr. Smith some notes on the transportation of the library, and as they give easily all the information you desire, I send a copy of them on the next leaf. They will inform you of the price of waggonage here, the number which will be requisite, the distance, and best roads, and that I shall send the books in the cases as they stand. I an now preparing and joining boards to cover the cases, and my own workmen will do whatever is wanting in their line without any additional charge. Wishing everything which may promote your interest. I salute you with my best wishes.

ThOMAS JFHFFRSON.

'Annals 28: 252, 257, 262, 267. 'J. Henley Smith MSS.

${ }^{3}$ Jefferson MSS., series 2, vol. 30, No. 140. 
On the same day, February 27, Jefferson wrote to Milligan, who, it was understood, would superintend the removal of the library. ' On the 2oth of March Milligan answered:

Your esteemed favor of the $27^{\text {th }}$ ult., postmarked "Milton," March Stil, reached me last week. When you have completed the review of the library, I am ready to come and pack the books. I will have the paper-shavings, and wrapping paper ready that they may be sent on as soon as I hear that you are ready. It will be necessary to have the packing cases, that each may contain about 300 weight, (but they need not be made until I come), so that they be made of such size that each waggon will hold eight cases.

With great respect, yours,

JOSEPH MiLIIGAN.

On the same day, March 2oth, the master wagoner, Joseph Dongherty, wrote to Mr. Smith regarding the compensation offered for his part of the work: ${ }^{2}$

In our conversation yesterday, relative to the transportation of Mr. Jefferson's library from Monticello to this place, I think you said, that the compensation to be given to me for superintending the bringing of the library is fixt by the President at $\$+$ per day.

I will now state what my travelling expenses will amount to per day,so that you may see what my compensation would amount to per day. Horse-hire, \$I.25 per day; breakfast, \$0.5O; dinner, \$0.75; supper and lodging, \$0.75, four gallons oats and hay, \$0.87. Expence per day, $\$$ 4. I2.

To go the upper road to Monticello, being a country route, the above charges would, perhaps, be considerably lessened.

I am, sir, your humble servant.

JOSEPH DOUGHERTY.

On the 4 th of April, Smith accordingly wrote to Madison, that Dongherty was dissatisfied with the proposed compensation for his services, and said that he asked $\$ 6$ a day. ${ }^{3}$ In response Mr. Smith received the following memorandum, dated April I I, I 8 I $5 .^{2}$

Joseph Dougherty will attend to the transportation of Mr. Jefferson's library on the conditions mentioned yesterday, (five dollars a day, he paying all his expenses, ) by Mr. Smith.

While this negotiation with Dougherty was being carried 011, Jefferson was supplementing his instructions of the 27 th

'Mr. Smith sent Jefferson a formal notification to this effect, March 2I, 1815.J. Henley Smith MSS.

J. IIenley Smith MSS.

3 Madison MSS. 
of Febrnary, regarding the transportation of the library. On the 2Sth of March he wrote to Milligan:

By a letter from Mr. Samuel H. Smith, I am informed that the President has engaged you to cone on here, as soon as I shall be ready, to exanine and pack the library, and that Mr. Dougherty was to superintend the transportation. I have been a fortnight laboriously engaged in revising the books, and placing them on their shelves, every one in the place and order in which it stands in the catalogue. This I shall finish the next Saturday (April Ist. $)^{x}$ We shall then have only to paste the numbers on the books corresponding with the catalogue, which will be a work of three or four days, say to April 5 th or 6 th, and I should be glad if you would be here as soon as that is done, say in the latter half of the ensuing week. There can be no better packing boxes than the pine cases in which they stand, not a book need be mored, only a leaf of paper be put between every two volumes, paper parings stuffed in the interval between the top of the books and shelf above, and sheets of waste paper spread on the whole face of the press orer which the lid is to be nailed. The presses are of the proper size to lay in a waggon, except two or three, which we can easily cut. You must bring the waste paper and paper parings, as they cannot be had here, and as I presume a waggon must come on with them, we can load her back with books now ready. For carrying the rest of the library, I have recommended to take the waggons of this neigliborhood, which can be had for $\$ 4$ a day. The library not having been revised for twenty years before, I expected great losses. They are not less than expected, some can be recovered, some replaced, and the rest more than countervailed by the many books which had by accident been omitted to be catalogued. When the President, while Secretary of State, was engaged in writing on neutral rights, I lent him Wynne's Life of Jenkins, two large folios, and a work in Latin, entitled "Scriptores de jure maritimo," sc. Stypmannus, Heinicke, Loccenius et Heinneccius, $4^{\circ}$. They have never returned, and are now probably with the books in the office of State, if they were saved from conflagration. Will you be so good as to inquire, and if there, brought on with the waggon. Many of those wanting, I think you can procure in Washington and Georgetown, at my cost, and have them brought on also. The waggon should arrive here the day after you. I am very anxious to get througl your part of this business, the packing and nailing up, because ny affairs in Bedford call for me distressingly, and I shall set out the moment you are done. Dougherty may then take off the presses at his leisure. I state below the books I wish you to try to get and bring on.

Accept the assurances of my esteen and respect,

Thomas JHFFreson.

'Note also Jefferson's letters to Madison, March 23, and to Girardin, March 27. Jefferson MISS., series 1, vol. If, Nos. 2S, 29. 
Finally, on the ISth of April, Jefferson wrote to Alexander P. Dallas, Secretary of the Treasury: "The books being now all ready for delivery, and their removal actually commenced, I may with propriety now receive the payment:" And on the Sth of May to Mr. Smith:" "Our tenth and last waggon load of books goes off today. This closes the transaction here. $\because \because \because$ It is the choicest collection of books in the United States, and I hope it will not be withont some general effect on the literature of onr conntry."

Within a week the library was in Washington, but of this Jefferson seems not to have been advised, for on the 26 th of June he wrote to Milligan, asking whether the library had arrived safely in Washington, and wishing to know whether it had yet been inpacked and replaced on its shelves, etc. Another month passed before Milligan answered, July 3I, I 8 I $5:{ }^{3} \because *:$

The library arrived in safety in Washington on Monday morning of next week after I left Monticello, that is in six days from the time it was put into the waggons, it was safely laid in the passage of the General Post-office, of Congress Hall. About three weeks ago I commenced unpacking it, and accomplished it last Monday. I am happy to inform you that it has not received the slightest injury by transportation. The room which has been appropriated for it is sufficiently large.

I Writings of Thomas Jefferson, edited by P. L. Ford, 9: 513-514.

${ }^{2}$ J. Henley Smith MSS.

${ }^{3}$ Jefferson MSS., series 2, vol. 6I, No. 86.

For packing and superintending the transportation of the library Milligan received $\$ 972.27$. Report of the Library Committee, January 26, 1816 .

After the sale of this first library to Congress Jefferson collected another, which he bequeathed to the University of Virginia, but the condition of his estate requiring that the bequest be diverted to the payment of debts, the collection was sold in Washington, in February, i 829 . In the catalogue of this sale there were 93 items. The sale was advertised in the National Intelligencer, February 27. The title-page and inpint of the catalogue are as follows:

"Catalogue. President Jefferson's library. Catalogue of the extensive and valuable library of the late President Jefferson (copied from the original manuscripts, in lis liandwriting, as arranged by liniself), to be sold at anction at the Long Roon, Penusylvania Avenue, Washington City, by Nathaniel P. Poor, on the 27 th of February, IS29. 'The sale to commence at 6 o'clock p. m., and will continue from day to day, until the whole library is disposed of. Price of catalogue I $21 / 2$ cents. Waslington. Printed by Gales and Seaton, 1829." I4 p1). $8^{\circ}$.

This is in the I,ibrary of Congress. Miscellaneous Panphlets, vol. 859, No. I4. 
(Thaptex Thive

DEVELOPMENT OF THE LIBRARY, 1815-1829 



\section{Chapter Five.}

DEVELOPMENT OF THE LIBRARY, 1815-1829.

In consequence of the ill feeling which arose over the destruction of the Library in ISI4, Patrick Magruder resigned his position as Clerk of the Honse, and at the same time, it is inferred, his position as Librarian of Congress, January 2S, ISI5. In consequence, too, of the loss of the old Library it was now determined, as Joseph Milligan had suggested in his letter of the 24th of September, ISI4, to Thomas Jefferson, to make the office of Librarian distinct from that of Clerk of the House of Representatives. Accordingly, on the 21st of March, ISI5, George Watterston was appointed.

George Watterston was a man ardent in temperament, yet modest and nnobtrusive in manner. ${ }^{1}$ Anne Royall saw him in I824, and spoke with admiration of these characteristics. She further remarked that he was a man of good size, neither spare nor robust, a fine figure, and possessed of some personal beauty. "His fair complexion and his striking countenance," she said, "show genius and deep penetration, marked with a grave and commanding spirit-a gentleman both in appearance and in manners."

It was shortly after this-in the summer of I 829 , in factthat Mrs. Royall was tried by Judge Cranch for being a common slanderer and disturber of the peace and happiness of the good people of the neighborhood. In the course of the trial Mr. Tims, Doorkeeper of the Senate, being called, was asked whether he knew of Mrs. Royall slandering anyone. He promptly replied, "Yes; she has slandered me; she called me an exemplary man-now that's slander." This was considered very funny; the court roared; bench,

'Obituary in Vational Intelligencer, February 6, I854.

${ }^{2}$ Sketches of history, life, and manners in the United States, IS26, p. 150. 
bar, and jury all lost their balance. Tims himself was the only man left unmoved. He looked around grave as an owl; just opposite to him stood Mr. Watterston laughing immoderately. Tins catching sight of him again opened his oracular jaws. "Yes, sir," said he, "I know of other persons whom she has slandered. She says in her book that Watterston and Gales are two of the handsomest men in Washington. Now I leave it to all the world if that is not a slander on all the other men in the city."

But Mr. Watterston had other qualifications for the position of Librarian besides those apparent to Mrs. Royall. He was a journalist, and therefore interested in live questions, public questions; an author of several books, and therefore understood books as only an author can; and above all he was a bookman-it is necessary only to quote from his commonplace books to indicate this. There we find such maxims as these: "A great book is a great evil," "Read much, but not many books," "A man who reads a great deal is like a cormorant-his literary appetite is never satisfied."

George Watterston was born in the harbor of New York October 23, I $7 S_{3}$. His father, David Watterston, a native of Jedburgh, Scotland, had purchased property in the neighborhood of the city of New York, and was at that time on his way to settle upon his new possessions.

In I79I, the founding of the new Federal capital offering opportunities for the talents of the father as master builder, the fanily moved to Washington, and George witnessed the laying of the comer stone of the Capitol by President Washington, September IS, r793.

This was the only event of importance in his life until he became of school age and was sent to Charlotte Hall School, situated in St. Mary Connty, Md. His associations with this place appear to have been of the happiest character, and led him to revisit the place twenty years after and write about it to the National Intelligencer.

After learing school Watterston studied law and finally opened an office in Hagerstown, MI. The death of a rich

$$
{ }^{1} \text { August } 17,1525 .
$$




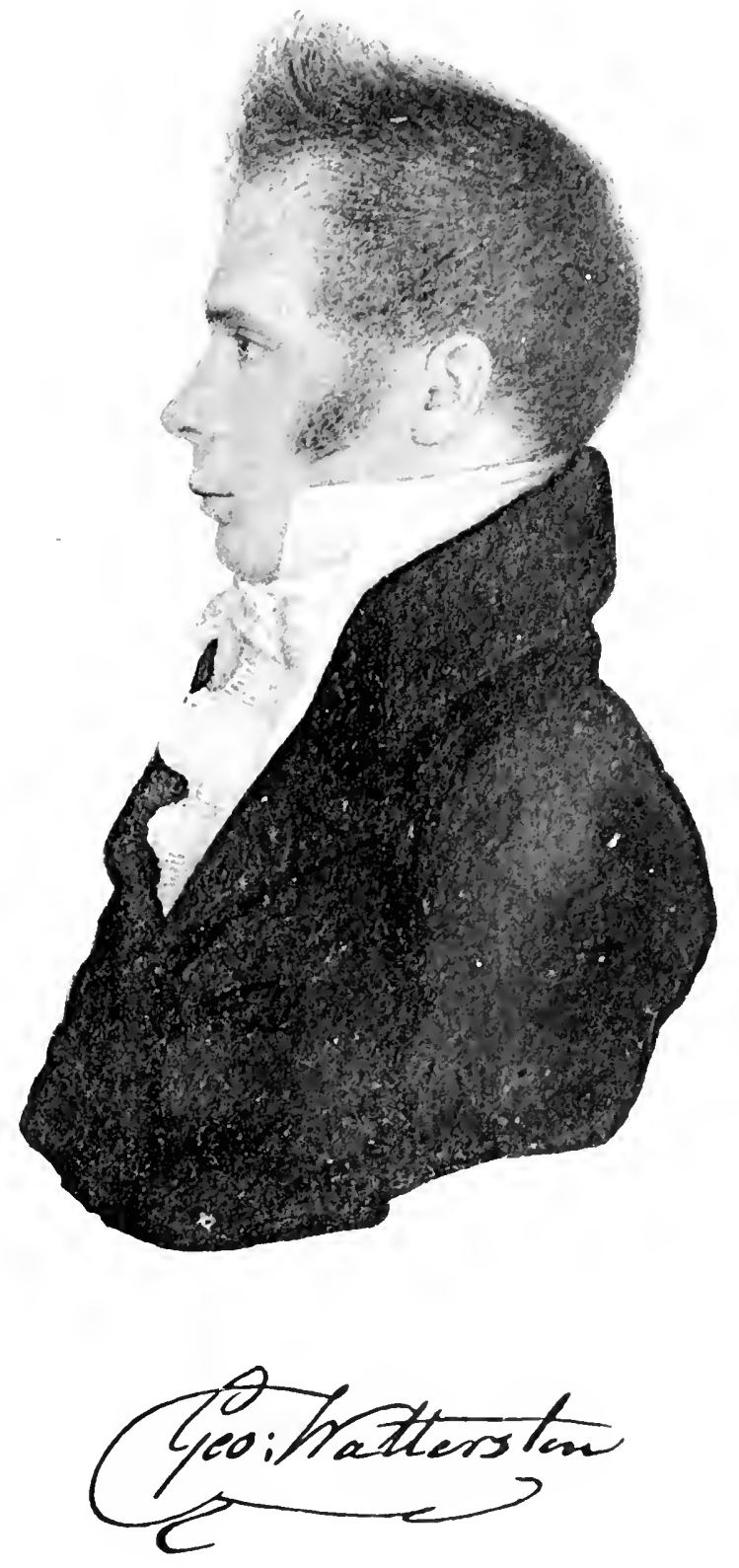



nncle in Jamaica, however, led him to give $11 \mathrm{p}$ his office in this place and make a trip to the WVest Indies, his journal of which is still preserved in manuscript among the Watterston papers. He was disappointed in the lot his uncle had provided for him, but the adventure gave him material for the poem entitled "The Wanderer in Jamaica," which he published in ISIo with a dedication to Mrs. Dolly Madison. This determined his future career as Librarian of Congress.

Returned from Jamaica, he set up in the practice of law in Washington, in partnership with Thomas Law, made his début as the annual orator of the Washington Benevolent Society of Young Men, January 26, ISII, ${ }^{1}$ and was married. The notice of this event in the National Intelligencer, October 29, I 8 I , was as follows: "On Saturday evening, by the Rev. Mr. Breckenridge, George Watterston, Esquire, to Miss Maria Shanley, all of this City."

In ISI 2 he was a candidate for the position of collector of the District of Columbia. ${ }^{2}$ The war with England now waged. In ISI4 the Britisl threatened the capital, and Watterston marched with Capt. Benjamin Burch's company to meet the enemy. No one gained renown in the ensuing battle- "the Bladensburg races," as the acquaintances of the returned warriors chose to call it-but during the consequent occnpation of the city ${ }^{3}$ the Library of Congress was destroyed and the old library administration discredited, as we have described. This was the immediate occasion of the appointment of Mr. Watterston as Librarian.

The real reason for Mr. Watterston's appointment as Librarian, however, lay in his attainments as a man of letters.

His first publication was a novel-to-day it might be called a psychological novel. It was entitled "The Lawyer, or Man as he ought not to be," was dedicated to the Hon. John Buchanan, chief judge of the fifth judicial district of Maryland, and was published anonymously. ${ }^{4}$

- National Intelligencer, November 26, I8ro; January 24, ISIr.

- Watterston to Madison, October 2S, ISI2, Madison MISS .

3 Watterston's house was among those pillager. Ingersoll, Historical sketch of the war of $18 \mathrm{i} 2$.

${ }^{4}$ Pittsburg: Printed for and published by Zadok Craner, and sold at his bookstore (Franklin's Hearl), Miarket street, I8o8, 236 pp. front. $12^{\circ}$. A second edition of 
In the preface to this work Mr. Watterston says: "The following sheets were written chiefly with the view to exhibit the pernicions effects which result from a vicious education, and thiss to show the propriety of early instilling into the youthful mind principles of justice, of truth, of honesty."

In his next work of fiction, "Glencarn; or, The Disappointments of youth. A novel. By George Watterston, Esq., author of The Lawyer, etc.," ' he attempted to prove that happiness is the result of a certain physical organization of the nerves, modified by habits of virtue, and to cantion youth against too implicit confidence in the integrity of man.

In I Sog he had made an appearance as the leader of a new school of literature in "The Child of feeling. A conedy, in five acts." In this he observed: "The scenes of American connedy have hitherto been laid in foreign nations; their effect has therefore been lost. The proper subject of American comedy is American character." This work was welcomed in the following "Prologue to "The Child of feeling,", written by a citizen of Washington and friend to $\mathrm{Mr}$. Watterston, and printed in the National Intelligencer July 27, ISIO:

Sweet cliild! Of Nature's son the rarest boy,

Subject to every pain and every joy:

Nursling of Genius! Deign his hopes to raise;

Correct with kindness, and with candor praise,

Thus shall the Comic Muse attain the end

To which her labors ever ought to tend; ete.

Watterston's next publications were poems. First, "The Wanderer in Jamaica." ${ }^{3}$ This poem, to which we have already referred, was dedicated to Mrs. Dolly Madison in the

this was published in Charlestown, MI., by G. Davidson, in IS29, withont the dedication. A note on the title-page of the New York State library copy, signed by S. G. Deeth, says: "Ly George Watterston, many years I,ibrarian of Congress. Proof catalogue Congress Library, 1839 edition, page 599." It is also entered in the Catalogue of the Alexandria library, 18 15 , under Watterston as both author and donor.

"Alexandria: Printed by Cotton and Stewart, and sold at their bookstores in Alexandria and Iiredericksburg, ISı. $265 \mathrm{pp}$. $12^{\circ}$.

${ }^{3}$ Georgetown: Publisherl by Joseph Milligan; Dinsmore and Cooper, printers. 1809. $113131 \% .16^{\circ}$.

${ }^{3}$ Washington City, W. Cooper, printer, $1810.36 \mathrm{pp} .12^{\circ}$. 
following language: "Madan1, I have presumed to address this poetical effusion to you, from the reputation you have acquired of being desirons to pronnote the canse of general literature." It was this dedication, gossip said, that led President Madison to appoint Watterston Librarian of Congress. "The Wanderer in Jamaica" was followed by "The Scenes of youth. A poem." I This was written somewhat after the manner of Goldsmith, and, on one occasion at least, ${ }^{2}$ inspired the muse of Noaln Brashears, a local bard of note in 1830 .

In I $_{3} 3$ Watterston becane editor of the Washington City Gazette, established by William Elliot in support of the Republican party. ${ }^{3}$

It was as a man of letters that Watterston received his appointment as Librarian. But after his appointment he became interpreter of the literature in his custody and ceased to make any notable contributions to literature himself.

In the National Intelligencer, July I 5, I820, there is a song by G. W., entitled "Columbia, the home of the brave and the free," etc., and in the same journal, August 29, I825, a poen by him entitled "The enigma," on the setting of the su1n Friday evening, August I2, IS25. But all his other writings were suggested by the books in the Library, or by the inquiries of readers, Congressmen, and others, or by events of the day.

Sometimes his subject was merely local or suggested by some local event-a sketch of Thomas Law, ${ }^{4}$ an essay on unusic occasioned by the first musical entertainment in the city-an oratorio in the Unitarian church; ${ }^{5}$ a description of the Capitol ${ }^{6}$ just then enlarged, of the Capitol Rotunda, ${ }^{7}$ and of plans for landscape gardening about the Capitol. ${ }^{8}$ Of

${ }^{1}$ Washington City, printed by Rapine and Elliot, near the Capitol, I8I3. 22 pp. $12^{\circ}$.

${ }^{2}$ Columbia's wreath, p. 4 I.

'This statement is found in a paper entitled "Concerning J. C. Calloun, Nay II. 1851," among the Watterston MISS.; also in New guide to Washington, I842, p. 104. The prospectus of the Washington Gazetle, William Elliot, publisher, J. Elliot, printer, is printed in the National Intelligencer, December 2, 1813.

4 National Intelligencer, October 22, 1822 .

${ }^{5}$ Ibid., June 7,1823 .

${ }^{6}$ Ibid., October 8, 12, 1825 .

7 Ibid., January $7,1826$.

${ }^{8}$ Ibid., June 23, July 1, 11; August 10, I825. 
this character were also some statistics upon the health of Washington ${ }^{1}$ and a letter to the National Intelligencer upon the formation of a temperance society. ${ }^{2}$

At other times his themes were political or literary. Of the former I have noted contributions to the local press describing a visit to Monticello and Montpelier, ${ }^{3}$ discussing Pinkney and Clay, ${ }^{4}$ and John Adams, ${ }^{5}$ letters on the Quarterly Review's strictures on the United States, ${ }^{6}$ on the Greek revolution, ${ }^{7}$ on Owenism, ${ }^{8}$ on canals, ${ }^{9}$ etc. Of mere literary or scientific essays those on La Place, ${ }^{\text {10 }}$ on Hamlet, ${ }^{11}$ on the Book of Job, ${ }^{12}$ and on Piers Plowman's vision ${ }^{13}$ are of interest.

Besides these fugitive journalistic contributions, he for short periods assumed the editorship of the National Register, a political paper published by J. K. Meade, established in I SI6, and of the Washington City' Chronicle, a literary paper published weekly by Rothwell and Ustick, established in I $828 .^{14}$ On the I 3 th of March, I 827 , finally, he commenced writing regularly for the National Journal at $\$ 500$ per annum. ${ }^{15}$

Of greater significance than these journalistic efforts, however, were the books which he published during his librarianship. The first of these was the ontcome of the horticultural studies encouraged by the Washington Botanical Society, of which he was a secretary. ${ }^{16}$ It was "A Memoir on the history, culture, manufacture, uses, etc., of the tobacco plant." ${ }^{17}$ Several other horticultural studies by him belong to this period. They may be seen in the letters printed by him in the National Intelligencer, February 24, I820, on a botanical musenim; June $I 6, I S I 7$, on crop prospects about Winchester; July $2 \mathrm{I}, \mathrm{I} \mathrm{SI}_{7}$, and June 2O, IS2O, on the culture of the potato;

'Hashington Gazelle, January $30,1826$.

2. Vational Intelligencer, August 29, 1828.

${ }^{3}$ Ibid., August 15,1820 .

4 National Joumal, November 22, $18_{23}$.

5 Ibid., September 7,1826 .

${ }^{6}$ Vational Intelligencer, April 26, $1 \$ 25$.

7 National Joumal, January 3, I4, 1824.

${ }^{8}$ National Intelligencer, May 5, $1 \$ 25$.

9 Ibirl., August 18, 1821.

${ }^{10}$ Ibid., April 12, 15, 21, 1317.
"Ibid., September 2, I 817 .

${ }^{12}$ Ibid., April 16, 24, I821.

${ }_{3}$ Natimal Journal, December $1_{3},{ }_{1} 823$.

14 Watterston's New Guide to Washington, 1842 , p. 104 .

15 Waterston MISS.

${ }^{16}$ National Intelligencer, March 22, I 8 I7. 17 Washington City, Printed by Jonathan Elliot, $1837 . \quad 12 \mathrm{pp} .8^{\circ}$. 
July I7, I 820 , on the night-blooming cereus, and in the National Journal, July I4, I826, on the silkworm and the mulberry tree.

The second book published during these years was the outcome of his work in the Library and of his position as the advisor of members of Congress. It was the "Letters from Washington, on the Constitution, laws and public characters of the United States. By a foreigner." This work is a short analysis of the laws and Constitution of the United States, together with sketches of the heads of Departments and some of the most distinguished members of Congress. In the composition of this work Watterston used Beaujour's Sketch of the United States, Mably's Observations sur le gouvernement et les lois des États-Unis, Jacques La Croix's Constitutions des principaux États de l'Europe, MacNevin's Switzerland, and Penchet's Statistique Élémentaire de la France. The book was unfavorably reviewed in the Federal Republican, ${ }^{1}$ but William Faux, in his Memorable days in America, ${ }^{2}$ acknowledges his indebtedness to it, and the popularity of the personal sketches led to a reprint of that part of the book, with some additions, in a work entitled "The gallery of American portraits," ${ }^{3}$ dedicated to Henry Clay.

Watterston intended to follow these Letters from Washington by a history of the Madison Administration, and wrote to Madison: ${ }^{4}$

August $4,1820$.

I have in contemplation to undertake a history of your Administration, which I conceive to be the most interesting period, except the Revolution, of American history. Conld I be so fortunate as to obtain your aid in explaining the more obscure events of that time, and in furnishing such other information as might be useful and important, it would not only render me more competent to the task, but the work itself more interesting. Contemporary history has been objected to, but I think it

\footnotetext{
'There was an answer to this review in the City of Washington Gazette November $20,1818$.

${ }^{2}$ London, 1823 , pp. 347 et seq.

${ }^{3}$ Washington, Published by Pishey Thompson; A. Kothwell, printer, IS30. 157 pp. $12^{\circ}$.

4 Madison MISS.
} 
is from that source, the future historian is the best enabled to obtain his facts and to select his matter. My respect for your character may indeed make me too partial, but I shall always endearor to keep in view the course an impartial historian should ever observe, when he writes for the edification of posterity.

Be so good as to make my respects to your excellent lady; may you both enjoy long life and happiness as you must enjoy the gratitude and respect of a generous and enlightened nation.

This project, however, seems to have received no encouragement.

Watterston's next pieces of literary work show his interest in education. One of these was a translation of a work by Simon Gueullette, the title-page of which reads: "An easy method of learning the Roman history; with a chronology of the Roman Emperors, and an abridged acconnt of the Roman usages and customs. Designed for the use of schools. Translated from the French, with additions." I

His other educational work was "A course of study preparatory to the bar or the Senate; to which is annexed a memoir on the private or domestic life of the Romans." 2 In the preface of this work he explains its publication as follows: "Placed in a situation in which I have had frequent opportunities of witnessing the lamentable waste of time in many who have been disposed to be studious, from the want of an instructor to point out the course of reading they should pursue, $: \because \%$ In the wide and desultory range of reading and of study adopted by young men in general, I have seen, with regret, that much time has been wasted, which, if employed in a more judicious manner, would have yielded the most lasting advantage." : : : * Of its cliaracter he goes on to say: "In speaking of each

${ }^{t}$ City of Washington, Printed and published by D. Rapine, 1820. 204 pp. I2 ${ }^{\circ}$. This was reviewed in the National Intclligencer November 24, 1820. Three years later Noah Brashears, principal of the Masonic Hall Academy, Waslington, published his Grammatieal tables, a work which Watterston thought well calculated to facilitate a knowledge of the English grammar in beginners, so ran the advertisement in the National Journal, December 20, 1823.

"Washington, Printed and publisleed by Davis and Force (Franklin's Head), Pennsylvania Avenue, $1 \$_{23}$. $240 \mathrm{pp}$. $12^{\circ}$. This work was first presented to the public in a course of lectures. - National Intelligencer, January 3, 1823. The essay on the manners of the Romans was based lipon the Mémoires de l'Académie des inscriptions et belles-lettres, and D'Arnay's work. 
science, I have endeavored to point ont the books proper to be read and the course necessary to be pursued with a view to render it more accessible and more easily attained." This instruction he put in the form-popular since the time of Chesterfield-of letters addressed to his son on the proper divisions of time, the study of languages, rhetoric, oratory, poetry, logic, mathematics, drawing, painting, architecture, music, history, chemistry, mineralogy, botany, zoology, moral and political philosophy, public law, and political economy. The book was reviewed favorably in the National Journal January IO, IS24.

In the year before the publication of his Course of study, Watterston had published, anonymously, a book which showed his continued attachment to fiction as a popular form of instruction, and at the same time indicated an increasing interest in the life and welfare of the city of Washington. This book was entitled "The L- Family in Washington; or a winter in the metropolis." I It was a humorous description of the follies of Washington life, with some reflections upon literature. In the preface he professed his admiration for the pen of Mrs. Radcliffe, and said that she was the only person to do justice to the beauties of Washington; he himself seemed called upon to picture forth the vulgarities of life at the capital. The result was that the book excited much interest but called forth many censures. The reviews in the Columbian Star, May II, IS22, and in the Washington Gazctte, May 2, I822, may be noted in particular. Only one opinion favorable to the book was uttered publicly, that was by a correspondent of the Gazette, May II, I822, who thought the book the best that had appeared for some time.

The reception with which the "L___ Family" met did not, however, deter Watterston from writing another and similar work in 1827 , entitled "The Wanderer in Washington." "This, like the "L_- Family," was an anonymous publication and written after the style of Fielding or

\footnotetext{
${ }^{x}$ Washington, Davis and Force, 1822. 159 pp., $12^{\circ}$.

2 Printed at the Washington Press. By Jonathau Flliot, jr., Penusylvania avenue, and sold by P. Thompson, I827. $226 \mathrm{pp}$. $12^{\circ}$.
} 
Smollett. In it the author says (p. 44), "I am here as an observer, cool, dispassionate, philosophical. I mingle in society not because I love it, but because I wish to study the character of my countrymen while revolving in the highest spheres of life and while surrounded by the trappings of office and the splendor of power." This book, like "Glencarn," was widely read and widely quoted, ${ }^{\mathrm{I}}$ and even went into a second edition. ${ }^{2}$

As writer of text-books and novels Watterston had shown a pedagogical bent. His scientific temper of mind was displayed in his connection with the Washington Botanical Society and in his communications to the local press upon horticultural subjects, and in I $82 S$ led him to the compilation and publication of a notable contribution to statistics, the Tabular statistical views of the population, commerce, navigation, public lands, etc., of the United States. ${ }^{3}$ This was a continuation of the statistical annals of Mr. Seybert and received the patronage of Congress by an act authorizing a subscription for it, approved April 3, I 828 .

Be it cnacted by' the Senate and House of Representatives of the United States of America in Congress assembled, That the Secretary of the Department of State be, and he is hereby, authorized and directed to subscribe for, and receive, for the use and disposal of Congress, six hundred copies of the Statistical tables proposed to be published by George Watterston and Nicholas B. Van Zandt, of the city of Washington.

SEc. 2. And be it further cnacted, That the sum of fifteen hundred dollars shall be, and hereby is, appropriated, to defray the cost of the said subscription; to be paid ont of any money in the Treasury, not otherwise appropriated.

The work was reviewed appreciatively in the Washington Chronicle, September I3, and December 6, I82S; the Telegraph, Deccmber 19, I828; the National Joumal, December 27, IS28; and in the Boston Courier (copied in the National Intelligencer, March 6, I829), and in I 333 was supplemented by the Continuation of the Tabular statistical views of the

\footnotetext{
"Washington Cily Gazette, IFebruary 21, IS29.

${ }^{2}$ In this, one piece of realism which liad offended readers in the first edition was altered.

${ }^{3}$ Washington, J. Filliot 1829 . I32 pp. $4^{\circ}$. With Nicholas Biddle Van Zandt, who had been for a number of years proprietor of a claims office in Washington. See advertisement in National Intelligencer, May Io, IS22.
} 
United States, published under the patronage of the Congress of the United States. ${ }^{\text {I }}$

This literary activity gained for Watterston the notice of contemporaries, though it did not earn for him a place in American literature. That notorious scold and journalist, Mrs. Anne Royall, writing in I $824{ }^{2}$ says: "It appears that Washington has produced one man of letters, George Watterston, Esquire." Here she gives an extended critique of the Letters from Washington and the L- Family, and concludes, "He writes with ease, and as one familiar with belleslettres, and may be regarded inferior to few in the United States." More judicial was the notice of the well-known Boston journalist, S. L. Knapp, who in his chapter on men of letters in Washington, remarks that the best accounts of the city of Washington were from the pen of Watterston, and goes on to say, "Mr. Watterston has written several popular and useful books, Letters from Washington, Course of study, L_ Family, Tabular statistics of the United States, etc. The public are much indebted to him for much useful information, conveyed in a good style. Some of the sketches of the great men in and about Washington, which are to be found in his works, are splendid and original, and give a very fair view of their character." 3

But both of these writers were obliged to come to Washington to find Watterston out. He was the only man of letters at the national capital, but his fane was only local. In I 8 I 7 he had ambitions to be heard by a larger andience, and seems to have written to J. K. Paulding with that in view, for the latter writes to Watterston, Washington, Jannary 25 , I $S_{\text {I } 7:{ }^{4}}$

I have no concern at present in the editorial part of the Analctic Magazine, or in any other way, but you will find, I think, on the cover of the last number, (for December), the price per page offered for each article that may be accepted, which is, I think, - - for I have not the book at present,- -three dollars. The manner of transmitting the articles, the mode in which the writer's name is either clisclosed, if his communica-

\footnotetext{
"Washington, Way and Gideon. 1833 . $210 \mathrm{pp} . \mathrm{S}^{\circ}$.

${ }^{2}$ Sketches of history, life and manners in the United States, 1826, p. 150.

${ }^{3}$ Sketches of public characters (etc.), by Ignatius Loyola Robertson (pseur.), New York, 1830, p. 124.

4 Watterston MSS.
} 
tion be accepted, or kept secret, if refused, as also that of receiving the money, is particularly printed out, if I recollect rightly.

As a reader of the Magazine I shall be glad to see your productions frequently appear in that work, but $I$ have no concern in it, that will enable the to forward your views.

This seems to have ended the matter.

This literary activity, the natural outcome of his previous experience as an anthor, of his existing position as Librarian, and of his interest in the life of the national capital, did not, however, exhaust his energies. He was a leading promoter of the society for the encouragement of botanical study, to which we have already referred. The circumstances of the establishment of this society, as narrated by Mr. Watterston, were these: In ISI6 there came to Washington a Scotchman named Whitlaw, who gave notice that he would lecture on botany. These lectures aroused so $111 \mathrm{ch}$ interest, and it was so desirable that the knowledge of the science which had thus been acquired might be retained and applied to some useful purpose, so Mr. Watterston thought, that he suggested the formation of a society for the purpose of exploring the flora of the District. The Washington Botanical Society was accordingly established in the spring of ISI7, with Mr. Watterston as secretary. ${ }^{\mathrm{X}}$

Watterston was also a supporter of the Columbian Institute, ${ }^{2}$ and a member of the general committee of that institute. $^{3}$

Mr. Watterston took an interest in the political life of the city likewise. He was a member of the commission appointed under the act of Congress, approved May 7, I822, authorizing the city to drain the low grounds on and near the public

\footnotetext{
${ }^{r}$ Watterston MSS. The journal of this society is now in the possession of Prof. I ester F. Ward. There are notices of the society and Watterson's relations to it in the Washington City Weekly Gazette, April 5 and 19, July 12, and August 9, I8I7. In the National Nagazine, December 3, I80I, a national museum and garden was suggested. In the second number of the Washington Expositor, January 9,1808 , there were proposals for establishing an experimental, agricultural, and botanical society in Washington.

"See Washington City Weckly' Gazette, January I8, I817, p. 485.

${ }^{3}$ City of Washington Gazette, October 7,1818 . There is an excellent notice of the early history of this institute in the National Journal, November 24, 1827, and in an address delivered before the Columbian Institute, January II, ISI7, by Edward Cutbush.
} 
reservations, and to improve and ornament certain parts of them; one of the trustees of the public schools of the second district in I 820 and in I823; president of the board of conlmmon council in I82I; and vice-president of the board of aldermen in I $829 .{ }^{\mathrm{I}}$

In the social life of the capital, too, he took a part. At a dinner given to Thomas Law upon his departure for England, Watterston responded to the toast, "Our respected guest; may he always escape the calumnies of English travelers and English reviewers," 2 and at the dinner to Lafayette, October I2, I824, he responded to the toast, "The gratitude of a free nation will always be extended to him who deserves well." 3

These were extraordinary occasions; for the rest the queries of the irate Anne Royal14 may suffice: "Why does he go to the black-coat church? Why does he entertain shoals of these missionaries? Pass his house when you will, you find it enveloped in a flock of black coats like ravens round carrion. Why is this?" 5 And the reminiscences of Mr. Watterston's son, who tells of the large number of slaves that his mother brought from her Maryland home upon her marriage and of the bother and annoyance that they were to his father, who discharged them one after the other, giving quarters to some to live by themselves and wholly emancipating others. Though they did not publish them, both he and his friend, Henry Clay, held abolitionist views, even before the Abolitionists.

${ }^{\mathrm{x}}$ In $\mathrm{I} 820$ he refused to be a candidate for the city council, or serve if elected. City of Washington Gazette, June 7, I82o.

'Washington City Gazette, July 21, 1824, from the National Intelligencer.

${ }^{3}$ National Journal, October 14,1824 .

4"Some of my friends," she writes, "suspect Mr. Watterston for writing a bitter critique on the second volume of the 'Black book,' published in the Emerald in Baltimore, but I can not think he would act so ungentlemanly, not to say ungratefully, toward me. * * But should the writer prove to be Mr. Watterston, no further evidence is necessary to prove him a dangerous man to our Government, and he ought to be dismissed as soon as possible." Black book 3: 2r r.

5 Black book 3: 210. 
THE LIBRARY ROOM, I8I5-I829.

On the Igth of September, I8I4, Congress met in extra session in what was known as Blodget's Hotel, or the PostOffice building. The design for this building was furnished by Capt. James Hoban and adopted by the city commissioners in I793. It had been erected out of the proceeds of a lottery. ${ }^{\mathrm{I}}$ The owners of the prize ticket were orphan children, who not having the means of completing the building suffered it to remain for several years in an unfinished and dilapidated state. It was a large brick structure, three stories high, situated on the corner of Seventh and E streets northwest, facing south, that is, about halfway between the White House and the Capitol. Having on the first floor a spacious center and two extensive wings, it was seized upon by the Wignell \& Reinagle Company of Philadelphia and converted into a theater in the year i $800 .^{2}$ After this the basement story of the building was occupied by Scotch and Irish emigrants, who, having to pay no rent, kept possession of it,-a ruin, with the greater part of its roof fallen in, Weld observed in I803-until in I8Io it was purchased by the Government and finished in a plain style for the use of the Post-Office and Patent Office. ${ }^{3}$

Now the building was called upon to accommodate both Houses of Congress, the Congressional committees, and what was left of the Congressional Library, as well as the General and City Post-Offices and the Patent Office. ${ }^{4}$

A library room does not seem to have been fitted up in this temporary Capitol until the following year. Then, March 3, I8I 5 , an act was passed providing both for the transportation of the newly acquired Jefferson library and for the furnishing of a room for its reception. March 2I Mr. George

I Washington Federalist, January 28 , ISo3.

${ }^{2}$ William I3. Wood, Personal recollections of the stage, Philadelphia, I855, p. 55.

${ }^{3}$ Watterston's New guide to Washington ( $\mathrm{I}_{42}$ ), pp. 63, I 46. Notice in the National Inlelligencer December 12, I853. Letter from the Postmaster-General inclosing a report stating the expense of finishing the public building called "Blodget's Hall," January 18, I8r2. Ordered to lie on the table. Washington, A. \& G. Way, Printers, I8I2. 2 I pp. $4^{\circ}$.

4 Panl Jennings, "A colored nan's reminiscences of James Madison," I865, p. I4. Milligan to Jefferson, September 24, I8I4, Jefferson MSS., series 2, vol. 6I, No. 80. 
Watterston was appointed Librarian, and on the $25^{\text {th }}$ he wrote to President Madison, who was particularly intrusted with the execution of the law of March 3:

I have had the happiness to receive the commission of Librarian with which you were so good as to honor me. I accept it with pleasure and tender you my thanks for the favor conferred. Unwilling to intrude upon your moments of leisure and relaxation, I nevertheless deem it my duty to apprize you that, according to an act of last session, you are "directed to cause an apartment to be immediately selected and prepared for a library room," etc. In the third story of the present Capitol, ${ }^{1}$ a room sufficiently commodious and convenient might, at a small expense, be prepared, and this could immediately be done, by authorizing the Commissioner of the Public Buildings, or the superintendent of the city, to have it prepared without delay. ${ }^{2}$

For fitting up and furnishing the library room in this building, including the expense of finishing the staircase and passage in the third story in which the room was located, the sum of $\$$ I, 520.77 was expended. ${ }^{3}$

\section{INCONVENIENCE OF THIS LOCATION.}

Before the first session of the Fourteenth Congress, December 4, I8I 5, the citizens of Washington had erected a temporary structure for the accommodation of Congress, east of Capitol square, now known as the Old Capitol. This building was occupied by the two Houses of Congress from that time until I8I9. So the question of a library room again presented itself: Should the Library remain where it was in the Post-Office building? Or should it be removed to quarters in the temporary Capitol; in the Capitol proper, then being rebuilt; or in some neighboring house? The question had been raised during the building of the temporary Capitol in the summer. On the I atli of September, Watterston wrote to the President regarding it. This letter has not been discovered, but it seems to have suggested that because there had been no law passed providing for another removal of the Library, it must remain for the present where it was. On the I5th Madison replied: "I have received your letter

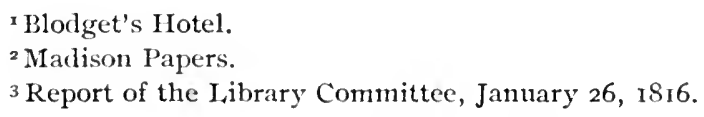


of the I2th, and have referred the case to the members of the Executive." I On the same day he wrote to Dallas: ${ }^{2}$ "I took the liberty of requesting through Mr. Rusli, the attention of yourself and other members of the Cabinet at Washington, to the difficulties arising in the business superintended by Colonel Lane, who thought with me, that a decision on them could be better formed on the spot, than by niyself at this distance. I have just received the enclosed letter from the Librarian, which presents a new one. Between the alternatives of a temporary building or the continuance of the Library where it is, the option seems to be prescribed by a want of legislative provision for the former. Will you be so good as to obtain from Colonel Lane a full view of the case, and to decide on it as may be found best by yourself and the other gentlemen? Mr. Watterston is informed of this reference of the subject."

Nothing further seems to have been done toward a removal of the Library from its distant location until the appointment of the new Library Committee, December 4, I8I5. This committee consisted of Senators Eligius Fromentin, of Louisiana, William Hunter, of Rliode Island, and Robert $\mathrm{H}$. Goldsborough, of Maryland, and of Representatives John W. Taylor, of New York, Joseph Hopkinson, of Pennsylvania, and Henry St. George Tucker, of Virginia. The record of their action regarding the Library room may be found in their report made in the Senate, January 26, I8I6. It is as follows:

The first care of the Joint Library Committee, immediately after their appointment, was to inquire into the possibility of removing the Library from where it now is, to a place more convenient to the members of Congress, but they were not able to accomplish this most desirable object. The Capitol does not afford any room which could, in its present state, be deemed a safe place of deposit for the Library. The room which has been selected for placing the Library in in the building now occupied by Congress, ${ }^{3}$ did not appear to your committee to offer the advantages, or to promise that security which, by your committee, was deemed indispensably requisite, before they could submit to you a reso-

"Watterston MSS.

${ }^{2}$ Letters and other writings of James Madison, Philadelphia, I865, 3: 20.

${ }^{3}$ The Old Capitol. 
lution recommending the removal of the Library to that room. The efforts of your committee to procure rooms or a louse which might have been used temporarily for the Library, in the neighborhood of the house where Congress now assemble, proved likewise unavailing. A sum not less than one thousand dollars per annum was asked for the rent of the only house which might have answered the object; and taking into consideration, not only the expense of the rent, but the expense of fitting out, for temporary purposes only, the necessary rooms for the Library; the expenses attending this temporary removal; the portion of the session already elapsed; the length of time which would be consumed in the removal, during which, instead of a rather difficult, under present circumstances, no access at all could be had to the Library; considering further, that nothing is more injurious to books than these frequent removals; and considering likewise, that the Library is perfectly safe where it is now, and that within a few weeks, at a period probably not much more distant than the period at which the Library could again be opened, if it should now be attempted to be removed on Capitol Hill, the greatest inconveniences now arising from the distance at which the Library is placed, will disappear with the season of the year which has created them, your committee are of opinion that the Library ought not to be moved this winter, and that their attention should be wholly directed in securing a permanent place in the Capitol for receiving the Library; which place ought to be ready before the next session of Congress, and with that view they have inserted a section which, to them, appears calculated to obtain the object, in the bill which accompanies this report.

This bill was, on the $2 \mathrm{~d}$ of February, taken up for consideration in the Committee of the Whole, where, on motion of Senator Roberts, of Pennsylvania, that section of the bill providing for a Library room in the Capitol, together with other sections, was stricken out.

\section{A LIBRARY BUILDING SUGGESTED.}

The bill reported January 26, I816, provided for a Library room. The next suggestion was for a Library building. During the second session of the Fonrteenth Congress, February I8, I8I7, Mr. Fromentin, from the Joint Library Committee, reported the following resolutions in the Senate: ${ }^{\mathrm{I}}$

Resolved, by the Senate and House of Representatives of the United States of America, in Congress assembled, 'That it shall be the duty of the Com- 
missioner of Public Buildings to cause to be erected and fitted up for the reception of the Library of Congress a suitable building, upon a plan to be approved by the President of the Senate and Speaker of the House of Representatives, to be situated on Delaware Avenue, north of the Capitol.

Resolved, That when the said building shall be ready for the reception of the said Library, it shall be the duty of the Librarian to remove the same and arrange the books therein.

On the 22d the consideration of the resolutions was taken up as in Committee of the Whole, and, no amendment having been made thereto, it was reported, and on the question, "And shall this resolution be engrossed and read a third time?" it was determined in the negative.

The failure of these resolutions was the occasion of the following communication from the Librarian to the National Intelligencer, March 25, ISI7. It appears under the caption "National Library," and is subscribed "W."

It is extremely to be regretted that the proposition to erect a building for the reception of the Library of the United States, presented last session, had not succeeded. A literary establishment of so much importance and benefit, ought to be accommodated in a style proportionate to its dignity and ntility,--in all other countries, this is an object of national pride, and edifices are erected for the acconmodation of national libraries, not only adnirable for their convenience, but distinguished for the taste, beauty, and excellence of their architecture. In the United States, where reading is so general, one would suppose that the lamentable rage for econony, which now seems to have gained such an ascendency, would not at least extend to their depositories of literature, and that a building would be erected for their library equal in grandeur to the wealth, the taste, and the science of the nation. It is to be apprehended, that if a building be not erected for that purpose, the Library will remain stationary for many years, isolated and inconvenient from its position; for there appears to be no apartnent in either wing of the Capitol, thongh they cover an acre of ground, calculated for its reception, and to wait until the main body be completed, would, to judge from the present economical nnania, be rendering the Library almost useless for a long time.

I have made these rentarks merely preparatory to the introduction of the following succinct description of an elegant and splendid design for a national library at Paris exccuted by C. Gisors, junior: An inmense galiery, of 266 feet long by 47 breadth, and six vast halls, which are contiguous, constitute principally the interior of the library. Four 
stories of cabinets, disposed in the form of an amphitheatre, adorn the halls in a display of 4,000 feet by an elevation of from seven to twelve feet. Four great depots and two halls, destined for manuscripts and engravings, have their entrance by the large gallery which has been mentioned. This gallery is terminated by' a temple of Apollo surrounded by the Muses. Behind the temple is an exterior portico, above which is advantageously disposed a circular hall designed for medals and various antiques; a garden situated behind the body of the principal building contains pavilions for the use of the librarians and others attached to the library. These pavilions have each a particular entrance from the street. On the right and left of the buildings are walks planted with trees and ornamented with statues of great men. The elevation presents a peristyle of eight Corinthian columns, bearing a front decorated with basso relievos which represent Parnassus. Other basso relievos and statues placed in niches enrich the walls of the edifice.

Such a building as this would indeed be a national ornament and contribute essentially to the beauty of the capital of the United States. ${ }^{x}$

\section{Such was the first dream of a building for the Library of Congress.}

REMIOVAL, OF LIBRARY TO NORTH WING OF CAPITOL, ISI8-IS24.

At the opening of the first session of the Fifteenth Congress a new Library Committee was appointed. This consisted of Senators Dickerson, King, and Tait, and of Representatives Seybert, Whitman, and Middleton. The appointment of this committee was hailed by the Washington Gazette December 8, I8I7, as a good omen. It said: "We are disposed to indulge a hope that this committee will be more active than the former, and that as literary men they will not neglect the interests of this establishment. To coop the Library of the United States in a garret almost a mile from the Capitol is degrading both to literature and the nation, and we trust that Congress will see the necessity of erecting a building for its accommodation nearer the Capitol." This article, it was said, was copied by several papers in different States.

\footnotetext{
"This proposition in favor of a Library building was indorsed by an editorial in the Washington City Gazelte, April 5, ISI7.
} 
On the 3ist of December, Mr. Burrill submitted the following resolution for consideration in the Senate:

Resolicd, That the Committee on the District of Columbia be instructed to inquire whether suitable apartments can be had in the Capitol for the reception and accommodation of the Library of Congress, and in case such apartments cannot be had there to inquire into the expediency of commencing the erection of the center building of the Capitol and of making provision for the speedy completion thereof. That said conmittee be also instructed to inquire whether suitable apartments can be had in the Capitol for the reception and accommodation of the Library of Congress, and in case such apartments can not be had there to inquire into the expediency of purchasing or erecting a convenient building for the Library. ${ }^{x}$

On the 2 d of January, I 8 I8, the resolution was adopted.

This resolution seems to have been the occasion for a communication from the Librarian to the Washington Gazctte, January 8, I8IS, over the signature "Philomath." This was merely a repetition of his letter to the National Intclligencer, March 25, ISI 7 .

Nothing was accomplished, however, until the second session of the Fifteenth Congress. On the 24th of November, I8rS, Mr. Dickerson introduced a bill in the Senate to provide for the removal of the Library of Congress to the north wing of the Capitol. On the $25^{\text {thl }}$ it was considered as in Committee of the Whole, and no amendment having been made, it was reported, and on the 26 th passed. On the same day the bill was concurred in by the House of Representatives. $^{2}$

AN ACT to provide for the removal of the Library of Congress to the north wing of the Capitol.

Be it enacted, by the Senate and House of Representatives of the United States of America, in Congress assembled, That the Joint Library Conlmittee of Congress be, and they are hereby, authorized to cause suitable apartments in the north wing of the Capitol to be fitted up and furnished for the temporary reception of the Library of Congress, and to cause the said Library to be renoved to and placed in the same.

SEC. 2. And be it further cnacted, That the accounting officers of the Treasury be, and they are hereby, authorized and directed to settle

"Senate Journal, Fifteenth Congress, first session, p. $5^{8}$.

'Annals 33: 21, 22, 23, 26, 320, 321. 


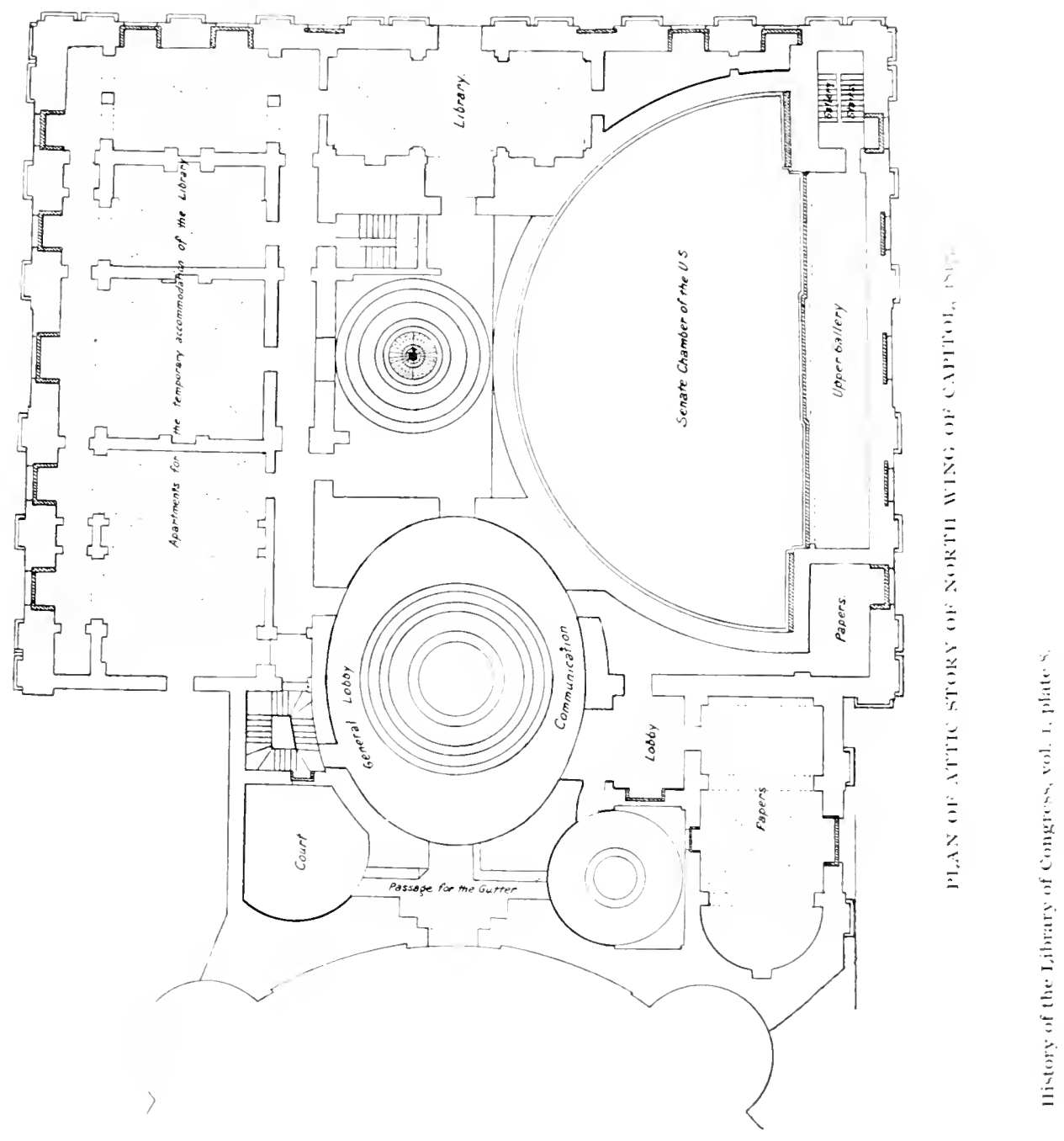



the accounts of the expenditures which may be incurred under this act; and that the amount, so settled, be paid out of any moneys in the Treasury not otherwise appropriated.

SEc. 3. And be it further cnacted, 'That the sum of two thousand dollars be, and the same is hereby, appropriated to the further purchase of books for the said Library.

Approved, December 3 , I 8 i 8 .

Before the close of the year the Library was, in accordance with this act, removed to the north wing of the Capitol, to rooms on the west side, on the same elevation as the upper gallery of the Senate Chamber. ${ }^{\mathrm{I}}$

From a Senate report on the Capitol, made December 20, I8r9, it appears that the apartments to which the Library had been consigned in the attic story of the north wing of the Capitol were hardly sufficient for the accommodation of the Library. The report ${ }^{2}$ of the Library Committee, December I9, IS2O, detailing the operation of the act of December 3, 1818, also represents the cramped conditions of the new quarters to which the Library had been consigned. It is as follows:

By an act of Congress of the 3 d of December, I8 18 , the Joint Library Committee were "authorized to cause suitable apartments in the north wing of the Capitol to be fitted up and furnished for the temporary reception of the Library of Congress, and to cause the said Library to be removed to and placed in the same." Under the provisions of this act suitable apartments were prepared and the Library of Congress deposited in the north wing of the Capitol. $* * *$ When the committee had thus caused the Library of Congress to be placed in the Capitol they presumed that all the duties required of them by the act were performed; and they have not thought themselves authorized to provide for the reception of such books as have been since purchased, or may be hereafter purchased, for the Library. They had intended to lay out the greater part of the funds on hand in the purchase of books during the late recess of Congress, but being informed by the Librarian that no preparations were making, or expected to be made, before the meeting of Congress, for putting up additional shelves in the Library room, and that a large portion of the books purchased during the last

'Watterston's New guide to Washington, r842, p. 64.

"Sixteenth Congress, second session, Senate report No. 25. See also Frances Wright D'Arusmont. Views of society and manners in Anerica. New York, 182r, p. 378 . 
year were still lying upon the tables, it was not thought expedient to make any considerable purchase of books before the meeting of Congress.

The Librarian gives us another and last glimpse of this old Library room in his story entitled "The L_- Family at Washington." In this one of his characters says: "After groping about some time in endeavoring to find the Representatives Hall, I came to a door, which I opened very unceremoniously, and found myself all at once in a region of learning, where, like the Alps, books on books arose. The room was filled with honourable members and their ladies, more intent, I thonght, in gazing at pictures than on feasting their reason. I confess I felt a little odd in being so suddenly soused among such honourable company, but knowing that I contributed as much to the public library as anyone else, I thought it was best to stalk about as if it was my own. $\because \because ;$ Presently I walked into an adjoining apartment, for the Library consists of a suite of rooms, where I met a man that I thought looked devilish sour at me-this was the Librarian."

THE LIBRARY ROOMI IN THE CENTER BUILDING.

The Latrobe plan of $\mathrm{I} \delta \mathrm{I} 7$ provided for the Library a main reading room and three smaller reading rooms and an office on the north. ${ }^{2}$ On the Sth of January, iSis, Charles Bulfinch superseded Latrobe as Architect of the Capitol.

The report of the Committee on Public Buildings, April 4, I $8 \mathrm{I} 8$, showed that plans had been made by the new architect for a library and two reading rooms in the proposed center building. On the $27^{\text {th }}$ of November, I $\$ 20$, the Commissioner of Public Buildings presented to Congress the following report from the Architect of the Capitol (November 19, 1820), regarding the progress of the work:

The external walls of the west projection, and the greater part of the internal walls connected with them, have been raised to the height contemplated in the estimate for the year; the roof is raised on the north

"Washington, I 822, pp. $35-37$.

${ }^{2}$ The Latrobe plan is reproduced in Glenn Brown's History of the Capitol, plate 70. 
flank of the center, and that for the south flank is prepared but has been prevented from being put on by the inclemency of the weather in October and by an unusual sickness among the workmen.

On January 4, IS22, the whole of the stonework of the western projection was reported complete, except the chimneys and some carved decorations in the cornice and some panels; the roofs all raised and covered with copper except a small portion over the Library; the window frames, shutters, and dressings ready for use, the glass, from the best Boston manufactory, on hand, and the carpenters engaged in making sashes, doors, etc. ${ }^{\mathrm{I}}$ Finally, on the gth of December, I822, the exterior of the western projection was complete, the copper covering being finished, the walls painted, the window frames and sashes inserted, and the scaffolding removed, and the front of the building exhibited the appearance which it was intended to retain, excepting only that the iron railing between the columns of the loggia was not yet in place. ${ }^{2}$ On the I $7^{\text {th }}$ of August, I824, the Librarian, with the assistance of three hired men, commenced moving the Library from its old quarters in the north wing of the Capitol to this new and spacious apartment in the center. ${ }^{3}$

On the Ist of January, I825, the following description of the completed Library room appeared in the National Intelligencer:

The room for the permanent accommodation of the Library of Congress has been completed in a style of great beauty and elegance, which entitle it to particular commendation. It occupies nearly the whole west front of the center building, is 90 feet in length, 30 in width, and about 35 in height. It is divided into 12 arched alcoves, ornamented with fluted pilasters, copied from the pillars in the celebrated Octagon

${ }^{I}$ Report of the Commissioner of Public Buildings, January I7, 1822. Seventeenth Congress, first session, House document No. 26.

${ }^{2}$ Report of the Commissioner of Public Buildings, December Io, I822, Seventeenth Congress, second session, Senate document No. 9. It is worthy of note that the danger of invasion from the Houses of Congress was not yet wholly past, for on March 2I, I822, Mr. IHill moved that the House do come to the following resolution: "Resolved, That the Committee on Public Buildings be instructed to inquire into the practicability of preparing, for the accommodation of the House of Representatives, the roon in the center building designed for the Library." The resolntion was, however, ordered to lie on the table. Annals 39: I337.

3 Watterston MSS.

$$
23399-04-9
$$


Tower at Athens. At the entrance, in the center of the roon1, which is approached from the great central rotunda, are two columns of stone, with capitals corresponding with those of the pilasters; and immediately opposite, and fronting the window which leads into the western colonnade, stand two similar columns of stone. Those pillars, with the alcoves, support two galleries, extending nearly the whole length of the room, from north to south, on both sides, and divided into the same number of shelved recesses as the lower apartment. From these recesses springs the arch which forms the ceiling, elegantly ornanented with rich stucco borders, panel, and wreaths of flowers. On the roof, which is about I 2 feet above the ceiling, are three skylights, the wells of which are also beautifully decorated with stucco ornaments; through these and the five windows on the west the light is admitted into the room, and can be lessened or increased at pleasure, by means of Venetian blinds. The principal apartment, as well as the reading room on the north, attached to it, is handsomely furnished with sofas, mahogany tables, desks, Brussels carpeting, etc. At each corner of this splendid apartment is a staircase leading to the galleries above, which are calculated to contain several thousand volumes, and which are so arrauged as to enable anyone to read or write in then with perfect convenience. This room opens into a magnificent colonnade, or loggia, formed by ten pillars of the Corinthian order, between which runs an iron railing to protect as well as to ornament this fine promenade. The Library room is admitted by all who see it to be, as a whole, the most beautiful apartment in the building. Its decorations are remarkably chaste and clegant, and the architecture of the whole displays a great deal of taste. ${ }^{x}$

In the furnishing of the room equal care was taken. By the act of May 26, I 824 , the su11 of $\$ I, 546$ was appropriated for this purpose. The act of February 25, r825, added to this the sinn of $\$ 339$. Stephen P. Morris, a Philadelphia stove m11anufacturer, was given Bulfinch's sectional elevation of the interior of the Library, with the ground plot of the room, in order that the two stoves, to be built in the form of pillars, 111ight correspond with the architecture of the room. ${ }^{2}$ For these stoves and 9 tons of coal $\$ 295.25$ was appropriated March 3, I826. A carpet costing $\$ 1$, OOO was laid on the floor of the I-ibrary. Spermaceti candles placed on the two mantelpicces, the desk, and the tables furnished light after nightfall.

'This description was copied by the Columbian Star, January 15 . See also the Washington City Chronicle, August 8, 1829.

${ }^{2}$ Clement C. Biddle to Watterston, Philadelphia, June 25, I825; S. P. Morris to Watterston, Philadelphia, November 17, 1825. Watterston MSS. 


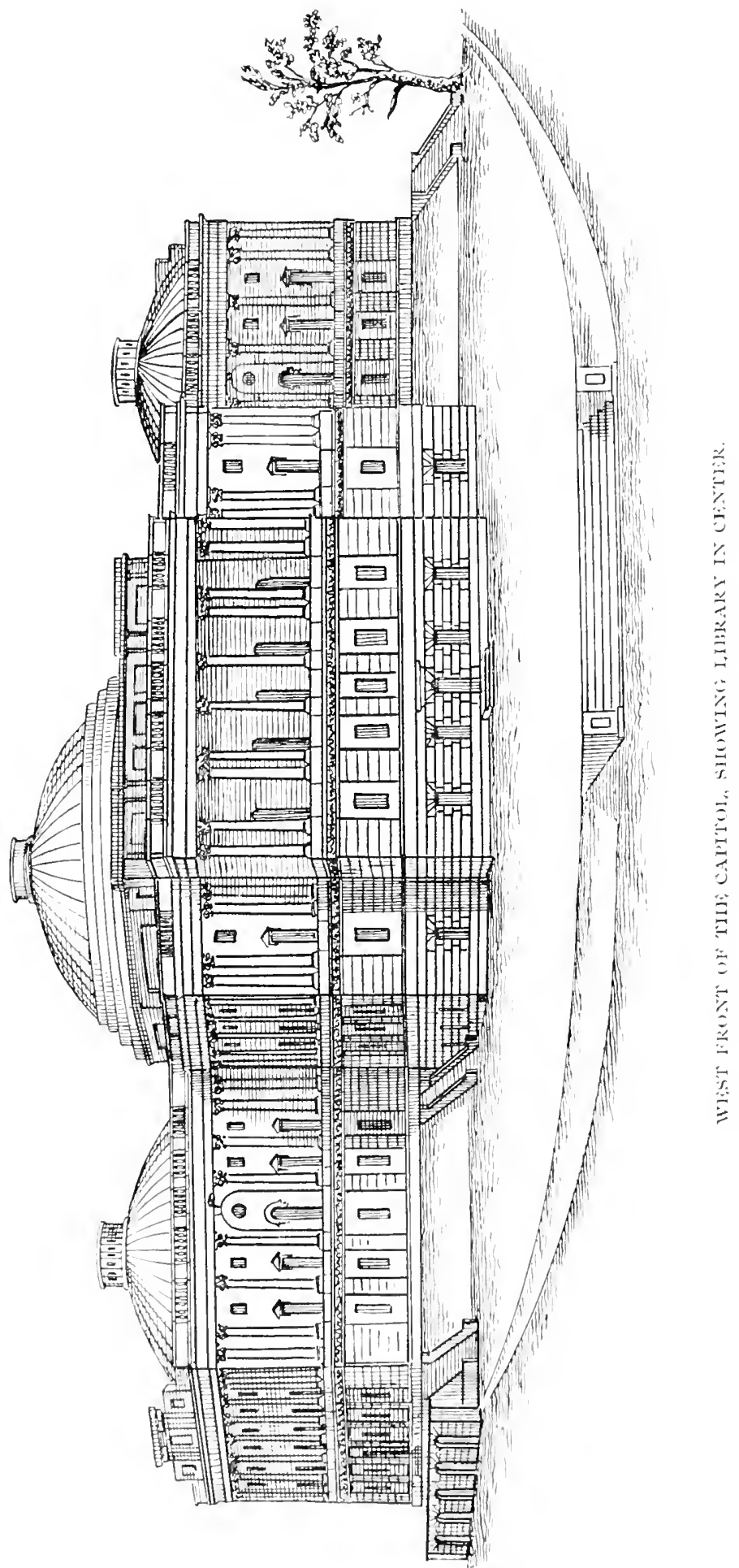





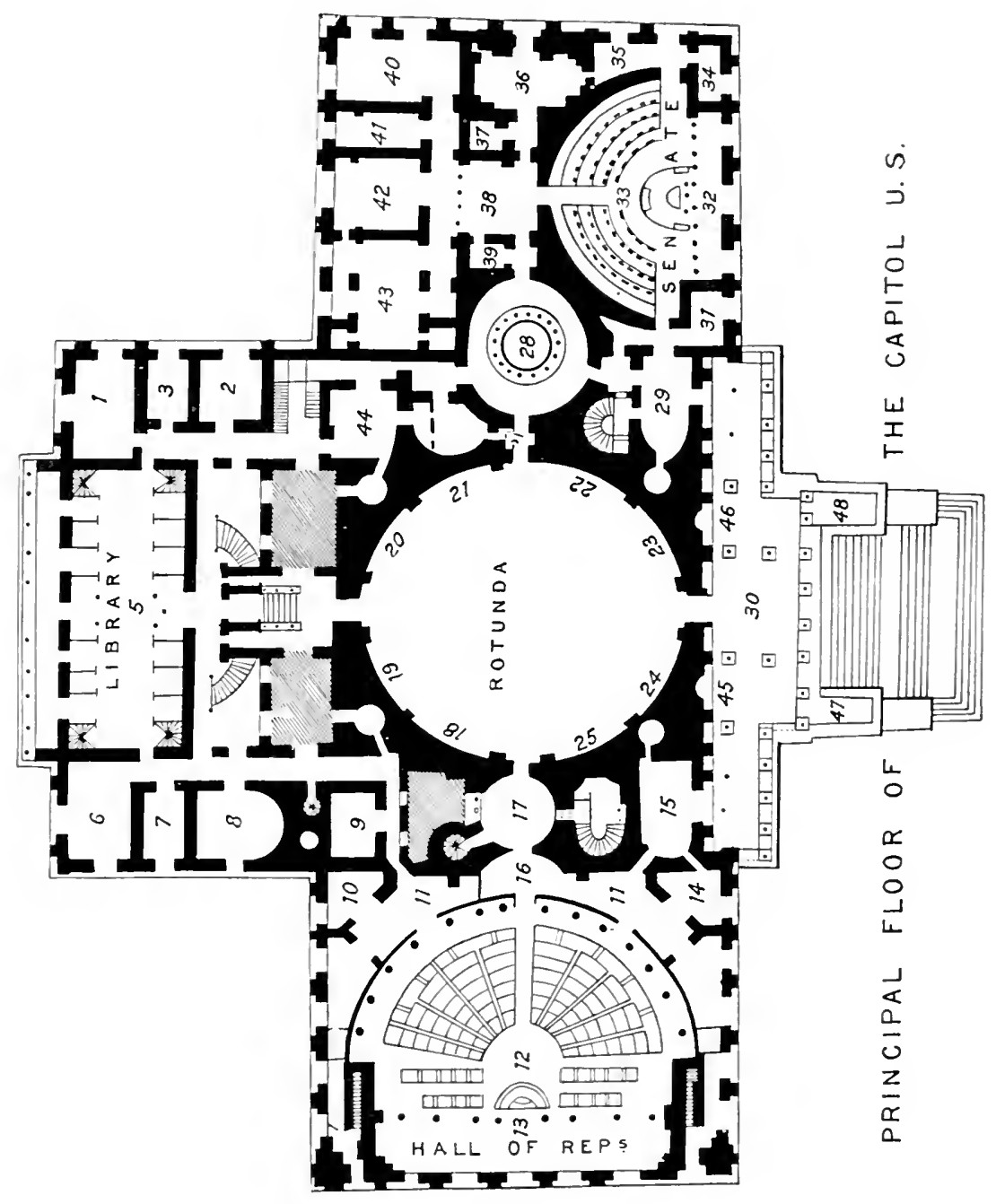



The ambition of the architect was satisfied and the dreann of the Librarian realized. Here was the most beantiful room in the Capitol; some thought the most beautiful room in the country.

The chief artistic attraction of the room at this time was a collection of bronze medals presented to Congress "for the use of the National Library" by George W. Erving in I $822 .^{2}$ This series of medals, cast by order of the French Government according to the design of M. Denon, commenced in the year I796 and terminated in IS I5. It embraced all the memorable battles and events which occurred during the reign of the Emperor Napoleon. There was among the number one commemorating his return from the island of Elba, which, in consequence of the small number cast and the destruction of the die, was especially prized. The subjects of the medals were as follows: The battles of Montenotte, Millesimo, Austerlitz, Jena, Friedland, Essling, Wagram, Moscow, Lützen; the surrender and capture of Mantua; conquests of Upper and Lower Egypt; passage of the great St. Bernard; death of Dessaix; peace of Amiens; La Muse Napoléon; Legion of Honor; the School of Mines; the Code Napoléon; the coronation at Paris; the distribution of Eagles; the tomb of Dessaix; the School of Medicine; the capture of Vienna and Presburg; three Emperors; the conquest of Venice, Istria, Dalmatia, and Naples; confederation of the Rhine; the occupation of the three capitals; peace of Tilsit; the marriage of the Emperor; birth of the King of Rome; the French Eagles upon the Volga and Borysthenes; fonndation of the School of Fine Arts; return of the Enperor; the Empress Maria Louisa; the Princesses Eliza and Panlina; the Queen of Naples; the Queen Hortensia, etc. After seeing this collection Harriet Martineau said, "I was never tired of the cabinet of Napoleon medals, the most beantifu1ly composed piece of history that I ever studied." 3

\footnotetext{
${ }^{2}$ See Life and letters of Charles Bulfinch, Boston, 1896, p. 250; Watterston's Wanderer in Washington, p. 218; Nationat Journat, April $11,1827$.

"New York Statesman, December 17, 23, 1822; copied in National Intelligencer, January $6,10,1823$.

${ }^{3}$ Retrospect of western travel, New York, $1838,1: 164$.
} 
Mr. Erving also presented a series, representing several American worthies, in Parisian bronze. The box which contained them was labeled "Post ingentia facta Deorum in templa recepti." [Their illustrious deeds have won them a place in the Pantheon.] In the arrangement of these last medals George Washington occupied the center, with the inscription "Supremo duci exercituum assertori libertates." [To the commander in chief of our armies and vindicator of onr liberties.] Encircling the Father of his Country were the heads of Columbus, Franklin, Kosciusko, Paul Jones, William Washington, and J. E. Howard.

\section{THE, FIRE OF DECEMBER 22, 1825.}

The lesson which the conflagration of August 24, I8r4, might have tanght had not been learned, or if it had been learned it had not been remembered in the construction of the new Library room of I824. A fire on the night of December 22, I $\delta_{25}$, now brought this to the attention of Congress. It is described in a letter supposed to have been written by Edward Everett, dated December 23, and printed in the Boston Daily Advertiser. ${ }^{\mathrm{I}}$

An unpleasant occurrence took place here last night, threatening a very disastrous result, but which happily passed off without any serious consequences. On returning from Mr. Senator Johnston's last evening, with my wife, at I I o'clock, we perceived when at the foot of Capitol Hill a bright light from some of the windows of the Capitol. Having occasionally perceived a light in some of the offices of the Capitol at a late hour, I supposed at first that the present appearance was that of a lamp or of a fire imperfectly extinguished in some of the fireplaces. On more attentive examination I saw that the light came from the Library, which I knew was regularly slut up at 7 o'clock p. m., and that it was strongest in the middle of the room, where there is no fireplace. My lodgings are directly adjacent to the Capitol, and having driven my wife home, I determined to go and examine into the cause of the light. On approaching the east front of the Capitol I was challenged by the sentry ( $\mathrm{I}$ was not previously aware that a guard was mounted in the Capitol square), and on informing him of the cause of anxiety he assured me nothing was more common than to see a light in the public rooms late at night. After some hesitation he consented to go with me and see what the light was. Finding I was leading him

\footnotetext{
${ }^{2}$ It was reprinted in the National Intelligencer, January $3,1826$.
} 
round to the western front, he refused to accompany me, saying that if the fire was on that side it belonged to the other sentry, who was there mounting guard. I hastened to the western front, but could find no sentry. I went down to the bottom of the steps from which alone a full view of the windows of the Library could be had and the light was then so faint that I was nearly persuaded it 1nust be from a brand in the fireplace. I resolved, howerer, to have it looked after, and returned up the steps with the intention of calling again on the sentinel of the eastern front. In doing this I was at length accosted by a sentry who came out of the door on the western front and challenged me. I had the same explanations to go through with him and the same difficulty to persuade him that there could be anything besides a flame from a half-extinguished firebrand. He, however, agreed to step with me to a spot where he could see the light. He pronounced it not greater than he had often seen, but agreed to call the sergeant of the guard, who, after some time, made his appearance. On my pointing out to him the light he made the same remark as had been made by the sentries-he had often seen such a light before. I begged him to go up and examine the Library or let me do it. It was, he said, locked, and he neither had the keys nor knew who had them nor where to go for information. I then urged him at least to go to the Library door and discover, if possible, by looking through the keyhole, whether there was fire. This he undertook to do, and as the light was at this time very faint I was overpowered by the continual assurance that it was an ordinary appearance, and having no authority (and had I thought it right or possessed the means) to break open the strong mahogany doors of the Library room, I left the sergeant with the remark that "I have done my duty, and he must now do his," and went to my lodgings. The sergeant, as I understood from him, went up to the Library door, but as it was a very closely fitted door with another of baize within, he neither saw any light nor perceived any smoke to issue from the room. He accordingly returned to the guardroom. The appearance which he had seen with me from the window and my urgency with him dwelt, as he stated, on his mind, and after about ten minutes, as he thinks, but I suspect rather longer, he went again to the bottom of the western steps to reconnoitre. The light was now so strong that he thought it his duty to endeavor to get the door opened, though he did not feel authorized in using force for the purpose. After making sereral unsuccessful inquiries in the neighborhood, he fonnd out where the Librarian of Congress lives. This was at some distance from the Capitol and considerable delay, of course, ensued. At length the Librarian and sergeant reached the Capitol, and on opening the Library door a bright fire was discovered in one of the galleries of the hall. A bucket or two of water if then at command would have extinguished it. But there were no buckets at hand and the distance from the pump on the eastern front to the hall of 


\section{I34 DEVELOPMENT OF THE LIBRARY, ISI5-IS29.}

the Library was so great as to prevent a rapid supply by a few hands. It was now after midnight. A small bell in the Capitol yard, used to call the workmen together, was the only means of giving the alarm, and it was necessary for the sergeant and his guard to run round the neighborhood and awaken the inluabitants. I had just gone to bed, but on the first touch of the bell hastened to the Capitol. The engine house was locked, but we wrenched it open. A few buckets were procured, and with these a little water carried to the Library. The nembers and citizens now began to collect rapidly, and an admirable hose, several hundred feet in length, was conducted wholly through this immense building into the hall. This saved the Capitol, though with great difficulty and with a very narrow escape. The fire was just reaching the timber of the arched vault of the hall, from which it would have been difficult to prevent its spreading very widely. It was between two and three hours before the fire was extinguished and by this time the Library hall, so lately one of the most beautiful rooms you ever saw, was a sad spectacle. Upon the whole, however, the loss had not been heary. No books are destroyed which can not be replaced, and the greater part of those burned in the gallery were duplicate sets of public documents.

This narrative is supplemented by the account given in the National Intelligencer, December 24:

About I2 o'clock on 'Thursday night Vincent, the sergeant of the guard on duty at the Capitol, being apprised of an unusual light in the apartment of the Library of Congress, alarmed the Librarian, who instantly came to the spot, and on opening the doors perceived a part of the western gallery (of wood) which runs round the apartment to be on fire. He immediately removed the books in the alcove adjoining, and the alarm being spread the citizens promptly assembled. An engine and hose were bronglit and by the very active exertions of the firemen, aided by a number of nembers of Congress, who ried with one another in their exertions to save the Library, the flames were extinguished in less than an hour.

Very few of the books, and those of little value, are consumed. Some others, of course, are injured by the wet and by a liasty removal, but the loss is trifling to what might have been expected. The ceiling of the saloon is partially destroyed and one of the alcoves of the beautiful apartment. It is believed that the fire originated from a candle, left in the gallery by a gentleman who was reading there till a late hour, and who being upstairs was not noticed when the Library was closed. $* * *$ Among the numbers earliest aroused and most active were Mr. Houston, Mr. Webster, Mr. Dwight, and Mr. Wickliffe. Mr. Ward, of New York, narrowly escaped great injury from the falling of the plaster. 
This list of names was supplemented in the Intelligencer of December 27 by those of Mr. Dickerson, Mr. Noble, Mr. Garnsey, Mr. Sloane, and Mr. Stewart. Of the citizens few were aroused except those on Capitol Hill. Among those Mr. Joseplı Ingle was conspicuously active. In a discussion in I 3 I over the necessity of a water supply for the Capitol it was further remarked that if the fire had continued five minntes longer than it did, the Capitol would have been a ruin on the sncceeding morning, for the two pumps in the yard gave out at the very moment the last bucket was thrown on the expiring blaze. ${ }^{\mathrm{I}}$

On the 2 Sth of December, on motion of Mr. Van Rensselaer, the Honse of Representatives "Resolved, That the Committee on the Library be instructed to inquire into the cause of the fire by which the Library room and the Library of Congress sustained damage on the night of the $22 \mathrm{~d}$ of December, instant, and to report whether any person or persons in the employ of the Government be chargeable with negligence in relation to the same." 2 On the 4 th of January the committee, by Mr. Everett, reported that they did not feel prepared to express an opinion on the question whether any person in the employ of the Government was chargeable with negligence, and the report was ordered to lie on the table. ${ }^{3}$

It was, however, more important to prevent future fires than to discover those responsible for the recent disaster. ${ }^{4}$ One suggested that several hundred cords of wood piled beneath the Capitol should be removed; if there was treachery

${ }^{1}$ National Intelligencer, April 6, I8 8 I.

${ }^{2}$ House Journal, p. Ior.

${ }^{3}$ Nineteenth Congress, first session, House report No. 22. Printed also in Washington Gazette, January 7, 1826 .

${ }_{4}^{A}$ versifier wrote in the Intelligencer, December 27:

The Congress Library has been on fire, But very little damage is sustained;

By error only, prudence we acquire;

'T'is well experience is so cheaply gain'd.

But for this very lucky accident

The Capitol were lost in flames once more;

Precaution, now, forever will prevent

A loss which all the Union would leplore. 
no better materials could be furnished another Guy Fawkes than that. Another wrote to the Intelligencer, December 27: "No lights ought ever to be used in the Library. As the books can be taken out to be read, there can be no necessity for the Library's remaining open after sunset. We have heard that the proper authority is disposed to establish a rule conformable to this suggestion." A "Looker-on" did not agree to this: "The excluding the members from the Library at candlelight would certainly be a preventative, but I have no doubt it would also be, in many cases, a great privation and inconvenience; but even then there might be urgent occasions when it would be indispensable to go into the Library, and with a lighted candle. I therefore take the liberty to offer the following alteration: Let all the wooden shelves be removed, and then let there be fixed as a substitute slabs of cast iron, of suitable length, width, and thickness, supported by light wrought-iron brackets at proper distances, and painted. The expense would be a mere trifle and it would render the Library, etc., completely fireproof." I

Finally, on the $3 \mathrm{~d}$ of January, I 826, the House of Representatives, on motion of Mr. Ward, "Resolved, That the Committee on the Library be instructed to inquire into the expediency of causing the Library room to be made fireproof." In consequence of this resolution the Library Committee sought advice from Charles Bulfinch, Architect of the Capitol, and obtained in response the following letter, dated February 3, I826:

In compliance with the direction of the Committee of the Library, communicated to me, I have taken measures to ascertain what mode could be adopted for rendering the Library fireproof.

The floor of this room is wholly of brick, constructed upon arches, and is incombustible. The arched ceiling is framed of wood, thickly plastered with a hard coat of mortar and stucco; no change could be made in this part, as the walls conld not sustain the strain and pressure of a brick arch of so great a span. The alcoves are of wood, with brick partitions; this woodwork might be removed and stone and iron substituted at an expense $* * *$ of $\$ 18,669.871 / 2$. But it is a subject which deserves consideration, whether such a mass of stone would

'Intelligencer, December 29.

Nineteenth Congress, first session, House Journal, p. I I3. 
not be injurions, and in a few years ruinous, to the books, from the condensation of noisture fron the atmosphere upon freestone. This might be prevented in winter by fires constantly kept in the room, but would prevail in all changes of weather of spring and summer. From an apprehension of damage from this cause to valuable books, I have observed in all the large public libraries which I have had the opportunity of seeing that no other material than wood is used near the books. This is the case at the British Museum and at the Bodleian Library in England, at the Royal and National Library of Paris, and at the Vatican at Rome, and in several instances the books are shut up in wooden cases.

In reply to the other part of your communication, I am of opinion that the danger of fire might be considerably diminished by taking away the part of woodwork that forms the parapet of the galleries, and by putting an iron railing in its place, and by paving the gallery floor with brick.

The amount of these alterations, with the expenses attending the repairs of the Library room, would be $\$ 4,000$, which sum is inserted in the estimates for continuing the work at the Capitol the ensuing year.

On the 6th of February, I826, the Library Committee, by Mr. Everett, presented this letter, together with their report to the House of Representatives. ${ }^{\text {I }}$ The report read as follows:

That this part of the Capitol could not be rendered perfectly fireproof without being wholly rebuilt from the foundations of the western front. The present walls of that part of the building are not of a solidity to sustain an arched roof. The wooden alcoves might be removed and others of stone substituted, but the introduction of such a quantity of stone into the hall of the Library would probably be productive of a dampness very injurious to the books. It would also be attended with great expense, as appears from the accompanying letter from the Architect of the Capitol.

It is supposed that the danger of fire would be diminished by removing the wooden parapet of the galleries and substituting an iron railing in its place. But as this would but partially preclude the possibility of fire, as it would be attended with considerable expense, and other inconvenience, and as the Library can, in the judgment of the committee, be made sufficiently safe by proper care of the lights and fires, the conmittee do not deem it expedient that the House should adopt any measure in the prenises. They therefore recommend the passage of the following resolution:

"Resolved, That the Library Committee of the House of Representatives be discliarged from the further consicleration of a resolution

"Nineteenth Congress, first session, House report No. 66. 
of the House of the $3^{\text {d }}$ of January last, on the subject of causing the I,ibrary room to be made fireproof."

The report was accordingly laid on the table.

In I 836, Richard Bartlett, ex-secretary of state of New Hampshire, called attention to the danger which the Library of Congress was in, but nothing was done to render the Library room fireproof until after the fire of $185 \mathrm{I} .{ }^{\mathrm{I}}$

\section{NEED OF A NATIONAL LIBRARY.}

The plans of the new administration for the library were as comprehensive as its plans for a library building; just as the private library which Congress had acquired must be transformed into a public library, so the Library of Congress must become the library of the nation. This idea was suggested on the title-page of the new catalogue of ISI5. It was also put forward in the National Intelligencer, July 3I, I8I5, in which the following article appeared under the caption "Congressional Library:"

This valuable collection of books has, with some difficulty and labor, been at length displayed and arranged in the honse now occupied by Congress. Fron the slight examination we have been enabled to make of this library as we are glad to find the selection judicious and the collection rare and valuable.

In all the civilized nations of Europe there are national libraries, the selection and increase of which occupy much of governmental attention. In a country of such general intelligence as this, so landable an example should by all means be imitated, and the Congressional or National Library of the United States become the great repository of the literature of the world-the medium of information and the source of improvement and gratification to all whom inclination nay prompt or whom curiosity may lead to literature. We are happy to say that this is the fonndation of such an establishment and that by the fostering patronage of Government it may, in a few years, be made the equal to the most extensive and splendid libraries of Enrope, the sneers of the British editors to the contrary notwithstanding. This Iibrary contains alnost every work of merit in the varions branches of literature and science in its original language, with various translations. Among its curiosities and varieties are a Gaelic or Irish Bible, Arabic translation of Euclid, the first edition of Paradise Lost, a copy of Shakespeare from an original manuscript, Domesday Book, etc., etc., etc. 
As the foundation of a great national library this is an excellent collection, but it is little more than a foundation. Many works will yet be necessary to complete it and render it worthy of so enlightened a nation. In some of the departments of literature Mr. Jefferson has not kept pace with the march of science or the progress of learning. There is a deficiency of modern authors in some branches, but of his collection of natural history, politics, and law too much can not be said. It is, we think, much superior to the old Library in the number of volumes and the scarcity and intrinsic value of those volumes.

With a view to render this important establishment more valuable the propriety is suggested of increasing the annual appropriation for the purchase of books from one to two thousand dollars. It gives us pleasure to say that the Librarian attends every day, which will render an examination of this fine collection of books easy to the curious and the literati.

Similarly, Walsh's American Register, ${ }^{1}$ in referring to the Jefferson collection in the possession of Congress, said:

A better nursery or substratum for a great National Library could not be found, and it surely will be admitted that nothing less is to come within the aim of Congress, both on the score of pride and patriotism. If it could be done by no other agency, it was a sort of duty with this body to transfer the literary treasures of Mr. Jefferson to a spot where they would be easily accessible to them and the nation; and stand out as a nonument of the national taste and discrimination.

There is an absolnte obligation on the part of the Federal Government, to provide in the Federal netropolis, in shape of a library, a great reservoir of instruction in all the departments of human knowledge for the use of the public as well as of its own members, and the library, certainly, nay be so administered as to be open to the one withont at all interfering with the studies or researches of the other. In fact, the idea of an establishment of the kind set apart, and peculiar in the character of its materials, for the use of Congress, could only spring either from great poverty of invention as to the discipline of such establishments, or of a very imperfect view of the qualifications of an accomplished legislator and statesman. It is not for Congress to presume that there is any branch of human science for which a body so universal in its composition, will not hereafter furnish, in some or others of its nnen1bers, a cultivated or active taste; or that there is any branch which may not fall within its immense scope of constitutional action, so as to make the possession of all the best means of judgment, that is the best treatises on it, highly desirable if not indispensable.

'Copied by the Washington Gazetle, July 12, I817, and by the National Intelligencer, July 14, I817. 
The president of Harvard College, John T. Kirkland, in an article in the North American Review for December, ISIS, said:

An extensive library, answering to the wants of the literary men, who are to use it, is essential to the public and effectual promotion of learning. In this country, the want of large libraries is a serious discouragement of superior attainments and accurate researches in almost every walk of study. The time necessary for reading or examining a particular book is often consumed in attempts to discover or obtain it; and frequently after every effort, it camnot be procured. We are obliged to give over our inquiries on subjects, where we would arrive at fulness and exactness in our knowledge, because destitute of the assistance, which the learned, in the same track of study, have furnislied, or to continue them under the disadvantage of ignorance respecting what has been done by others. Thus we are liable to be occupied in solving difficulties, which have been already cleared, discussing questions, which have been already decided, and digging in mines of literature, which former ages have exhausted. Every one, who has been in the way of pursuing any branch of study in our country beyond the mere elements, or the polite and popular literature of the time, knows how soon the progress is often arrested for want of books. This is not the case merely with persons of moderate means, who are unable to purchase a library of their own, but it is a want felt under the most favorable circumstances. *** Our libraries are miscellaneous, their number of books small, the sum total scattered over all the branches of knowledge, and introduced by separate contributions, without mutual reference to each other.

It may still be said we do not want books. What do we then want? Do we want literature? Do we want science? Do we want knowledge to be in the land? Do we want something written, that will give a tone to the nation, that will promote a general taste in the people, that will furnish our children something to boast of? Will it be said, a great library will not supply these wants? Let Mr. Ames answer:--"all the libraries in America would not furnish materials for a work like Gibbon's Decline of the Roman Empire." Whatever causes may stand in the way of such a work being written, this is one and an adequate one, - for all the gifts and graces within the circle of the seven sciences, cannot confer the power of working without tools. One would think that a library should be that, wherein least division of opinion should exist. In this, all other nations have agreed, ancient and modern, Greek and Roman, Catholic and Protestant, all have their large libraries. We alone will take upon ourselves to do with them; either despising the literary character, or nudertaking to invent over again the arts and sciences, and rewrite the books of all the other countries and ages. 
And Henry E. Dwight wrote in I $826:$ " "I should look upon the individual who should establish such a library in the United States as that of Göttingen as the greatest benefactor to my country who has lived since the days of Washington."

At that time, however, Washington was not a good location for a large library. It was the home of few stndents and it was too far removed from the homes of such students as there were at that time in other parts of the country.

\section{CLASSIFICATION OF THE LIBRARY.}

The first problem of the administration, after a room had been fitted up for the reception of the new Library in the Blodget Building, was the classification and arrangement of that Library in its new quarters. Already, on the 26 th of

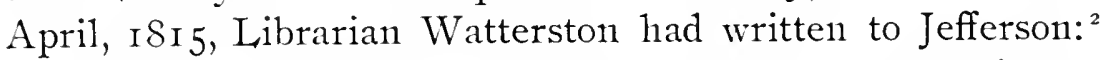

You will excuse the liberty I take, as a stranger, in trespassing on your attention. The President has been pleased to appoint me Librarian to Congress, and consequently superintendent of the books now in your possession. I am solicitous to obtain your opinion as a gentleman of literary taste on the subject of arrangement. Your long acquaintance with books and your literary habits have, doubtless, led you to the adoption of some plan of arrangement with respect to libraries, which I should be happy if you would communicate. If you think the plan you have followed in the arrangement of the present library be the most judicious, you would oblige me by having the books packed up in boxes according to that arrangement. I have long thought the arrangement of the old Library was incorrect and injudicious, and must therefore, be avoided in the present which is considerably larger, and I presume, much more select and valuable.

You would oblige me by advising me when you think the books will reach this place. I am preparing a room for their reception, which I think will be completed in the course of a month. You will not neglect to forward a catalogue if you have a spare copy, as I wish to have it printed as early as possible. I fear the room selected is not quite large enough to contain the books. If so, I will have some artificial stands erected to receive them.

In response Jefferson sent him an account of his system of library classification. This system, like that of D'Alembert

'Travels in Germany, p. $18_{3}$.

2Jefferson MSS., series 2, vol. 88, No. 53 . 
and the Encyclopedists, and like that of Augustus Brevoort Woodward, a friend of Jefferson's, an early resident of the District of Columbia, and for a time judge of the Territory of Michigan, was based on the Baconian classification of science. Librarian Watterston expressed the belief in the National Intelligencer, June I5, I853, that Jefferson was much indebted to Woodward in the elaboration of his system of classification, but the correspondence between the two seems to indicate that if there was any indebtedness at all it was on the other side, for in a letter of August I6, ISI3, some years before he had published his own system, Woodward wrote to Jefferson about the latter's system, ${ }^{\mathrm{r}}$ and when Jefferson's system was published in I $\delta_{15}$, criticised it as not being capable of indefinite division and expansion. ${ }^{2}$

Jefferson explained his system of classification, first in a letter to Librarian Watterston, dated May 7, I8 I5, and afterwards in a preface to "A catalogue of books forming the body of a library for the University of Virginia," ${ }^{3}$ written between the years I $S_{20}$ and I $S_{2} 5$.

The latter was Jefferson's only formal explanation of his system of classification; it is also more theoretical than the letter to Mr. Watterston. It may, therefore, be given first:

An explanation of the Views on which this Catalogue has been prepared.

I. Great standard works of established reputation, too voluminous and too expensive for private libraries, should have a place in every public library, for the free resort of individuals.

2. Not merely the best books in their respective branches of science should be selected, but such also as were deemed good in their day, and which consequently furnish a history of the advance of the science.

3. The opera onninia of writers on various subjects are sometimes placed in that chapter of this Catalogue to which their principal work belongs, and sometimes referred to the Polygraphical chapter.

4. In some cases, besides the opera omnia, a detached tract has been also placed in its proper chapter, on account of editorial or other merit.

'Jefferson MISS., series 2, vol. 88, No. 155.

'Charles Moore, Augustus Brevoort Woodward, in records of the Columbian Historical Society (I9OI), 4: I24-I25; see also the National Intelligencer, October 7, 1818 , and the explanations of "Woodward's epistemic system, chiefly notable for its nomenclature," in the National Intelligencer, Nay 26, 1819, and January 26, 1821.

${ }^{3}$ This preface is printed from the MIS. preserved in the University of Virginia by the University librarian, Mr. F. W. Page, in the Alumni Bulletin of the University of Virginia, 2: 79, November, 1895 . 
5. Books in very rare langtuages are considered here as specimens of language only, and are placed in the clapter of Philology, without regard to their subject.

6. Of the classical authors, several editions are often set down on account of some peculiar merit in each.

7. Translations are occasionally noted, on account of their peculiar merit or of difficulties of their originals.

8. Indifferent books are sometimes inserted, because none good are known on the same subject.

9. Nothing of mere anusement should lumber a public library.

Io. The Sro. form is generally preferred, for the convenience with which it is handled, and the compactness and symmetry of arrangement on the shelves of the library.

I I. Some chapters are defective for the want of a more familiar knowledge of their subjects in the compiler, others fron schisms in the science they relate to. In Medicine, e. g., the changes of theory which have successively prevailed, from the age of Hippocrates to the present day, have produced distinct schools acting on different hypotheses, and headed by respected names, such as Stahl, Boerhave, Sydenham, Hoffman, Cullen, and our own good Dr. Rush, whose depletive and mercurial systents have formed a school, or perhaps revived that which arose on Harvey's discovery of the circulation of the blood. In religion, divided as it is into multifarious creeds, differing in their bases, and more or less in their superstructure, such moral works have been chiefly selected as may be approved by all, omitting what is controversial and merely sectarian. Metaphysics have been incorporated with Eithics, and little extention given to them. For, while some attention may be usefully bestowed on the operations of thought, prolonged investigations of a faculty unamenable to the test of our senses, is an expense of time too unprofitable to be worthy of indulgence. Geology, too, has been merged in Mineralogy, which may properly embrace what is useful in this science, that is to say, a knowledge of the general stratification, collocation and sequence of the different species of rocks and other mineral substances, while it takes no cognisance of theories for the self-generation of the universe, or the particular revolutions of our own globe by the agency of water, fire, or other agent, subordinate to the fiat of the Creator.

The letter which President Jefferson wrote to Librarian Watterston, May 7, I $\delta_{\text {I } 5}$, was, under the circumstances, of a more practical character. It was as follows: ${ }^{\mathrm{r}}$

I have duly received your favor of April 26th, in which you are pleased to ask my opinion on the subject of the arrangement of libraries. I

$$
\text { 'Jefferson Miss., series I, vol. I4, No. } 4 .
$$




\section{I44 DEVELOPMENT OF THE LIBRARY, I 8I5-IS29.}

shall conmunicate with pleasure what occurs to me on it. Two methods offer themselves, the one alphabetical, the other according to the subject of the book. The former is very unsatisfactory, because of the medley it presents to the mind, the difficulty sometimes of recalling an author's name, and the greater difficulty, where the name is not given, of selecting the word in the title, which shall determine its alphabetical place. The arrangement according to subject is far preferable, although sometimes presenting difficulty also, for it is often doubtful to what particular subject a book should be ascribed. This is remarkably the case with books of travels, which often blend together the geography, natural history, civil history, agriculture, manufactures, commerce, arts, occupations, manners, etc. of a country, so as to render it difficult to say to which they chiefly relate. Others again, are polygraphical in their nature, as Encyclopedias, magazines, etc. Yet on the whole I have preferred arrangement according to subject, because of the peculiar satisfaction, when we wish to consider a particular one, of seeing at a glance the books which have been written on it, and selecting those from which we effect most readily the information we seek. On this principle the arrangement of my library was formed, and I took the basis of its distribution from Lord Bacon's table of science, modifying it to the changes in scientific pursuits which have taken place since his time, and to the greater or less extent of reading in the science which I proposed to myself. Thus the law having been my profession, and politics the occupation to which the circumstances of the times in which I have lived called my particular attention, my provision of books in these lines, and in those most nearly connected with them was more copious, and required in particular instances subdivisions into sections and paragraphs, while other subjects of which general views only were contemplated are thrown into masses. A physician or theologist would have modified differently, the chapters, sections, and paragraphs of a library adapted to their particular pursuits.

You will receive my library arranged very perfectly in the order observed in the catalogue, which I have sent with it. In placing the books on their shelves, I have generally, but not always, collocated distinctly the folios, quarto, octavo, and duodecimo, placing with the last all smaller sizes. On every book is a label, indicating the chapter of the catalogue to which it belongs, and the order it holds among those of the same format. So that, although the numbers seem confused on the catalogue, they are consecutive on the volumes as they stand on their shelves, and indicate at once the place they occupy there. Mr. Milligan in packing them has preserved their arrangement so exactly, in their respective presses, that on setting the presses up on end, he will be able readily to replace then in the order corresponding with the catalogue, and thus save you the immense labor which their rearrangement would otherwise require. 
To give to my catalogue the convenience of the alphabetical arrangement I have made at the end an alphabet of authors' names and have noted the clapter or chapters, in which the name will be found; where it occurs several times in the same chapter, it is indicated, by one or more perpendicular scores, thus $11 \mathrm{I}$, according to the number of times it will be found in the chapter. Where a book bears no author's name, I have selected in its title some leading word for denoting it alphabetically. This member of the catalogue would be nore perfect if, instead of the score, the number on the book were particularly noted. This could not be done when I made the catalogue, because no label of numbers had then been put on the books. That alteration can now be readily made, and would add greatly to the convenient use of the catalogue.

How these instructions were carried out in the classification of the Library will be made clearer by an examination of the table of contents and chapter headings of the catalogue of I8I5. There 44 main classes are set down, and under them several subclasses, as follows:

I. History, civil; ancient history.-2. Modern history, foreign, southern: General works, Italy, Rome, Florence, Naples, Venice, Spain, Portugal, France. Northern: General works, Lapland, Russia, Poland, Hungary, Sweden, Denmark, Prussia, Germany, Flanders, United Netherlands, Switzerland, Geneva, Turkey, Asia, Africa.--3. Modern history, British, Scotland, Ireland.-4. Modern history, American, Ante-Revolutionary: General, particular. Post-Revolutionary: General, particular. Newspapers.-5. History, ecclesiastical.-6. History, natural: physics, natural philosophy.-7. Agriculture.-8. Chemistry.9. Surgery.-10. Medicine.-1 1. Natural history: Animals, anatomy.12. Natural history: Animals, zoology.-13. Natural history: Botany.14. Natural history: Mincralogy.-15. History, natural: Occupations of man, technical arts.-16. Philosophy, moral: Ethics, (I) moral phi1osophy, (2) law of nature and nations.-17. Religion.-IS. Jurisprudence: Equity.-19. Jurisprudence: Common law, bodies of law, statutes, courts, entries, conveyancing, criminal law, tracts, reports.-2o. Jurisprudence: I aw, merchant.-21. Jurisprudence: Law, maritime.22. Jurisprudence: Law, ecclesiastical.-23. Jurisprndence: Foreign law.-2.4. Politics: General theories of government, special governments. Ancient. Modern. France: Monarchical, revolntionary, inperial, her colonies. Fngland: Constitution, Parlianent, dependencies. United States: Colonial, Revolutionary, reconstituted, States. Political economy: General, statistics, commerce, finance.-25. Mathematics, pure: Arithmetic.-26. Nathematics, pure: Geometry.-27. Physics-mathematics: Mechanics, statics, dynamics, pneumatics, phonics, optics.-28. Astron- 
on1y.-29. Geography, general: Europe, Asia, Africa, America.-30. Fine arts: Architecture.-31. Fine arts: Gardening, painting, sculpturing.-32. Fine arts: Music.-33. Poetry, epic.-34. Romance, tales, fables. - 35. Pastorals, odes, elegies, etc.-36. Didactic. - 37. Tragedy.38. Comedy.-39. Dialogue, epistolary - 40. Logic, rhetoric, orations.4I. Criticism: Theory.-42. Criticism: Bibliography.-43. Criticism. Languages, general: Polyglot, Oriental, Greek, Latin, Italian, Spanish, French, Northern, English, Welsh.-44. Polygraphical.

These were the 44 chapters or classes in which the Library remained, with slight changes, until the end of the century. How they were derived will be made clear by the accompanying plan, a facsimile of that printed in the catalogue of ISI 5 .

This system of classification was an innovation in the book world, which seems to have been appreciated by intelligent visitors to the Library. One of these, Mr. Mackenzie, editor of the Colonial Advocate, York, Canada, wrote that the Library was "remarkably well arranged, each description of books being kept by themselves," "and the editor of the Washington City Chronicle, in commenting upon his remarks, said: "The arrangement, of which the writer speaks so favorably, is one which has been much admired for the facilities it affords of finding any volume or subject that may be required." The criticism of the Washington City Chronicle, July I I, I 829, was similarly flattering, and at the same time instructive. Its observation regarding the system of classification was this: "It is, perhaps, the best that has yet been introduced. It is indeed, scientific, and by keeping all books upon the same subject together and under one head, it affords facilities that no other mode hitherto adopted has been found to yield. This classification is, however, not so well calculated for display as the common mode of arranging according to size, because one division being often much less than another, large volumes are some times placed above smaller ones, or chasms are left in the shelves which are not agreeable to the eye. But the subjects being kept apart, each can with more facility be consulted. To render this arrangement more complete it would be proper to make some addi-

'Colonial Advocate, reprinted in Washington City Chronicle, November 7, 1829, and in Nalional Intelligencer, November 9, 1829. 

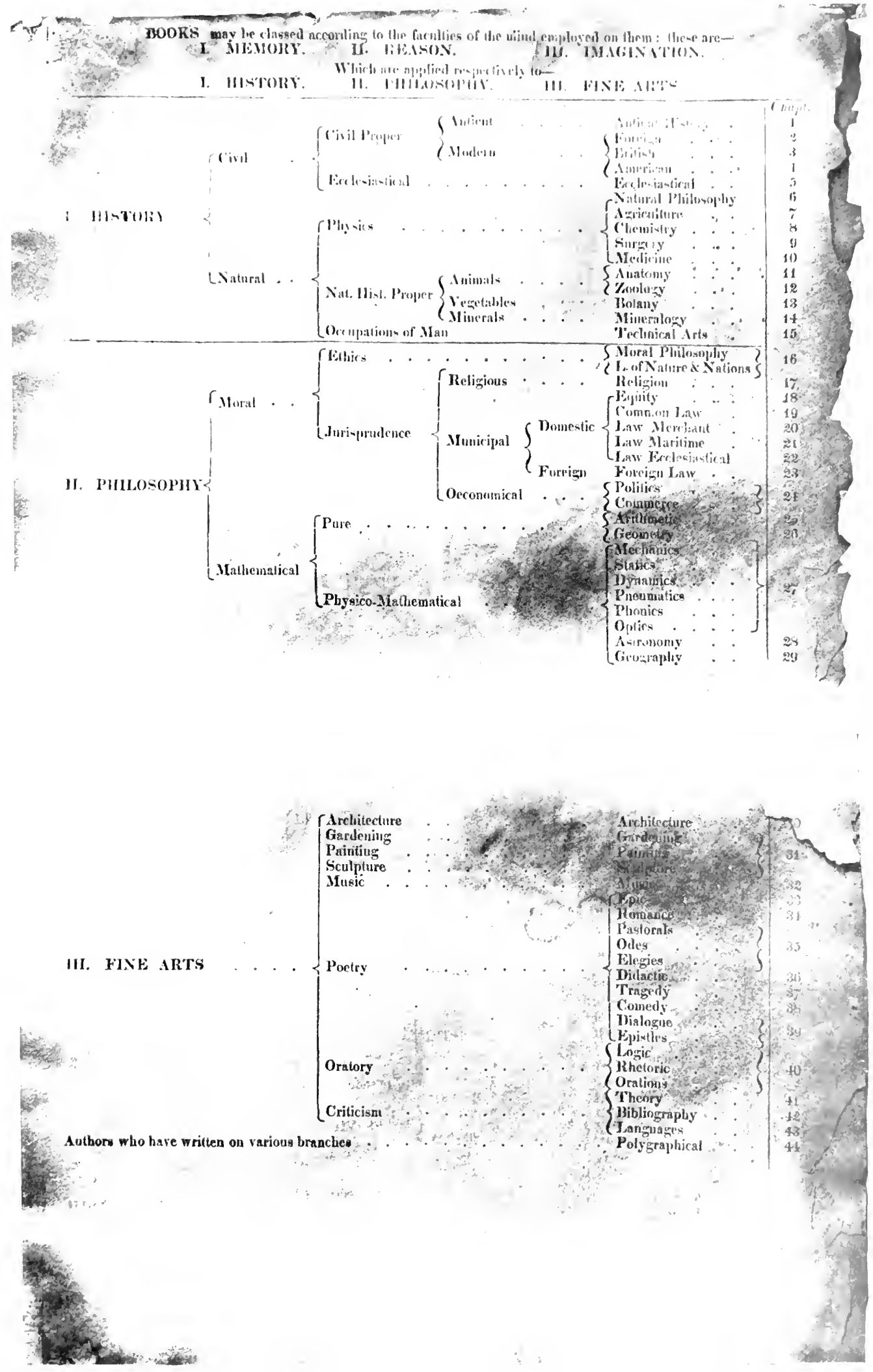

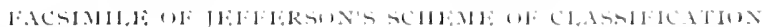



tional subdivisions, as Biograplyy, ancient and modern, Archæology, Conchology, etc."

It is interesting to note that Jefferson himself would have clianged the system somewhat. In a letter to Woodward, dated March 24, I 824, acknowledging the receipt of Woodward's system of nuiversal science, he said: ${ }^{1}$

"Were I to recompose my tabular view of the sciences, I should certainly transfer a particular branch. The naturalists, you know, divide the history of Nature into three kingdoms, or departments, Zoology, Botany, Mineralogy. Ideology, or mind, however, occupies so much space in the field of science, that we might perhaps erect it into a fourth kingdom, or department, but inasmuch as it makes a part of the animal construction only it would be more proper to subdivide Zoology into physical and moral, the latter including ideology, ethics, and mental science generally. In my catalogue, considering ethics as well as religion, as supplements to law in the government of men, I had placed them in that sequence, but certainly the faculty of thought belongs to aninal history, is an important portion of it, and shonld there find its place."

\section{CATALOGUFS OF THE LIBRARY.}

In the cataloguing of the Library Jefferson's advice was not followed with equal fidelity nor with equal applause. On the I $3^{\text {th }}$ of October, I8I5, Librarian Watterston wrote to Mr. Jefferson: ${ }^{2}$

"I am happy to inform you that the catalogue is now in press, and that in a few weeks, it will be published. I have preserved your arrangement, as one that I think excellent and that I had previously thought of adopting. I lave introduced but one alteration, and that is in arranging each chapter alphabetically. Having pasted printed labels on each volume, it gives them a unifornity of appearance quite agreeable to the eye. Having put them up in a very beautiful and commodious appartment, the display is really beantiful, and seems to meet with the approbation of all. The proof-sheet 
of the catalogue is examined several times, and by several persons, so that it is as accurate as can well be made. I have from the very scant and limited appropriation made by Congress (only Soo dollars), been obliged to exercise some ingenunity to get the catalogue printed before the session of Congress. As soon as it is completed, I will send your a copy."

Watterston had retained Jefferson's chapter divisions in the catalogue, but had thrown the different subdivisions and paragraphs together. For example, he had retained "Chapter 2. Modenn History: Foreign." But the subdivisions and paragraphs of that chapter- "Southern: General works, Italy, Rome, Florence, Naples, Venice, Spain, Portugal, France. Northern: General works, Lapland, Russia, Poland, Hungary, Sweden, Denmark, Prussia, Germany, Flanders, United Netherlands, Switzerland, Geneva, Turkey, Asia, Africa"according to which the books had previously been classified, were merely indicated in the chapter headings of the catalogue; the titles were arranged in one alphabet.

This arrangement was satisfactory neither to Jefferson nor to the Library Committee. The former thought it too unscientific and objected to any modification in the system of cataloguing and classification which he had suggested. He wrote March 2, I $8 \mathrm{I} 6$, , "I received three copies of the catalogue from Mr. Milligan, for which I thank you. The typography is handsome, and the execution generally pleasing to the eye. There are some errors of the press, but with such a number of titles in so many different languages it could not be expected to be otherwise. You ask how I like the arrangement of the chapters. Of course, you know, not so well as my own; yet I think it possible the alphabetical arrangement may be more convenient to readers generally than mine, which was something analytical, something chronological, and sometimes a combination of both."

The Library Committee, on the other hand, thought the arrangement of the catalogne too scientific, and objected because the Librarian had not made further modifications in the system suggested by Jefferson. To this the Librarian

\footnotetext{
'Jefferson MSS., series 2, vol. 88, Nos. 51-52.
} 
referred in his letter to Jefferson, dated Jannary 29, I 8 I6, as follows:" "The Library Committee are dissatisfied witl me for having the catalogue printed without having waited to consult their superior judgment; but the nuembers generally speak very highly of your arrangement and disposition of the books, and, I suppose, will have no hesitation in allowing for its printing, the report of the committee to the contrary notwithstanding."

The report of the Library Committee here referred to had been made three days before, and was as follows: "Your committee are persuaded that however ingenous, scientific, philosophical, and useful such a catalogue may be in the possession of a gentleman who, as was the case with the former proprietor of this now the Library of Congress, has classed his books himself, who alone has access to them, and has become from long habit and experience as perfectly familiar with every book in his library as a man who has long lived in a city is familiar with every street, square, lane, and alley in it; still this form of catalogue is much less useful in the present state of our Library, consisting chiefly of miscellanies, not always to be classed correctly under any particular head, than a plain catalogne in the form which had been adopted for the formation of the catalogue of the old Library, which probably might not have cost more than $\$$ IOO, if that much, whilst the catalogue with which we were presented, including three copies of it bound half gilt, costs the United States $\$ I, 360.50$, one-third more than the annual appropriation made heretofore by Congress for the additional increase of the Library, and more than one-twentieth of the actual cost of our whole Library." The main point against the catalogue was its cost.

Impartial observers, however, and among them the editor of the Colonial Adrocate, above mentioned, adnired the form of the catalogue as one particularly useful in large libraries, and facilitating the finding of not only any author wanted, but also of other works treating upon related subjects. The later Library Committee, too, recognized this, and in the

$$
\text { 'Jefferson MSS., series 2, vol. 88, No. } 56 \text {. }
$$


compilation of the next considerable supplement to the catalogine of ISI5-the catalogne of IS27-the same arrangement was observed. ${ }^{1}$

The first step taken by the new administration to complete the collection of books in its custody was to publish the following notice in the National Intelligencer September I5, ISI 5:

CARD.

LIBRARY OF THE UNITED STATES.

Congress having supplied the loss occasioned by the rude and conflagrating hand of our late enemy by the purchase of a library perhaps equal in value, as far as it extends, to any in Europe, and intending, as they no doubt do, to make it the great national repository of literature and science, and in sone instances of the arts also, it is desirable that Anerican authors, engravers, and painters who are solicitous to preserve their respective productions as mementos of the times, would transmit to the Library a copy of such work as they may design for the public eye. This will serve not only as a literary history of this now interesting country, but will also tend to exhibit the progress and improvement of the arts. The Librarian, so far as his power and means extend, will take due care that such productions, literary or graphic, as may be forwarded to him shall be properly preserved and advantageously exhibited.

\section{GEORGE WATTERSTON,}

Librarian of Congress.

In this letter it is possible to see the influence of Doctor Thornton and the Patent Office, at this time located in the Post-Office building also, and possibly of the English copyright laws, which provided copies of copyrighted works for each of the leading libraries of the Kingdom.

Of more immediate consequence were the recommendations of the Library Committee touching the deficit in the Library account incurred in the classification and cataloguing of the Library. On the I 5 th of December, ISI5, on motion of Mr. Forsyth, the Honse instructed the Library Committee to inquire into the expediency of increasing the sum appropriated for the salary of the Librarian of Congress, and for the contingent expenses of the Library, and of allowing additional compensation to the Librarian for services performed since the last session of Congress; and on the 26th

\footnotetext{
'The supplements of $18_{20}, 18_{25}$, and $\mathrm{I}_{2} S$, numbering respectively 28,40 , and 16 pages were naturally arranged in one alphabet.
} 
of Jannary, isi6, Mr. Fromentin, from the Joint Library Committee, made the following report: ${ }^{\mathrm{t}}$

* * * Your committee have received from the Librarian several accounts of expenditures, amounting together to the sum of three thousand one hundred and sixty-five dollars and sixty-seren and a half cents, exclusive of a sum of fire hundred and serenty-two dollars and thirtyseven and a half cents paid for packing and transporting the library, and of the sum of $\$ 1,520.77$ for fitting up the room where the library is now kept, which several sums were appropriated by the act of the 3 rd of March, I8I5, entitled "An act to provide a Library room, and for transporting the library lately purchased." Both the letters receired from the Comptroller of the Treasury, as far as respects the expenses of packing and transporting the library; and from the superintendent of public buildings in Washington, so far as respects the expenses for fitting up the room where the library is now kept, and the accounts exhibited by the Librarian are subnitted with, and your committee pray that they may be considered as a part of, this their report.

With respect to the account of expenditures delivered to your committee by the Librarian, your committee observe that, except the annual appropriation of eight hundred dollars which has been received by the Librarian, there has been no appropriation made by Congress, nor, as far as your committee could ascertain, any authorization given by any person to the Librarian. This unauthorized expenditure leaves a deficit to be provided for, of $\$ 2,365.67 \%$. Your committee submit it to Congress whether the peculiar circumstances in which the Librarian was placed, justified in part or in totality the expenditures incurred by him. They cannot, however, help observing that some of the charges appear to them exorbitant, and therefore, in the bill which they have reported, they recommend that an authorization be given to the committee, before payment be made, to have a due investigation made of the several items of the accounts, advising at the same time, an appropriation for the whole sum claimed: provided that if a surplus should be unexpended, in consequence of the investigation, it may be added to the annual Library fund of one thousand dollars for this year, to be expended for the purchase of books, under the direction of the Joint Library Commintee.

It is enough to cast a rapid glance over the catalogue of the Library of Congress to be immediately sensible of the immense hiatus which some of the departments of arts or sciences exhibit. Some of the brauches of the arts and sciences are swelled to a prodigious size, which at the same time that it is by no means a certain proof of a greater degree of health in these parasite branches, manifests every symptom of threatening decay in the tree itself. This was observable likewise in the old Library of Congress, although in a less ciegree. This result is

'The first paragraph, relating to the roum, has been quoted on p. I 22. 
not to be wondered at, if we consider that the inconsiderable sums put from time to time at the disposal of the joint committee precluded the possibility of their availing themselves of the many opportunities which, for twenty-five years past, were daily offering in Europe of purchasing large collections of very valuable books on reasonable terms. Those opportunities are not yet all gone by, and your committee think that the convulsions of the eastern might, in a literary view, be made conducive to the interests of the western world. The present Library of Congress is a good foundation; and one half of the sum which it has cost, judiciously employed under the direction of the Joint Library Committee, would place within the reach of every menber of Congress all the most valuable books in every department of arts and sciences, of which there is now such a lamentable deficiency. With that view your committee propose an appropriation of ten thousand dollars for the purchase of books and maps, independent of the annual appropriation of one thousand dollars for the same purpose, which they submit to Congress to make perpetual.

The Joint Library Committee have taken into their consideration, a resolution referred to them by the House of Representatives on the I $5^{\text {th }}$ of December last; and upon the most serious consideration given to the subject, your committee do not deem it necessary to recommend the allowing any additional compensation to the Librarian for services performed since last session of Congress. The L,ibrarian has received from the Treasury the sum of 480 dollars, which, according to the law as it was at the time of his appointment; and as it is yet, by which he is entitled to two dollars per day for every day's attendance at the Library, computing the number of days during which he was bound to attend at the rate of three days every week during the recess of Congress, and six days every week during the session, exceeds the sum to which he would be entitled by law for his services to this day.

By the accounts of the expenditures exhibited, it appears that the mechanical part of the duties required by law to be performed by the Librarian, has been actually performed by people hired by the Librarian, and for whose compensation you are now called upon to make an appropriation. The manner in which the scientific part of the duties, devolving upon the Librarian, has been fulfilled, do not, in the opinion of your connintee, warrant the allowing of an additional compensation which your committee suppose must be interpreted as conveying on the part of Congress, something like an approbation for past conduct. The only evidence of the literary services of the Librarian, within the knowledge of your conminttee, is the publication of the catalogue with which we were presented at the time of the beginning of the session; and the nerit of this work is altogether due to Mr. Jefferson, and not to the Library of Congress. $* * * *$

"The ensuing paragraph, relating to the catalugue, has been quoted on p. 149. 
The committee have no hesitation in recommending to Congress to increase the sum appropriated for the salary of the Librarian of Congress, and in the bill which they have the honor to submit is to be found a section to that effect.

In looking over the several acts concerning the Library of Congress, your committee have observed, not without astonishment, that by an act passed the 26th of January, I802, the Librarian of Congress was to be appointed by the President of the United States solely. It is difficult to conceive why an officer of both Houses of Congress, as much so as the Clerk of the House of Representatives, and the Secretary of the Senate, are officers of their respective Houses, should not be appointed by the anthority to which he ought to be amenable. The case might happen that a Librarian should neglect his duties; are the nembers of Congress in that case to complain to the President of the United States? Such a thing need merely to be mentioned to demonstrate the impropriety of vesting the President with the sole right of making so inconsiderable an appointment. Accordingly your committee have deemed it their duty to propose, in the bill which accompanies this report, the repeal of so much of the act concerning the Library of Congress, passed January 26 th, I 802 , as provides that the Librarian shall be appointed by the President of the United States solely, and to vest, in future, the appointment of the Librarian in the Joint Library Committee. Provided that, neither the Secretary of the Senate, nor the Clerk of the House of Representatives, nor any of the clerks employed in their offices, or any other officer of either house of Congress, be eligible to the office of Librarian.

On February 2 the bill submitted with this report was debated in Committee of the Whole, amended, and on the 8th read the third time and passed.

Be it enacted by the Senate and the House of Representatizes of the United States of America, in Congress assembled, That the acconnting officers of the Treasury be, and they are hereby, anthorized and required to investigate and settle the accounts against the Library of Congress, exhibited by George Watterston, Daniel Rapine, and Willian Elliot; and the amount thereof, which shall be deemed equitable sliall be paid out of any moneys in the Treasury not otherwise appropriated.

SFC 2. And be it further cnacted, That there shall be allowed the Librarian for attending said Library, an annual salary of one thousand dollars, payable quarterly at the Treasury of the United States, to commence and take effect from and after the twenty-first day of March, eighteen loundred and fifteen. ${ }^{2}$

It was not until the 12 th of April that the bill received the attention of the Honse of Representatives. On that day

'Annals 29: 104, 106, 126, 127.

${ }^{2}$ Eingrossed bills, Senate files. 
it was considered in Committee of the Whole, and reported with the following amendment: "Insert the following as the third section:

"SEC. 3. And be it further enacted, That the privilege of using the books in the Library shall be extended to the Attorney-General of the United States, and the members of the diplomatic corps, on the same terms and conditions, as it is enjoyed by the Judges of the Supreme Court."

2. Amend the title by inserting after the word "Congress," the words, "for extending the privilege of using the books therein."

This amendment was read and concurred in by the House, and on the following day passed as amended. ${ }^{2}$

April I5, the Senate took up the Honse amendment, and "Resolved, That they concur therein." 3

AN ACT providing for the settlement of certain accounts against the Library of Congress, for extending the privilege of using the books therein, and for establishing the salary of the Librarian.

Be it enacted by the Senate and the House of Representatives of the United States of America, in Congress assembled, 'That the accounting officers of the Treasury be, and they are hereby, authorized and required to investigate and settle the accounts against the Library of Congress, exlibited by George Watterston, Daniel Rapine, and William Elliot; and the anount thereof, which shall be deemed equitable, shall be paicl out of any moneys in the Treasury not otherwise appropriated.

SEc. 2. And be it further enacted, That there shall be allowed to the Librarian for attending said Library, an annual salary of one thousand dollars, payable quarterly, at the Treasury of the United States, to commence and take effect from and after the twenty-first day of March, one thousand eight hundred and fifteen.

Skc. 3. And be it further cnacted, That the privilege of using the books in the Library shall be extended to the Attorney-General of the United States and the members of the diplomatic corps, on the same terms and conditions as it is enjoyed by the Judges of the Strpreme Conrt.

Approved, April 16, i8 86.

The committee's recommendation regarding the settlement of the deficit in the accounts of the Library was thus adopted, but their recommendation that the sum of \$ \$o,ooo be appropriated for the purchase of books, in addition to the annual appropriation of $\$ \mathrm{I}$, OOO provided for by the act of December

\footnotetext{
${ }^{2}$ Engrossed bills, Senate files. ${ }^{2}$ IIouse Journal, pp. 645, 646. ${ }^{3}$ Senate Journal, p. 462.
} 
6 , IS I I, was not adopted. The bill appropriating $\$ 2,000$ for a law library, introduced by Senator Harper on the I6th of February, also failed to pass. On the 2oth it had been referred to a select committee consisting of Senators Talbot, Harper, and Hunter, which on March 2 had reported the bill with amendments. On the I2th of March it passed the Senate, but in the House, April 29, it was postponed indefinitely. But the Library had still to its credit for the purchase of books $\$ 3,000$ or $\$ 4,000$. This the Library Committee at once set to work to spend in such a manner as to at once enlarge and strengthen the collection of books in the Library of Congress.

The following letter from the chairman of the Library Committee, Eligius Fromentin, to the Register of the Treasury, Joseph Nourse, asking for information, preceded the action of the committee. It is dated April II, I8I6, and reads as follows:

The Library Committee having it in contemplation to authorize one or more of their members to purchase books for the use of the Library of Congress, during the recess, I an desirous to be informed whether it has formerly been the practice and whether you deem yourself authorized to pay any draft from the chairman of the committee within the amount of money in your hands for the use of the Library, during the recess of Congress.

The Committee have bought books from Coale and Maxwell, booksellers in Baltimore, to the amount of three hundred and eleven dollars and forty-four cents. Would it be convenient to you to send those gentlemen a draft for the amount in Baltimore upon the authorization in this letter, or is there any particular form previously used, and to which you deem it more proper to adhere? In that case, please to give me the information, and send me a blank form for the regulation of my future conduct in that respect.

The committee suppose that the further sum of one thousand dollars for the year 1816, in addition to the sum of sixteen hundred and odd dollars which you informed them was in your hands in December last, is now in your hands at the disposal of the committee. ${ }^{x}$

In a letter from J. G. Palfrey to Jared Sparks, dated Washington, September 5, I 816 , Palfrey says:" "When I was in the city of the Quakers Doctor Priestley's library was exposed for sale at Dobson's. A committee of Congress had gleaned

'Miscellaneous MISS., I,ibrary of Congress.

${ }^{2}$ H. B. Adams, Life of Sparks I: 1 Ig. 


\section{I56 DEVELOPMENT OF THE LIBRARI, ISI5-IS29.}

all the best books. I bouglit a few, not because they were valuable, but because they were Doctor Priestley's."

The following report of the Library Committee, presented in the Senate January 6, I $\delta_{I} 7$, indicates with some detail what was accomplished by the committee during the year ISI6, and what bibliographical plans had been formed by them for the development of the Library. The committee reported:

In pursuance of the duty derolving upon them, to purchase books for the Library of Congress, they have bought, during the recess, the books, a catalogue of which, with the prices and the names of the persons from whom they were bought, is anmexed.

By a reference to the accounts rendered by Joseph Nourse, register of the Treasury, and acting as agent of the Joint Library Committee, which are annexed to (and the committee prays, may be considered as part of) this report, it appears that, since the last account rendered there was paid at different times by order of the Joint Library Committee, a sum of 3,074 dollars 9 cents, leaving in the lands of the agent of the library committee, subject to their order, an unexpended balance of 1,526 dollars $6 \mathrm{I}$ cents. The committee have now under consideration several proposals which, when finally acted upon, shall have employed the whole of the appropriation made in is 2 .

The committee further report, that they have given direction for the following periodical, both literary and political, publications, to be regularly sent to the Library as soon as published, to wit:

The Edinburgh and Quarterly Reviews, republished in New York.

The British Review, The Annual Register, The Analytical Review, Cobbett's Political Register, published in Great Britain.

The North American Review, published in Boston.

The Port Folio, The Analectic Magazine, Walsh's American Register, published in Philadelphia.

The Portico, The Weckly' Register, published in Baltimore.

The National Register, The Daily National Intelligencer, The Historical Register, published in Washington.

All the above periodical works, now are or will soon be completed, from the beginning of publication to the present day.

Of not exactly the same character, but yet liable to the same annual expense, are the following works, if it be deened advisable to complete the publications of this description, which are now deposited in the Library, to wit:-

The Transactions of the American Philosophical Society.

The Transactions of the Royal Society of I,ondon.

The Transactions of the Irish Acadeny. 
Bath Society Papers.

Transactions of the Society of Arts.

Mémoires de l'Académie des Sciences.

Mémoires de l'Institut de France.

Delaplaine's Repository.

Cobbett's State Trials.

Public Characters.

General catalogues published every year in Great Britain, in Leipsic, and in Paris; to which may be added works of merit to be subscribed for occasionally, and which will require a disposable fund to be used on the emergencies created by the publication of such works, either in this country or in Europe.

In order the better to promote the views of Congress in establishing a Congressional Library, and the more securely to provide for, as far as attainable, a proportionately equal application of the Library fund to the several branches of human knowledge, and thereby stamp the Congressional Library with that degree of usefulness contemplated in its establishment, the committee invite the chairmen of the several comnittees in both Houses, to furnish the Library Committee with a list of such books or maps, as may be deemed by them more particularly to refer to the business devolving upon each respective committee.

The committee have, moreover, directed to be placed in the Library a box, where may be deposited by the members of both Houses, the titles of such books as they may be desirous to procure.

The collection of law books, now in the Library, is as valuable and as complete as it is possible to have expected it to be, considering the time at which the books were purchased. But the many late publications which have appeared since, both in this country and in Europe, and the indispensable necessity of laying open all possible sources of the most extensive information on that head, have induced your committee to propose to Congress, to appropriate a sum of three thousand dollars, for the completion of that particular department of the Library of Congress.

The law appropriating one thousand dollars per annum, for the purchase of books for the Library of Congress, has expired. The committee beg leave to report a bill, making a further appropriation of $\mathrm{I}, 000$ dollars per annum, for five years.

In revising the laws passed by Congress concerning the Library, the committee observed that no provision had ever been made, to extend to the heads of the Departments, the privilege of using the books in the Congress Library, on the same terms on which nembers of Congress are permitted to use them. In the bill making a further appropriation for the purchase of books, the committee have inserted a section to remedy that omission. 
The bill accompanying this report, increasing the appropriation for the purchase of books from $\$ I, 000$ to $\$ I, 500$ per annum, on the $9^{\text {th }}$ of January passed the Senate, but in the House, on the following day, it was referred to a Committee of the Whole and forgotten. ${ }^{1}$

On the 9th of January a second bill passed the Senate which was of even more significance than the first. In the Librarian's communication to the public through the National Intelligencer, September I5, I8 I5, he had suggested that the Library be made a place for the deposit of all American books, engravings, etc. This idea was embodied in the bill which now passed the Senate: "That the Joint Library Committee be, and they are hereby, authorized to make, from time to time, a selection of such books as they may deem proper to have deposited in the Congressional Library, out of the books which by the existing laws are to be deposited by the authors or publishers in the office of the Secretary of State, and are now lodged in the Patent Office." z This bill, too, failed to become a law. The committee had on hand an unexpended balance of $\$$ I,526.6I for the purchase of books. That is the only reason, apparently, why Congress failed to pass these two bills, each of which was of great importance to the development of a national library.

DEVELOPMENT OF THE LIBRARY, I8I7-I824.

The anthorities of the Library had elaborated magnificent plans for the Library of Congress between the years I 8 I 5 and ISI7. An11ong them were the plans for a law department, a copyright department, and, above all and embracing all, the plan for a national library, but these plans, like those for a Library building, came to naught.

Nor was the Library Committee much more successfu1 between the years ISI7 and IS24. On the ist of Decenber, ISI7, Mahlon Dickerson, of New Jersey, was made chairman of the commintee, and remained in that position for the next ten years. Senator Dickerson was famed for his love of books. The Librarian called him a biblical

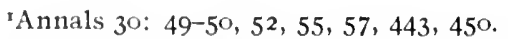

- Senate files, Engrossed bills, Fourteenth Congress. 
cormorant, ${ }^{1}$ and the National Journal (April I I, I827) said that it was due to his indefatigable exertions and literary taste that the additions made to the Library during this time were at once valuable and splendid. Mr. Joel Poinsett also took an interest in the Library and was a nember of the Library Committee during the Seventeenth and Eighteenth Congresses. Of his services the Librarian said: "His taste and judgment in the selection of books, while acting for the committee, were displayed in a manner that pleased all who were concerned." On a visit to England Mr. Poinsett secured for the Library, among other valuable works, a set of the Parliamentary Papers. ${ }^{2}$

The Library also profited during this period by the interest which ex-President Jefferson continued to show in it. September I, I 820, he wrote to the Librarian: "Having lately met with a very full catalogue of books relating to America, I have supposed that it could not be better placed than in your hands for the use of the Library Committee, with whom I presume it is a primary object to obtain everything of that description. By taking the trouble to mark on this catalogue those you possess (which make a great part of those most valuable), the unpossessed will be obvious. I think, however, that in the catalogue of authorities stated in Robertson's America there must be several important works omitted in this, and which I could never get. A standing instruction to the minister in Madrid might in time procure them."

But this knowledge of books was without avail unless appropriations for the purchase of books for the Library could be secured, and in securing these appropriations this committee was hardly more successful after I 8 I 7 than it had been before. In I8I 8 it secured $\$ 2,000$, in I $820 \$ 2,000$, in I 82 I and $I 822 \$ I, 000$, that is, for the years I $8 I 7$ to $I 822$, an average of $\$ I, 000$ per annum, the same sum which had been voted February 2I, ISo6, for a period of five years, and again, December 6, I 8 I I, for the same period. It was not until I 823 that the committee succeeded in securing an increase from $\$ I, 000$ to $\$ 2,000$ in the annual appropriation. It is to be

'The I-Family at Vashington, 1822, p. 77; see also Washington City Chronicle, November 7, I\$29, and National Intelligencer, December 5, 1834 .

${ }^{2}$ Washington City Chronicle, November 9, 1829 . 
noted also that the civil-appropriations act of I $82 \mathrm{I}$ provided $\$ \mathrm{I}, \mathrm{OOO}$ for the purchase of books for the Library, comprehending the statutes and the reports of the decisions of the courts of law and chancery of the different States, with the latest maps of the several States and Territories. This was the condition upon which the appropriation was made at all.

There was only one other legislative measure affecting the interests of the Library during this period, but that too cane to nothing. On the 3oth of April, I822, Mr. Lincoln submitted in the House of Representatives the following resolution: ${ }^{\mathrm{r}}$

Resolved, That the President of the United States be requested to cause to be deposited in the Library of Congress the originals or copies of all such reports, memoirs, or documents, not heretofore published, as have been made by public officers, Indian agents, private individuals, or exploring parties, to the executive department of the Government; together with any maps, drawings, or charts, or copies of the san1e, which in his opinion it may be consistent with the public service to have there deposited.

The resolution was ordered to lie on the table.

The results of the activity of the Library Committee during this time are all shown in the two little catalogues of 1820 and $\mathrm{I}_{2} 5$, the first a quarto of 28 pages, the second an octavo of 40 pages. As we have pointed out in the preceding section, the period from I 8 I 5 to I 824 was the garret period in the history of the Library.

DEVELOPMENT OF THE LIBRARY, I824-1829.

Until i 825 the question of a room for the Library had been uppermost. Before the War it had been kept in a committee room; from i 8 I 5 to 18 I 8 it had been kept in the attic story of the Post-Office building; from I 8 I 8 to $\mathrm{I} 824$ it had been kept in the attic story of the Senate wing of the Capitol. In I 824 , howerer, the completion of the library room dreanied of by the Library Committee for ten years made possible the realization of some of its other dreams.

The completion of the library room, together with the gift of the Royal library to the British people, led the National Intelligencer (August 28, 1823) to say, under the caption 
"National Library:" "We wish we could promise ourselves to see the day when the Library of Congress should be more than half filled with books of acknowledged excellence, in every branch of science, and collected from every country. We should like it, also, to be something more national and truly literary in its arrangements and objects than it has hitherto been. $* * *$ We do hope that Congress will make such regulations for the increase and utility of this noble institution as will contribute greatly to the improvement of our country, the satisfaction of literary men of leisure who reside near the seat of Government, and will increase our respectability in this respect in the eyes of foreign nations. It is obvious that a certain frivolous class of books may and ought to be excluded; but there should be no work of high character and unquestionable utility published in any part of the world which ought not, in time, to find its way into the National Library of the United States."

On the 2Ist of January, I 824, Mr. Poinsett, from the Joint Library Committee, reported the following resolution in the House of Representatives: "Resolved, That the Committee of Ways and Means be instructed to inquire into the expediency of appropriating five thousand dollars for the use of the Library of Congress;" and on the question to agree to the resolution, it passed in the affrmative. In accordance with these instructions, on the 24th of February Mr. McLane, of Delaware, from the Committee on Ways and Means, made the following report: ${ }^{\mathrm{X}}$

That they find upon inquiry that the sum which it has been usual to appropriate annually for the use of the Library is little more than suffcient to purchase laws, reports of cases, periodical publications, and such works as the Library Committee are annually under the necessity of purchasing. The balance is so small as, generally, to confine the purchase merely to works of the day, and if, on any occasion, the committee are enabled to purchase a standard work, the cost is augmented nearly roo per cent by the duties on importation and the profits of the bookseller.

By their own observation, as well as by a reference to the gentlenen charged with the particular superintendence over this subject, the com-

Eighteenth Congress, first session, House report No. 69. 23399-O4-I I 
mittee have discovered the Library of Congress, in its present state, to be defective in all the principal branches of literature; and they deem it of the first necessity that this deficiency should be speedily supplied, at least in the important branches of law, politics, commerce, history, and geograpliy, as most useful to the members of Congress.

It is believed, also, that most of the works which are now required for the foregoing purposes are not published in the United States, and that for this reason, as for motives of economy, it is deemed advisable to make the purcliases in Europe; but this can not be effected witlout an appropriation considerably larger than that annually given.

It is known to the committee that a drawback to a considerable amount is allowed on the exportation of books from England, of which the Library Committee could avail themselves in their purchases, and a disconnt of 25 per cent is allowed by all the booksellers in London, on the catalogue prices, where purchases to any considerable amount are made; and it is believed a saving of more than 50 per cent may be effected by importing books from Europe. A much larger saving might be made on French books; but the committee are of opinion that it would be better to purchase English books and English translations of foreign books in all cases where such translations have been made. They would propose only to import such standard works in foreign languages as have not been translated, and of those only such as can not be dispensed with.

When the committee consider not only the utility, but the absolute necessity of an extensive and judiciously selected library for the use of Congress; when they reflect upon its advantages, for the purposes as well of amusement as instruction, they are persuaded that it can not be too early supplied with all the important standard works in every department. Nor can they perceive any well-founded objection to an appropriation for this object of a sum very little exceeding the amount which individual taste and liberality often annually bestow upon private selections.

The conmintee believe that the defects in the present library can not be supplied for a less sum than $\$ 5,000$, which, in their opinion, may be afforded without inconvenience to the public resources; and they therefore report a bill.

This bill was read twice and committed to a Committee of the Whole. May 22 the bill was taken up in Committee of the Whole, amended, reported to the House, read the third time, and passed. ${ }^{1}$

The same day a message from the House informed the Senate that the House had passed a bill entitled "An act

${ }^{x}$ Annals 41: 1627; 42: 2695-2696. 
making an appropriation for the use of the Library of Congress, and for furnishing rooms in the Capitol;" on the 24th it was referred to the Joint Library Committee, on the $25^{\text {th }}$ reported and considered in Committee of the Whole, and on the 26 th passed. ${ }^{\mathrm{I}}$

AN ACT making an appropriation for the use of the Library of Congress, and for furnishing rooms in the Capitol.

Be it enacted, $\mathcal{E}^{\circ} \mathrm{c}$., That the sum of five thousand dollars be, and the same is hereby, appropriated, out of any unappropriated money in the Treasury, for the purchase of books, under the direction of the Joint Library Committee, for the use of the Library of Congress.

Sec. 2. And be it further enacted, That the sum of fifteen hundred and forty-six dollars be, and the same is hereby, appropriated, out of any unappropriated money in the Treasury, for the purchase of furniture for the new library.

SEc. 3. And be it further enacted, That the sum of three thousand two hundred and eighty-nine dollars and fifty cents be, and the same is hereby, appropriated, to be paid out of any money in the Treasury, not otherwise appropriated, for furnishing the rooms in the centre building of the Capitol, under the direction of the Commissioners of the Public Buildings.

Approved, May 26, I824.

In 1826 the sum of $\$ 5,000$ was appropriated for the purchase of books, in $1827, \$ 3,000$, and in $1828, \$ 5,000$.

Another result of the report of the Committee on Ways and Means was the passage of the law of February II, I825, a measure of similar, though perhaps not equal importance to the law of May 26, I824.

AN AC'T to remit the duties on books, maps, and charts imported for the use of the Library of Congress.

Be it enacted by the Senate and House of Representatives of the United States of America, in Congress assembled, That the Secretary of the Treasury be, and he hereby is, directed to remit all duties upon such books, maps, and charts, as have been, during the present year, or hereafter may be, imported into the United States, by the authority of the Joint Library Committee of Congress, for the use of the Library of Congress.

Approved, February II, I825.

${ }^{1}$ Annals $4 \mathrm{I}: 773,776,782,786,789$. 
These legislative measures made it possible for the committee to enlarge the Library very considerably before IS $30 .{ }^{1}$ In ISI9 and $I S 20$ there had been expended for books $\$ 4, \mathrm{O}_{3} \mathrm{~S}$. I 4 ; in $\mathrm{I} S 2 \mathrm{I}, \$ 53.75 ;$ in $\mathrm{I} 822, \$ \mathrm{I}, 985 . \mathrm{I} 9$; in $\mathrm{I} 823$, $\$ 1,324.48 ;$ in $1 S 24, \$ 2,796.74 ;$ in $1825, \$ 464.37$; in 1826 , $\$ 173 ;$ in $1827, \$ 2,592.46 ;$ in $\mathrm{I} 828, \$ 1,035.7 \mathrm{I}$; in $\mathrm{I} 829$, $\$ 3, S 63 \cdot 30$, in all, $\$ 18,327.14$. The most extensive purchases were made from Pishey Thompson, a local bookseller, Carey \& Co., Philadelphia booksellers, and J. Eastburn \& Co., New York booksellers. The record of the accessions to the Library which resulted from these purchases is contained for the most part in the catalogues of $\mathrm{IS}_{27} 7$ and I828, octavos of Io9 and 16 pages, respectively.

The purchases were made as in former years by the members of the Library Committee of which Edward Everett, appointed December 6, I825, was now the most active member. Senator Dickerson's taste had been more scientific than literary, and the books which he had purchased had therefore been of a scientific character. Mr. Everett's taste, on the other hand, was more literary than scientific, and he at once began to supply the deficiencies in the Library which had escaped the notice of the Library administration before his appointment. On the 16 th of October, $I \& 26,{ }^{2}$ he wrote to Librarian Watterston, "Please inform me (if possible by return of mail), whether the Library of Congress possesses the following works: The Congressional Register, by Thomas Lloyd, $\delta^{\circ}, 3$ volumes (being a register of the debates in the Honse of Representatives of the First Congress); the Collections of the Massachusetts Historical Society, $8^{\circ}$, Io volumes, old series; Io volumes, new series; I volume third series (I see a work in the catalogue, Chapter IV, No. 27, which may be one volume of the preceding)," etc.

On the 29th of October he wrote, "I beg leave to trouble you with another list of books, most of which I suppose not

\footnotetext{
'There is an account of these expenditures in the report of the Library Committee, May 16, I826, Nineteenth Congress, first session, Senate report No. 98; in the report of the Library Committec, May 17, I828, Twentieth Congress, first session, Senate report No. I 98; and in the report from the Secretary of the Senate, December Io, 1835, Twenty-fourth Congress, first session, Senate report No. I1.

2 Washington City Chronicle, November 7, 1829.
} 
Boston, 31. Det: 526

Dear du

$$
\text { I have aguen to terati you, for zoun }
$$

prompot altentess. to mone of the ryth. -

Yillinans fournal ot have onderal uf to the

Cusent time : it is un excallent bork. Busdes. Dithints

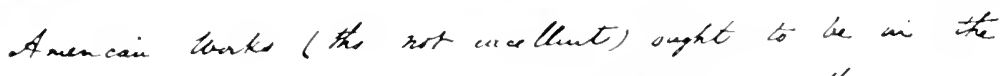

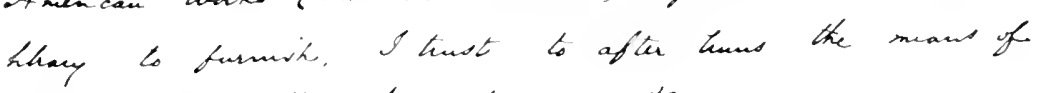
hooring the ratia of edeance nent...

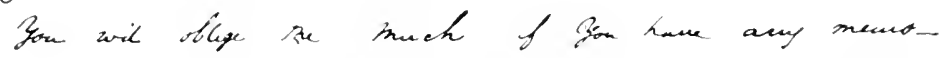

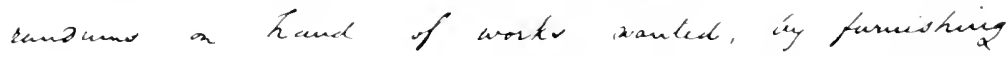

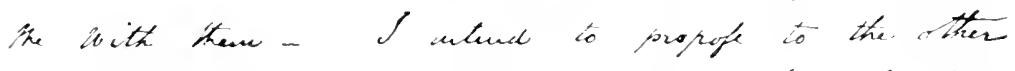

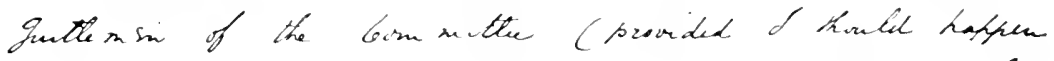
to be of the hhary borat at be seat offrein, that

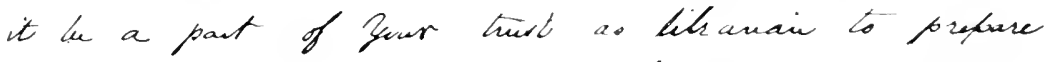
rtup an hand a Citalogen of loothe phoot wan..

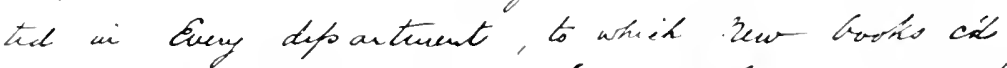
he adeled As they atprem. It he othe way can the

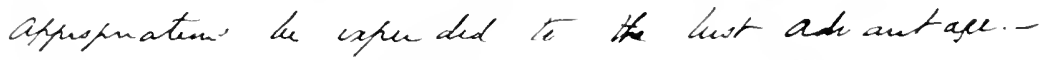
If wid also be disinabe that somentere there be an

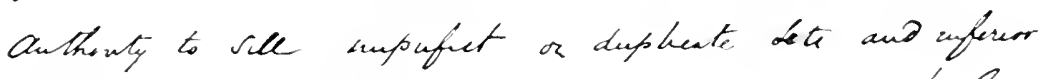
lonts, and mi that, any bovks which way by beceluar have found thes way wits the Whary rwhich an not wouled there. -

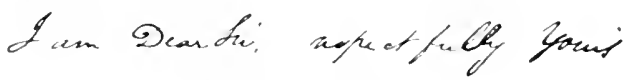

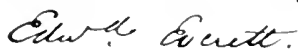

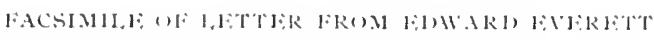

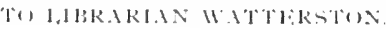

History of the library of congre..., vol. 1. plate 12 . 

to be in the Library of Congress. Being, however, uncertain, from the causes intimated in my last, I will trouble you to make a mark against such as are already in the Library and return me the catalogue."

On the 3ist he wrote: "Silliman's Journal I have ordered up to the present time; it is an excellent work. Besides, I think, American works (though not excellent), onght to be in the Library to furnish, I trust, to after times the means of proving the ratio of advancement.

"You will oblige me much if you have any memorandums on hand of works wanted, by furnishing me with them. I intend to propose to the other gentlemen of the Library Committee (provided I shall happen to be of the Library Committee at the next session) that it be a part of your trust as Librarian to prepare and keep on hand a catalogue of books most wanted in every department, to which new books could be added as they appear. In no other way can the appropriations be expended to the best advantage. It will also be desirable that somewhere there be an authority to sell imperfect or duplicate sets and inferior works, and, in short, any books which may by accident have found their way into the Library and which are not wanted there."

$\mathrm{He}$ also wrote to Joseph Story regarding the law collection. Judge Story replied, November 4, I826: " "I entirely agree with you respecting the civil-law books to be placed in the Congress Library. It would be a sad dishonor of a national library not to contain the works of Cujacins, Vinnins, Heineccius, Brissonius, Voet; etc. They are often useful for reference, and sometimes indispensable for a common lawyer. How conld one be sure of some nice doctrines in the civil law of Louisiana without possessing and consulting them? What is to become of the laws of Florida withont them?"

On the $23 \mathrm{~d}$ of May, I828, he wrote Librarian Watterston on the same subject:" "I take this way of reminding you that it is the wish of the Committee of the Library that you should have completed the laws and law reports of each State, also the periodical works of which the numbers hitherto pub- 
lished are in the Library, particularly the Annual Register and the Parliamentary Debates. I enclose you a note from Mr. Wickliffe on the subject of law books from Kentucky, and I would suggest that application by letter to some member of Congress in each State learned in the law, would enable you to effect the object. P. S. Would it not be well to nake a little interest with the Senators for an appropriation bill."

Of the activity of Edward Everett as a member of the Library Committee there were also notices in the records of Congress and in the columns of the metropolitan newspapers. On the 24th of February, I827, Mr. Everett, from the Committee on the Library, who were instructed by a resolution of the House of the I 4 th of the previous December to inquire into the expediency of adopting measures to procure from the different public offices in England copies of such papers and documents as might be of value in relation to the history of America, reported: ${ }^{1}$

That the United States of America in general and the several States that compose the Union enjoy an advantage possessed by no people of the ancient world, that their entire political duration falls within the period of authentic history. Whatever advantageous influence on national character or gratifying effect on national feeling can result from authentic details of the discovery, the first settlement, and early progress of our beloved country may consequently be realized by us in a higher degree than by any other community, excepting those on the American Continent sinilarly situated, in this respect, with ourselves. The only circumstance which diminishes and qualifies this advantage is the fact that the 110st important sources of our early history are deposited in the archives of foreign governments, over which, of course, the United States have 110 control. Most of the documents illustrating the early history of nearly all the United States are deposited in the various public offices at London, and it has long been the wish of such of our citizens as have devoted themselves to the study of the early history of the country that measures might be adopted to procure from those offices, by permission of the British Government, copies of such documents so interesting to the American people.

In one or two cases, on special application, this has already been done. Copies of documents relative to the early history of North Carolina and

'Nineteenth Congress, second session, House report No. 9I. 
Georgia have been procured from the public offices in London; and permission has lately been given by the principal secretary of state for foreign affairs, in London, to take copies of any documents contained in an ample list of papers relative to the listory of Georgia. The subject has excited considerable interest in different parts of the country. The governor of Georgia has made it the subject of a special message to the legislature of that State. The governor of New York, in a late message, has alluded to it as a matter of interest and importance. 'The assembly' and senate of Rhode Island have adopted resolutions requesting that provision be made by Congress to effect the object; and the Massachusetts Historical Society and the American Antiquarian Society have taken measures to bring it under the consideration of Congress. The resolntion of the legislature of Rhode Island, the memorial of the Massachusetts Historical Society, and the doings of the American Antiquarian Society have been referred to this committee and have received their respectf 11 consideration.

Regarding the object as one of public interest, and feeling a confidence that the liberal consent given by the British Government in reference to the Georgia documents would not be withheld in regard to the documents illustrating the early history of the other United States, the committee deem it highly desirable that the proper measures be taken to this end, and therefore report the following resolution:

Resolved, That, in the opinion of this House, it is expedient that proper measures be adopted, at the discretion of the President, to procure from the public offices, in England, copies of documents illustrative of the history of America; the expense of the same to be defrayed out of the contingent fund for foreign intercourse.

On the 27th of December, 1827, Mr. Everett, from the Committee on the Library, submitted a list of manuscripts and printed books relating to America in the possession of Obadiah Rich, esq., consul of the United States at Valencia, dated Madrid, September 28, 1827, among which was the manuscript "Indice de la coleccion de manuscritos, pertenecientes á la Historia de Indias, que escribió Don Juan Bautista Muñoz y á su muerte se han hallado en su libreria, fo., pages 1 20," with this note: "This catalogue of the manuscripts collected by Muñoz is curious as showing how rich this country [Spain] is in unpublished documents relating to the history of America. All those of most importance are in my collection, and several which were unknown to Muñoz."

'Twentieth Congress, first session, House report No. 37. 
No step seems to have been taken to acquire this valuable collection and eventually it was secured by Mr. Lenox. ${ }^{\mathrm{I}}$

An attempt to secure another and less important collection was more fortunate. Of this the New York Evening Post (quoted by the National Journal, January 3I, I829) said:

We learn that Professor Everett, acting officially as one of the Library Committee of Congress, has purchased about $\$ 500$ worth of the rarest and most valuable books in Signor Dupontes's collection.

We are informed that one of our members from New York, whose love of all that is valuable in learning attends him, even in the midst of party dissensions, presented the catalogue and suggested the idea of the purchase. We lardly know which deserves the most praise, the good taste which selected these inestimable books for the Library of the Capitol or the interesting enthusiasm which prompted this venerable savant to risk, with extremely limited means, the importation of a collection which, we reluctantly confess, New York has not been able to appreciate. As a proof that we have not overrated the works we will simply mention to the initiated that it contains a vellum edition of Muratori's Rerum italicarum scriptores in 39 volumes folio; the Padman edition of Forcellini's Lexicon totius latinitatis; the entire works of Visconti; the extremely rare Voyages of Marco Polo and other celebrated navigators, by Ramusio, and a splendid edition of Dante, in 4 volumes folio, with illustrative designs, which from their majesty and simplicity are sufficiently characterized by being pronounced as worthy as they are explanatory of the author.

\section{COLLECTIONS AND DEPARTMENTS IN I829.}

The result of these legislative appropriations and of the activity of the Library Committee was that by 1829 the Library of Congress was raised to the fourth place ${ }^{2}$ among the libraries of the country.

Of these libraries Harvard was the largest and contained the best and most extensive collection of books relating to America-it possessed, indeed, the best collection of Americana in the world. The next best, according to Jared Sparks, ${ }^{3}$ was the collection at Göttingen. Of the collection

\footnotetext{
${ }^{x}$ William C. I ane and C. K. Bolton, Notes on special collections in American libraries, p. 46.

${ }^{2}$ Harvard had between 30,000 and 40,000 volunes, Philadelphia about 34,000, and St. Mary's College, Baltimore, about I0,000. Yale, Princeton, and Bowdoin had between 8,000 and 8,500 volumes each.

${ }^{3}$ I. B. Adams, Life of Sparks, I:462; 2:85.
} 
in the Library of Congress he wrote May i8, I826: "On American history the Library is exceedingly meager, containing nothing but a few of the commonest books, but on American politics it is full, particularly to the year ISo8, when Mr. Jefferson left the Government. It was his habit to preserve pamphlets and papers, and they are all deposited in this Library." The poet Henry Cogswell Knight, ${ }^{1}$ looking at the collection from another point of view, spoke of an undue proportion of antiquated editions and of works in French and other foreign languages, of little use to members of Congress. Still a third critic, that interesting eccentric, Anne Royall, took Librarian Watterston to task for permitting the books of the Sunday School Union to be placed in the Library of Congress, and said: "These Sunday school books are lying useless in the Library, as I suppose no member of Congress reads them. Let Mr. Watterston sell them and give the amount to the suffering poor, if he is so pious." 2

These criticisms are not altogether fair indications of the character of the Library at this time. Indeed, any general criticism of the collections in the possession of the Library would be either incomplete and misleading or as detailed and comprehensive as the catalogues of the Library themselves. Of the general criticisms, however, that made by Mrs. Trollope was, perhaps, as fair as any. She said of the Library that it was very like that of a private English gentleman, but with less Latin, Greek, and Italian. ${ }^{3}$

Of the special collections in the possession of the Library at the close of the Watterston administration, the collection of manuscripts was the least considerable. Mr. Lincoln's resolution of the 3oth of April, I822, providing for the deposit in the Library of Congress of all the manuscript records of the Government, failed to pass. Mr. Everett's resolution of the 24th of February, I827, providing that copies of all papers in the archives of Great Britain relating to the history of the American colonies be secured and placed in

${ }^{x}$ Letters from the south and west, by Arthur Singleton (pseud.), Boston, IS24, p. 54.

${ }^{2}$ Black book, 3: 2 ro.

${ }_{3}$ Domestic manners of the Americans, London, 1832, I: 326 . 
the Library of Congress, also failed to pass. Only one mannscript, indeed, was secured during this period which seemed to the contemporary chronicler worthy of notice. This manuscript was described as follows:

"There is among the treasures of the Library of Congress an illuminated manuscript of considerable antiquity and of unquestionable beauty. Its date is I59I; the material is parchment, the characters are German, and the illumination is, for its size, splendid. The work is a Catholic missal or breviary, in Latin and French, but though admirably executed with the pen it is rather difficult to read, from the peculiarity of the characters. It contains, moreover, some illustrations which are badly drawn and executed, but the specimens of illumination are very rich and beantiful." This from the popular point of view.

From the scholar's standpoint, however, the Virginia records acquired in the early part of 1829 were far more valuable. With the Jefferson collection the Library had secured in IS 5 the manuscript laws of Virginia used by Hening. ${ }^{2}$ At the sale of the second Jefferson collection in I829, the Library secured four volumes of the records of the colony of Virginia and two volumes of the records of the Virginia Company. ${ }^{3}$

The listory of the latter is given in a letter written by Jefferson to Hugh P. Taylor, esq., October 4, I 825 : "The only manuscripts I now possess relating to the antiquities of our country," he says, "are some folio volumes; two of these are the Proceedings of the Virginia Company in England; the remaining four are of the Records of the Council of Virginia from 1622 to 1700 . The account of the first two volumes you will see in the preface to Stith's History of Virginia. They contain the records of the Virginia Company, copied from the originals under the eye, if I recollect rightly, of the Earl of Southampton, a member of the company; bought at the sale

"Washinglon City Chronicle August 22, 1 \$29.

${ }^{2}$ See Catalogne of the Jibrary, $1815, \mathrm{pp} .73-74$. These were not received until some years later. See p. 178 .

${ }^{3}$ See Catalogue I'resident Jefferson's library, 1829, p. 4, and Catalogne of the Library of Congress, 1830,1 . 167. 
of his library by Dr. Byrd, of Westover, and sold with that library to Isaac Zane. These volumes happened at the time of the sale to liave been borrowed by Col. R. Bland, whose library I purchased, and with this they were sent to me. I gave notice of it to Mr. Zane, but he never reclaimed them. $: * *$ The other four volumes, I an confident, are the original office records of the conncil. My conjectures are, that when Sir Jolnn Randolph was abont to begin the History of Virginia which he meant to write, he borrowed these volnmes from the council office to collect fron them materials for his work, and they remained in his library, probably nnobserved, during the whole life of the late Peyton Randolph, his son. From his executor I purchased his library, in a lump, and these volumes were sent to me as a part of it. I found the leaves so rotten as often to crumble into dust on being handled; I bound them, therefore, together, that they might not be unnecessarily opened, and have thus preserved them forty-seven years." I $* * *$

The law collection was somewhat better off. The civilappropriations act of IS2I provided $\$ I, O 00$ for the purchase of books for the Library, comprehending the statutes and the reports of the decisions of the courts of law and chancery of the different States, with the latest maps of the several States and Territories. Mr. Everett's letter to the Librarian, dated May 23, 1828, also showed that the Library administration was anxious to complete the collection of laws and law reports of the several States. And on the 24th of January, I829, on motion of Mr. Blake, the House of Representatives "Resolved, That the Committee on the Library be instructed to inquire into the expediency of providing more effectual means of obtaining copies of the laws of the several States as they are

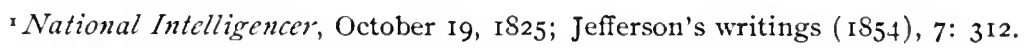

The discussion regarding the Virginia Company's records, begun by Hugh Blair Grigsby in the Southern Literary Messenger, in February, I854, was continued by $\mathrm{J}$. Wingate Thornton in the Historicat Magazine, February, IS58; by Willian Green in the Southern Literary Messenger, September, I863; by Justin Winsor in his Narrative and critical history of America (IS85), 3: 158; by Alexander Brown in the Magazine of American History, April, I893, and by President Lyon G. Tyler in the Report of the American Historical Association for Igor, vol. I, pp. 545-550. 
annually enacted." Accordingly the committee reported, by Mr. Everett, February I2, I829, as follows:

The inportance of having within the reach of the members of Congress copies of the laws of the several States need not be enforced. The means hitherto adopted of procuring them have been but partially effectual. By a resolution of Congress approved 23d Sept., I789, it was made "the duty of the Secretary of State to procure from time to time such of the statutes of the several States as may not be in his office." The committee are not apprised what particular mode was resorted to for the discharge of this duty till a comparatively recent period. On the $4^{\text {th }}$ Nov., I 819 , a circular letter was addressed to the district attorneys of the several States and Territories by the Secretary of State, requesting them to purchase and forward to the Department of State copies of sucl editions and sets of the laws as were not already deposited there. On the $4^{\text {th }}$ of Dec, I 8 I9, a circular letter was addressed to the governors of the several States by the Secretary of State, requesting a copy of the statutes of each State, respectively, as published from year to year. It was also stated in this circular letter that, by a standing order of the legislature of Massachusetts, four copies of the laws of that Commonwealth are regularly transmitted to the seat of the General Government, one for the use of each of the two Houses of Congress, one for the President of the United States, and one for the Library of Congress, and recommending the adoption of a similar order by the other States.

The committee are not informed what success attended this application. They learn from the Librarian of Congress that the statutes of the States of Massachusetts and Delaware only have been regularly received at the Library since i8 6 , and that a few years ago Holl. Mahlon Dickerson, chairman of the Joint Library Committee, was requested by that committee to address a letter to the governors of the several States, desiring thein to furnish the Library annually with copies of their laws; but that this request had been complied with by but few of the States, and not regularly by them.

The committee consider it as very desirable that a prompt and regular supply of the laws of the several States should be made to the Public Library. Sonse of the reasons which exist for furnishing the acts of the National Legislature to the several States make it desirable that those of the several States should be accessible at the seat of the General Goverument; and these reasons, no doubt, led to the adoption at a very early period of the resolution which made it the duty of the Secretary of State to procure the laws of the several States.

The want of authority in the General Government to direct any of the State functionaries to furnish the laws of the States, and the circumstance that these laws are not, it is believed, usually published for sale, 
and consequently are not to be procured in the ordinary way of purchase, have probably been the causes which have prevented a regular supply of the laws of the several States. The committee, however, feel no doubt that, whenever the subject shall be brought before the legislatures of the States by Congress they will cheerfully cooperate in effecting an object mutually important to the General and State governments.

The General Government furnishes annually to the several States a very large number of copies of its acts, as appears from a statement accompanying this report. It is not necessary that many copies of the acts of the States should be deposited here, but it is believed by the committee that a number somewhat larger than has hitherto been furnished would be of essential utility. They accordingly report a joint resolution, requesting the governors of the several States to recommend to the legislatures thereof the adoption of a standing order, providing for the furnishing of six copies of their acts annually-one for the use of the President of the United States, one for each House of Congress, and three for the Library of Congress. ${ }^{x}$

This resolution was not acted upon.

The resolution submitted by Mr. Wickcliffe in the House of Representatives February 24, I826, and again February I9, I 828 , "Resolved, That the Committee on the Library be instructed to inquire into the expediency of separating the law books from the other books of the Library and placing them under the control of the Supreme Court," "2 also failed to pass.

The collection of public documents was the largest of the collections in the Library. The whole western gallery of the Library room was occupied by them- "an awful pile," the Telegraph ${ }^{3}$ said, 25 feet high and roo long. The eastern gallery was occupied by the duplicate collections of United States Statutes, Pitkin's Statistics, etc.

Another part of the collection of documents was noticed by the editor of the Colonial Adrocate, who said, "I perceive they have got British copies of a great many reports of committees of the House of Commons, some of them well thumbed, too." Mr. Watterston, then editor of the Washington City Chronicle, copied this notice in his issue for November 9, I $\delta 29$, with the

\footnotetext{
${ }^{x}$ Twentieth Congress, second session, House report No. 77 .

"Journal of the House of Representatives.

${ }^{3}$ December I9, IS28.
} 
following comment: "The reports of the British Parliament. are not so well thumbed as he supposes, or as they ought to be by the American legislators. These volumes of reports contain an inmense mass of political information, and are the result of the wisdom and research of the legislators of Great Britain, which can not be too accurately or frequently examined by those who have been delegated to make laws for their country. On roads, canals, education, currency, the Army, Navy, etc., these reports are full, minute, and able, and deserve the most serious attention of the members of our National Legislature. We are sorry to say, however, that there are but few who have as yet discovered their value. They have been more thumbed by some of the Departments of the Government than by those for whose use they were obtained.

"Rich as this collection is in rare, valuable, and splendid works, it is a remarkable fact that one-fourth of the members never avail themselves of its literary treasures. The laborers in this vineyard are few compared with the number who have the privilege of drawing from it, and whose parliamentary duties require that they should furnish themselves with at least some of the information it contains."

This department of the Library was still charged with the duties which have since been delegated to the document rooms of the two Houses and the Superintendent of Docnments. The following resolution relating to the collection of docnments deposited in the Library has, therefore, a two-fold interest:

RESOLUTION Providing for the distribution of certain public docunnents, and the removal of certain books from the library.

Resolved by the Senate and the House of Representatives of the United States of America in Congress assembled, That of the public documents, and other works, of which several copies are deposited in the Library of Congress, a portion be distributed in the following manner;

First, of the return of the last census, and of the Digest of Manufactures, and of Gales and Seaton's Register of Debates, and of Watterston's and Van Zandt's Statistical 'Tables, one copy to each member of the present Congress, and to each new member of each succeeding Congress, till all the copies shall be distributed, with the exception of twenty-five of each work, which shall be reserved in the I,ibrary; and the I,ibrarian of Congress is hereby authorized and directed to deliver to each nember, as aforesaid, the copies of the said documents to which he is hereby entitled. 
Secondly, of the Journals of the Federal Convention, of the Secret Journals of the Old Congress, of Pitkin's Statistics, and of Seybert's Statistical Annals, onc copy to the public library of the legislature of each State in the Union, and one copy each to such universities and colleges as may not already have received thenl, and one copy to one incorporated Atheneum in each State: Provided, There remain a sufficient number of the said works beyond what are needed for the use of the Library.

Thirdly, to the United States Military Academy at West Point, one set of all the works of which copies have been distributed to the nniversities and colleges; Provided, There remain any copies of the same deposited in the Library of Congress, beyond the number reserved for the said Library.

Fourtlly, that, of the three hundred copies of the laws now ordered to be deposited in the Library of Congress, fifty copies be furnished to the library of the Hotse of Representatives, in addition to the fifty copies already ordered for the said Library; and that the clerk of the House of Representatives be, and he hereby is, anthorized to receive the same.

Fifthly, that of the journals, documents, and reports, heretofore ordered to be printed by the Senate, and of which copies are deposited in the Library of Congress, and of the journals, documents, and reports, which may lereafter be ordered to be printed by the Senate, five sets be furnished for the House of Representatives; and that the Clerk of the House of Representatives be, and he hereby is, anthorized to receive the same.

II. And be it further resolved, That the clerk of the House of Representatives be, and he hereby is, authorized and directed to deliver to the Department of State, properly prepared for transmission, by mail or otherwise, the copies of the books mentioned in the second and third paragraphs of the foregoing resolution.

III. And be it further resolved, That, instead of the twenty-five sets of the journals, executive papers, reports of committees, and other documents of Congress, authorized by law to be placed in the Library of Congress, ten sets only, well bound, shall hereafter be deposited, in the said Library.

IV. And be it further resolved, That the Joint Library Committee be, and hereby are, authorized to remove from the Library of Congress, and dispose of in such manner as they may think expedient, any duplicate, imperfect, damaged, or other work or works, not wanted for the use of the Library.

Approved, May 24, 1828.

How this resolution was carried into execution is made partially evident by the following letter from Mr. Watterston

'Statutes at Large 4: 32 ; also act of February 5, IS59, Statutes II: 38 I. 
to the chairman of the Library Committee, dated February, IS 3 o. The letter is also of considerable interest for the light which it throws on the Watterston administration and on the conditions created by the removal of the Librarian from office in IS29, a subject which we shall dwell upon at length in another chapter. It is as follows:

FEBRUARY, I83o.

SIR: In compliance with the request expressed in the resolution of the Joint Library Committee, I send you the explanation desired. The list and resolution were not received until the $4^{\text {th }}$ instant, and I have since been so much engaged that $I$ have not been at leisure to attend to it before. The books marked thus $\checkmark$ on the list furnished, and contained in the accompanying paper, marked (A), were selected by me two winters ago at the request of the committee, to be disposed of agreeably to a resolution of Congress. These consisted of old editions, duplicates, and imperfect sets, a list of which was furnished to Governor Dickerson and Mr. Everett, and the books were left in charge of the present kecper of the Library. They were in the reading room at the period of my removal, and shown to him at that time, and the reason of their being there explained. What has since become of them it is not for me to say. Some of those, however, were distributed by the committee in compliance with the resolution to which I have referred, which may be seen in paper marked (P), and some delivered to the Clerk of the House of Representatives (see paper marked C). The books contained in paper marked (D) were taken out by the members to whose names they are affixed and not returned. The committee will understand that it is made the duty of the Librarian, by a rule of the institution placed under his charge (rule I8), to report to the Speaker of the House and the Secretary of the Senate the names of such members as have failed to return the books borrowed by them, and the presiding officers of the two Houses are empowered to remit or enforce the penalty. This report was made by me regularly every session, for during every session while I held this office several books were taken out and not returned, and in very few instances was the penalty enforced. It will be seen that as soon as the matter is laid before the President of the Senate and Speaker of the Honse of Representatives all obligation on the part of the Librarian ceases, and that he is not longer held answerable for the books thus lost or renoved. It may be proper to observe that I have on several occasions suggested to those gentlemen the propriety of enforcing the rule, to prevent the Iibrary from sustaining a serious injury by frequent losses; but they were unattended to, and I have often been censurerl by those whose negligence I liad wished to correct. As one of $11 y$ receipt books is not in my possession, there may be some 
members charged whose nanes are not gircn. Being, in consequence of my report to the presiding officers, discharged from all obligations, I preserved no list of the defaulters, and an indebted for the information now furnished to the records which I took the precaution to bring with nie. The books contained in paper (E) are supposed to have been purloined or, at least, taken out withont my knowledge. It may not be improper to renlark that for twelve years I acted as Librarian alone, had no assistant and but one servant; that I superintended the first removal of the Library to the post-office; had all the books labeled inside and out, the labels of which I prepared with my own hand; that a few years after I superintended its removal to the north wing of the Capitol, and thence again to the apartment it now occupies.

In consequence of these frequent removals and the free ingress of strangers of all classes it must be a matter of surprise that more books were not purloined than appear to have been. This may be attributed to the constant and unremitting attention $I$ found it necessary to exercise when I acted alone; but being often called upon to aid the members in their researches and examination of books, the other part of the Library was necessarily left unattended and possibly sone volumes may thus have been withdrawn without ny knowledge. But in no library in this country or in Europe, except when the books are chained to the shelves, is there an instance of smaller loss in this way than in the Library of Congress while under my care. For these, if Congress require it, I will pay whaterer they may be valued at. With this, however, the committee are, I presume, aware that they have no concern as their duties are confined (unless otherwise directed) cxclusizely to the purchase of books, maps, etc.

The paper marked $(F)$ contains the list of the books which were lcft in the libraries at the time I delivered it up to the order of the President of the United States. This fact is established by the certificate of Mr. Stelle, my late assistant, and leave it to the committee to saywhat must be the feelings of the man who can thus trump up a statement which he know's to be erroncous and which he has no doubt made from an impression that it would never reach my ears. He may have been misled by the practice, which has lately prevailed in a higher sphere, of shooting the poisoned arrows in the dark and leaving the victim to stuffer without his knowledge by whom it was discharged. It would seem that he had mistaken his man. It appears he has charged as missing the very books he knew' to be in the Library and has put down others, a list of winich was left with him at the period of my removal. This must be ascribed either to malignity or ignorance or may possibly originate from a requisition to justify an act of usurpation by misrepresentation and falsehood.

The resolution which anthorized the committee to withdraw the books which he has cliarged as missing, likewise authorized the distribution of 


\section{I $7 S$ DEVELOPMENT OF THE LIBRARY, I 8 I5-IS29.}

all the copies of the State papers, journals, etc., above a certain number and which encumbered the shelves of the Library. These were put up in boxes and are now in the circular room above the small Rotunda in the north wing. A list of them was left with the keeper of the Library, and the Secretary of the Senatc has another. The paper marked $(\mathrm{G})$ contains a list of books which were never received. The following extract of a letter from Mr. Jefferson to me, dated May 7 th, I815, will account for some of them: "I gave to Mr. Milligan a note of those folio volumes of the Laws of Virginia belonging to the Library which, being in known hands, will be recovered. One is a manuscript volume from which a printed copy is now preparing for publication." Some, too, he has marked as missing that were never obtained, as the and and 3 rd volumes of Hanilton's works (sce Paper $\mathrm{H}$ ), and some he has not given that were taken ont and not returned or given by the committee (see Paper I).

In relation to those books which are set down as missing and not on the catalogue, it is only necessary to remark that it is a mistake. In labelling a large number of volumes I or 2 letters have occasionally been omitted by mistake. For example, in labelling number 4 with the additional letter $a$ or $b$, I hare sometimes omitted it in consequence of the number of volumes of the sane number and letter, though in a different chapter, and hence has originated the apparent deficiency. The manuscript catalogue of the Library was given to me by Mr. Jefferson, if I could save it from the printer. It was of no use to him or the Library, and I therefore claim it as my property.

I tender my thanks to the committee for thus affording me an opportunity to account for the books charged as missing by the keeper of the Library, and beg them to do me the farour to preserve these papers to prevent the necessity of future explanation.

Geokge WATterston.'

The Hon. A. Robbins, C. J. L. C.

THE LIBRARY STAFF AND SERVICE.

On the 2 ist of March, I 8 I5, Mr. Watterston became the Librarian at a salary of $\$ 2$ per diem for every day of necessary attendance. By the act of April 16, I8I6, the office of Librarian was raised from the rank of that of day laborer and his salary fixed at $\$ 1$, ooo per annum, payable quarterly at the Treasury of the United States, to commence and take effect from and after the 2 ist of March, I 8 I 5 , and on the i 8 th of April, I 8 I 8 , this salary was raised to $\$ I, 500$. This enabled the occupant of the office to devote all his time to the duties of the office, bibliographical and clerical, and out of the con- 
tingent fund he hired a servant at a dollar a day to act as messenger during the days the Library was kept open. ${ }^{1}$

In I 223 there seems to have been some talk of Mr. Watterston resigning the office of Librarian, and on the igth of December Jefferson wrote to President Monroe regarding the expected vacancy: "Mr. Girardin, President of the College of Baltimore, understanding that the office of Librarian of Congress is expected to become vacant by resignation and desirons of being placed in it, has requested me to state to you what I know of his qualifications. He lived at Milton in this neighborhood two or three years, while writing his History of Virginia, and during that time was in great intercourse and intimacy with myself. I willingly, therefore, bear witness to the truths concerning him which are within my knowledge. $\mathrm{He}$ is a scholar of high grade, industrious, methodical, careful, of correct morals and conduct, and particularly proficient in bibliographical knowledge, an important qualification in that office. I have thought it a duty to bear witness to what I know of him in these respects, and that I render a service even to yourself by enabling you to judge between him and other competitors for the appointment, and to give it to the worthiest, as I know is your first wish. Accept the assurance of my constant and high esteem and respect." " Nothing, however, came of this, and no change was made in the Library staff until i 827 .

On February 16 of that year Mr. Cook, from the Committee on Ways and Means, reported a bill in the House of Representatives recommending an allowance for an assistant librarian, which was committed to the Committee of the Whole. On the $23 \mathrm{~d}$ it was reported with amendments and on the $24^{\text {th }}$ passed. ${ }^{3}$

In the Senate this bill was, on the $26 \mathrm{th}$, referred to the Library Committee, on the $27^{\text {th }}$ reported with an amendment, on March 2 considered in Committee of the Whole, further amended, and passed. ${ }^{4}$

'Globe, October 29, I844, and National Intelligencer, November 2, I $\$ 44$.

${ }^{2}$ Jefferson MSS., series 2, vol. 5S, No. II9.

${ }^{3}$ House Journal, pp. 304, 327, 329.

4 Senate Journal, pp. 220, 226, 232, 276. 
On the same day these amendments were agreed to in the House $^{\mathrm{I}}$ and the bill passed, providing $\$ 400$ as compensation to the assistant employed by the Librarian of Congress during that session of Congress. The act of May 24, I828, made the office of assistant librarian permanent by authorizing the Librarian to employ an assistant at a salary of $\$ 800$, commencing March 4, I 827 , and Mr. E. B. Stelle, who had already served in the Library, first without pay and then for a compensation of $\$ 400$, was appointed to the position.

The Librarian during this period superintended the removal of the Library three times-first, the removal to the PostOffice building; second, that to the north wing of the Capitol, and third, that to the west center of the Capitol. He kept a book recording "Books received since the arrival of Mr. Jefferson's library," and "Books, maps, etc., presented to the Library of Congress," the latter received apparently in consequence of his card published in the National Intelligencer September I 5, I 8 I 5. This record, however, does not seem to have been preserved longer than September, ISI6. Its place was taken by the catalogues of additions to the Library, supplements to the general catalogue of $\mathrm{I}_{\mathrm{I}} \mathrm{5}$, of which four were issued, in the years $1820,1 \delta_{25}, \mathrm{I} \delta 27$, and $\mathrm{I} \delta 2 \delta$, respectively, numbering in all $\mathrm{I} \delta 4$ pages. The Librarian had also to classify the Library and to label the books.

Then, from first to last, came the direct service to the reader. Of this Librarian Watterston wrote in the third person, as follows: "His knowledge of books and the extent of his reading and attainments were such that it was thought by those who visited the Library, he was acquainted with the contents of every volume in it. He discharged all its duties for years alone and gave universal satisfaction." These antobiographical reflections do not appear to have been published, but some less personal remarks on the office of Librarian, also, without doubt, written by Watterston and in the same vein, appeared in the Washington City Chronicle Ju1ly I I, I 829, just after his removal from office. They were as follows: 
"Custom has rendered it necessary for the Librarian, when called upon by nembers, to furnish such information as they may require, and which can be obtained in the Library. The mere knowledge of the location of a book is but sinall part of his duty. He is frequently called upon for facts, dates, passages, acts, official communications, and even lines of poetry; and to do this requires memory and reading. The Librarian, too, must have a knowledge of bibliography, and be able to point ont the best and rarest editions, as well as to furnish lists of books to the committee. For the useful discharge of these duties it will be seen that none conld immediately, and very few after an apprenticeship of several years, be properly qualified."

The President and Vice-President of the United States, nuembers of Congress, Judges of the Supreme Court, and a few other privileged persons might borrow books from the Library, and of the issue and return of these borrowed books it was the duty of the Librarian to keep a record. A facsimile of a page of this record, which is still preserved in three great folio volumes, is here presented. This record was of first-rate importance in the execution of those rules of the Library which provided that a folio should be returned within three weeks, a quarto within two, and an octavo or duodecimo within one week. The violation of these rules was punishable by fines- "for a folio, 20 cents per day for each day of the first week's illegal detention and 40 cents for each succeeding day thereafter; for a quarto, Io cents per day for each day of the first week's illegal detention and 20 cents for eacl succeeding day thereafter; for an octavo, 5 cents per day for each day of the first week's illegal detention and io cents for each succeeding day thereafter; provided, that if the book illegally detained be returned the fine or penalty shall in no case exceed the value thereof." I But this penal system, being enforced only occasionally, was insufficient to prevent violations of the law, so that it was neces-

${ }^{\mathrm{t}}$ Additional rules and regulations for the government of the Library of the United2States. Signed by John Gaillard, President of the Senate pro tempore; H. Clay, Speaker of the House of Representatives, ist January, i816. Jonathan Elliot, printer, 1816. Broadside. 
sary for the Librarian not only to issue books but also to go after them and solicit their return. Of this part of the work of the Librarian some amusing illustrations have been preserved among the Watterston Papers. One of these, a letter from Sam Houston, dated Nashville, July 27, I 824 , reads as follows:

A few days since I received your letter in relation to the books which I drew from the Library. I instructed William Brown, a free man, who waited on the mess at Mrs. Claxton's, to take care of all things which I might leave at my room. I left a trunk of clothes and some other articles, witl them the books referred to, to the best of my recollection. I had purchased a quantity of books at auction during the session, and the morning I left the city directed a boy to take them in a hack to Poor's auction room and have them packed and sent to Baltimore, but I am satisfied those books were not with them.

My impression is that William Brown has them in his care; if not, they were left in my room, and a boy by the name of Nace can tell where they are. At one time I did intend to send them to Mr. Rapin's, but I did not send them there, in my opinion.

Employ some person to go and bring William Brown to you, and I will pay the expense of any trouble you may be at. If you can see Brown, he is perfectly honest, and will take great care to have the books forthcoming. If he has not got them, tell hin that I am satisfied they were left in my room and he will have them hunted up. Inquire at Messrs. Poor's, for they were to keep an invoice of all the books sent to me.

The books must and shall be forthconing, and, if you please, write to me soon.

Truly, thy friend,

Sam Houston. ${ }^{x}$

Another, a letter from Watterston to Daniel Brent, chief clerk in the Department of State, dated Junc 2, I8I8, sheds still further light on the system of loaning books from the Library as it was at this period. It reads: "I lent you a book some time before the commencement of last session, and, though I lave written to the Secretary for it twice, have not yet received it. I hold you accountable to me for it, as I am individually accountable to the Govermment, it having been kept without anthority and under the impression it would be returued when required. I did not suppose it would have been so difficult to procure it."

IVatterston MSS.

2Jepartment of State, Miscellaneons letters, vol. 63 . 


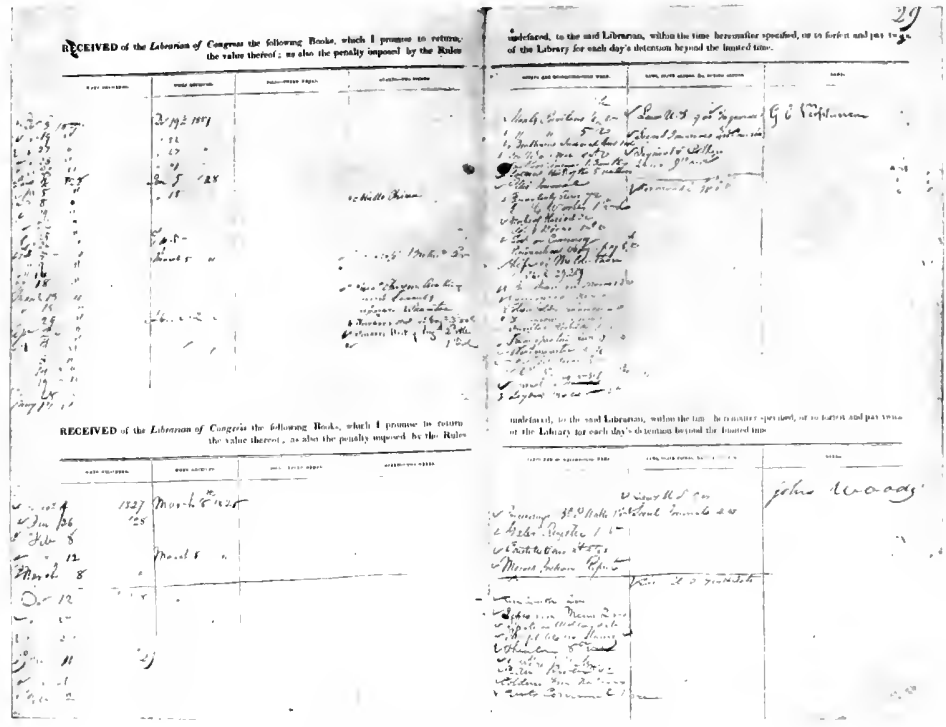


In the Nalional Intelligenes April 2\&, I $\$ 2$ I, the Librarian advertised the loss of a manuscript in the handwriting of Thomas Jefferson, entitled "Bacon's Rebellion."

For the performance of these various duties-recording accessions, cataloguing books, classifying, numbering, and labeling them, answering the questions of readers, and registering the issues of books to readers-the Library was kept open from 9 o'clock until 3 and from 5 o'clock until 7 three times a week during the recess for the purpose of airing and receiving, labeling, and arranging such books as might be purchased by the Joint Library Committee, and every day in the week, except Sunday, from 9 o'elock until the adjournment of Congress, during the sessions of Congress.

\section{PRIVILEGES OF THE IIBRARY.}

The privileges of the Library were in I 8 Io extended to the agent of the Library Committee, and in I 8 I 2 to the Judges of the Supreme Court. By the act of April I6, I8r6, they were extended to the Attorney-General and to the members of the Diplomatic Corps also. But further attempts in this direction during this period were in vain. January $9,18 \mathrm{I} 7,{ }^{\mathrm{r}}$ a bill passed the Senate extending those privileges to the heads of Departments, and to the Chaplains of Congress, but got 110 further. February i 5, I8I9, Mr. Fromentin submitted to the Senate the following motion for consideration: "Resolved, That the Library Committee be instructed to inquire into the propriety of further extending the privilege of using the books in the Library of Congress." February I6 the Senate resumed the consideration of Mr. Fromentin's motion and agreed thereto. March I, on motion of Mr. Dickerson, the Library Committee were discharged from the further consideration of the question. ${ }^{2}$ On the 27th of April, I820, Mr. Storrs submitted the following resolution in the House of Representatives:

Resolved, by the Senate and House of Representatives of the United States of America in Congress assembled, That the President of the Senate and the Speaker of the House of Representatives, for the time being, be, and 
they are hereby, authorized to grant the use of the books in the Library of Congress, during the recess of its sessions, to the Secretary of the Senate and Clerk of the House of Representatives of the United States, on the terms, and under the rules, regulations, restrictions, and penalties, that members of Congress are allowed to use the said books.

The resolution was read twice, and ordered to lie on the table. May 3 Mr. Smith, of North Carolina, moved to amend it by including therein the Superintendent of the Patent Office; which motion was rejected. The resolution was then ordered to be engrossed and read the third time on the morrow. Debate on the resolution was accordingly resumed on the following day (May 4), and some objections heard from Mr. Livermore and Mr. Taylor, the latter of whom moved to postpone the same indefinitely. The objections were that the extension of the permission to take the books ont of the Library would tend to impair and deface what was intended for the ornament as well as for the exclusive use of Congress; that if the use of the Library was extended as proposed, it ought also to be further extended on the san1e principles-but that it was altogether needless to pass the resolve, inasmuch as the Library was open three times a week during the recess, and daily during the session, and night be consulted at pleasure by the officers in question. The motion for indefinite postponement was accordingly agreed to. ${ }^{\mathrm{I}}$

That, however, the privileges were extended to others than those provided for by law the following notes preserved anong the Librarian's papers will show. One reads:

Mr. WATTERSTON:

Permit the bearer, G. S. Btifinch, to take books from the Library in my privilege.

WIILIAM WIRT, Attomey-General.

Another is from Richard Rush, asking that an eminent literary gentleman, whom he refers to without naming, nuay borrow books from the Library. It is dated July I9, I8I5, and concludes as follows: "Without knowing precisely what your rules are as to letting out books, I can not say as well as you will dombtless be able to, if they are so strict as to admit of no relaxation. If chancery powers are mixed with 
them sure I an that you will think this a fair case for their exercise. If not, I declare I feel lialf inclined to wish that, where an object so interesting to the scientific researches of our country seems at stake, we could fall upon some snug method of committing a pious breach of the law itself."

The Intelligencer (August 28, I823) also suggested the extension of the hours of opening. It saicl: "Why should the Library of Congress not be accessible every day, at proper hours between sunrise and sunset, to every citizen who may wish to avail himself of the use of such treasures of wisdom as may be collected there for the public benefit? It may, of course, require more arduous duties than one person alone could discharge to attend to it; but if the nation felt interested in accumulating and maintaining such a monument of its literary taste it would not begrudge the small appropriation necessary to render it a constantly increasing source of pleasure and profit, not only to Congress nor to the reading population of Washington, but to all our countrymen, and even foreigners who pass through or who occasionally reside in the metropolis."

\section{USF, OF 'THF, LIBRARY'.}

"The Library was a favorite resort of nembers of Congress during these years, and not unfrequently becomes the scene of very interesting conversation. Debate is done away, and the sage actors in the field of politics revel for a while in the delights of literary discussion, to return with still more ardor to the mighty labors of legislation," so says the Joumal (p. 73) of a tour of a detachment of cadets from the A. L. S. and M. Academy, Middletown, Conn., to the city of Washington, in December, I 826 . Of this remark there are a number of interesting illustrations in the Librarian's "IFamily at Washington."

In strictness, no one was allowed to enter the Library unless admitted by the Librarian or introduced by a member of Congress.' 'This rule was generously interpreted, however, and so the Library became more and more the resort not only of statesmen but men of letters. Annong the nore noted 
visitors of this class we have already mentioned Jared Sparks. Rufus Choate, then in the office of the Attomey-General, was also an habitué. Writing to his friend James Marsh of Andover Theological Seminary, August I I, I82 I, he said, "I am sadly at a loss for books here, but I sit three days every week in the large Congressional Library and am stndying our own extensive ante-Revolutionary history and reading your favorite Gibbon. The only classic I can get is Orid."

The Library was also the morning rendezvous of the ladies who were acquainted with Congressmen ${ }^{2}$ and of other fashionable loungers who came there to pass the time in conversation, in looking at pictures, or in reading. ${ }^{3}$ There was much amusement, Mrs. Ellet says, in looking over the pamphlets published about ISOI, and the nuarginal notes in Jefferson's small, round, delicate handwriting. ${ }^{4}$

'Samuel G. Brown, Life of Rufus Choate (1870), p. 25.

"Reminiscences of Washington, in the Allantic Monthly, 45: 58, January, 1850 .

3 Watterston, Wanderer in Washington, p. 2 I $\$$.

${ }^{4}$ F. F. Fillet, Court circles of the Republic, Hartford, 1869, p. 130. 


\section{Uithaptex $\mathfrak{S} \mathfrak{i} \mathfrak{X}$}

THE LIBRARY IN POLITICS 


\section{Chapter Six.}

THE LIBRARY IN POLITICS.

On the 2Stl of May, IS29, President Jackson appointed Joln Silva Meehan Librarian of Congress, in the place of George Vatterston, and the assistant librarian, Mr. Stelle, "the sole support of an aged mother and her family," was superseded by Mr. E. J. Hume. ${ }^{1}$

The Petersburg Intelligencer observed that the new Librarian was the third person attached to the Telegraph who had been appointed to public office. "In mentioning this fact," it added, "we are far from wishing to disturb the tender nerves of our brethren of the Administration presses by urging it as eridence of dictation exercised over the Chief Magistrate. Perhaps it may be more agreeable to their sensibility to style it a curious coincidence." 2

The New England Palladium said: "The removal of Mr. Watterston will be the subject of great regret with all menlbers of Congress and others who have been in the habit of frequenting the Library for the purpose of availing themselves of its literary and scientific stores. He is himself a sort of compendium of all that the Library contains, for he is a man of sense and learning, a good linguist, au accomplished bibliographer, and has been assiduously devoted to the Library for fourteen years. Withal he was always prompt in aiding the inquiries of every visitor. $\mathrm{He}$ is formed by liabits and education for the place which he has filled, and would fill with reputation the same place in the first libraries of Europe. Mr. Watterston, we believe, was not dependent on his salary; he can do better withont the office than the office without hinı.

'Vational Intelligencer, June 11, 1829; Trenton True American, reprinted in Sational Intclligencer, June 23, 1829.

${ }^{2}$ Copied in Vational Joumal, June 15, IS29. 
"The new Librarian, Mr. Meehan, does not possess the peculiar qualifications of his predecessor. But as he is an amiable and respectable man, we are better pleased with his appointment than we should have been with that of any other on whom, he being out of the question, it would probably have fallen."

In the local press the war of words over the removal was much more vigorous and protracted. On the $9^{\text {th }}$ of Jume, I 829, Watterston joined the editorial staff of the National Joumal, and on the same day an article on the removal, donbtless from his pen, appeared in its editorial column. It was as follows:

This is one of the most extraordinary removals as well as appointments which the weak and tyrannical heads of the present Administration have yet made. We regard this act as a gross outrage on the rights of Congress and an open violation of law. It is an outrage on the rights of Congress because it is an unnecessary and unwarrantable interference with the officers of the legislative assembly of the nation, without deigning to consult its members as to the expediency of the change, and without condescending to inquire whether such a change would be acceptable to them or not. Common sense as well as common delicacy, we should have thought, would have suggested such a course as this to a man of ordinary reflection and sensibility. It is saying to the members of a coordinate branch of the Government, "I wish to place a creature of mine in an office formed expressly for your accommodation and benefit, but you are too contemptible to be consulted. Anyone that I please to give you you shall receive, nor shall you dare to murmur. I do not think it worth while to consult you on the subject, because I am the sovereign and you are the slaves." If Congress will submit to this insult they are not the men their countrymen have taken them for.

The appointment is, moreover, in violation of law. The act requires that "previous to the Librarian entering npon the duties of his office, he shall give a boud in strch a sum and with such security as the President of the Senate and Speaker of the Honse of Representatives, for the time being, may deem sufficient for the safe-keeping of such books, maps, and furniture as may be confided to his care, etc., which bond shall be deposited in the office of the Secretary of the Senate." As no such officer as the Speaker of the Honse of Representatives now exists, no bond can be legally given, and therefore no Librarian can enter upon the duties of the office unless he does so by an act of usurpation. The object of this law was to hold the incumbent responsible for the large 
amount of property placed under his charge, and to give to the presiding officers of the two Houses a control over the appointment by the President. Congress reserved to themselves the right of saying who should be their Librarian, by giving to the President of the Senate and the Speaker of the House the power of demanding such security as they might think proper, thus intending to prevent the President from placing in so responsible a situation any irresponsible individual he might, in the exercise of his caprice or despotism or for his own special purposes, think proper to thrust into this office. We are clearly of the opinion that Mr. Watterston would have been entirely justified, under these circumstances, in retaining the key of the Library until the requisitions of the law had been complied with. We understood that he wonld consent to surrender it to the President only, conceiving that he could not in any other way be discharged from the obligation of his bond. The President has therefore assumed the responsibility and must be amenable to Congress and the nation for this open violation of law.

To this the organ of the Jackson Administration, the United States Telegraph, made answer on the same day:

After a full week's labor the Journal gives birth to the lamentations of the late Librarian of Congress. Mr. Watterston complains that the President has not only usurped the power of Congress, but has violated the law in his remoral. * * * How circumstances alter cases! Mr. Watterston, who never has given any bond, who has acted for many. years as Librarian to Congress in open violation of the law, asserts that because there is no Speaker of the House of Representatives, he can not be removed. Now, the truth is that, according to Mr. Watterston's own doctrine, inasmuch as the law requires bond shall be given previous to entering upon the duties of his office, he not having given bond as required by law, never was legally authorized to act as Librarian.

The appointment of Librarian is rested in the sole potver of the President, and Mr. Meehan has given bond in stch stum and with such securities as are approved by the President of the Senate. When Congress meets, and a Speaker shall have been appointed, the bond will be approved by hin. Its sufficiency can not be doubted. As to the new incumbent, no objection has been made to him. He has been many years a resident of this city, is a firm and consistent Republican, and has not, that we know of, a personal enemy.

On the I th of June the National Joumal replied to this:

The veracious Telegraph asserts, with its habitual disregard to truth, that Mr. Watterston "never has given any bond," and has, therefore. acted as Librarian for many years in violation of law.

We know this to be false; and that the man who so boldly asserted it knew it to be false. The bond given by Mr. Watterston, agreeably to 
the requisitions of the law, is in the handwriting of the then Speaker of the Honse of Representatives, approved by the presiding officers of the two Honses, and deposited in the office of the Secretary of the Senate, where it is now on file. This has not been done by the person whom the President has now enployed as his agent in this business. We contend that no legal bond can be given by any man, according to the requisitions of the act, before the next meeting of Congress, becanse 110 Speaker exists till then to give it validity by his approbation; and that, therefore, to enter upon the duties of the office before this is clone is to act in open violation of law. The approbation of one of the presiding officers, if really given, has no more validity than if none were given; because the law imperatively requires the sanction of both before the person appointed can enter upon the discharge of his duties. If he do so, he enters npon them on the responsibility of Mr. Watterston, whom Congress will hold answerable for the charge confided to him, and from whom they will expect a surrender only when their presiding officers shall approve the bond of another, and thus release him from his obligation.

We again repeat that this appointment is a gross ontrage on the rights of Congress. There is something due, in common conrtesy and politeness, from one bratich of the Government to the other, and the head of one would necessarily, if he possessed common sense, consult the wishes of the other before he took any step that might be injurious to the interests or disagreeable to the feelings of its members.

We understand that the amount of security given in the informal bond by the acting agent of the President is preciscly that given by Mr. Watterston fonteen years ago, when the Library was estimated at $\$ 20$, 000 . Its value at present is, we learn, abont $\$ 80,000$, and yet no higher security has been required. The whole affair, both as it relates to the removal and appointment, is one which onght to excite the indignant feeling of Congress and the nation.

On the following day, the i 2 th, the Telegraph returned to the charge:

It will be necessary, since we are forced to the task, to review the whole affair. Mr. Watterston characterizes his dismissal, first, as a "most extraordinary removal;" second, as "a gross outrage on the rights of Congress;" and third, as "an open violation of the law." These are the su1n of the ex-Librarian's charges, and we shall dispose of them in his own order.

First, his "most extraordinary removal." We are not aware of anything stperlatively extraordinary in this dismissal. The astonishment was that an individual altogether unfit for the situation should have been so long tolerated in it. It is notorious that the manners of the exLibrarian were of a peculiarly disgusting order. His conduct to those 
who had occasion to visit the Library, as well as to those who had a right, was of the nost crude and supercilious description, so much so that many of our members of Congress and citizens rather than encounter the obliging Mr. Watterston sought elsewhere the information they might have obtained more readily in the Library.

The Library itself, we have often heard, owing to the carelessness or incapacity of the Librarian, was in a state of great derangement. It has been said for many years past, and there is no doubt of the fact, that the books are misplaced, incomplete, and in many instances lost, or not to be found, according to the catalogues; and the whole establishment is, we believe, at this moment in such confusion as to require the labor of many months before it can be properly arranged. These facts of themselves are fully sufficient to justify his removal; but who does not know that Mr. Watterston was one of the most servile of the tools of the coalition and one of the main prompters, if not contributors, to the "We, the people," blackgnardism. Nay, so conscious was the exLibrarian of his deserts that the Executive had not been in Washington many days till he was inundated with begging solicitations to retain him and was actually furnished with certificates in his favor from the most violent caluminators of the people and their President. $* * *$

In Mr. Watterston's second attempt he insists that he clid give a bond for the due performance of the duties of his office. 'There was, indeed, an instrument in existence purporting to be a deed of this description, but so far from its being a legal bond it was inchoate; it had, in fact, never been properly executed and was no better than a mere piece of waste paper. It is not only entirely deficient in legal validity, but has been actually null for many years. One of the securities has been dead for a length of time, and what is more it bears no approval either from the President of the Senate or Speaker of the Honse of Representatives, and was, in short, of about as much security to the people as Mr. Watterston's services were valuable to them. Should it be necessary to call upon the late incumbent to answer for the damage the Library may have sustained in the loss or destruction of any part of the property committed to his charge, his security will have no difficulty in evading the obligations of the pretended bond. It is rather odd to hear an objection raised by Mr. Watterston, who has been Librarian for fourteen years with no security whatever, against Mr. Meehan's bond, which is perfectly unexceptionable on this point, which has received the approval of the President of the Senate and nndergone all possible legal solemnities. The amount, also, is objected to witl equally bad grace. It is for the same sum that Mr. Watterston's own piece of informality bore, and that was not thought insufficient by Mr. Watterston till after his dismissal. $\because * *$

$$
23399-04-13
$$


At this Mr. Watterston was wroth, and wrote in the National Joumal, June 15 , this time over his own signature, in the following fashion:

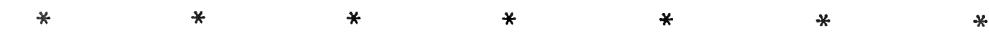

It is surely not for such a man to prate about the manners of another; he is as incompetent to judge of them as the rude savage would be to form a correct estimate of the polish of a French courtier. If my manners were at any time "supercilious," it was found necessary to assume them to get rid of such impertinent and vulgar intruders as he and his satellites, and to save the books from being purloined.

It is false that the Library has ever been in a state of derangement, and if it be now "in confusion," as he asserts, the confusion has been produced by the person who has been thrust into the office contrary to law. That it will require the labor of many months before he can even understand the arrangement is unquestionably true, for as the arrangement is a scientific one, an ignorant and uneducated man like the vulgar slangwhanger of the Telegraph and his agent would be utterly at a loss to comprehend it. To any man of ordinary capacity, information, and taste the Library, axhen left by me, must have appeared, as it actually was, in a state of order and beauty. It is my pride to say, and the fact is known to everyone who has been in the habit of visiting this literary establishment, that I have labored for years to perfect the arrangement, and to render the Library an object of utility and beauty, and I have every reason to believe that my efforts have met with the entire approbation of all who are capable of judging, and especially of those for whose exclusive convenience and benefit it was established. I have so arranged and catalogued every volume that there is no book that I conld not find instantly and without difficulty, and with the contents of which I was not obliged to be in some nanner acquainted.

Very few books lave been lost in the course of my long superintendence that have not been, or that can not be, acconnted for (except one, taken out by the very man who makes this hazardous assertion), and if they can not be found according to the catalogues it is not my fault. I an not to be answerable for the iguorance or stupidity of those who have been put into a situation for which they may be wholly unfit.

The next charge which I shall notice is one that, if true, I should care very little about; but it happens to have the Telegraphic curse upon itfalsehood. That I was one of the main pronpters, if not contributors, to "We, the people," has been proved by the written declaration of the publisher of that sheet to be utterly untrue, and it is in the characteristic style of impudence and effrontery of the vulgar and pensioned Telegraph again to reiterate it.

If solicitation were made to the Executive in my behalf, they were made by his and n1y friends in Congress, who were apprised of the base and 1nuprincipled efforts which the hinngry officina gentinu, who were 
inundating the city, would make to displace all the most useful and efficient officers of the Government, no matter by what means. This was one of the fabrications got up by Duff Green and his coterie to injure me; and, like the Inquisition, it was only necessary to lodge secret information to consign the victim to the stake or to lead him out to the auto de fe. Such is the present deplorable condition of our conntry, a condition which every patriot must lament and resist, if he wishes to save its fair fame from pollution and its liberties from destruction. But it would seem that against the express desire of those for whose special benefit the Library was created, the Executive has undertaken, upon the gross misrepresentations and falsehoods of such a creature as Green, to put one of his foremen into an office over which the President ought not to have, if delicacy did not prevent him from now having, any possible control.

I deem it umnecessary to notice the paltry and contemptible quibble about my bond. It is on a par with everything he has asserted and shows to what desperate efforts the slanderer is driven when pusheddeserves no further remark than it is nonsensical and absurd. The perfectly "unexceptionable bond," as he terms it, which has been given by Mr. Meehan, is, in fact, no bond at all; because it has not the necessary legal formalities - has not the sanction of either the President of the Senate or the Speaker of the House of Representatives, and is therefore of no more validity than a piece of blank paper. The amount of his security, if security it can be called, is the same which I gave when the Library was estimated at $\$ 20,000$, and yet property to the amount of $\$ 80,000$ has been illegally put under the charge of a man wholly irresponsible, on the bare word of a pensioned calumnniator without decency and without truth.

Another power will yet determine upon the legality of this proceeding, and no doubt take such steps as their insulted rights demand. I ans myself indifferent as to the result, and should not now have intruded on the public attention with these remarks if the insufferable arrogance and falsehood of the minion who has assailed me had not rendered it inclispensable. Everyone who knows him must know that "S'il n'avait pas écrit, il aurait été assassin."

GEORGE IVATTERSTON.

At this the opposition rejoiced, though Mr. Watterston meant that it should quail, and the Telegraph, June I6, observed:

THE, EX-LIBRARIAN.

Poor Mr. Watterston was yesterday literally foaming at the mouth. The very editors of the $A s y l \mathrm{hm}^{2}$ were ashamed of him; and in place of admitting his distressed article into the elitorial columns as heretofore, 
they not only placed it in the most obscure corner, but before unclertaking to publish it at all actually obliged him to add name at full length, that it might not be mistaken, by its resemblance, for a bona fide lucubration of either Mr. Fenclall or Mr. Agg. A more ludicrous ebullition of frenzy has seldom been exhibited, and for unadulterated billingsgate even the gifted thirty-six ${ }^{2}$ must yield the palm to Mr. Watterston. So great indeed is the extent of vituperative talent displayed that we are inclined to suspect that it is actually one of his own best papers in "ITe, the people" resuscitated. To read his abuse with any tolerable degree of gravity is much more difficult than to answer the solitary objection to the legality of his successor's appointment, in which he still pe-sists. We quote his own language as a tolerable specimen of his style and facts. The classical requirements, of which he takes occasion to $1 \%$, t as a proof of lis fitness for office, may be estimated from the circumstance that of the three quotations in lis tirade the first is in bad Latin, the second in had Spanish, and the third in bad French.

After quoting what Mr. Watterston said about the bond, ti:e editor of the Telegraph then proceeded:

An effectual and, to all but Mr. Watterston, a conclusive answer to the above statement is to be fonnd in the following extract from the receipt by Mr. Lowrie for Mr. Meehan's bond and the approval of the same by the President of the Senate. The said bond is accompanied by a letter from the Hon. Sannel Smitl, President of the Senate pro tempore, dated the $2 d$ instant, in which is stated that he approves of the said securities and of the sum of $\$ 2,000$, the amount stated in the bond-Walter Lowrie, Secretary of the Senate. This very document was, some time ago, put into the hands of the cx-Librarian and rad by him. Will he again assert "that Mr. Meehan has given no bond, that it lias not the sanction of cither President of the Scnate or the Speaker of the House of Representatives, and that it is of no more salidity than a piece of blank papor?" Will he deny, at the same time, that his bond was invalid, that it never bore the approvai of either of the officers required by law? Will he tell us what the nominal amount of his own bond was at the poriod of his dismissal, that we may compare it with the sum of Mr. Meehan's, and say, in conclusion, if he is prepared to make good the lost and clamaged books for which that bond was granted?

But the ex-Librarian's case has broken down so fairly on his orwn slowing that we feel it umnecessary to follow him farther through the insane vulgarity of his yesterday's effusion in order to satisfy the people of the strict propriety of his dismissal. He has admitted his "supercilious conduct," and we have shown his utter unworthiness as well as his mental and physical unfitness for such a trust. We therefore leave him to reflect on his past conduct, with perfect liberty in future to be as abusive

\footnotetext{
EEditors of the Jonlunal.
} 


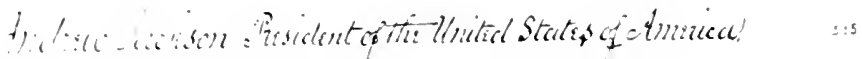

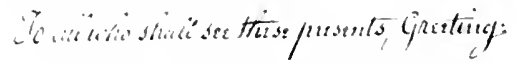

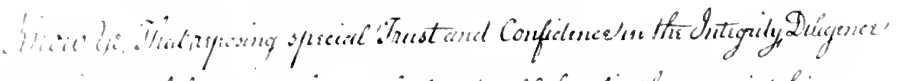

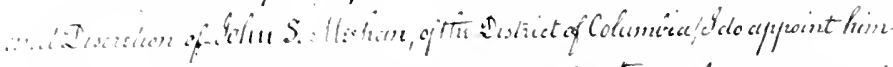

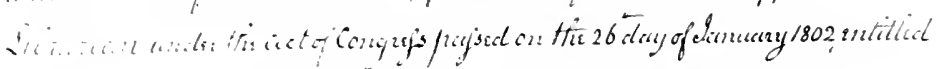

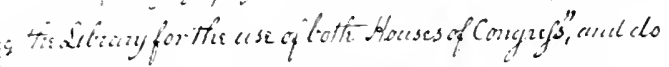

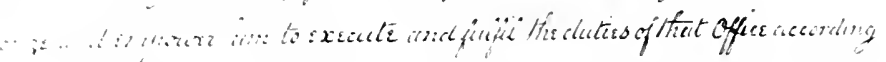

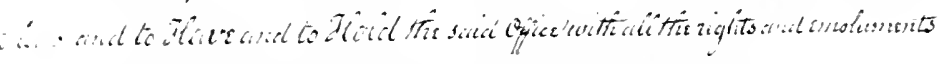

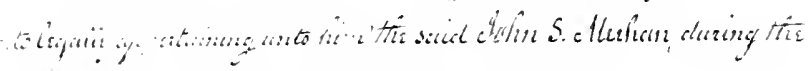

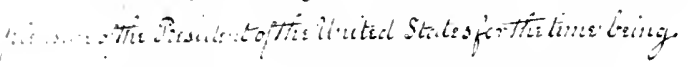

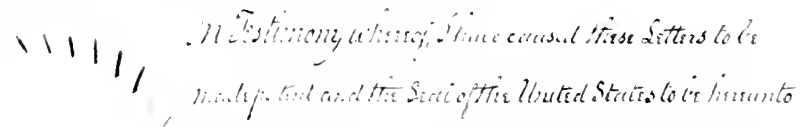

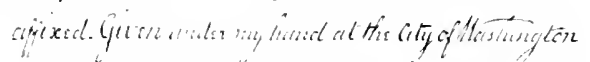

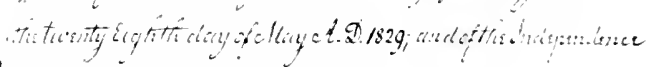

$$
\begin{aligned}
& \text { ( } \\
& 11
\end{aligned}
$$

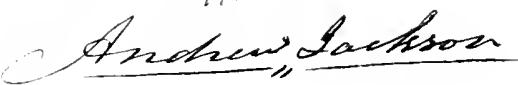

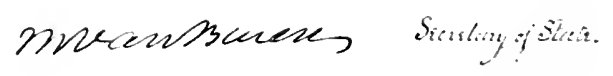

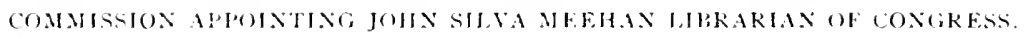



as he may choose. Shonld his classical reminiscences be scanty as reported, he may have forgot the saying of the poet, though he can not now aroid feeling its truth, "Raro antecedenten scelestun deseruit pede poena claudo."

We give Mr. Watterston this parting recomncndation-to read his last lucubration in the foumal whenever le wishes to be particularly self-satisfied, dignified, or supercilions, and should a perusal not insure perfect complacency, let linin recall the affair of the burning of the Library itself, a few of the choicest and most cliaste passages in that delicate production of his pen, The L__ Family in Washington, and believe that, whaterer his own situation may be, the people are not blind, and can see farther than either Mr. Watterston or the Asylum will admit.

This was a severe rebuke, but the National Intelligencer, which had up to this time kept out of the dispute, now cane forward and in its issue of Jume I6 quoted Mr. Watterston's article-though not in full-with the following remarks:

"The late Librarian of Congress has thought it proper to reply, under his proper signature, to certain pretenses for his removal, which have been publicly assigned. It is no n1ore than just to Mr. Watterston to copy the following passage from his letter, his official conduct, as far as our observation has enabled us to judge, having been not only unexceptionable, but assiduous and praiseworthy." $\because \because:$

It was because this was true and because sucl able n1en as the editors of the Intelligcincer recognized its truth that the position of the ex-Librarian was a strong one and the position of the administration of the Library correspondingly wcak. This is seen again in the following communication to the National Joumal, August S, is20:

The following extract of a letter from a late member of Congress of distinguished legal talents, relating to the illegality of the removal of the late Librarian of Congress: "In my opinion, you are still the Librarian of Congress, and though temporarily thrust from the room and the possession of the books, your salary does by law go on as if no intrusion had been made into your place. The third section of the act of Jannary, I 802, strangely enough, it must be owned, gives to the President the sole power to appoint a Librarian, but neither that act, nor any other that I can find, gives him any power to regulate the office or exercise the slightest control over the officer. These powers belong to the President of the Senate and Speaker of the Honse of Representatives. 'They' 
must not only approve his security, but must fix the amount of the penalty of the bond, the main condition of which is that he shall faithfully discharge his trust according to such regulations as they shall establish. I presume the right to remove is claimed as a necessary attendant upon the power to appoint, but as regards this office, I can conceive of no ground on which the claim can be sustained. No one will contend that the right is given by the words of the Constitution or any act of Congress, and I think it is not hard to show that it is against both principle and analogy. I assume it as a principle that when an office of indefinite duration is established and a man is appointed to fill it without limitation as to time, he has a freehold in the office. Hence I infer that the Librarian can not be removed at all but for misdemeanor in office. And who shall examine into such misdemeanor? The power that appoints or the power that controls? The President has exhausted all his statutory power when he has appointed the officer, and then the powers of the President of the Senate and the Speaker of the House begin, but, unlike the President's powers, they have no end. Their powers are as general as the objects of the establishment and as perpetual as the Library itself, for, in the language of the law, 'they are empowered to establish such regulations and restrictions in relation to the said Library as to them shall seem proper, and from time to time to alter and amend the same.' In fact, the Executive Government has nothing to do with the Librarian nor with the regulations made for his government, and consequently it is a great breach of principle for the President to meddle with an officer who pertains to Congress alone. The President's power to remove executive officers, civil and military, has been doubted by many on the ground that there is no written law to justify it, yet there the reason is strong in favor of the power because all executive officers are in fact the President's subordinates and political servants. $\mathrm{He}$ is responsible to the nation for their actions and they are responsible to him and receive their orders from him. But what has he or the people to do with the keeper of the books of Congress? It is the President's business to see that the laws are faithfully executed, and subordinate agents are allowed him for the purpose of enabling him to discharge that duty. If the power to appoint draw after it the power to remove, then not only will the State legislatures have power to dismiss Senators, but the electors may dismiss the President, nay, the President may dismiss the judges, the marshals, the jurors, whom they have respectively appointed. $* * *$

If Congress submit to this usurpation I shall not be surprised if the President should take it into his head to remove the clerks of the two Houses and appoint some of his own or Green's creatures to succeed them, but I do not look for submission at their hands. 
PARTISAN ATTACKS UPON THE IIBRARI.

If Mr. Watterston's removal had been merely illegal or 1111ust the injury to the Library would have been great, but because it was also a partisan act and because Mr. Watterston was a prominent Whig journalist the injury to the Library became incalculable. The partisan character of the removal of Mr. Watterston from the office of Librarian was shown by the journalistic war which followed his removal. It is shown even more clearly in Mr. Watterston's correspondence.

A letter from Henry Clay, July 2I, IS29, said: " "Prior to the receipt of your obliging letter of the roth instant, I had seen with mingled sentiments of indignation and regret your removal from the office of Librarian. It was a step in keeping with the despotism which now rules at Washington, and it has a precedent in that act by which the fantous Alexandrian library was reduced to ashes. In your particular case, as in some others, I have been inexpressibly grieved by the reflection that friendship for me may have been one of the canses which led to the exercise of vengeance upon you and upon them." ***;

On the floor of the Senate, too, the obligation of the Whigs to Mr. Watterston was recognized, and during the following session of Congress (April 28, I830) Mr. John Holmes, of Naine, a little baldheaded, ruddy-faced man, with a keen face and a roice like the trumpet tones of an organ, ${ }^{2}$ in the course of a speech on the power of the President over appointments, said: ${ }^{3}$

* * * But the greatest outrage of all is that the President has invaded our dominions, and actually removed, and in the recess, too, an officer of the two Houses of Congress! Sir, the President has as good a right to remove the Secretary of the Senate as the Librarian. This library is the Library of Congress; the purchase of Mr. Jeffersou's library was for the two Houses of Congress. The rules for goveruing it are to be made by the presiding officers of the two Houses. The law, to be sure, gives the power of appointment to the President, but so soon as he has exercised it he is functus officio to all intents and purposes.

'Watterston NISS.

- National Journal, August 20, $\mathrm{r}_{3} \mathrm{O}$.

${ }^{3}$ Register of Iebates, vol. 6, pt. I, p. 393. 
The President has no control over this Library any more than one of our clerks or any stranger. We permit him to take books under our regulations, as we do the justices of the Supreme Court and other officers, but he can not, any more than they, dictate a single word as to its management or control. Instead of his having the power to direct this officer in the performance of a single duty it is directly the reverse; the Librarian luas the right to direct him, and to punish him for a violation of its rules. If the power of removal is in this case consequent upon that of appointment, the President can impose upon us an officer of the two Houses against the will of both. If he can remove at discretion he can also refuse at his discretion. He might, consequently, return a Librarian utterly offensive to us, who mismanaged our property, disobeyed our directions, and set our rules at defiance. But, sir, this usurpation is further manifest from the fact that he can never judge when the officer becomes disqualified. He, neither by himself or any of his subordinates, has any right whatever to inspect the Library or inquire how the duties have been performed. He can, therefore, never know when there is cause for removal. It, with him, would always be a haphazard business, quite as likely to be done wrong as right. The President did not, for he could not, remove for cause. He had, when this removal was made, been inaugurated but three months. Now, had he devoted all his time to examining the regulations of that Library he would not have learned whether the Librarian had managed well or ill, even in three years. But, sir, we know that Mr. Watterston was not removed because he was unfaithful or incapable. We know that he was both faithf ul and capable, and preeminenty so. Not a murmur has been whispered against him. I appeal to the Joint Committee of the Library, who have from time to time superintended it, if this is not the fact.

But, sir, there is another reason which should have convinced the President that he was doing wrong, if he is capable of reasoning at all. The law required that the Librarian, who was to have the custody of such valuable property, should give bonds with sufficient sureties, to be approved by the President of the Senate and the Speaker of the House. When this removal was made there was no President of the Senate here, and no Speaker of the House in existence. This puts the flat negative upon the President's power to remove and fill in the recess. He could not possibly appoint this officer according to law. The whole was illegal; a responsible officer was thrust out by arbitrary power and another man ordered to take our property into his custody of 110 legal responsibility. But, sir, if he had the power to remove aud appoint at his discretion an officer of our own, we should have thought that common courtesy would have demanded that he should have consulted us. But he did not; indeed, he could not; Congress was not in session; there was in fact no Congress in existence when the removal was made, for some States had not then elected their members. I then call upon the 
gentlemen to give the reasons why, how, and by what authority our Librarian has been remored! * * * *

Before the return of the Whigs to power in I84 I Mr. Watterston had lost many of the qualifications for the office of Librarian which he had possessed in 1829 . For this reason-there were doubtless others, also-he was not restored to his lost position by either Harrison or 'Tyler. Mr. Watterston's disappointment at this was aggravated by the appointment of lis successor's son as second assistant Librarian by the act of March 3, IS4I. He gave rent to his feelings in the following communication, evidently intended at first for publication, but as far as can be discovered not published. It was preseived among the Watterston MSS., and is without date:

Mr. Watterston was for fourteen years Librarian, and for twelve years had no assistant but a servant at a dollar a day, Sundays excepted. *** The expense of the Library was for many years not more than \$I,900 per amnum. The present Librarian has a salary of $\$ 1,500$; two assistants at $\$ 1,150$ each, and a messenger at $\$ 750$, with a contingent fund of $\$ 500-\$ 600$, naking an aggregate of above $\$ 5$, I 00 annually; and they do not render the service performed by Watterston alone, because they are not qualified for it, either by education or reading. They can find a book that may be wanted, but the subject is quite beyond their reach. Meehan was a proof reader and was never fitted for such a place. His education is very ordinary and he has no fondness for reading, and therefore can not make himself useful as a Librarian. His son receives \$I, I 50 a year as an assistant, merely because he lost one of his hands very foolishly while gunning, and that gonrmand [Willian C.] Preston, who is easily played upon by flattery, must needs have him stuck in the Library and billeted on the Govermment. Mr. Stelle, the first assistant, is a competent and useful man, and worth both the others together. He understands his business well and yet he grets no more than the son of Meehan, who can scarcely do anything. Mr. Mangum says he has roted for but one additional clerk in the executive offices during this Administration, but he is mistaken; he roted to throw away \$I,150 on this young man and to pay old Meehan for being a furious locofoco. Why don't Congress look into this matter? Why do they let the President appoint these officers, especially when they see how inproperly and foolishly he executes this duty? Why don't they insist upon his turning ont this low fellow and putting back the gentleman who had been so unjustly and causelessly removed? Have they no feeling-no sense of honor left as a party? They have the power to 
alter the law appointing the Librarian at any time; and why don't they place it in their own hands and not allow this secret locofoco President to palmu upon them any fellow he may choose to pick out of the streets to associate with them? But why is so heavy an expense tolerated, at any rate? Is it not outrageous that these men should receive upwards of $\$ 5,000$ a year for doing no more than was done by Watterston and Stelle for about $\$ 2,500$ ? Is this the economy of the Whigs? It is a scandalous waste of the public money and should be put a stop to at once, etc. ${ }^{\mathrm{T}}$

Again in $\mathrm{I} 844 \mathrm{Mr}$. Watterston was provoked to attack the Library administration by an article in the Globe, October 29. This, in speaking of Watterston's work as secretary of the Washington City Clay Club, said: "Watterston is himself a slaveholder. He was once Librarian of Congress and was dismissed by General Jackson. He had the unconscionable avidity (to characterize it gently) to charge the Government $\$ 700$ hire per ann11m for one of his slaves who occasionally went on his errands as Librarian." In reply to this Mr. Watterston wrote to the National Intelligencer November 2, I 844 , in his most vigorous style:

My attention has been called to a couple of editorials in the Globe of Tuesday and Wednesday last, in which, among other extravagances, I notice a statement in relation to nyself which I pronounce a base falsehood, and for which, if repeated, I shall make the conductors of that journal answer at another tribunal. This is the second time I have been obliged in self-defence to nail to the counter the gross fabrications of that print; but I do not regret the necessity in the present instance, as it affords me an opportunity of contrasting the promises and performance of the "Democratic" Administration of Andrew Jackson, which came into power minder the solemm pledge of retrenchment and economy.

The Globe of 'Tuesday asserts, with its usual effrontery and recklessness, that "he [I] had the unconscionable avidity to charge the Government $\$ 700$ per anmum for one of his [my] slaves who occasionally went on his [my] errands as Librarian," etc. I pronounce this assertion utterly false, and its falsehood can fortunately be easily established. If anyone will take the trouble to refer to the acts of Congress from the year I 816 to 1829 , while I acted as the Librarian, a period of nearly fourteen years, he will find that the contingent appropriation for the I ibrary never cxceded $\$ .50$ per annum, and out of this small sum I was required to procure fuel, stationery, some articles of furniture, and a servant. The hired servant was never allowed by the President of the

\footnotetext{
${ }^{2}$ Watterston MSS.
} 
Senate and the Speaker of the House, who had control of the fund, nore than one dollar per dicm during the day's the Library was kcpt open, namely, three times a week during the recess, and every day, Sundays excepted, during the session of Congress. His pay, therefore, seldom exceeded \$200 a ycar, and he was the only assistant I had for twelve years. All the duties were performed by myself alone, and for which I received a portion of the time $I$ acted but $\$ 1,000$ per annum. This was under the very extravagant Administrations of Madison, Monroe, and J. Q. Adams. The retrenching and cconomical Administration of Andrew Jackson succeeded, and I became one of the many victims of proscription. In a short time the scene was changed, and instead of one Librarian and a servant at an expense, including everything, of $\$ 1,950$ per annum, there are now one principal Librarian, two assistants at a salary of \$ I, I 50 each, and a messenger at $\$ 750$, with occasional extras, while the whole annual expense amounts to some $\$ 4,550$, making a difference of $\$ 2,600$, and sometimes $\$ 3,400$ a year added to the annual expense of that establishment, when I kept it with a single servant under an Administration so often denounced as extravagant. If it will afford any satisfaction to these concoctors of falsehood, I may now state that the servant referred to has long been free, and is figuring as a preacher in one of the Northern States. The conductors of the Globe, however, should be the last men to talk of " unconscionable avidity" in making charges against the Government. But I shall not attempt to retaliate. It is enough for me to show that in the statement referred to, and which they have twice repeated, they have asserted what they must have known to be an atrocious falsehood, and which the acts of Congress and the books of the Treasury will demonstrate to be so.

In 1845 the Democrats returned to power. But in $x \$ 49$ the Whigs were again triumphant; Zachary Taylor became President, Millard Fillmore Vice-President, and Mr. Watterston's friend, J. M. Clayton, Secretary of State. On the zoth of April, 1849, Watterston wrote to Clayton:

I called at your residence yesterday to see you, but was not successful. My object was to inquire what progress had been made in relation to my application to be returned to $11 y$ former office, and to know whether it was at all likely that I should succeed. Every Whig citizen in Waslington seems to think that it would be but an act of bare justice, and expresses his surprise that it has not been done. To your discretion and friendship I have submitted the whole matter, and, of course, have taken no further steps to promote my application. If I fail, I slall certainly regard it as an instance of ingratitude that nust be painful, and the Administration may retain a political opponent, but they will lose some friends in such a course. If Meehan must be provided for, why not give him another place. $* * *$ Another press (not the Republic), is 
about to be established here, of which I have been requested to becone one of the editors. I desired to have a conversation with you on the subject, as I propose in due time to nominate you as the successor of General Taylor, and to support your claims to the Presidency. ****

The following letter was probably written to Mr. Clayton, and at a later date than the foregoing:

Mr. Whittlesey informs me that in a conversation with you a few days ago [he learned] that no further progress has been made towards my restoration, and that you say the President remains still mndecided. I think this most extraordinary. I depended mainly upon your efforts and representations for success, and felt assured that the thing would be effected. I can not conceive why there should be the least hesitation in a case so obviously proper and just. If Mr. Key, Wallace, Scott and Co. could be removed for their mere opinions, I do not see why Meehan should not also share the same fate and be removed. Indeed, it would be more proper and just to remove him and restore me, than to remove the persons I have named. Why shonld this distinction be nnade in my case? Meehan, I have sliown you and Mr. President, was not only appointed for his political opinions, but is absolutely incompetent and therefore ought to be removed. It is an act of gross injustice to me which I can not and will not submit to calnly. Wallace, a boy whose associates are of the lowest order, has been appointed to an office of $\$ 600$ per annum. Bradley, who has been partly Whig and partly locofoco, to one of $\$ 2,000$. Mudd, who has done nothing for the party and can not write English, to an office of $\$ 2, \infty 00$, while I who have done more than any five of them an kept out of an office from which I was most unjustly and improperly removed, and to which I have undoubted claims. If the Adninistration were influenced by the common feclings of gratitude, it wonld withont hesitation offer me not only the place I seek, but one at least that I might accept. I shall call upon Mr. President in person in a few day's to know from him his ultimatum. I have letters from influential individuals of Lonisiana requesting $m y$ restoration, and if the papers I sent you are not before him you will oblige me by letting me have them.

If iny application be rejected I shall know what course to pursue. If I have done the party some good, I can yet do it some injury.

A third letter, also to Mr. Clayton apparently, is dated Octobcr I 5, I 849 .

I called upon General Taylor a few days ago to deliver a letter from an influential Whing of Isouisiana, recommending my restoration to the office from which, as you know, I had been so wrongfully removed by Jackson; but his manner and reception were such as to lead me to believe that there was no intention on his part to make a removal or to do me 
the act of simple justice I desired. I have therefore abandoned all expectation of being restored, and should be obliged to you if you would withdraw the papers I requested you from time to time to lay before him and return then to me. I have 110 doubt you are as nuch disappointed and mortified at this singular hesitation and apparent determination not to renore Meehan, as I am. I am, I confess, at a loss to account for sucl impolitic and extraordinary conduct. It will certainly not make 1ne rery ardent in my support of him or the Administration hereafter. If he can retain such men as Meehan in office and exclucle his political friends who have made most sacrifices and unceasing efforts for the Whig cause, and wio are perhaps able to do them still greater scrvice, be it so, but the consequence is now beginning to be realized in the defeat of the party everywhere, because everywhere the Whigs are disgusted and irritated at a policy which punishes friends and rewards enenies by excluding the one from and retaining the others in office. I despise ingratitude in parties as well as in individuals, and I certainly never dreamed that the party which I had so long supported with so much ardor and at such loss would prove ungrateful, especially to one to whom, I may say it without vanity, they owe more than to three-fourths of those that have been appointed. The appointments, too, have been generally of such a character as to produce dissatisfaction and astonishment. I know and hear what is said and thought on this subject by Whigs here, and who have been from the first the warmest supporters of the cause. Even those in office do not fail openly to express their surprise and mortification at the treatment nany of the old and original Whigs receive. I an conscious that you are and have been $111 \mathrm{y}$ friend, and I thank you for the efforts you have employed to do me justice. It is in your power, however, still to befriend me. * * *

The rest is rather illegible, but is to the effect that he would like one of the positions which was at his correspondent's disposal.

President Taylor was inmovable. But on the gth of July, I 850 , he died and Vice-President Fillmore succeeded him. At this Mr. Watterston at once wrote to his friend Henry Clay (Jully I7, is 50 ):

SIR: From our long acquaintance I take the liberty to trespass upon your attention for a few monents. You are aware of the friendship I have always entertained for you and no doubt of the efforts I have made during the last twenty years in your belialf. In I $8 \mathrm{~S}$, I believe, I gave you some little notoriety by my "Letters from Washington," written nucter an assumed character and circulated extensively at home and abroad, and on all occasions either as the conductor of a press or a contributor I liave constantly and unceasingly labored to extend your fane 
and rebuke your calumniators. You know how unjustly and wrongfully I was treated by Jackson in consequence of my attachment to the Republican cause and to you in particular. I had formed and cradled the Library of Congress and made it what it now is, except some additional volunes. I was thrown out by the miserable old tyrant who then ruled the nation with a rod of iron, and have been proscribed and persecuted ever since for my party opinions. About this, however, I cared but little; I supposed that when the party triumpled which I had so long and so derotedly sustained, not only by my intellectual efforts, but by all the little pecuniary means in my possession, that justice, simple justice, would be done me. General Harrison was elected (I $8+1$ ), and instead of acting promptly and immediately, as he ought to have done, he died and "gave no sign," though he knew how I had been treated and had himself been the victim of proscription. Tyler succeeded, and he proved a traitor from whom no Whig could expect favor. My two sons had long before been driven from the city of their nativity to seek their fortunes in Louisiana from the want of employment here, which was refused them because the name was obnoxious to the locofoco party, and I remained to battle the watch as I could. When Harrison's Administration cane in, the first act of the Cabinet instigated by Webster was to decide against restoration, the only act of justice they could render to those who had been unjustly proscribed, and the fiercest mode of proscribing proscription. I felt indignant, but I remained true to the party. I was anxious that you should succeed and become the President of the United States. I felt that you had been treated with the basest ingratitude, and I exerted every effort in my power to elevate you to the position to which I thought your services and talents entitled you. A press under the title of the National Ithig was established here to advocate and support the election of General Taylor. The editor, Gaither, became unpopular, was obliged to withdraw, and I was selected to conduct the paper, gratuitously, of course. I did so, and supported your clains till the nomination of General Taylor by the convention, and then retired from the editorial chair. When General Taylor became President Mr. Clayton volunteered to restore me the office from which he knew that I liad been so unjustly removed, and declared that if he did not succeed he would be more disappointed than myself. I left the matter to him and though through the influence of one of my sons in I.onisiana some letters were written to Taylor from the most influential citizens of Lonisiana in nyy favor, he paid no attention to them, but through the secret influence of Bliss, a locofoco, and several Whig members of Congress, the man who liad taken my place and is, from defective education and want of study, altogether unfitted for the office, has been retained; while $I$, who have sacrificed everything for the Whig cause and made the I, ibrary what it was, have been left out, to the trinmph of the locofoco party and the mortification of my political friends. I wished 
tc be restored, if but for a few days, to show that the party was not ungrateful and that the present incumbent had obtained nily place unjustly and wrongfully. In one of your letters to me soon after my removal you were so good as to say that if it should ever be in your power you would do me justice. That time has, I think, now arrived, and it is only necessary for you to speak to Mr. Fillmore in my behalf to effect the purpose I have so long had in view. I have been like yourself the victim of the basest ingratitude, but I entertain the hope that Providence in His wisdom has produced a change that may be the salvation of the country, as well as the Whig party, and that I liave lived to see the consummation of my long-indulged hopes and wishes.

Very truly and sincerely, yours, etc.

What response, if any, Clay made to this appeal, has not been discovered, but if he did anything it seems from the following letters to have been without effect. A copy of a letter from Watterston to President Fillmore, dated October 16,1850 , reads as follows:

In the interview heid with you yesterday, I regretted to find that you deemed it necessary to refuse the simple act of justice I desired and that you had thought it advisable to consult your Cabinet about the expediency of removing a political encmy and appointing a political friend in his stead. When Mr. Madison appointed me to take charge of the library of Mr. Jefferson in I 8 is he did not think it necessary to consult anyone, nor did General Jackson when he appointed Meehan and removed me. The members of the Cabinet whom you consulted are, I suspect, strangers to me and unacquainted with the circumstances attending my removal. I am sure Mr. Conrad could not have advised you to such a course, for if he did he may have reason to regret it in Louisiana.

The reason which you assigned for refusing me the humble appointment which I once held for several years, namely, that it might offend Congress, surprised me greatly. Congress have now and will have a majority against you, and it will be in vain to attempt to conciliate that majority by an act of this kind; you will lose more than you will gain by such policy. As to their abolishing the office in consequence of the removal of the present incumbent, that is a matter that wonld affect me and not yon were I appointed, and would not be done if it could. That no complaint was ever made against me may be seen from the speech delivered by Mr. J. Holnes in the Senate in I830. * * *

But you and your Cabinet have undertaken to decide in favor of retaining a Democrat to the exclusion of a Whig who has, for the last twenty years, devoted himself to the support of the Whig cause: who has, he believes, done as nucli as you or any of your advisors to render 
it tritumphant. But this is not all; a simple act of justice is denied me. I am excluded from an office from which all admitted I was wrongfully removed, and the man who took my place is from fear or some other cause, permitted to retain it, to the surprise and astonishment of every Whig in this city. But [by] such a timid policy you neither promote your own fame nor the tottering cause of your party. Ingratitude in parties as well as in individuals renders both unworthy of support, and both will be repudiated by every honorable inan. The fate of the Whig party is, however, sealed, and it has been produced by the timid and selfish policy which has been adopted by Whig Administrations.
Yonrs, etc.,
G. W.

Another letter, seemingly to the same and evidently subsequent to the foregoing, reads as follows:

I an induced to make another effort to give you one more opportunity to do me an act of justice if not a favor. Your refusal to restore me to the place from which I was so causelessly and therefore unjustly remored by General Jackson hurt me no little. Everyone who knows what I have done and suffered for the party thinks that great injustice has been done me and that I have been treated badly. But let that pass. The opportunity to which I refer is that which is likely to soon occur by the death of the present Commissioner of the Public Buildings [John Mudd]. This is an office within your gift and the duties of which I think I ann qualified to discharge from the attention I have paid to arboriculture, landscape gardening, architecture, etc., which it is highly important an efficient oficer of this kind should possess. It is not an office which a mere mechanic can properly fill, who can merely execute what is suggested by others of ligher attainments and better taste. I have, moreover, perhaps, some clains to this office, as I an now, with one exception, the oldest citizen of Washington and perfectly familiar with its history and wants.

From the friendship you lave long manifested for me and ny family, and the regret you expressed at being unable to restore me to my former office, and the promise you made some of my friends on that occasion that you would be happy to avail yourself of the first opportunity to give nue such a place as would suit me, I now feel it nuy duty to ask you to appoint me to the office of commissioner when the present incumbent shall no longer fill it, which I an sorry to say is likely to occur soon, if it has not already occurred. It is the last request I shall wake of you, and if I fail in obtaining what I now ask, I shall consider it as wholly unnecessary to trouble you with any other request in the future.

'This letter seens not to have been sent; there is another of the like tenor following it, apparently written a little later: "The death of the late J. Mudd has made a vacancy in the office of Commissioner of Public Buildings, which I should be pleased to fill," etc. 
On the $4^{\text {th }}$ of February, I $854, \mathrm{Mr}$. Watterston died. To the last he suffered keenly from the loss of his position as Librarian. The correspondence which we have here reproduced is sufficient evidence of this. And the Library also suffered. This will appear evident in the listory of the Library from i 829 to I 854 , - not so evident, it is true, as the suffering of the rejected Librarian, because no one who was in a position to know how the Library suffered cared to speak about it, and those who cared to speak about it-the friends of Mr. Watterston-were not in a position to know, but by reading between the lines of the Watterston correspondence and of the Library history it is possible to see that the removal of the Librarian in I 829 was a reason for the tabling (by Henry Clay) of Preston's motion for the purchase of the Boutourlin library,- the Whigs could hardly entrust such a library to a Democratic Librarian,- -and a reason for other failures in legislation and administration, perhaps, of which we shall speak at length in the ensuing chapters. Another experience of a similar kind, however, was necessary before it was learned that the Librarian of Congress should be a Librarian rather than a politician. That was the short, unfortunate career of Librarian Stephenson. 
Griaptex Seurex

DEVELOPMENT OF THE LIBRARY, I829-1851 



\section{Chapter Seven.}

DEVELOPMENT OF THE LIBRARY, I829-185I.

John Silva Meehan, appointed Librarian of Congress May 28 , I829, was described by his contemporaries as a man of aniable and nnobtrusive manners, punctual and assiduous in his duties, eminently qualified for the position to which President Jackson had appointed him. ${ }^{\mathrm{r}}$

Mr. Meehan was born in New York City February 6, I 790. During his boyhood and early manhood he lived in New York City. In ISI2 or ISI 3 he went to Burlington, N. J., to superintend the printing of Walker's Dictionary. After the completion of that work he was appointed a midship111an in the Navy and served on board the "Fire-Fly" n1ntil the close of the war. He then received an appointment as lientenant in the Marine Corps through the influence of Hon. Tench Coxe, of New York, ex-Assistant Secretary of the Treasury. Preferring civil to military life, however, he declined this appointment and returned to his trade as a printer, in Burlington. In I 8 I $_{4}$ he married Miss Margaret Jones Mornington, of that city.

Shortly after this he moved from Burlington to Philadelphia, where he entered into partnership with Robert Anderson as printer and publisher. The firm of Anderson \& Meehan were the publishers of the Latter Day' I.uminary, a religious monthly issued under the auspices of a committee of the Baptist board of foreign missions. ${ }^{2}$

In 1822 the firm was removed to Washington, then beconing a center of Baptist interests because of the location of

\footnotetext{
Willian Q. Force, Picture of Washington, IS.15, p. 14; Obituary notice by his friend of more than thirty years, John M. Brodhead, Second Comptroller of the Treasury, in the Nalional Intelligencer, April 27, 1863 . There is also a notice in The Huntress, December I4, I839. It should be noted that the librarianship was first offered to Charles Pendleton Tutt, who, however, preferred the office of navy agent at Pensacola.
}

2'The first number was publisherl in liebruary, $1 \$ 18$. 
Columbian College in that place, and there he commenced the publication (February 2, I 822), under the auspices of the Baptist general convention, of the Columbian Star, a weekly newspaper devoted to the religious and educational work of the denomination. On July 9, I825, Mr. Meehan resigned his interest in this newspaper, and early in the following year purchased the Washington Gazette. Jonathan Elliot told John Quincy Adams in I $S_{3}$ o that Meehan had been only the nominal purchaser; that John $\mathrm{H}$. Eaton had written a letter to him making himself responsible, and that John P. Van Ness indorsed the notes, but that the paper had been purchased by a subscription, to which several persons had contributed, and he had been obliged to sue the notes. ${ }^{2}$

Upon becoming proprietor of the Gazette he changed its name to United States Telegraph, and remained its publisher from February 6 until October I7, IS26, when Duff Green became the sole editor and publisher. In the following year he became secretary of the board of trustees of Columbian College. On the 29th of May, IS29, he was appointed Librarian of Congress by President Jackson because of the support which he had given Jackson during the preceding Presidential campaign.

After Mr. Meehan's appointment as Librarian all his energies seem to have been devoted to the duties of his office. On June 23, I 832 , the Library Committee voted that he be authorized to visit the public libraries at Baltimore, Philadelphia, New York, West Point, and Boston to instruct himself in their modes of managing libraries for preservation, exhibition, use, etc., and that he be allowed his reasonable expenses for traveling, to be paid ont of the Library fund. On the IIth of Augnst, I 856, he appeared as one of the incorporators, with James Dumlop, chief justice of the circuit court of the District of Columbia; John T. Towers, mayor of the city of IVashington; Henry Addison, mayor of the city of Georgetown, and Joseph Henry, Secretary of the Smithsonian Institution, of the library for young men in the District of Columbia, called "Columbia's Library for Young Men."

"Washington Gazetle, February 2, 1826.

${ }^{2}$ J. Q. Adams Memoirs, S: 217.

${ }^{3}$ Statutes at Large, I 1: $45^{8}$. 


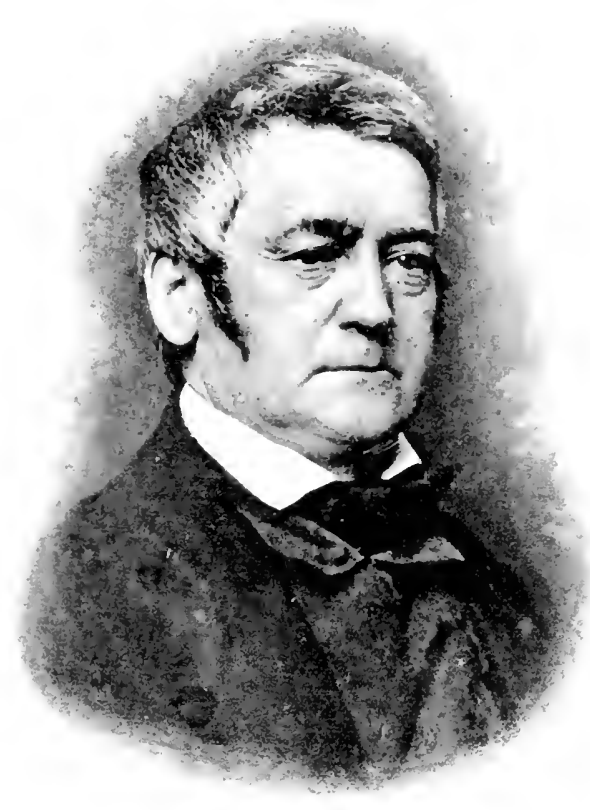

Ghn S. Meehan. 

Librarian Meehan was said to be acquainted with no language but English, and not very well acquainted with the books written in that language. 'This was perhaps true in I $S_{3}$, it must have been far from true in i 860 . The experience of thirty years had made him acquainted with the books in his custody, at least, with the most popular of them. Like other librarians of the period he attempted simply to supply such books as were immediately in demand, and did not attempt to anticipate the demand, or to provide for other than present or local needs. Such bibliographical policy on the part of a national library was undoubtedly weak, and its weakness was felt, especially when it became necessary to replace the collection destroyed in the fire of $\mathrm{I} 85^{\mathrm{I}}$. At this juncture Congress should have had a Cogswell or a Jewett.

Librarian Meehan did, however, possess the second qualification of a successful administrator, that is, business ability, and therefore enjoyed the confidence not only of the Democrats but of the Whigs, until I86I, when being regarded as a Southern sympathizer he was removed from office by President Lincoln (May 24). On the 24th of April, I863, he died."

THE LIBRARY' ROOMS IS29-185I.

From I 829 to $I 85$ I the chief changes in the Library rooms were in the additions of furniture. On February 6, I830, the Library Committee voted that the Librarian purchase a suitable table for prints, maps, etc.; April ro, I $8_{30}$, that the Hon. Mr. Verplanck be requested to see to the purchase of a print case or cabinet for the accommodation of the valuable books of the Library, containing plates, etc.; February 9, I $8_{3}$ I, that John McDucll's bill for painting and gilding the titles of the chapters in the alcoves of the Library, amounting to $\$ 1 S_{5} .96$, be paid.

The civil appropriations act of May 5,1832 , provided $\$ 3,000$ for repairs and furniture for the Library. With this the committee had shelves and closets fitted up and painted in the law room and committee room, and doors of mahogany

\footnotetext{
'Watterston MISS. materials for a history of Washington, p. $3^{8}$.

'I am indebted to Librarian Meehan's daughter, Miss I aura G. Meehan, for much of the above information.
} 
woren with brass wire hung in front of the bookshelves in the main room. ' The civil appropriations act of March 3: I $S_{35}$, provided $\$ I, 500$ more for new articles of furniture; that of May IS, IS $42, \$ \mathrm{I}$, Soo for carpet, repairs to furniture, and contingent expenses.

January 9, IS40, the Library Committee had under consideration the application of the Librarian for more room for the acconmodation of the Library.

In $\mathrm{I}_{4} \mathrm{I}$ an additional room was provided for the use of the Library in the passage adjoining the Library room, ${ }^{2}$ and on the ISth of February, I $S_{42}$, a resolution anthorizing the removal of the law library from the room north of the main Library to a room on the floor below, near the Supreme Conrt, occupied by the stationery of the Senate, passed the Senate and on the following day the House. On the rst of March, IS43, accordingly, the Library Committee ordered that the Librarian cause the room in the passage near the Library to be shelved and put in order as early as practicable; that he also cause the room for the law department of the Library, near the Supreme Court, to be shelved, carpeted, painted, and fitted up for the reception of the law books, and that he defray the expenses incurred for the two rooms and for removing the books out of the contingent fund of the Library. ${ }^{3}$

The civil appropriations act of March 3, I843, provided $\$ 225$ for laying the floor of the principal Library room with hydraulic cement, and authorized the Librarian to sell at public anction any portion of the old and useless furniture of the Library rooms. The Library Committee, Jume r2, IS44, ordered that the Librarian purchase a cheap carpet for the committee room and the room adjoining it, used as a Library room; February 27, I $847,{ }^{4}$ that the stairs and gallery in the Library room be carpeted; February 26, i 85 I, that the Librarian cause two new stands, with shelves for books, to be made and placed for use in the room adjoining the Library.

\footnotetext{
'Minutes of the Joint Committee on the J,ibrary (MSS.), May 26 and December $29, \quad 1832$.

${ }^{2}$ Minutes, March 3 and Fiebruary 15, I 8.4 .

${ }_{3}^{3}$ See also Minutes, January 28 , February 4 , and December $2 S, I_{42}$.

${ }^{4}$ See also Minutes, August I, 1846.
} 


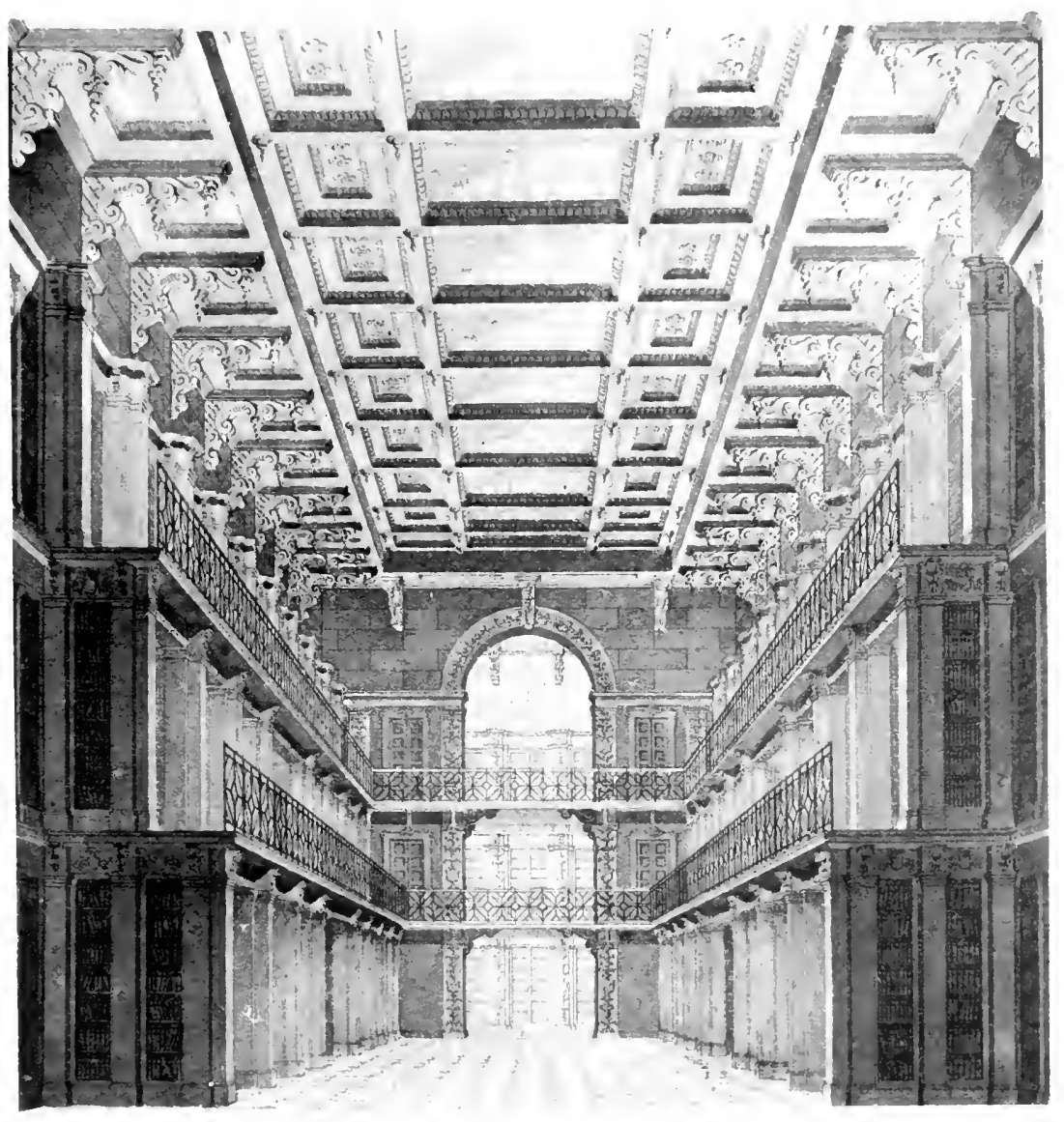

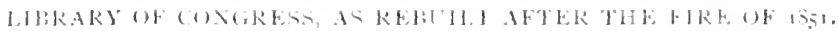



The enlargenent of the Library room by the addition of the two rooms in $S_{43}$ fast became insufficient. In IS 44 it was suggested that the Library be accommodated in the Hall of Representatives, and the Honse of Representatives in the Library room mntil a more suitable Hall of Representatives could be eonstructed, when the Library room would be converted into additional committee rooms for the use of the Senate. ${ }^{1}$ December 23, I 845 , the National Intelligencer spoke of the want of space in the Library. Angust I, IS46, the Library Committee roted "That the committee will endeavor to procure a room for the accommodation of the printed documents, etc., that are ordered to be placed in charge of the Librarian." August Io, the civil appropriations aet provided for enlarging the law library, constructing a new stairway, and other work, and the materials therefor, according to the plan of John Skirving, dated July 20, I\$46, \$2,412. And in I $S_{4} S$ Mr. C. B. Cluskey reported to the Committee on Publie Buildings, with reference to the main library, that the light could be much improved, especially on the west side in the recesses where there were no windows, by inereasing the apertures of the skylights at the line of ceiling from eircles to ellipses, and that mueh additional shelf room eould be secured by running galleries across eacli end of the room and by removing two of the stairways. ${ }^{2}$

But the question of the enlargement of the main Library room was bound up with the question of the enlargement of the Capitol. On the 2Sth of May, IS 50 , the Committee on Public Buildings made a report, with plans for the extension of the Capitol by Robert Mills. These plans provided for the building of north and sonth wings to the Capitol to accommodate the two Houses. The Library room was to remain in its old position, but be enlarged so as to oceupy the whole of the western projection. This would provide a room of 155 feet from north to south, by nearly 60 feet from east to west, and 45 feet high, capable of holding four tiers of aleoves and over 250,000 volumes. The aleoves on each side

\footnotetext{
${ }^{1}$ Report of Conmittee on Public Yuildings and Grounds, May' 24, 15.4, Twentyeighth Congress, first session, House report No. 5 I6.

${ }^{2}$ Thirtieth Congress, second session, IIouse report, go.
} 
were to be lighted from interior courts, and external communication with each wing was to be supplied by a colonnade gallery on each side of the western projection. In connection with the Library room it was further proposed to bring in the aid of the circular part of the Hall of Representatives, to which miscellaneous objects of art, etc., before deposited in the Library, might be renoved. The Library room would thus be relieved from the crowd of visitors who frequented

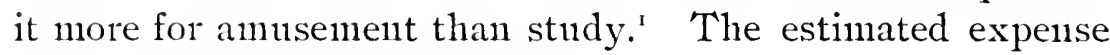
of these alterations was $\$ 75$, 000 .

Among the other plans for the extension of the Capitol those of Charles F. Anderson, a New York architect, provided for the Library as follows: "To give effect to the west front and change its monotonous appearance, I have availed of the necessity for enlargement of the Public Library by attaching two square projections, which will give relief to the eye and add massive grandeur to the effect of the entire building when viewed from the city. $: *: *$ I have opened the present Library at each end into two additions, each 64 feet square, with retiring rooms off; making the Public Library 2 I $S$ feet long and two stories ligh, with grand circular stair in the center of each new building, by which you approach the upper floors of the Library, as well as by the passages and corridors from the old building. These two square additions are surmounted by lanterns, on the summit of which flagstaffs are placed, as shown by the elevations. The height to the top of the lanterns on top of the new Library buildings will be 25 feet. The cost of altering and enlarging the Public Library according to these plans, it was estimated, would be $\$ 300$, o0o. ${ }^{2}$

This proposition was placed before members of Congress December I, I 850 . For want of opportunity the Committee on Public Buildings and Grounds presented no report upon the subject of the enlargement of the Capitol cluring the ensuing session. A report was, however, drawn up, and on

\footnotetext{
'Thirty-first Congress, first session, Senate report No. I45; Republic, May 7 and June 10, 1850.

${ }^{2}$ Report in explanation of the plans, etc., submitted in answer to public advertisement for enlargenent of the (apitol, at Washington. New York, Butler \& Brown, I850. $6 \mathrm{pp}$.
} 
the 7 th of March, 185I, it was published in the columns of the National Intelligencer. Their plan, as regarded the Capitol, differed from the plans of Mills and Anderson in providing for the erection of a building to the eastward of the Capitol instead of the erection of wings at the north and sonth ends of the Capitol, the two buildings to be united in the center and at the ends, so as to present the appearance from the outside of a single structure. While the two Houses of Congress were to be accommodated in this new building, the old Hall of Representatives was to be appropriated to the use of the Library without removing the columns, and the existing Library either continued or divided into committee rooms. Neither of these plans, however, was to be realized immediately, for on the 24 th of December, I $S_{5}$ I, the Library suffered from a third conflagration, less disastrous than that of August 24, I8I4, it is true, but far more so than that of December 25, I825, out of 55,000 volumes only 20,000 being saved, and those mainly the books shelved in the law department.

Before the fire of $185 \mathrm{I}$, then, the Library room presented essentially the same appearance that it did in 1825 . Robert Mills said of it, in I $847:^{1}$

The first thing that attracts the attention when entering is the admirable order of arrangement of the different subjects embraced in this room. The several works are classed according to Mr. Jefferson's arrangement, corresponding to the faculties of the mind employed on then-Ist, Memory (result, history); 2d, Reason (philosophy); 3d, Imagination (fine arts). Labels in large characters point out the position of the several classes of books in the order named above-for instance, alcoves Nos. I to 4 contain works connected with history, ancient, modern, and ecclesiastical; natural philosophy, agriculture, chemistry, surgery, medicine, anatomy, zoology, botany, mineralogy, technical arts; alcoves Nos. 4 to 8 , works connected with philosophy, namely, moral philosophy, law of nature and nations, religion, common law, equity, ecclesiastical, mercliant and maritime, codes, statutes, politics, commerce, arithmetic, geometry, mechanics, statics, dynanics, pnenmatics, phonics, optics, astronomy, geography; alcoves Nos. 9 to I 2 , works connected with the fine arts, arcliitecture, gardening, painting, sculpture, music, epic, tales, fables, pastoral

\footnotetext{
${ }^{x}$ Guide to the Capitol, p. 30 ; see also the Supplement to the Catalogue of the Library of Congress, December, 1833, where the alcove numbers are indicated opposite the titles of the chapters.
} 
odes, elegies, didactics, tragedy, comedy, dialogue, epistles, logic, rhetoric, orations, criticism, bibliography, languages, and polygraphical, or authors who have written on various branches.

An original likeness of Columbus, presented by Mr. George Barrell, American consul at Malaga, and found by him in an old castle in Seville, was linng over the mantelpiece at the sonth end of the room, but in rather too elevated a position, said William Elliot, to gratify the spectator. ${ }^{I}$ In other parts of the room, on the walls and between the alcoves hung Stuart's paintings of the first five Presidents, portraits of Peyton Randolph, of Hancock, of Tyler, of Bolivar, of Baron Steuben by Pyne, of Cortez, of Baron de Kalb, and of Americus Vespucius. ${ }^{2}$

On each side of the door leading into the balcony were marble busts, the one on the right was of Thomas Jefferson, by the celebrated Cerracchi, the rival of Canora. It was a splendid work, the bust was elevated upon the frustrum of a finted black marble column based upon a circular pedestal, which was ornamented at the top by a continued series of cherubs' heads, under a broad band encircling the pedestal, on which were sculptured the twelve signs of the zodiac. The pedestal bore the following inscription: "Summo rerum moderatori cui tanden Libertas Americæ Septentrionalis curæ fuit; cui in posterum curæe erit nomen Thomæ Jefferson." (To the Supreme Ruler of the Universe, under whose watchful care the liberties of north America were finally achieved, and under whose tutelage the name of Thomas Jefferson will descend forever blessed, to posterity.) Opposite the bust of Jefferson was that of Lafayette, also in marble. This was the work of P. J. David d'Angers, IS2S. On one side of the base block was inscribed an extract from Lafayette's speech in the Honse of Representatives, December IO, I $\$ 24$, in the following words: "What better pledge can be given of a persevering rational love of liberty, when those blessings are evidently the result of a virtnous resistance of oppression, and institutions founded on the rights of man, and the republican principles of self-government." On the other side were

"Washington guide, 1837 , p. 94.

'Grorge Moore, Voyage across the Atlantic, I845, p. 33. 
inscribed Lafayette's last words in his answer to the President's farewell speech, Washington, September, I 825. "God bless you, sir, and all who surround us. God bless the American people, each of their States, and the Federal Government. Accept the patriotic farewell of an overflowing heart, such will be its last throb when it ceases to beat."

Over the cornice of the alcoves, upon the blocking of the gallery, and in other parts of the room were marble busts of Washington, Marsha11, John Quincy Adan1s, Van Buren, Taylor, and plaster busts of Jackson and Moultrie, the latter by Col. J. S. Cogdale, of South Carolina. There was also a medallion of Madison. ${ }^{\mathrm{I}}$

Besides the works of art already enumerated, there were in the Library a number of bronze medals arranged in cases on either side of the mantelpiece at the south end of the room. Of these the Erving collection, presented to the Library in I 822 , has already been described. In addition to the Erving collection there were two medals struck at the mint of Philadelphia, the one in honor of General Gates and the other of Captain Hull. On the face of the former was a likeness of the General with the inscription "Horatio Gates, duci strenuo." The reverse contained a representation of the surrender of Burgoyne, with the words at the top, "Salus regionum septentrional," and beneath, the legend "Haste ad Saratogan in deditionem accepto." On the other medal there was a good likeness of Captain Hull, with the motto "Perilos arte superat certamine fortis." The reverse exhibited the action between the "Constitution" and "Gnerrière," with the classical inscription "Horæ momento victoria."

There were also the following American medals struck by order of Congress, arranged in the order of date. Navy: Jacob Jones, October IS, ISI2; Steplen Decatur, October 25, I $\delta$ I2; William Bainbridge, December 29, ISI2; Thomas Macdonough, September I I, I $S_{14}$; James Biddle, March 23, 1815. Army: Isaac Shelby, October 5, ISI3; William $\mathrm{H}$. Harrison, July 5, I813; Jacob Brown, July 5 and July 25,

\footnotetext{
${ }^{2}$ Robert Mills, Guide to the Capitol, I847, p. 34; Watterston, Guide to Washington, I 842 .

${ }^{2}$ William Enliot, Washington guide, 1837 , pp. 94-97.
} 
I8I4; James Miller, July 5, I8I4; Winfield Scott, July 5 and July 25, I 8 I4; Peter B. Porter, July 6, I8I4; Edmund P. Gaines, August I5, I8I4; Alexander Macomb, September I I, I8I4; Andrew Jackson, January 8 , is 5 .

The middle of the main room was furnished with tables containing drawers to receive large sheets of engravings, a table and chair were placed in each of the alcoves, and labels indicated the contents of the different shelves, though the books were protected by wire screens. A Brussels carpet and furnace heat completed the comfort of the room.

\section{ORGANIZATION OF LIBRARY COMMITTEE.}

We have already presented an extract from the records of the Library Committee of I 806 . These records were probably destroyed in I8I4; in a letter to Joseph Nourse, Register of the Treasury, requesting a report upon the condition of the Library funds, October 3, I 8 I 4, Mr. Goldsborough said: "The late conflagration has deprived us of every record and paper appertaining to the Library." " No further efforts to preserve the records of the Library seem to have been made until January 9, I830, when the committee "Resolvcd, That all letters, accounts, etc., of this committee be filed by the Librarian, and that he record the minutes of the committee in a book which he is authorized to purchase for that purpose." This minute book, with supplement, extends froml December 30, 1829 , to the present time and is an invaluable record of the acts of the committee and of the principal events in the history of the Library, especially for the period $x \$ 29$ to $I 866$, when the annual reports by the Librarian began to appear. The letter-books for this period are five in number. The letter files are valuable but incomplete.

The Library Committee consisted, as a rule, of members of Congress of high literary or scientific reputation. Among these some are still remembered: ${ }^{2}$ Samuel Latham Mitchill, Gulian C. Verplanck, John Quiucy Adams, Adam Seybert, Edward Everett, George Perkins Marsh, John G. Palfrey, Rufus Choate, Horace Mann, Lewis Cass, Thomas $\mathrm{H}$. 
Benton, and Charles Francis Adams. The committee iwas appointed by the President of the Senate and the Speaker of the Honse of Representatives. It seems, however, to have had the power of filling vacancies in its membership, of excusing from membership any appointed by the Houses of Congress, and of appointing successors to those thus excused. The committee voted, June 16,1832 , "That future meetings of the committee be commenced at 9 o'clock a. m. on Saturdays," but on the 3 d of January, I834, the hour of meeting was changed to Wednesdays at Io o'clock; on the 2 ist of December, 1836 , to Tuesdays; on the $15^{\text {th }}$ of January, 1838 , to Mondays, and so on.

The principal function of the committee, as we have already seen, was the selection of books for the Library. This task, a contemporary observed, ${ }^{1}$ was usually left to the chairman of the committee, who generally made the selection at his leisure, a leisure which he often did not find till after he had reached Washington. This was, perhaps, true during the time when Mahlon Dickerson was chairman of the committee and afterwards when James Alfred Pearce was chairman. The services of the former, of which we have already spoken, extended from December I, 1817, to May 26, I828. The services of the latter extended from December 2, i 844 , to March 4, 1863 . "To him probably more than to any other Senator," said Alexander D. Bache, in I863," "The Library of Congress was indebted for the augmented fund which it has now for some years enjoyed, and for the care taken in the selection of the materials which render the shelves so useful." ${ }^{3}$ In the selection of books for the Library $\mathrm{Mr}$. Pearce was particularly careful to exclude all works calculated, in his opinion, to engender sectional differences, and

National Intelligencer, December $5, \mathrm{I}_{34}$.

2Eulogy on the Hon. James Alfred Pearce, Washington, Smithsonian Institution, I $86_{3}$, p. 8.

${ }_{3}^{3}$ The augmented fund which the Library enjoyed in 1863 dated from the resolution presented by Mr. Poinsett, from the Library Committee, January 21, 1824, which led to the report presented by Mr. McLane, from the Committee on Ways and Means, February 24, and the act of May 26. A writer in the National Inlelligencer, January 5. 1835 , said that Colonel Benton was the first to propose the aunual appropriation of $\$ 5,000$, but there is no more evidence for this statement than for that of Professor Bache. 
when the Atlantic Monthly was established he refused to order it for the Library on that ground.

The selection of books for the Library was largely left to these two men, Mahlon Dickerson and, after him, James Alfred Pearce, not becanse they were chairmen of the connmittee, but becanse of their long service on the connuttee and consequent knowledge of the Library. Other members, however, shared in this bibliographical work, Edward Everett and Joel Poinsett, for example, the former of whom served on the committee from December 6, I825, to March 3, I 835 ; the latter from December 3, IS2 I, to March 3, IS25. 'The Library owed much of its value, also, to the work of Messrs. G. C. Verplanck and Levi Woodbury, ${ }^{2}$ the former of whom served on the committee from December 7, I829, to March 2, IS33; the latter from December I, IS2S, to March 3, I 33 I.

Concerning the services of the lattcr, there arose a controversy of considerable interest to the historian of the Library. In a sketch of the career of Mr. Woodbury in the National portrait gallery of distinguished Americans ${ }^{3}$ the remark was made that it was to Mr. Woodbury's enlarged and systematic views as to the proper mode of filling up the collection of books in the Library of Congress that it owed much of its utility and prosperity.

To this "A friend to Literature" made reply in the National Intelligencer December 5, I $8_{34}$ : "It is believed that during the short period Mr. Woodbury was a nember of the committee no very important or visible improvement was made in that institution. Nearly the same class of books and the same species of litcrature continued to be received."

In answer to this, one who signed himself "A Friend to Truth," said in the National Intelligencer; December II ${ }^{4}$ "After Mr. Woodbury became a member of the committee an alteration did take place in the general system of filling up the Library, and, as I have always nnderstood and have no doubt, at the instance and suggestion of that gentleman.

"The change was this: Instead of procuring books of the

\footnotetext{
${ }^{5}$ Ben: Perley Poore, Reminiscences, I: 176.

- National Inlelligencer, December 5, 1834 .

3 Philadelphia, $1 \$_{35}, 2: 265$.

4 National Intelligencer, December 11,1834
} 
character and in the manner stated by your correspondent, it was resolved by the committee that in ordering books it should be a paramount consideration to procure such as would render the Library as complete as possible in the branches which were deemed most important in view of its great object, taking them up in the order of their relative utility, as, first, parliamentary works, next American history, and so on. This correct principle has since been generally pursued. Whether the introduction of this principle is sufficient to justify the remark made in the National Gallery the public will determine."

In answer to this "A Friend to Literature" said: "I call upon Mr. W.'s enlogist to point out what particular works of merit were added to the Library at the suggestion of the present Secretary of the Treasury while he was a member of the committee. The works mentioned by your correspondent, or a large part of them, were in the Library, it is believed, before Mr. W. had anything to do with it. If the suggestion of Mr. Bradley, of Vermont, when a member of the committee, to whom the merit attributed by your correspondent to Mr. W. belongs, had been followed it would ere this have been vastly more valuable and complete as a body of literature and science than it now is or is likely soon to be, from the very general manner in which the books are selected and purchased by the committee. His plan was to fill up each department of the Library in succession and not purchase promiscuously and add a few to all. He preceded Mr. W. several years." "The history of this controversy shows that other members of the committee besides the chairman took part in directing the policy of the Library.

The executive work of the committee, however, was usually delegated to the chairman or to subcommittees, and later, to the agents of the committee and officers of the Library. This custom may be illustrated by the following extracts from the minutes of the committee:

December 30, 1829: "Resolved, That the chairman of the Joint Library Committee be authorized to pay all bills for periodical publications taken by the authority of the committee for the Library." 
January 9, 1830: Catalogues of books were presented from Messrs. Carey and Hart, of Philadelphia, from Mr. Pishey Thompson, and by the Librarian, for the examination of the Committee.

"Resolved, That the following-named works, or such of them as are not already in the Library, be purchased: The Jurist (a periodical published in Boston)," * * *

"Resolved, That the catalogues received from Messrs. Carey and Hart, etc., this day be referred to Messrs. Robbins and Verplanck; and that they be requested to make further selections from those catalogues, and report at the next meeting of the committee."

March I3, is 30 : "Voted, That the Hon. Messrs. Everett, Verplanck, and Wayne be a subcommittee, to make a selection of books to be purchased for the Library."

May 21, I830: "Resolved, That the list of books prepared by the Committee be purchased for the Library. That the English books in that list be purchased by Mr. Obadiah Rich, in London; and that the Amercan books in the list be purchased by Mr. Pishey Thompson.

"Resolved, That Mr. Rich be authorized to purchase, at his discretion, valuable books not contained in the Library nor in said list, to an amount not exceeding f.ioo sterling.

"Resolved, That each member of the committee be authorized, during the recess, to purchase to the amount of $\$ 50$."

January 12, I $8_{33}$ : "Ioted, That Mr. Everett be authorized to attend the auction sale of books at Mr. Mauro's room, this evening, to purchase books on account of the Library."

May 8, I 844: “' I'oted, That the Hon. Mr. Marsh be requested to examine the catalogue of books ${ }^{x}$ to be sold at auction this evening by Mr. Morrison, and mark such as may be advisable to purchase for the Library of Congreas."

\section{BIBLIOGRAPHICAL, PLANS.}

The history of the controversy between the "Friend to Literature" and the "Friend to Truth" illustrates further the impossibility of drawing up a bibliographical programme which the committee could agree upon, or, if they agreed, remain in agreement upon. It would have been possible, by following the plan proposed by Mr. Bradley-of filling up each department of the Library in succession-to have built up a great library. Samuel L. Knapp saw this, and said that under the proper direction the annual appropriation of $\$ 5,000$ might be so ntilized as to make the Library in twenty years one of the first libraries in the world. ${ }^{2}$ It might even have 
been possible, by agreeing further to buy great collections of books as opportunity offered, to have made the Library the first of the great libraries of the world. As it was, however, some were not interested in the Library at all, others were interested in that part of the Library only which was of direct or immediate use to them. Dickerson would have made it a library of science; Everett, on the other hand, would have made it a library of literature; still other members of the committee thought it necessary to cater to the various tastes and peculiar fancies of divers and many members of Congress, members of the diplomatic corps, heads of Departments, and others to whom the privileges of the Library were extended, who wanted anything new, and everything, if possible, entertaining. ${ }^{1} \quad$ Only a few members of the committeeonly a few members of Congress-took a bibliographical interest in the Library-cared to see there the books which had interested their predecessors, would interest their successors, and were of interest to legislators in other lands. Few in or out of Congress, indeed, had dreamed the dream of a national library, and fewer had attempted to define the functions of a national library. The result was that while bibliographical plans for the Library were drawn up, some of which even received the formal assent of the committee, none of them were realized.

The first of these plans aimed at the formation of a Library universal in its scope. The need for such a library was enlarged upon in the following communication to the National Intelligencer, January 8, i $834:^{2}$

MEssRs. EDITORS:

I was much gratified, a day or two since, in taking a survey of the Congress Library, to see how many valuable works it contained, and with how much judgment the selections had been made.

But I was also not a little surprised to learn that so small a sum as $\$ 5,000$ a year was all that was appropriated for its increase. This is

${ }^{1}$ National Intelligencer, December 5, I $8_{34}$.

${ }^{2}$ It is possible that this was written by Francis Lieber, for in his diary, December 8 , 1833, he says: "MIr. Peters, recorder of the Supreme Court of the United States, wishes me to draw up a report to get a large appropriation for the Congressional Library."-Life and letters of Francis Lieber, p. 98. 
hardly sufficient to obtain the new works of merit which are generally published, and is altogether inadequate to purchase the many rare and costly books which should be found in every such library. Why, Messrs. Editors, even Harvard University expends $\$ 5$, ooo per annum on its library, and surely we ought to expect a powerful and wealthy nation to make a more liberal appropriation than a mere college.

It seems particularly desirable that we should have in our country at least one grand and extensive library, which shall contain all, or nearly all, the works that may be wanted for reference or consultation in every department of human knowledge, and to which the curious and learned may have easy access. Now, it is very evident that, if we are ever to have such a library, it must be that established by Congress, for the very obvious reason that there is not a single literary institution in our country that has funds sufficient for such an undertaking.

Will not Congress, then, look to this matter, and appropriate hereafter more than the scanty pittance of $\$ 5$, ooo for this noble and very important object? Considering the small extent of the Library at present, and also that in some departments (as medicine and the kindred branches), it contains almost nothing, $\$ 20,000$ annually would be too little.

Contrast for a moment the advantages enjoyed by the European Literati for scientific research with those of our own country. It is calculated that in 3 $\mathbf{I}$ libraries of Germany there are at least 4,000,000 volumes, while probably the 3I largest of our country do not contain more than 350,000. The University of Göttingen, which is of more recent establishment than some of our colleges, contains 300,000 , the library at Leipzig has 100,000 , Dresden 260,000, and 4 at Vienna present an aggregate of 590,000 volumes.

When will the United States, the boasted land of civilization and knowledge, afford to its students such facilities for the advancement of science and learning as these?

This need was again referred to in an address upon the purposes of the American historical society delivered before that society in the Hall of Representatives, January 30, 1836 , by the Hon. Lewis Cass, at that time Secretary of War. He said:

An extensive library has already been collected, at the national expense, which contains many rare and valuable works, illustrating our general and local history. This collection is annually augmented, but not in proportion to the great means of the nation. There should be one place in our country where every work may be found which has any relation, however remote, to the discovery, settlement, and history of America. $* * *$ And why should not such additions be made to 
this collection, in all the departments of human learning, as will render it worthy of the age and country, and elevate it to an equality with those great repositories of knowledge, which are anong the prondest ornaments of modern Europe.

In consideration of this need the committee, March I, I $S_{3}$ I-

Resolied, That the committee procure to be made out a complete catalogue of the remains of literature and science and didactic works on the arts contained in the ancient Greek and Latin languages; and also a complete catalogue of all the works of literature and science in the modern languages, viz, English, French, Italian, Spanish, and German, including didactic works on the fine arts, but excluding works of professory learning and on the mechanical arts.

Resolzed, That the labor of procuring such catalogues be distributed as follows: To Mr. Everett the catalogue of Greek and Latin works, and that each member bring his account of expenditure on this subject, for audit and allowance, to be paid out of the Library fund.

Resolved, That the committee from said catalogue will make ont a list of the books intended to be purchased for the L,ibrary, progressively, and as fast as the funds will permit.

Resolved, That the chairman be anthorized to fill up the blank left for the distribution of labor in making the above-mentioned catalognes.

It was impossible to carry out such a programme as this. Mr. Everett 111ight select Greek and Latin works as long as he was a member of Congress, but who was to succeed him, and who were to select the English, French, Italian, Spanish, and Germinan works?

Another method, however, presented itself; it might in time be possible to gather a library universal in scope by purchasing, as opportunity afforded, the book collections of specialists in the different branches of science and letters.

The first opportunity to carry out this plan was presented by the offer of the Buturlin library to Congress. 'The history of opinion regarding this offer and of the measures taken to secure this magnificent collection is as follows:

On the $9^{\text {th }}$ of February, i 836, the following letter from Richard Henry Wilde, a recent member of the House of Representatives, and at this time engaged in research in Florence 
upon the life of Tasso, was published in the National Intelligencer: ${ }^{\mathrm{T}}$

This rich and curious collection, on which the late Count de Boutourlin employed many years and expended upwards of a million of francs, is now, in consequence of his death, for sale in Florence. It contains ta'enty-fiz'e thousand printed volumes, embracing the earliest and richest specimens of the Greek and Latin classics that ever issued from any press-the Aldine and other celebrated editions-and upwards of two hundred and forty manuscripts, some of them unique, most of them scarce and curious. It is fullest in those departments in which the Library of Congress is deficient, particularly the ancient authors, belles-lettres, literary history, the fine arts, and the standard productions of France and Italy. The number of English books is small, and there are a few of the books that would be duplicates. These, however, might readily be sold whenever it was not advisable to retain both on account of their utility or the difference of editions. After a careful examination of the books and the catalogue I have no hesitation in saying, so far as my opinion may have any weight, that the collection is a most admirable one of its kind, and would be a valuable addition to the Library of Congress. It is offered for fifteen thousand pounds sterling, but I think might be purchased for even something less, perhaps fifty or sixty thousand dollars. Payment may be made, if desirable, in six, eight, or ten years, so as to spread the appropriation over a greater length of time and without interest. The rolumes are for the most part of the folio or quarto size, of excellent typographical execution, often embellished with plates, all in perfect preservation, and a great many of them richly bound. I have noted a few of thein, and some of the manuscripts most remarkable either for their beauty or rarity. ${ }^{2}$

The offer of this collection to the Government was hailed with delight. The National Gazette said:

As there is now every reason to believe that we shall not require our surplus funds to enable us to entertain our "ancient friend and mag-

'There is a biographical sketch of Mr. Wilde in the Literary Horld 2: 234.

-Catalogue de la bibliothèque de Son Exc. M. le Comte D. Boutourlin, Florence, 1831. 31., 26, I56, IS, 13, 74, 26, 42, 50, 54 pp., I 1. So. 200 copies. Contents: Manuscrits, 26 pp.; érlitions du XV siècle: avec date, sans date, opuseules de Savonarola, liscours, sermons, etc., I56 pp.; collection Aldine, ou recueil d'éditions exécutées à Venise, Bologne, Rome, Paris, Lyon, etc., par les Mannucci, les Torresani, et autres imprineurs, Is pp.; eollection Bodonienne, ou recueil d'éditions exécutées dans l'imprimerie de Jean-Baptiste Bodoni, de Parme, I3 pp.; classiques italiens, on: collection de livres eités par l'Académie de la Crusca et de ceux indiqués par Gamba, Poggiali, Colombo, etc., comme pouvant servir à la compilation d'un vocabulaire de la langue italienne, $7+$ pp.; théologie et histoire ecelésiastique, 26 pp.; sciences, arts et leaux-arts, 42 pp.; belles-lettres et listoire littéraire, 50 pp.; liistoire: géographie, voyages, chronologie, histoire, antiquités, biographie, 54 pp. 
nanimous ally" "over the water with the music of guns and drums, we can not perceive how the small ontlay demanded for the objects in question could be better applied than in furnishing a choice repast on which our "bookworms" may banquet until the end of time. The race has increased to an extent which may well entitle it to some manifestations of kindness from our National Legislature, and it must continue to increase every year. The gratitude which they will feel towards the authors of the delight afforded them by the possession of such a jewel as the Boutourlin collection will be rather more fervent and durable than that which will be experienced for any gift which may be bestowed for the party objects of the day. ${ }^{x}$

The North American Review, in an extended article on libraries, July, I837, said:

What public library in this country contains the materials for an accurate history of any one department of science? Take eren the most limited, or rather one of the most recent of all, the science of political economy. Here our researclies are confined to one definite period. We have no dusty archives to explore, no time-iworn manuscripts to decipher. The origin of the science is within the memory of our fathers, and we ourselves have witnessed its sudden growth and rapid development. Yet how nuch is to be done, how many authorities to be weighed, how many different treatises to be analyzed and compared before we can venture to say, Here is the history, for such was the rise, such the progress, such the changes of opinion, such the received and such the rejected theories of political economy! The writers of the first French school, of the Scotch school (and if we wish for history we must go beyond the publication of Adam Smith's great work), the Italian, the new French, and the new English schools-all have not merely a claim upon our attention, but are entitled to a full and accurate examination. And event then our task would be incomplete, for literary justice would require us to trace, through the works of general political writers, the hints and remarks which have contributed to the progress of the branch we are studying, by the discovery of truth or by the exposition of error.

If such be the obligations of the student, whose researches are confined to a subject so new, what must be the necessities of the historian who attempts to throw light upon those periods for which the testimony of printed anthorities is to be confronted with that of mantscripts and public documents, and where ignorance and prejudice have combined with the more powerful incentives of interest to perplex his path by contradictory statements and conflicting opinions! It has been said that the history of the "Decline and fall of the Roman Einpire" conld not liave been written in America, and in fact, althougl the personal fortune of Gibbon enabled him to purchase for his own library nearly all the mate-

"Copied by Nalional Inielite'n(e', February I9, 1836. 


\section{DEVELOPMENT OF THE LIBRARY, I 829-I 55 I.}

rials which he employed in the composition of his great work, yet he was more than once indebted for important facts and views to the great libraries of the Continent. Now, most of the works by neans of which his history was compiled were of necessity works of reference, works which few perhaps may consult, fewer still would think of reading, but which nevertheless supply the materials for our richest and noblest instruction.

If it be said that the class of readers whose wants extend to works of this description is small, we would reply that as far as America is concerned it is true at the present moment, but that every appearance indicates a great and speedy augmentation in their number. The present state of things is a necessary consequence of the actual condition of our literature. Holding a distinguished rank in several branches, there are still many in which we have yet accomplished little or nothing. There are exceptions. But how far do they go, and what is the true character of them? The very best life of Columbus is the work of an Anerican, but it was written in Spain. The "History of the Northmen" is a work of great learning and research, but Mr. Wheaton collected his materials and wrote in Europe, with all the advantages of a high public station. These cases, therefore, instead of making against us, show how great a change has taken place in the literary aims of our countrymen, and how rapidly their wants are extending beyond the bounds which individual wealth can meet.

How far is our community prepared to supply these wants? The call for a sound literature is universal, and there is no one who understands the real state of the country who does not perceive how promptly the impulse already given to our literature in some departments has been followed by the ambition to carry out the work into other branches. A literary class is gradually forming itself into a distinct order, opening for many new springs of wealth, for all new sources of enjoyment, but still dependeut upon the other classes of society for its subsistence and its success, and destined to form for them a literature either superficial and ephemeral, or profound and durable, in exact proportion as its intellectual wants are neglected or supplied. Of the nature of these wants we have already spoken. Books are needed, not confined to any single branch, but embracing the whole range of science and of literature, which shall supply the means of every species of research and inquiry, and which, placed within reach of all, shall leave idleness no excuse for the lightness of its labors, and poverty no obstacles which industry may not surmount. What has been done, or what is doing, toward the performance of this duty?

No reply can be given to this question which will not require many limitations. Much has been done at Boston and at Cambridge. The Boston Athenæum has made already a large collection of valuable works, and follows, we believe, though perhaps at too respectful a distance the 
progress of the literature of the day. The library of Cambridge is of a high order. Forty thousand volumes of printed works go far toward supplying the ordinary wants of the members of our oldest university. And when we consider the care and judgment with which a large part of them have been selected, we are still disposed to place this far above many of the European libraries, which, in a numerical point of view, are vastly its superiors. In the department of American history it is the richest in the world. It contains the choicest works of English literature, and it is prorided with good editions of the classics of Greece and Rome, as well as of many of the most valuable among the great writers of Italy, Germany, France, and Spain.

The Pliiladelphia library is estimated at about 42,000 volumes. Among these there is a considerable proportion of valuable articles, and the Spanish department is uncommonly complete. The New York Athenæum has 25,000 rolumes; the Library of Congress has about 20,000; but in this last, if we except the law library, which, though too exclusive in its character, has been formed upon a sounder basis, there are far too many of those trifling productions which, after the year of their publication is over, become a useless burden to its shelves. Besides these, there are libraries in many of our cities, and each of our universities and colleges contains a collection of more or less value and pretty well adapted to the wants of academic students.

The general regulations of these libraries do not, as far as we have been able to learn, differ in any material particulars. With few exceptions the libraries of our colleges are restricted to the use of the students, the professors, and the members of the corporation or directors, under whatever name they may be classed; none of these are supposed to study in the library but call at stated hours for the books they want, and strangers and students not connected with the institution can only obtain books by a special concession or through some individual of the privileged body. The other libraries are generally held by shares open to subscription.

Such, we believe, is the general character of our public libraries. And here we may be allowed to renew the question, How far do they meet the wants of our community?

Whoever reflects, though but for a moment, upon the numerous branches into which modern literature runs and remembers that the literary glory of a nation can only be secured by a certain degree of success in each of them; whoever considers the immense mass of varied materials, without which no historical work of importance can be composed, or the extensive learning which is required of even the most gifted genius of an age like ours, and adds to these considerations the general and undeniable fact that of those who would gladly derote thenselves to literature but a few can ever hope to obtain by their own resources the command of the works that are essential to the successful 


\section{DEVELOPMENT OF THE LIBRARX, IS29-I 85 I.}

prosecution of their studies, will be ready to acknowledge that we have as yet done but a small part of what may be justly claimed from a nation which aspires to the first rank for the liberality and politeness and high moral tone of its civilization. Late, however, as we are to begin, scarce anything in this department has been accomplished in Enrope which might not be done with equal success in America. And so numerous and manifest are our advantages in some important particulars that a prompt will and sound judgment in the execution of it might, in the course of a very few years, render the American student nearly independent of those vast collections which, in Europe, have required centuries for their formation. The undertaking, however, in order to be successful should be a national one. Without urging that no State is fully equal to it, or that in the hands of any single State it would not answer the same purpose, we may be permitted to say that the enlargement of the Library of Congress upon those broad principles, the application of which to the collection of books has become a difficult and important art, would reflect an honor upon the country equal to the permanent advantages which it would secure to every member of the community.

The first class in such an institution should be devoted to national history. And here, although we have neglected to do what miglit easily have been done a few years ago, yet it is still in our power to do more than any nation has ever done for its own history. The purchase of the manuscripts of Washington was the first step. The papers of Mr. Madison are another valuable acquisition. Were these to be followed up by the purchase of the papers of the other distinguished men of our Revolution, what a body of invaluable documents would be brought together for the historians of the country! No individual, no single State could accouplish an undertaking like this. But the voice of Congress would be heard in every part of the Union; and with whatever veneration these relics might be regarded, and however unwilling their owners might feel to intrust them to the hands of an individual, or to the library of any State institution, gladly would they meet the first offers of Congress, and feel as if they had performed their duty toward their ancestors, by placing within a sure asylum the best records of their worth and the materials from which posterity will raise the most durable monument to their glory. If the same course were to be pursued with regard to the other public men of our country; if the private papers of our Presidents, or, to avoid an enumeration of which it is easier to find the beginning than the end, if the papers of all those men whose lives will forn an integral part of American history were collected in the same archives, instead of being left to the chances of preservation or destruction, to which they are inevitably exposed while passing through the hands of heirs differing in their tastes and pursuits, a large and perhaps the most valuable portion of our history would be placed beyond the control of chance and the influence of those casualties which liave 
involved so many portions of European history in impenetrable obscurity. Many important documents also which, for fear of premature publication, are now likely to be destroyed would be readily intrusted to a public and responsible institution, which should undertake to withhold then from every eye until the proper monent for making then public had arrived. What collection of manuscripts could conpare with such a collection as this? What parchment, however venerable from the dust of ages, conld awaken emotions like those with which we should contemplate the original records of the events which interest us most, prepared during the hurry of action and in the hour of trial, and speaking to us, as it were, with the very tones of the epoch which they commemorate?

Another important source of history is supplied by the industry of our historical societies. Many of the documents which they collect must, from their nature, remain in the archives of the societies; but all the published volumes, which, in many cases, form valuable accessions not merely to the materials for our history, but to our historical literature, might be regularly transmitted to the Library of Congress and deposited in the class of national history. And this circumstance itself might perhaps contribute to awaken new energy in those societies which languish for want of encouragement or of that stimulus which a consciousness that an attentive public is watching their course never fails to impart. In this nanner the history of the past would be secured npon the evidence of incontrovertible and characteristic documents, while that of the present and of the future would be placed under the sure protection of the pride and emulation of rival bodies.

For the other departments of our Library, our chief dependence would necessarily be placed on the acquisition of books from Europe, both by the direct purchase of private libraries and the subsequent collection of such works as are not to be found in private sales. The first of these methods, as we have already shown, has ever proved the surest method of important and extensive acquisitions. It was thus that nearly 58,000 printed volunes and 800 manuscripts were added, at different epochs, to the Imperial Library of Vienna. No other part, perhaps, of that immense collection can be compared with this, whether we consider the choice and elegance of the editions or the taste and learning with which the works themselves were selected. It will be long before such opportunities can become frequent in America; but they still occur from tine to time in Europe. When the 50,000 volumes which the library of Sir Janes Mackintosh is said to have contained passed under the hammer, what an occasion was offered for laying the foundation of a perfect library! We have never seen the catalogue of that sale nor heard the price at which it was nuade; but no one acquainted with the cast of Mackintosh's mind and the extent and variety of his acquisitions can doubt that his library was nearly complete in some departnents, and highly valuable in all. Here the purchase of the whole collection would 


\section{DEVELOPMENT OF THE LIBRARY, I829-I85I.}

have secured, for a moderate price, many things which can not be obtained separately but at a great and even extravagant one.

The library of Count Boutourlin, which has been recently offered to Congress, is a parallel case. It is smaller than that of Sir J. Mackintosh, for it contains barely 24,000 volumes. Yet in these 24,000 the scholar will find ample materials for the gratification of his curiosity in some of the most interesting branches of literature.

The Count Boutourlin deserves to be classed among the most intelligent and industrious of European bibliophilists. During the course of a long life he formed two of the most remarkable libraries ever collected by a private individual. The first was destroyed in the conflagration of Moscow. The second is still in the hands of his fanily. This last was made in Italy, and with the concurrence of several peculiarly favorable circumstances. Many books and manuscripts which had hitherto been inaccessible to any purchaser had been put into circulation by some changes connected with the political revolutions of the country, without being brought into the ordinary course of trade. Other works of great value were exposed for sale, but in that indirect manner well known to the amateurs of rare books and paintings in Italy. The extensive pecuniary resources of Count Boutourlin enabled him to avail himself of these opportunities, and his profound knowledge of bibliography secured him from imposition. The purchase of a private library, which had been originally formed after the suppression of some of the old convents of Tuscany, gave him the basis of his new collection and put him in possession of some of the rarest articles which it contains. The remainder was the work of a patience and assiduity seldom, if ever, surpassed. Nearly every article was a personal purchase. Many were brought to him in sheets, others merely divested of their original binding. These were to be numbered, and subjected, in short, to that rigorous examination by which the skillful bibliophilist distinguishes the really rare from spurious editions. Thus, unwearied in his labors and unsparing in his expenditures, he continued to the last years of life daily adding to his collection, and has left behind him a monument of taste and skill which any bibliophilist might envy.

Job R. Tyson, esq., in an address before the Athenian Institute and Mercantile Library Company of Philadelphia, April I $3,{ }_{1} 83$, referring to the need of the establishment of a national library and to the offer of the Buturlin collection, said:

However learning and genius have added to the national fame, partiality itself must admit that little active aid has been contributed from

'North American Review, July, 1837, pp. 137-I43. This article was written by George Washington Greene, United States consul at Rome, at the suggestion of Mr. Wilde. It is reprinted in Greene's Historical studies ( I 850 ), pp. 277-322. 
the public bounty. Astronomical science yet asks for an observatory and the National Library languishes for the want of encouragement. When we compare the pigny collections of Philadelphia and Cambridge, the largest libraries in this country, with the magnificent cabinets of Paris, Vienna, London, and many others, it need not be concealed that the national pride receives a wound. In the various departments of history except domestic, modern literature and science, our collections do not embrace all which the wants of the learned student demand. The life of Colnmbus, by Irving, a work destined to imperishable fame, could not, from the absence of materials, have been written in America. Mr. Wheaton conld not have brought to completion his learned and elegant history of the Northmen except in Inturope. The admirable work of Ferdinand and Isabella, by Mr. Prescott, though written on this side of the Atlantic, was cliefly dependent for its materials on the other.

The library of Philadelphia is upward of a century old. Its late highly intelligent librarian computes the present number of volumes at 46 , 000, a number exceeding, it is true, any other library on this side of the Atlantic, but not commensurate with the growing wants of the literature and science of the city. The Royal Library of Paris less than half a century ago numbered only 80,000 printed volumes and nuanuscripts. It now presents in its totality upward of 700,000 volumes. The British Museum, founded long since the establishment of the Philadelphia Library, now amounts to 240 , 000 volumes. The value of a library, it is true, does not depend upon its numerical superiority alone; but there is no doubt, from the bibliographical knowledge which guards the Royal Library of Paris and the British Museum, that the excellence of their contents is in proportion to their number.

It becones a wise and enlightened people, intent upon a high destiny, to adopt the means necessary to subserve it. It was one evidence of decay that in the luxurious age of the Roman Empire the reading of Roman senators was confined to Marius Maximus and Juvenal. In a country in which native energy has not been debilitated by luxury; where mind, intrammeled, roves with perpetual activity, explores new regions of thought, and penetrates new sources of truth and intelligence; where every man is a reader and all have a keen appetite for knowledge, the means should be multiplied commensurately with its importance and necessity. Withont dwelling longer upon a theme which might be amplified by so many reflections, it is cnough to say that no act would confer higher literary glory upon the United States than adding to the treasuries of its Public Library. 'The Government of France requires a copy to be deposited in the Royal Library of every work which is issued from the press throughout the kingdom. A similar regulation obtains in Austria and Russia for the benefit of the royal libraries of Vienna and St. Petersburcr. From the operation of so wise and salutary a provision these libraries are monuments of honor and renown to those despotic 
nations. The British Museum, which has proved in England the great nursery of merit, the light of genius, the ladder to eminence, has been fostered by the same liberality, aided by the direct munificence of the sovereign. Congress has already purchased the papers of Washington and Madison. It could present adequate inducements to private persons for the opening of their private cabinets, in which are deposited those documents which are so material to illustrate our national history and transmit our national fame. It could enact a law similar to those which augment the libraries of France and England, Austria and Russia. It conld enrich the present collection by a purchase now offered to its acceptance of the greatest treasure of one of the greatest bibliopolists of this bibliothecal age. ${ }^{1}$

The legislative history of the proposition to purchase the Buturlin collection was different. On the r8th of February, I 36 , Mr. Preston submitted to the Senate a resolution directing the Committee on the Library to inquire into the expediency of purchasing the library of the late Count Buturlin,

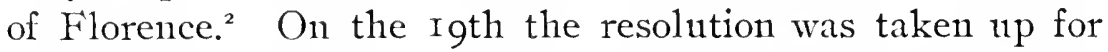
consideration. Mr. Preston said that this library had been examined by a late and distinguished member of Congress from Georgia (Mr. Wilde), who was a gentlenuan of great literary attainments, and eminently qualified to judge of its value, and who had strongly recommended to this country the purchase of it. It was worth much more than it was offered for. He (Mr. Preston) believed there was no difference of opinion in regard to the great value of it, and that it would be a proper acquisition to the Library of Congress. An opportunity would never perhaps occur again to purchase such a collection. It was by mere accident that this opportunity had presented itself.

Mr. Webster also had a high opinion of the great value of this library. It was one of those collections rarely found, and such as he believed did not exist in any library of any of the United States, private or public. He understood the expense would not be very great. He thought this was a favorable opportunity to make a valuable addition, if Congress saw fit to make such addition to their Library.

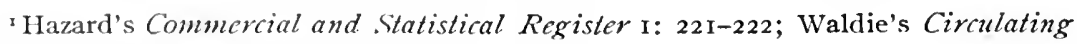
Library 12: 225-228.

${ }^{2}$ Register of debates in Congress, I2: 578 .
} 


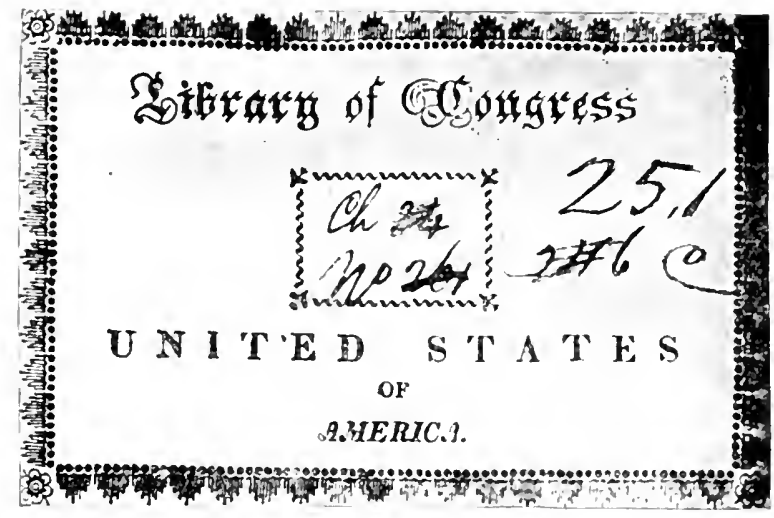

IS15.

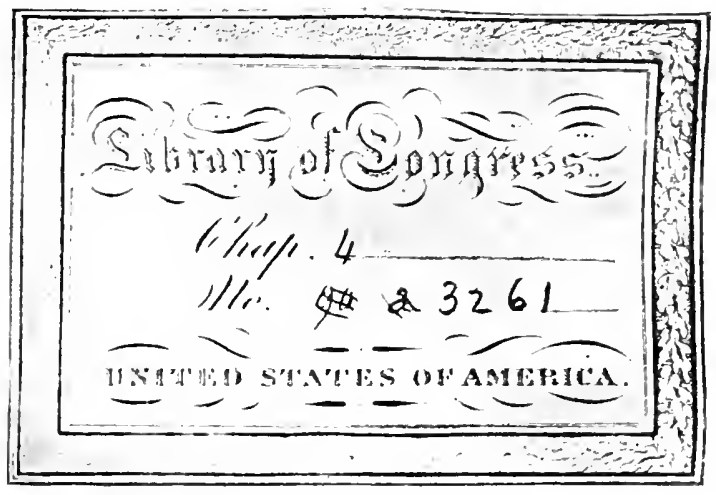

IS22.

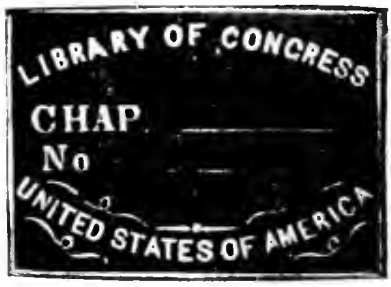

I 85 I.

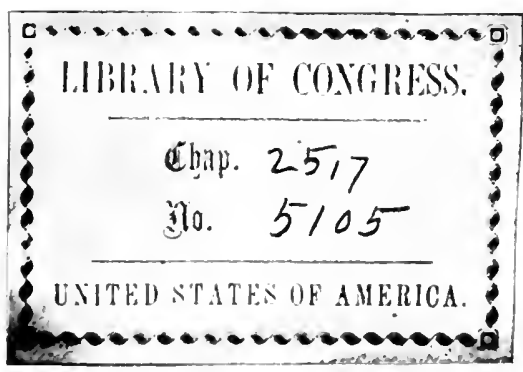

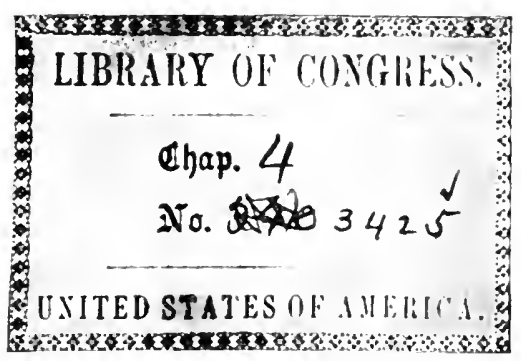

1852.

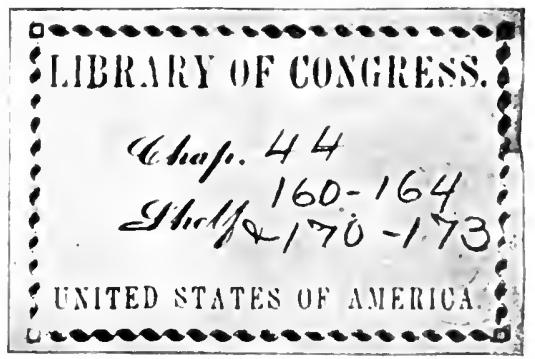



The resolution was then adopted.

On the ${ }^{4} 4_{\text {th }}$ of March Mr. Preston, from the Comnittee on the Library, made a report, which was ordered to be printed. In this report, after speaking of the history of the Library of Congress, he goes on to describe its existing condition:

Since the destruction of the Library in 18I4, [he said,] \$99,950 had been expended in the purchase of books. The whole number of volumes in the Library, exclusive of Congressional documents and laws of the United States, was about 24,000 , so that the Library had thus cost about $\$ 4$ a volume. Of the 24,000 volumes thus purchased there were about 6,000 volumes in other languages than English, of which $4,08_{3}$ were in French, 844 in Latin, 314 in Spanish, 268 in Italian, 28I in Greek and Latin, 66 in Greek, 29 in Chinese, 13 in Saxon, $x 2$ in German, and 52 in ail other languages, ancient and modern.

In the additions which the joint conmittee lave purchased with the annual appropriations made to the Library, they seem to have been governed by the practical declaration of its intention made by Congress in the purchase of Mr. Jefferson's library. They had to build it up on this most various and miscellaneous foundation, and in the absence of any specific instructions in regard to its character (while they have had a special view to the pecnliar wants of Congress), have made additions to the original stock in all the branches of general science and literature. The primary object in instituting the Library unquestionably was to afford to members of Congress the means of knowledge necessary for the intelligent discharge of their official business. It is very difficult to prescribe bounds to the demands which may be nade for books in every branch of learning by the multifarious subjects brought before Congress and its committees. "There is no subject," Mr. Jefferson says, "to which a member of Congress may not have occasion to refer." The absolute necessity of Congress suggested the Library, the utility of extending it beyond actual necessities early become apparent, and erecting an institution upon these foundations it was competent to Congress to extend and adorn it in reference to the dignity and opulence of the Government. As it was manifestly proper that, in the erection of the public buildings, vastness and elegance should be united with utility and comfort, so these qualities may be fitly consulted in whatever is required to be done for the use and accommodation of the Government. The public buildings have been erected at a cost of $\$ 6,000,000$, and, in many instances, with an elaborate display of architectural ornament, intended to gratify and perhaps to inprove the public taste, or to indulge a just national pride.

${ }^{x}$ Register of debates in Congress, i 2: 578 . 
With the same feelings Congress has not hesitated to make requisitions upon the arts of sculpture and painting. This enlightened and liberal regard to the gratification of the tastes and elegant improvement of the country, though made secondary by the nature of the Government to other objects, is not without great importance. It is not a substantive power of Congress to furnish means of knowledge or models of taste, but, in the necessary and proper arrangements of its establishment, they may and ought to be so extended or modified as to contribute to both these objects. A library is necessary; that it should have a certain degree of completeness and elegance is as proper as that the shafts of the columns around the halls should be polished or surmounted by a capital, and the remark applies with greater force to the Library, not only on account of the superior value of learning, but on account also of the great destitution of the means of knowledge in a country as new as the United States.

In all the public libraries of the United States, including those of schools and colleges throughout our wide territory and counting all the duplicates, there are not as many books as are contained in the Bibliothèque du Roi in Paris. It is a very large calculation to estimate all our libraries at 400,000 volumes, and of these there are not more than 50,000 distinct works. In Paris there are I, 200,000 books deposited in public libraries, and in all France 4,200,000. In Germany the reading public is still more liberally provided with books. The whole number of printed volumes of distinct works in the world may be estimated at 600,000; of these there is certainly not nore than one-tenth in the United States. Our whole body of literature, if collected in one place, would not afford the means of investigating one point of science or literature on it. Here where the foundations of the Government repose upon the aggregate intelligence of the citizens, the assistance afforded by public institutions to the exertions of intellect is but one-tenth of that within the reach of the mind of civilized Europe.

Besides private libraries of much greater extent than the greatest public collection in this country, there are in many of the German towns collections of from 100,000 to 250,000 . The number of books in public libraries in Germany are to the population as one to ten; in the United States as one to forty. And this disparity is still more striking if we compare the means of knowledge within the reach of the functionaries of this Government with those which are furnished at the principal capitals of Europe.

London and Paris, of course, are replete with means of knowledge, which would require much time even to enumerate; but it may be stated that there are in the British Museum, besides its rich and vast collections of art, 180,000 volumes and 60,000 manuscripts.

The Royal Library in Paris has between 400,000 and 500,000; Royal Library at Berlin, 200,000; Imperial Library at St. Petersburg, 300,000; Imperial Library at Vienna, 300,000; the Vatican, 400,000, print and 
manuscripts; at Stuttgart, 120,000; at Copenhagen, 250,000. In slort, it would not be going too far to say that there is not a Govermment in Europe, down to its principalities and dukedoms, which has not provided its functionaries with more ample means of useful, elegant knowledge than ours. We do not, however, ascertain our wants merely by a contparison with the abundance of other Govermments. The experience of nembers of Congress has taught them how often their inquiries are arrested by the want of books. No day elapses during the session of Congress that there is not a call for many volumes which can not be furnished. On a recent occasion the Senate's Committee on the Judiciary, in the investigation of an important question regarding the boundary of a State, was compelled to borrow the necessary materials from colleges and societies at a distance from the seat of govermment.

Whether it be proper for Congress to remedy in some degree these defects by the purchase of the library of the late Count Boutourlin at Florence is the immediate subject of the committee's consideration, and they are not without difficulty in coming to a satisfactory conclusion. This collection consists of 25.000 volumes, of which a catalogue has been before the committee, and other information in regard to it has been furnished by an intelligent and public-spirited gentleman, lately of the House of Representatives. The collection was made under the most favorable auspices during the French war in Italy, when the monasteries and all the depositories of art and literature were thrown open to the plunder of invading troops or exposed to the purchase or acquisition of public agents or wealthy private collectors. To this last class belonged the Count Boutourlin. At the price of a million of francs and with many years of enthusiastic industry he made the present collection, which is perhaps richer and more valuable in its kind than any which is now or can be expected to be hereafter on sale in the world. It is especially rich in that species of literature which can be scarcely said to exist in this country, for neitler the Library of Congress nor any of the public or private libraries of the Lnited States possess any thing in bibliography beyond an occasional spccimen, or of that noble literature (the whole body of which is contained in this collection) which was the first that came into existence upon the revival of learning, awakening the genins of modern Europe and inspiring new views of literature from Chancer to Milton.

The catalogue presents a complete collection of the Italian classics, as designated as such by the Academy Della Crusca, a collection so complete as perhaps to leave nothing to be added. It contains also a very full collection of the ancient, especially the Latin, classics, leaving little more to be desired in this department. There are fig copies of Alline editions, 368 from the Bodoni press, many lundred volumes printed in the fifteenth century, and many others illustrative of the early achierements of ty pography and its progress to perfection.

$23399-04-16$ 
The library also contains many valuable nannscripts. In the preface to the catalogrue it is said that there are "very few private libraries which present such a collection of valuable books, as well manuscript as printed, ancl in sucl perfect preservation," and less questionable testimony is griven to the same effect by the gentleman above referred to. After an attentive examination, and writing from the spot, he says: "It contains about 25,000 printed volumes, embracing the earliest and richest specimens of the Greek and Latin classics that were issued from any press, the Aldine and other celebrated editions, and upward of 240 manuscripts, sone of them unique, most of them scarce and curious. It is most complete in those departments in which the Library of Congress is most deficient, particularly the ancient anthors, belles-lettres, literary history, the fine arts, and the standard productions of France and Italy. After a careful exanination of the books and catalogue $I$ have no hesitation in saying, so far as my opinion has any weight, that the collection is a most desirable one of its kind, and would be a valuable addition to the Library of Congress."

The 25,000 volumes are offered at fifty or sixty thousand dollars. The 25,000 now in the Library have cost $\$ 100,000$, and it will always happen that the books bought by retail will cost a great deal more than when purchased in large collections. In the collection of this library, the committee is informed by Mr. Wilde, the founder expended a million of francs upon it, or nearly $\$ 250,000$. If it be the pleasure of Congress to add this collection to its Library, the whole number of volumes will be about 50,000, and of them about one-half will be in our ow1 language, and the others in foreign, ancient, and modern languages. It will add several thousand duplicates in French, Spanish, Italian, and Latin, which might either be sold without loss or exchanged for works in English.

The number of works in foreign languages would form an insuperable objection to the purchase if it was intended that the Library should be completed by it; but this the committee by no means believe to be the intention of Congress, and when the collection shall consist of 100,000 or 150,000 volumes, 30,000 or 40,000 in foreign languages may not be an unclue proportion when it is considered that not a fourth of the literature of the world is in our own language; still, however, this purchase will nuquestionably give for the present an undue proportion to the literature of the Italian language over that of other foreign languages, especially the French and German. In the German language the Library contains, at present, twelve works, and the proposed purchase makes but inconsiderable additions to them; and the number of books in the French langnage, whose literature is more extensive than that of any other, and the knowledge of which is most extensively diffused, is left entirely too small.

In Latin, Greek, and Italian the Bontourlin library would wake the collection complete, would add rery considerably to the Frencl and 
Spanish. It wonld make with the library now owned by Congress about 50,000 volumes, of which 20,000 would be in Finglish, 10,000 in Firench, 20,000 in Greek and I atin, Italian, and Spanish, with a few German. The collection in (ireek, Latin, Italian, and Spanish niight be considered complete. Future alditions would be necessary in Einglish, French, and German. If it be the purpose of Congress to extend the Library to IOO,000 or I50,000 volumes, the committee think that the proposed purchase is very desirable; and, believing that such ought to be and is the intention, the committee recommend the following resolution:

"Rcsolied, Thlat the Joint Library Committee of the two Houses of Congress be, and they are hereby, empowered to contract, on their part, for the purchase of the library of the late Count Boutourlin at Florence.' '

On the $4^{\text {th }}$ of June this resolution was read the second time, and considered as in Committee of the Whole. On motion by Henry Clay, "Ordered, 'That it lie on the table."

In I 844 a second opportunity to establish the Library upon a wider and nuore substantial basis was presented by the offer of the Durazzo collection to Congress. On the Ioth of January, I 844 , the Library Committee received a letter from C. Edwards Lester, American consul at Genoa, recommending the purchase of a library belonging to the Durazzo family, consisting of about 10,500 volumes, principally folios and quartos, in handsone uniform binding, price $\$ 30,000 .-$ "Referred to the Hon. Mr. Burke and the Hon. Mr. Marsin to report on the subject."

Oir the 26th of January, I 844 , the following letter from Mr. Lester, addressed to the editor, was published in the Globe:

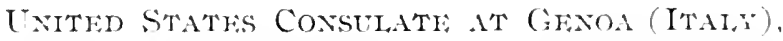

October $15,18+2$.

DFAR Sir: Since the object of this commnnnication can not fail to interest every patriot and friend of learning, I offer no apology for acidressing you. Owing to reverses of fortune, the present representative of the Durazzo fanily (one of the most ancient and illustrious of Genoa, and incleed all Italy), has offered his clcbratcd librar' for sale.

I'Twenty-fourth Congress, first session, Senate report No. 242, March 15, I 36 . [Mashington, Gales \& Seaton, printers, I836.] 6 p. $8^{\circ}$. Caption title.

"Senate Journal, 1). 405. Regarling this collection Charles Sumner wrote to G. WV. Greene, Jecenloer 3", 18.39: "Cogswell has conle abroal again $* *$ * to purchase the Boutrurlin lihrary. Mr. Astor is abont founling a public library in New Iork, and this library was to be the lasis of it, but unfortunately it is alrearly under the hammer in Paris, selling piece-meal, and Cogswell has abandoned the purchase.Erlward I. Pierce, I,ife of Summer, 2: $13 \mathrm{I}$. 


\section{DEVELOPMENT OF THE LIBRARY, I829-185I.}

As soon as I learned his intention I called on the proprietor and obtained his lowest terms, with the refusal of the library for five 110ntlis, with the view of writing in the meantime to the United States to see if Congress could not be prevailed upon to purchase it for the use of the Government. This library has been in the process of collection for several hundred years and always in the possession of the same family, who have at all times been distinguished friends of learning. It has long been esteemed one of the choicest private libraries in Europe. It contains over ten thousand volumes of the most valuable and beantiful editions of the most celebrated authors of the ancient and modern world, with several hundred rery rare and valuable manuscripts in different languages (many of them older than the art of printing), works of inestimable value never printed, and of which no other copies are known to exist. Although the number of volumes is no greater, yet almost every celebrated author of every language is found in it, since the entire library is made up of large folio and quarto editions, which are very comprehensive. It is bound uniform in the most beantiful and durable style, and the whole is in a perfect state of preservation, not an imperfect copy or volume. The catalogue can not be forwarded, as only one exists (in seven manuscript volumes), and only a general idea can be given of its contents. Of the great departments of learning, the most extensive are history, laws, jurisprudence, and diplomacy; the classica! is also very $\mathrm{ftull}$, containing all the Greek and Roman classics in mant:script by the scholars of the I4th, I5th, and I6th centuries. These among the most valuable in Europe. I have spent several days expressly in the examination of the library, and obtainet the opinions of some of the best Italian scholars, and they all concur with the books of bibliography in the opinion that it is one of the choicest and most valuable private libraries in Europe. The price is so low it can offer no obstacle, it being only thirty' thousand dollars, which is much less than the original cost of the binding, and I an universally assured it is not one-tentl of the original cost of the printed volumes, not to mention the manuscript. The want of such a library is felt by American statesmen and scholars, and it may safely be asserted that a more valuable treasure could not be possessed by the present or left to future generations. I then, dear sir, make this appeal to you in the name of country and education, and for these two sacred objects I ask that you will in every manner in your power do all you can to have the matter brought up before Congress this session. The library can be had for no less. It can be boxed, insured, and sent to Washington in a perfect state for $\$ 5, \infty 00$, and I am willing to propose to do it for that sum; otherwise, to merely clarge costs alone. Let Congress choose its own mode, however, and its own agent, only let the library be bought for the American people.

I lave the honor to be, dear sir, your obedient servant,

C. EINWARDS LESTER, U. S. Consul at Genoa. 
On the 29th of Jannary, i 844 , on motion of Mr. Joseph R. Ingersoll, the House of Representatives, "Resolied, That the Joint Committee on the Library be instructed to inquire into the expediency of purchasing the library of the Durazzo family in Italy." And, on the 7 th of June, I 844 , just before the close of the session, Mr. Marsh, from the Committee on the Library, made the following adverse report, which was read, and laid upon the table:

The Joint Committee on the Library, to whon were referred the memorials of the faculties of Amherst College and Illinois College proposing to Congress the purchase of the library of the Durazzo family at Genoa, report:

That the subject of the purchase of the library in question was brouglit to the notice of the committee by the President of the United States, before the presentation of the memorials; and the natter was then informally considered by the committee, and measures taken to obtain further information respecting the character and value of the collection. A printed catalogue of the library ${ }^{-1}$ has been lately obtained through the agency of Mr. C. E. Lester, United States consul at Genoa, and submitted to the cxamination of the committee, who have come to the conclussion that the purchase of the collection i.s inexpedient. The catalogue being of great extent, and arranged alphabetically, a full analysis of its contents would be a work of so much labor that the committee hase not thought it necessary to undertake it; but they submit the following statement of the results obtained by a careful examination of the first half of the catalogue:

Works in the Italian language, 700; in French, 24o; in Greek and Latin classical literature and criticism, 350; in modern Latin miscellaneous literature, 250; in Latin and Greek theology, including the fathers, 240; in English, 11; in other langnages, 14; modern manuscripts, 72; mantsscripts of ancient authors, 33. A large proportion of the books in the Italian and French languages, as well as of those in modern Latin, consist of local histories and scientific works; and neither in these languages, nor in the department of classieal literature and criticism, is the collection furnished with the investigations of scholars of the modern school of historical and literary criticism. Indeed, the connnittee have observed but a single work printed within the last half century upon the catalogue. In the department of classical literature the library is rich in palæotypes; and early editions of both ancient and modern anthors are numerous, and lescribed as in excellent condition. The mantscripts are represented as being of extraordinary beanty, thougl there are few of great antiquity; and both these and the early printed books are of great

\footnotetext{
'Catalogo della biblioteca di mu anatore bibliofilo, Italia. :1., 251 1). $8^{\circ}$.
} 
interest as illustrations of the history of literature, but the manuseripts do not in general appear to be otherwise of great value. Duplicates in different editions are very numerons; and there are not less than one hundred copies of parts or the whole of the works of Cicero and commentaries on his writings. The books are described (and no doubt truly) as being very select copies, in excellent condition and beautifully bound; but the committee observe few illnstrated works, and few which, apart from their rarity, would be very costly.

The library is principally interesting as furnishing abundant nuaterials for literary history, and in this respect it is of great value; but it contains few works which hare not been superseded by later authors or editions; and, thongh it would be a highly desirable acquisition to a well-endowed literary institution, it is not, in the judgment of the connittee, suited to the purposes of Congress. ${ }^{x}$

Botl of these movements to form a national library universal in its scope by the purchase of special collections thus failed. It was easici to adopt a more linited programme, and make the chief ain of the national library the collection of the nation's literature. The British Muscum was beginning to think the collection of Anerican publications worth while; in $1 \$ 46$ ordered the purchase of American publications of every kind, including pampliets, sermons, schoolbooks, children's books, etc., ${ }^{2}$ and in $\mathrm{I} \delta 4 \delta$ had the largest collection of books relating to America in the world. ${ }^{3}$ Moreover, such an aim did not require either so much knowledge or so much labor on the part of the purchaser. Accordingly, on the 24th of Jannary, I 844 , the committee ordered that the Librarian send to Mr. Rich, agent of the committee in London, a full catalogne of the books in the Library, to enable him to furnish a list of books relating to America which he could supply in completion of that division of the Library. On the I6tin of December, I844, a letter was received by the committee in reply, accompanied by a printed catalogue of books in relation to America which he offered to sell to the Library, and the consideration of the subject was postponed until the next meeting of the committee, and then apparently forgotten.

'Twenty-eighth Congress, first session, IIouse report No. 553.

" Viational Intelligencer, August 5, I8.46.

3 l.itcruly World 3: 529. In 1859 the collection was sail to number 30,000 books, or more than clouble that of any library in this comntry. - Historical Magazine 3: 213. 
On the Ioth of August, I 846, too, it was provicled that the Library should receive one copy of every work copyrighted under the laws of the United States.'

But the collection of books even within the field of Americana went on slowly-most of it seems to have been done in London-and the Library continued its hand-to-nouth existence. At the time of the excitement over $\mathrm{Cuba}_{11} \mathrm{I}_{32}$ the committee roted that Mr. Shaler be authorized to purchase, at Havana, books and periodical publications to the amount of $\$ 50$ annually." At the time of the Mexican war it "Resolved, That the Librarian be authorized to purchase all the constitutions and laws of Mexico, and also to subscribe for a newspaper published in Vera Cruz and for one published in the City of Mexico." 3 At the time of the revolution of IS4S it ordered that the Librarian purchase inmediately all works of any reputation touching the modern history, existing conditions, and prospects of Hungary and Germany; ${ }^{;}$and during the Civil War the committee ordered that the Librarian expend from the book fund a sum not exceeding \$IOO in procuring pamphlets relating to the existing war, ${ }^{5}$ and a law was passed June 25, I864, appropriating $\$ 4,000$ to enable the Library Committee to purchase a complete file of selections from European periodicals from I86I to I 864 , relating to the rebellion: Provided, That no part of said sum should be expended until the entire collection and an index thereto was completed and approved by the committee. ${ }^{6}$

At the same time it refused Henry Stevens's offer of the Laws of Vermont and Journals of the general assembly of Vermont from 1779 , together with about 500 volumes of Vermont newspapers from ${ }_{7} S_{3}$ on ${ }^{7}$ and though the Senate, on motion of Mr. Clarke, directed the committee to ascertain from the owner of the library of George Washington whether

\footnotetext{
'This law was so generally disregarled that it was repeated February $5,1859$.

${ }^{2}$ Minutes, December 29, 1832 .

3 Minutes, August 4, I848.

4 Minutes, February 13,1950 .

5 Minutes, May $7,1862$.

'This sum, having failed to he used for this purpose, was authorized April 7, 866 , to be expended in the purchase of books, one-half for the law department of the Library.

7 Minutes, Jamuary $31,1846$.
} 
the same was for sale and of what number and value the books in the library were and at what price they might be purchased, nothing seems to have been done to bring the library to Washington, as the manuscripts had been in 1834 , and the library was saved from being carried to a foreign land only by the patriotic efforts of a few citizens of Boston, who subscribed the amount necessary to purchase the library, and presented it to the Boston Athenæum. ${ }^{\mathrm{I}}$

\section{THE LAW DEPARTMENT.}

Although the committee did not accomplish much in the formation and realization of plans for the bibliographical derelopment of the Library during the period before the war, it did succeed in passing two legislative measures affecting the organization of the Library which were of considerable importance. These were, first, the act to increase and improve the law department of the Library of Congress, approved July $I_{4}, I_{3} 2$, and, second, the acts providing for the exchange and distribution of public documents, approved June 26 , I848, and January 28 , I 857 .

On the I6th of February, I 816 , a bill had been introduced into the Senate providing for the establishment of a law library for the use of the Supreme Court. On the 24 th of February, I826, and again on the Igth of February, I828, and on the gth of February, I 830, Mr. Wyckliffe had subnitted a resolution in the House of Representatives that the Conmittee on the Library be instructed to inquire into the expediency of separating the law books from the other books in the Library of Congress and placing them under the superintendence of the Supreme Court. On this last occasion the National Journal said:

Mr. Wyckliffe wishes to separate the law books from the rest of the Library of Congress and to place the former in the Supreme Court, under

"A catalogue of the Washington collection in the Boston A thenaum, compiled and annotated by Appleton P. C. Griffin. In four parts: I. Books from the library of Gen. George Washington. II. Other books from Mount Vernon. III. The writings of Washington. IV. Washingtoniana. With an appendix: The inventory of Washington's books drawn up by the appraisers of his estate, with notes in regard to the full titles of the several books and the later history and present ownership of those not in the Athenam coliection. By William Coolidge Lane, Jibrarian of the Boston Athenceum. The Boston Athenceum, is $87 . \mathrm{xi}, 566 \mathrm{pp}$. front. (port.), plate. $\mathrm{S}^{\circ}$. 
the superintendence of a new librarian. This would certainly afford great facilities both to the bench and the bar, but the members themselves are often in want of books of jurisprudence, and should not be deprived of those which are now in the Library of Congress. Mr. W'yckliffe does not seem to have any peculiar penchant for any other reading than that of law, and one would think his inclination might be amply indulged during the session by the access he has to the fine law library of Congress and the facilities which the knowledge of its present keeper is so well calculated to afford. From the very scanty majority in favor of the appropriation for the purcliase of books it wonld seen that Congress is either satisfied with the number of volumes already in the Library or dissatisfied with the manner in which they are kept. Mr. Mycklifie has for some time been anxions to remore the law department of the Congressional Library, but his efforts have never been successful. To allay this anxiety, it would perliaps be better to alter the rule for Mr. II.'s special accommodation, and allow him to have full range among his farorite volumes during the sessions of the Supreme Court. Mr. W.'s desire to remove will, if gratified, be a reform like that produced by the present Administration, as it will take away the most valuable part of the Library and perhaps fill its place with something that is less so. ${ }^{\text {t }}$

Finally, on the I $4^{\text {th }}$ of December, I $S_{3}$, on motion of $\mathrm{Mr}$. Grundy, the Senate "Resolved, That the Committee on the Judiciary be instructed to inquire into the expediency of providing a law library for the use of the Supreme Court of the United States," and on the 2oth of the next month Mr. Marcy, from the same committee, reported a bill to increase and improve the law department of the Library of Congress, which on the I4th of July following became a law:

AN ACT to increase and improve the law department of the Library of Congress.

Be it enacted by' the Senate and House of Representatives of the United States of America, in Congress assembled, That it shall be the duty of the Librarian to prepare an apartment near to, and connected by, an easy communication with that in which the Library of Congress is now kept, for the purpose of a law library; to remove the law books, now in the Iibrary, into such apartment; and to take charge of the law library, in the same manner as he is now required to do of the Library of Congress.

SFc. 2. And be it further enacted, That the Justices of the Supreme Court of the United States shall have free access to the said law library; and they are, hereby, authorized and empowered to make such rules and regulations for the nse of the same, by themselves and the attorneys and counsellors, during the sittings of the said court, as they shall

$$
\text { 'National Journal, February 15, } 1830 .
$$


deen proper: Provided, Such rules and regulations shall not restrict the President of the United States, the Vice President, or any member of the Senate or House of Representatives, from having access to the said library, or using the books therein, in the same manner that he now has, or may hate, to use the books of the Library of Congress.

SEC. 3. And be it further cnacted, That the law library shall be a part of the Library of Congress, subject to the same regulations, except such alterations as are herein provided for, as now are, or hereafter shall be established for the Library of Congress; and the incidental expenses of the law library shall be paid out of the appropriations for the Library of Congress.

Sec. +. And be it further cnacted, That there shall be, and hereby is, appropriated, for the present year, a sinn not exceeding five thousand dollars, and a further annual sum of one thousand dollars, for the period of five years, to be expended in the purchase of law books; and that the Librarian shall make the purchases of the books for the law library, under such directions, and pursuant to such catalogue, as shall be furnished him by the Chief Justice of the United States.

Approved, July I4, I 832 .

In accordance with this law a room north of the main Library was fitted up for the use of the law library. This it occupied until i 843 , when, as we have already noticed, it was removed to an apartment on the west side of the basenient of the nortl wing of the Capitol, near the Supreme Court room. There it remained $11 n t i l$ December, 1860, when it was removed to its present quarters in the old room of the Supreme Conrt, on the east side of the basenent.

In the formation of the law library the most important steps besides the act of ${ }_{1} S_{32}$ were, first, the resolutions passed by the committee Jannary 9, I 830 : "Resolved, That the reports of cases determined in the superior conrts of the several States of the Union be purchased for the Library whenever published, and that the existing deficiencies be supplied as early as possible;" "Resolved, That the laws of every State of the Union not now in the Library be purchased or otherwise obtained." 'The second important step was the delegation of the duty of selecting books for the law library to experts in legal literature. On the 7 th of February, I835, the committee voted "That Mr. Preston and Mr. Binney see the Chief Justice on the expecliency of appointing a conmittee of the bar to select law books to be purcliased for the law library," and 
on the 3 oth of Jannary, I $\&_{3} 6$, it voted "That the honorable Mr. Porter and the honorable Mr. Preston be a conminttee to consult the Supreme Court on the subject of law books for the law library;" and the act of March 3, i $8_{37}$, stipulated that the books purchased for the law library be chosen from a catalogue furnished by the Chief Justice. Mr. C. H. W. Meehan, who was intrusted with the custody of the law department of the Library, remained in that position until his deatl, July 5 , I 872 .

The law library was thus, as the North American Reriew observed," placed npon a sound basis, and with the appropriations provided by the act of $\delta_{32}$, supplemented by an additional grant of $\$ 5,000$ March 3,1837 , and by the annual appropriation of $\$ 1,000$-increased to an annual appropriation of $\$ 2,000$ in I 850 - grew from a collection of 2,0 I I volumes (639 of which belonged to the Jefferson collecton) in 1832 , until at the close of this period it was considered the best and largest collection of law books in America. Catalogues of this collection were printed in ${ }_{1} S_{39}$ in $9 S$ pages, in ${ }_{1} S_{49}$ in I 39 pages, and in I 860 in 225 pages.

\section{THE, DOCUMENT DEPARTMENT.}

The changes in the department of documents-that other important branch of a legislative library-were more extensive than those in the department of law, but not of so lasting a character. Up to this time the Library had been both a collector and a distributer of public documents, but in both capacities its activities had been limited.

In I 839 , however, new steps were taken to complete the collection of documents in the Library. On the $15^{\text {th }}$ of February Mr. Allen submitted the following resolution in the Senate: "Resolied, That the Librarian be directed to make ont and to report to the Senate at the conmencement of the first session of the next Congress a catalogue of all the laws and of all the legislative and executive journals and documents of the several States and Territories now in the Library." 
Mr. Allen said it was necessary to offer some remarks explanatory of this resolution. Being npon the Library Committee, he felt it his duty to make some inquiry as to the contents of the Library, and he was very much surprised to learn that the journals and documents of the States and Territories of the Union were not to be found there; and indeed but few complete sets of the laws of the States and Territories were there. In a conversation with the Librarian, he had learned that with the exception of the State of New York there was no instance of a complete set of the public documents of the legislature of any State in the Union being in the Library; and in the case of the State of New York this was true for only a few years back. His object in submitting the resolution was to show the extent of the deficiency, in order to predicate on it a movement at the next session to supply this nnaccountable defect in the National Library. "It is a remarkable fact," said Mr. Allen, "that you can lay your hands on all the proceedings of the English Parliament in our Library, and yet you can not find the journals and public documents complete of any State in the Union." He believed that in most cases the journals of the State legislatures might be found from the foundation of the State governments. There could be no question with the members of Congress as to the necessity of having these documents preserved in the National Library. This was all he had to say in explanation of the resolution, "which, from its nudity, might appear light and ridiculous." The resolution was then adopted. ${ }^{\text {r }}$

In accordance with this resolution, Librarian Meehan submitted a report to the Senate December 27, I839, containing a catalogue of all the laws and of all the legislative and executive journals and documents of the several States and Territories in the possession of the Library; ${ }^{2}$ and on the 9 th $^{\text {of }}$

\footnotetext{
' Congressional Globe, 5: 496.
}

"Twenty-sixth Congress, first session, Senate report No. I6. Report of the Librarian of Congress, transunitting, in compliance with a resolution of the Senate, a catalogue of all the laws and of all the legislative and executive journals and documents of the several States and Territories now in the Library. December 27,1839 .Rearl and orlered to be printed. [Washington], Plair and Rives, printers, [1839]. I4 pp. $3^{\circ}$ 
January, I 840 , the Library Committee roted that the Librarian prepare a letter to be addressed to the execntives of the several States, requesting them to supply the Library of Congress with copies of the laws, journals, and documents of the States. ${ }^{1}$

This interest in State documents naturally led to a renewed interest in Federal documents, and on the 24th of March, IS4O, it was "Ordered, That the Librarian be authorized to complete the set of documents and journals of Congress in the Library by purchasing from Mr. George Templeman or others, as he can do it on best terms."

The acts of June $26, \mathrm{I} 848$, and January 28 , I 857 , providing for the exchange and distribution of public documents, were of much greater significance. $U p$ to this time all documents ordered to be printed by any Congress were distributed to members of that Congress only, and others could only obtain them by buying them either from those members or in the second-hand book market. ${ }^{2}$ The first exception to this rule was in the resolution of May 24, I828, which provided for the distribution of the duplicate books and documents in the Library to members of Congress, State and college libraries. This distribution erentually relieved the Library of much useless material, but the Library had received nothing in turn except the room occupied by the material thus distributed.

On the igth of June, I 834 , however, a resolution was approved providing that 25 copies of every work printed by the order or at the expense of the United States should be placed at the disposition of the Joint Library Committee to be by them disposed of in return for donations to the Library of Congress. On the Ioth of Jannary, I 837 , too, the Library Committee "Ioted, That the Librarian be anthorized to exchange Gales and Seaton's State Papers, if they could be obtained, and other public documents with the French Gov-

\footnotetext{
'Another orler to the same effect was issued February 19, 1845; and April 9, i862, it was "Ordered, That the chairman introduce in the Senate a proposition to annend the statute providing for the transmission of State documents by mail, so that they might be receiver at the Library without postage."

${ }^{2}$ National Intelligencer, lebruary 3, 1860.
} 
crnment;" "Ioted, That the Librarian report how far the Library is furnished with documents to exchange with the French Government."

Finally, the joint resolntion of July 2O, I 840 , authorized the Librarian to exchange such duplicates as there were in the Library, and provided 50 additional copies of documents printed by order of either Honse for the purpose of exchange in foreign conntries. The history of the systen of international exchange thus established was as follows.

\section{INTERNATIONAL EXCHANGES.}

In I I $_{5}$ Alexandre Vattemare, ${ }^{1}$ of Paris, began an investigation into the conditions of European libraries, which resulted in his discovering large collections of duplicates. Munich, he said, had 200,000; Jena, r2,000; St. Petersburg, 54,000; Vienna, 30,000, and other cities like numbers. This discovery led him to establish a system of exchange among the different nations of Enrope which would bring into circulation these valuable bit useless treasures. In four years the enthusiastic projector of this system was so successful, according to his own story, that in France 600,000 volumes had been forwarded to the central depot for either international or internal exchange, and in the varions countries of Enrope a total of nearly 2,000,000 volumes had been withdrawn from dust and oblivion and placed where they might assinue their real value. The movement had led also to the interchange of the modern publications of the various countries, the publishers of both Saxony and France having placed at the disposal of their Governments for the purpose of exchange five copies of all their publications.

Encouraged by Lafayette, Cass, and Cambreling, M. Vattemire embarked for the United States September 20, IS39, to lay the plan before our Government and learned societies. The Boston Allas said of him: "M. Vattemare is rather nnder the mediun size, spare, with long hair, sparkling eyes, and an energy of gesticulation which well accords with his ani-

'There are biographical sketches of Vattemare in the Neze' England Mistorical and Ceneralogical Register 19: 367 (October, 1865 ), and in the Historical Magazine, 2d series 4: 297 (I)ecember, I868). 


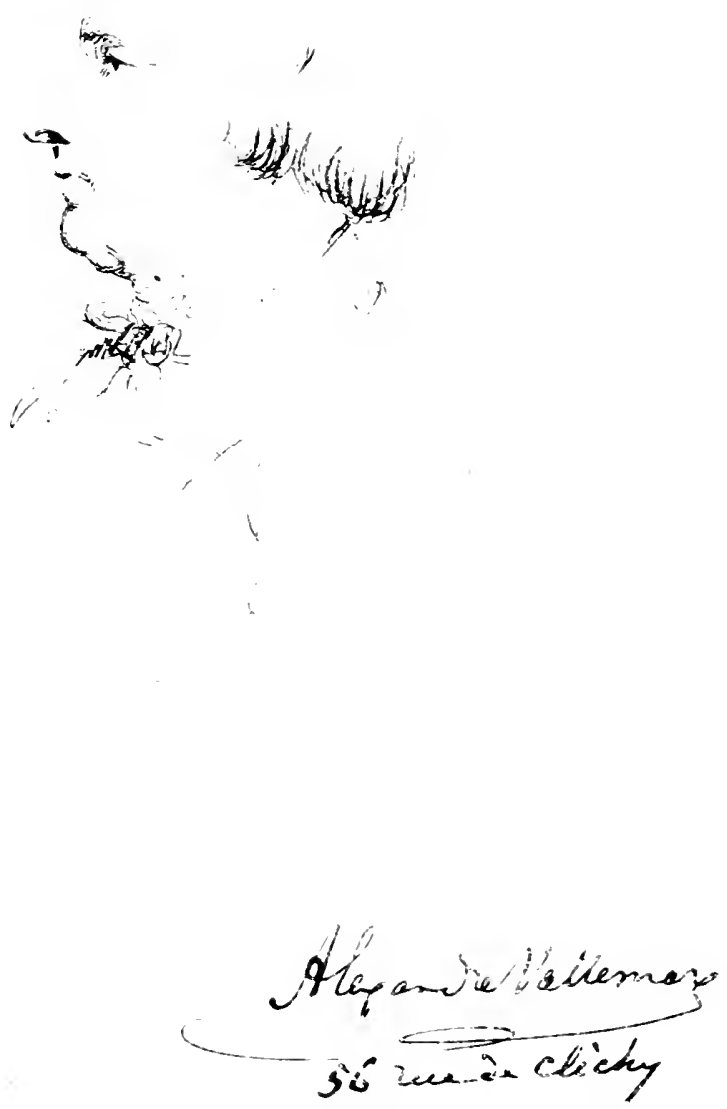

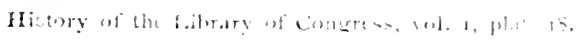



mated conntenance. $:: ;$ Everybody with whom he converses becomes enlisted in his project, nor is it possible to withstand his earnest argunents, which evidently conle direct from the heart. Meet hin where you will, you have to stop and listen to his account of some success-some valuable contribution-some legislative enactments-and though you may be busy, before he has talked to you five minutes, you will lend hin yonr attention with interest."

On the roth of December M. Vattemare addressed a 11emorial to the House of Representatives.' In this lie said concerning the system of international exchange:

Of all the conntries in the world, America will have the most to gain in entering into this plan. The libraries of Europe, splendid, copious, rich, have been the slow accumulation of nearly four centuries. Few in the United States can date back laalf a century. If our best-endowed public institutions possess works which show the present state of science, and the triumphs of modern literature, they are wanting in all that can be called the history of art, of science, and of the gradual progress of the human mind, from the time that Faust and Guttenberg first called into action that mighty engine which has established the future liberty of the human race, upon the basis of intelligence diffused and everywhere accessible. Were he to venture any suggestion on the subject, it would be that the Librarian of Congress, under the direction of the Joint Library Committee, be authorized to open correspondence with the executives of the several States of the Union, and with the representatives of foreign powers, for the purpose of obtaining catalogues of such articles as might be available for exchange on the part of the United States or disposable as a return on the part of foreign nations; and that for the purpose of making a beginning, the copies which are now by law directed to be deposited in the Department of State of every copyright book or engraving, with the printed reports of the two Houses of Congress, be placed at the disposal of the Library Committee for the purpose of exchange. $* * * *$

'This memorial was referred to the Committee on the Library, and on the $5^{\text {th }}$ of June, I 840, Mr. Preston, from that committee, made the following report in the Senate:2

*** The committee believes that this Government may, to a linited extent, advantageonsly enter into the proposed arrangement.

\footnotetext{
'Twenty-sixth Congress, first session, House document No. 50, read February 5, 1840.

${ }^{2}$ 'Twenty-sixth Congress, first session, Senate report No. 52r; House report No. 586.
} 
The passed and passing history of this Government, as embodied in its published documents, necessarily produces the annual publication of many volumes, containing the most anthentic and exact account of the progress of national events and the working of our political machine. To the intense and enlightened curiosity of the world is thus exhibited, at each step of their progress, the new and great experiments we are making, the accurate knowledge of which by foreign nations may subserve our interest and promote a favorable estimate of our institutions. It is very desirable, too, that we should have the means within the reach of Congress of as minute a knowledge as authentic records can furnish in regard to foreign goveruments.

There are now in the possession of Congress many hundred rolumes of public documents, some of which might well be distributed among friendly governments, and, for a like return and at a very small expense, permanent provision might be made to supply them in future. As, in this department of publication, we probably exceed most foreign nations, the exchange would be equalized by receiving in return national works of science or art, which the more ample powers of other governments enable them to execute.

Besides this not inconsiderable means of profitable exchange, Congress also has, occasionally, the disposition of duplicate books in the Library; and this might be increased by an amendment of the copyright laws, directing three copies of every publication under a maximum value in the Congressional Library.

For the purpose of carrying out these views, the committee offer the following resolutions, and a bill:

* * * * * * * * * *

On the Igth of June action was again urged in a letter from M. Vattemare, submitted by Senator Benton, ${ }^{2}$ and on the 2 oth of the next month a joint resolution for the exchange of books and public documents for foreign publications was passed. ${ }^{3}$

JOINT RESOLUTION for the exchange of books and public documents for foreign publications.

Be it resolved by the Senate and House of Representatizes of the United States of America in Congress assembled, That the Librarian, under the supervision of the Committee on the Library, be authorized to exclange such duplicates as may be in the Library for other books or works.

Second. 'That he be anthorized, in the same way, to exchange documents.

'Twenty-sixth Congress, first session, Senate document No. 521, p. 2.

z Twenty-sixth Congress, first session, Senate document No. 559 .

3 Statutes at Large, 5: 409. 
Third. That hereafter fifty additional copies of the documents, printed by order of either House, be printed and bound for the purpose of exchange in foreign countries.

Approved, July 20, I840.

The bill to furnish the Librarian with three copies of every work copyrighted in the United States for exchange with foreign libraries, presented at the same time as the resolution, after the first and second reading was laid on the table:

A BILL In addition to the acts now in force for the encouragement of learning, for securing the copies of maps, charts, and books to the authors and proprietors of such copies during the times therein mentioned.

Be it enacted by the Senate and House of Representatives of the United States of America in Congress assembled, That in order to entitle any author or proprietor of any map, chart, book, or books, not exceeding in price as hereinafter mentioned, to the copyright thereof and to the benefits of the acts now in force for securing the same, such author or authors, proprietor or proprietors shall, in addition to the deposits and delivery of copies now required by law, and within six months after the publishing of any such work, also deliver, or cause to be delivered, to the Librarian of Congress three copies of the same, if the price of each copy as sold does not exceed ten dollars, to be exchanged for other works or productions according to the provisions which Congress shall have made or shall make in relation to exchanges thereof. ${ }^{\text {t }}$

In consequence of the resolution of July $20, \mathrm{I} 840, \mathrm{M}$. Vattemare left Washington with some 700 volumes of Congressional documents, a collection twice as large, he said, as any in Washington." In return, proposals for the exchange of public documents were received by the Library Committee from the Governments of Württemberg, ${ }^{3}$ Portugal, ${ }^{4}$ Belgium, ${ }^{5}$ France, ${ }^{6}$ and Great Britain. ${ }^{7}$ These proposals came through the consul, chargé d'affaires, or minister representing the respective Governments in the United States or through American ministers or secretaries of legations abroad or directly from the ministries of foreign affairs. But no agent for carrying into effect the provisions of the act of 1840 was

'Trenty-sixth Congress, first session, bill No. 447 .

${ }^{2}$ National Intelligencer, March I, I848.

3 Minutes, I)ecember 22, 1840 .

${ }^{4}$ Ibid., February $14,1844$.

5 Ibirl., December 22, I 840 , and January $31,1846$.

${ }^{6}$ Ibid., March I, 1841; July 2u, IS.11; April 29, I842; I'ebruary 15, 1843; March 20, IS44: February 20, 1947 .

7 Ibid., June 17, 18.11; December 24, 1341; January 21, 1848 .

$$
23399-04-17
$$


appointed, though the committee received a communication from Henry Wheaton, L. Draper, and others, on behalf of the American Athenæum in Paris, April 29, I842, requesting the committee to instruct the Librarian to make his exchanges under the act of I 840 through the medium of the Athenæum. Consequently the resolution remained practically inoperative, though some 340 volumes were received from France. $^{\text {. }}$

To remedy this defect in the system of international exchange established by the act of July 20, I840, M. Vattemare presented a memorial to Congress ${ }^{2}$ February 9, I 848, proposing the establishment of a central agency in Paris, with subordinate agencies in the different countries of Europe and in the different States of America, whose duty it should be to collect and distribute the various objects of exchange. He said:

After consulting on the subject the most learned scientific bodies, as well as the most illustrious statesmen here and abroad, and reflecting maturely on the result of many years' personal experience, he is led to the conclusion that the most direct, easy, and certain mode of effecting the object in view was to establish and organize a general international agency for the exclusive purpose of conducting scientific and literary exchanges between the governments and legislatures, and municipal and scientific bodies in the nations of Europe on the one hand, and the Federal Govermment and the States of the Union on the other.

The seat of such agency to be in the city of Paris, having subordinate agents for the United States and in the capitals of European nations, whose duty it shall be to collect and receive the objects of exchange in the district assigned to each and forward them to the central depot in Paris, from which point the general exchange between the two hemispheres shall be directly made and thence distributed to the subordinate agencies, and so spread for universal benefit throughout every part of the respective countries which sliall enter into the plan. Of course these subordinate agencies may be multiplied to any extent, as the growing population, especially of this conntry, may demand and as the benefit of the system shall attract to it increasing patronage and support.

Connected with the Federal agency should be a system of authentic reports stating what has been collected for exchange and also what has been received in return. These reports (while they act as a salutary check on agents disposed to be unfaithful) would be a means of furnish-

'Southeril Literary Messenger, 9: 757.

${ }^{2}$ Thirtieth Congress, first session, Senate miscellaneous documents, No. 46. 
ing mutnally to the two continents what each might obtain from the other, and where the objects desired were to be found.

Your petitioner most respectfully prays further:

First. That the law securing patent right and copyright may be so amended as to require all authors or publishers taking ont a copyright for works to be printed to place one copy in the American library of the city of Paris, in France, subject to the order of the Gorernment, in addition to the two copies now deposited in the Library of Congress.

Second. And, in like manner, requiring one copy of the specification, with the drawings and model accompanying the same, of each machine or new invention or improvement for which patent shall be granted.

Third. The enactment of a law, accompanied by all necessary guards for the prevention of fraud, admitting duty free all works and other objects addressed by gorernments through the general agency in Paris to the branch depot, exclusively for the purpose of international exchange.

Fourth. That the resolutions heretofore passed by both Houses in July, I840, in the words following (and which have hitherto remained a dead letter on the statute book), be carried into full effect (amending the word "authorized" to those "hercby directed"):

I. That the Librarian, under the supervision of the Committee on the Library, be authorized to exchange such duplicates as may be in the Library for other books or works.

2. That he be directed in the same way to exchauge documents.

3. That hereafter fifty additional copies of each volume of documents, printed by order of either House, be printed and bound for the purpose of exchange in foreign countries, and placed at the disposal of the central agency in Paris.

Fifth. The above regulations being understood as applying exclusively to works of a scientific character and promotive of intellectual improvement, works of a different description being allowed to seek the usual channels opened by those engaged in the book trade. ${ }^{x}$

This memorial was referred to the Library Committee, which reported by Mr. Murphy in the House of Representatives, May 4, I $84 \delta$, as follows:

With these general views of the plans of the memorialist, the committee believe that permanency, regularity, and efficiency to the system of international exchanges can best be secured by the establishment of a common general agency or agencies by the different nations entering into the arrangement. Such agency could act not only for the governments, but when once established could be used for the same purpose by societies, authors, inventors, and publishers. By devolving the duty at home upon some competent agent, with provision for the expense of packing the books and transmitting them to and from the general agent, there is

${ }^{2}$ Thirtieth Congress, first session, Senate miscellaneous documents, No. 46, pp. 9, 10. 
no reason why the interchange should not continue as long as it may be the pleasure of the goveruments concerned. The committee do not, however, assent to the proposition of the memorialist that the copyright law be so amended as to require authors and publishers to furnish to the Government, for the purpose of this exchange, a number of copies of their works in addition to those now required for the libraries of Congress and the Smithsonian Institution. They have already expressed it as their opinion that the power of Congress to patronize this system is limited and for the most part confined to the books published for the use of the Govermment or of Congress in the performance of their delegated duties; but eren if the power existed, they deem it would be oppressive and unjust to exact from the proprietors of books applying for the protection of the law anything more than is necessary to aid the operation of the law. The tax of two copies is now seriously objected to by many publishers, and an increase of the burden, as it undoubtedly would be in the case of large and expensive publications, would, in such cases, tend to retard rather than "promote the progress of science and useful arts," the purpose for which the authority to enact copyright laws is conferred by the Constitution. In fact, this may well be left to the publishers themselves, and the committee believe that if the international agency be established they will soon discover it to be of such advantage to them, by making their publications known in quarters where both fame to the author and profit to the publisher might be acquired, as in many cases gladly to arail themselves of it.

But in the views of the memorialist generally the committee are happy to concur. After the success which has thus far crowned his unwearied and voluntary labors they think his expectations of aid from us have been justly formed and should be promptly satisfied. They therefore recommend that the committee be authorized to establish such agencies and organize such a plan of donation and exchange as they may deem best for this purpose; that all books sent to the Federal or State goveruments, to any departments, or libraries of either, to the Academy at West Point, or to the National Institute be admitted duty free, and that the stim of $\$ 2,000$ be appropriated to enable the committee to carry the measure into effect. $* * *$ r

Accordingly, on the 26 th of June the following act to regulate the exchange of certain documents and other publications of Congress was passed:

Be it cnacted, $\mathcal{E}^{\circ}$. . That the Joint Committee on the Library shall appoint such agents as they may from time to time deem requisite, to carry into effect the donation and exchange of such documents and other publications as have been, or shall be, placed at their disposal for the purpose.

${ }^{2}$ Thirtieth Congress, first session, House report No. 590, pp. 3-4. 
SEC. 2. And be it further enacted, That all books transmitted through such agents for the nise of the Government of the United States, or of any government of a State, or of its legislature, or of any department of the Government of the United States, or of a State, or of the Academy at West Point, or of the National Institute, shall be admitted into the United States duty free.

SEC. 3. And be it further enacted, That the sum of two thousand dollars is hereby appropriated, out of any money in the Treasury not otherwise appropriated; and the same is put at the disposal of the Library Commintee, for the purpose of carrying into effect such agency and donation, and exchange, and of paying the expenses already incurred in relation thereto. ${ }^{\mathrm{T}}$

Approved, June 26, 1848 .

In consequence of this act the Committee on the Library, July $25, \mathrm{I} 848-$

Resolved, That Alexandre Vattemare be appointed agent of the Joint Committee on the Library to carry into effect the donation and exchange of such books and other publications as are or shall be placed at the disposal of the committee for this purpose, under the "Act to regulate the exchange of certain documents and other publications of Congress," said agent to be in all respects subject to the direction of the committee.

Resolved, That the said Vattemare's agency shall extend only to exchanges between the United States and foreign countries or governments, and not to domestic exchanges.

Resolved, That the chairman draw from the Treasury, and place in the hands of the said Alexandre Vattemare, $\$ I, 500$, part of the sum appropriated by the said act, to be applied to his personal expenses already incurred, and to be incurred during the year ending the 3 oth of Jume, 1849, and to defray the expenses of clerk hire, freight, rent of rooms, and other necessary expenditures of his agency; and that said agent shall annually account to and with the committee concerning the expenditure of said sum. ${ }^{2}$

And the Secretary of the Treasury issued the following circular instructions to collectors and other officers of the customs: ${ }^{3}$

To prevent fraud and imposition, all documents and other publications transmitted to the United States must bear the stamp of the central agency at Paris, to be impressed, in the case of books or pamphlets, on the first and last pages of the text of each rolnme; in the case of charts, maps,

\footnotetext{
${ }^{3}$ Two thousand lollars more was appropriated september $30,185 \%$, and $\$ 5,000$ August 31, $1 S_{52}$.

"Thirtieth Congress, first session, House niscellaneons documents, No. 99, 1) 12.

${ }^{3}$ Thirtieth Congress, first session, House miscellaneous ducunents, No. 99, 1. 16.
} 
prints, etc., the stamp to be on some convenient place on the face thereof. The boxes or packages will be addressed to the care of the collector of the customs of the port in the United States to which they may be shipped, accompanied by a letter of advice and a descriptive list. On their arrival the collector is enjoined to take careful charge of the same, notifying the Department of their receipt, and await instructions for their disposal.

Before leaving Washington M. Vattemare addressed a letter to the House of Representatives (August I I, IS48), in which he begged to be further favored by contributions of the newspapers, periodicals, and public documents of the various States represented in that body; these, he observed, he could not expect, unless they could be sent free of postage. But, although the Senate had passed a bill (July I I, I848) which provided "That Alexandre Vattemare, agent of the United States for international exchange, be, and he is hereby authorized to frank letters or packages containing books, public documents, maps, specimens of the arts, medals, sent to him from any foreign country to the United States, or from the United States to any foreign country; and, also to receive letters and packages appertaining to international exchanges free of postage; this privilege to extend to the mail lines of the United States, to foreign countries: Provided, That such letters or packages shall be endorsed on the envelope 'International exclianges,' and shall not exceed three pounds in weight; and it shall be lawful for any deputy postmaster to remit the postage on any letter or package not so endorsed, and charged with postage, directed to said Vattemare, if, on opening the same, he shall be satisfied that it appertains to intermational exchanges;" " the bill got no further, and M. Vattemare was obliged to depend upon the benevolence of the State governments and of private citizens for contributions of State docnments, books, periodicals, and newspapers.

Before leaving America M. Vattemare addressed Congress a second time upon the matter of State publications, books, periodicals, and newspapers. ${ }^{2}$ The publications of the Govermment at Washington, he felt, were but a small part of

\footnotetext{
'Thirtieth Congress, first session, House miscellaneous documents, No. 99.

" Thirty-first Congress, first session, Senate miscellaneous documents, No. I26. Report of Alexandre Vattemare to the Joint Committee on the Library in relation to international exehanges. September 28,1850 .
} 
the publications of the United States; a system of domestic exchanges was the natural complement of the system of international exchanges; the agencies in such a systen of domestic exchanges might be made agencies in the system of international exchanges, and so State publications, municipal publications, and the issues of the local press might become the objects of exchange between the libraries not of one land only, but of all lands. "If," he said, "a well-regullated and permanent systen of domestic exchanges were established between the United States and city corporations of the Union, these libraries would soon acquire great importance and usefulness. The nucleus of such libraries might be very readily and economically formed on the plan alluded to. They would not only present a faithful picture of the political affairs of the Union, present and past, and a correct view of American industry and genius in other departments of intellectual labor, but by a system of exchanges with Europe they would grow every year more universal in their character, and contain in the end works of all countries and languages, illustrating every people and epoch, and by the liberal principle of their formation be freely open for the instruction and delight of all." I

The desire of M. Vattemare to see the system of exchange fully established by the institution of agencies in all the great libraries of this and other conntries was not to be satisfied. As far as the Library of Congress was concerned, however, the movement was so successful that in I $S_{5}$ o a member of Congress had better opportunities for information regarding France than he had for almost any State in the Union. ${ }^{2}$

\footnotetext{
'Thirty-first Congress, first session, Senate miscellaneous doctuments, No. 126, p. 2.

${ }^{2}$ There are lists of books received by the Library through international exchange in the supplementary catalogues of 1948 and 1850 . There is a list of works presented by the Frencl Government to the I,ibrary, from May 4, 1848, to June, 1850 , in Thirtyfirst Congress, first session, Senate miscellaneous documents, No. 126, pp. 27-38. More were received in $I 8_{5} I$ (Minutes, January $15,18_{5} \mathrm{I}$ ) and in $18_{52}$. liorty-four volumes were received from Baden, 217 from Holland, 774 from Belgium, and I,64I from France, besides 630 volumes forwarded to the Library from M. Vattemare's depot in New York to supply sone of the losses oceasioned by the fire of 1951. I,ibrary of Congress nunuscript entitled "Fifth annual report on international exchanges," dated Paris, January 25, 1853 . 2 I pp. $44^{\circ}$. This refers to a report for $195 \mathrm{I}$, dated November 14, $185 \mathrm{I}$. 'The first report of the ageney' (Washington, IS.4S, $29 \mathrm{pp} ., 8^{\circ}$ ) contains a good summary of the listory of the Vattemare moventent to the end of 1845 .
} 
The exchange of documents between the United States and France led also to the receipt of further offers of exchange on the part of other governments-Canada, ${ }^{1}$ Spain, ${ }^{2}$ Liberia, ${ }^{3}$ Bavaria, ${ }^{4}$ Russia ${ }^{5}$-and the donation of public documents by the Governments of Switzerland, ${ }^{6}$ Sardinia, ${ }^{7}$ and Great Britain $;^{8}$ the last through the British Museum, in response to an order of the Library Committee that the Librarian be authorized to propose to Mr. Panizzi, librarian of the British Museum, an exchange of a copy of the legislative documents published by order of Congress for a copy of legislative documents published by order of the British Parliament.9

The success of the system did not, however, come up to the expectations of members of Congress, and wlien on the 3 Ist of August, I 852 , the further sum of $\$ I, 000$ was appropriated to defray freight and other expenses incurred under the act of Jume $26, \mathrm{I} 848$, the act was repealed. In explanation of this action the Librarian wrote to M. Vattemare, on June 15 , I 853 , as follows:

I an directed to inform you that Congress, on the 3 rst of Angust last, rescinded the law under which you were appointed agent of the Library Committee, to attend to international exchanges between them and such governments, \&c., as they might designate; and that, at the same time, Congress appropriated one thousand dollars to settle up and close the business of the agency.

The committee have been greatly disappointed in not receiving from the Government of France, or from any other government, through your agency, complete copies of the official reports made by the ministers to the National legislatures, and such other printed documents, legislative and ministerial, as would enable them to acquire the same

${ }^{2}$ Minutes, February 6, IS50, December IS, I850.

${ }^{2}$ Ibid., March 27, I 850 .

3 Ibid., February 5, I 85 I.

${ }^{4}$ Ibid., January Io, 1853 .

5 Ibid., December Io, 1856 .

${ }^{6}$ Vational Intelligencer, December 9, I854; Star; Deeember 7.

7 House resolution, June $14,1860$.

${ }^{8}$ Minutes, January 2I, I 8.4 ; 'Thirty-seventh Congress, third session, Senate report No. 73 , January $1_{3}, 1863$.

Minutes, July 27, I854. April 29, I836, President Jackson transmitted to Congress a copy of the catalogue of the Arundel MSS. in the British Museum which had been forwarled to him by the trustees of that institution for the purpose of being placed in the United States Library.-James D. Richardson, Messages and papers of the Presidents, 3: 226. 
satisfactory knowledge of their public affairs as is given of our public affairs in the printed docunnents of the United States.

The documents we sent to the Government of France were perfect in every particular, and they were well bound. We deemed this necessary to our own self-respect, and particularly due in courtesy to so liberal and so 11oble a nation and friend as we have always considered France.

The first supply of documents we received from France came in conplete sets, and they were bound in the best style. We felt proud of them, and took pieasure in exhibiting them in our Library because it was evident that they had been carefully prepared for us, as each volume had recorded on it, "From France to the United States." These documents came to us through Mr. Paget, Minister Plenipotentiary of France, to the United States.

The documents we have received since, through your agency, have been imperfect as a collection, were done up in pamphlet style merely as they were prepared for ordinary use, and seenled rather to have been selected by yourself than to have been intended by the Government as a continuation of the supply first sent to the Library.

The cause for this change has not been communicated to the Library Committee. We feel satisfied that it did not originate in an mwillingness on the part of France to interchange printed documents and other publications with us, and have been constrained to believe that an unwillingness exists in regard to the mode in which the interchange has been attempted. France may consider it undignified and consequently be opposed to holding national intercourse except through recognized officers of Government. Application will therefore be made for an exclange through an official agency.

Dissatisfaction seems to prevail, too, among the cities and societies to which the Library Conmittee have sent our printed documents, \&c., through your agency. Not even an acknowledgment of the receipt of them has been communicated to the committee. An acknowledgment at least was due and expected from them. $* * * *$

On the I 3 th of July, I 854 , the committee "Foted, That the chairman be authorized to pay M. Vattemare \$I,OOO of the fund for international exchange in full for his services."

During the remainder of the period before I865 only $\$ I, 200$ was appropriated for the purpose of international exchanges- $\$ 600$ in ${ }^{8} 87$ and the same amonnt in ${ }_{5} 88$.

I Library of Congress. I,etter book. There are further letters of interest on this subject from Jibrarian Meehan to Senator Pearce, Sept. 6, IS54, to M. Vattemare, Oct. 8, 1858, and from Vattemare to Meehan, Feb. 19, 1859. 


\section{Distribution of Public Documents.}

The failure of the Library of Congress as a bureau of literary exchange, together with the increased interest in the publications of the Government which was the ontcome of the Vattemare movement, led Congress, in ${ } S_{57}$, to transfer the distribution of public documents to the Department of the Interior and the exchange of public documents with foreign conntries to the Department of State. From a general standpoint this was an unfortnnate separation of the functions of distribution and exchange; from the point of view of the Library it was nothing less than a disaster, because it degraded the Library from its position as custodian of the public documents and withdrew from it the most important source for the supply of a class of literature of the greatest importance in a national library.

In I855 (February 26) a resolution to effect this had passed the Senate, but got no further. In i 856 (August II) the same resolution had again passed the Senate, but again had got no further. Finally, however, on the 2 Sth of January, IS 57 , the following joint resolution respecting the distribution of certain public docnments was passed:

Resolved by the Senate and House of Representatives of the United States of America in Congress asscmbled, That the ten copies of the journals and other documents of Congress, authorized by law to be deposited in the Library of Congress, by section three of the joint resolution of May twenty-fourth, eighteen hundred and twenty-eight, shall hereafter be deposited with the Secretary of State for foreign exchanges; and the fifty copies of the journals and documents of the Senate and House of Representatives ordered to be placed in the Library of Congress for foreign exchanges, by joint resolution of July twentieth, eighteen hundred and forty; and the fifty copies of the journals and documents of the Senate and House of Representatives anthorized to be deposited with the Secretary of State by the joint resolution of April thirtietl, eighteen hindred and forty-four, shall hereafter be deposited with the Secretary of the Interior.

SEC. 2. And be it further resolved, That instead of one hundred copies of the journals and clocuments of the House of Representatives, authorized to be printed by the joint resolution of April thirtieth, eighteen lnundred and forty-four, there shall hereafter be printed fifty copies only.

SEC. 3. And be it further resolved, That the journals and Congressional 
documents heretofore deposited in the Library of Congress by authority of the above-cited resolutions, and so many of the four hundred copies of the public doctments sent to the State Department as are now distributed by that department to colleges and other literary institutions, shall be deposited with the Secretary of the Interior, for distribution to such colleges, public libraries, athenæums, literary and scientific institutions, boards of trade, or public associations as may be designated by him.

SEc. 4. And be it further resolved, That two copies of the journals and documents indicated in the above-cited resolutions, so far as they have been saved from the late fire, shall be reserved for the Library of Congress.

SEC. 5. And be it further resolved, That in future two copies only of the journals and documents, or any book printed by either House of Congress, well bound in calf, shall be deposited in the Library, and not to be taken therefrom. ${ }^{\mathrm{x}}$

Approved, January 28, 1857 .

May Io, I 858 , the Speaker laid before the House of Representatives a list of books removed from the basement of the Capitol, prepared by the Doorkeeper of the House. Mr. Pettit moved that the paper be referred to the Committee on the Library, and, since the subject had attracted some public notice, took the opportunity to say that in his judgment most of the books listed had been legally under the control of the Secretary of the Interior since the passage of the act of January 28, I 857 , authorizing the distribution of journals and other public documents by that Department. The motion was agreed to and the communication printed as Thirty-fifth Congress, first session, House miscellaneous document No. I29. These books consisted of United States public documents and of French and Latin works, the latter probably received through the Vattemare exchange. The documents were transferred to the Department of the Interior. The foreign publications were transferred to the Library of Congress. ${ }^{2}$

\footnotetext{
'Note also the amendments to the above act passed during this period-the resolution of March 20, 1858, and the act of Iebruary 5, IS59, neither of which, however, offered anything new regarding the Library.

${ }^{2}$ There is a list of documents receiver of the Librarian of Congress at the Department of the Interior A ugust and September, $1 S_{5} S$, in the Report of the Secretary of the Interior for 1858 , Thirty-fifth Congress, second session, Senate executive document No. 1, pp. 99-105. Note also the letters fron Jibrarian Meehan to Moses Kelly, Aug. 3, 1858, to Joseph I. Wright, Aurs. 5, 10, 16, and to Jacob Thompson, Aug. 19.
} 
In addition to these legislative measures affecting the organization of the departments of law and of documents, another must be mentioned, viz, the reenactment March 29, I 848 , of the provisions of the act of February II, I825, providing for the remission of duties on books, maps, and charts imported for the use of the Library of Congress.

On the Igth of December, I846, the committee received a letter from Edgar Irving, agent in the New York customhouse, to attend to cases of books, etc., imported from Europe on the orders of the committee, in which he stated that in future duties would be charged on all such importations, agreeably to the new tariff law, and suggested that it would be found necessary to give a power of attorney to an agent in New York to pay such duties and take the books, etc., from the custom-house. And it was "Ordered, That the Librarian send such power of attorney to the agent, Edgar Irving, and give him the necessary instructions in relation to the payment of duties and forwarding the books, etc., to the Library of Congress." And on March 3, I 848 , it was "Voted, That the chairman of the committee be requested to report a joint resolution to the Senate authorizing and directing the Secretary of the Treasury to admit, free of duty, all books, maps, charts, etc., that may be imported for use in the Library of Congress." Accordingly, on the 4th of March, I 848 , Mr. Pearce introduced a bill in the Senate to remit the duties on books, maps, and charts, imported for the use of the Library of Congress. He explained that it was merely a transcript of the former law, which had just expired. He anticipated no objection to the bill, as it must be apparent to everyone that the payment of duties in this case was merely taking money out of one pocket to put it in the other. It was accordingly passed. On the $23 \mathrm{~d}$ this was reported in the House, with an amendment which was agreed to, and on the following day concurred in by the Senate.

AN ACT to remit the duties on books, maps, and charts imported for the use of the Library of Congress.

Be it enacted, \& $\mathcal{E}_{\text {. }}$, That the Secretary of the Treasury be, and he hereby is, directed in remit all duties upon such books, maps, and charts as have been during the present year, or hereafter may be, imported into 
the United States by authority of the Joint Library Committee of Congress, for the use of the Library of Congress: Provided, That if, in any case, a contract shall have been made with any bookseller, importer, or other person, for books, maps, or charts, in which contract the bookseller, importer, or other person aforesaid, shall have paid the duty or included the duty in said contract, in such case the duty shall not be remitted.

Approved, March 29, I848.

CHARACTER OF THE LIBRARY IN I $8_{5}$ I.

As a result of these activities of the Library authorities and of the annual appropriation of $\$ 5,000$ for the purchase of books, - "Congress votes for its Library $\$ 5,000$ and for stationery above $\$ 100,000, "$ said the Literary World, January 6, I 849 , - the Library in I 85 I was considered locally as unquestionably the most intrinsically valuable for its size in the world. "It is selected," said the Intelligencer, "and contains little trash. All branches of human learning are well represented, and the collections relating to history, politics, religion, natural science, mechanics, the fine arts, and geography are especially full and valuable." " Indeed, mineralogy, medicine, and botany were the only branches in which the Library was at all deficient. ${ }^{3}$

Those who were acquainted with the great libraries in the northern cities, however, viewed the collections in the Library of Congress with a more critical eye.

The North American Review, for example, thought that the Library possessed "far too many of those trifling productions which, after the year of their publication is over, become a useless burden on its shelves." 4

To-day, a Boston literary journal, said of the Library: "It was collected by different committees, of course without any continued system, and it exhibited quite curiously the whims of Congresses and Congressmen. For instance, there was always a demand for heraldry books. In compliance with this

\footnotetext{
${ }^{\top} \$ 2,000$ more was appropriated for the purchase of law books.

' National Intelligencer, February 3 and June 8, I849; Charles J. Ingersoll, Second war between the United States and Great Britain, sccond series, 2: 274 (IS52). Francis J. Grund, Aristocracy in America; from the sketchbook of a German nobleman, 2: 235 (1839).

${ }^{3}$ Elliot, Washington guide, p. 92: National Intelligencer, January 8, r8 34 .

${ }^{4}$ North American Review (1837), 45: 139.
} 
the committees kept it up to the time in all the English publications of that sort. Our members from the West thronged that alcove on their first arrival, and many an honorable gentleman could not rest till the Chairman of the Library Committee had translated his Latin family motto for him.

"There had to be assortments of showy picture books for the danglers who made the Library room their flirting place in the session. These are all gone, but they had been terribly thumbed first.

"Any private person, with the $\$ 250,000$ spent for this Library, would have a collection of four times its value. But "Uncle Sam never gets his money's worth.'" I

And the Hon. George Perkins Marsh in his speech on the bill for establishing the Smithsonian Institution delivered in the House of Representatives, April 23, I 846 , gave the following account of its deficiencies from the point of view of the scientist and bibliographer:

The Library of Congress [said he] contains more than 40,000 volumes, in general valuable and well chosen, with not many duplicates-not many books that one would altogether reject. It is not composed, like too many of our public libraries, in any considerable degree of books which have been given because the proprietor found them too worthless to keep, but it has been almost wholly purchased and selected from the best European sale catalogues, and yet there is no one brancl of liberal study, even among those of greatest interest to ourselves, in which it is not miserably deficient. *** $*$ It does not probably contain onefourth even of the small proportion of Brunet's list, which I have described as of intrinsic and permanent value. $* * *$ The Bibliotheca Historica Sueo-Gothica of Warmholtz, the last voluine of which appeared in I 817 , enumerates no less than 10,000 works illustrative of the history of Sweden alone; and the thirty years since have added greatly to the number. The literatur-lexicon of Nyerup, published in I 820 , gives the titles of probably an equal number of Danish works. Holland, too, has noble historians, naturalists, poets, and dramatists, and has produced many works of unsurpassed value upon the history of commerce and navigation. Of all these the Library of Congress, as far as I remember, does not possess a volume. You have none of the numerous writers of the vast Empire of Russia, or of Poland: nothing of the curious literatures of Hungary and Bohemia; not a volume in the 
language of Portugal, rich as it is in various literature, and especially in the will yet true romance of oriental discovery and conquest; only the commonest books in Italian and Spanish; and in the boundless world of oriental learning, of which our increasing commercial relations with the countries of the East render it highly desirable that we should possess the means of acquiring a knowledge, you have nothing to show but a few translations of the Bible and perhaps some works of devotion or elementary religious doctrine which American missionaries have presented you; and if you tnrn to the two great literatures-to that of Germany, which embraces every field of human inquiry, the efforts of whose scholars have done more to extend the bounds of modern knowledge than the united labors of the rest of the Christian world-while more than one-half of our population is of recent German origin and German is the vernacular tongue of extensive districts of American soil, the Library of Congress contains not 100 , probably not 50 , volumes in that noble language. And even in English literature our Library is sadly meager. How far are we from possessing a tolerably complete series of the English printed books of the fifteenth and sixteenth centuries, or even of that best age of English learning, that age with which every honest American most truly sympathizes-the age of Cromwell and Milton? Would it not be well to have at our command the means of enabling some diligent scholar to write what has not yet been worthily written, or indeed, scarce even attempted - a complete history of the literature of our Anglo-Saxon mother tongue, or to perform that herculean task which, in spite of the vaunted but feeble labors of Webster, remains still to be accomplished-the preparation of a respectable English dictionary? If there is any department of learning in which a library selected for the use of the representatives of a democracy should be complete, it is that of history. But what have we of the sources of historical investigation? Histories, indeed, we have, but little history. True, we have Robertson and Hume and Voltaire and Gibbon, and, above all, Alison, a popular writer in these days. *** But of those materials from which true history is to be drawn we have little, very little. The works belonging to the proper history of the American continent alone, everyone of which it would be highly desirable to possess, number certainly more than 20,000 volumes-fully equal to onehalf the Congressional Library-and of these we have as yet but a small proportion. 


\section{(UKa)tex Tight}

DEVELOPMENT OF THE LIBRARY, I852-1864 



\section{CHAPTER EIGHT. \\ DEVELOPMENT OF THE LIBRARY, I852-I864.}

On the morning of the 24 th of December, I 85 I, the development of the Library was interrupted by a fire which destroyed more than half of the collection of books in the Library, including about two-thirds of the Jefferson collection. The part destroyed was shelved in the main library room, to which the conflagration was mainly confined. The parts saved were in the north rooms and in the law room in the basement beneath.

The following account of the fire was given in the National Intelligencer on the following day: ${ }^{\mathrm{T}}$

A fire broke out in the Library of Congress yesterday at about a quarter to 8 o'clock, and about 35 , ooo volumes of most choice and valuable books were destroyed, together with precious collections of manuscripts, paintings, maps, charts, medals, statuary, and articles of vertu, the property of the Government and people of the United States. The origin of the fire is enveloped in mystery, which we hardly think will ever be cleared up. From the best information we have been able to obtain, it appears that smoke or flame, or both, were observed through the windows from without. Immediately upon this Mr. John W. Jones, one of the guards in charge of the Capitol, with another person, a Mr. Hollohan, forced their way into the Library by the principal entrance and found that the large table at the north end of the room was on fire, together with a portion of the shelving and books in the alcoves on the right or northeast and between the table and the door at the north end of the room leading to the law library.

At this time Mr. Jones says that half a dozen buckets of water would liave sufficed to extinguish the fire. His companion and himself, perceiving this, immediately ran below for the purpose of bringing the requisite fluid, but the draft which their entrance had necessarily produced lent such vigor to the flames that by the time they returned the whole room was irrecoverably won to the power of the destroying elenent. The flames seemed to glide over and above the gallery as if its material

'The same account, in the main, is given in the Telegraph December 24,27 and $3^{\circ}$, I851, and January 2 and 5, 1852; in the Globe December 25; in the Union Deccuber 25, 28, and $3^{\circ}$; in the Republic December 25, 27, and $3^{(4)}$; and in the Ncrus December 27, I 851 , and January 3, 1852 . The observations of the Huntress January 3, IS52, may also be noted. 
were of the most combustible character, for scarcely any appreciable time was occupied in wrapping the whole vaulted hall in mingled rolumes of smoke and fire.

At the earliest possible moment the fire companies of the city repaired to the scene, the Columbia, as we think, being the first; but the hose being in a frozen condition from its use a few hours before at the fire on Eighth street, with the thermometer at zero, had to be taken to the new gas factory on the canal to be thawed. Five mintutes afterwards the Anacostia engine arrived, and, its apparatus being in good working order, it was the first to act with effect. In quick succession seven engines were on the ground, gallantly vieing with each other to render service.

Very soon a body of United States marines from the navy-yard were ordered up to assist in bearing water, keeping order, and protecting property; and very useful indeed did they prove throughout the day. A large engine was drawn $11 \mathrm{p}$ the steps of the east portico, and another run into the Rotunda, and from thence supplied a jet of water of great porver and efficiency. 'This was done, we believe, without any injury being sustained by the great historical paintings around the Rotunda walls.

Notwithstanding the fortunate circumstances that the walls of the Library rose so high as, in a measure, to separate that department of the Capitol edifice from the rest, at least to the extent of giving it a distinct roof, it was found that fire had communicated to the main roof, which was, however, stopped by the gallant members of the Anacostia company, who cut away with their axes so much of the roof as seemed to be in harm's way. In like manner a portion of the stairway leading to the top of the Dome having taken fire, it was extinguished by the samie devoted band.

The heat of the fire at the distance of the pillars in front of the Library (for the fire itself never reached them) was so great as to scale them off in places a quarter of an inch thick, taking not merely the painting but the stone under it.

We have stated above that about 35,000 volumes of books were destroyed; this is estimated from the number saved, which is 20,000 , the original contents of the Library being about 55,000 volumes in all. The contents only of the principal hall were consumed, the north room and the law library not having been risited by the fire owing to the thickness of the intervening walls.

Besides the number of books, a number of superior paintings, langing around the I,ibrary walls and between the alcoves, were included in the destruction. ${ }^{x}$ Of these we can call to mind Stuart's paintings of the first five Presidents; an original portrait of Columbus; a second portrait

'Of these portraits, at that time on exhibition in the Library, those of Madison and Monroe, somewliat damaged, were rescued ( Union, March 18, I857). The history of those portraits is given by Clarence $\mathrm{W}$. Bowen, in his History of the centennial celebration of the inauguration of George Washington, New York, I892, p. 505 . 
of Columbus; an original portrait of Peyton Randolpl; a portrait of Bolivar; a portrait of Baron Stenben by Pyne, an English artist of merit; one of Baron De Kalb; one of Cortez, and one of Judge Hanson, of Maryland, presented to the Library by his family. Between eleven and twelve bronze medals of the Vattemare exchange, ${ }^{2}$ some of them more than ten centuries old and exceedingly perfect, are amongst the valuables destroyed. Of the statuary burnt and rendered worthless we recollect a statue of Jefferson; an Apollo in bronze by Mills; a very superior bronze likeness of Washington; a bust of General Taylor by an Italian artist, and a bust of Lafayette by Darid.

We have only heard of three books saved from the principal Library, namely, the Librarian's record, an account book, and an odd volume of Lord Kingsborough's magnificent work on the antiquities of Mexico.

We must say that we consider the system adopted by the Gorernment for the protection of the public buildings and property as essentially defective, as the various conflagrations which have taken place-first of the War Office building, next of this very Library part of the Capitol in 1826 , then of the Treasury building, next of the General Post-Office edifice, and now the Congressional Library again-must prove.

We must express our unqualified adniration for and warm thanks to the firemen and other citizens who, in such a freezing night, turned ont to save from destruction, if possible, the property of their fellow-citizens, and with an energy and perseverance beyond all praise continted their exertions till noon the next day, when the fire at the Capitol was at length subdued and they permitted to seek rest at home-indeed, the engines were as late as $3 \mathrm{p}$. 111. yesterday still throwing water into the burnt hall and upon its immense mass of charred and smoking, steaming rubbish to insure the entire extinction of the fire.

A strong guard of marines from the nary-yard, with a body of the city police, were posted last evening around the Capitol, to be ready in case any new emergency should arise. Congress, at its resumption of business on Friday, will no doubt take neasures by which a searching investigation into all the circumstances of this sad conflagration will be had. ${ }^{2}$

On the 26th of December the Speaker of the House of Representatives received the following communication regarding the effects of the fire from Librarian Meehan:

\section{Lrbraky ol Congress, December 25, 1851 .}

SiR: It is my very painful duty to communicate to Congress the destruction of the books, paintings, statnary, medals, and other property of the principal saloon of their Library, yesterday morning, by fire that originated in the room, in a manner to me altogether unaccountable, as no fires have been used in it for a long time, and no cancles, lamps, or

'The medals damaged by the fire were in 186 I presented to the smithsonian Institution.

2National Intelligencer, December 25, is $5 \mathrm{r}$. 


\section{DEVELOPMENT OF THE LIBRARY, I $852-I 864$.}

other lights have ever been used in it during the whole time that it has been under my charge.

I have not been able to ascertain the precise number of the books that were destroyed, but believe that it may be estimated at about thirtyfive thousand.

It is truly gratifying to have it in my power to add that about twenty thonsand rolumes of books that were in the law room and in the two rooms adjoining the saloon of the library are safe. Many of these books belong to the library of the late President Jefferson that was purchased by Congress in the year i 815 .

They constitute the several chapters in the catalogue of the Library, agreeably to Mr. Jefferson's classification, under the following heads: Ancient history, American history, Ecclesiastical history, Chenistry, Mineralogy and conchology, Moral philosophy, Law of nature and nations, the five chapters composing the law department of the Library, Religion, Politics (including the science of legislation, political economy, commerce, banking statistics, etc.), part of the chapter on Architecture, and the entire chapter on Music, Dialogue and epistolary, Logic, Rhetoric and orations, and the Theory of criticism.

I sincerely hope the searching investigation Congress will give to the distressing event, which every lover of science and literature must deeply deplore, will lead to a detection of the causes that produced it, and to the adoption of means that will prevent, in all future time, a recurrence of the sad calamity.

With the most respectful regard, I have the honor to be,

Your obedient servant,

JOHN S. MEEHAN,

Librarian.

To the Hon. Lynn Boyn,

Speaker of the House of Representatives, U. S. Congress. ${ }^{x}$

This communication having been laid before the House and read, Mr. Stanton, of Kentucky, introduced the following resolution, which was read the first and second time:

JOIN'T RISOLUTION authorizing an inquiry into the origin of the late fire by which the National Library was destroyed.

Resolved, That the Joint Committee on Public Buildings and Grounds be instructed to inquire into the origin of the fire by which the National Library was consuned on the twenty-fourth instant, and whether the sance occurred from the negligence of any officer of Governnent, or person in the employment of either or both Honses of Congress, or from the defective construction of furnaces or flues, or was the act of an incendiary, and also the extent of injury to the building and the best 1110de of reconstructing the I,ibrary room so as to afford perfect security

'Congressional Globe 26: I53. 
in the future against the like disaster and report the facts to the House. The said committee shall have the power to send for and examine, on oath, such persons as may have information touching the premises.

This resolution being under consideration it was suggested that the library should be denominated the Library of Congress, not the National Library. The resolution was altered accordingly. Mr. Stanton, of Tennessee, suggested that the inquiry onght to extend to the means of making the whole Capitol fireproof. Objection was made to this, and the resolution was read the third time and passed.

On the same day the question of the expenses occasioned by the fire was brought up by Mr. Stanton, of Kentucky. He had received a communication from the Commissioner of Public Buildings stating that great expense had been incurred in extinguishing the fire, and that an appropriation was needed to meet this expense, as well as for the purpose of putting the building in a condition to be secure from the action of the weather. He therefore asked the consent of the House to introduce a bill: ${ }^{1}$

AN ACT making appropriation to meet the expenses incurred in consequence of the late fire at the Capitol.

Be it enacted by the Senate and House of Represcntatives of the United States of America in Congress assembled, 'That the sum of five thousand dollars be, and the same is hereby, appropriated out of any money in the Treasury not otherwise appropriated, to be expended, or so much thereof as may be necessary, under the direction of the Commissioner of Public Buildings, in discharge of the expenses incurred in the extinguishment of the late fire in the Library room, the removal of the rubbish, and the preservation of such books and other articles as may have been saved, and the construction of a tin roof for the preservation and protection of the portion of the building now exposed.

The communication from the Commissioner of Public Buildings was then called for and it was read, as follows:

OfFicf; OF Commissionfer or Public Buildings.

Washington, D. C., December 26, $185 T$.

Honorable RichaRd H. STANTON,

Chairman Committee on Public Buildings and Grounds.

SIR: The late destruction of the IIall of the United States Iibrary by fire has left a mass of burning books and papers, which I an now having removed. I am also constructing a temporary roof (covered with tin) 
over the exposed arches which cover the rooms immediately east of the Library, which I hope to finish this week.

To enable me to pay the cost of these works, and also the buckets, axes, etc., purchased during the fire, and wages of men employed to guard the premises and prevent further extension of fire to other parts of the Capitol, I very respectfully pray your committee to ask for an appropriation of five thousand dollars, which I hope will be sufficient for these purposes.

I am, with great respect, your obedient servant,

William EASBY, Commissioner of Public Buildings. ${ }^{\mathrm{x}}$

The bill was accordingly passed.

On the 27th of December, the following correspondence regarding the cause of the fire passed between William Easby, Commissioner of Public Buildings, and Thomas U. Walter, Architect of the Capitol:

OfFice of the Commissioner of Public Buildings, Washington, D. C., December 27, 1851 .

Thomas U. Walter, Eisq.,

$$
\text { Architcct of the Capitol. }
$$

SrR: I am instructed by the Honorable Secretary of the Interior " to make a thorough investigation of the causes which led to the destruction of the Congressional Library, and injury to the Capitol by fire on the morning of the 24th instant," and to "make a report to him on the subject witl as little delay as practicable."

In view of these instructions, I would thank you to make an immediate examination of the premises and report to me, in writing, your opinion as to the cause of the fire.

I am, sir, with great respect, your obedient servant,

$$
\begin{gathered}
\text { WIILInMr EAsBy, } \\
\text { Commissioner of Public Buildings. }
\end{gathered}
$$

\section{Architect's OfFice, United STATES Capitor,}

Washington, D.C., Decomber 26, 1851 .

Wirmram Easby, Esq., Commissioner of Public Buildings.

SIR: In compliance with the request contained in your letter of this morning, I have exannined the Capitol with reference to the origin of the fire which took place in the Library of Congress on the morning of the 2 thl instant, and find that it was eansed by the timbers which formed the alcoves of the I, ibrary having been inserted in the climney flues. 
On examining the holes in the brick wall which have peen exposed by the removal of the burnt timbers, I found an opening of about two inches by the thickness of a brick into one of the flues, near where the fire was discovered. The chimneys from the lower rooms were then examined, and it was found that the flue from the room of the Comnittee of the Senate on Indian Affairs had been recently burnt ont. A chimney sweep was sent up this flue, and found the opening into the Library alluded to. His voice was heard at the aperture in the chimney, and he brought down with him a portion of the burnt timber that had protruded into the flue.

Large wood fires are made in the committee rooms very early every morning, and the rooms shut up until they are occupied by the committees. This chimney must have taken fire while the room was thus closed and burnt out without being observed, as might easily be the case with any of the chimneys in the building.

After a careful examination of the subject, I am of opinion that the fate of the Library depended on this chimney. If it had taken fire years ago the result would have been the same. The timbers were too far above the fireplace to be set on fire in any other way than by the burning of the chimney, and such an event could not have occurred at any time without communicating fire to the Library.

The alcoves of the Library were formed of timbers filled in with "brick-1logging." The horizontal pieces were let into the walls for the purpose of strengthening the structure, thus affording the means of communicating the fire to the vertical scantling, one of which was placed against the wall in each partition.

The evidences of the fire having occurred in this way are too conclusive to admit of a doubt, and are sufficient to remove all censure from those who have charge of the building; no huma: forethought or vigilance could, under the circumstances, have prevented the catastrophe.

I am, sir, very respectfully, your obedient servant, THO. U. WALTER, Architect of U. S. Capitol.

This correspondence did not satisfy all. A correspondent of the Republic said:

Mr. EDiToR: That the statement of the "Architect," 'Thomas U. Walter, as to the cause of the fire which resulted in the destruction of the Congressional Library is erroneous, and calculated to expose that portion of the building to another destruction in the same manner, if an entire change is not made in the mode of leating it, will be evident to anyone who will take a moment to reflect upon its msound reasoning. The "Architect" lays down the postulate that the fire commenced in

"Hashington Kepublic, Derember 27, 1851. 
the flue of a chimney leading from one of the committee rooms, which, he says, ignited a piece of timber inserted in said chimney to support one of the alcoves of the Library, and states that a chimney sweep was sent up said flue, when his voice was heard at the opening, and he bronglit down with him a piece of the charred timber which still remained in the aperture. Now, if the fire had taken from the flue, as stated, there would not, and conld not, have remained any timber in the wall of the chimney, for it must have been all consumed before the fire made its appearance in the Library. The fact that the piece of charred timber was found there is conclusive proof that the fire originated in some other place than that designated, and the water discharged from the engines extinguished the same on the outside and not on the inside of the chimney. Scientific gentlemen will have to look elsewhere for the cause of that fire, and they will, no doubt, find it in the superficial construction of the flues designed to heat the building by hot-air furnaces. I ask you to give this hint a place in your paper, that those who may be cliarged with the duty of rebuilding the Library nay be on their guard to prevent a like disastrous occurrence hereafter. ${ }^{\mathrm{t}}$

A correspondent of the Union ${ }^{2}$ (December 30, I85I), on the other hand, was not satisfied that there should be a change in the heating apparatus only; everything that was necessary to make the Library fireproof should be done. He said:

It lias gencrally been our lot to find the voice of the well-instructed Librarian totally disregarded when raised in opposition to the ambition of architects, the conceits of corporations, or the cupidity of competing contractors.

An Italian architect, a man of genius, has said, "Il primo e piu abile architetto é il padrone della casa" - the first and ablest architect is the master of the house. The Librarian knows, or ought to know, what is wanted for the safety and convenience of his charge. He is the master of that house.

It should be known that within the last twenty-five years everything relating to the construction of edifices for libraries, their arrangenent and conveniences, the means of their preservation from fire, from clampness, from insects, and from depredations and injuries, has been studied most laboriously and thoroughly in England, in Frauce, in Germany, and in Italy. The management of librariss has been reduced to settled principles, and been dignified in Germany by the name of a science. Magazines are devoted exclusively to the subject, and some of the most organizing and ingenious minds in the world lave been working out its problens and arranging its apparently incongruous details. If we wish

"W'ashinglon Kepublic, January 6, 1852. Note, also, IIuntress, January 3, IS52.

"Irobably Professicr Jewett. 
to be "à la hauteur dı siècle," or anywhere near the present age, we can not neglect the lessons of their experience and their labors. Yet who has read, for the benefit of the public archives and the National Library of America, the Reports and minutes of evidence of the Parliamentary commissions upon the British Museum and upon public libraries? They are in six large folio volumes. Who has read the books and pampllets recently published respecting the national library of Paris? Who has read for this purpose the memoirs of the lamented Dellessert or the works of Laborde, Della Santa, Molbech, Schrettinger, Namur, Hesse, Reiffenberg, Peignot, and many others, and the journals conducted by Dr. Naumann and Dr. Petzlooldt? Without studying these one can not feel confident that he is moving in the light of modern knowledge upon such matters. $* * *$

Some of the most important conditions of security of libraries against fire, some especially of those most neglected:

I. Isolation is an important means of safety. The proximity of dwelling houses or buildings requiring only ordinary care should, if possible, be avoided. A library should on other accounts be by itself, subject solely to laws framed for its own welfare. When, however, it must be kept in one portion of a building the other apartments of which are occupied for other purposes, it should be completely separated from them by thick walls of stone or of brick and by double iron doors at least a foot from each other. The windows should also be guarded by sliding iron shutters, if they would be exposed to flames from other buildings or to incendiary projectiles. The roof should not only be fireproof on the outside, but it should be protected from fires within, either by being built wholly of incombustible materials or covered by such above and shielded by such below. What chance would there be for saving any part of a library when the flames were spreading along its roof?

2. Insulation of alcoves and shelves.-Each alcove or range of shelves should be so constructed that the books in one alcove or case might be completely burnt out without communicating fire to the next. To this end there should be thick walls of brick or iron between the alcoves. The floor should be incombustible. Wooden galleries and roofs shonld be entirely prohibited. Pictures, maps, and wooden ladders slould never be extended from one bookcase to another.

3. The use of iron for bookcases, shelves, stairs, galleries, and furniture. To prevent injury to books from the deposition of moisture, and from friction upon rough surfaces, all parts that come in contact with the books should be covered with woolen cloth, or (particularly in warn climates) with leather, which is less liable to invite or liarbor insects.

4. The heating apparatus should receive special attention. Warning by hot-air furnaces is always unsafe for such an establishment. 'Tlee accidents which have recently occurred, where the idea of danger would 
have heen ridiculed, should be carefully considered. In many imaginable ways a furnace may be dangerous when pronounced entirely safe. Suppose one: A lucifer match is accidentally dropped; it falls upon a newspaper lying upon a chair near the furnace flue; the stream of hot air ignites the match, which kindles the paper, and thus the destroying element is quickly spread. One source of danger from hot-air furnaces, which is seldom thought of, is the facility offered by the flues for conducting flames from one part of a building to another. Fires have thus spread with almost inconceivable rapidity. The best mode of heating libraries is doubtless by warm water or by steam.

5. Precautions as to lamps.-A large public library should never be lighted by means of movable lamps. If studies must be pursued in the evening, let there be, if possible, a separate room to which the books required during the evening may be carried before dark. There can be no certainty of safety if lamps are permitted at all. At the British Musenm a candle is not allowed even for the sealing of a letter. We have been there when London darkness has settled down upon the establishment at noonday. As it came on, visitors, nnable to read, one by one withdrew. The librarians, unable to pursuc their work, and forbidclen either to leave the building or to light a lamp to aid them, were fain to sit down in groups to hours of conversation in the dark. The precautions in this case were not adopted without due consideration or much discussion. Whenever it is considered indispensable to light a library it should be done by fixed lamps or gas burners so far removed from all books and papers as to be as safe as possible. The lighting and extinguishing of them should be intrusted to one responsible person. Movable lamps and matches should be positively and rigorously prohibited.

In the Senate on the 29th of December the resolution authorizing an inquiry into the origin of the fire was discussed. Mr. Badger observed: "It seems to me to be a very great outrage that we should pass a resolution to inquire into a fire in our building in such a form that it can not go into effect without the signature of the President of the United States. The resolntion ought to be amended. It should not pass in its present form. I move to lay it on the table for the present." The motion was agreed to.

Mr. Cass subunitted resolutions of a like tenor for consideration:

Resolved, 'Tliat a committee be appointed, jointly' with such connintee as may be appointed on the part of the House of Representatives, to inquire into and report the canse of the recent fire in the Capitol; and also what measures it is proper to take to prevent the occurrence of a 
similar accident hereafter. And the said committee be also instructer to exanine the proposed mode of construction of the addition to the Capitol, and ascertain whether it is intended to rencler the same fireproof, and, if not, what should be done to secure it, as far as possible, from the danger of fire.

Resolicd, 'Tluat the Conmittee on the Library be instructed to examine and report what measures should be taken immediately to procure such books as may be most indispensable; and what plan it is best to adopt to procure a library which, in its extent and in the character of the works, shall be sufficiently useful and honorable to the country.

These, too, like the Honse resolutions, were without legislative result.

An amendment to the bill making an appropriation to meet the expense incurred in consequence of the fire was introduced by Senator Cass. It was as follows:

And be it further enacted, That the sum of - dollars be, and the same is hereby, appropriated for the purchase of books for the Library of Congress, to be expended under the direction of the Joint Committee on the Library. ${ }^{\mathrm{x}}$

On motion of Senator Badger the bill and amendment were referred to the Committee on Finance. This committee, on the 6th of January, I852, reported them back by Mr. Hunter and recommended their passage. The blank in the amendment was accordingly filled with $\$$ Io,ooo, and the bill passed as amended.

On the same day, January 6, I852, Mr. Hunter submitted the following resolution:

Resolved, That the Committee on Public Buildings be instructed to inquire into the expediency of appropriating a sum not exceeding dollars, to fit up the document room near the Library and a part of the adjoining passage, for the temporary reception of the books of the Congressional Library. ${ }^{2}$

On the gth of January the blank was filled with $\$ I, 200$, and the resolution passed.

On the Iatl of January the Senate amendment to the House bill, making an appropriation to meet the expense incurred in consequence of the fire, was taken $11 \mathrm{p}$ in the House. 
Mr. Clingman urged its passage. With the sum of $\$ 10,000$ appropriated by the bill and the standing appropriation of $\$ 5,000$, the Library Committee would be able to get those books which Congress most needed. The books could be procured in the course of two or three weeks in the principal cities. In the meantime by passing the second bill which had come from the Senate, making an appropriation of $\$ 1,200$ to fit up rooms, temporary quarters for the books purchased wonld be provided. So the amendment was concurred in.

AN ICT making appropriation to neet the expenses incurred in consequence of the late fire at the Capitol.

Be it enacted, $\mathcal{F}_{c}$., That the sum of five thousand dollars be, and the same is hereby, appropriated out of any money in the Treasury not otherwise appropriated, to be expended, or so much thereof as may be necessary, under the direction of the Commissioner of Public Buildings, in discharge of the expenses incurred in the extinguishment of the late fire in the Library room, the removal of the rubbish, and the preservation of such books and other articles as may have been saved, and the construction of a tin roof for the preservation and protection of that portion of the building now exposed.

SFC. 2. And be it further enacted, That the su11 of ten thousand dollars be and the same is liereby appropriated for the purchase of books for the Library of Congress, to be expended under the direction of the Joint Committee on the Library.

Approved, January 13, is 52.

On the same day, January I3, Mr. Stanton, of Kentucky, observed, respecting the second bill which had passed the Senate relating to the Library - the bill providing rooms for the temporary accommodation of the Library: "I an authorized by the Committee on the Public Buildings to state that there is a bill from the Senate now lying upon the Speaker's table appropriating the sum of $\$ \mathrm{~T}, 2 \mathrm{OO}$ for the purpose of fitting up two roons to be occupied as a Library, and for containing the books which shall be purchased with the money which was appropriated for that purpose by a bill passed yesterday. The Committee on Public Buildings are desirous that the bill should be passed immediately, and I an authorized by them to ask the unanimous consent of the House that it may be taken up and acted upon now."

Objection, however, being made by Mr. Dumham, the 
House proceeded with the regular order of business. But on the 5 th of January the bill was passed.

AN ACT to provide a room for the Congressional Library.

Be it cnacted, $\mathcal{F}^{\prime} c_{\text {. }}$, That the sum of twelve hundred dollars be hereby' appropriated, to be expended under the direction of the Commissioner of Public Buildings, for the purpose of fitting up the document roon and a portion of the adjoining passage to receive temporarily a portion of the books of the Congressional Library.

Approved, January 23, 1852.

In consequence of these acts of January I 3 and 23, and of the activity of the workmen who were employed in removing rubbish, and sorting out of the mass of books those which with trimmed margins and new bindings might be suitable for placing in the new collection, the Library, though greatly crippled, was soon in running order again in the rooms appropriated for the purpose adjoining the old Library. The question of a permanent library room was, however, still unsolved.

\section{THE NEW LIBRARY ROOM.}

In 1840 the crowded condition of the old Library room had been relieved by the creation of reference libraries in the rooms of the different committees of the two Houses of Congress. In I 843 additional rooms for the collections in American history and law had been secured and fitted up, but as we have seen none of these measures provided adequately for the expansion of the Library. The fire of December 24, I 85 I, however, made an answer to the question of adequate accommodations for the Library imperative. Accordingly, on the 27 th of January, I 852 , the chairman of the Library Committee, Mr. Pearce, submitted to the Senate the following resolution, which was considered by unaninous consent and agreed to.

Resolicd, That the Committee on Public Buildings be instructed to inquire into the expediency of enlarging, repairing, and refitting the principal apartment heretofore occupied by the Library of Congress, so that it may be entirely fireproof and capable of further extension in harmony with the general plan of the Capitol, upon the removal of the Sen-

: Washington Republic, December 27, 30, $185 \mathrm{r}$. 
ate and House of Representatives and their offices to the wings of the Capitol.

Accordingly, on the $4^{\text {th }}$ of February, I852, Mr. Hunter, from the Committee on Public Buildings, made the following report in the Senate:

In connection with this subject they have examined the report of the Architect, Mr. Walter, to the Commissioner of Public Buildings, upon the subject of repairing the Library. After an examination of the plan proposed in this report and the drawings which accompany it, they have concurred in the recommendation of the Architect and submit his report, which is hereto annexed, as expressing their views. But being well aware that experience often suggests the propriety of changes in the details of a plan during the process of construction, they deem it best to leave to the discretion of the President to make such changes in the details of the plan as may be consistent with the general arrangement and yet improve the appearance and usefulness of the room. In view of the necessity for some immediate provision to meet the want of a Congressional Library, the conmittee have deemed it advisable to repair at once the former library room, and for that purpose submit the accompanying bill. In the event of the passage of this bill your committee recommend that the drawings shall be deposited with the Secretary of the Interior.

\section{Architect's OfFice, U. S. Capitol, Washington, D. C., January' 27, 1852 .}

SIR: In compliance with the request contained in your letter of the $27^{\text {th }}$ ultimo, I have made an examination of the Capitol, in reference to the extent of the injury done to the building by the burning of the Library of Congress, and the best means of repairing the damage. I have likewisc prepared plans for reconstructing the Library, which are herewith submitted.

In view of the irreparable loss the country has sustained by the destruction of the old Library, I have considered it an indispensable element in the design now presented, to use no combustible materials whatever in any part of the work; the alcoves, cases, galleries, doors, window shutters, ceilings, and the brackets that support then are all designed to be cast iron; the shelves for the books of thick glass or enameled iron; the franing of the roof of wrought iron; the sleathing of copper and the floor of stone. In a library thus constructed fire will be out of the question, and the materials of which it is formed will not be subject to decay nor deterioration.

By the plans here proposed it is contemplated to enlarge the Library so as to cmbrace the entire western projection; this will give a room of 


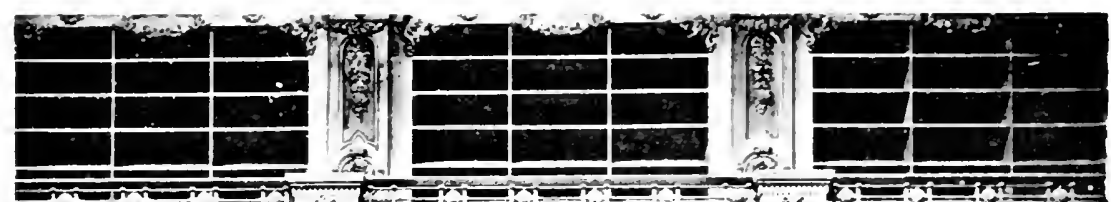

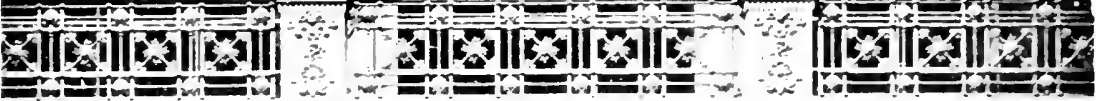

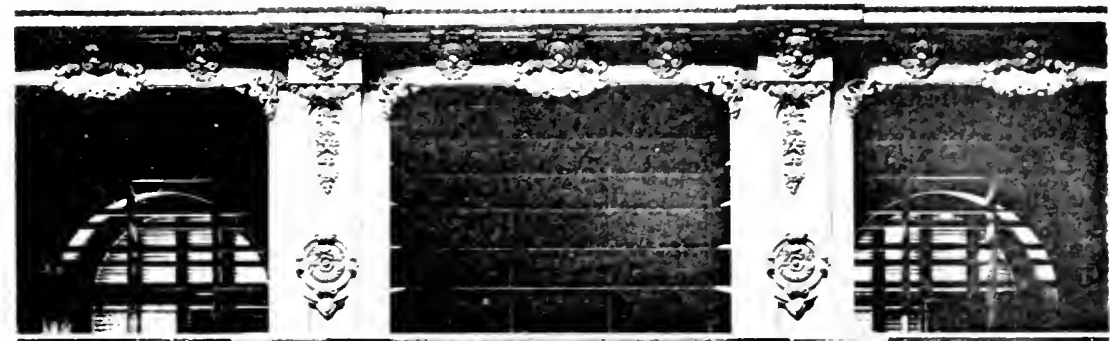

Gib M.

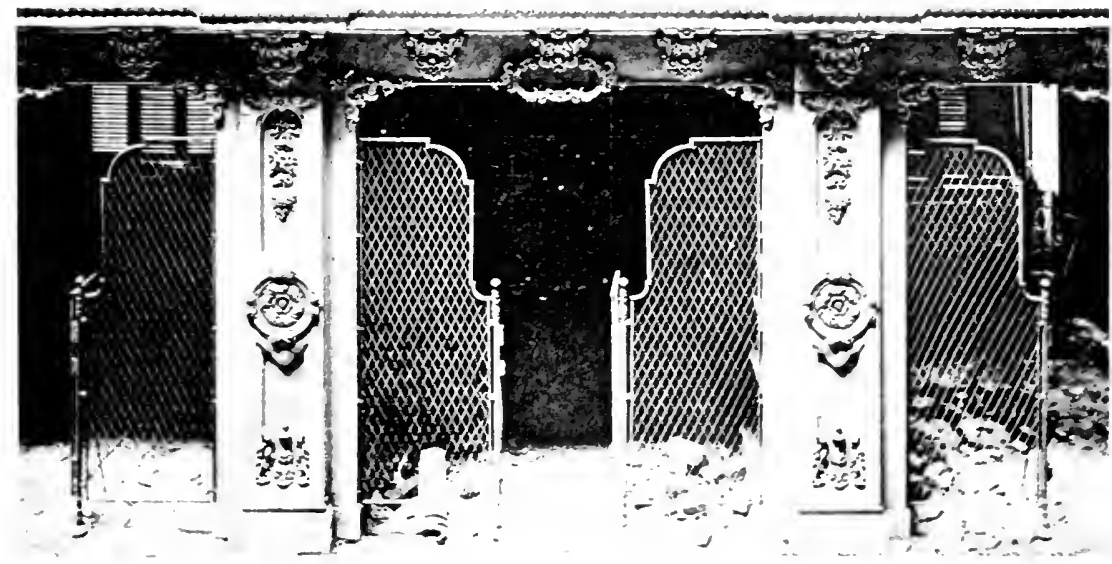


29 feet 6 inches by 70 feet 2 inches at each end of the original Library, extending to the roof, liglited by skylights, with two additional apartments, ${ }^{3}$ each is feet 6 inclies by 35 feet, for private reading rooms for Senators and nembers of the House of Representatives, respectively, thus making a suite of five rooms, embracing an extent of 302 feet.

It will not, however, be possible to carry ont the entire plan until accommodations are provided in the new wings for the officers of Congress and commintees now occupying the north and south rooms of the western projection. I therefore propose to fit up the old Library according to the plans, without changing its dimensions, and to complete the archway intended to lead into the end rooms, leaving a sufficient thickness of wall remaining to separate the Library and the said rooms until the proper tine arrives for carrying ont the entire design.

In this portion of the plan, which, as before remarked, constitutes the reconstruction of the old Library, there will be two stories of alcores, the second story receding 3 feet from the front of those below, so as to admit of forming a gallery on top with but little projection. The same arrangement will be repeated on the top of the second-story alcoves, so as to form a gallery to the third story, which will consist of cases against the wall, with divisions and ormamental pilasters corresponding to the openings below. The galleries will all be protected by continuous railings of iron. The floors of the galleries will consist of cast-iron plates, and the approach to them will be by means of two semicircular stairways formed of iron and recessed in the end walls.

Each of the lower alcoves will be inclosed by ormamental iron gates. The ceiling will be composed of thin iron plates, cast with deepsunken panels, filled in with enriched moldings and center ornaments.

The room will be lighted, in addition to the 5 windows in the west front, by 8 skylights, each 6 feet square in the clear, making 288 square feet of glass. Eacl skylight will be filled in with ornamented glass, forming part of the design of the ceiling, and protected on top by thick plates of glass placed on the line of the roof.

The floor will be composed of marble tiles, the walls plastered, and the interior painted in colors appropriate to the materials of which it is composed.

I propose to warm this portion of the building by means of hot-water pipes inclosed in chambers erected in the present furnace rooms in the cellars and connected with boilers for heating the water; the external air to be admitted into these chambers, where it will be warmed and conducted by flues to the Library and sucl of the adjacent rooms as are heated by the present furnaces. The quality of the lieat thus produced is not only unobjectionable, as regards health and comfort, but it is peculiarly adapted to the warming of libraries, as it retains its original

I One of these rooms was then occupied by the Library as temporary quarters.

23399-04-I9 
moisture and is not injurious to the binding of the books, besides being free from dust and other impurities.

The room will be ventilated by means of apertures in the ceiling, opening into the space between the ceiling and the roof, from which the foul air will be extracted by means of an air shaft, in which a vacuum will be produced by artificial heat.

The execution of the entire plan here proposed will in no way impair the stability of the structure, but rather promote it; none of the main walls will be disturbed, the removal of the arches over the rooms will relieve the outer walls of horizontal pressure, and the aggregate weight of the superstructure will be reduced; all of which are importaut considerations when it is remembered that the western projection has always had a tendency to settle off from the rest of the building, which is shown by the cracks in the angles on the outside.

The injury to the building produced by the fire is almost exclusively confined to the Library. The floor being composed of bricks laid on the arches of the rooms below, and the surrounding walls being of great thickness, extending above the roof in the form of parapets, the firemen were enabled to keep the fire under control and prevent it from communicating to other parts of the building. The walls are, however, so mucl injured as to make it necessary to take down and rebuild the upper portion of them, including the entire parapets, and to repair them generally throughout.

The western front has sustained so much injury around the windows as to make it necessary to take out the stonework between the pilasters as high as the bottom of the upper panels and substitute it with new material; the panels and sculpture appear to be uninjured, and as far as I can now judge they may remain.

The inner portions of the columns have suffered very seriously. The injured parts may, however, be cut out and replaced by new stone without removing them, as the repairing will be obscured by repainting them.

I would further suggest in connection with these improvements the removal of the stairway leading into the attic in front of the main door of the Library. This stairway is of but little use, as both ends of the building have other convenient approaches. I therefore propose its removal, with all the columus and archways connected with it. The stairway by which the Rotunda will be approached will then be better lighted, the approach to the Library will be free and liglit, and the Library door will be in full view from the Rotunda. This door may be richly embellished with the columns and entablature which now support the stairs in question, and a rich marble balustrade may be placed around the stairways leading from below, which will form a tasteful and convenient improvement. This colonnade, with the low arches leading to the Library, are the most objectionable features of the building, besides interfering with the passage of light to the stairway most used by the 
members, and also to the approach to the Library. I can therefore see no reason why they should not be removed.

I have estimated the cost of carrying out that portion of the plan now proposed, embracing the space heretofore occupied by the Library, together with all the aforementioned repairs and alterations, the whole of which are to be executed of incombustible materials, as hereinbefore stated, and find that it will amount to $\$ 72,500$.

I am, very respectfully, your obedient servant,

THO. U. WALTER,

WILIIAM EAsBy, Esq. Architect United States Capitol.

Commissioner of Public Buildings. ${ }^{\mathrm{T}}$

On the $7^{\text {th }}$ this report and the accompanying bill were taken up for consideration as in Committee of the Whole. On the gth of February the bill was passed.

In the House, February i 2, Mr. Chandler called the attention of the House to the bill. It was absolutely necessary, he said, that the Committee should receive immediate authority to issue their proposals. But Mr. Orr insisted on the regular order of business. Mr. Chandler then moved that it be made the special order for the following Monday. To this Mr. Stephens, of Georgia, objected. He was opposed to all special orders.

On the Ioth of March, however, Mr. Clingman brought the bill before the House, with the following remarks:

We ought certainly to make an appropriation for the Library. We all feel the want of it, and we had better make an appropriation at once, and let the men go to work. We ought also to appropriate the necessary money to continue the work on the extension of the Capitol, if that work is to go on. Why not let it progress, and thus provide employment for the laborers who have been induced to come here under an implied assurance of continuous employment?

And so the bill was passed.

AN ACT to provide for the repair of the Congressional Library room lately destroyed by fire.

Be it enacted by the Senate and House of Representatives of the United States of Amcrica in Congress assembled, That the sum of seventy-two thousand five hundred dollars be, and the same is hereby appropriated to the repair of the Congressional Library room, which was lately destroyed by fire, according to the plan described in the report and

${ }^{2}$ Thirty-second Congress, first session, Senate report No. 63. Republic, February $2,185^{2}$. 
drawings which were submitted by the Architect to the Secretary of the Interior, and approved by the Committee on Public Buildings of the Senate: Provided, however, That the work shall be executed under the direction of the Secretary of the Interior, and be subject to such modification of the details as may be consistent with the general arrangements of the plan, and necessary and proper in the opinion of the President of the United States.

Approved, March 19, I852.

The Secretary of the Interior, Alexander H. H. Stuart, appointed Thomas U. Walter architect of the new Library room March 30, 1852: "SIR: Yon are charged with the superintendence of the repairs of the Congressional Library and with the disbursement of the funds appropriated for that purpose, and you are requested to proceed with the work as rapidly as practicable."

This letter was followed by a second dated April 23, I 852 , signed by the Assistant Secretary of the Interior, William A. Graham: "Sin: By direction of the President you are hereby" instructed to enter into bond, in the penalty of $\$ 20,000$, for the faithful discharge of the duties under the appointment from this Department as disbursing agent and superintendent of the work to be executed in repairing the Congressional Library room in the United States Capitol."

Mr. John Skirving was made superintendent of the construction of the new Library room, and Janes, Beebe \& Co., of New York, were awarded the contract for its construction. At first it was thought that the room might be completed by the Ist of July. ${ }^{3}$ Then it was hoped that it might be completed by the ist of December, in time for the opening of Congress. By September the workmen were coppering the roof, while the interior fittings, the fluted columns, shelving, and stairway had been received and were ready to be put in place. ${ }^{4}$ By the ist of November much of the ironwork had

"United States Statutes at Large, I0: 3.

${ }^{2}$ Fifty-third Congress, second session, Senate report No. 178 , p. 6 . At this time Mr. Walter held the office of Architect of the Capitol extension and received a salary of $\$ 4,500$ per annum. Twenty years later he presented a claim for $\$ 7,4$ Io for services in connection with the construction of the Library room, in addition to other claims amounting to $\$ \operatorname{II}_{3}, 360$. A report upon this claim, allowing $\$ 14,000$ in payment of the entire claim, was made in the Senate January 24,1894 , and in the House April 19, IS94.

${ }_{3}^{3}$ National Intelligencer, February 2, 1852.

4 IIashington Kcpublic, September 17, IS52. 
been erected, and the mechanics were working until a late hour at night trying to finish, ${ }^{\mathrm{b}}$ but before the end of the month it was nnderstood that the work would require at least three months nore. ${ }^{2}$ The report of Thomas U. Walter, Architect of the Public Buildings, to Alexander H. H. Stuart, Secretary of the Interior, December I, IS 52 , said: ${ }^{3}$

On the 27 th of January last I submitted designs for reconstructing the main Library room, with arrangements for future extension, which were adopted, and on the 19 th of March an appropriation of $\$ 72,500$ was made to carry out the plans. The work was immediately commenced, and every possible exertion has been made to complete it before the assembling of Congress. It will, however, be out of our power to finish it entirely for several weeks to come, notwithstanding the workmen have been constantly and energetically employed night and day. The entire room is fitted up with iron, and the ceiling is composed of the same material, so that nothing combustible enters in any way into its construction.

The damage done by the fire to the western front has been all repaired.

The hot-water furnaces for warming the Library and the adjacent rooms are completed and in operation.

The appropriation made for "the repairs of the Congressional Library"

by the act of Congress approved March I9, I852, amounted to . . . $\$ 72,500$. 00 Of which there have been expended to the present date (December I,

1852) . . . . . . . . . . . . . . . . . . . . . . $51,703.24$

Leaving an unexpended balance of . . . . . . . $\frac{20,796.76}{60}$

Before the end of December, however, it was apparent that not only much more time would be needed in which to finish the room, but also a larger appropriation. Accordingly Mr. Walter wrote to the Secretary of the Interior, as follows: ${ }^{4}$

\section{Architect's OfFice, U. S. Capitol, Washington, D. C., December 28, 1852 ,}

SIR: I find that there will be a deficiency of appropriation for "the repairs of the Congressional Library" of $\$ 20,500$, which has occurred in consequence of the injuries fron. the fire being greater than were at first supposed, and from the impossibility of estimating accurately the cost of so novel and difficult a work, as well as from a more expensive finish having been decided upon than was at first contemplated.

I find my estimate of quantities in the ironwork (which is the largest item of expense) to correspond very nearly with the actual amonnt of

Washington Republic, November 6, $15_{52}$.

"Washington Republic, November 25, I852; copied in National Intelligencer, November 28.

${ }^{3}$ Thirty-second Congress, second session, House executive rlocument No. I, p. 5 s.

${ }_{4}^{4}$ Thirty-second Congress, second session, Honse exccutive document No. 18, pp. 2-3. 
material used; but it was impossible to say with certainty what the prices would be until the bidders for the work had submitted their proposals. In order to show the uncertainty of the cost of so unusual a work, I subjoin a list of the aggregate of each of the bids founded on the quantities ascertained by my own estimate, which, as before remarked, has proved to be substantially correct:

E. Corning \& Co., of Albany . . . . . . . . . . . . . . \$87,636

Theo. J. Gillies, of New York . . . . . . . . . . . . . . . . 85,869

J. T. Ames, of Massachusetts . . . . . . . . . . . . . . . . 77,492

R. H. Lathrop, of Albany . . . . . . . . . . . . . . . . . 72,968

John B. King \& Co., of Albany . . . . . . . . . . . . . . . 72,851

Carnley, King \& Co., of New York . . . . . . . . . . . . . . 72,646

Bogardus \& Hoppen, of New York . . . . . . . . . . . . . 72,518

Janes, Beebe \& Co., of New York . . . . . . . . . . . . . . 59, 872

It will be observed that all the bids except the last exceed the whole amount of the appropriation, viz, $\$ 72,500$, and the difference between the liighest and the lowest is $\$ 27,764$. The lowest bid was accepted, and I have the satisfaction to say that the work has been executed as well and as faithfully as it could have been done by anyone.

The style of finish I propose to give to the work is as follows:

All the plain surfaces of the ceiling, both horizontal and vertical, to be gilded in three shades of gold leaf, so disposed as to give depth and effect to the panels.

All the ornamental moldings, pendants, and drops of the ceiling to be finished in gold bronze, and the prominent parts to be tipped with gold, burnished, so as to produce a decided and sparkling effect against the dead gold surfaces.

The large consoles to be painted in light bronze green, tipped with gold bronze and burnished gold, for the purpose of giving relief to the fruits and foliage.

All the cases, the railings, and the remaining iron work to be finished with liglit gold bronze, tipped on all the parts which receive the strongest light with burnished gold.

The walls to be frescoed in ornamental panels, corresponding with the rest of the work.

In the finish of this room I desire to keep up the idea of the whole being composed of metal, which could not be done if other than metallic colors were used; and I think that the effect of the finish here proposed will be perfectly harmonious, and will impart to the room a brilliancy and richness consistent with its architecture. The estimate here given is founded on this description of finish.

I am, sir, very respectfully, your obedient servant,

THO. U. WALTER, Architect of "Repairs of Congressional Library."

Hon. Als.x. H. H. STUART, Secretary of the Interior. 


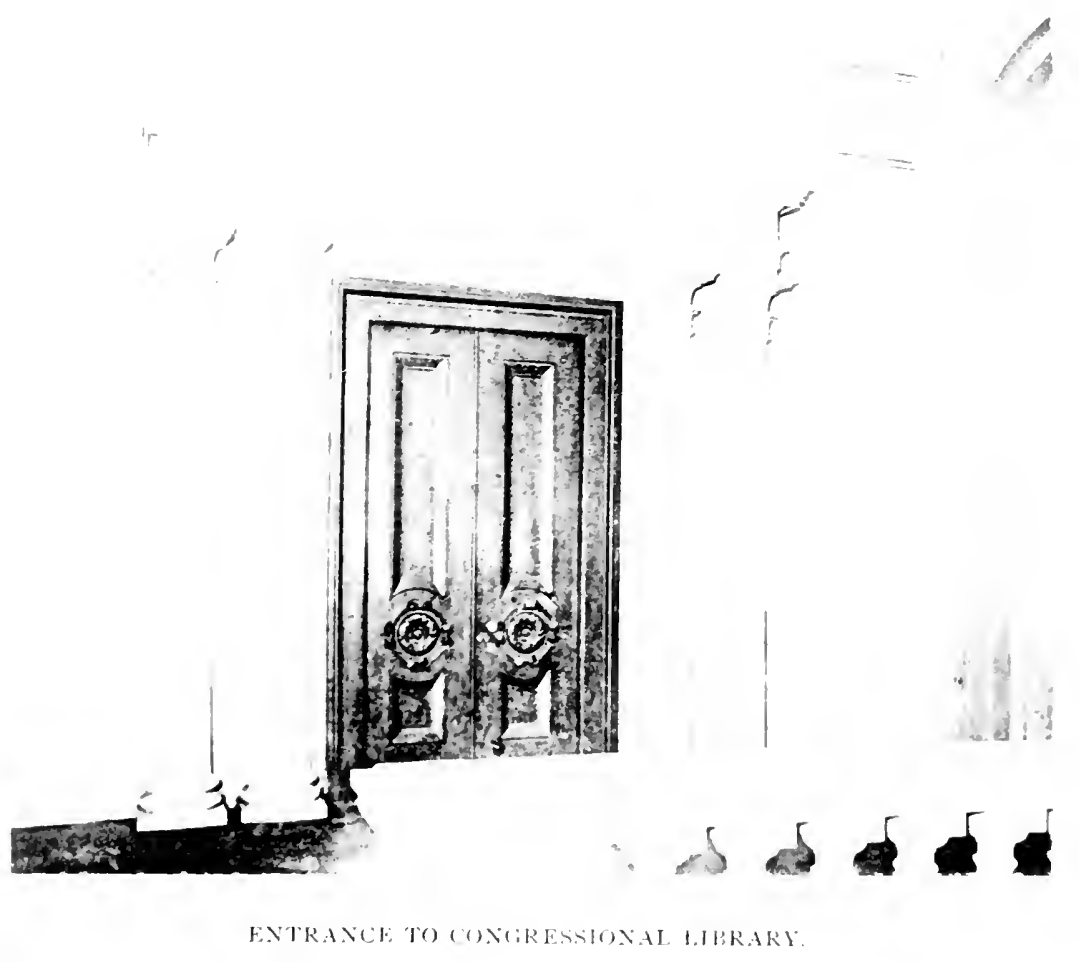



Architect's OfFich, U. S. CAPI'TOL, Washington, D. C., December 28, 1852.

Estimate for furnishing "repairs of Congressional Library," wrought-iron door, with lock and hanging, in nortl end of room, now in hands . . . \$100

Main entrance door of Library, with architraves inside and outside, all of iron.

Balance due on roof . . . . . . . . . . . . . . . . . . . . . . . 850

Bill for priming and painting all the ironwork at the foundry, and after it was put up . . . . . . . . . . . . . . . . . . . 950

Balance due on cast-iron work . . . . . . . . . . . . . . . 6, 600 Ornamental iron railing around all the galleries, including putting up . . 2,700 Due for December pay roll of bricklayers and laborers . . . . . . . . 320 Due John Skirving, foreman, wages . . . . . . . . . . . . . . . 350

Estimate for finishing plastering . . . . . . . . . . . . . . . . 250

Do. cement and workmanship of floor . . . . . . . . . . 350

Do. gilding, bronziıg, and painting, including scaffolding . . . . 12,000

Incidental expenses, say . . . . . . . . . . . . . . . . . . 935

Balance of appropriation on hand this day, December 28,1852 . . . . $\quad 5,355$

20,500

This letter was forwarded by the Secretary of the Interior to the Secretary of the Treasury, and by him to the House of Representatives, where on the I4th of January, I 85.3 , it was referred to the Committee on Ways and Means. Nothing seems to have been done by this committee, but in the course of the debate on the deficiency bill January 25, I853, Mr. Stanton, of Kentucky, under instructions from the Committee on Public Buildings, offered the following amendment to the clause of the bill providing for the extension of the Capitol:

For the completion of the repairs of the Congressional Library room, authorized by an act approved March nineteen, eighteen hundred and fifty-two, twenty thousand five hundred dollars.

Mr. Stanton. I simply desire to say, in reference to the amendment which I have offered, that it has been recommended by the Secretary of the Interior upon estimates furnished to him by the Architect. The original estinate furnished by the Architect for the completion of the Library room was $\$ 72,000$. That sum, or nearly that amount, has been expended, and it has not been sufficient to complete the wlole structure. The reason why it is necessary to have an additional appropriation is that when the first estimate was made it was made simply to supply the ironwork, which has cost, indeed, just about the sum estimated, or within a few thousand dollars, showing that as far as the estimate went it was correct. After the Architect took possession of the room he found that much more danage had been done by the fire than was at first anticipated. He had to cut out a great deal of the stonework and tear up the 
foundation. The foundation was not found sufficiently solid. The floor, instead of being made solid from the top of the arches up to the pavement, had been filled in with sand, rubbish, loose bricks, etc., and was by no means compact. It was necessary for him to dig down and remove that rubbish in order to secure a solid foundation for the ironwork, by wlich means the expense has becn greatly increased beyond the first estimate. $* * * *$

Mr. MCMulins. I take it for granted that the committee will adopt the amendment. I only desire to say that this Architect has not proved, to my nind, his worthiness of the station he now occupies. He has made a very wide mistake-11ot only upon this, but upon former occasions. I hope the time will come when we shall have more accurate calculations submitted to us.

The question was then taken on the amendment offered by Mr. Stanton, and it was agreed to. ${ }^{\mathrm{I}}$

On the $5^{\text {th }}$ of February the bill was brought before the Senate, where Mr. Brodhead, desiring to make an inquiry of the chairman of the Committee on Finance, who was also a nuember of the Committee on Public Buildings, (Senator Hunter, of Virginia,) moved to strike out the clause "For the completion of the repairs of the Library room authorized by the act approved March I9, I $8_{52}, \$ 20,500$," saying:

At the last session we appropriated $\$ 75$, 00 for this purpose. This appropriation will make $\$ 95,500$ for fitting up and repairing one room. I know nothing against the integrity of the Architect who has this work in charge; but I thonght when the $\$ 75$, 000 were asked for that it was a very large sum to require to fix up one room and to repair it for the reception of books, and now, when $\$ 20,500$ in addition is asked for, I think there ought to be some explanation of it given to the Senate. It may be proper that $\$ 95,5$ oo should be appropriated for this purpose, but it does seem to me to be a very large amount.

Mr. Hunter. It is true that the expenditure for the repair of the Library room is likely to exceed the estimate originally made by the Architect. We all know that that room was destroyed by fire. It was impossible to ascertain from a superficial inspection how far the building had been injured. In taking down the portions which were burned, it was found that the injury was much greater than had been supposed. In addition to that it is to be observed--this I am told by the Architect, and I presume it is so-that this is the largest room made of iron in the world, and, of course, there would be a greater liability to error in estimating for a roon of that sort, when the first experiment was to be made than 
there would be in regard to any other. The Architect showed me the bids for the iron alone, and they ranged from seventy-odd thousand dollars-nearly the anount originally appropriated-down to fifty thousand dollars. He took the lowest bid; and it seems to have been rery well executed. But it was found that in order to funish this room it would require an additional sum. I believe it passed through the supervision of the Connuttee on Public Buildings in the House of Representatives. This is the estimate. When completed the room will probably be one of the most beantiful in the world. The Architect designs to finish it in such a style as may present this new species of architecture in a more elegant and inviting forn1, and surely no man has nore interest than the Senator from Pennsylvania in the material which is adopted in the construction of that room. ${ }^{\text {I }}$

At this point Senator Borland, of Arkansas, made some general criticisms upon the character of the Architect's contracts; Senator Walker was also disposed to think that the Architect's contracts required investigation, but Mr. Hunter observed:

The contracts to which the Senator from Arkansas alludes are contracts in relation to a subject which has been passed by-not to the Library room. We are all anxious to have that room completed, and withont this additional appropriation it can not be done. We must either vote the money or suspend the work, and thus postpone, perhaps for another year, the advantages which we derive from the Congressional Library. But I suppose that the Senator from Arkansas is not opposing this additional appropriation for the Library. $\mathrm{He}$ is only deriving from this an opportunity to expose the frauds which he discovers in relation to other matters. I hope we shall be allowed to take a vote upon the anendment.

Mr. Brodhead accordingly withdrew his motion, and the amendment, providing $\$ 20,500$ for the completion of the repairs of the Library room, was passed.

With this additional sum at his disposal, Architect Walter resumed work upon the Library, hoping to finish it early in the summer. On the i 8 th of May the Washington correspondent of the Nerw York Tribune wrote: "The workmen are rapidly pushing the finishing off of the chamber of the Library of Congress, though they have an awful time of it. They are compelled to keep all the doors and windows closed while putting on the gold leaf, creating a heat so intense as

$$
\text { "Congressional cilobe, } 30 \text { : } 623 \text {. }
$$


to compel them actually to labor shirtless, the atmosphere being next in intensity to a Turkish bath. Faith, they should indeed be well paid." " And on the 6th of July the Librarian took possession of the room.

The Library was closed from July 2 I to August. 23, to give opportunity for the transfer of the books to the new room. ${ }^{2}$ On the 23d of August it was opened, and Librarian Meehan, "with his well-known cordiality and bonhomie," made welcome many who had been accustomed to frequent the old library room. ${ }^{3}$ President Pierce visited the room in company with Sir Charles Lyell, and Sir Charles pronounced it the most beautiful room in the world. Few ventured to suggest anything in the way of improvements. ${ }^{4}$

It is not necessary in this place to copy any of the enthusiastic descriptions of the new Library room which appeared in the local press. $^{5}$ They were all based upon Architect Walter's report to the Commissioner of Public Buildings, January 27,1852 , which we have already given. We may, however, set down here a few architectural details not mentioned in that report. The new room was 9I feet long, 34 feet wide, and 38 feet high-the old room had been 90 feet by 30 feet by 35 feet. The openings between the main room and the end rooms were to be ro feet in width by 28 feet 6 inches in height, crowned by elliptical arches. Each of the galleries encircling the room was 9 feet 6 inches in height. Norton's Literary Gazette, July I5, I 852, took particular notice of this height as rendering unnecessary the use of stepladders. The first gallery projected 8 feet 6 inches into the room, the second 5 feet, leaving a platform 3 feet 6 inches in width. There were 12 alcoves, each 9 feet 8 inches in width, with a paneled pilaster, marked by richly ornamented medallions in the center, forming the head of each projection

'Washington Ncres, May 21, 1853 .

${ }^{2}$ National Intelligencer, July 8, I853. Meehan to Everett, July 22, I853. Library of Congress MSS.

${ }_{3}$ National Intelligencer, August 15 and 24, 1853.

"Vertical sections of the library room: (I) from north to south, (2) from east to west, are griven in Glenn Brown's History of the Capitol, vol. 2, plates 169, 170.

5 The best was publisherl in the Nere's April 16, 1853, and eopied by the National Intelligencer $\mathrm{A}_{\mathrm{P}} \mathrm{ril}$ 23. 'There are notices in the Star, August 23; Union, August 28. 
between them. The architraves which crossed the alcoves were furnished with shields, crowned bands, and corner ornaments. The shields were designed as tablets to receive the names of the general subjects to which the books in the respective alcoves related.

The ceiling, said to be the only iron ceiling in the world, was composed of immense iron plates looking like massive blocks of brown marble panel work. It rested upon 24 massive consoles, ornamented with foliage, fruits, and scrolls. Each of these was 5 feet 4 inches in height by $2 \mathrm{I}$ inches in width, weighed nearly a ton, and projected from the face of the wall 5 feet 6 inches. The ceiling was divided into deeply sunken panels, embellished with ornate moldings and foliated pendants. The upper skylight was ornamented with a cluster of stars, and was 77 feet in length by ro feet 6 inches in width. The furniture of the new room was made expressly for the Library, in harmony with the surroundings; the coloring of the room, of the pilasters and panels was a neutral hue tinged with pale green and burnished with gold leaf.

Among other provisions for the Library room before 1865 was $\$ 3,500$, March $3, I 855$, to construct suitable iron railings in front of the alcoves, etc., and for additional furnaces. ${ }^{\mathrm{I}}$ Upon the latter subject the Commissioner of Public Buildings said, October II, IS 56 :

* * * A hot-water-heating apparatus has been erected in the crypt in the south end of the main building of the Capitol in the place of the two hot-air furnaces, which from long use had become nearly good for nothing. The furnace is principally intended to aid in heating the Congressional Library. It has a heating surface of $\mathrm{I}, 500$ square feet, and when the water is kept up to the boiling poiut a current of air equal to the size of the flue through which it passes flows into the Library at a temperature of $\mathrm{IIO}^{\circ}$ to $\mathrm{I}_{2} \mathrm{O}^{\circ}$. I am satisfied that this furnace does all that was expected of it and that it will contribute its full share of heat toward rendering the Library comfortable.

Congress at the last session made a further appropriation for heating the Library, and I was requested by those immediately in charge of the Library to cause two hot-air furnaces to be erected in the place of the

${ }^{1} \$ 1,000$ March 3,$1855 ; \$ 500$ May 15,1856 , and $\$ 5,000$ August is, I 556 , the last for fuel also. A correspondent of the Star (February 6, 1856) had complained of the want of heat. In the summer, on the other hand, it was suffocating, at least in the top gallery.--Star, July 23,1853 . 
hot-water furnaces in the crypt under the north end of the Capitol. I could not well refuse yielding my assent to this request, but I must in justice to myself state that I do not approve of heating apartments with air that has been in contact with intensely heated iron, and for many and substantial reasons which it is unnecessary for me to state in this report. The old furnaces have been removed, and workmen are now engaged in erecting the hot-air furnaces, which will no doubt be ready for use as soon as they will be required. $* * * x$

It was this, perhaps, that made it necessary to appropriate $\$ 900$ March I4, I862, to ventilate the Library.

This last appropriation provided also for replacing the thin glass in the roof of the Library with thick glass, and an appropriation of $\$ 3,500$, March $3, \mathrm{I} \$ 6_{3}$, provided further for a new roof. One fatal casualty attended the construction of this. One of the laborers in passing in under the rafters incantiously jumped from the opening in the gable on to one of the cast-iron panels in the ceiling of the Library, which broke beneath his weight, and he was precipitated, with the fragments of the panel and its moldings, into the Library. The man struck upon one of the iron railings of the gallery and was killed. The fragments fell upon the main floor, destroying some furniture of the Library and striking very near some visitors who were at the time in the room. ${ }^{2}$

At the same time a tiled floor of black and white narble, for whicl $\$ 4,000$ liad been appropriated by the act of February 25, I 863 , was constructed. Concerning this Mr. B. B. French, Commissioner of Public Buildings, said, October I 3, I 863 :

The work was done under my supervision, at the request of the Librarian, Colonel Stephenson, who was absent as a volunteer officer in the Army of the Potomac fighting valiantly the battles of his country. The work has been well and faithfully, as well as beautifully, done. In consequence of the large increase of the wages of workmen and the cost of material, as well as the nnforeseen necessity of raising the iron railing all around the Library, the expenditure exceeded the appropriation alout \$I,200, for which deficiency I have estimated in my regular estimates. When it is considered that the floor now laid will last through nnany generations, and that the Library had to be carpeted as often as once in three years, at an expense of between two and three

'Thirty-fourth Congress, third session, House executive documents, No. I, p. 849 .

"I'hirty-eighth Congress, first session, House executive documents, No. I, p. 660. 


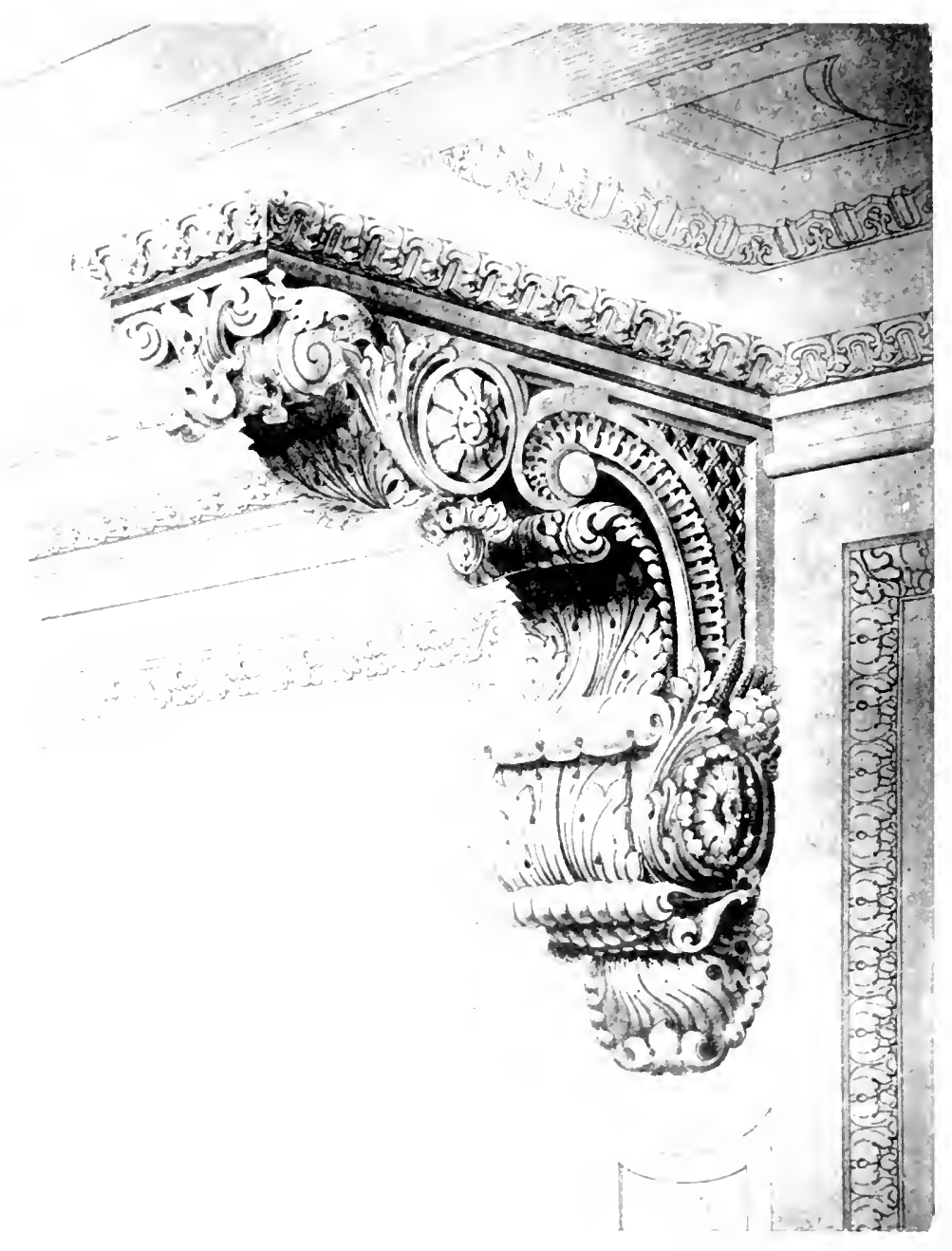

DRAWING OF CONSOLE IN LIPRARY 

thousand dollars, it will be admitted that, in an economical point of view, the money has been well expended. As a matter of utility, in avoiding the dust incident to a carpeted floor, more injurious in a library than in any other room, it is a great improvement. ${ }^{x}$

Nothing, however, was done to enlarge the accommodations of the Library and to carry out the plans drawn up by Architect Walter providing for two additional rooms at each end of the Library, beyond the appropriation (June I2, I $\left.S_{5} 8\right)$ of $\$ 270$ to fit up with shelves two rooms at the south end of the Library, used as reading rooms by members of Congress, and put up a partition in the passage to them. In his annual report (October $\mathrm{I}_{3}, \mathrm{I} 86_{3}$ ) the Commissioner of Public Buildings called attention to this in the following words:

The Librarian of Congress has addressed an official letter to me urging the necessity of enlarging the Library of Congress according to the plan of Mr. Walter, the Architect of the Capitol extension. That letter, with the plan of Mr. Walter, adopted by Congress in 1852 , and his estimates, I shall submit to the proper committee during the ensuing session. The enlargement, by the addition of at least one wing, is a matter of urgent necessity, as there is actually no place for the books on hand. ${ }^{2}$

Nothing, however, came of this until after the war.

PURCHASES OF BOOKS.

The difficulty of restoring the Library was much greater than that of restoring the Library room. On the one hand, there was no one connected with the Library sufficiently expert to select the books; on the other hand, there were comparatively few good books in the market. Paris and London booksellers said they had all gone to America, wrote the famous collector of the Astor library, Joseph G. Cogswell, ${ }^{3}$ April 22, I85I; and by America they meant New York and Providence.

No one seems to have suggested that it would be well to advertise for bids for supplying the losses of the Library, and that the catalogues of the old Library be placed in the hands

${ }^{2}$ Thirty-eighth Congress, first session, House executive documents, No. I, p. 660.

${ }^{2}$ Thirty-eighth Congress, first session, House executive documents, No. I, p. 660.

${ }^{3}$ Life of Joseph Green Cogrswcll, p. 255. 
of American and European booksellers to that end; no one denied that the new Library should be a better one than the old Library; no one doubted that selection in its purchase would be necessary, but how was the selection to be madethat is, by whom and on what principles? Was the Library to be administered by experts or not? Was it to be a national library or not? These questions, which had been agitated before, particularly in connection with the purchase of the Jefferson collection and the proposed purchase of the Buturlin collection, now presented themselves again, and were ably discussed in a series of communications to the Intelligencer, April 8 and $14,{ }_{1} 8_{52}$.

The anonymous writer of these two articles upon the bibliographical policy of the Library - probably Professor Jewettsaid:

The loss of the Library of Congress is every day more deeply felt and deplored. There is now no public library in the city which can to any good degree supply its place. The collections belonging to the War and State Departments, the Patent Office, and the Smithsonian Institution are comparatively small, the largest not exceeding 10,000 volumes. They do not contain the class of books most needed in such an emergency, nor can they be conveniently used. Accuracy of statement and correct judgment in matters requiring investigation of authorities are for the time rendered almost impossible.

Such being the case, it is to be regretted that measures have not yet been taken by Congress for restoring the Library. The best months of the year for European purchases are now nearly past. There are few sales of importance later than May. The libraries of Cardinal Mezzofanti at Rome, of the late King Louis Philippe and of Peignot at Paris, the remainder of the immense stock of Verbeyst at Brussels, and many others of almost equal importance have been bought under the hammer within the last few weeks The books have, to a considerable extent, most probably fallen at low prices into the hands of traders; some to be hereafter bought up at from three to six times the auction price to fill orders for the Library of Congress.

The appropriation which has been made of $\$ 10,000$ for the purchase of books was understood to be merely for the purchase of such books of reference as are most immediately important. Everybody anticipates a much larger grant before this session closes; one more worthy of an intelligent, rich, and liberal nation. That this will in time be made is not to be doubted; but we regret the delay, for many reasons; first and principally, because we need the books now and every day. Had Con- 
gress moved in the matter at once, and sent a suitable agent with proper instructions to Europe in order to take advantage of the auctions of this year, a very large collection of books might have been received by midsummer, at prices far below anything before known at the Capitol. Now it is too late for the present season. Books can not be bought except from dealers at secondhand, and at prices much in advance of what were really necessary.

Again, we regret the delay because many of the orders can not at any reasonable price be filled as soon as given. Time is an important element, even when funds are unlimited, in gathering books whicll have become rare. We regret the delay further, because the longer it lasts the greater is the throng of competitors eager to serve their country by sharing in the job; and lience, most obviously, the less the probability of a judicious selection of books or the best arrangements for purchasing. If Congress be not even now prepared to rote appropriations, why may it not take means to insure a proper selection of books? A judicious choice is of far more importance than economy in purchasing. The latter, under Government direction, is hardly to be expected at any rate. In the interest of learning, of science, of enlightened statesmanship, we say, give us a good and well-selected Library, whatever be its cost, wherever and by whomsoever purcliased.

It was proposed several years ago, by one of the most accomplished scholars that has ever graced the Senate, that Congress should order a catalogue to be prepared by competent bibliographers, under the direction of the Library Committee, containing the titles of books, to the number of 100,000 , such as are held to be most important for the Library of Congress, the whole to be arranged in five or more classes, according to their relative importance. It is much to be regretted that this suggestion was not adopted. It was universally approved, but delayed, neglected, and at last forgotten.

The Library of Congress was not, as a whole, so well selected as if more system, science, and unity of plan had been regarded in its composition. True it was one of the best libraries in the country. It was one of the four largest and cost proportionately very much more than either of the others, at all events enough to have made it far better than it was.

The new Library should be a systematic collection of books chosen with competent bibliographical learning for a specified and well-defined purpose.

This article was continued in the National Intelligencer, April I4, as follows:

In a former article upon the Library of Congress we considered the paramount importance of a judicions selection of books. 
In order to be judicious the selection should have primary reference to the design of the Library, the special purpose for which it is formed. It is not to be supposed that a library is to be procured merely as an ornamental appendage to the Capitol. It is intended for use, principally for the use of Congress during their sessions and of the officers of the Government at all times, and incidentally for the use of the public.

Everyone may see the absurdity of taking as a guide, in selecting sucl a library, a catalogue made by the most competent men for the library of a medical school or of a theological seminary or of a mining academy. Not less unsuitable, though less obviously so, would it be to follow a list chosen most skillfully for a miscellaneous city library-a collection of books for popular reading-though many of the books may be deemed equally indispensable in each of these collections. The selection should be made especially and independently for this Library and substantially according to the suggestions of the honorable Senator to which we have already referred.

The Library of Congress has frequently been styled the National Library. In one sense it is such. It belongs to the nation. But so does the library of the War Department. Yet neither of them has ever answered, or indeed aimed at answering, what we understand to be the design of a National Library, nor do we think it likely that the Library of Congress will ever supply this great demand of American scholars.

There ought to be in every country at least one library, accessible to all students, which should aim at possessing every book-at meeting the wants of every investigator; one great literary depot where no books should be esteemed as tiash.

There are probably more than 2,000,000 different books extant. Now, if all men engaged worthily in literary pursuits could be brought together and each book of the 2,000,000 be separately offered for total destruction, unless some roice in the throng declared it to be for some assignable reason worthy of preservation, every book would find an advocate. The books which to one man are trash are to another above all price. Those which to one age are well-nigh worthless are the cloicest treasures of the next. Milton's Paradise Lost and Newton's Principia would hardly have been selected for a choice library when they were first published, if we may judge from their early reception. A contemporary of Shakespeare and the founder of one of the largest libraries in the world (Sir 'Thomas Bodley) wrote thus to his librarian: "Haply some plays may be worth the keeping, but hardly one in forty; for it is not alike in English plays and others of other nations, because they are most esteemed for learning the languages, and many of them compiled by men of great fame for wisdom and learning, which is seldom or never here among us. Were it so again that some little profit might be reaped (which God knows is very little) out of some of our playbooks, the benefit thereof 
will nothing near countervail the harm that the scandal will bring upon the library when it shall be given out that we stuffed it full with baggage books, etc." One of the largest libraries in Iingland rejected as unworthy" a place on its shelves when offered as gifts the Antiquary, Mrs. Opie's novels, one of Wordsworth's odes, Cobbett's publications, Jameson on Minerals (second edition), the Edinburgl Medical and Surgical Journal, the Siege of Corinth, Lord Brougham's speech on agricultural distress, IcCulloch's essay on the national debt, Beethoven's musical compositions, and many more works in one year. These were trash to the librarian or the committee who rejected them, but not to the world. Yet similar misapprehensions occur continually where rejection is allowed. In at least one library, therefore, reception and preservation should be imperative. We know not what among all the publications of the present may a century hence be esteemed most valuable. It savors of arrogance and of ignorance for any man to say that any book is and must ever remain utterly useless to everybody. The book that contains no new fact or thought and no happier way of stating old ones may yet be useful. It may show incidentally some custom of the age; something respecting the state of the language at the time when it was written. It may illustrate the history of typograply or of binding. It may eren teach a lesson by its very unprofitableness.

We have seen in the library of a distinguished citizen of Washington a row of books from which he has drawn most valuable information, made original, striking, and important discoveries respecting the history and practice of printing in its early days; books, the subject-matter of which is to him unknown or totally a matter of indifference. The first diagram of iron suspension briclges is to be found, it is said, in a volume of neglected and forgotten plates published in Venice by Fausto Verantio toward the end of the sixteenth century. "Who would have imagined," asks Libri, "that the obscure author of a small pamphlet, 'Le Souper de Beaucaire, 'would subsequently become the Emperor Napoleon, and that to write fully the life of the execrable Narat one ouglit to have the very insignificant essays on physics that he published before the revolution?"

Sucl examples could be multiplied a thousandfold. We fear, however, that we are illustrating this topic at too great length. We wislied to show that at least one library which rejects nothing and desires everything in the shape of literary productions is demanded by the interests of science and of literature in every country; that every govermment should take pricle in its own, slould foster and aid it as far as possible. Sucl would be our idea of a National Library-an cstablishment like the Bibliothèque Nationale in Paris and the British Musenn in London. We suppose it was the intention of Congress and of the officers of the Smithsonian Institution to lay the foundations of sucl a 
library there. The rapidity with which it will grow must, of course, depend mainly upon the liberality of men who appreciate the value of such an enterprise. The spirit which made the bequest, and which dictated its direction, is but stinulated by success, and will, no doubt, in time make a collection worthy to be called the National Library of America. To this end Congress will, we trust, be ever ready to contribute.

But the Library of Congress we suppose to be intended principally for the use of members of Congress and of other officers of the Govermment. Great liberality has always been shown in extending its privileges to others. But we doubt whether it is desirable to aim at making it the great library of reference and research for the country-the National Library. It would be difficult, perhaps it would defeat its chief end, to subject it to the regulations which would be inclispensable to the proper conducting of a National Library. It should rather, we think, be regarded as a legislative library, and the aim should be to make it the best in the world of its kind. The Chamber of Deputies in France possess a library of more than 60,000 volumes in the sane city as the National Library of 800 ,ooo volumes. The House of Commons of Great Britain is collecting for itself a valuable library, though in the same city with the British Museun-the National Library of Great Britainwith its 450,000 volumes.

In sad contrast with the wise plans here set forth was the performance of the Library authorities. 'The easily satisfied public, represented by the easily satisfied members of Congress, was pleased with the number and cheapness of the books purchased, but those who needed the books for use and those who desired to see a library in the capital worthy of the nation were disappointed. Among these one who believed that there should be a national library in the United States, and that sucl a library wust be maintained by the Government, wrote from Washington to the New York Tribune:

With the inexhaustible means at the disposal of Congress, and its undoubted good will to do sometling grand and worthy of the name of a Congressional Library of such an unparalleled great country as the United States, it ought and can be the first library for choice and even for number in America, and could become one without precedent and unrivaled-to be counted among the first libraries of the civilized world. Being intended to serve the use of a political body, its fundamental idea, its principal ain, ought to be to possess the most complete standard collection in those branches of knowledge which concur to form and nourish the mind of the real statesman, and not to be merely a s'ade mecum for an accidental, superficial busybody of a politician. Any enumeration of these so varied and all-embracing hranches belongs not here. Such a 
selection, made on a large, on an immense scale, ought not to be limited to encyclopedias, or to productions in the Einglish language alone. As is now the case, and will be more and more the case, America represents humanity; and all the beacons, all the various products of the inexhatustible versatility of the louman mind, all its manifestations ought to be within the reach of its citizens, of its legrislators. The belles-lettres, the fine arts, and the like rather light literatures ought to form wellchosen aids. In its principal object, that of satisfying, or even unfolding the mind of a statesman, the Congressional Library ought above all to be suggestive and stimulating, and to exercise such an action it must be as complete as it is allowed to any human work to be. Suggestive and stimulating, say we; that is, evoking, directing, and encouraging an inquisitive mind in its studies, researches-opening before him, as it were, unawares, without exhausting and annoying efforts and troublesome details, the accumulated treasures and higher products of the luman intellect, thus conducting him gently by the hand, exercising on him an irresistible attraction to penetrate deeper and deeper anong those clear and lofty regions of a new, and, for very many, an unknown intellectual world. How pleasantly refreshing is it to make the hearty confession that the American mind at large distinguishes itself above all others by its eagerness, its craving after instruction, information, knowledge! And this is still more the case with those fresh natures coming here from the remotest parts of the continent, where the scarcely settled state of society renders it impossible to have good libraries, to offer to the mind a wholesome, solid, and strong nourishment. A well-filled and systematically organized Library will of itself give a direction to such minds, and exercise over them a beneficial tuition. Gorl grant that the wish for such a Library here may not remain among those pious desires which are never to be realized!

What has already been done toward replenishing the empty shelves of the Congressional Library has been directed rather by booksellers, eager for lucre, than by a bibliograph, or a bibliophile, or any systematic intellect whatever. It shows clearly before one's eyes that these booksellers wislted to get rid of costly works and editions which for years had found no purchasers and thus formed a dead capital in their shops. They have succeeded thus far. As we are told, a well-known house from Boston, supported by influential men, discharges in this manner upon the slelves of this Library all its useless editions and gets well paid for this bilbliographical trash. By and by booksellers from other cities will follow and share the spoils. Next will be the turn of some European louses. And thus very likely a great number of volumes will be scrambled together, but will there be a world of real, higher intellectual life? Dubito, but utinam sin falsus. I doubt, but hope to prove nistaken. 
In answer to this a correspondent of Norton's Literary Gasette, July I5, IS 52 , said:

Having recently had the pleasure of visiting this Library, we are enabled to state, from personal observations, that the attack made through the columns of the Tribune and by its regular correspondent upon the selection of books lately added is entirely undeserved; the books are well selected, of good editions, and as we were enabled to learn from information afforded us by the gentlemanly Librarian, Mr. Meehan, they have been bought at fair prices, and are not "the old stock of some bookseller foisted on the Government at a high price." What motires conld have given rise to so uncalled-for an attack we can not imagine.

But there was, without doubt, some truth in the Tribune correspondent's remarks. The purchase of books had not been conducted systematically and upon bibliographical principles. The Library Committee saw this, and at their next meeting, August IS, I $8_{52}-$

Resolzed, That it is expedient to procure complete lists of books in the various chapters included in the catalogue of the Library; and that the chairman be instructed to address scientific and literary gentlemen on the subject.

'This plan, of course, failed, and consequently at the meeting of the committee Marcl 3, I $S_{53}$, it was-

Resolved, That for the purpose of collecting a Library for the Congress of the United States on the most complete and systematic plan the Librarian be requested to prepare as soon as may be catalogues of books according to chapters or departments, including all geological works under the head of geology, all ancient and modern histories, with American, Inglisl, and French, etc., all works in the departments of ancient classics, and modern belles-lettres, etc. (so far as the same are not in the Library), under their respective heads and according to the language in which they are written.

And further resolied, That when said catalogues shall be prepared all persons who wish to supply the books so clesignated may take a copy thereof and propose terms for furnishing the same; and those persons who, all things equal, shall propose to funish the books on terms most economical to the Govermment shall have the contracts awarded to them on condition of giving security for the faithful performance of the same.

The bibliographical direction of the Library, which was formerly the work of the Library Committee, was thus delegated to the I.ibrarian. From one point of view this was fortnnate, 
because the work of selecting books for the Library was the best preparation for that of using them after they reached the Library shelves. On the other hand, it was unfortunate that the selection should be made by one man, and that one a person of very linited bibliographical experience.'

On the i 3 th of Jannary, I $S_{52}$, Congress had placed $\$$ IO,, 00 at the disposal of the Library authorities for the purchase of such books as were inmmediately necessary. On the 3ist of August, IS 52, \$75, OOO more had been voted for books, furniture, and contingent expenses, and the committee anthorized to sell any works in the Library which were rendered imperfect by the fire and appropriate the proceeds of said sale to the purchase of other works.

Most persons were of opinion that Congress conld not be brought to make an appropriation exceeding $\$ 30,000$ for the purchase of books; but when Mr. Chandler, of the Library Committee, proposed $\$ 75$, ooo it was readily granted, and Professor Jewett thought it would have been had he asked $\$ 200,000$, if Congress had thought that sum necessary and believed it wonld be honestly and judiciously devoted to the gathering of a good library. ${ }^{2}$

Upon this plan and with these means at his disposal the Librarian made lis purchases for the Library, largely through the Library's London agent, Rich Brothers, whose activity in the interests of the Library was noticed in the London Athencum, September IO, IS53, in the following pleasant fashion:

Last advices from America tell us that the Library of Congress, so lately damaged by the fire at Washington, has been reopened. We notice this as showing with what care and readiness our cousins on the western shores of the great waters look to literary interests. In our rambles through the bookshops of London we have lately found innumerable traces of American activity in the book-binying line. All the good editions of old books are rising in value. Within these dozen years memoirs and collections of the contemporary litcrature of the sixteenth and seventeenth centuries in this country have advanced in price

\footnotetext{
${ }^{1}$ 'The lists which the librarian drew up in eonsequence of this resolution embraced, for the most part, merely such works as had been lost in the fire, and were made up from the last printed catalogue of the library.-Meelian to Senator Pearce, May 4, 1853 .

'Norton's Literery' Gazette, 3: 173, October 15, 1853.
} 
from jo to 100 per cent. Partly; no doubt, this advance arises from the fact of greater attention being paid to historical matters, the day being past when a minister of the Crown might confess, as in the anecdote told by Mr. Macaulay, that he had never heard of "Empson and Dudley." But the rise has been occasioned chiefly by the growth of a large demand for such books in America. Congress has two agents in London-one literary, one political, and we fancy the former is the more active and important functionary of the two. One of these agents has his headquarters in Piccadilly, and his papers accredit him to the Court of St. James; the other has his quarters at Charing Cross, and his commission is to the bookstalls of London streets. We could tell the story of many a literary treasure which has found its way-sometimes at the price of "an old song" -into this officer's hands, and thence into the archives and libraries of the United States. He is always on the spot, he has a liberal discretion in his purchases, and he never throws away a good thing for lack of power or appreciation. Witl such agencies at its scrvice we need not feel surprised that accidental losses of literary treasures, whether by fire or by flood, are speedily repaired in the United States. ${ }^{3}$

\section{COLLECTIONS AND DEPARTMENTS, I852-1864.}

As a result of this activity of the officials and agents of the Library, between 3,000 and 4,000 volumes were added to the collection by the $22 \mathrm{~d}$ of May, I $852,{ }^{2}$ and when the new room was opened Angust 23, I 853, the books numbered about 35,000 volumes, of which from 25,000 to 30,000 were already in place. ${ }^{3}$ This was abont three-fourths the size of the old collection, and the additions, the National Intelligencer said (Augnst I 5, I853), had been made at prices considerably lower than the previons cost, ${ }^{4}$ while in many cases the editions were later and better and the books in better bindings.

Ben: Perley Poore said that the Library did not at that time contain a good modern encyclopedia, ${ }^{5}$ but in this he was

\footnotetext{
'Athenaum, September I0, 1853, p. 1072, copied in National Intelligencer October 24, 1853. Among the rarities thus acquired was the bull of Pope Alexander VI, by which he divided the new world between Portugal and Spain, published in Rome in 1493. An interesting incident in the history of this treasure is recorded in the Publishers' Weekly' 39: 705, May 23, IS9r.

'Washington Republic, May 22, 1852.

${ }_{3}^{3}$ Washington Republic, June 20, 1853; National Intelligencer, August 24, I853.

${ }^{4}$ At an average cost of $\$ 1.95$ per volume. -Star, Jantary 6, I854; Norton's Literary Cazette, February 1, 1854, p. 60. The Astor Library had cost \$1.25 per volume.Literary World, February 12, 1853, p. 135. The library collected before the fire had cost \$3.50 per volume. - Edward Edwards’s evidence before the Parliamentary committee on public libraries, June 5, 18.49, p. 245.

${ }_{5}^{5}$ Reminiscences $1: 387-388$.
} 
mistaken. The Library was a good reference library for the average legislator, though it was little more, and aimed to be little more.

The United States Magazine (August, I856), noticed some rarities, among them De Bry's Voyages, Lord Kingsborough's work on Mexican antiquities, Napoleon's work on Egypt, Champollion's works, etc. ${ }^{1}$

But the collection of Americana was very poor. A correspondent of the Union (September I6, I853) called attention to this fact, referring particularly to the desirability of strengthening the collection of American topography. Continuing he said: "The plan which we would respectfully suggest is to have contributions of such volumes as we have described from the several States of the Confederacy arranged and classified under different State heads. From the New England States everything pertaining to the Pilgrim colony should be carefully gathered and placed under the protection of the old colonial coat of arms. From the Central States all that is identified with the discoveries of Hendrick Hudson, etc. : : $:$ What galleries of sacred memorials would these be to the American people! And what pride would each State of the Union take in sending its authentic record of the time-honored and man-honored events that have helped to make our nation what it is! Such a Library would be national indeed." : : No serious effort to complete the collection of local histories and local prints, however, seems to have been made, and the Library remained exceedingly weak in this direction until the acquisition of the Force collection in I 867 .

One other notice of the collection of books in the Library before the close of this period may be quoted. It appeared in the Washington Chronicle, November I3, I864, and was as follows:

We learn that the additions to this noble collection of books during the current year will number nearly 4,000 volumes, embracing valuable works, old and new, on a great variety of subjects, and especially rich in books relating to the discovery, settlement, history, and topography

\footnotetext{
${ }^{1}$ The offer of the collection of Persian literature made by Prince Dimitri Dolgorukov of Russia was leclined May 14, 1859 , as the offers of the Durazzo and Buturlin and other collections had bre:s declined before.
} 
of the American continent. This latter branch of literature has been made a special feature of the selections for increase of the Library under its present management, and if continued as zealously as heretofore, there will soon renain few works on our history, geography, or politics of which the Congressional Library will not possess a copy. The law department of the Library, which is used alike by Congress and the Supreme Conrt, lias also received valuable additions, especially in the department of trials, American and foreign, including, in addition to all the nost celebrated collections, liundreds of interesting trials reported separately. This collection embraces nearly every trial for treason, ancient or modern, and is undoubtedly the most complete one ontside of the Britisli Museum.

In the department of finely illustrated works the Library is steadily growing. The most noteworthy addition of the present season is, perhaps, the splendid French edition of Don Quixote, in two large folio volumes, illustrated by Gustave Doré, whose wonderful illustrations of Dante and other strikingly original works have rendered him famous among living artists.

Of the policy of the Library regarding the special departments of law and documents before the war we have already spoken. Of the other special departments-manuscripts, newspapers, and maps-we have still to speak.

The collection of manuscripts contained but little. There was a journal kept on board the British ship Zealous in the year 1792, presented to the Library by Col. Joseph Watson, a resident of the city, March I 3, I 830 ; a copy of "Instructions of the Count Revillagigedo, viceroy of Mexico, to his successor in I 794," presented by José María Tornel, minister from Mexico, April Io, I $\delta 30$; the Jefferson MSS. acquired in I 8 I 5 and in 1829,28 volumes, including laws and orders of the general assembly of Virginia, I622-I 7 I2, 8 volumes; minutes of the assembly and other colonial records, I606-I700, 7 volumes; records and papers of the London Company of Virginia, 1619-1624, 2 voln1mes; Notes on Virginia, law notes, historical notes, and copies of treatises upon religious and philosophical subjects. 'These were all. ${ }^{2}$ One attempt

\footnotetext{
"The Literary Horld called attention to the value of these, but the National Intelligencer, April 2, 3849 , observed that of the 75 pages in this manuscript only about ten were in the antograph of Jefferson. This manuscript had only recently been presented to the Library.-L'nion, March 10, I849.

${ }^{2}$ An exhibition in the Library of the oriental nanuscripts collected by William B. Horlgson, consul-general at Algiers, is noticed in the National Intelligencer, March 2,1830 .
} 
on the part of the committee to add to this collection is recorded. On the 28th of January, I 848 , they "Resolved, That the Honorable Mr. Pearce, chairman of the connunittee, be requested and anthorized, in behalf of this connunittee, to purchase on such terms as he may deem reasonable, of Harvard University, if it will sell the same, De Bralnule's MSS., reports, and maps, ancl other mannscripts owned by it relating to Florida, for the Library of Congress, and if said university will not dispose of sucl manuscripts to obtain, if practicable, the loan thereof for a few weeks, and permission to have the same transcribed for said library npon such terms as said nniversity may prescribe; and that in such case the chairman procure the same to be copied and defray the expense thereof ont of the Library fund." Nothing, however, seems to have colle of this.

As far as the department of manuscripts was concerned, nothing more than the passage of this resolution seems to have been accomplished during this period. December 27, I 856 , the remarkable collection of manuscripts made by Willian Upcott, of Islington, England, was refused; J Jannary 29 , I 845 , a letter was received from Obadiah Rich, agent of the committee in London, in which he offered to sell the connmittee for the sum of $f 240$ sterling 24 volumes of unpublished manuscripts in relation to the earliest history of America, and it was referred to the honorable Mr. Pearce for exan1ination. February 23, I86I, the mennorial of Charles B. Norton, praying Congress to make an appropriation, not to exceed $\$ 4,000$, for the purchase of a collection of original manuscripts now in his possession, containing, with many others, the famons "Hartley correspondence" and the original map of the United States sketclied by Benjanin Franklin, referred to in the treaty with Great Britain in the year I $7 \delta_{3}-$ the manuscript bound in five volumes folio and the map bound to match-was considered and laid on the table.

But, worse than all was the treatment accorded the important propositions made by Mr. Converse, Mr. Somerby, and

\footnotetext{
${ }^{2}$ Minutes, December $27,18_{3} 6$. This was sold by Sotheby in 18.46 , and is said to have realized 6.4 .125 I7s. 6d. There is a catalogue of it entitled "Original letters, manuscripts, and state papers, collected by William Upcott." London, pr. pr., r 836 . I p. $1 ., 6+$ pp. Facsimile. $4^{\circ}$.
} 
Mr. Sainsbury, for the copying or calendaring of manuscripts in the English archives relating to the Anerican colonies, propositions which were first treated with neglect and finally rejected altogether, so that the work which might have been done by one anthority once for all was left to be done by different persons having different objects in view, and so never completed. ${ }^{\mathrm{i}}$

These propositions for the calendaring of manuscripts in the English archives relating to the American colonies are of such lasting interest that, although they came to nought at the time, their history may be given here as an indication of what scholars looked for from the Government in these early days.

On the 24th of February, I827, Mr. Everett had introduced into Congress a resolntion providing that copies of all papers in the archives of Great Britain relating to the listory of the American colonies be secured and placed in the Library of Congress.

February S, i828, Mr. McDuffie, from the Committee on Ways and Means, reported a bill ('Twentieth Congress, first

${ }^{r}$ Anong local efforts to index this material, the results of which have been printed, the following may be noted: "Indexes to locuments relative to North Carolina during the colonial existence of said State, now on file in the offices of the board of trate and state paper office in London," Raleigh, $\mathrm{x} 843$; "Calendar to the London documents in the office of the secretary of state, etc., transcribed from the originals in the Queen's state paper office, in the office of the privy conncil, in the library of the British Muscum, and in the library of the Archbishop of Canterbury," in the final report of John Romeyn Brodhead made to the governor, February I2, IS45, New York, Senate document No. 47; "Catalogue of papers relating to Pennsylvania and Ilelaware, deposited at the state paper office, London," in Pennsylvania historical society memoirs ( 1850 ), vol. 4, pt. 2; "The list and abstract of papers in the state paper office, Idondon, relating to Sontli Carolina," published in the collections of the Soutl Carolina Historical Society, vols. I-3, IS57-59; "A catalogue of original docunents in the English archives relating to the early history of the State of Naine," collected by H. G. Somerby and edited for the Maine Historical Society by George I'olsom, New York, I858; "An analytical index to the colonial rlocuments of New Jerscy in the statc paper offices of England," compiled by Henry Stevens and erlited by W. A. Whitchead for the New Jersey Historical Society's collections, vol. 5, 1858 ; "I.ist of documents in the public record office in London, England, relating to the province of New Hampshire," New Hampshire Historical Society collections, rol. IO, Manchester, $18_{93}$.

Sone of the diffenlties which stood in the way of these local undertakings are shown in the correspondence relating to the investigation instituted by the State of New York. 'Twenty-seventh Congress, second session, House document No. Io8, February 19, 1842. 
session, H. R. r54) anthorizing the President of the United States to employ an agent to procure from the plantation office and other offices in England copies of snch documents as rould serve to illinstrate the early history of the States of the Union up to the year ${ }_{1} \delta_{3}$ and appropriating the sum of $\$ 2,000$ for the purpose. Referring to the failure of this measure, Jared Sparks said: ${ }^{\mathrm{T}}$

It was hoped that Congress would take measures to procure copies of these papers, as both the States of Georgia and North Carolina had made application to the General Govermment for this object in reference to those States. $* * *$ Congress have so much to do with the present that they have no time to think of the past. We all love to boast, and even our members of Congress are not loath to proclaim in the halls of legislation that we are an enlightened, liberal, and improving people; yet the British Parliament nake an anmual appropriation for printing ancient manuscript records and documents to more than double the amount it would cost to procure a copy of all the American colonial papers.

Judge William Law in an address before the Georgia Historical Society, February I 2, I 840 , quoted this and continued: "Yet these essentials of American colonial history remain shut up in the office of the board of trade and plantations in England. The National Library at Washington is represented as being remarkably deficient in books and information relating to America. Copies of these papers deposited in the national archives would constitute an invaluable addition and secure the necessary materials for the future history of our country."

On the $I^{\text {th }}$ of January, I $\delta_{3} \mathrm{I}$, the Library Committee received a letter from S. Converse, esq., saying that it was his intention to visit England during the coming snumer for the purpose of selecting from the records of the Colonial Office, etc., such "interesting matter as is indispensable to a full and accurate history of the American colonies." On the $9^{\text {th }}$ of February the committee received mennorials from New Hampshire and from the Historical Society of Rhode Island relative to historical documents in the public offices of Eng-

\footnotetext{
"North American Rewne 30: 3 .

${ }^{2}$ Collections of the Georgia Historical Society r: 6 .
} 
land. On the 25th of Jannary, I $\delta_{32}$, it "Voted, That the chairman of the Library Committee of the House of Representatives be instructed to move for leave in the House to introduce a bill for the appropriation of $\$ 2,000$ to be used in procuring copies from the plantation records in England."

Again, on the r4th of April, IS56, the matter was bronght up by the following remarks of Mr. Clayton in the Senate:

Mr. President, the Committee on Foreign Relations have received a comminuication from the Secretary of State, transmitting a copy of a letter of H. G. Somerby, esq., suggesting the importance of having copied, under the direction of this Government, the manuscript documents relating to our country's history now in the state paper office in London. Mr. Somerby states that there are upward of 2,000 folio rolumes of manuscripts in the archives of the British Government, containing original, yet almost unavailable, materials, in the history of the founding and progress of the original States of the Union, illustrating almost every possible interest, public and private, during our dependence on the mother country; that they show the origin, character, and position of the individual colonists; the physical, moral, and religions history of the founders of the nation, the men who determined its character, and whose history is that of the nation; the periods and amounts of emigration; the products of the country; the course and changes of trade; the amount and increase of navigation from time to time; the revenue laws and their operation; that they throw light on the history of the aborigines, and the mutual relations of the Indians and colonists; that they contain copies, and in many instances the original records, of the legislative assemblies of the colonies, occasionally supplying a hiatus in our own records; the private and official correspondence of the royal governors and subordinate officers of the Crown; the reports and res gesta of cases appealed from the colonies to the higher judicial tribunal at home; these often involve the titles and boundaries of large tracts of territory, occasionally of towns, counties, or even colonies; original charts and strveys; that though these documents belong to the English Governnnent, they historically belong especially to our own conntry and Government, and historical justice and good faith to ourselves manifestly require that copies of them shonld be preserved at the seat of the National Government, where the statistician, the historian, and the general student may consult them at the smallest possible expense of time and money; that of a large proportion of these papers there are no duplicates, and the originals are constantly exposed to loss and destruction by accident and decay; and this is suggested as a sufficient reason for the prompt and efficient action of the Government.

Accompanying this communication are letters from Henry Barnard, president of the Connecticut Historical Society; of S. F. Streeter, secre- 
tary of the Maryland Historical Society, and of Robert C. Winthrop, late a distinguislied nuember of this body, and now, I believe, president of the Historical Society of Massachusetts, and from other gentlemen of distinction. reconmending strongly the suggestion of Mr. Somerby.

It may, be recollected that on the $26 \mathrm{th}$ of January, i 854 , Mr. Iiverett, then a menber of the Senate, presented a nemorial of the Massachusetts Historical Society praying that an appropriation be made to defray the expense of procuring from the archives of the British Government, and especially from the state paper office in London, copies of documents, records, and correspondence pertaining to the early history of the colonies and of the United States. The memorial was then referred to the Committee on the Library, but 110 action was taken by the Senate in the matter during that session.

Concurring as I do in the views expressed by the Historical Society of Massachusetts, I move, by authority of the Committee on Foreign Relations, that this memorial be withdrawn from the files of the Senate and again referred to the Committee on the Library, and that the communication from the Secretary of State, with the accompanying correspondence, be also referred to the same committee."

The motion was agreed to, ${ }^{\mathrm{T}}$ but 110 thing seems to liave come of this movement, either.

Finally, however, Henry Stevens, who had compiled "An analytical index to the colonial documents of New Jersey in the state paper offices of England" " for the New Jersey Historical Society, together with indexes to the colonial records of Rhode Island, Maryland, and Virginia, issued proposals for a calendar of all the colonial papers, I497-I $78_{3}$, in the custody of the Master of the Rolls, including sucli other important papers pertaining to the British colonies as were known to exist in the British Musenun and other libraries, public and private. His proposals were these:

The plan of arrangenent of the nine volumes of calendars, donestic series, already published, will in general be followed, but witl some modifications.

Of each document there will be given an abstract and a clescription. The abstract will present, in as condensed a manner as possible, the date, positive or asstuned, and the leading points, however numerous, of each paper, particular attention being given to the names of places and persons. The description will convey an idea of the length of each document in the estimated number of folios, with consequently the cost of

'Congressional Globe, 39: S94.

"Collections of the New Jersey Historical Society, vol. $5,185 \$$. 
transeribing; the language, if other than English; whether holograph, original, copy early or late, minute, draft, or entry; if printed, when and where; and, if deemed important, when received, when read in conncil or elsewhere, and how disposed of. In short, such information respecting the character and condition of each paper will be given, consistent with the linits of the work, as may be deemed of importance to the student at a distance, to whom access to the papers themselves is difficult or impossible.

It is proposed to have but one index to the entire series, but much greater prominence will be given to it than heretofore. As every topic of each paper is to appear in the abstracts, so they will all reappear in a condensed form in the index, with a precise reference not only to the page, but to the number of the abstract in the page. In this way it is designed that there shall appear, under any given heading, a recapitulation of every point in the entire series on that subject.

Notes, biographical, historical, statistical, genealogical, and literary will be given when thought necessary, including references to original n1aps and portraits, parish registers, n11iversity records, etc.

A specimen of the proposed work was annexed. This was in I $S 59$.

In the following year the first volume of the Calendar of state papers, colonial series, edited by W. Noël Sainsbury, ipon the same plan as the domestic series, was published by the Master of the Rolls; and on the I ath of June the Library Connnittee received letters from Mr. Sainsbury in relation to an extra edition of that part of the calendar relating to the American colonies and offering to continue the calendar from the year I 688 to the year I $7 S_{3}$. But it roted that the proposition of Mr. Sainsbury be not accepted.

The nuatter did not rest there, lowever, for on the 2 Ist of June, r S60, the following article in explanation of the proposition, with further suggestions, was published in the National Intelligencer:

It is known to some among our readers that a series of works is now in course of publication by antlority of the British Government, under the general nane and title of "Chronicles and memorials of Creat Britain and Ireland diring the Middle Ages." 'The Master of the Rolls, early in the year 1857 , submitted to the department of the British treasury a proposal for the publication of works coning within this category and comprising materials for the illustration of the history of Great Britain from the invasion by the Romans to the reign of IIenry VIII. Of this series 18 volumes have been already published, and copies of each may be found in the Congressional I,ibrery. 
Another enterprise similar in design with this and published by the same authority, under direction in like manner of the Master of the Rolls, relates to the colonial papers found in the state paper office at London. In order to afford a knowledge of the general contents and value of a portion of these documents the British Government has made appropriation for the publication of a series of volumes under the designation of "Calendars and indexes of the state papers," down to the year I68S. The first volume of this series is now in course of publication, if it is not already completed, and brings down the record of these colonial papers from the year 1574 to 1660 . The papers relating to the period comprised within the remaining twenty-eight years, being relatively much more numerous, will, it is calculated, require for their proper description and classification + additional volumes.

As this work will end precisely at the point of time where its continuation might be made specially valuable to the history of British colonization on the American continent, it has been suggested to the Joint Committee on the Library of Congress that scme provision slould be made by the Government of the United States for the further prosecution of a work which would doubtless shed much light upon the founding and planting of those colonies which have now strengthened and widened into the United States of America. For here it is that we look for the very incunabula gentis nostre.

It is said that the papers relating to American colonization, as now found in the British state paper office, are comprised in two large series of documents, termed those of the "Board of Trade," and those concerning "America and the West Indies," of which the former, detailing the proceedings of the body in question, are continuous and regular, while the latter are subdivided into several minor series, according to the order of time or subject in which they were differently received at the State Paper Office, or as they accumulated in that department by being separated and sorted from other state papers. In regard to the nature and quality of these latter documents, we may add that they consist of original letters and papers from governors and other officers of the different provinces.

A gentleman connected witl the British state paper office, Mr. W. Noël Sainsbury, has recently desired to bring the question of publishing a description and analysis of these documents to the serious consideration of our Government. To this end, we understand, he has addressed a commnnication on the subject to our minister at London, Mr. Dallas, as also to Mr. Senator Pearce, chairman of the Senate's Comnittee on the Library. He gives it as his opinion that the whole series of papers comprised within the period extending from 1689 to 1783 might be appropriately calenclared and annotated within about 25 volumes octaro, of 700 pages each, of which 600 pages would be devoted to the calendar and roo to the copious index. He further states that the cost of printing each volnme of 1 , ooo copies would be, accorling to the estinate of 
the Queen's printer, about $\$ I, 500$; and as Mr. Sainsbury proposes that the compiler shotld receive for his labor of researclı and digest $\$ \mathrm{I}, 250$ per annum during a period of twenty years (within which he thinks the whole 25 volumes might be completed), with an additional compensation of $\$ 5$ for every sheet ( 8 pages) passed through the press under his critical revision, it follows that an annual sum of $\$ 30,000$ would, according to these calculations, be required to insure the execution of the work, which, if completed within the time and in the manner designated by Mr. Sainsbury, would cost altogether $\$ 600$, 000 .

This amounts, in the aggregate, to a very considerable sum, and we learn that the Joint Committee on the Library declined acceding to the proposals made on these terms by Mr. Sainsbury, who, being connected with the state paper office, would naturally possess superior facilities and, we may also suppose, superior qualifications for the due performance of the task.

It has been suggested, however, that the work may be more readily effected through another agency than that of the General Government, if only' the necessary concert of action could be secured on the part of the iarious historical societies cxisting in the scveral States of the Union. It will be perceived that, if each volume of 1, ooo copies could be disposed of at the price of Io shillings $(\$ 2.50)$ per copy, the sale would realize more than the outlay demanded for the compilation and publication. The whole series of 25 volumes, if published at this rate, would amount in the aggregate to $\$ 625$, 000, or $\$ 25$, ooo more than the cost of the work according to the estimates of Mr. Sainsbury. If, then, the historical societies of twenty of our States would severally agree to take 50 copies of each volume for a period of twenty years, they might, by an annual outlay of only \$I 25 for each society, launch this great work upon "the full tide of successful experiment."

The significance and value of stuch an enterprise will, we hope, secure for it the early consideration of those associations which have already done and are still doing so much for the perpetuation and diffusion of the records which constitute the materials of American history. It will not, we shotld think, be found difficult to devise the way any more than to raise the means necessary to the attainment of the end proposed; and if measures could be efficiently taken by any one society for advising and consulting with the various affiliated historical societies in the country, we prestme that at least twenty conld be found ready to further a novement so pronising to the catse which they all have at heart.

This interesting article was the subject of a connunuication to the Mistorial Magazine for October, IS6O (4: 3 I 4), entitled

¿Nalional Intelligencer, June 21, IS60. Mr. Sainshury requested the Massachusetts historical socicty to lend its influence in behalf of his proposals. - Procecolings, Sept. 13, $1860(1001.5,11.60)$. 
"A great historical enterprise," but beyond this it seemed to excite no attention.

More interest was shown in the manuscripts relating to our early national history. On the 3 oth of June, $1 S_{34}, \$ 25$,000 was appropriated for the Washington Papers; on the $3 \mathrm{~d}$ of March, $1837, \$ 30$, O0O was appropriated for the Madison Papers, and on the I 2 th of August, i $848, \$ 20,000$ was appropriated for the Jefferson Papers and a like sum for the Hamilton Papers. Neither of these collections was at that time transferred to the custody of the Library of Congress, which then had no department of manuscripts. We need therefore only refer to the documents describing them. ${ }^{\mathrm{I}}$

There seems, however, to have been some idea of depositing the Madison MSS. in the Library of Congress, for in the report upon that subject, March 9, I $S_{4} 6$, the committee to whom the matter had been referred said: "It is deemed useless to raise and discuss the question of the power of Congress to make such a purchase. Congress has established a Library, and has procured on its account works both printed and in manuscript. The question is at rest. $* * ;$ Congress by the purchase and publication will secure for the Public Library, and thereby for the benefit and information of the whole Union, the valuable writings of one of its most useful, virtuous, and distinguished statesmen."

The debate in the House of Representatives July I I, I 848 , on the purchase of the Jefferson and Hamilton MSS. is also of permanent significance, as showing the intention of Congress, at first, to place these manuscripts in its own Library and as indicating the policy of the Government at that time in the matter of national records. It was as follows:

Mr. Goggin moved to add an item to those for the Library of Congress to appropriate $\$ 20$, 000 for the purchase of the manuscript papers of the late President Jefferson.

\footnotetext{
'Twenty-third Congress, first session, House report No. 381 , April I, 1834, relates to the Washington Pajers; Twenty-nintl Congress, first session, Honse report No. 410 , March 9, I846, relates to the Madison Papers; Twenty-ninth Congress, second session, House report No. 39, January 20, 1847 , Thirtietl Congress, first session, House Miscellaneous Documents, No. 7, December 30,1847 , and Thirtieth Congress, first session, Senate report No. 167 , June 8 , I848, relate to the Jefferson Papers, and Twenty-ninth Congress, first session, Senate documents No. 52, January 12, is 46 , relates to the Hamilton Papers.
} 
Mr. G. II. Jones interposed, and inquired if the motion was in order, there being no law authorizing the appropriation. He based his objection on the eighty-first rule, which provides that "no appropriation shall be reported in such general appropriation bills, or be in order as an annendment thereto, for any expenditure not previously authorized by law."

Mr. Goggin said it was an amendment relating to the Library of Congress, for which it proposed a purchase of books, and it was therefore in order.

The Chairman said the annendment was in order.

Mr. Jones submitted that there was no law authorizing the purchase of these papers, and therefore it was not in order to introduce an item in the general appropriation bill to pay for them.

The Chairman said that the item was proposed for the purchase of books for the Library, which was now in existence; and the rule from which the gentleman from Tennessee had quoted gave anthority to make appropriations "in continuation of appropriations for such public works and objects as are already in progress." He lteld the amendment to be in order.

Mr. Goggin said he did not want to discuss the amendment at all, but simply to remark that a menorial had been presented to this Honse, and it had been referred to the Library Committee, thus bringing the subject under consideration, and hence he had been induced to offer this amendment. The object was to make an appropriation to purchase mannscripts which were saict to be very valuable and of which he had some proof if it was deemed necessary to produce it. He referred to two letters which he held in his hand from two gentlenen who belong to the two political parties of the country (Mr. Van Buren and Mr. W. C. Rives). The author of these papers belonged to the Democratic party, but he nevertheless desired that those papers should be published, for he believed they were very valuable papers, many of a character which showed that they belonged to the country, and he hoped they would share the fate of others which this House had heretofore purchased. He would not detain the Honse witl a speech on the subject, but refer the gentlemen to a report which was made during the last Congress by the gentleman opposite (Mr. Brodhead) on this very subject.

Mr. Palfrey moved, for the purpose of obtaining an opportunity to make a few remarks, to amend the amendment, by adding $\$ 20$, ooo for the purchase of the papers of Alexander Hamilton. The subject had come upon him very unexpectedly, but as allusion had been made to the views of the Library Committee, though he was not anthorized to speak for that committee, as no other member of the Library Committee was present he would say a word or two expressive of his own views upon the subject. He was not aware that the Library Conmittee had ever had the subject under consideration. If they liad, it was at a time when 
he was absent; but if he was to express his opinion of this set of manuscripts he should say that he deeply regretted that their purchase had not been earlier ordered, so that the writings of Mr. Jefferson could have been given to the world under the responsibility of the nation and not under such auspices as those under which a part of Mr. Jefferson's papers had been published. They should all be published in a manner that would be creditable to the fame of that great man and of this nation.

The Chairman reminded the gentleman from Massachusetts that five minutes were allowed to him to explain his amendment, to which he must confine himself.

Mr. Palfrey submitted that in order to make his own amendment satisfactory it was proper that he should make some remarks on the subject contemplated by the amendment which he proposed to amend. However, the remarks which he desired to make applied equally to the papers of Mr. Jefferson and Mr. Hamilton. What he had to say was true of both, and therefore when he spoke of Mr. Hamilton he hoped the committee would understand him as speaking likewise of Mr. Jefferson. The papers which yet remained in manuscript, both of Mr. Hanilton and Mr. Jefferson, he understood were very voluminous; they were intimately connected with the history of the country through a long series of years; nothing could be more important than tlese writings were to our history, and it was in the highest degree material that these papers should be rescued from the possession of anybody where they would be exposed to any chance or accident, and placed in the possession of this country and of the world through a channel such as this nation could approve. He felt confident that the Library Committee entertained these opinions in common with himself.

Mr. Nicoll inquired if these matters had ever been referred to any committee of this House. If so, he would like to have the report read.

The Chairman reminded the gentleman from New York that this was not a debatable question under the order of the House. The Chairman had not the information required by the gentleman from New York.

Mr. Nicoll supposed the information could be obtained at the Clerk's desk.

The Chairman said, doubtless; and the gentleman from New York could obtain it there and relieve the Chair from further responsibility.

Mr. Bowlin said it was proper that the point should be settled whether these amendments were in order under the eighty-first rule of this House. The Chair, on the question being raised by the gentleman from Tennessee (Mr. Jones), decided that they were in order, and he now again raised the question for the purpose of taking an appeal from the decision of the Chair.

Tellers were demanded on the appeal, and Messrs. Venable and Pollock were appointed, and they reported 66 in the affrmative and $5^{\mathrm{r}}$ in the negative. The decision of the Chair was therefore sustained as the judgment of the committee. 
The question then recurred on the amendment of the gentleman from Massachusetts (Mr. Palfrey) to the amendment of Mr. Goggin, and it was adopted by a majority of 63 to 55 .

The question recurred on the amendment as amended.

Mr. Venable made a pro forma motion, that he might express his uncompromising opposition to this whole matter, from beginning to end. He believed it was the introduction of a system which involved an incalculable amount of money. He would vote for the purchase of the manuscripts of Thomas Jeffersonl and Alexander Hamilton as soon as for those of anybody; but if this course was to be pursued, it would not be many years before the hnudred volumes of Mr. J. Q. Adams's journal and writings and perhaps the papers of ex-President Tyler would be purchased.

Mr. Palfrey with some warmth denied that the House would ever be asked to purchase the papers of Mr. Adams.

Mr. Tenable said they should have been told the same thing about these Jefferson and Hamilton papers ten years ago. He was opposed to the whole system, as one which would inevitably be attended with mischievous results. As to the purchase of Mr. Adams's papers, he hoped the question never would be tested. When papers were valuable, they wotnld most assuredly come to the light. If he had been present when the Madison papers were purchased, he should have voted against that motion for the same reason that influenced him to vote against this. The whole was wrong in principle.

Mr. Miller also made a pro forma motion. He was opposed to the amendment, and he was opposed to the manner in which it was urged on the attention of the committee. The gentleman from Virginia, in offering his amendment for the purchase of the papers of 'Thomas Jefferson, addressed himself to the members on the Democratic side of the House, and the gentlenlan from Massachusetts made a motion which commended itself to the gentlemen on the other side of the House; and by these means both sides of the House were appealed to, these two gentlemen-Jefferson and Hamilton-being the founders of the two great parties which now divide this country. As these questions were presented to the committee in such a manner, it was apparent that the gentlemen who made the motions were satisfied that they could not be sustained by argument, and hence they appealed to the prejudices of both sides of the House. Now, he was opposed to this system. He was opposed to the purchase of the papers of Mr. Madison, and he should be equally opposed to the purchase of the papers of anybody else, even of the illustrious Jefferson. He would give no vote for any such purpose, for the whole system was wrong. If any writings were valuable and worthy of publication, they would present inducements for their publication withont the interference of the Govermment. By private enterprise they would come to light, and hence no justification could be 
furnished for such an extravagant waste of the public money. He might here remark that all the papers of Mr. Jefferson which were deemed valuable had been published already. What evidence was there before the committee that these papers were of the value which was placed on them by the movers of these amendments, and which the committee was called upon to vote? He did not even know what these papers were. It might be that the papers of Alexander Hamilton advocated a policy which had been repudiated by this Government from its foundation to the present moment. What, he asked, was their object? He was unwilling that the committee should be brought to sanction the purchase of papers until they knew what it was they were called upon to publish. Who had given them that information? The chairman of the committee said that he did not even know that they had been before the Library Committee. Did any of them know? And yet they were asked to appropriate $\$ 20,000$ for each of two sets of papers of which they knew nothing. He thought it was a matter of some importance, and, especially as the case of Mrs. Madison had been quoted, it was time that this system should be arrested; but if it was to be adopted and carried out, he hoped that when it was carried to the House that the record would be made to show who it was that advocated the system.

Mr. Clarke, having made a pro forma motion, said he took occasion to object to the appropriation of $\$ 25$, ooo for the purchase of the Madison papers, and he then argued that that appropriation was designed and intended to fasten and rivet on the country an enormous pension list; that it would furnish a precedent for all time to come which, if it would not be dangerous to the well-being of the country, would be disastrous to its finances.

There were various reasons why they should not tolerate the amendment which had been proposed. They had heard yesterday from the other side of the House-and not yesterday only, but on all occasions when those gentlemen obtained the floor-that, by the prosecution of the Mexican war, and by other Democratic measures and policy, they had involved the country in a debt which would put the face of the people of this nation to the grindstone for years to come. And yet, in the face of these charges and statements, which were designed to have an effect on the approaching elections-statements and charges made, in many instances, by a direct suppression of the truth-there was not a solitary proposition in our whole legislation where an attempt was made to appropriate the public money which had not met the approbation of the gentlemen on the other side of the House. All propositions for wild and extravagant expenditures have invariably been sustained and voted for by the gentlemen on the other side of the House. And yet the charge was to go to the country that the Denocratic party here was in favor of squandering the public money, and comparisons were instituted between the expense of this and former Administrations for the purpose 
of fixing on the Democratic party the charge of extravagance. And, in bringing this House into disrepute, and in casting reproach on the President, language was used which was only fit for a fish market; certainly not adapted to the halls of legislation.

The Chairman reminded the gentleman that he must confine himself to his amendment.

Mr. Clarke then proceeded to protest against the amendment as a dangerous precedent.

Mr. C. J. Ingersoll rose and moved to reduce the two sums of $\$ 20,000$ to $\$ 5$, ooo each.

Mr. Sawyer rose to a question of order. He said it was not in order to move an amendment solely for the purpose of making a five minutes' speech.

The Chairman decided that the gentheman from Pennsylvania was in order,

Mr. Ingersoll said that he should vote in favor of the amendment. As to establishing a system of literary pensioning, if gentlemen could produce any number of such men as Thomas Jefferson and Alexander Hamilton, he, for one, was ready to pension them all; but he greatly feared that such men would continue to be very rare. There was very little danger, indeed, that the pension roll of men like these would be ruinously extended. As to Jefferson, we knew, from such of his writings as were already in print, what it was we expect to get should the resolution be adopted. After all his public situations and advantages, Mr. Jefferson died $\$ 50$, ooo in debt, and two of his granddaughters were for many years keeping a school, out of the proceeds of which they had paid \$15,000 of it; and he had been told that they were still employed in the same way. And, in regard to Alexander Hamilton, the act of I 789 establishing the Treasury of the United States was a monument of his public character such as he had been assured by Albert Gallatin and Alexander Dallas and Richard Rush and Robert J. Walker and other men competent to judge was not to be found in England, nor in France, nor in the government of any other country in the world. For his part, Mr. I. was quite ready to take all the responsibility of voting not only this $\$ 20$, ooo but a much larger sum.

Mr. Goggin said he had letters before him from William C. Rives and Martin Van Buren in favor of the purchase, and these, on such a subject, were good authority.

Mr. Houston, of Alabama, said that neither of them was good authority.

The question was then put and decided in the affirmative-ayes, 6o; noes, $5^{8 .}$

The debate over the purchase of the manuscript of Washington's Farewell address is also instructive. On the $24^{\text {th }}$ 
of January, I 850 , Henry Clay presented in the Senate the following resolution: "Resolied, That the Joint Committee on the Library of the Senate and House of Representatives be authorized and directed to purchase the mannscript of the Farewell address to the people of the United States of George Washington, if the purchase can be effected on just and fair terms in the opinion of the committee."

The ensuing debate then took place:

Mr. CLAY. Mr. President, I intended that that resolution should be a joint one, and I believe that the Secretary has given it that form at my instance.

Sir, I did not wish to trouble the Senate in presenting this resolution. I was anxious to accomplish the object it proposes without the formality of the passage of a resolution by Congress, and I addressed myself to the Joint Committee on the Library in consequence of a wish to avoid the passage of $\mathrm{my}$ resolution. The committee took the subject into their consideration, and came to the conclusion that, as they had never heretofore applied the funds intrusted to them to the purchase of manuscripts without the sanction of Congress, they could not venture on any expenditure for the purcliasing of this manuscript without some other authority than that which they now possessed. This reply led me to the presentation of this resolution. If the object which it contemplates could have been accomplished without presenting it here, I would not have taken up one moment of the precious time of the Senate.

I will now state some of the motives which led me to the presentation of this resolution.

It is about fifty-three years ago since General Washington, the Father of his Country by universal consent, addressed to the people of the United States the document described in that resolution. At the time of the preparation of it there was a paper which, those who are conversant with the history of the country at the time will recollect, was published at Philadelphia by an extremely respectable and intelligent gentleman, Mr. Claypoole, called the Daily Advertiser. General Washington selected that paper for the publication of his Farewell address; and, after it was committed to print, Mr. Clay poole proposed to return the original document to General Washington and waited upon him for that purpose; but being extremely desirous to possess it he expressed his wish that, if the General did not wish it limself, he would like to retain it as a menorial. General Washington assented to the request, and the paper from that day to this has been in the hands either of Mr. Claypoole or some of his descendants.

But I was struck by an advertisement which I saw some short tine ago, published in one of the papers of Philadelphia, to this effect: 
"The original manuscript of General Washington's valedictory address to the United States will be sold on Tuesday, February i2, I 850 , at $6 \mathrm{I} / 2$ o'clock. 'The paper, in the handwriting and bearing the signature of General Washington, was presented by him to Mr. Claypoole, the then editor and proprietor of the Daily'Advertiser, the paper which General Washington had selected for its publication. The sale will be peremptory."

Well, sir, when I read that advertisement I said to myself, "What is to become of that precious document? Is it to be sold, to be perhaps transferred out of the country and made the ormament of the parlor of some of the distinguished men of Europe-men of rank or title or literary fame-or shall it remain here?" Sir, I could not for a moment hesitate as to the promptings of my heart. I said, "Here-here in this Capitol, in the Library of this nation-ought this document to be deposited." * * *

Mr. PFARCE. I suggest to the gentleman from Kentucky that the resolution is scarcely complete without a clause for an appropriation proper to provide the Joint Committee on the Library with the means of paying for this manuscript.

Mr. CLAY. I do not think there can be any difficulty on that subject. It can be provided for when the appropriation bill comes in.

Mr. KIsg. I rise to ask the Senator from Maryland (Mr. Pearce), as a nember of the Joint Library Committee, a question. Is it not entirely in the province of the Joint Committee to purchase such papers, if they think proper, without a resolution of this kind on the part of Congress?

Mr. Pfarce. We thought not. The Library fund we believed to be appropriated for the purchase of books, and not of manuscripts valuable merely as relics.

Mr. KING. I was under the impression-and certainly this is the first time that anything las occurred to induce a change in the opinion which I have alway's entertained-that the Library Committee had the power to purchase either printed or manuscript works. I think I know instances since I have been here where the Library Committee have purchased manuscript books.

Mr. PkARCE. The Library Committee do not think that they are authorized to purchase manuscripts which are valuable as relics merely. Certainly they may purchase a manuscript work, but they would only make such purchase when the work could not be procured in print. They think they would misapply the appropriation for the increase of the Library by purchasing any relic, whether of manuscript or of another kind. The appropriation for the increase of the Library would place very few volumes on our shelves if it were diverted from its legitimate purpose to the purchase of interesting and valuable relics. Even if the comnittee had the authority they would prefer not to exercise it without the instruction of Congress. 
Mr. Krxg. I would suggest an alteration in the resolution to the Senator from Kentucky. It is that the committee should be "authorized," and not " directed " to purchase the manuscript, provided it can be purchased on fair terms. I move to strike out the word "directed" and insert in lieu thereof the word "authorized."

Mr. CLAY. I have no sort of objection to strike out the word "'directed,"' but if the Senator from Alabama will attend, the latter part of the resolution expressly provides for the contingency of the nuanuscript being purchased on what, in the opinion of the committee, shall be fair and reasonable terms. But I have no objection to the amendment.

The motion to strike out the word "directed" and to insert in lieu thereof the word "authorized" was agreed to.

The joint resolution as amended was then reported to the Senate.

The Vice-President announced the question to be on ordering the resolution to be engrossed for a third reading. *** $*$

Mr. Davis of Mississippi. If the vote is about to be taken on this resolution, I shall have to submit a few remarks. I made the motion to pass it by informally, in order that the special order, now delayed for half an hour, might be considered.

The amendment which was proposed by the Senator from Alabama [Mr. King] removes part of the objections which I had to the resolution as it was originally drawn. It is not now mandatory in its terms; still it conveys authority, and construed in connection with such expression as will, probably, be given by the Senate, it does, after all, amount to nearly a mandate; it approaches very nearly to instructions to the committee. It becomes us at the present stage of our proceedings in reference to such matters to ascertain where we are to stop before we take the first step; before following this path to inquire whither it will lead us. We have purchased the manuscripts of Washington; everything, even to the copy book which he kept when a boy. This is but a corrected copy of his Farewell address, known not to have been entirely the result of his own mind; and if what we desire is merely manuscripts of Washington, we have enough of them to satisfy more than moderate desire. The value of the Farewell address is twofold: First, for the opinions contained in it, and next, the authority from which they are derived. I am of opinion that 10 benefit can result to the country or to the people generally from the owning of these sheets of manuscript. No one scarcely will be allowed to read it, for it will have to be locked up securely where it can not be touched, because if handled it will soon be worn out. It will therefore merely gratify that feeling to which the Senator from Kentucky [Mr. Clay] has so eloquently alluded, and to which undoubtedly every heart will respond, that feeling which endears everything pertaining to the beloved or venerated dead. But are we, the representatives of the people, justified in making appropriations from the Treasury to gratify our sentinents? 
Certainly not. We should regard no such feelings, but should act as practical men. We should become as nearly as possible an abstraction, to use the expression of the gentleman from Kentucky, as far as may be-direst ourselves of all feeling in legislation.

If we are to indilge the desire to possess all objects associated with the "Father of his Country," we shall have to purchase the walking: canes he used, the medals and other personal articles identified with him by possession. His residence, the battlefields he illustrated, the routes of his marches through the old thirteen States, over which he shed unfading glory-all, all are closely associated with his memory. Shall they be purchased, too, and held as the property of the Government? But what is there so sacred in the manuscript of this address? It is known to have been the joint production of Washington and one, at least, of his Cabinet-not the emanation of his mind alone. I feel no such respect as has here been expressed for it, and can not see how this manuscript is to effect such happy results. Anyone can have a printed copy, and read it, who desires. There is nothing to be gained by the purchase of this manuscript any more than there would be in the purchase of a walking stick which Washington used. I must be pardoned for a want of reneration for relics, or for symbols of faith in the faithful; nay, more, for saying that a devotion to men which extends to the inanimate objects connected with them is an extrene unworthy of our people. We are utilitarians, and it is not in keeping with that character to be led away by sentiment.

I have no objection that the resolution should go to the committee, as a mere authority further to inquire whether it would be well to purchase this manuscript. The rough sketch of this address, connected with the work of others, and showing what was his own, would be far more valuable to us than this, the form to which it was modified and extended, and is the same as every printed copy. I believe we have the first sketch of the address, and perliaps a copy of it in the form in which it was printed, purchased among the Washington MSS. This and other questions the committee will have for inquiry, if left to their discretion.

Mr. Borland. Mr. President, I will yield to none in my veneration and respect for the services of Washington, and I agree with the Senator from Mississippi [Mr. Foote] that if the objects proposed by this resolution, so eloquently spoken of by the Senator from Kentucky, could be accomplished, I should be willing to vote not only the price required for the manuscript but millions besides. But it seems to me the main object to be accomplished by the passage of this resolution is to reiterate what I have seen session after session, and what I think is disgraceful to many citizens of this country-that is, the disposition to speculate upon the patriotism of the country, and to bring here and hawk about at the door of this Capitol, and offer to the Senate or the House of Representatives, the relics of the patriots who achieved our independ- 
ence. And, in passing this resolution, I consider that the only tangible object we will accomplish by it will be to put money in the pockets of various speculators who, under color of professions of patriotism, come here and ask the Senate to purchase these relics. Perhaps the very persons who have this mannscript for sale received it as a donation or purchased it for a small amount, and now come here as speculators upon our patriotism and ask a pecuniary compensation for it.

Mr. Clay. A single work. The Senator from Arkansas [Mr. Borland] is laboring under a total misconception in regard to this matter. The proprietors of this paper have not come here; it is not at their instance; not one single word has come from them to me, or from any friends of theirs. For is the paper hawked about the Capitol, as the Senator seems to suppose, and offered for sale with a view to speculation or the acquisition of a large sum of money; no such thing. The representatives of the respectable Mr. Claypoole have not moved in the affair at all. It is my own motion, and if there is any responsibility in regard to it I bear it, and not them. But I do not wish to detain the Senate for a moment, especially as the Senator from South Carolina [Mr. Butler] ought to have been heard before this time.

Mr. BorLAND. My remarks were not particularly applied to the individuals offering this manuscript for sale. I think the Senator from Kentucky is mistaken in saying they have not been here; for I learn from Senators that the manuscript has been exhibited here.

Mr. CLAY (in his seat). I certainly had no knowledge of it.

Mr. BoRLAND. What I referred to was the practice which has hitherto prevailed of the representatives of distinguished revolutionary characters coming here and offering for sale, and getting appropriations of large sums of money, for the relics of their ancestors. I should not be surprised, if this manuscript is purchased, to have the sacred bones of Washington himself brought here for sale.

The question was then taken on ordering the resolution to be engrossed for a third reading, and it was agreed to. $* * *$

The resolution was then read a third time and passed.

In the House, January 29, IS5O, the joint resolution from the Senate to authorize the purchase of the manuscript of the Farewell address of General Washington, coming up in its order, was read the second time.

Mr. Jones moved that it be referred to the Commintee on the Library.

Mr. Casey remarked that he hoped the reference would not be made, but that the resolution wonld be put upon its final passage, nor could he see any objection to this conrse, as erery gentleman wonld feel proud to see this precious relic of the Father of his Conntry among the archives of the Government, and that if the resolution be committed it would, in all probability, be delayes till a time when it will be beyond the 
reach of Congress-as it is announced in the public papers that this manuscript will be sold at public action on the 12th of February nextand, therefore, requires prompt and immediate action on the part of this Honse. I lope, therefore, that the affection for the name and character of George Washington, and the patriotism of the House, will promptly vote down the motion to refer, and that the country shall be put in possession of this invaluable document.

The question was then taken on the motion to refer to the Library Committee, and decided in the negative.

The bill then received a third reading with a view to its passage.

Mr. Carter moved so to amend the bill as to limit the amount to be paid by the committee to $\$ 500$. He said the amendment was to protect the Government against an exorbitant demand.

Mr. Brown of Mississippi said that if such a limitation were inserted in the resolution it would be tantamount to saying that Congress would give that amount. If the manuscript was worth being purchased by Congress, it was worth paying more for than would be paid from any other source. He hoped the gentleman from Ohio would withdraw his amendment.

Mr. Johnson of Tennessee adverted to the appropriation of $\$ 20,000$ which had heretofore been voted for the papers of General Washington, and asked if Congress was willing now, because the name of Washington was made the pretext for this new claim, to submit to anything like this. He characterized it as an attempt to rob the Treasury. Why may not some one come to Congress hereafter for the purchase of a uniform or the sword of General Washington, or for the cracked brandy bottle said to have belonged to him, which he believed was now in the Patent Office, with a little brandy remaining in it? What would there be to prevent an application to Congress hereafter for the purchase of any or all of them? It appeared to him that this was merely a scheme to extort money from the public Treasury. $* * *$

Mr. Chandler said the lowest price which had been fixed was $\$ 1,000 . * * *$

Mr. Johnson hoped that if it was the understanding that \$I, ooo would buy this document, that this sum would be inserted as a limit. Why should Congress, by leaving out the limitation of price, put it in the power of any one to make a speculation on the public Treasury? He would move to fill the blank with the words "one thousand," and then if that was agreed to, he loped the resolution would be rejected. *** *

Mr. Chandler saicl that if he could ever bring himself to believe that General Washington had ever entertained a thought that anything he had ever written or worn would be kept as relics to be worshiped by those who would come after him, he (Mr. C.) should entertain a much lower opinion of that distinguished man than he ever had entertained. The General had given this document to Mr. Claypoole, and it was given 
him without restriction as to his disposal of it. The family of Mr. Claypoole were always proud of it. But, in consequence of his death, it must now be exposed to sale by public auction, under the laws of the State of Pennsylvania. And when he liad named \$I,OOO as the price of the manuscript, he had only placed on it the estimate to meet the demands of the law.

The gentleman from Tennessee liad asked why the uniform, the sword, and the brandy bottle might not hereafter be purchased by Congress. He could give no reason except it might be the brandy was all out of the flask. The manuscript was offered and ought to be purchased by Congress or it would fall into other hands. It had become necessary that it should be sold. There had been no hawking of it about, no cutting of it up to be sold by installments. If the Government does not buy it others will, and according to the estimate which is set upon it, on the other side of the Atlantic. He repeated that there could be no doubt of the genuineness of the document, which had been substantiated by persons who had known General Washington and who were familiar with his handwriting.

Mr. Johnson asked if the gentleman from Pennsylvania believed that General Washington would have permitted the present possessors of the document to retain it had he supposed it would have been offered at public sale.

Mr. Chandler had no means of answering the question.

Mr. Jolinson of Tennessee repeated the question.

Mr. Chandler replied, but his exact words did not reach the reporter's desk.

Mr. Stephens of Georgia thought it extraordinary that gentlemen were not disposed to place confidence in the committee in reference to the subject. They argued as if the manuscript had been pressed on Congress for purchase. The fact is that the executors and heirs of the proprietor had no control over it. Had the original owner been yet alive Congress would not have had the opportunity of becoming possessed of it. He had deceased and the heirs had no control over the matter. The document must be sold; and he hoped the day would not be consumed in debating whether $\$ 1,000$ or $\$ 500$ should be given for it, but that the purchase should be left in the discretion of the Committee on the Library.

Mr. Stephens concluded by remarking that he had risen principally to move the previous question, which he now did. He, however, withdrew the motion at the request of Mr. Holmes, who said that if there were a relic of Washington which should be treasured in the Capitol it was this identical paper. It had been often disputed, and until this paper had come to the view of the public it had been seriously doubted whether that Farewell address was the production of Washington, or whether the great mind of Alexander Hamilton had not conceived and 
expressed the sentiments of that immortal paper. And now, as if Providence had come to vindicate the fame of Washington, it so happened that upon the decease of the person with whom this precious document had been deposited the fame of Washington was vindicated and all doubt was removed. In the Capitol, where it was intended by act of Congress that his ashes should repose, we ought to preserve as a sacred deposit this memorial of lis living rirtues.

Mr. Stephens renewed his demand for the previous question.

There was a second.

And the main question was ordered to be now taken (which was first on the amendment limiting the amount of purchase money to $\$ I, \infty 00$ ).

The yeas and nays were asked and ordered.

And, pending the question,

The House adjourned.

Finally, on the 6th of February, I850, the joint resolution from the Senate, authorizing the purchase of the manuscript of the Farewell address of General Washington, came up in its regular order.

The pending question was on the amendment heretofore offered by Mr. Carter, limiting the annount to be paid for the manuscript to \$I, Ooo.

On which amendment the yeas and nays had been ordered.

Mr. Stephens of Georgia asked Mr. Carter to withdraw his amendment.

Mr. Carter said that if the gentleman from Georgia (Mr. Stephens) conld assign any good reason why the amendment should be withdrawn, he (Mr. C.) would withdraw it.

The yeas and nays were then taken, and resulted-yeas 66, nays 93 as follows:

Yeas.-Messrs. Albertson, Allen, Ashe, Bay, Beale, Bingham, Bissel, Booth, Bowlin, Boyd, Burt, Joseph Cable, Carter, Cleveland, Williamson R. W. Cobb, Daniel, Dimmick, Disney, Edmundson, Featherston, Fitch, Fuller, Gilmore, Green, Hammond, Isham G. Harris, Sampson W. Harris, Thomas L. Harris, Hubbard, Hunter, Andrew Johnson, Jones, Kaufman, Preston King, Littlefield, Job Mann, Mason, McQueen, McWillie, Miller, Millson, Morris, Olds, Orr, Parker, Potter, Robbins, Savage, Sawtelle, Frederick P. Stanton, Stetson, Strong, Sweetser, Thomas, Jacob Thompson, James Thompson, William Thompson, Toombs, Venable, Walden, Waldo, Wallace, Whittlesey, Wildrick, Wood, and Young-66.

Nays.-Messrs. Alexander, Alston, Andrews, Baker, Bayly, Bowie, Breck, Briggs, Brooks, Buel, Burrows, Chester Butler, Thomas B. Butler, Joseph P. Caldwell, Campbell, Casey, Chandler, Colcock, Conrad, Corwin, Dixon, Doty, Duncan, Nathan Evans, Ewing, Fowler, Goodenow, Gott, Gould, Halloway, Hampton, Harrolson, Hay, Hay- 
mond, Henry, Hibbard, Hilliard, Holliday, Holmes, Houston, Howard, Howe, Inge, Jackson, Julian, Kerr, Daniel P. King, George G. King, James G. King, John A. King, Horace Mann, Marshall, Matteson, McKissock, Robert M. McLane, Meachann, Meade, Moore, Morse, Morton, Nelson, Ogle, Otis, Peaslee, Peck, Phoenix, Pitman, Putnam, Reed, Rockwell, Root, Ramsey, Sackett, Schenck, Schermerhorn, Schoolcraft, Seddon. Shepperd, Spalding, Sprague, Stanley, Richard H. Stanton, Alexander H. Stephens, Taylor, John B. Thompson, Underhill, Van Dyke, Vinton, Watkins, White, Williams, Wilson, and Winthrop--93.

So the annendment was rejected.

Mr. Sweetser moved that there be a call of the House.

The Speaker decicied the motion to be out of order, the previous question haring been ordered.

The question then was on ordering the bill to be engrossed for a third reading.

The resolution was read a third time by its title, and the question then being on the passage thereof-

Mr. Johnson of Tennessee understood, he said (addressing the Chair), that the previous question had now been exhausted, and that, on the question of its passage, the bill was open to debate.

The Speaker assented.

Mr. Johnson said he understood from the rote just taken the House intended to authorize the committee to pay any price they might think proper for this manuscript. It seemed that the House was not satisfied to limit the amount to be paid to $\$ I, 000$. It was conclusive, then, to his mind, if not to the minds of others, that the committee was expected to pay more than this sum. Now, he asked in the name of his constitnents and in the name of the American people, what was this whole manuscript worth? He presumed that erery gentleman on this floor had the Farewell address of Washington in its spirit, as correctly printed. On what principle was this manuscript now offered to the Congress of the United States? * * * Was there not the same reason to purchase the pen, if it could be found, with which the manuscript was prepared, or to purchase the old printing press and the type upon which the Address was printed? $* * *$ If Congress paid a large price for this manuscript, there would soon be a dozen copies of the manuscript which Congress could purchase. $* * *$ There had already been too many impositions of this character practiced upon the Government, under these appeals to the patriotisn of Congress. There was a good deal nore of pretense than of reality in this thing called patriotism. A great many men-gentlenen, as they were called-were ready to make a display of their patriotism by putting their hands into other people's pockets. Their views were then very large and patriotic, but they were very different when it cane to pulting their hands into their own pockets. *** The opinion was becoming very common that he who plucked the Government most was the best fellow. *** 


\section{DEVELOPMENT OF THE LIBRARY, I852-I864.}

Mr. Inge rose and said that he had voted against the amendment which had been moved by the gentleman from Ohio (Mr. Carter), although the rejection seemed to imply that it was the sense of the House that the committee should be empowered to purchase the manuscript at any price at which it could be obtained. Had the amendment of the gentleman from Ohio been adopted, it was clear that the purchase could not have been made for any sum less than $\$ I, \infty 00$, the amount linited in the amendment, because that would have been considered as conveying the opinion of the House that this was the value set upon it by the Government. This was the reason which had influenced him when he gave his rote against the amendment. He was opposed to the resolution in any form, while he was willing to give it that shape which would be most acceptable to the House.

He was as much disposed as any gentleman to attach a high value to everything which was represented to us as a relic of the immortal Washington. There was no man who could be more eager than himself to treasure up the sacred memory of that great man. But he thought that this was no time for the adoption of this resolution. The glorious sentiments embodied by General Washington in his Farewell address had faded away. These sentiments which were so wisely, so patriotically expressed in that important paper had passed away, and were now lost sight of. Does public opinion respond to the sentiments contained in that Address? No. There is no such response. Instead of responding to the exhortations contained in that paper our country throughout her whole extent is at this moment torn by dissensions which threaten, in their progress and their termination, to tear down the existing fabric of our Government and to destroy the most precious relic which has heretofore been preserved in the ark of the Constitution. He could not give his assent to this resolution, which contemplated a measure derogatory to the character of General Washington.

He renewed the motion to lay the resolution on the table, but subsequently withdrew it.

Mr. Stephens of Georgia had no desire to say much in reply to the gentleman from Tennessee and the gentleman from Alabama. But the truth, the solemn, warning truth, of the present dissensions in the country uttered by the gentleman from Alabama, and on which he had based his opposition to the resolution, was, in fact, the strongest argunent in its favor. It was true, indeed, and a mournful truth it was, that the spirit of Washington's Farewell address seems no longer to govern and guide our councils. But was it not the more important that gentlemen from all sections of the Union should pause and consider well the grave and weighty lessons taught in that paper, which by every American should be cherished as the most valuable legacy bequeathed us by the greatest benefactor of his country? It is true we hear nothing but discord in the land. It is not my purpose to speak of the cause or 
origin of this lamentable state of things. Perhaps the gentleman from Alabama and myself might not disagree as to them. We conceive that a portion of the people in one section of the Union, disregarding the solemn injunctions of the parting farewell of the Father of his Country, are threatening aggressions upon our section, which, if persisted in, may bring upon us all those dire calanities which are so prophetically set forth in this Address. Could we address to that spirit of aggression a stronger or more suitable argument than an appeal to the principles of brotherly kindness and mutual forbearance which that address so forcibly and eloquently inculcates? Before we despair, let us again invoke that same spirit of justice, forbearance, harmony, and amity which breathes throughout that Address, and which has never failed in times past to save us in times of the greatest danger and peril.

The gentleman from Tennessee had put the question, "IVhat is the old writing worth?" He would not give an answer to this question. He trusced that we had not yet arrived at that point when the value of the sentiments of the immortal penman of that paper was to be estimated by a money standard. He hoped that in no part of the Union had we come to this low point. He hoped we had not for the honor of the country. He believed that if all the people in all parts of the country could meet together and listen to the noble sentiments of that address, the flickering hope of tranquillity, which is now scarcely visible, would be speedily strengthened and would reillumine the country from one end of its limits to the other. *** Who was there who had not placed a high estimate on the autographs of the distinguished men of England and of her old writers? Who did not know how eagerly the original facsimiles of the writing of the letters of Junius, with all the interpolations and corrections, were sought after? Who did not attach a high value to the facsimiles of the writings of Byron-even the interlineations and erasures of the most beautiful and sublimest parts of Childe Harold? What would you not give, Mr. Speaker, for the original manuscripts of Manfred or Hamilton? Yet who among us would compare these with the original of the most important paper ever written by Washington? He could not consent that a manuscript of that distinguished man should be compared with the writings of any other man who had ever lived.

Mr. Johnson asked if the Government did not pay $\$ 40,000$ for all the original papers of Washington, and now it appeared that this manuscript was not among the papers thus paid for.

Mr. Stephens said this inquiry showed that there was a wide difference between the sentiments of the gentleman from Tennessee and his own. He (Mr. S.) could not estimate the value of these papers by mere dollars and cents. If the Government had paid one million for the papers of Washington, and had the Government been even cleated in the purchase, he would not suffer such considerations to influence his course.

$$
23399-04-22
$$


If the father of any gentleman before his death had left a letter full of instructive suggestions and of solenn warnings against evils which were likely to come, and that letter had been lost, and if it had fallen into the hands of sone individnal, who, actuated by mercenary views, desired to make sale of it, would not the person to whom it was addressed, and to whom it was dear as a relic of paternal love, stubmit to any sacrifice to prevent it from passing into other hands? * * * *

Let the paper, then, be bought; let it be placed in the Library, where the people from all sections, when they come up to the Capitol, may look upon it and read it; and when they behold the lines made by the hand of Waslington may they invoke and catch the spirit of patriotism, harmony, and love of country which animated his breast when he traced these wise and fatherly admonitions to his countrymen. Let the casement that shall contain the sacred treasure be a national altar, about which and around which the true friends of the Republic from all sections may come and renew their vows to the Constitution and its compromises in the spirit in which it was formed; and from this may the spirit of Washington rise from its slumbers and go forth amidst the roar and tumult of the storm now raging and calm the excited waves of popular opinion now running so high and portentously speaking to those dismayed by the revolutionary prospect before us, in the language of Him who spoke as never man spake, when $\mathrm{He}$ allayed the boisterons sea, "Be of good cheer, It is I, be not afraid."

Mr. Chandler said he had not risen to make any speech. He trusted it would be found that the Father of his Country, although dead, would be heard speaking through the House. Whatever fate then might await this resolution, it would be subject for gratification with him that it had been brought forward. He trusted that the House would consider itself brought not to estimate the value of the Union but of these sentiments which are now brought back vividly to our remembrance; and that we would suffer ourselves to be carried back to those times and those scenes when these sentiments flowed from the Father of his Country and found expression on the paper which it is now proposed to purchase.

He would rejoice, with the gentleman from Georgia, to see the original document deposited among the precious things in the Library. He would rejoice could all the people of the Union be assembled here, and that you, sir, should read to all the great truths contained in that interesting paper, and we should all consider ourselves as brothers, members of the same family, having the same interest and united by one common feeling of love.

He esteemed the yellow paper on which the manuscript was written as far superior in value to any paper of this time, as much so as he regarded the sacred tomb at Mount Vernon as above all other tombs, the one as the depository of the bones sanctified there, as the other for the spirit of the immortal chief which breathed in it. 

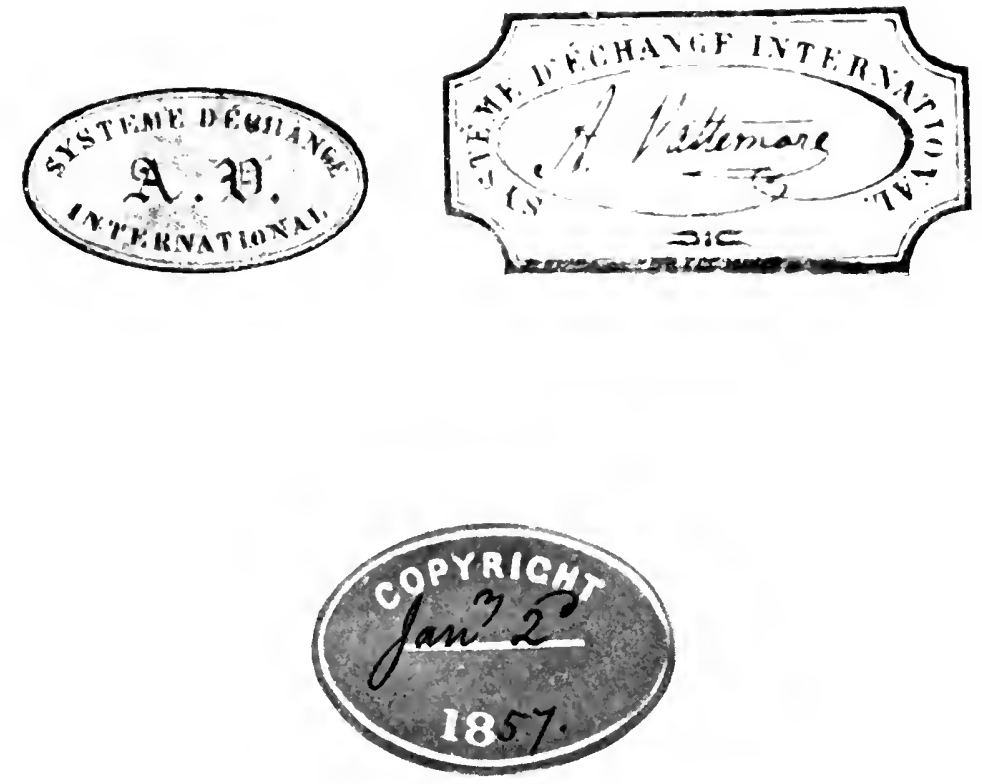

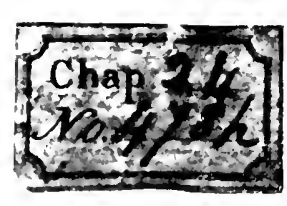

Before Is6o.

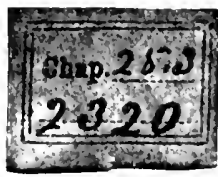

After I 960 . 

He did not believe, with the gentleman from Alabanna, that the spirit of this address had departed from annong us. He thought it was not dead, but sleeping, and he agreed with the gentlenan from Georgia that the influence of this paper would reanimate it. He had no desire to make a speech, but merely a brief explanation. If the possessors of this docnment canne here as the sellers of it, he had not been so informed, or that they had come into the market with this paper, or are anxions that the Government should become a competitor for its purchase. Therc are some who may want it and not be able to bry it. We may not want it, yet ought to buy it. * * *

The question on the passage of the resolution being ordered, Mr. Mason and Mr. Carter asked the yeas and nays, which, being taken, were-yeas, 103 ; nays, 45 -as follows:

Yeas.-Messrs. Allen, Alston, Anderson, Andrews, Baker, Bayly, Bowie, Briggs, Brooks, Allen G. Brown, Buel, Burrows, Chester, Butler, Joseph P. Caldwell, Campbell, Carter, Casey, Chandler, Conrad, Corwin, Deberry, Dickey, Dimmick, Disney, Dixon, Duncan, Nathan Evans, Ewing, Featherston, Fiteh, Fowler, Fuller, Gerry, Goodenow, Gott, Gould, Halloway, Thomas L. Harris, Hay, Haynond, Henry, Hibbard, Hilliard, Holmes, Houston, Howard, Howe, Hunter, Jackson, Kerr, Daniel P. King, George G. King, James G. King, John1 A. King, Marshall, Matteson, McDowell, McKissock, Robert M. McLane, Meacham, Meade, Millson, Moore, Morton, Nelson, Ogle, Otis, Parker, Peaslee, Peck, Phoenix, Pitman, Potter, Putnam, Reed, Robbins, Rockwell, Root, Rumsey, Sackett, Savage, Schenck, Schermerhorn, Schoolcraft, Seddon, Spalding, Sprague, Stanly, Richard H. Stanton, Alexander H. Stephens, Taylor, Underhill, Van Dyke, Vinton, Walden, Waldo, Watkins, White, Whittlesey, Williams, Wilson, and Winthrop-Io3.

Nays.-Messrs. Albertson, Ashe, Arerett, Bay, Beale, Booth, Boyd, Burt, Joseph Cable, IVilliamson R. W. Cobb, Colcock, Conger, Daniel, Edmundson, Giddings, Green, Hammond, Isham G. Harris, Sampson W. Harris, Hubbard, Inge, Andrew Johnson, Jones, Preston King, Littlefield, Job Mann, Mason, McQueen, McWillie, Miller, Morris, Orr, Phelps, Frederick P. Stanton, Strong, Sweetser, Thomas, Jacob Thompson, William Thompson, Toombs, Venable, Wallace, Wildrick, Wood, and Young- 45 .

So the resolution was passed.

Mr. Stephens of Georgia moved a reconsideration of the vote, and that that motion be laid on the lable.

Mr. Mason moved that the House adjourn.

The House refused to adjonru.

The question then recurred, and was taken on the demand for the previous question, and was decided in the affirnative.

So the motion to reconsider was laid on the table.

And the joint resolution stands passed. 
Resolved by the Scnatc and House of Representatives of the United States of America in Congress assembled, That the Joint Committee on the Library be authorized to purchase the manuscript of the Farewell address to the people of the United States, of George Washington, if the purchase of it can be effected on fair and just terms, in the opinion of the committee.

Approved, February 12, I850.

On the same day that the resolution was approved the inanuscript was sold at auction, as had been advertised. The purchaser was James Lenox, of New York. The price paid for the manuscript was $\$ 2,300$.

\section{MAPS.}

The only evidence there was of an interest in the collection of maps before ${ }^{2} 86_{5}$ was the vote in the committee, March 20, I 830 , that the Librarian be instructed to procure Burr's County atlas of the State of New York, and the best maps of the several States which were not already in the Library; and in the appropriation, July 2, I864, of $\$ \mathrm{I}, 000$, to enable the Library Committee to purchase of Edward Everett Hale a collection of maps and plans, chiefly manuscript originals, illustrative of the French and Indian war and the Revolutionary war. ${ }^{2}$

During this period, however, Lieut. Edward B. Hunt, U. S. Army, formulated a plan for the geographical department of the Library of Congress, which he discussed at the annual meeting of the American Association for the Advancement of Science, at Cleveland, July 28 to August 2, I853, as follows :

The present occasion seems peculiarly appropriate for bringing forward and initiating a plan or project which has been for some months maturing in my own mind, and which has been well received by those

Public Ledger, February I3, IS50; North American, February I3. There is another interesting newspaper notice of the MIS. in the National Intelligencer, September $18, \mathrm{i} \& 57$.

2Catalogue of a curious and valuable collection of original maps and plans of military positions held in the old French and Revolutionary wars; with plans of different cities, and maps of the country. Mlost of these are original manuscripts, drawn at the tine by officers in the English army. $* * *$ [Boston, I862]. I3 pp. $8^{\circ}$. These maps and plans, about 100 in nnmber, were secured by Rev. MIr. Converse at the sale of the collection of William Faden, geographer to the King, and passed from MIr. Converse into the possession of Nathan Hale, the father of Edward Everett Hale. - Letter from Edward Everett Hale, January 7, I904. 
to whom I have nuentioned it. I trust I do not exaggerate its merits or overrate its importance in anticipating that this association will give it the whole weiglit of its influence and indorsement.

Having occasion, as an assistant on the Coast Survey, to make various researches into special points of our coast geography, I found it a matter of great difficulty to collate the various authorities bearing thereon, and still more difficult to make sure that I lad not omitted some such authoritics, possibly of the first importance. It then occurred to me to attempt the collection and methodizing of information relative to maps and charts, and of the localities where they might be found. Something was being done in this way, but it was soon clear that a formidable difficulty would still remain in the dispersion of the materials thus indexed. To remedy this in part, some tracings and printed copies were added to the Coast Survey collection, though the limited means thus applicable prevented anything bordering on completeness, even in regard to our own seacoast.

At this stage of affairs it occurred to me that a complete and special geographical library, not only of materials on the United States seacoast, but of those relating to the whole country-to America at large, and to the whole world-would be a highly valuable aid to all researches, whether undertaken for the Coast Survey or for any other purposeeither of history, of commerce, of home policy, or of foreigu relations. This idea at once connected itself with the Library of Congress as the place of all others where it could best be executed and where it would prove of most value and convenience. Congress is reinstating the Library, after its burning, and now is the time when this plan can best be undertaken.

These geographical aids are greatly needed in Congress for the clear understanding and discussion of many important questions, both domestic and foreign, and in no place could such a collection better serve all interests.

The definite plan which seems to me most worth to be adopted is essentially the following:

I. Let a geographical department of the Congress Library be established as a distinct and independently organized department, with its own executive officer, the general direction being by the Joint Library Committee.

II. Let special appropriations be made for this department, or let the Library Committee set apart a portion of the general Library appropriations for this purpose. During the period of collecting the great mass of existing materials these appropriations would require to be proportionately large.

III. Let the appropriated funds be applied to the collection, arrangement, and indexing of all important geographical materials relating to the whole world; also in part to the necessary expenses of adninistration. 
IV. Among the materials thus to be collected, the following classes nua be mentioned: I. A first-class terrestrial globe. 2. All materials illustrating the early and recent geography of the United States, both its seacoast and interior, including traced copies of all valuable maps and charts in manuscript and not published. The materials for illustrating the past and present geography of each State, county, township, and city should be gathered by purchase, correspondence, and tracing. 3 . All maps and charts on the remainder of America. 4. The Admiralty or seacoast charts of all the European and other foreign States and the detailed topographical surveys of their interiors where such have been made. 5. The most approved maps published from private resources, whether as atlases, nautical charts, or mural maps, including publications on physical geography, guide books, railroad maps, and city handbooks. 6. A complete collection of all the narratives of voyages of discovery and exploration, especially those undertaken by the English and French Governments. 7. Geographical, geodetic, and nautical mannals and treatises with all the requisite bibliographical aids to the amplest geographical investigation.

V. Having an organization and appropriations for gathering such a mass of materials, it would be of the first importance to arrange complete and systematic indices or catalogues, which would at once make known all the material on each locality, and to have those materials so arranged as best to facilitate special research.

VI. A drawing room, in which materials for the collection could be copied either for its files or to answer public and private calls, would be indispensable for the completeness of this scheme. In this room compilation could be conducted in answer to Congressional calls and in keeping constantly corrected and filled out a set of State maps on large scales to which map publishers should have free access.

VII. A competent executive officer would be able to maintain correspondence with persons having special geographical knowledge, and to keep a list of persons who could be addressed for additional information on foreign and domestic localities. Also, corresponding relations should be maintained with foreign geographical societies, and their publications secured with promptness.

VIII. The head of this department conld present, through the Library Committee, an annual report on the geographical explorations by our own and foreign Governments, or by individuals, so far as their results can be learned; making this, indeed, a synopsis of all the interesting and important geographical facts or publications for the year.

IX. Among the duties which should belong to this department would be that of calling attention to points demanding examination, or localities needing exploration. Also it would be able to furnish the preliminary information for such explorations or to indicate the sources whence it could be derived. 
Anyone who will reflect on the outline now presented, nust, I an sure, concede that here is a field hitherto nnoccupied among 11s, wherein much good can be done by one possessing the proper qualifications, and that these qualifications must be eminently special if snccessful results are to be obtained. No collection in the United States approaches to the organic completeness or efficiency here contemplated. The Harvard collection, so excellent in old maps, is very deficient in those great works of interior and exterior survey which characterize the last fifty years. No collection exists in our land which furnishes full materials for extensive investigations, such as are now more and more demanded by questions of history, science, commerce, and policy. There is 110 probability that such a collection can soon be formed anywhere besicles in the Congress Library. As Congress has so much to gain by this plan, and as the several Execntive Departments in Washington would find so great an advantage in such a systematic collection, it should really be made a national undertaking. In the facilities it would furnish the State Department, the Engineer and Topographical Bureaus, the Coast Survey, the National Observatory, and the several naval bureaus the Government would derive a full equivalent for all its cost. The value of such a collection in its relation to legislation; in its illustration of river and harbor questions; in its prospective use for illustrating history, and, generally, as a means of exalting and correcting onr geographical knowledge, gives it, most truly, the character proper for a national enterprise. Nor need we doubt the liberal action of Congress if the subject be well and earnestly brought before it. All intelligent members must at once perceive its advantage and convenience to themselves in discharging their high trusts. There is scarcely a day of Congressional session without some question of home or foreign localities so coming up as to need full and correct geographical resources. Moreover, Congress is always well inclined toward actual surveys and explorations, and it would be peculiarly inconsistent for it to lack liberality in appropriating the comparatively trifling amount needed to bring together and arrange the published and manuscript results of such surveys. There appears, on the whole, no valid objection to the plan proposed and no reason to question that it can be really executed if those who know how to appreciate it will exert themselves somewliat, as is always requisite for the attainment of even the least questionable improvements.

Hoping that this association will cordially approve the views thus presented and be ready to act in faror of their realization, I will now respectfully submit the following resolution:

"Resolved, That the president of this association be requested to appoint a committee of five members to prepare and present, in the name of this association, a memorial to the Joint Library Committee of Congress, urging on it, and through it on congress, the advantages of 
establishing a complete, thoroughly organized, and liberally sustained geographical department of the Congress Library, and presenting therein such a project or plan of organization of this department, as shall seem to the committee best adapted to promote its final usefulness and success in relation to the Government and country at large." =

This resolution was accordingly passed and the following committee was appointed to memorialize Congress upon the subject: Prof. A. D. Bache, Gen. Joseph G. Totten, U. S. Army, Col. J. J. Abert, U. S. Army, Lieut. M. F. Manry, U. S. Nary, Lieut. C. H. Davis, U. S. Navy, Peter Force, Prof. A. Guyot, Lieut. E. B. Hunt, U. S. Army.

The committee at once drew up a memorial urging the importance of such a department in the Library, stating what the collection should consist of, and what would be necessary to its continued usefulness. They said:

There is not in the United States nor on this continent a single collection of geographical materials which is even tolerably complete. The Harvard collection, the collections of the State Department, the Hydrographic Office, the topographical and engineer bureaus, the Coast Survey, the Smithsonian Institution, and those of libraries, colleges, societies, and scholars generally throughout our country, have been formed for some special and limited purpose, and hence, all are at present very imperfect. None rises to the rank of a true geographical library, in which should be found the means of investigating all geographical questions, both of sea and land, at home and abroad. ** * In the French Dépôt de la guerre, on the contrary, we would be able to trace each step and probability, because the French Government has been systematically collecting, through many years, all possible information on this as on all other supposable theaters of war or policy. It is a singular and striking fact that the most extensive collection of maps now in America even in the American department, was collected by Professor Ebeling, of Hamburg, and that this collection, purchased by Mr. Thorndyke, of Boston, and by him presented to the Harvard Library, has been laid under serious contribution for some of our most important negotiations, especially that on the northeastern boundary question.

Next are enumerated the several materials which should be embraced in such a collection. These are, first, all maps and cliarts, whether published or unpublished, which relate to the United States and its waters or to any portion thereof, however minute; second, a complete collec-

'Norton's Lilerary Gazelte 3: 129-130; Proceedings of the American Association for the Advancement of Science (1856), 7: 171-175. 
tion of maps and atlases which have been published abroad, and which relate to other countries; third, geographical-society publications, the results of the various exploring expeditions sent out by the various governments, and such other books and periodicals as are especially devoted to such intelligence; fourth, works on geographical bibliography, and, lastly, a pair of first-class terrestrial and celestial globes. The amount which would be requisite for the establishment of such a department is estimated somewhat as follows: For the purchase of the 2,000 Admiralty charts, the I, 400 French charts, the Einglish, Irish, French, German, Prussian, etc., surveys; the principal atlases; the English, French, Russian, Spanish, American, and other volumes of explorations; the geodetic and nautical works; the gazetteers, encyclopedias, handbooks, etc.; the globes, and many other items which should be procured almost at once, it would seem that an appropriation of $\$ 30,000$ would be no more than a judicious and efficient beginning would require. For subsequent years a less amount would suffice, as the requisite appropriation would but slightly exceed that needed for administration and for the purchase of the special publications of the year.

The qualifications of the superintendent of this department are thus described:

A geographical library can only be formed and duly administered by being placed under the special direction of one versed in geography as a science. In this respect it differs much from any other section of a general library. The materials to be accumulated must be procured from sources so diverse and special that a general bibliographer can not be informed thereon. Many valuable maps and charts exist only in manuscript, and tracings should be procured and verified. This demands an acquaintance with drawing. An active and laborious correspondence would be necessary to bring together the vast number of local maps which are or will be published on the subdivisions of the United States; also the best foreign maps of cities, provinces, etc. Nor can anyone but a geographer of superior capacity attain that critical knowledge of the character and reliability of different maps and charts which is the first essential before using them. The system to be employed in storing, arranging, and indexing an aggregate of many thousand maps and charts differs entirely from that pursued in book libraries. The charge of compiling new maps and of tracing copies for the Library and for individuals, which would be cardinal features in such a library, is totally foreign to the sphere of a general librarian. It would be incumbent on the head of this department to maintain correspondence with geographical societies, with explorers, and with map publishers, all of which could only be done by a geographer. Moreover, it would be highly desirable that an annual report on the progress of geographical discovery and science should be submitted to Congress for the benefit of all who are interested in this important branch. All care should be exercised in pro- 
curing prompt information on such dawning and passing events as involve geographical elements, by corresponding with well-informed authorities, by collecting and studying the publications bearing thereon, and by maintaining a complete reference index in as perfect a condition as practicable. ${ }^{\prime}$

This memorial was presented in the Senate March 30, I 854, by Mr. Everett, with the following renlarks:

This is a very able memorial, and presents in a very striking light the importance of and the necessity for such an establishment. It is signed by the Superintendent of the Coast Survey (Professor Bache); by the Superintendent of the National Observatory (Lieutenant Maury); by the Chief Engineer (Colonel Abert); by Colonel Force, of this city, well known for his acquaintance with this subject; by General Totten; by Lieutenant Davis, who is the Superintendent of the Nautical Almanac; by Professor Guyot, a very distinguished geographer; and by Mr. F. B. Hunt, an intelligent officer of the Engineers of our Army connected with the Coast Survey. I will not take up the time of the Senate by dilating upon the importance of the subject, but I move the reference of the memorial to the appropriate committee, which is the Committee on the Library."

It was so referred.

Mr. Hunt had proposed the establishment of a geographical department of the national library. Mr. J. G. Kohl, on the other hand, desired to begin with a cartographical depot to which a small library might be added as subsidiary merely. ${ }^{3}$

Congress, however, profited by neither suggestion, and the national collection of maps, like that of manuscripts, remained in an inchoate state.

One of the first signs of a recognition of the importance of newspapers was the vote of the committee January 16,1836 , that the newspapers of Washington City not yet taken be subscribed for by the Librarian. After the fire, however, these and other files, including complete files of the National Intelligencer and of the Richmond Enquirer, had to be replaced. February 2, I852, a file of the Pliladelphia Aurora

'Norton's Lilerary Gazelle, new series, I: 189, April 15, 1854.

'Congressional Globr, 33: 789 .

${ }^{3}$ Substance of a lecture delivered at the Smithsonian institution on the plan of a cartographical depot for the history and geography of the American continent. Washington, I856. I p. 1., 93-146 pp. $8^{\circ}$. Reprinted from the Smithsonian report for 1856 . These lectures were printed in full in the National Intelligencer September 9, IS56, etc. 
was purchased; April 19, files of the National Intelligencer and of the Boston Centinel; March 23, I 854 , a file of the Paris Monitcur. 'There was also a file of the London Gazette, I665 to I846, and a file of the London Times, but as Poore observed, ${ }^{\mathrm{r}}$ no New York newspapers, and though the London Court Journal was regularly received and bound at the end of each year, the only American magazine taken was De Bow's Revicu. The difficulty in getting periodicals as periodicals, particularly those published in Europe, is illustrated by the Librarian's complaint that the Harnden express had charged \$I.5O for the carriage of a number of the Edinburgh Review to Washington, besides $121 / 2$ cents for its delivery at the Library. ${ }^{2}$

\section{LIBRARY STAFF AND AGENTS.}

When Librarian Meehan came into office in I $\$ 29$ he was allowed one assistant. The office of second assistant librarian was created by the act of March 3, I84I; the office of third assistant librarian by the act of March 3, I $S_{55}$. By the act of March 2, I83I, a messenger was also added to the staff; by the act of July 27 , r86r, two laborers, and by the act of June 25, IS64, one laborer.

The office of Librarian was held by Mr. Meehan until May 24, I861. Upon the accession of President Pierce in I $S_{53}$, a rumor was started by the Portsmouth (N. H.) Chronicle that Librarian Meehan was to be displaced in favor of Samnel E. Cones, esq., of that city, ${ }^{3}$ whereat the Washington News on the following day observed:

As we have no knowledge of Mr. Coues, personal or otherwise, we have nothing to say either for or against this appointment, but we do regret that so excellent a citizen as Mr. Meehan, of whom we have never heard an evil word spoken for more than twenty years by members

\footnotetext{
${ }^{2}$ Reminiscences, I: $387-388$; note Meehan to Everett, March 23 , IS43.-Library of Congress MISS. The Intelligencer was purchased from the Washington City library at the subscription price of $\$ 10$ per volume. The Librarian expected to pay for newspaper files the subscription price; periodicals he expected to get for less. Meehan to Pearce, March 23, 1857. The file of the London Gazctle had been intended for Windsor Castle.

${ }^{2}$ Meehan to O. Rich, May 16, 1844 .

3. Nationat Intelligencer, May 2n, 1853. See also Meehan to Pe:urce, May $30,1853$.
} 
of Congress or citizens of any party, should be deprived of a valuable office, the duties of which he has so acceptably discharged.

Again upon the accession of President Buchanan, Donald Macleod wrote to Eliza Watterston, daughter of the former Librarian. ${ }^{1}$

IRVing Place, New York,

March 19,1857 .

*** Entre nous, my application for the office of Librarian of Congress has been placed before the President. I also took occasion, as I could not see him again before leaving Washington, to leave a note alluding to days of "auld lang syne" and very delicately to yourself, our common friend. I mention this in case he should mention the circumstance in your first interview. $* * *$

Nothing came of these changes of administration. But with the accession of President Lincoln, Librarian Meehan, being regarded as a Southern sympathizer, was removed from office and his place filled by Dr. John G. Stephenson, who held the office until December 3I, I864, when he was succeeded by Mr. Spofford.

The salary attached to the office of Librarian at the beginning of this period was $\$ I, 500$. By the act of August 4 , I 854 , it was increased to $\$ 1,800$, and by the act of March 3 , I 855 , to $\$ 2,160$.

The office of first assistant librarian was held by E. J. Hume for a year only apparently, for in r8zo E. B. Stelle was restored to the position and held it until, in the political revolution of I86r, he was displaced by Ainsworth R. Spofford.

The salary of the office of first assistant librarian was by vote of the committee, January $\mathrm{I} 2, \mathrm{I} 833$, increased to $\$ \mathrm{I}, \mathrm{I} 5 \mathrm{O}$. This was confirmed by the act of August 26, I842; by the act of August 4, r854, the salary of the assistant librarians was increased to $\$ \mathrm{I}, 500$, and by the acts of March 3, I855, and May 15,1856 , to $\$ 1,800$.

Before the creation of the office of second assistant librarian the committee had voted (February I 2 , I833) that C. H.W. Meehan (the Librarian's son) be employed as assistant in the Library, at $\$ \mathrm{I} .50$ per day during the Congressional sessions, and the act of May 9, I836, provided $\$ 398$ for his services at

\footnotetext{
"Watterston MSS.
} 
this rate from December 2, I 833 , to March 4, I835, Sundays excepted. Like appropriations were made for this office by the acts of March 3, 1837 , and April 6, 1838. Finally, the act of March 3, I84I, made the position permanent, at a salary of $\$ \mathrm{I}, \mathrm{I} 5 \mathrm{O}$ per annum, commencing December I, I 840 ; increased to $\$ I, 500$ August 4, I854, and $\$ I, 800$ March 3, I $855^{\circ}$

Before the creation of the office of third assistant librarian the committee ordered, April 6, I854, that Charles W. Hinman be employed, at a salary of $\$ I, I 5 O$, to be paid from the contingent fund, beginning March I, I854; the salary was increased to $\$ 1,500$ August $4, I 854$, and to $\$ 1,800$ March 3, I 555 , at which time the office was established by law. Mr. Hinman was succeeded by Mr. L. L. Tilden in I86I, and Mr. Tilden was succeeded in 1862 by Mr. George A. Morris, a former resident of Cincinnati, like Mr. Spofford, and librarian of the Young Men's Mercantile Library Association in that city. ${ }^{2}$

The salary of the messenger, by the act of March 2, I83I, was $\$ 500$ per annum. On the $25^{\text {th }}$ of February, I8 32 , however, the committee voted that he be allowed, out of the contingent fund, \$I 50 in addition to his regular salary for that year and the year previous; on the 27 th of March, $18_{34}$, it voted that his annual salary be $\$ 700$. This was confirmed by the act of August 26, I 842 . It was increased to $\$ I, 200$ by the act of August $4, I 854$, and to $\$ I, 440$ by the act of March 3, I 855 .

On the 28 th of January, 1842 , the following minute regarding labor was entered in the records of the committee:

The Committee on the Library believe that in addition to the pay recommended for the messenger of the Library; that officer should be allowed also, during the session of Congress and for a month or two before, and at the short session a month or two after, a reasonable compensation for the expense he is obliged to be at for labor to provide for fires, etc., which the committee understand is about $\$ 25$ per month, or whatever it may be shown to be.

Ordered, That a copy of the foregoing minute be sent to the Committee on Ways and Means. 
On the $7^{\text {th }}$ of February, $\mathrm{I} \$ 44$, the committee ordered that a boy be employed to make fires and do the chars of the law room during the sessions of Congress, at a compensation of $\$$ IO per month. J11y 27, I $\delta 54, \$$ I.25 per day was voted for a laborer to do all the chars of the Library. June I2, I860, \$1.25 per day was voted for an additional laborer to do the chars in the law library during the session of the Supreme Court, and for two weeks before and two weeks after each session of the court. Finally, the act of July 27, IS6I, provided regularly for these two laborers, at a salary of $\$ 500$ each per annum, beginning Jily I, IS6I. One laborer was employed in the general library, the other in the law department.

The position of financial agent of the Library Committee was filled by the appointment of Thomas L. Smith, Register of the Treasury, to that office March 7, I830. The business of this officer was to pay the bills of the Library and keep and settle its accounts. This became more onerous each year and finally, July $9, \mathrm{I} \delta_{3} \delta$, the committee voted $\$ 250$ per annum for the services of the financial agent, to commence January $\mathrm{I}$, I $S_{3} S$.

Mr. Smith's successors in the office of financial agent of the Library, as well as in that of Register of the Treasury, were R. H. Gillett, appointed in the spring of I845, Michael Nourse, appointed August 4, I848, Finley Bigger, appointed December I3, I860, and Lucius E. Chittenden, appointed July I9, IS6I, giving bond in \$20,000.

Book agents were appointed by a resolution of the committee, May 2I, I830-Pishey Thompson for America, and Obadiah Rich for England; these agents to procure and furnish for the Library all such books as were ordered from them, they procuring such books on the best terms they could obtain, at wholesale prices, and delivering the same in the Library at the prices actually paid by them for the books, with 10 per cent thereon for their compensation including all services, profits, and expenses of transportation or otherwise. ${ }^{\mathrm{I}}$

The position of agent for American publications was thus occupied by Pishey Thompson, of Washington, until I843,

\footnotetext{
'Minutes, February 16, I843. Wiley \& Putnam offered to supply the Iibrary with any work whatever within 35 days after receiving an order for it. - Meehan to Rich, Oenier 28,1844 .
} 
when he returned to England. He was succeeded by Mr. Franck Taylor, of Washington, who served the Library in this capacity from February I6, I 843 , to Jannary 7, I863. The position of agent for English publications was held by Obadiah Rich until his death, January 20, I $S_{5} \mathrm{O}$. He was succeeded by the firm of Rich Brothers, and June Io, I858, by Edward Allen. ${ }^{\mathrm{I}}$

The position of agent on the Continent was not created until after the establishment of the line of steam packets to Havre in I847. June I $7, I S 42$, a letter had been received from Hector Bossange, with a copy of his catalogue, tendering his services as agent for purchasing books published on the Continent, at 5 per cent commission, very low terms, remarked the Librarian, considering the interest on the bills against the Library for the months that necessarily intervened between supply and payment. ${ }^{2}$

This offer had been repeated after the institution of the system of international exchange, with this modification, that if the services of M. Bossange as buyer were accepted and compensation made therefor at a small percentage, M. Bossange would, without any charge whatever, attend to the interchange of public documents, etc., for the Library, with the public offices in France. Wherenpon the committee roted that the chairman be authorized to make arrangements with M. Bossange for the purchase of French books. ${ }^{3}$ These arrangements were completed and the appointment made July $27, \mathrm{I} \delta 54$.

Imported books were consigned by the European agents of the Library to the care of the collector at New York. After I 830 the committee had an agent in the New York Custom House, assigned by the collector to look after importations. In I 847 he was given a formal power of attorney:

Know all men by these presents that I, John S. Meehan, Librarian of the Congress of the United States of America, have constituted and

\footnotetext{
'The compensation for their services just after the fire of 1851 , i. e., from January 26 , I 852 , to July 25 , I856, was reduced from to to 5 per cent on all purchases made by them. Messrs. Rich did not charge a commission for hooks drawn from their own stock.-Meehan to Pearce, December 3, i852.

= Meehan to Woodbridge, October 19, I 8.43 ; November $3,18.43$.

${ }^{3}$ Minutes, January $29,185 \mathrm{r}$.
} 
appointed, and by these presents do constitute and appoint Edgar Irving, of New York, my agent and attorney, to enter bond and receive any and all books and packages imported into the Port of New York from foreign countries for the Library of the Congress of the United States, and to transmit said books to me at Washington City, and draw upon me for the duties and expenses to be paid out of the appropriation by Congress for said Library. This authority given under direction of the Joint Library Committee of Congress and in virtue of my office as Librarian. The necessary bond to be in my name.

Wituess my hand and seal at the Congressional Library in the Capitol, Washington, April 23, 1847.

[SEAL.]

JOHN S. MEEHAN,

Witnesses--

$$
\text { Librarian of Congress. }
$$

E. B. STELLE,

ROBER'T KEARON.

In the same year an agent was appointed in the Boston Custom House to look after the business of the Library thereperiodicals and other works wanted without the delay attending their transmission by the New York liners being sent by the Cunard line of steamers to that point. ${ }^{\mathrm{r}}$

THE LIBRARY SERVICE-CATALOGUING.

Into the routine of the Library and the services of the Library staff, during this period, we have some interesting glimpses. On the I $3^{\text {th }}$ of July, I 854 , the Librarian reported that a case of books, sent to the Library by the agents of the Library Committee in London, had been injured by falling into the river at Havre de Grace, Md., while in charge of Adams \& Co.'s Express. On the 26th of February, I855, the committee received a letter from Adams \& Co., in relation to the books, and it was "Ordered, that the Librarian be authorized to settle with them the amount to be paid for the injured books." July 25, I856, the loss of this case of books being under consideration it was "Ordered, That the Librarian be directed to consult the Solicitor of the Treasury as to the legal steps to be taken to coerce payment, or supply the books." The Librarian bought books as opportunity offered at home, at anction sales or otherwise. ${ }^{2}$ For gifts of books to

'Meehan to J. W. Arnold, May 29, June 4, 1847.

= Minutes, $\Lambda$ pril 17,1830 . 
the Library a copperplate form of acknowledgment was ordered, January 3 , IS 34 . For the binding of books the Librarian was made responsible by resolutions of the conmittee, December 30, IS29, and Jannary 9, IS3O. The binding was generally calf, varied occasionally by substantial half bindings in calf, morocco, or Russia leather, the sides of munslin marbled to resemble in appearance the best and neatest marbled papers. ${ }^{1}$

For the convenience of readers the Librarian was instructed, January 9, I 830 , to place on the tables the latest numbers of periodicals received by the Library, and, May 8 , I 844 , to purchase cheap paper, to be supplied to persons who desired to make extracts from the books in the Library. The service of the staff to the Library and to the reader was not, however, limited to these activities. The absence of a good catalogue and the existence of the iron grating in front of the shelves and alcoves made the services of the members of the Library staff indispensable, if anything whatever was to be done by the reader. And, as the following testimonial of Caleb Atwater will show, these services were appreciated:

Mr. John Meehan, the Librarian, and Edward B. Stelle, C. H. W. Meehan, and Robert Kearon, his assistants, "are among the most polite and agreeable gentlemen in this city [Washington]. They are always ready to attend to the wishes of all who call on them. Personally acquainted with nearly all who call at their room, they are always ready to introduce a stranger to any gentleman who is in the room. Fatigued as they sometimes are with the constant labor of a long day, yet they never complain of their toil, but cheerfully attend to all the wants of the visitors. This room is opened very early in the morning, and not closed until a late hour. If any officers of the Govermment deserve all their salaries and more too, they are the Meehans, father and son, Stelle, and Kearon. Their salaries are small ones, and their labors are great and fatiguing all day long, during the whole session of Congress. During the long intervals between the sessions their labors are not so fatiguing, but they are even then constant, unremitting, and useful to the visitors, who are always all day long in this Library. Having known these gentlemen fourteen years and upward in their present stations, I take a real pleasure in bearing this testimony in their favor. ${ }^{2}$

IMeehan to Bossange, March 29, IS53.

2 Mysteries of Washington City during several months of the session of the Twentyeighth Congress. By a citizen of Ohio. Washington, 1844, pp. 73-74. There is a pleasant notice of Kearon in the Huntress, December 14, IS39.

$23399-04-23$ 
During the period I829-I86I four general catalogues were issued-that is, one every ten years. Each of these, except the first, was accompanied by a special catalogue of the law library reprinted from the general catalogue, and each was supplemented by annual catalogues of accessions to the Library. The first of these general catalogues, that of i 830 , was compiled by merely cutting up the catalogue of I 8 I 5 and its three supplements and rearranging the titles. It followed the classification of the Jefferson catalogue and even preserved its typographical errors. It was an improvement upon the old catalogue in only one respect-it indicated at the head of each chapter the number of the alcove in which it was located, so that with the aid of a printed catalogue a stranger might at once obtain the object of his search withont reference to the Librarian. This improvement excited the applause of the Telegraph (January I I, I83I).

The catalogue of 1840 was even worse. It necessarily became worse and worse the larger the Library became. It did not contain the feature of the catalogue of 1830 which had aroused the admiration of the Telegraph. Wheatley describes it as a typical specimen of bad work. "The index of authors in it," he says, "contains such vague references that in some cases you have to turn over as many as 70 pages to find the book to which you are referred. The third entry in the index, for example, is 'Abdy', and the reference 'XXIX, 2I 5, i.' 'Xxix' applies to the class, which is geography. The title is to be found in section $\mathrm{v}$, America, so that actually 70 pages of the catalogue have to be glanced througl before the work of Abdy can be found." I

There was but one Abdy, but there were many Smiths. The index entry for Snith was as follows: "Smith I, 84,84 b, I69; III, I65b, I8I; IV, 27a, 90, 9I, I37, I77, I93, 238; VIII, 29; Ix, 9, I5, 20; NII, 8, 8a, 43, 8o; xiII, 7c, 22e; Xv, 44, 74, i64a; Xvi, 1, I68, I69, I74c; xvil, 260, 262b, 284a; xxiv, 64, 370a, 38ob, 405, 406, 407, 445, 460, 470, 471, 474, 594; xxv, 24a; xxix, I03a, 550, 554, 807a; xxxil, I 2 b; xxxvi, 62; xLI, I6a; XiIII, I8; XlıI, I34a, I43." So that if one desired to

${ }^{x}$ H. B. Wheatley, How to catalogue a library ( 1889 ), p. I8. 
ascertain whether the Library contained Cliarles Hamilton Smith's "Ancient costnmes of Great Britain and Ireland," which was classed in chapter 29, Geography, section 2, Enrope, with the bookmark Xxix, So7a, he would have to go through many times 70 pages before he discovered the object of his quest.

The catalogines of IS49 and IS6I were no better, except that they dropped this poor anthor index, - a questionable improvement.

On the other hand, as they became larger and as an anthor catalogue more useless, they became ninore expensive. The catalogue of 1840 cost $\$ I, 673,{ }^{1}$ that of $I 849$ cost $\$ 2,000,{ }^{2}$ and that of $186 \mathrm{I}$ cost $\$ 4,000 .^{3}$ And in these sums are not included those expended upon the supplementary catalogues, which were also becoming each year more and more expensive.

The necessity for an improved and less expensive catalogue led to an interesting correspondence in the National Intelligencer, which we must reproduce. The author of these letters on cataloguing was not the former Librarian, as some thought, but another gentleman. The correspondence was as follows:

\section{MESSRS. EDITORS:}

I'ill you allow me to avail myself of the medium of your paper to offer a few suggestions which may be found not unconducive to public utility?

I am led to understand that it is in contemplation to give a new catalogue of the Congress Library. Such an improvement is much called for. In the first place, the supplements to the present catalogue are growing much too numerous and embarrassing; but by far the most important reason for an entirely new catalogue is the very imperfect character of the present one. The principle on which it is framed is defective, not to say preposterous. It is one of the varions modes that have been derised for facility of reference, but which has been abandoned as defeating its own purpose. The old alphabetical plan has been returned to in drawing up the catalogues of the principal libraries in Europe, as being found, after all, the most simple and effective. In the face of such examples, it is matter of surprise that the good old rule should have been departed from in forming the catalogues of the Con-

${ }^{1}$ Acts of July $7,18_{3} 8$, and September $11,18_{4} 1$.

${ }^{2}$ Act of March 3, I849.

3 Act of March 3, I857. 
gress Library, important as that collection is in richness of materials, though not numerically imposing. The method followed has been the very difficult one of a classification of the subject-matter-a method frequently doubtful, and always perplexed and embarrassing, and which is followed by a list of anthors, attempted to be adapted to it. Now, let but the inverse order be followed, and all will be found lucid and harmonious; and of this order a masterly exemplification will be found in Watt's Bibliotleca Britannica, of which there will be found a copy in the Library. Nothing can be more simple and inartificial, and yet notliing more lucid and satisfactory. Let the body of the catalogue be purely alphabetical, ranging anonymous works under their respective heads and dates. To this may be appended a synoptical table of classification according to subject-matter, comprising merely the names of the authors, a reference to which in the body of the catalogue will be immediate and unerring.

As new accessions are continually making to the Library, in order to obviate the necessity of often renewing the catalogue, let the example of the British Museum be followed; let a copy of the catalogue be pasted in one or more blank folio volumes of substantial paper, leaving every other page blank to receive new-coming authors, who will find their proper alphabetical position opposite the respective printed names. Such interlined catalogue should be kept in one conspicuous place in the Library for general reference.

Hoping that these hints, which are the result of some experience, may be found practically useful,

I an, gentlemen, yours, etc.,

W.

NOVEMBER IO, $183 \%{ }^{\mathrm{T}}$

\section{MEssRs. EDITORS:}

I have, among others, to acknowledge my obligation to your correspondent under the signature of $\mathrm{W}$. for the excellent hints thrown out by hin relative to the best method of accomplishing that important object, a good Library catalogue. He says that the information communicated by him is the result of some practical experience. I an sure that every one who has read his communication will give him full credit for his assertion, but as they were merely hints, and as he did not stop to particularize, I would beg leave to trespass on his kindness by proposing one or two queries fur my practical guidance.

He speaks of a "printed catalogue to be pasted on one or more folio volumes of blank paper, and the blank pages to be kept open for the insertion of additional works." Would he oblige me by giving some more specific particulars of a method which nust be important if adopted in the great European libraries mentioned by him?

He also says that in cataloguing anonymous works, one of the most difficult tasks in the operation, they should be entered according to the

'National Intelligcncer, November 13, 1837. 
subject and date. As I can not clearly see how this is to be done withont militating against the very rule laid down, of clearness, and more particularly, of succinctness, will he also oblige me by specifying the 111anner in which this is to be done?

Such are the queries on which I would solicit him to throw some further light, and in doing which, at least as far as I am concerned, your correspondent would be carrying out his wish to be useful.

MESSRS. EDITORS :

Happy at all times in having it in my power to be useful, and particularly when a favorite subject is in question, I hasten to respond to the queries put to me by your correspondent " $\mathrm{L}$."

In the first place, with respect to the folio catalogue of the Library of the British Museum, it is constructed as follows: On each right hand page of a folio volume of substantial paper is pasted in the centre of the page a leaf of the ordinary catalogue, which is of the octavo size. The page opposite being left blank all addenda to the Library are entered on it, as nearly as possible opposite the corresponding name in the printed page. For instance, in the printed page is found Smith, J.; should any new work by a J. Smith be added to the Library, it is entered in the blank page opposite this name, and consequently presents a ready means of reference.

N. B. - The blank folio page may be divided into two columns, which will allow room for ample additions; should the page become filled, there should be a reference to an addenda page at the end of the volume, carrying on the letter.

Another useful hint that may be taken from the catalogue of the British Museum is the following: With a view to bring together as far as possible, under one point of view, all that appertains to a given author, not only the different editions should be specified (and that in chronological order), but also the names of translators, commentators, etc., though their works are found under their respective headings; for instance, under the head Homer, after an enumeration of the various editions of his work, should appear: Sec Ogilvie, Pope, McPherson, Cowper, Southeby, Wolf, Coleridge, etc. The value of this to the student is far greater than appears at the first view.

With respect to the anonymous works, they should, as I observed before, be classed under the respective heads of their subject-matter, and according to the order of date, as, for instance:

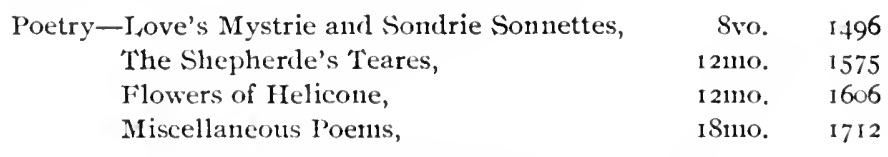

${ }^{2}$ Vational Intelligencer, November 17,1837 . 
And so on through all the different headings found in the well-arranged synoptical table, by which the present catalogue of the Congress Library is prefaced.

By the way, while speaking of this excellent table my suggestion would be to retain it in the new catalogue, and, exactly in the inverse ratio to the present catalogue, range the names of the authors alphabetically under each heading, so that the classification of subject-matter may exist as perfect as in the present catalogue.

Another advantage of this arrangement is that it furnishes a chronological list of subject-matter highly valuable to the curious.

Before concluding, there is another suggestion which I would beg leave to offer. It would be found highly conducive to mutual interests, that, as in Europe, so throughout the Union, a correspondence should be maintained between the different librarians; so that if, as frequently happens, some library is in possession of duplicates of rare and valuable works, such duplicate may be exchanged for some other duplicate possessed by that establishment. Such an arrangement would be found of great reciprocal advantage, and highly conducive to the interests of letters.

$W^{x}$

This correspondence seems to have had no immediate effect upon the cataloguing of the Library. But with the coming of Professor Jewett to Washington and the initiation of his plan of cooperative cataloguing a reform was at last inaugnrated, and after the arrival of Mr. Spofford, accomplished in the author catalogue of I864. A part only of the history of this movement may be given in this place; the remainder will be given in a following chapter.

In 1850 Professor Jewett said in his "Notices of public libraries" (p. 139): "The Library of Congress is one of great value, and is worthy of a minute and accurate catalogue, one in which every book, pamphlet, map, handbill, speech, and important article in a review or magazine should be entered carefully and accurately under the name of its author, and alphabetical and analytical indexes of subjects should be made; it should be a model performance, but it should not, of course, be required from the present force employed in the Library, which is not sufficient for the regular work of the establishment. The making of a catalogue should be a separate affair."

'National Intelligencer, November 24, 1837. 
In an address before the American Association for the Advancenient of Science in the sane year ${ }^{\mathrm{I}}$ lie called attention also to the cumbersomeness of the systen of catalogue supplements. The supplements to the last general catalogne of the Library of Congress numbered nine. The student was thus obliged to grope his way through ten catalogues instead of one in order to ascertain whether the book which he sought was or was not in the Library. And he could not be certain even then that the book was not in the collection, for it might have been received since the last supplement was printed.

The commission appointed by the Secretary of the Smithsonian Institution to which Professor Jewett's plan for cataloguing was submitted made a report October 26 I 850 , which concluded as follows: ${ }^{2}$

In order that a beginning may be made in the execution of the plan, under circumstances highly favorable to its success, the undersigned take the liberty of suggesting that it would be advisable for the Regents of the Smithsonian Institution to obtain the requisite authority to prepare a catalogue of the Library of Congress on the above-described plan. A catalogue of this Library is now very much wanted. Originally constructed on a defective plan, and continued by the publication of a large number of supplements, it is now almost useless, and, as the Library increases, it becomes daily more so. The preparation of an alphabetical catalogue has in this way become a matter of absolute necessity for the Library itself, while it affords the best opportunity for commencing an arrangement by which the various libraries of the country will be brought into a mutually beneficial connection with each other on the plan proposed by Professor Jewett.

The undersigned consider the permanent superintendence of this plan to be an object entirely within the province of the Smithsonian Institution. They are satisfied that it will tend both to the increase and diffusion of knowledge, and they therefore hope that the sanction of the Regents and of Congress will be given to the undertaking.

The Library of Congress, it was felt, could bear the cost of the first collection of stereotyped titles better than any other library. Moreover, it was desirable that the first catalogue

'This alldress was printed in the Proceedings of the association and reprinted with the title, A plan for stereotyping catalogues by separate titles, and for forming a general stereotyped catalogue of public libraries in the Uniterl States. By Charles C. Jewett. Washington, :\$51. 14 p. $8^{\circ}$.

${ }^{2}$ Charles C. Jewett, On the construction of catalogues of libraries, $1852, \mathrm{pp} .77-78$. 
should be prepared near the Institution, where the work could be more conveniently supervised and rendered accurate. Nor wonld it be necessary on this plan to finish the preparation of the entire catalogue before beginning to print it. The stereotyping might commence with the cataloguing, and the catalogue might begin with any part of the Library. The catalogue might thus be published in parts, each containing the books on a particular subject, and these parts afterwards be combined to form a complete catalogue, either alphabetical or classed. The stereotype blocks of the titles would be preserved in the Institution, and a complete annual catalogue of the Library furnished at a cost less than that of the old decennial catalogues. The same titles would also be employed in printing the catalogues of other libraries, and the new titles which might be prepared for these would, in turn, be used without charge for the Library of Congress.

Accordingly, at a meeting of the Board of Regents of the Smithsonian Institution, February I2, I853, the following preamble and resolution were adopted:

Whereas a plan for stereotyping catalogues by separate titles, and for preparing and printing the catalogues of the various libraries in the United States in uniform style and at greatly dininished cost, as well as for forming a general catalogue of all these libraries, was presented to the Smithsonian Institution and referred to the two commissions-one to report upon the literary advantages of the plan and the other upon the practicability of the means proposed for its execution; and

Whereas on the recommendation of these conmissions the Suithsonian Institution has incurred the expense of procuring type and apparatus, of educating workmen, and of developing and perfecting processes to be employed, so that all arrangements are now made for the successful prosecution of the work; and

Whereas the first commission appointed to examine the plan, in their report, recommended that, "In order that a beginning might be made in the execution of the plan under circumstances highly favorable to its success, the undersigned take the liberty of suggesting that it would be advisable for the Regents of the Smithsonian Institution to obtain the requisite authority to prepare a catalogue of the Library of Congress on the above-described plan:", Therefore,

Resolved, That the Secretary of the Institution be requested to call the attention of the Library Committee of Congress to the above-described plan, to inform them that the Institution is now ready to execute the proposed work, and to invite their cooperation in aid of an enterprise so 



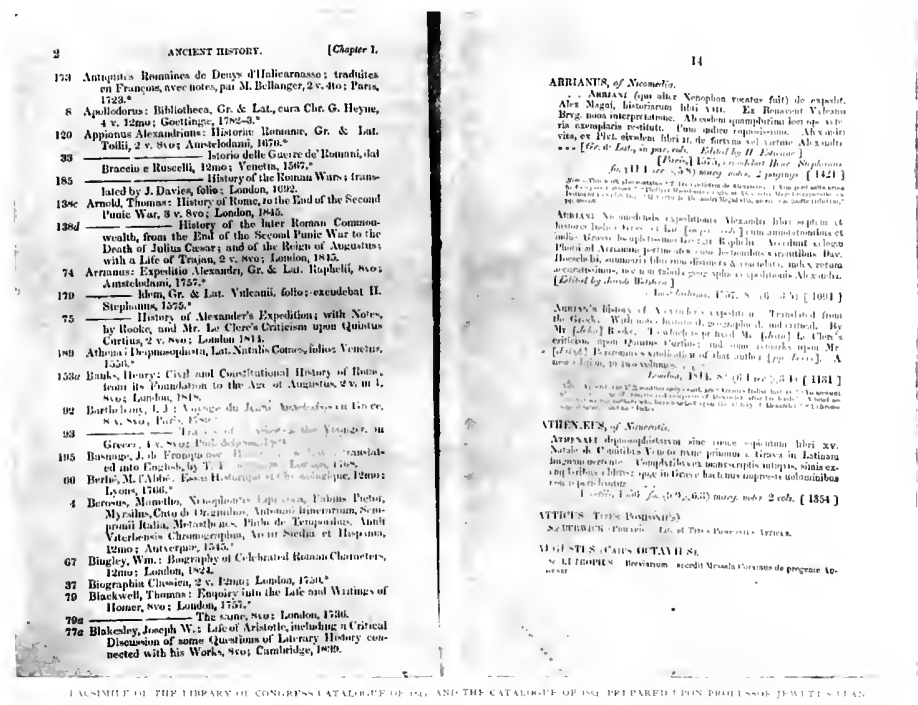


important to the Library of Congress, to all the libraries in the country, and to the great object of this Institution, "the increase and diffusion of knowledge." '

In consequence, on the $3 \mathrm{~d}$ of March, i $S_{53}$, the Library Committee "Resolved, That a general catalogue of the Library of Congress be prepared upon the plan recommended by the Smithsonian Institution. That the selection of a cataloguer or cataloguers, be left to the determination of the Librarian and the Secretary of the Suithsonian Institution, and that a contract be made on the part of the Library Committee, with the said Institution, in accordance with the plan submitted to the committee, and that the Librarian be directed to make said contract with the approval of the Chairman, to whose decision, in case of necessity, reference shall be had." And on the $3 \mathrm{~d}$ of March, I853, Congress appropriated $\$ 3,000$ for the preparation and publication of the catalogue.

The plan met with equal favor among librarians. On the I6th of September it was explained by Professor Jewett ${ }^{2}$ to the librarians assembled in convention in New York in much the same language as he had used before the American Association for the Advancement of Science two years before, and on motion of Mr. Folsom the convention passed resolutions to the same effect as those passed by the Association for the Advancement of Science, as follows:

Resolved, That we have considered attentively the plan for constructing catalogues of libraries, and a general catalogue of the public libraries of the United States, by means of separate stereotyped titles originated and prepared by Professor Jewett and developed by him while librarian of the Smithsonian Institution. That we regard it as an object of high importance to the interests of our public libraries and to the promotion of learning, and worthy to share in the funds of the Institution and the zealous exertions of its officers; the more so as it is an enterprise which can not be successfully prosecuted except under the guidance, protection, and pecuniary support of this central establishment for the increase and diffusion of knowledge.

Resolved, That we have learned with pleasure that Congress, on the recommendation of the Library Committee, made an appropriation

\footnotetext{
'Seventh annual report of the Board of Regents of the Smithsonian Institution, p. 95; Thirty-second Congress, second session, Senate miscellaneous docunents, No. 53, March r, $1 S_{53}$

'This is reported in Norton's Lilerary Cazelte, 3: 173; in the Lilerary World, I3: 154, and in the National Intelligencer, November 26, 1853.
} 
for the practical testing of the plan in its application to the Library of Congress, and that the work is now in successful progress.

Resolied, That, as practical librarians and bibliographers, we take pride and satisfaction in the fact that a measure of so great literary utility has received the prompt and efficient support of our national legislature; and we would express the earnest hope that this support may be extended to it liberally till its first great result in the complete stereotyped catalogue of the Library of Congress shall be attained. ${ }^{x}$

Work upon the catalogue had been begun in August, I 853 . By the end of the year 6,000 volumes had been catalogued, 4,000 of which were in Chapter I, Ancient history. This part was then published, at the suggestion of the chairman of the Library Committee, as a specimen of the proposed work. The rolume was entitled: "Catalogue of the Library of Congress. Chapter I. Ancient history. Complete to January, I 554. Washington: Stereotyped and printed at the Smithsonian Institution, I 854." The work appeared both as a manual in octaro, and as a reference book in folio in double columns. The catalogue being intended to contain a full and accurate description of the books in the Library, every title was as far as possible an exact transcript of the original, and notes were appended where essential. The book also contained cross references and an index of subjects. A general index to the contents of the Library was planned to supplement the classed catalogue.

In the preparation and publication of this catalogue, however, two-thirds of the appropriation had been expended. The cataloguing was thus costing about $33 \mathrm{x} / 3$ cents a volume, whereas the actual outlay upon the former catalogues of the Library had not exceeded 5 cents per volume. To meet the objection which might be raised on this score, Professor Jewett said in his report for ${ } S_{53}$ :

It is obrious that the cost of the first catalogue will be greater than if it were not stereotyped. The work of preparation will also be more expensive, but the additional cost of the first edition will be more than saved in the reprinting of the whole catalogue. It will be further understood that the sum paid by the first library is not only for its own benefit, but for that of every other library hereafter adopting the plan, so far as its books are the same. Congress is, therefore, now conferring a great

"Eighth antual report of the Smithsonian Institution, p. 32; Thirty-third Congress, first session, House miscellaneous documents, No. 97. 
boon upon other libraries, while at the same time it is taking the course the most economical for the procuring of its own catalogue. * * *

As soon as the catalogue of the Library of Congress shall be completed, other institutions, and even individuals, are ready to avail themselves of the scheme for procuring their catalogues. Its general adoption-the crowning point of all our efforts-seems, therefore, as sure as the completion of the first work. ${ }^{x}$

On the 3 Ist of May, I $854, \$ 5,000$ more was roted for this catalogue. But in the summer Professor Jewett was obliged to resign his position as librarian of the Snithsonian Institution, and thongh his work was carried on under the direction of Professor Jillson, of Brown University, and some 9,654 titles, or 21,So5 volumes, catalogued by the end of the year I 854 , no more of the catalogue of the Library of Congress was printed upon this plan. In his report for $\mathrm{I}_{54}$, dated February 28,1855 , the Secretary of the Smithsonian Institution expressed the hope that an additional appropriation would be made during that session of Congress sufficient to complete the whole catalogue. The Institution, he said, wonld then have the statistics necessary to ascertain the cost of preparing a catalogue of this kind, and the means necessary to give definite information in reference to it to the principal libraries of the country.' In his report for IS 55 , dated July 24 , I 856 , Secretary Henry said that the number of titles prepared was 15,885 , with 7,949 cross references, the whole number of volumes catalogned being 32,986 . This number, he said, embraced all the volumes which were in the Library at the time the catalogue was commenced, with the exception of the law department, the bonnd volumes of tracts, and some incomplete works. It also included the additions made in the general library to Chapters I, II, III, and IV, previous to April, I 85.5 , the additions to the different chapters previons to the time they were catalogued, and at least one-half of the additions made during the past year. The whole amount expended on the preparation of the I 5,885 titles was $\$ 4,97$ I.O7, and that of stereotyping abont 4,000 titles, \$2,974.9I. The

\footnotetext{
${ }^{2}$ Fighth annual report of the Suithsonian Institution, pp. 31,32 .

"Ninth annual report of the Smithsonian Institution, 1). 23; Thirty-third Congress, second session, Senate miscellaneous documents, No. 24 .
} 
appropriations made by Congress were therefore exhausted, excepting $\$ 54.02$. $^{\mathrm{T}}$

On the I4th of November the American Organ announced that the printing of the catalogue of the Library prepared upon the Smithsonian plan had been abandoned, and that a catalogue of the recent accessions prepared upon the usual plan was in press.

The catalogue of the Library of Congress published in I 86I was constructed upon the same plan as previous general catalogues, except that like the catalogue of I 849 it was without the poor index which was the characteristic feature of the catalogues of I8I5, I $8_{3} 0$, and I840. The scheme of classification was also modified somewhat.

In the "Alphabetical catalogue of the Library of Cougress," published in $\mathrm{x} S 64$, the one desideratum of a large library, an alphabetical author catalogue, was finally secured. The preface to this volume explained this departure in the cataloguing of the Library in the following language:

The last general catalogue of the Library of Congress was issued in 1861, and embraced the accessions to the close of the year 1859. Four general catalogues, besides numerous annual supplements, had been published previously, viz, in $1815,1831,1839$, and 1849 , respectively. Since the last issue, in I861, nearly twenty thousand volumes have been added to the Library, and five annual supplements to the catalogue have been issued. To consolidate all these catalogues into a single volume, and to facilitate reference by reducing the multifarious alphabets of former general catalogues to one alphabetical arrangement is the object of the present volume.

All former general catalogues of this Library have been arranged upon a system of classification prepared by Thomas Jefferson, and based upon Lord Bacon's division of knowledge. This classification, however well adapted, in some respects, to a small library, like that of Mr. Jefferson when adopted in I 8 I 5 as the basis of the present collection, is wholly unsuited to the necessities of readers consulting a large library. It was never designed by its author as a bibliographical system, but rather as a scientific arrangement of the various branches of human knowledge. No further illustration of its defects need be given than the fact that in the last catalogue of the Library of Congress the titles are distributed through a series of 179 distinct alphabets, arranged in an arhitrary sequence, and without an index. Few readers have the

\footnotetext{
${ }^{1}$ Tenth annual report of the Smithsonian Institution, p. $3^{\text {I }}$; Thirty-fourtl Congress, first session, Senate miscellaneous documents, No. 73.
} 
leisure and fewer still the inclination, to study the intricacies of such a system of classification. In abandoning it for a 1110re simple method, the officers of the Library are assured that they liave consulted the convenience as well as the wislies of Congress and of other frequenters of the Library.

In the arrangement of any catalogue of books, the clief desideratum, next to accuracy of description, is facility of reference, and to this end all minor considerations should be sacrificed. This volume embraces the present contents of the Library, arranged in all cases under the names of the authors, when known, anonymous works being entered, for the most part, under the leading word of the subject they treat of. This method, while it is a departure from the more n11iform rule of entering anonymous works under the first word of the title, as practiced by some bibliographers, is unquestionably of greater utility to the general reader, and is not without high bibliographical authority.

To complete the plan adopted, the present alphabetical catalogue of authors will soon be followed by an analytical catalogue of subjects, also arranged alphabetically, and covering the whole field which the works embraced in the present volume illustrate. Those consulting the Library' will thus have before them the means of determining, by a single reference, whether the Library contains any work, if the author's name is known; and also, by a single reference, whether it contains any book of which the subject is known.

Library of Congress, September, I864.

This catalogue, the first fruits of the service of Mr. Spofford on the staff of the Library, was in I869 supplemented by a "Catalogue of the Library of Congress. Index of subjects," in two volumes. Chronologically, this work does not belong to the period to which we have limited our discussion, but as it was an essential part of the reform in cataloguing introduced by Mr. Spofford as chief assistant librarian, we must present the preface of the latter work in this place as the sequel to the preface of the former. The preface to the subject catalogue of IS69, reads as follows:

The purpose of this catalogue is to afford the readiest available key to the books upon every subject wlich the Library of Congress embraces. It is not its purpose to furnish a bibliographical system, nor to add another to the numerous existing attempts toward the classification of human knowledge. In any such classification any arrangement except the alphabetical one must, from the nature of the case, be purely arbitrary. While every man can construct a system which sufficiently suits himself, it is commonly found that it is clear to very few others. The 
one thing needful in a catalogue of subjects is instant facility of reference; and if a scientific arrangement of topics is sometimes sacrificed to this end, the student whose time is saved will be little disposed to quarrel with the bridge that carries him safely over.

The alphabetical arrangement of topics has been adopted and adhered to, both in the general alphabet and under each subordinate head, with occasional modifications where there seemed to be an overruling reason for it. This method has one undeniable advantage over all others-it is its own interpreter. The alphabetical arrangement of topics, with a sufficiently copious system of cross-references, solves every difficulty as soon as it arises, instead of keeping the reader on a baffled search for knowledge. It thus fulfills the end of the highest utility.

Some catalogues have endeavored to accomplish the object of a systematic index by grouping the names of authors on each topic as catch words in an alpliabet of subjects, placed after a catalogue of authors, or mingled with such a catalogue in the same alphabet. This system, while it is unquestionably better than none, is open to the serious objection that it demands from every reader seeking specific information a double reference for each work; first to the index of subjects to find the topic, and next to the index of authors to find the full title and the date of the rork. This involves a considerable loss of time in the case of each work, and when this is multiplied by all the books to be consulted on a given topic the delay becomes incalculable. The present catalogue is constructed upon the principle that the reader is entitled to find all the works upon any topic fully described under that topic, and by a single reference, thus saving the time of the student for more important investigations than catalogue hunting.

The only important deviation from this rule consists in the grouping of subordinate topics under the general class to which they belong. Thus the various divisions in theology, law, and medicine will be found arranged in subordinate alphabets under those general heads, instead of being scattered throughout the catalogue. While much may be said in favor of the latter arrangement, it is believed that the assemblage of all the titles belonging to a given subject, along with their related topics, is more in consonance with the convenience of readers, as well as far more suggestive in point of the information conveyed by the catalogue. Especially where the catalogue, as in the present case, extends beyond a single volume, the synthetic arrangement under a comprehensive head becomes a labor-saving expedient to the student, who is thus saved the constant turning from one volume to another in his investigation of one general subject. The sole objection to this method is met by a great number of cross-references from particular to general topics, and by an alphabetical arrangement of subordinate topics under their general head.

The imperfections of the catalogue are many, and they represent not only the limitations of the Library which is here catalogued, but defects of plan and arrangement which would have been obviated by more time 
devoted to the publication. But the printing of some kind of a catalogue of subjects with the least possible delay being deened a necessity, these discrepancies and faults of execution could not be wholly aroided. The work is presented, therefore, as but an approxination to a thoronglily digested index of stubjects which it is hoped to issue hereafter, incorporating the numerous valuable accessions to the Library which have been made while this work was passing through the press.

Librari OF Congress, Washington, December, IS69.

Provision for the distribution of the catalogues of the Library was made by joint resolution approved Jannary I 4, I $84 \mathrm{I}:{ }^{\mathrm{I}}$

Resolved by' the Senate and House of Representatives of the Unitcd States of America in Congress assembled, That one copy of the catalogue of the Library of Congress be presented to each of the incorporated universities, colleges, athenaeunns, and historical societies in the United States, not exceeding three hundred in number, and to the American Antiquarian Society.

These changes in cataloguing were accompanied by changes in classification. The classification by format of $\mathrm{ISO} 2$ and the classification by general subject and subclassification by format of I 8 I $2_{2}$ and ISI5 was in I 86 I superseded by an arrangement by subject throughout. The substitution of a narrow for a broad classification, made necessary by the increased size of the Library, by the changes in the boundaries of the sciences, and by the growth of professional interests, involved a readjustment of the relations of the general classes as well as a subdivision of those classes. This is shown in the transfer of "Writing," "Printing," and "Bookbinding," from chapter I 5, "Technical arts," to chapter 38 , "Literature and bibliography;" "The law of nature and of nations" from "Moral philosophy" (chapter I6.2) to a distinct place (chapter 24) between law and politics; mathematics, physics, and astronomy from philosophy to natural history; ecclesiastical history from history to religion, and a rearrangement of literature along lines dictated by more modern taste.

In this reclassification of the Library it was necessary to adopt a new scheme of notation. In the Jefferson scheme ethics had been marked I6.I, ${ }^{2}$ law of nature and nations i6.2.

'And Jan. 20, I843: This distributed the remainder to colleges not already provided and persons entitled to use the Library.

${ }^{2}$ This is not a decimal number. 
An inserted book was $111 \mathrm{mbered}$ by adding a letter to the book number of the book next preceding, or by renumbering the entire class. For example, a Collection of papers relating to the history of Massachusetts being numbered $2_{2}^{4}$, the Collections of the Massachusetts Historical Society when added to the Library were marked $\frac{4}{2 i a}$. As many as a dozen or more insertions, arranged in order of accession, were sometimes made and numbered thins by the added letters $1, \mathrm{~m}$, etc.

In the reclassification of 1860 the subdivisions of the class Politics were marked 24.I, 24.2, 24.3, etc., as the subdivisions of moral philosophy had been marked in ISI 5 ; the book numbers were superseded by shelf numbers, and new book labels and book plates were prepared to correspond to the notation. With the rapid development of the Library after I86I the shelf numbers came in a measure to have the significance of class numbers, and the fixed location to give way to a movable one.

\section{INDEXING OF DOCUMENTS.}

The Library staff had no time for bibliographical work, ${ }^{1}$ although such work clearly constituted one of the functions of the institution, both as a Library of Congress and as a national library. The custody of Congressional documents, for example, involved properly the cataloguing of them, just as the custody of the nation's literature involved the cataloguing of it, and the publication of the catalogues. Such work was still left to private initiative; the question of Government patronage of such work, however, was referred to the Library Committee, and thus requires notice from the historian of the Library.

In IS23 an index to the House documents of the Fifteenth, Sixteenth, and Seventeenth Congresses had been printed by order of the House of Representatives. In IS24 an index to the House documents of the First to the Fourteenth Congresses had been printed by the order of the House. The desirability of a more comprehensive work was, however, felt.

\footnotetext{
${ }^{2}$ It was necessary to close the Library for a month in the autumn to gain time to shelve the new books and prepare the annual supplement to the catalogue. -Meehan to Everett, AIarch 2, IS31; Library of Congress MSS.
} 
Accordingly, on the 20 th of February, I 830 , at the suggestion of Mr. Watterston, Mr. Burges moved in the House "That the Clerk of the House of Representatives be directed to cause a digested index to be prepared to the Executive papers, reports of committees, and all other public documents from the origin of the Government, and also a general index to the journals of the two Houses." On the 24th this was referred to the Committee on the Library. The resolution was introduced at the beginning of the next session of Congress by Mr. Taylor, but its consideration postponed indefinitely. It appears from the correspondence between Watterston and Edward Everett that this index was to be in two volumes, one an index to the documents, the other an index to the journals. It was to have been compiled by Watterston and Fendall, the two editors of the National joumal.

The measure for a comprehensive index having failed, Mr. Taylor moved, December 28, i830, for a supplement to the two existing indexes. This passed February I I, I $8_{3}$ I.

In 1839 Thomas F. Gordon presented a memorial to Congress asking for the patronage of that body for an index to the journals and documents of the two Houses of Congress. The strbstance of his memorial was as follows:

The existing indices are confessedly insufficient and are liable to the following objections:

1. They do not remore the great difficulty and labor, to which every member of Congress is subject, in tracing the action of the Government upon any matter.

2. Nor do they lessen the labor and perplexity of ascertaining the proceedings of any department upon its ordinary duties or upon watters specially referred to it. Hence, are induced calls upon the departments for information which has been previously rendered, and consequently sreat delay and expense.

3. They afford an imperfect clue to the indigested mass of valuable matter which the several hundred volumes of the Congressional proceedings contain, and the light of experience is thus frequently unattainable.

4. For want of a better guicle these volumes, which contain the greater part of the only veritable history of the country, are sealed books to the people and their representatives.

'Watterston to Everett, February 25, December 29, IS 30 ; Vehruary 12, IS31; Journal of the House of Representatives.

$23399-0.4-24$ 
To remedy these erils I propose to make three sets of indices, the first comprising the executive documents and reports of committees of both Houses, the second the journals of the Senate and the third the journals of the House of Representatives, each series containing the matter pertaining to it from the institution of the Government to the present time, the first in order above mentioned to be the first executed.

The first index would show on its page an analytical abstract of every document referred to, with the year, the Congress, the session, the volume, and the page to which it belongs.

The matter of the index will be classed alphabetically under as many titles as possible (the more titles the better), giving, however, the synopsis of each volume under one title only, with reference to that from all the other titles under which the matter of the document is noticed. The matter under each title will be arranged numerically, in placita, or sections, for the convenience of reference and the avoidance of repetition. The abstracts under the general titles will give the full scope of the documents, whilst due care is had to aroid redundancy.

Such an index would present a general and connected view of the whole action of the Gorernment in each and every department; a satisfactory analysis of erery document and report; a ready access to each component part or principle, however widely dispersed through the records, with the means of direct recurrence to each document and report in extenso. It would be a national work, opening inlets, now impervious, to a correct and useful knowledge of the national history. To the agent of every department of Government it would prove a great labor-saring machine, abridging his labors, whilst it directed his proper course when seeking for light to his orn path or to guide the steps of others. Knowledge is power, and this power it would be efficient to give.

Such a work is one of great labor, requiring more ability than is ordinarily needed in a clerk; requiring, also, exclusive devotion to it for a long and unbroken period; much attention to comprehend correctly the matter, and to preserve its due connexion; the command of language, and the tact to condense closely; in a word, the skill necessary for correct and lucid abridgement. May I say that my pursuits for some years past have, in a measture, specially qualified me for such a labor?

The work is one not only of great labor, but one requiring mucl time. There are some lundred rolumes of documents and reports pertaining to the two Ilonses. It is one also of great risk, since no recompcnse is anticipated until the whole work shall be compiled. Death or disease, which may obstruct the work, will impose on the laborer the loss to hinnself or fanily of the fruits of his labor.

It is a national work, intended chicfly for the officers and agents of the Covernment, and must be created at the national expense. One 
hundred copies beyond the number taken by the Government would be as many as I wonld dare to print. If the work be executed, Congress must order such number of copies as will remunerate the labor and cost. What should that number be? You will readily admit, I presume, that it would be convenient for every nember of Congress to have at his chambers a copy of the work; that if he carried it home with him it would enable his family and his neighbors to acquire a knowledge useful to everyone destined to public station, and that, therefore, it might not be nnwise to supply the members of several successive Congresses with the work. Less than I,500 copies would scarcely serve these views.

I am not unaware, however, that a proposal for such a number will find many and resolute objectors, to avoid whom it will be proper to reduce the amount to that which will be absolutely requisite to pay for the labor, expense, and risk of the enterprise.

It is somewhat difficult to get at this desideratum from the uncertain extent of the labor. To render the rork most useful it should be put into as compact a form as possible, and consequently in as small type as may be easily legible—say brevier. Each volume should make a convenient manual, and might contain soo pages. The size would be properly determined by the space necessary for all the matter under the classing letters of the alphabet which it might contain. Thus, if Volume I have the indicative letters A, B, C, D, E, F, etc., it should comprehend all the subjects under them. The page would necessarily be a heary one, containing about twice as much matter as the page of Gordon's Digest of the laws of the United States, and being of tabular form, with nuch figure work, would cost double price for composition. Such a volume, therefore, could not be printed and properly bound for less than 2,000 dollars; from the balance must be paid the compilers, copyists, proof readers, etc.

It is not possible, a priori, to state the number of volumes requisite for each series of indices. The executive documents and reports of committees might probably be comprised in three such rolumes as I have described above, perhaps in two.

Viewing, therefore, the labor, the cost, and the risk, the remuneration should be liberal, and payable in portions on delivery of the several volnmes. By reason of the alphabetical form, the whole of each series 111ust be compiled before any part of it can be put to press. This circumstance assures the compilation of each series before demand for remuneration, and subjects the compiler alone to all the risk of the enterprise. We can not fix the price per volume, but may per page; and I propose to receive I cent for every printerl page, 5oo copies being taken. This is the price paid for printing the laws in the newspapers for pages laving abont onte-third the matter I propose; stch was the price paid ne by the Treasury Department for an edition of the Digest 
of the revenue laws. These terms will leave to the compiler little more than the wages of a Government clerk, whilst his labors will be treble those of such a clerk, if he wonld niake wages at all.

You will perceive, from the preceding view, that the proposed indices will differ widely in character, utility, and cost from the crude, meager brochures which nsurp the name of indices, now in nse in Congress. You will perceive, also, that a work faithfully executed npon the proposed plan will be a manual for every American statesman. ${ }^{2}$

This memorial was presented to Congress witl a favorable recommendation from the Library Committee February r6, I $S_{39}$, again January 7, I $S_{43}$, January I I, $S_{45}{ }^{2}$ and March 3 , I $\$ 46,3$ but with no success.

Other bibliographical enterprises met with a similar fate. The memorial of E. R. Irivingston, submitting to the Senate his system for arranging and indexing legislative documents and papers, and his proposal for arranging and indexing all the documents and papers of Congress by that system, referred to the conmittee by the Senate, was on the $14^{\text {th }}$ of May, I $\delta 5 \delta$, referred by them to Mr. Bayard, and on the 2otl laid on the table.

Willian Elliot compiled a list of all the books deposited for copyright in the Department of State, alphabetically and analogically arranged. The National Intelligencer (March 24, I 834 ) expressed the hope that it would be published, and on the r6th of December, 1834 , Mr. Robbins presented in the Senate a petition from IVillian Elliot praying for the patronage of Congress in the publication of the work; but the Library Connuittee, to whon the petition had been referred, voted, January $3 \mathrm{I}, \mathrm{I} \delta_{35}$, that a motion be made to discharge the conmittee from its further consideration.

On the 2 ist of $J u l y, ~ I S 4 S$, a resolution was received from the Senate instructing the committee to inquire into the expediency of purcliasing for the use of the Senate an index to the National Intelligencer, from in $S_{10}$ to i 820 , prepared by H. Morfit, esq., of the city of IVashington. "Foted, 'That

\footnotetext{
'Twenty-seventh Congress, third session, House report No. 4I. This was presenter January 7,1843 , but is in substance the same as that in the umpublished report presentel February 16,1839 .

'Twent, -eighth Congress, seconr session, Ilouse doeument No. 46.

3' 'wenty-ninth Congress, first session, Senate document No. 184.
} 
the subject be laid over for the purpose of making some inquiries."

On the $24^{\text {th }}$ of June, IS64, on motion of Mr. Anthony, the Senate resolved "That the Committee on the Library be instructed to inquire into the expediency of causing a catalogue of all the publications relating to the Rebellion to be compiled."

\section{PRIVILEGES OF THE I.IBRARY.}

The privileges of the Library, until this time confined to members of Congress, the judges of the Supreme Court, the members of the diplomatic corps, and one or two others, were now extended to the heads of Departments and other officers of the Government. On the gth of January, ISI7, a bill to this effect had passed the Senate but got no further. On the 22d of December, IS29, however, on motion of Representative Davis, of Sontl Carolina, the use of the books in the Library was extended to the heads of the Departments; on the $23 \mathrm{~d}$, on motion of Mr. Pearce, the resolution was amended so as to extend to ex-Presidents of the United States resident in the city of Washington; on the 3oth the Library Committee, to whom the resolution had been referred, reconnmended the further extension of the privileges of the Library to the Secretary of the Senate, the Clerk of the House of Representatives, and the chaplains of Congress; and on the $3_{3}$ th of January, I $S_{3}$, the resolution was approved:

RESOLC'TION granting the use of the books in the Library of Congress to the heads of Departments, to certain officers of Congress, and to ex-Presidents of the United States

Resolied by the Senate and House of Representatives of the Lnited States of America, in Congress assombled, That the President of the Senate and Speaker of the House of Representatives, for the time being, be, and they are hereby authorized to grant the use of the books in the Library of Congress, to the Secretary of State, the Secretary of the Treasury, the Secretary of War, the Secretary of the Nary, the PostmasterGeneral, the Secretary of the Senate, and the Clerk of the House of Representatives, the chaplains of Congress, and any indiridual, when in the District of Columbia, who may have been President of the United States; at the times, and on the same terms, conditions, and restrictions, as members of Congress are allowed to use said books. 
By the act of August II, I848, the privilege was also extended to the Solicitor of the Treasury.

On the other hand, the joint resolntion granting the nse of the Library to the judges and Solicitor of the Court of Clainis, was reported upon by the Committee on the Library as follows:

That, in their opinion, it is inexpedient to extenct the privilege of taking books from the Library of Congress further than is now allowed by law.

The law of r8O2 allowed no book to be taken out of the Library, except by the President of the United States and by members of Congress for the time being. But this privilege has since been granted to all members of Congress, heads of departments, and diplonatic corps; to the judges of the Supreme Court of the United States; to ex-Presidents when in Washington; to the Secretary of the Senate and Clerk of the House of Representatives, and to the Solicitor of the Treasuryin all, more than 300 persons. Besides this, the Supreme Court is authorized to allow the use of the books in the law department of the Library to the attorneys and counsellors of the court during its sessions.

Thus it will be seen that the list of those who are entitled to take books from the Library of Congress is very large; and the privilege is often abused by those who are entitled to it, using it for the supply of others than themselves and their own fanilies.

Under the rules which were prescribed many years ago by the VicePresident and Speaker of the House of Representatives, by anthority of law, visitors are admitted to the Library. Although these rules are silent as to the use of books by visitors, they are, in fact, allowed the use of the books by reading them while there, and the means of making notes of what they read are readily furnished. They are also cheerfully aided by the Librarian and assistants in making researches.

This is greater liberality than is usually practiced in great libraries, and much increases the labor of the Librarian and his assistants. But the number of books taken ont of the Library by parties entitled to do so is quite large, and, incleed, often so large as not unfrequently to impcle very serionsly the researches of those making extended inquiries. This inconvenience increases with every addition to the number of privilegerl persons, and it has been so obvious to the Library Committee that they have long opposed all applications made for the extension of the privilege. 'These applications have been made on behalf of numerous officers of the General Government, but for many years they have been invariably refused. The last addition to the list was made by Congress without reference to the Committee on Library and without due consideration. 
In regard to the books in what is properly called the law department of the Library, their use is still more largely enjoyed since the act of I 3 2. This act anthorized the justices of the Supreme Court to make such rules and regulations for the use of the sane by themselves and the attorneys and connsellors of the court, during the sittings of the said conrt, as they shall deen proper. During the sessions of the Supreme Court, therefore, so many books are required by the judges, and used by the gentlemen of the har attending the court, that members of Congress (notwithstanding there are many duplicates of certain works of general use) are frequently unable to prosecute satisfactorily the study of legal questions arising in Congress or in the conrse of their professional business. If the use of this department of the Library were granted to the judges and solicitor of the Court of Claims the present inconvenience to nembers of Congress wonld be largely increased.

The committee, therefore, can not recommend the adoption of the resolution referred to them, though, if the list of those anthorized to take books from the Library is to be extended they know no functionaries of the Government better entitled than the judges of the Court of Claims. They are very sensible that it is important to the Court of Claims to have the command of a select Library of law books and of a complete set of statutes and public documents. They venture to express the hope that an appropriation may be made to purchase law books for this court, and they report a bill making an appropriation for this purpose, and providing them with a copy of the statutes and public documents, so far as the same can be obtained from such as are now on hand, as also with all that may be published hereafter, which they recommend as an independent bill. ${ }^{\mathrm{T}}$

The joint resolution granting the use of the Library to the justices of the supreme court of the District of Columbia was also reported 11 pon adversely. ${ }^{2}$

The suggestion of the Commissioner of Patents that if he were permitted to take books from the Library of Congress, it would relieve him from the necessity of purchasing some rare publications for his office was not even taken into

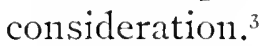

Still, those who wished to borrow books from the Library could do so by obtaining a card from a member of Congress. ${ }^{4}$ This was done to such an extent that on the 21 st of

${ }^{1}$ Minutes, June 10, 185s; Congressional Globe, June 12, 1858 ; Thirty-fifth Congress, first session. Senate report No. 328, June 12, r 858 .

"Congressional Globe, January 12, 1864.

${ }^{3}$ Report of the Commissioner of Patents for 1844, p. 8.

${ }_{4}$ Round Table I: 38. 
April, I 854, Mr. Taylor, of New York, asked the manimous consent of the Honse to offer the following resolution:

Ricsolicd, 'That the Committee on the Library be instructed to incuire whether it be not expedient that one copy of each work belonging to the Library be constantly retained therein. Also, whether books taken from the Library should not be required to be returned within a definite time, to be fixed by the rules regulating the Library.

Mr. Clingmax. That is the rule now.

Mr. TAYıOR. Yes, sir; but it is not put in force.

Mr. Clingman objected to the introduction of the resolution.

While only privileged persons were allowed to borrow books from the Library, all were admitted to the use of the reading room. There was, it is true, a rule which required that visitors should be introduced by members of Congress, and because of some abuse of the privileges of the reading room, the conmittee roted March $3 \mathrm{I}$, I $8_{32}$, "That the rule should be strictly enforced, and that the Librarian should give public notice to that effect." But it seems to have fallen again into abeyance.

But while the committee were jealons of any extension of the privileges of the Library, the public was equally jealous of any limitations of those privileges.'

Among the limitations complained of was the closing of the Library every other day when Congress was not in session, and for the space of a month in the autumn of each year for the purpose of cleaning and arranging the books and the rooms ${ }^{2}$ - this Library, said a writer in the United Slates Magasine for August, i $856,{ }^{3}$ should be opened on every secular day during the year.

Anotler limitation complained of was the closing of the Library in the evening. This led to the publication of the following interesting letters in the National Intelligencer, January 3, I $\$_{44}$, and May 25, I 853 :

To the Enitoks:

If you have at command a copy of the rules and regulations for the custody and govermment of the Congressional Library, you would render some public service by publishing them.

\footnotetext{
'A writer in the Star (January 23, 1853) went so far as to protest against the custom of excluding boy's from the Iibrary.

= Vational Intelligencer, October 20, 1830, and October 7, 1834; Washington Capitol, October 30, 18.43; Minutes, July 7 , is61.

'Vol. 3, p. ros.
} 
Is it reserved for the exclusive use of the members of Congress? If not, who else, and on what conditions, can participate in the use of it? Is it open daily, and for how many hours, as well during the session as in the recess of Congress? If it be not, ought it not to be open as well to other persons employed in the public service as to members of Congress? Or is it that they contribute more than others to its purchase, or pay more for its preservation? The use of the I ibrary would contribute to beguile the evenings of those who have labored assiduously throngh the day, when the lnumbler employees in the public service can find time to devote, which many of them can not even, their evenings to the perusal of nseful and entertaining books. But, if the cloors of the Library are closed even to the very few who are entitled to its benefits each day as soon as Congress adjourns, and if in the recess it be open but three days in the week, and even on those days shut up at 3 o'clock, might it not as well be hermetically sealed against persons necessarily confined in the public offices, at least until that hour?

Finally, would it not be liberal and better comport with the spirit of the times if Congress would appoint one or two assistant librarians aud otherwise make provision which would render the National Library accessible at all hours of the day and until $s$ o'clock at right to all persons employed in the Departments!

The postage on newspapers and on letters transmitting noney to editors of papers, which now go free of postage, would anount to more than \$ro,ooo a year, and this on the ground that the Post-Office Department should so contribute to the diffusion of knowledge. Might not Congress, acting in the spirit of the same liberal policy, make a small appropriation to give freer vent and diffusion to the useful knowledge shut up in this great national repository? But one objection can be perceived to this suggestion and that is that the monopoly of the whole collection is necessary to satisfy the studious propensities of that honorable body.

S. S. I.

To the fintors of THE NATIONAI, INTELLIGENCE:

I an a clerk in one of the Departments. I sought an office here in preference to an engagement equally advantageous in a pecuniary point of view elsewhere for the reason that I have a taste for the study of certain sciences for which the libraries of the part of the country in which I resided do not afford the requisite facilities. The Govermment has provided an extensive Congress Library, to which the public are permitted access, and where the lovers of knowledge can feast without expense. The foundation for a still more valuable library has been laid in the Smithsonian Institution. It was my wish to avail myself of these wells of science and to digest their rich products in the society and conversation of those of kindred tastes. Judge, then, of my mortification and disappointment at finding that, for all purposes of practical benefit 
to me and those similarly circumstanced, these libraries might as well be at the antipodes as in this city. It is the duty of clerks in the public offices to give their attention to business from 8 or 9 o'clock in the morning until 3 or 4 in the evening. We are paid for this service, and every conscientions clerk feels it to be his duty to render a full equivalent for the wages he receives. The libraries are open during our hours of business and closed at all other hours. Few of us can afford to buy all the books we wish to study, and even if we could the bookstores would afford but a meager satisfaction to those whose studies are of a recondite nature. If the inconvenience were only personal, I would not ask the space in your valuable columns necessary to call the public attention to it, but it involves grave considerations which relate to the welfare of the large number of persons from every part of the Union who are engaged in the public service in this metropolis. Most of the clerks in the Departments are young men of liberal education and of literary tastes, ardent and impetuous in feeling, and peculiarly susceptible to the impressions with which circumstances surround them. They are not destitute either of claracter or influence-an influence which, as they return to their homes, will be felt in every part of our country. Around them, too, cling the hopes and expectations of many friends and relatives. They come here and are cut off from the social restraints to which they have been accustomed. Books and the society of cultivated men would go far to preserve them from the follies and vices of city life. They are practically denied access to the public libraries, and what is the consequence? The energy and enthusiasm which might be lead into a healthy current is diverted into the thousand polluted channels which present a moral counterpart to the alleys and sewers of the city. It is no liglit thing to be responsible for such consequences, and I confidently trust that the mere mention of them will lead to the adoption of the measures of remedy which readily suggest themselves.

It may be the impression that if the libraries were made accessible to us but few would resort to them. I can not undertake to decide in adrance, but in the limited circle of my acquaintances the complaint of the want of books has been almost universal. I hope that if these libraries should be thrown open at stuch hours that the clerks can visit them, they will be the resort of as numerous and earnest votaries as during the sessions of Congress.

WABASH.

No attention was paid to these petitions, however, for almost half a century. 
ISE, OF THE: IIIIRARY'.

While these restrictions upon the use of the Library remained, they do not seem to have hindered the growing utility of the institution as a reference library and its continued popularity as a place of resort.

The beanty of the room made the Library one of the attractions of Washington, and consequently one of the objects of interest to the numerous strangers who risited the Capitol. Its location between the two Houses of Congress made it a pleasant lonnge for nembers wearied with the prosings of some tireless debater. The alcoves in the Library made convenient reception rooms for the wives and daughters of members, and the illustrated works were nice picture books for their children. ${ }^{\mathrm{I}}$

The English traveler James Silk Buckingham visited the Library in IS4I and, seeing the throng which frequented it, concluded that it was a public library and said: "As access to the Library is just as free from all restraint as access to the halls of Congress, in the galleries set apart for strangers, or to the President's levees and drawing rooms, so this Library is a very valuable resource both to residents and visitors in the city. If our English authorities could but learn the important truth that freedom of access to public institutions is not necessarily attended with rudeness of behavior or injury to their contents, a vast benefit and a most softening and refining influence would be obtained for the British population by familiarizing them through the medium of such institutions with the pleasures of literature, science, and art, and the whole nation, nay, the whole world, would be directly or indirectly benefited by the change." 2

Those who saw more of the Library than Mr. Buckingham, on the other hand, knew that it was only a privileged class who were permitted to use the Library, and saw, as the English visitor did not, that some of that class misused the Library

\footnotetext{
'Ifenry Tudor, Narrative of a tour in North Anerica (1 834 ), I: 64; Captain Marryat, Diary in Anerica (1839), 1: 166; Mary Clemmer Ames, Ten years in Washington (1S73), p. 131; National Intelligencer; Narch 30, IS $S_{32}$, December 5, IS 34 , and Uay 22, $18_{39}$; Washington Capitol, June 12, $18_{43}$.

'America, historical, statistic, and descriptive (IS41), I: 310 .
} 
most deplorably; books were mutilated and lost, and readers were worried by the buzz of conversation or crowded out of the room by the multitude which thronged it. The committee, therefore, attempted to remedy matters by voting, March $3 \mathrm{I}, \mathrm{I} \delta_{32}$, that the rule which required that visitors must be introduced by members of Congress should be strictly enforced, and January $3, \mathrm{I} \delta_{34}$, that the gratings put up for the security of the books be kept locked and opened only by the Librarian on request; and, after the fire of $I 8_{5} \mathrm{I}$, these measures were supplenented by the erection of bronze gates in front of the alcoves. The result of these measures was that the abuse of the books in the Library was diminished, but the use of them was also diminished, for neither student nor lonnger now had access to the shelves, and only privileged persons could borrow books for home use. Among the latter we niay note Senator Cass, who was an omnivorous reader, ordering to his room large collections of books of travel and novels, and Senator Benton, who, it was said, always consulted all available encyclopedias before he made one of his ponderous and exhaustive speeches. ${ }^{\mathrm{T}}$

These restrictions, together with the rise of other interests, made the Library less popular as a resort toward the end of this period. These clianged conditions nunst be illustrated by extracts from contemporary records. The first of these refers to the abuse of the Library in the earlier part of the period.

On the $3 \mathrm{~d}$ of Jannary, is 85 , The Champagne Club, "a chronicle and critic of military and fashionable events and things, and criminal record of literary and other misdoings, by Ebenezer Lovemuch and Capt. Marcius Mucklewratl, aided and abetted by a secret society of bored gentlemen," gave the following description of the reading room of the Library:

Crowds of pretty, fair ones with their pretty beaux filled the area and chatted and flirted and carolled their merry lays of laughter as they thumbed irreverently the hallowed and illumined page of "Paradise Lost" to look at the pictures or, disdaining the society of the master spirits of time, occupied themselves with the self-styled Byrons and 


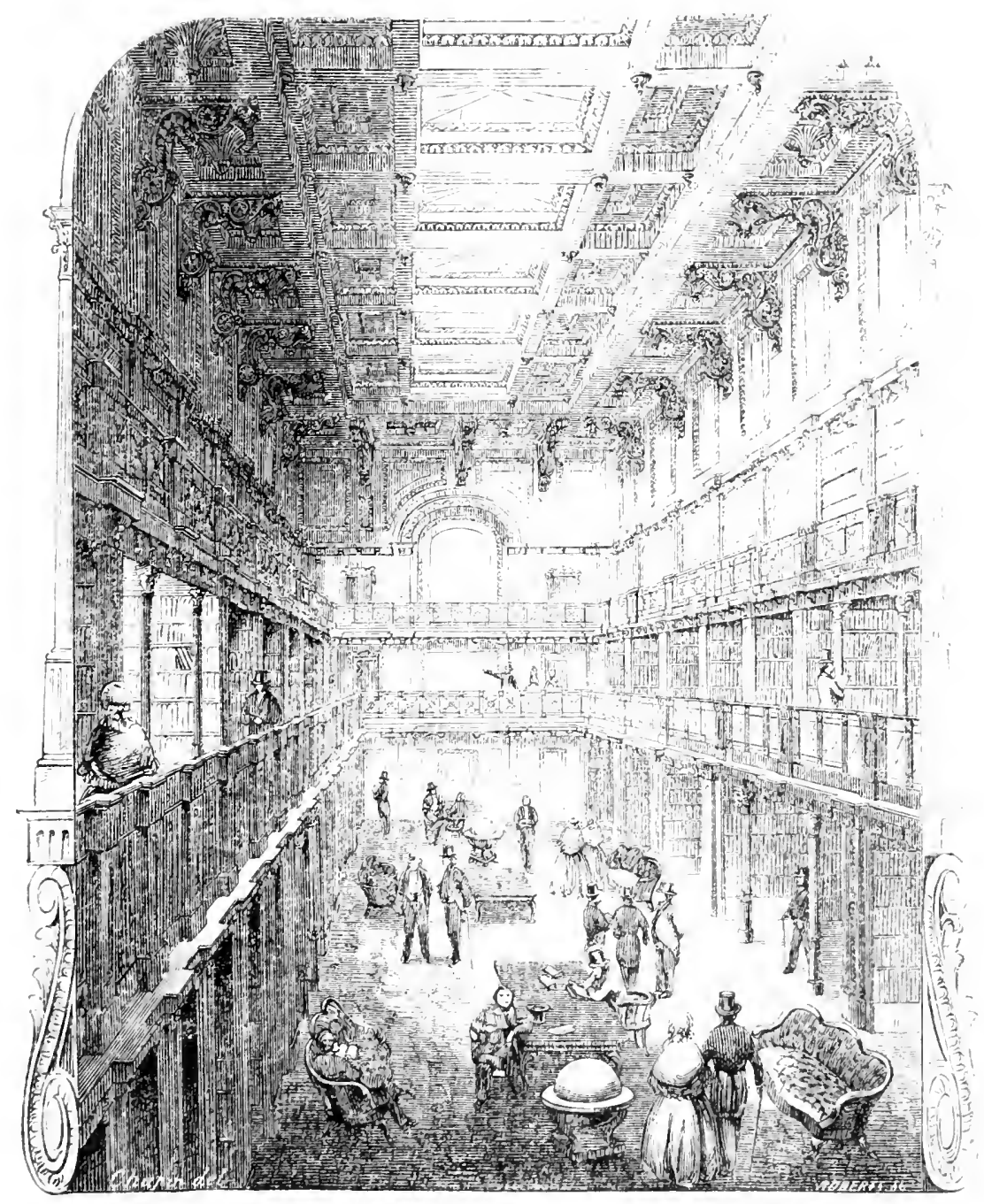

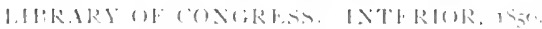




$$
\text { . }
$$


living Tom Thumbs of the day. One old gentleman alone, almost hidden in a corner, seemed to be aware of the place in which he was, and to have come witl the wedding garment to the feast. I approached him upon pretence of looking for a look, and had an opportunity of observing him. His countenance was caln1, and yet enthusiastic; benignant, yet stern. His forehead was lofty and full, and overhung his quiet, dark eyes. He wore his few surviving hairs tied into a queue, and I remarked that le was lane. The book in his hand, like its reader, must have relied upon its subject rather than its body for distinction, as it was bound in pale and nupretending sheepskin and had an ancient look. It was one of the rare Latin authors, and it had the good fortune just then to fall into the hands of one whose mind seemed devoted to its attractions.

"Percy," said the Baron, "why don't somebody give that gentleman a hint of the usages of this place? Bless me! I slould not have dreamed of such rudeness. To sit down in the very heart of the dominions of fashion and the ladies, turn his back upon them, hold his tongue, and read a book! Abominable! Is he mad? Really, this is a beneficent and generous Government of yours! To give the fair sex a chatting room in the very Capitol itself! A lounge! A sort of public boudoir for belles and their favorites! Bon diable! This is the climax of liberty! the apex of civilization!"

The Baron was startled, when he learned that the old gentleman was a Sentator, one of the few who have the true and simple dignity of nature, and that he was actually putting the apartment to its legitimate use. $^{2}$

On the 2 Ist of February, I 835 , it continued this interesting description of the reading room, nuder the caption, "An extract from the notebook of Petrus Penwaggler, Esquire," showing how an act of presumption in the Library of Congress was turned into a learned disquisition:

Almost thrown into aspliyxia, a few days ago, by the upas eloquence of a member from the far West, I instinctively sought the Library of Congress as a means of relief. A group of langling, cliatting ladies were nonchalantly' turning over the elephant sheets of Audubon's ornitlology; a sort of obligato amusement, like a flute accompaninent in a concerto, for all the fashionable idlers, who put to the test the urbanity of the Librarian. Here and there a bon ton saunterer cast a listless, unmeaning eye on the glorious array of the shelves, such as would say, I care not to cultivate acquaintance with unk11own persons. But not so in one of the alcoves, the nintli, I think it is, on the right, after you have entered; not so with an individual who seened entranced in the

"The Champagne Club, Waslington, January 3, $1 \varsigma_{35}$, p. 55. 
contemplation of a splendid folio, adorned with numerous and admirable engravings, after the manner of Sanzio. A set of pale features, almost worn to ascetic thinness, a forehead of premature wrinkles, and still more prenature baldness; a sharp, quick eye, fixed in deep intensity on the page before him; full and restless eyebrows, knitted into a lundred creases, spoke of the workings of an active mind, and the pursuits of a trimmer of the midnight lamp. Drawn toward that person by an irresistible impulse, I approached him, and, setting aside the conventional rules of politeness, apologized for looking over the work which he was pernsing, and inquiring into the strbject of the engravings, which were illustrated in a foreign language. ${ }^{\mathrm{T}}$

Ten years 1ater Caleb Atwater fonnd in the Library room only persons of the most refined taste, polite manners, and agreeable conversation. "I have always found reading people," he said, "more placid and more agreeable in their manners than others, and were any whole nation wholly composed of such materials it would be the happiest and the best nation in the world." 2

\section{In I 859 Mary McLane said of the Library:}

When we paid our last visit we found it gaily peopled as usual; conches filled with groups conversing in the customary library undertone, which is a drowsy murmur. In spite of the early hour we saw in the various alcoves scores of mute readers, who sometines lifted t1p a glance as we passed and then, like Dante's ghosts, relapsed into their penance.

Our eye fell on several of the habitués of the place, timidly propitiating the attendant with small fragnents of whispered conversation, listened to with impartial politeness, again glancing up from their books with visible discomfiture as some gayly dressed belle, in all the grace of fashionable costume, floated up to the same attendant (who is especially the good genius of female bookworms) and begged to see some ponderous tome, which she carelessly turned over, to the imminent peril of delicate lenon-colored gloves, grievously interrupting our elderly friend, who, we have 110 doubt, devontly wished all female literati, and this one especially, in some distant paradise not particularly specified.

Dear readers, he with us for a brief time in these secluded alcoves, for they seen very nests for hunnan thoughts. Stand reverently, for the voices of the dead are all about us. What hundreds of literary laborers have toiled upon the mental fumiture of these walls, and many, ah, how many, that the world has never rewarted! All the struggles, the sorrows, and the cares which wait on those who worked with hand and

"The Champagne Club, Washington, lebruary 21, 1835, p. 133; Nlexander Mackay in his II estem II omld, quoted in the Southern P'ress, Augnst 19, 1S50, also dwelt at length upon the arlvantages of the Library as a place for flirtation.

${ }^{2}$ Mysteries of Washington City. By a citizen of Ohio. $1844, \mathrm{P}, 72$. 
brain, alas, for bread, unwinds itself as we gaze on the works of these dead patriarchs of thought.

During the War few visited the Library and those mostly nembers of Congress. ${ }^{2}$

\section{LIBRARIAN STFPHENSON.}

One more event in the history of the Library before the administration of Mr. Spofford remains to be chronicled-the appointment to the office of Librarian of John G. Stephenson.

John G. Stephenson was the son of Reuben Stephenson, of Lancaster, N. H. He attended Lancaster Acadenny, where, in $\mathrm{I} 844$, he assumed the part of Fontrailles in "Richelieu: a drama;" and in the sanne exhibition, given at the old meeting house in Lancaster, Tuesday evening, November 26, r\$44, the part of Frank Webber in a comedy of college life written by Judge Nelson Cross, of Boston. ${ }^{3}$ He was afterwards a practicing physician in Terre Haute, Ind. He accompanied Senator Henry S. Lane, of Indiana, to Washington in February, I86r, and, through the influence of Caleb B. Smith, of Indiana, Secretary of the Interior, was appointed Librarian of Congress May 24. He left the work of the Library to his assistants, however, and went ont to take part in the war then being waged between North and Sonth. In the report of Maj. Gen. Abner Doubleday, U. S. Army, commanding the Third Division and First Army Corps during the Gettysburg campaign, dated December I4, Is63, the J,ibrarian gained the following honorable mention: ${ }^{4}$

Colonel John G. Stephenson, Librarian of Congress, acted as volunteer aide to General Meredith. He exposed himself freely on all occasions and rendered many valuable services.

Afterwards Doctor Stephenson became interested in speculations created by the war, ${ }^{5}$ and toward the end of the year I 864 resigned from his office. He died November I I, I $88_{3}{ }^{6}$

'Mary Jane McLane, Life in Washington (is59), p. 239.

'Washington Chronicle, November i 3,1864 .

${ }^{3}$ A. N. Somers, History of Lancaster, N. II. (1899), p. 419.

4 War of the rebellion records, series 1, vol. 27, part 1, p. 256; liffy-first Congress, first session, House miscellaneons documents, No. 1.46 .

5 Congress, by resolntion of June 6,1872 , made an appropriation to pay Edward G. Allen $\$ 1,480$ purchase money for books for the I,ibrary of Congress, dne in 1862.

${ }^{6}$ Eviening Star, November 12, 14, 1883 . 
$3 S_{4}$ DEYFILOPMENT OF THE LIBRARI, IS 52-IS64.

Charles Lanman, former librarian of the House of Representatives, was a candidate for the expected racancy. Among his credentials I have found the following:

Baltimoris, November $17,1867$.

DE.AR SIR: From my knowledge of you, I know no one better fitted for the offices of Congressional Librarian than yourself, and should the present excellent incumbent resign I shall be glad to see you his stuccessor.

With respect, RFverdy Johsson.

On the 3 Ist of December, IS64, the chief assistant librarian, Mr. Spofford, was appointed Librarian. 
Citraptex Ifine

OTHER LIBRARIES OF CONGRESS AND OF THE GOVERNMENT 



\section{Chapter Nine. \\ OTHER LIBRARIES OF CONGRESS AND OF THE GOVERNMENT.}

These records of the early history of the national library wonld be incomplete without an account of the early history of the two libraries of Congress, located in the House and Senate wings of the Capitol, and of early relations with the libraries of the other departments of the Government on the one hand, and on the other hand of the development of the idea of a national library, as illustrated in the early history of the Smithsonian Library.

\section{HOUSE, LIBRARY.}

In a letter to Edward Everett Narch 5, I82S, George Watterston refers to a library connected with the House of Representatives. ${ }^{1}$

The House librarian was appointed by the Clerk of the House of Representatives. His salary was $\$ 1,500$, the same as that of the Librarian of Congress. ${ }^{2}$ Anne Royall thought the office a sinecure. "Where is the library of the Honse?" she exclaimed, and "What do they want with an extra library?"3 An assistant librarian was added in 1852 , and by I 864 three assistants were required to attend to the business of the Library.

\footnotetext{
'The act of MIay 24,1828 , also mentions the Library. The early librarians were Eleazer Jarly, 1837 ; Iiliab Kingman, is 40 ; Simon Brown, s $8_{43}$; Philip Willians, IS4S; Joln A. Parker, 1852 (see Huntress July 17, I852); Matthias Martin, 1854; Cornelius 13. Adams, 1856; Andrew R. Pott:s, 1858 ; Calvin C. Chaffee, I860; Charles Lanman, I S63; Whitelaw Reil, i 863-1S66. - Constitutional Cnion, December I5. I S63. ${ }^{2}$ By the act of August 4,1854 , it was increased to $\$ 1,800$, as was the salary of the Librarian of Congress.

${ }^{3}$ Huntress, December 14, 1839.
} 
The duties of the library staff are illustrated by the following printed circular letter:

\section{LIBRARY OF THE HOUSE OF REPRESENTATIVES,}

February 27, 1835 .

Gentlemen of the House of Representatives, who may have books in their possession belonging to the library of the House, are respectfully requested to place them in a situation to be easily come at by the messenger, as application will be made, from day to day, at their rooms, to bring them back to the library. ${ }^{\mathrm{T}}$

The library consisted mostly of public documents, of which it was in IS64, according to Librarian Lanman, the chief depository. Of these it contained several sets nearly complete. It also possessed at that time the best collection of Washington newspapers in existence. ${ }^{2}$ In ${ }^{8} 5_{5}$ the library was said to contain I 2,000 rolumes; in I $853,30,000$; in I 559 , 50,000 ; in $1864,70,000$.

In IS4 I Mr. Watterston says in his "Picture of Washington," when speaking of the Hall of Representatives: "On the left of the eastern lobby are the Speaker's room and that of the Sergeant-at-Arms, and above the latter an apartment for bound documents and State papers called the library of the House." 3 In I 850 Professor Jewett refers to the library quarters as a series of closets, triangular rooms, and attics, and the Star (October I 4, IS53) characterized the place as a disgrace to the House of Representatives.

A partial remedy for this condition of affairs was found in I 858 by making a room near the Hall of Representatives a branch of the House library. ${ }^{4}$ A more effectual remedy was hoped for after the completion of the Capitol extension. In Robert Mills's plan for the extension of the Capito1, reported May 28, I 850 , room for the House library was obtained from the square recess of the existing Hall of Representatives. Connmunication with the library was afforded by a gallery leading across the court from the center of the Hall on the sane floor. In is6o the librarian and the House Com-

'Watterston Misi.

round Table $1: 3^{S}$.

3 It was reached by a flight of stairs at the left of the entrance of the Hall.

+ "nion, Jannary 3, $135 \%$.

5 'Thirty-first Congress, first session, Senate report No. I $45, \mathrm{P} .4$. 
mittee on Public Buildings still hoped that this plan might be carried ont, but it was nuderstood that a majority of the Conmintee on Public Buildings were opposed to the plan, believing that the old Hall shonld be devoted entirely to art, under the supervision of the Art Commission. ${ }^{\mathrm{P}}$

The most interesting incident in the early history of the House library is described in the following legislative records:

In the House of Representattres, February If, IS6I.

Mr. Pryor subnitted the following resolution, which was adopted:

Whereas the following statements have appeared in the Nca' York Times newspaper:

"PRONIDING A LIBRARY FOR THE SOLTHERN CONFEDERACY.

"It is ascertained that, in addition to the other fraucis perpetrated by the seceding nembers of Congress, they have taken from the Congressional Library, which is probably the best in this country, containing many books which can not be obtained elsewhere, some of the most valuable volumes in the whole collection. Thousands of dollars' worth have been thus abstracted and carried off by these members. Among them, a single South Carolina member, I an informed, has more than $\$ 400$ worth of digests of the most valuable claracter, and which can never be replaced. Scarcely one of these gentlemen took the trouble to return his books, but, on the contrary, were very cautious to have them carefully packed and sent off. I an further informed that a member from one of the border States, who farors secession, and thought his State sure to secede, sent orders for upwards of $\$ \mathrm{I}, 000$ worth of books recently, which, under the rules of the Library, were refused. This is regarded here to be very near akin to what Webster defines as 'theft.', Therefore-

Resolicd, That a select committee of three be appointed to inquire into the truth of the above accusations, and that said committee have power to send for persons and papers and have leave to report at any time.

Ordered, That Mr. Pryor, of Virginia, Mr. Maynard, of 'Temmessee, and Mr. Edwards, of New Hampsirire, be the said committee.

Oil the 2Sth of February this committee reported as follows:

A brief statement will place the House iin possession of the facts as they appear from the eridence given before your committee. Not long since an employee in the library of the House prepared a statement of the accounts of the late members from the seceding States, whicli was taken to their respective residences for the purpose of reclaining the

'State's and Lnion, March 24, 1960. 
books that they lad procured from the library, and which had not been returned. (See statements appended to this report.) Failing to find them, Mr. D. A. McElhone, one of the assistant librarians, was directed to take the accounts and endeavor to obtain the books. He also failed to get them, and thereupon carried the list to the House post-office in order to have the mail messengers institute a search for them. Mr. Soulé, one of the assistants in the post-office, was the only person present when Mr. McElhone called there, and to him the list was given with the request that he would see that the matter was attended to.

Up to this point it does not appear that there was any belief entertained by any person that there had been any wrong or fraud perpetrated upon the library in connection with these missing books. But Mr. Soulé, as he testified, seems to have jumped to the conclusion, not from anything told him but from inferences of his own, that these books had been appropriated by the late menbers to their own use. Active in propagating the suspicion, he voluntarily inforned Mrr. Hutchins, clerk to the Committee on Indian Affairs of this House, and a correspondent for several newspapers, that he had an "item" for him, and then proceeded to state what he innagined to be the facts about the missing books. Mr. Hutchins repeated that statenent to Mr. H. H. Pangborn, of the New York Daily Times, who, with little if any investigation, prepared his version of the transaction, which was telegraphed to the Times newspaper. In the Times office the heading "Providing a library for the southern Confederacy" was prefixed to the statement, which appeared in that paper the next morning.

The same issue of that paper also contained the allegation that a member "from a border State," "who favored secession," had ordered " more than one thousand dollars' worth" of books from the library, which order was refused. A subsequent statement in the paper named Mr. De Jarnette, of Virginia, as the nember alluded to. It appears from the testimony before your committee that Mr. De Jarnette was engaged at one time in preparing a speech for delivery in this House. While thus occupied he remarked to Mr. Sheehy, who happened to be present in his roon, and who was then an employee of the House, that he wanted certain information to enable him to prepare his speech. Mr. Sheehy replied that he could obtain it from the House library, and was requested by Mr. De Jarnette to attend to it for him. Subsequently lie told Mr. De Jarnette that his order was necessary to enable him to get the books, and at his request he (Mr. S.) wrote an order which Mr. De Jarnette signed without reading, supposing, as he stated to your con1mittee, that it called for not more than 25 volumes. The order, lowcver, was written in general terms, calling for a "set of Congressional Globes, Annals of Congress, Jefferson's and Adams's works," those sets including, the volumes Mr. De Jarnette desired for reference. Full sets of these works would embrace more than too volunes, instead of the 
20 or 25 volumes that Mr. De Jarnette intended to liave ordered. This order, dated January 28 , I 861 , was presented by Mr. Sheehy to the person in attendance at the library, and to whom Mr. Sheehy was a stranger. The fact that an order for so large a number of rolumes, the body of it written in a different script from that of the signature, was presented by a stranger to him at so late a period of the session led the assistant librarian to refer it to others before proceeding to fill it. And the same reasons led the chief clerk to suspend it for a tine, until he conld get more information in regard to it. Upon the assurance, sometime afterwards, that it was the order of MIr. De Jarnette, directions were given to comply with it. But by that time Mr. De Jarnette had prepared his speech without the assistance of the books and no longer needed them. In this case, as in the other, there seems to have been no idea entertained of any improper design in reference to the books until the account of this transaction had reached the same persons who had given the objectionable coloring to the other.

It does not appear from the testimony taken by your committee that any of the books belonging to the library have been taken away by any of the late members. Nor does it appear that the books they obtained while here have not been returned to the library, except that they have not been credited with them on the account books of the library.

Your committee regard this entire charge against the late and present members of this House as a fair specimen of the many sensational dispatches sent from this city during the present session of Congress by the various persons employed as special correspondents of papers at a distance, but more especially of the New Ycrk City papers. A desire to state something that shall be more startling, from its enormity or novelty, than their competitors have been able to discover or derise, or even a more culpable desire, would seem to be the controlling motive on the part of those who are thus engaged. With little if any inquiry into the correctness of the many rumors that come to their ears, with the most reckless and mwarranted inferences from them, with little regard to the effect of their statements upon public interests, or the character and reputation of individuals in public and private life, these sensation mongers daily send forth to the country statement after statement as entirely unfounded and baseless as those to which the attention of your committee has been called. Your committee, however, are not of the opinion that this House can proride any remedy for this evil. It can only be remedied either by the public becoming convinced of the little credit and reliance to be placed upon these "special dispatches," or by the proprietors of the public press exercising more care in the selection of the agents they employ for this purpose, and endearoring to secure the services of those who shall be more influenced by considerations of truth and justice, and a proper appreciation of the privileges and courtesies gratuitously extended to them by this House. 
While considering the subject referred to them, the attention of your committee has been called to the present condition of the library of the House, as being such as to almost necessarily render impossible its proper management, and leading to the commission of errors in the accounts of members, such as, in this instance, have furnished the little foundation required for such statements as those to which your committee have referred. 'The library, as many members of this House are well aware, is contained in a room illy adapted for that purpose. There is no catalogue of the books contained in it; the different sets of the same work have no mark or number on them to designate the one from the other. Those having charge of them, while they may know the number of the different works there, can have 110 certain information of the number of volumes that the library contains, or whether all the books taken out at any time have ever been returned. The accounts and books of the library are their only guide, and the testimony taken by your committee establishes the fact that they are not free from mistakes. For instance, Mr. Bonham, of South Carolina, was charged with 42 volumes upon the account made out and handed to Mr. Soulé, of the House post-office, to enable the messenger to reclaim books not returned; yet, upon reference to the account books, it appears that Mr. Bonham never obtained these volumes at all. Mr. Hamilton, of Texas, is charged upon the account books with in rolumes, obtained at the last session, as not yet returned. The testimony before your committee shows that Mr. Hamilton gave those books, before the close of the last session, to a messenger of the post-office, to be returned to the library; and it was not until so informed during this inrestigation that Mr. Hamilton had any intimation that his directions had not been complied with. The necessities of the House have required their removal to a more commodious Hall. The increase of the library, corresponding with the increased demands of the Honse, renders the accommodations provided for it when it contained a nuch less number of books totally inadequate. Without recommending any particular action in this respect, your committee would say that they deem this a subject which demands the early consideration of the House.

Your committee herewith submit the testimony they have taken, and recommend that the same, with the accompanying report, be printed. ${ }^{x}$

\section{SENATE: LIBRARY.}

In I 849 (September 24) the Intelligencer reported that a circular library room had been provided for the Senate over the small rotunda in the north part of the Senate wing. This

"Thirty-sixth Congress, second session, House report No. 9o: Alleged abstraction of books from the Ifouse library. February 28, 1861. $6.4 \mathrm{pp}$. 
roon was said to be divided into 20 compartments or recesses and to be capable of holding 15,000 or 20,000 volumes.

Either this report was based upon rumor or the roon was afterwards appropriated to other purposes, for July $S$, I $S_{56} 6$, Mr. Weller submitted the following resolution, which was considered and agreed to: "Resolved, That the Committee on the Library be instructed to inquire into the expedicncy of having a suitable room fitted up for a Senate library, and the appointment of a proper person to take charge of the same." December 23, IS59, a similar resolution was submitted by Mr. Mallory, and passed February I, IS60.

December I4, IS63, resolutions to the same effect were submitted by Mr. Solomon Foot, as follows:

Resolved, That one copy of each of the books, and sets of books, maps, charts, atlases, and printed bound documents in the possession of the Senate be collected together by the Secretary from the various rooms and apartments set apart for the use of the Senate; so as to form one complete set or copy of each and all of the same, which shall be properly arranged in classes and sections, and which, together with such other books and matters as may from time to time be directed to be procured by the Committee on the Library of the Senate for that purpose, shall be formed into a library of the Senate for the special use of its members and committees, and the business of the Senate and the Secretary's office, under such regulations as may be prescribed by the Committee on the Library of the Senate for the time being, which regulations shall be printed and furnished to the nembers, committees, and officers of the Senate at the commencement of each session, and shall be observed and conformed to by them until modified or changed by the committee or by the order of the Senate.

Resolied, 'That a librarian shall be appointed by the Secretary of the Senate to take charge of the said library, whose duty it shall be to keep a complete and faithful record of every book, map, atlas, received or placed in such library, and diligently to malse hinself acquainted with the same, so as to be able, whenever called npon by a nember, or on the part of a committee of the Senate, or the office of the Secretary, to furnish such book or other article for use in the library, or any information, in tabular or other form, that may be required from them, and to take a particular account of every book or other article delivered out of the library to any member, or committee, or the Secretary, and to require

'On the flh of January, I859, the Senate had moved into their present Chamber in the north wing of the Capitol extension. 
its return into the library according to the regulations prescribed by the said Committee on the Library, or the Senate, and also to perform such other duties in the said library as may be prescribed by the said committee, the Senate, or the Secretary of the Senate; and the compensation of the said librarian shall be two thousand dollars per annum, with the same official qualification, under oath, and subject to the same penalties for neglect or violation of the rules as are the other officers of the Senate.

Resolied, That the arrangement made for the occupation of the rooms of the north extension of the Capitol, set apart for the Senate by the resolution of the 18 th of January, 1858 , be so far changed that the rooms numbered 99, I0O, and Io s shall be appropriated for this library, and the rooms numbered 87,89 , and II shall be appropriated for the use of select committees and such other committees not already occupying separate rooms as may be assigned to them by the presiding officer of the Senate for the time being, unless otherwise ordered by the Senate.

These resolutions were accompanied with the following communication to Mr. Foot from Mr. W. Hickey, chief clerk in the office of the Secretary of the Senate:

Office of the Secretary of the Senate, U. S., August 27, 1863.

DFAR SIR: Agreeably to the request made when last I had the pleasure of seeing you in Washington, I have now the honor of submitting the following remarks in relation to the establishment of a library for the Senate, which you have so favorably contemplated and desired for some years past.

The Public Library of Congress, containing books on all the various branches of history, literature, science, and on miscellaneous subjects, is accessible to and may be used by members of both Houses of Congress, the President, heads of Departments, the judges of the Supreme Court, and other public officers, as well as by other persons, under certain rules and regulations applicable to them according to circunstances.

The Congressional law library, containing a full and complete collection of the laws of the United States and of the sereral States, the reports of the decisions of the Supreme Court of the United States and of the States, as well as of the English and other foreign courts and anthorities, and an extensire collection of the most valuable works on jurisprudence in all its departments and branches, and by the best authors, may also be used by the same persons having access to the Public Library of Congress, and under like regulations.

The private library of the House of Representatives, containing the bound documents and reports, the journals of both Houses of Congress, and the documents and books compiled and printed under their anthority, as well as other publications, is intended for the special use of the 
members of that House. It has a librarian to take care of these books and furinsh then to the members when desired.

The President and each of the Executive Departments has a private library, appropriately selected, and kept for his and their private use.

But the Senate of the United States has no private library for the special use of its members; which privation has subjected them, for many years past, to much inconvenience and disadvantage.

The library here alluded to would consist of the journals, documents, reports, and debates of the two Houses of Congress, the laws, treaties, and other books and publications, which contain a full and complete history of the national legislation, the principles governing the same, as illustrated by the reports, debates, statistics, and information upon which the action of the Gorernment has been founded. All this information is constantly essential to the members of the National I.egislature and should at all times be entirely accessible to the conrenient use of erery nember.

The books containing this information, together with many other publications referred to in the statement accompanying these remarks, have been printed, collected, or purchased from time to time for the Senate, for the use of its members and committees, and are now in its possession, in different rooms and apartments, but for the want of a proper library and librarian of suitable qualifications to take care of the books and to furnish promptly whaterer information might be wanted from them, the books have been comparatively useless. Great inconvenience has resulted to members, on pressing emergencies, from not knowing where to find particular books, and a considerable loss of books has occurred from having no person particularly responsible to keep an account and take care of them, which evil threatens, in process of time, the loss of the most valuable of them.

The private library of the Senate may properly be formed or constituted of books and documents which are almost wholly within its orru possession, but which, being scattered about in various rooms and apartments, as before stated, have heretofore been in many cases mavailable and inaccessible as sealed books, they being in different places, without any systematic arrangement and without any individual particularly responsible for their care and preservation or for their prompt use by members who may desire it.

This individual or librarian should, by attention and study, acquire a knowledge of the books which would enable hinn to aid the members in obtaining the desired information from them, and to collect and arrange, in tabular and other forms, statistical information for their use.

Much inconvenience will always arise from the nere bulk or multiplicity of the books and documents, unless they are kept properly classified and arranged under the particular care and responsibility of an 
individual well qualified for the duty. This officer should be under the direction of the Seeretary of the Senate.

This dity of furnishing information from these books has heretofore, in many cases, been performed by clerks in the Secretary's office whose experience in the public business has enabled them in this way to serve the members by collecting for them statistical, historical, political, and other information from the books and documents; but this duty has been extra official, or out of the line of the ordinary official business, niaking it necessary frequently for the clerks to leave or postpone, for a time, such business, in order to enter into researches and examinations requiring in many cases 11 uch industry, time, and labor to accomplish. The manner in which these clerks, when called upon, have performed this duty has been well known to their friends in the Senate, and, it is believed, has generally given satisfaction where the public duties of the Senate, from their pressing nature, have not absolutely precluded the possibility of attending to such calls for information to be collected by the clerks; but members have, no doubt, on some pressing emergencies, been embarrassed by not speedily obtaining in this way information, and such members can more particularly appreciate an arrangement by which all these sources of information will always be within their own reach, aided by a well-qualified person whose exclusive duty it will be at all times to refer to or to collect and furnish stch desired information.

This arrangement would be intended mainly for the accommodation of individual nembers, but every committee would find in this emporiun1 all the facts, precedents, and information appropriate to the business of such committee, to be derived from past opinions, decisions, and experience upon all subjects which had ever been before Congress; nor would this necessarily interfere with the employment or occupation of the committe clerks, for they would, without doubt, find in this library erery proper aid and facility in the more thorough and prompt execution of their respective duties to the committees by whom they were appointed.

Experience has shown that legislators have frequent occasion in the preparation of their views, in the progress of clelivering them, or in the preparation of reports, bills, or resolutions, to refer to, examine, and digest the proceedings, action, and results upon the same or kindred subjects on previons occasions, in order to ascertain or be well assured of ophinions, argunents, facts, and decisions which might otherwise be nnknown, or having been once heard or seen, would depend npon the menory alone. The necessity for such preparation is acknowledged by all who believe that statesmanship comes from attentive study, as well as calm, deliberate, and prudent deductions from established principles and practical experience, rather than from hasty conclusions founded on mere chineras, speculative notions, intuitive presumptions, or on inconsiderate and unstrstained opinions. 
On occasions requiring such investigations, much time and labor liave been expended by members in the mere occupation of hunting up the sources and the means of obtaining the desired information, which might otherwise have been saved by this arrangement, and been more profitably employed upon the subject in hand.

For these reasons it wonld, indeed, seen to be an object worthy the attention of the Senate, collectively, to provide sucl means to every individual nember, to enable him to perform his high and important functions conscientiously and acceptably.

The consistency, wisclom, and propriety of measures of legislation may frequently depend upon the proper use of such means of information and its practical application to objects necessary to secure the general interests, welfare, and happiness of the country.

The proposed private library for the Senate may be located in proper apartments deroted exclusively to the use of the Senators, where a member seeking facts or information upon any given subject may, at any time, have recourse. There he would find convenient tables, comfortable chairs, with the books properly classified and arranged on shelves around him, where he could help himself to any books he might desire to read or examine, or, by asking for what he desired to use, be furnished with it by the librarian. Here he might resort from time to time withont interruption to pursue or resume investigations, or obtain information to his entire satisfaction, and with the least possible inconvenience or loss of time, for this library should be accessible both day and night during the sessions of Congress or of the Senate.

A long course of experience in the service of the Senate authorizes me to say that the proper establishment, judicial regulation, and faithful attendance upon such a private library for this honorable body is a desideratum of much importance, so much so that when once established and enjoyed it will be considered so indispensably necessary as to form a subject of astonishment that it had not long since been authorized.

That this expectation may be fully realized, and all the advantages contemplated by this arrangement secured to the lonorable Senate, to which I owe, in gratitude, my best services and the fruits of my experience in its service, and that it may result in the more general and correct diffusion of facts and the dissemination of the fundanental principles of the Constitution, as expounded by George Waslington and the noble galaxy of American patriots and statesmen who have succeeded him, all of which will be illustrated by this library, are my only motives for these remarks.

As mucl of the convenience or usefulness of this library will depend upon the description, proper classification, and arrangennent of the books, I beg leave to submit the accompanying programme, which presents to view not only an appropriate classification, but a description of the 
books and means of information which the Senate has already in its own possession for the commencement of this library.

These books will form a library embracing political history and the whole national legislation of the country, including reports, bills, resolutions, debates, proceedings, votes, and acts of Congress under the Constitution, and proceedings of the Congress of the Confederation; the acts and proceedings of the executive department of the Government, so far as they have been communicated to Congress; the intercourse with foreign nations, illustrating the American polity and its views of international law, and principles based 11pen the Constitution of the United States; the statistics of population and emigration, of the finances, commerce and navigation, the post-office, relations with the Indian tribes, the public lands and private land claims, the nilitary and naval affairs, and public and private claims, and of all the various branches of the public service; the writings and papers of eminent American statesmen and patriots; books and compilations containing national and international laws and principles; the decisions of the Supreme Court of the United States, and many books of a public character that go to make up a collection peculiarly adapted to the use of Senators and statesmen.

In this library should be collected and found the indexes of the Congressional and law libraries, of the libraries of the several Executive Departments as well as of other public libraries in the States and the District of Columbia that have been printed and can be obtained.

Experience has suggested the expediency, as well as the necessity, of establishing this library for the use of the nembers of the Senate, if it were for no other purpose than that of preserving the books, etc., from being lost and of securing them for future use, under the special care of a competent individual made particularly responsible for their continued care and preservation and their readiness at any and all times for the use of the members and conmintees of the Senate.

When I first entered the service of the Senate, at the session of I 824-25, there had been no printed documents or bills of either house of Congress preserved from one session to another, except the few copies that were bound, but every loose or surphs copy of every document, report, bill, or resolution that had not during the session been taken away by the subordinate enployees of the two Houses and sold to grocers and other merchants for wrapping paper were, at the close of every session, by those employees, gathered up and thus disposed of, so that at any future session not a single copy of any docnment, report, bill, or resolution could be obtained by a nember for lis public or private use or to facilitate the business of the committees. The only mode of obtaining a copy was by having it reprinted or copied in manuscript, either of which modes was attended witl extra expense and consumption of time, which excluded the idea of availability for present or inmediate use.

Taking the matter in hand as soon as I entered the service of the 
Senate I preserved at least ten copies of every document, report, bill, and resolution both of the Senate and House of Representatives that had been printed for the future use of the nembers and committees of the Senate and the official business of the Secretary's office. The convenience and advantages of this conservative arrangement were at once recognized and acknowledged by both Senators and Representatives, the latter of whon frequently availed themselves of this arrangement for the Senate, and it was not long before a similar arrangement was necessarily made for the House of Representatives. These documents, reports, bills, and resolutions have been regularly filed and labeled and continued down to the present tine in both houses, whose members and committees have too often been supplied and accommodated with these documents, reports, bills, and resolutions for the facilities of the public business to require any further explanation upon the subject.

These are now on the Senate side under the care, management, and responsibility of Mr. Titcomb, a worthy, intelligent, and obliging officer, and in such hands will always be a very great convenience to the members and committees of the Senate.

These accommodations, however great and numerous as they have been in the ordinary business of the Senate, are of a minor order and degree compared with those which will result in the examination and consideration of the more important affairs of state from the establishment of the library now recommended for the especial use of the members and committees of the Senate.

All of which, together with the following programme for the classification of the books for the proposed library, is most respectfully submitted by your faithful and obedient servant. ${ }^{\mathrm{x}}$

This programme for the classification of the Senate library arranged the collection in twenty classes: ${ }^{2}$

I. The colonial history of the United States and documentary and other history of the Revolution. 2. Legislative proceedings and acts of the Congress of the Confederation from the commencement of the Rerolution to the commencement of the Government under the Constitution. 3. Journal, acts, and proceedings of the convention which framed the Constitution of the United States. 4. The journal of the House of Representatives of the United States from March 4, I789, to March 3, 1863. 5. The legislative journal of the Senate of the United States from March 4, 1789 , to March 3, 1863 . 6. The executive journal of the Senate from March 4, I789, to March 3, 1863. 7. The journal or record of the Senate on trials of inpeachment from March 4,1789 , to March 3, I863. 8. Documents or papers communicated to both Houses of Congress since the $4^{\text {th }}$ of March, I789. 9. Documents printed in octavo form by order of the Senate during each session from March 4 ,

'Thirty-eighth Congress, first session, Senate miscellaneous document No. 3 .

I Ibid, No. 4. 
I789, to March 3, I863. Io. Documents printed in octavo form by order of the House of Representatives from March 4, I789, to March 3, I863. II. Debates in Congress, embracing the speeches made in the two Houses of Congress from March 4, I789, to March 3, I 863. I2. Laws of the United States. I3. Abridgments and digests of the laws of the United States. I4. Indexes prepared in conformity with orders or resolutions of the Senate and House of Representatives of the United States, respectively. I5. Reports of the decisions of the Supreme Court of the United States. I6. Publications on the subject of the public lands and private land claims under the authority of the United States. I7. Revenue laws, commercial regulations, digests of tariff laws, etc. IS. Miscellaneous books printed or furnished under the authority or patronage of the United States and not noticed under particular heads. I9. Miscellaneous publications containing useful political, statistical, and other information. 20. Atlases or books of maps.

These documents were referred to the Committee on the Library, who, on the ISth of January, I864, submitted by Mr. Collamer an adverse report, which was concurred in.

The tendency to keep the control of the Government libraries in the liands of Congress, to establish branches of the Library of Congress rather than independent libraries, is well shown in the legislation regarding the library of the Patent Office. The appropriation for that library, July 4, I 836 , provided $\$ 1,500$ to be expended under the direction of the Committee on the Library of Congress. The advantage of such centralization was felt by the Commissioner of Patents also. In his report, Jannary 29, IS45, he said that if he were pernitted to take books from the Library of Congress it would relieve him from the necessity of purchasing some rare publications for liis Office.

In the relations of the Library of Congress with the only public library of the District-the Washington Library-this same tendency toward centralization is manifest. This is show1 particularly in the vote of the Joint Library Committee, March I 3 , I $S_{3}$ o, "That the books separated from the Library, for sale, be deposited with the Washington Company, they giving a receipt therefor and becoming responsible for their return to the Library of Congress when required."

\footnotetext{
"Journal of the Washington Library Company, October 3, 1828 , March 12, I829; Minutes of the Join Library Committee, March I3, I830; Telegraph, July 23, IS3O.
} 


\section{Cratuter Ten}

THE SMITHSONIAN INSTITUTION AND PLANS FOR A NATIONAL LIBRARY 



\section{CHAPTER TEN.}

THE SMITHSONIAN INSTITUTION ANI) PLANS FOR A NATIONAL, LIBRARY.

Although at the middle of the nineteenth century Washington was probably better supplied with books than any other city in the Union, the United States was without a national library. The reasons for this were many. There was little local interest in libraries. An extract from the London Times on the British Musenm in the National Intelligencer for September 30, I842; articles on the new Astor Library in New York in the National Intelligencer for September 24, I 858 , and February 25, I862, and an extended series of articles on the history of libraries in the National Intelligencer for September I I and is, October S, Norember 3, 5, and 2I, and December I and I8, I846, are the only pieces of mere library literature to be found in the columns of the local press. Nor was there much interest elsewhere in the establishment of a national library; one political party was opposed to the establishment of any national institutions, and others were opposed to the establishment of any such institutions at Washington. Besides, as the United States Magarine' said, the great geographical extent of the United States, the number of cities scattered over the country, metropolitan in their wealth and character, the absence of any recognized national university, and the fact that Washington was only the political capital, not, like London and Paris, the center of wealth, literature, and population also, all lindered the realization of the idea of a national library which had formed in the minds of a few students anxions for the literary as well as political independence of the country. This condition of affairs is illustrated by the fact that while about half of the volumes in the British 
Musenm at this time were presents to the library, a very small per cent of the books in the Library of Congress had been presented to the institution.

The Smithson bequest to the people of the United States seemed to some students to present the long-desired opportunity for the creation of a national library.

The most prominent advocate of the library plan for the organization of the Smithsonian Institntion was Rufus Choate. 'Tlue causes in which this distinguished man was engaged during his career were for the most part private, not public causes, but here an opportunity was presented to champion a measure of national importance, to lay a foundation for American learning, and he grasped it, for to him the real world was the world of books, particularly Greek books.

On the gth of December, IS44, Mr. Choate wrote in his journal: "About to set off to Washington. : : : The business of the session ought to engross, and shall, my chief attention. The Sunithsonian fund ought to be applied to a great library, and a report and a speech in favor of such an appropriation are the least $I$ owe so grand and judicious a destination of a noble gift." 3

A bill to establish the Sinithsonian Institution for the Increase and Diffusion of Knowledge among Nen was introduced into the Senate, December I2, IS44, by Mr. Tappan, of Ohio. Section I of this bill provided that the library of the institution should consist of works on science and the arts relating to the ordinary business of life, mechanical and other inprovements and discoveries.

On the Stl of Jannary, I $S_{45}$, the 'Tappan bill was taken 11p for discussion, and Mr. Cloate, in a speech which the North Amerian Rrilca' said would in future times render nore menorable the day on which it was delivered than that

\footnotetext{
"There is a history of the Smithsonian library, hy Cyrus Adler, in "The Smithsonian Institution, $18.4-1896$. The history of its first half century, edited by George Brown Gomle" (1897), pp. 265-302. I shall present in this place in more detail a listory of opinion regarding the smithsonian as a national library and of the early undertakings of the Smithsonian library in its capacity as a national hbrary.

" Fillin P. Whipple, Some recollections of Rufus Chonte (1879), pp. $38,57$.

'Samnel (i. Brown, I.ife of Rufus Choate, 2 d ed., IS7o, p. I2S.

4 Tol. 79,1 1) 459.
} 


$$
8
$$



gallant military achievement of which it is the anniversary, advocated the devotion of the larger part of the Sunithsonian fund to the establishninent of a national library. After reviewing the provisions contained in the bill for a college of applied science, he said:

It is easy to waste this money; it is easy to squander it in jobs, salaries, quackeries; it is easy, even under the forms of utility, to disperse and dissipate it in little rills and drops, imperceptible to all human sense, carrying it off by an insensible and ineffectual cvaporation. But, sir, I take it that we all earnestly desire-I am sure the Senator from Ohio does so-so to dispense it as to make it tell. I am sure we all clesire to see it, instead of being carried off invisibly and wastefully, embody itself in some form, some exponent of civilization, permanent, palpable, conspicuous, useful. And to this end, it has seemed to me upon the most mature reflection, that we can not do a safer, surer, more unexceptionable thing with the income, or with a portion of the income--perhaps $\$ 20,000$ a year for a few years-than to expend it in accumulating a grand and noble public library, one which for variety, extent, and wealth shall be, and be confessed to be, equal to any now in the world.

I say for a few years. Twenty thousand dollars a year for twentyfive years are $\$ 500,000$, and $\$ 500,000$ discreetly expended, not by a bibliomaniac, but by a man of sense and reading, thoroughly instructed in bibliography, would go far, very far, toward the purchase of nearly as good a library as Europe can boast. I nean a library of printed books, as distinct from manuscripts. Of course, such a sum would not purchase the number of books which some old libraries are reported to contain. It would not buy the 700,000 of the Royal Library at Paris, the largest in the world, nor the 500,000 or 600,000 of that of Mtunich, the largest in Germany; nor the 300,000 , 400,000, or 500,000 of those of Vienna and St. Petersburg, and the Vatican at Rome, and Copenhagen, and the Bodleian at Oxford. But mere numbers of volumes afford a very imperfect criterion of value. Those old libraries have been so long in collecting; accident and donation, which could not be rejected, have contributed so much to them, a general and indiscrininate system of accumulation gathers up, necessarily, so mucl trasli; there are so many duplicates and quadruplicates, and so many hooks and editions which become superseded, that mere bulk and mere original cost must not terrify us. Ponderantur non numerantur. Accordingly the Library of the University at Göttingen, consisting of perhaps 200,000 volumes, but well chosen, selected for the most part within a century, and to a considerable extent by a single great scholar (Heyne), is perhaps to-day as valuable a collection of printed books as any in the world. 'Toward the accumulation of such a library the expenditure of two-thirds of this income for a quarter of a century would make, let me say, a magnificent 
advance. And such a step taken we should never leave the work minfinished; yet when it should be finished, and your library shonld rival anything which civilization had to show, there would still be the whole principal of your fund unexpended, yielding its income forever, for new and varying application for increasing and diffusing knowledge in the world.

(Dr. Clioate here read a letter of Professor 'Torrey, of Burlington, showing at what reduced prices valuable books may now be purehased.)

I hesitate, from an apprehension of being accused of entering too far into a kind of clissertation unsuited to this assembly of men of business, to suggest and press one-half the considerations which satisfy my mind of the propriety of this mode of expenditure. Nobody can doubt, I think, that it cones within the terms and spirit of the trust. That directs 11. "to increase and diffuse knowledge among men." And do not the judgment of all the wise--does not the experience of all enlightened states-does not the whole history of civilization, concur to declare that a various and ample library is one of the surest, most constant, most permanent, and most econonical instrumentalities to increase and diffuse knowledge? There it would be-durable as liberty, durable as the Union; a rast storehouse, a vast treasury, of all the facts which make up the history of man and of nature, so far as that history has been written; of all the truths which the inquiries and experiences of all the races and ages have found out; of all the opinions that have been promulgated; of all the emotions, images, sentiments, examples, of all the richest and most instructive literatures; the whole past speaking to the present and the future; a silent, yet wise and eloquent teacher; dead, yet speaking-not dead! for Milton has told us that a "good book is not absolutely a dead thing-the precious life-blood rather of a master spirit; a seasoned life of man enbalned and treasured up on purpose to a life beyond life." Is not that an admirable instrumentality to increase and diffuse knowledge among men? It would place within the reach of our minds, of our thinkers, and investigators, and scholars, all, or the chief, intellectual and literary materials, and food and instruments, now within the reach of the cultivated foreign mind; the effect would be to increase the amount of indiridual acquisition, and nultiply the number of the learned. It would raise the standard of our scholarship, improve our style of investigation, and conmunicate an impulse to onr educated and to the general nind. There is no library now in this conntry, I suppose, containing over 5o, ooo volumes. Many there are containing less. But, fron the nature of the case, all have the same works; so that I do not know, that of all the printed books in the world, we have in this conntry more than 50,000 different works. The consequence has been felt and lanented by all our authors and all our scholars. It has been often said that Gibbon's History conld not have been written here for want of books. I suppose that Hallam's Middle Ages, and his 
introduction to the literature of Europe, could not. Irving's Columbus was written in Spain. Wheaton's Northmen was prepared to be written in Copenlagen. See how this inadequate supply operates. An American mind kindles with a subject; it enters on an investigation with a spirit and with an ability worthy of the most splendid achievement; goes a little way, finds that a dozen books, one book, perhaps, is indispensable, which can not be found this side of Göttingen or Oxford; it tires of the pursuit, or abandons it altogether, or substitutes some shallow conjecture for a deep and accurate research, and there an end. Let me refer to a passage or two of the complaints of studious men on this subject:

[Here he quoted the articles on a national library published in the North American Revicu', which we have presented on pages I 40 and $23 \mathrm{I}$. He then continued:]

Yet these writers had access to the best library in this country.

Now, there are very many among us, and every day we shall have more, who would feelingly adopt this language. Place within their reach the helps that guide the genius and labors of Germany and England, and let the genius of Germany and England look to themselves! Our learned men would grow more learned and more able, our studies deeper and wider, our mind itself exercised and sharpened, the whole culture of the community raised and enriched. This is, indeed, to increase and diffuse knowledge among men.

If the terms of the trust, then, authorize this expenditure, why not make it? Not among the principal, nor yet the least, of reasons for doing so is that all the while that you are laying ont your money, and when you have laid it out, you have the money's worth, the value received, the property purchased, on hand, to show for itself and to speak for itself. Suppose the professor provided for in the bill slould gather a little circle of pupils, each of whom should carry off with him some small quotient of navigation or horticulture or rural economy, and the fund should thus glide away and evaporate in such insensible, inappreciable appropriations, how little there would be to testify of it! Whereas here, all the while, are the books; here is the value; here is the visible property; here is the oil, and here is the light. There is something to point to if you should be asked to account for it unexpectedly, and something to point to if a traveler should taunt you witl the collections he has seen abroad, and which gild and recommend the absolutisms of Vienna or St. Petersburg.

Another reason, not of the strongest, to be sure, for this mode of expenditure is that it creates so few jobs and sinecures, so little salaried laziness. There is no room for abuses in it. All that yon need is a plain, spacious, fireproof building, a librarian and assistants, an agent to buy your books, and a fire to sit by. For all the rest, he who wants to read goes and ministers to hinself. It is an application of noney that almost excludes the chances of abuses altogether. 
But the decisive argument is, after all, that it is an application the most exactly adapted to the actual literary and scientific wants of the States and the country. I have said that another college is not needed here, because there are enough now, and another night do harm as much as good. But that which is wanted for every college, for the whole country, for every studious person, is a well-chosen library somewhere among us of 300,000 or 400,000 books. Where is such a one to be collected? How is it to be done? Who is to do it? Of the r 50 colleges, more or less, distributed over the country one has a library of perhaps 5 o,ooo volumes; others have good ones, though less; others smaller and smaller down to scarcely anything. With one voice they unite, teacher and pupil, with every scholar and thinker in proclaiming the want of more. But where are they to come from? No State is likely to lay a tax to create a college library or a city library. No death-bed gift of the rich can be expected to do it. How, then, is this one grand want of learning to be relieved? It can be done by you and by you alone. By a providential occurrence it is not only' placed within your constitutional power, but it has become your duty; you have pledged your faith; you have engaged to the dead and living that, withont the cliarge of one dollar of the people, you will meet the miversal and urgent demand by the precise and adequate supply. By such a library as you can collect here something will be done, much will be done, to help every college, every school, every studious man, every writer and thinker in the comntry to just what is wanted most. Inquirers after the truth may come here and search for it. It will do no harm at all to pass a few studious weeks among these scenes. Having pushed their investigations as far as they may at home, and ascertained just what and how much more of help they require, let them come hither and find it. Let them replenish themselves and then go back and make distribution among their pupils; aye, through the thousand channels and by the thousand voices of the press, let them make distribution among the people! Let it be so that-

Hither as to their fountains other stars

Repairing, in their golden urns, draw light.

I have no objection at all-I should rejoice rather to see the literary representatives of an instructed people come hither, not merely for the larger legislation and jurisprudence, but for the rarer and higher knowledge. I am quite willing, not only that our "Amphictyonic conncil" should sit here, but that it should find itself among sone such scenes and influences as surrounded that old renowned assembly, the fountain of purer waters than those of Castalia, the temple and the oracle of our Apollo! It will do good to have your educated men come to Washington for what has heretofore cost voyages to Germany. They will be of all the parts of the conntry. They will becone acyuainted with each other. They will contract friendships and nututual regards. 'They wili 
go away not only better scholars, but better unionists. Someone has said that a great library molds all minds into one republic. It might, in a sense of which he little dreaned, help to keep ours together.

I have intimated, Mr. President, a doubt whether a college or university of any description, even the highest, should be at present established here. But let it be considered by the enlightened friends of that object, if such there are, that even if your single purpose were to create such a university you could possibly begin in $n$ way so judiciously as by collecting a great library. Useful in the other modes which I have indicated, to a university it is everything. It is as needful as the soul to the body. While you are doubting, then, what to do, what you will have, yon can do nothing so properly as to begin to accumulate the books which you will require on whatever permanent plan of application you at last determine.

I do not expect to hear it said in this assembly that this expenditure for a library will benefit a few only, not the mass; that it is exclusive and of the nature of monopoly. It is to be remembered that this fund is a gift, that we take it just as it is given, and that by its terms it must be disbursed here. Any possible administration of it, therefore, is exposed to the cavil that all can not directly, and literally, and equally partake of it. How many and of what classes of youth from Louisiana, or Illinois, or New England, for example, can attend the lectures of your professor of astronomy? But I say it is a positive and important argument for the mode of application which I urge that it is so diffusive. Think of the large absolute numbers of those who, in the succession of years will come and partake directly of these stores of truth and knowledge! Think of the numbers without number who, through them, who by them indirectly will partake of the same stores! Studious men will come to learn to speak and write to and for the growing millions of a generally educated commuuity. They will learn that they may conmunicate. They can not hoard if they would and they would not if they could. They take in trust to di-tribute; and every motive of ambition, of interest, of duty will compel them to distribute. They buy in gross to sell by retail. The lights which they kindle here will not set under a bushel, but will burn on a thousand hills. No, sir; a ricli and public library is no anti-republican monopoly. Who was the old Egyptian king that inscribed on lis library the words "The dispensary of the sonl?", Yon might as well inscribe on it "armory, and light, and fountain of liberty!"

It may possibly be inquired what account I make of the Library of Congress. I answer that I think it already quite good and improving; but that its existence constitntes no sort of argument against the formation of such a one as I recommend. In the theory of it, that Library is collected merely to furnish Congress and the Government with the neans of doing their official business. In its theory it must be, in some sort, 
a professional library; and the expenditure we now make- $\$ 5$, 00 in a year, or, as last year, $\$ 2,500$-can never carry it up to the rank and enable it to fulfill the functions of a truly great and general public library of science, literature, and art. The value of books which could be added under the appropriations of the last year can not greatly exceed \$2,200. Doubtless, however, in the course of forming the two it would be expedient and inevitable to procure to a great extent different books for each.

I do not think, Mr. President, that I am more inclined than another to covet enviously anything which the older civilization of Europe possesses which we do not. I do not suppose that I desire any more than you, or than any of you, to introduce here those vast inequalities of fortune, that elaborate luxury, that fantastic and extreme refinement. But I acknowledge a pang of envy and grief that there should be one drop or one morsel more of the bread or water of intellectual life tasted by the European than by the American mind. Why should not the soul of this country eat as good food and as much of it as the soul of Europe? Why should a German or an Englishman sit down to a repast of 500,000 books and an Anerican scholar, who lores truth as well as he, be put on something less than half allowance? Can we not trust ourselves with so nucl of so good a thing? Will our digestion be impaired by it? Are we afraid that the stimulated and fervid faculties of this young nation will be oppressed and orerlaid? Because we have liberty which other nations have not, shall we reject the knowledge which they have and which we have not? Or will you not rather say that because we are free, therefore will we add to our freedom that deep learning and that diffused culture which are its grace and its defense? ${ }^{\text {r }}$

He concluded by moving the following amendment:

Strike ont the eighth section and insert:

SFC. 8. And whereas an anple and well-selected public library constitutes one of the permanent, constant, and effectual means of increasing and diffusing knowledge among men; therefore

Be it further cnacted, That a sum not less than twenty thousand dollars be annually expended, of the interest of the fund aforesaid, in the purchase of books and manuscripts for the formation of a library of the Institution aforesaid, which, for its extent, variety, and value shall be worthy of the donor of the said fund, and of this nation and of this age. $^{2}$

\section{Mr. Tappan next addressed the Senate:}

He doubted the utility of such an extensive and costly library as had been suggested by the Senator from Massaclunsetts; he cloubted the possibility of laying out usefully and advantageously $\$ 20,000$ a year-or

\footnotetext{
'Congressional Clobe, 14: Appendix, 63-64.
} 
even more than four or five thousand dollars a year-in the purchase of books. It would be impossible to make such a rast collection of books as \$500,000 would purchase, without including cartloads-nay, shiploads-of trash not worth in reality the cost of transport. There was the Library of Congress, to the increase of which $\$ 5$, , oo was annually appropriated, and it was well known that this sum enabled the committee to procure everything coming out in print worth procuring. Yet, in this library, snall in comparison to any of those foreign libraries alluded to by the Senator, he protested there was more than half the books that he would not take a gift of for the cost of transportation to Ohio. ${ }^{\mathrm{s}}$

On the following day Mr. Choate withdrew his motion of amendment, and moved instead to strike ont the proviso in the first section of the bill, which runs thus:

Prozided, That the books to be purchased for said institution shall consist of works on science and the arts, especially such as relate to the ordinary business of life, and to the various mechanical and other improrements and discoreries which may be made.

His object was to aroid a premature decision on the point at issue as to the plan of a general library, or special one limited to works on physical science. By striking out the proviso the Senate would not commit itself, the question as to the nature of the library being reserved for amendment to another section of the bill.

Mr. Tappan considered the motion to strike ont the proviso must produce a test rote on the very point at issue; and if that test was desired, it might as well be taken on it as on any other amendment.

He argned that a library limited to the works on science and the arts, specified in the proviso, would be the only suitable and appropriate library for the institution. There was no necessity for another general library in the city of Washington, where the Government had already the Library of Congress, the libraries of the State, War, Nary, and other public Departments, annually augmented by means of large appropriations. ${ }^{2}$

Mr. Pearce also wished to strike out this proviso.

If he minderstood the object aimed at by the Senator from Massaclinsetts, it was to make the interest of this mmificent bequest accomplish

'Congressional Globe', I4: 107. Ihirl., 14: 115. 
the injunction of the clonor by such an increase and diffusion of knowledge among men as a complete national library, worthy of him and of this country, wonld undoubtedly insure. The Library of Congress, though no larger than the private collections of many private gentlemen in Enrope, had been thirty years collecting, and now numbered only 40,000 volumes. The library of the British Musenum consists of 200,000 rolumes; yet by a recent report it appears that $\mathcal{E}_{100,000}$ is required to render it complete. The libraries of the Government alluded to by the Senator from Ohio are indispensable to the Departments, as is that of Congress to the Capitol. They can not, with due regard to the interests of national legislation, be transferred for public use as a national library. By carrying out the suggestion of the Senator from Massaclinsetts a great national library, worthy of the conntry and of the donor of this fund, may be established. ${ }^{x}$

The question was then taken on the motion of Mr. Choate and the proviso was stricken ont.

Mr. Choate next moved to strike out the eighth section and to substitute the following:

SFC. 8. And whereas an ample and well-selected library constitutes one of the most permanent, constant, and effectual means of increasing and diffusing knowledge among men; therefore,

Be it further enacted, That an annual expenditure be made from the interest of the fund aforesaid, nnder the direction of the said managers, on the purchase of books and mannscripts for the formation of a library of the institution aforesaid, which, for its extent, variety, and value shall be worthy of the donor of the said fund and this nation and of the age.

Mr. Crittenden moved to add to it a proviso that, in the purchase of books for the said institution, it should be regarded as a principal object to purcliase works on science and the arts, especially such as relate to the ordinary business of life and to the various mechanical and other improvements and discoveries which may be nuade.

Mr. Choate argued that this limitation was not only unnecessary, but would most certainly prove injurious. It was nnnecessary, because no national library such as he contemplated and such as he hoped the Senate would anthorize could be made complete withont every one of the works on science and the arts which the Senators from Ohio and Kentucky could possibly desire. The proviso would operate injuriously by raising a constitutional question of disputation anong the managers as to the quantity of money to be applied to this special description of books and to general literature. If it was stated that ont of a given sunn two-thirds should be devoted to these books and one-third to other books they could 
easily agree; bnt indefinitely directing a preference wonld be to limit exceedingly in effect the portion to be devoted to works of general literature.

This point was debated at great length by Messrs. Crittenden, Choate, and Woodbury; Mr. Choate being opposed to any proviso, and Messrs. Crittenden and Woodbury in favor of one sufficiently explanatory to show a preference for the works indicated, without putting an nndue restriction on the purchase of all other books suitable to a general library.

Mr. Rives said he should feel very great repugnance to any provision in this bill which shonld assume to recognize any important distinction between the different branches of human knowledge. The general object of this bequest-of which we are constituted the trustees-is described to be "the increase and diffusion of knowledge among men." Now, if we were to have a library at all to carry out this great object, it really seemed to him that that library ought to be coextensive with the limits of human knowledge. Some of his honorable friends on both sides of the House had dropped observations in the course of this debateand he had heard them with surprise-which would seem to imply that moral science is not knowledge, and that nothing but what are regarded as the natural sciences-astronomy, mathematics, and other of that classis knowledge. The great field of modern inquiry relating to the moral and political sciences is not to be considered at all as a branch of human knowledge! Was this so?

And was this the country, or this the age, in which we were to recognize such a doctrine? It did seem to him that the most important of all the branches of human knowledge is that which relates to the moral and political relations of man. It is intimately connected with the rights and duties and privileges of citizens, whether in public or in private life. How would gentlemen designate that great branch of human science, which is of very modern origin, and even now in its infancypolitical economy? Is it not a most important part of human knowledge? And are the legislators of this country, who are so deeply concerned in the destinies and progressive civilization of the lnuman race, to regard the science of gozernment and legislation as no part of hunnan knowledge? It really seemed to him that, as representatives of the Anerican people, they could recognize no such distinction. We have been told from high classical anthority that " the proper study of mankind is man;" but here the idea npon which the original form of this bill seemed to stand was that the proper study of mankind is that of animals, exotics, and plants only-not including at all the great moral and civil relations of man. Now, he took it npon himself to say that if gentlemen would survey the field of moral science they would find that it embraced a much larger portion of knowledge than the physical sciences, however important they may be. * * * He had no dispo- 
sition to depreciate the value of the physical sciences, but he insisted upon it that the moral and political sciences were equally important and, if any distinction was to be drawn, more important. At a very early period of his life, he was struck with a graphic remark made by the great Commentator on English law, in illustrating the fitness of associating a professorship of law with the University of Oxford-and his honorable friend from Kentucky (Mr. Crittenden) no doubt well recollected the passage-that "the sciences are of a sociable disposition, and flourish best in the neighborhood of each other." He would make no distinction. He must be permitted to say that he thought the Senate had already decided the question in regard to the extension of this library, by striking out the proviso of the first section, and the whole of the eighth section, which provides for professors on the subject of natural sciences only.

He saw no reason for any distinction between the noral and physical sciences. If such a library as was contemplated by the honorable Senator from Massachusetts was established, there would be no danger of the physical sciences being slighted; but lie hoped that these great moral and political sciences, which so intimately concern the temporal and eternal destinies of man, would have their appropriate space in this great receptacle of human knowledge.

He had been led to these remarks because his firm and solemn conviction was that we now have it in our power to do more good to this nation in our day and generation by a judicious and wise application of this $\$ 500$, ooo than by the application of the twenty-five or thirty millions that we are in the habit of annually appropriating.

He was glad that it was the sense of the Senate that this subject should go back to the committee, to be matured and deliberately acted upon, and that there was to be brought forward a plan of some great and noble foundation, which would realize, to the fullest extent, the magnificent conception which suggested this donation. He was opposed to any limitations; he was opposed to any distinctions between the great branches of human knowledge. In the republic of letters all stood upon a platform of equality; and if we have a library at all, it should be coextensive with the limits of human knowledge, and with the design of the (lonor-w" the increase and diffusion of knowledge (of all sound knowledge) among men.", x

Mr. Choate's amendment was accordingly adopted, and, on motion of Mr. Woodbury, the bill and amendments were recommitted to the Committee on the Library.

On the 2 ist of January, $1 S_{45}$, this committee reported a new bill, which provided for a building for the reception of 
an extensive library, equal to the first class libraries in the world; and-

An annual expenditure of not less than twenty thousand dollars out of the interest of the fund is authorized to be made in the purchase of books and manuscripts for the library of the institution, which library is to comprehend in due proportion, without preference or exclusion of any branch of knowledge, works pertaining to all the departments of human knowledge, as well as physical science, and the application of science to the arts of life, as all other sciences, philosophy, history, literature, and art; and for its extent, variety, and value, said library shall be worthy of the donor of the fund, and of this nation and the age. The managers to employ a librarian and assistants and to fix their salaries; also to prescribe the regulations under which the library shall be kept, visited, and used.

The discussion being continued, Mr. Woodbury proposed that the board of managers of the Smithsonian fund consist of the officers of the National Institute.

Mr. Buchanan observed that he had but rery few mords to say on this subject. According to the will of the donor this fund was to be distributed for "the increase and diffusion of knowledge among men." Considering our peculiar position in the District of Columbia, he (Mr. B.) had arrived at the conclusion that the best mode of distributing this fund was by the purchase of a great library. If (said Mr. B.) you attempt to establish a literary institution here, with the great expense attendant upon living in this District, and from other causes which I need not enumerate, this fund in its benefits would be confined to a very suall portion of the people of this country. From the rery nature of our Gorernment and the condition of the people of this country we could nerer expect to erect in our day a library to compare with the great European libraries except by the application of this fund to that purpose. It was impossible, everybody knew, for any of our citizens who proposed to write a history, or any other work that required an examination into ancient books and anthorities, to do so without going to Europe for that purpose. Now, he believed that an extensive library, in which all the means of human knowledge should be collected, and in which they should be equally open to all the citizens of this country, was the very best mode in which to apply the money so liberally bequeathed by Mr. Smithson for the "increase and diffusion of knowledge annong men." He was clearly of that opinion, but he had no idea of making a speech upon the subject. The question now before the Senate resolved itself into a very simple proposition, and that was, Shall Congress retain and direct the immediate and efficient control of this fund and of its application, or shall it be administered through the agency of the National Institution? That was the question; and on the decision of the question his own vote might 
depend. Now, he entertained all proper respect for the members of this Institution, and he believed it had been already instrumental in diffusing knowledge among men, but he thought Congress was bound to keep the application of this fund distinct from that or any other literary incorporated body. What was proposed by his honorable friend from New Hampshire (Mr. Woodbury) in the amendment under consideration? Why, to connect the National Institute with the Smithsonian libraryto form a sort of partnership between the two. The National Institute is to hold its meetings in a room in the building to be erected for the use of the Smithsonian library. This was in the printed amendment, and would be the inevitable consequence of intrusting the management of this fund to that Institute! In a great national institution like the Smithsonian library, calculated for the benefit of the whole people of the country, he desired to keep it clear, or detach it and keep it distinct from the National Institnte, or any other literary corporation whatever. Congress ought to take upon itself the immediate control of this library. It would never succeed unless this course be pursued.

For one, he was not acquainted with the rules of the National Institute, and he did not know in what manner the managers of that institution were elected; but the proposed amendment placed the direction and supervision of the Library in the hands of managers not elected by Congress, not responsible to Congress, and over whom the people of this country, by their representatives, could have no control whatever. Congress was undoubtedly capable of administering this fund without the aid of the National Institute; and it was their duty to do so.

Withont, therefore, troubling the Senate with any further observations, he should certainly go for separating the operation of this Library from those of the National Institute; wishing and hoping that that Institute might have all the success which he believed is so well deserved; and if it should be made a rival in disseminating knowledge among men with the Library, well and good. The more knowledge communicated, the better for the people of this country. He, therefore, should rote against the anendment of the honorable Senator fron New Hampshire (Mr. Woodbury) and, although there were some provisions in the bill to which he nilight object, he wonld vote for it, nerertheless, should it remain substantially as it came from the Committee on the Library. ${ }^{\text {" }}$

So Mr. Woodbury's motion was lost, and on the 23 d the bill moved by Mr. Choate and reported by the Library Com111ittee, devoting the larger part of the income of the Smithsonian fund to the establishment of a general library, passed the Senate. In the House, however, where the majority favored the devotion of a part only of the income to a library, 
and that to the establishment of a special library, the session ended before the matter came to a rote.

On the 22d of April, I846, the question of the disposition of the Smithsonian fund was finally taken up in the House. On that day a bill allowing an expenditure of $\$$ IO,OOO a year for a library was introduced by Robert Dale Owen, of Indiana, with the following remarks upon the library plan suggested by the Senate bill for the establishment of the Smithsonian Institution and by Mr. Choate's speech delivered on the Sth of January, is 85 :

The library contemplated by this bill, it was expressly provided, was to be "of the largest class of libraries now in the world." We shall better understand both the object and the cost of this proposal by taking as a commentary thereon some of the remarks with which it was introduced by its author, then a distinguished member of the other branch, but no longer there to adorn its debates with the gay flowers of his brilliant eloquence.

He objected to limiting the cost of the library building to \$Ioo, ooo; seeing, as he reminded the Senate, that the "largest class" of public libraries contain from a quarter of a million to upward of half a million of volumes. $* * * *$

He adds, a little further on, that "such a step taken, we should never leave the work unfinished;" and that when finished it would rival anything civilization has erer had to show. * * * $*$

Then the Senator branches off, in his own brilliant style, into a dissertation on the value and importance of such a library; " a vast storehouse," says he, "a vast treasury of all the facts which make up the history of man and of nature;" * * * * "a silent, yet wise and eloquent, teacher; dead, yet speaketh—not dead, for Milton las told us, 'A good book is not absolutely a dead thing - the precious lifeblood of man, rather, of a master spirit; a seasoned life of man, embalmed and treasured up on purpose to a life beyond life." "'

If the question were between a library and no library-between books and no books-the langnage thus employed, fervid as it is, would be all insufficient to shadow forth the towering magnitude of the subject. John Faust-if, indeed, to the goldsuith of Mentz the world owe the art of typesetting-conferred on his race a greater boon than ever before didl living man. There is no comparison to be made between the effects of the art of printing and those of any other discovery put forth by human wit. There is nothing to which to liken it. It was a general graol delivery of the thonght of the world. It was a sending forth of those winged messengers, hitherto bound down each in his own narrow sphere, emancipated, over the earth. And that was the great day, not 
of intellect only, but of freedom also. Then was struck the heaviest blow against lawgiving for the mind. The Strombolean Cave was opened; the long pent winds of opinion set free; and no edict-framing Eolus could crib and confine them to their prison house again.

Jes! well might Faust incur the charge of demonocracy! for, almost to the letter, has his wondrous craft realized, in our day, the fables of Eastern romance. Draw a chair before your library, and you have obtained the magical carpet of the Arabian tale; you are transported, at a wish, farther than to Africa's deserts or India's groves; to other times also. The speaking page introduces you, not to your contemporaries alone, but to your ancestors, through centuries past. The best and wisest of former generations are summoned to your presence. In books exists the bygone world. By books we come into contact with the mankind of former ages. By books we travel among ancient nations, visit tribes long since extinct, and are made faniliar with manners that have yielded centuries ago to the innovating influence of time. Contracted, indeed, is his mental horizon, limited his sphere of comparison, whose fancy has never lived among the sages and the heroes of the olden time, to listen to their teachings, and to learn from their achievements.

As far as the farthest, then, will I go, in his estimate of the blessings which the art of printing has conferred upon man. But stuch reasoning bears not on the proposal embraced in the Senate bill. It substantiates not at all the propriety of spending half a million, or two, or three half millions of clollars to rival the bibliomaniacs of Paris and of Munich.

A Library of Congress we already have, a Library of forty or fifty thousand volumes, a Library increasing at the rate of one or two thousand volumes a year. The Smithsonian bill before you permits, in addition, an expenditure not exceeding an average of \$10, ooo a year for this object. Say that but half that sum is annually expended by the managers; and still, in some twelve or fifteen years, the two libraries will probably number from eighty to a lumdred thousand volumes. Are there roo, ooo volumes in the world worth reading? I doubt it much. Are there 4,000 volumes published yearly worth buying? I do not believe there are. A small garner suffices to store the wheat; it is the chaff that is bulky and fills up the storehouse. Books are like wealth. An incone we must have to live; a certain amonnt of incone to live in comfort. Beyond a certain income the power of wealth to purchase comfort, or eren wholesome luxury, ceases altogether. How much more of true comfort is there in a fortune of a million of dollars than in one of fifty, or, say, a hundred thousand? If more there be, the excess is hardly appreciable; the burden and the cares of the millionaire ontweigh it tenfold. And so, also, of these vast and bloated book gatherings that sleep in dust and cobwebs on the library shelves of Iinropean monarchies. $U_{p}$ to a judicions selection of thirty, fifty, a hundred thousand volumes, if you will, how vast-yea, how price- 
less-is the intellectual wealth. From one to five hundred thousand what do we gain? Nothing? That would not be true. A goblet emptied into the Pacifie adds to the mass of its waters. But if within these limits we set down one book out of a hundred as worth the money it costs we are assuredly making too liberal an estiniate.

I pray you, sir, not to streteh these strictures beyond their precise application. I an not one of those who judge slightingly the learning of the past. We find shining forth from the clark mass of ancient literature gems of rare beauty and value, unequaled, even to-day, in purity and truth. But then, also, what clouds of idle verbiage! What loads of ostentations technicalities! It is but of late years that even the disciple of science has deigned to simplify and translate; formerly his great object seems to have been to obscure and mystify. The satirist, in sketching an individual variety, has aptly described the species, when he says:

\footnotetext{
"The wise men of Egypt were secret as dummies, And evell when they most condescended to teach

They packed up their meaning, as they did their mummies, In so many wrappers 'twas out of one's reach."
}

But there are such noble enterprises as those of Gibbon and Hallam, valuable to all; doubly valuable to the moralist and the statesman. And in regard to such it is argued that if one of our own scholars, fired with generous ambition to rival the historians of the Old World, enters on such a task lie may find that a dozen books, or perhaps a single book, necessary for reference "can not be found this side of Göttingen or Oxford." Suppose lie does, what is the remedy? A very simple one suggests itself-that he should order through an importer of foreign books the particular work which he lacks. To save him the trouble and expense of so doing the friends of the mammoth library schente propose what? That we should begin by expending half a million of dollars, which would "go far toward the purchase of as good a library as Europe can boast;" that "such a step taken, we should never leare the work unfinished;" and that when finished it would rival anything civilization has ever had to show.

It is prudent, before we enter on this rivalship, to count its cost. Without seeking to reach the joo,ooo volumes of the Parisian library, let us suppose that we try for the half nillion of volumes that form the boast of Munich, or fill up the shelves of the Bodleian. Our Librarian informs me that the present Congressional I ibrary (certainly not one of the most expensive) has cost 11pward of $\$ 3$ a volume; its binding alone has averaged over a dollar a volume. The same works could be purchased 110w, it is true, much more cleaply; but, on the other hand, the rare old books and curious manuscripts necessary to complete a library of the largest class would raise the average. Assuming then, the above rate, a rival of the Munich library would cost us a million and a half of 
dollars; its binding alone would amount to a sum equal to the entire Sinithsonian fund as originally remitted to us from England.

And thus not only the entire legacy which we have promised to expend so that it shall increase and diffuse knowledge among men is to be squandered in this idle and bootless rivalry, but thousands on thousands must be added to finish the work, from what source to be derived, let its adrocates inform us. And when we have spent thrice the amount of Smithson's original bequest on the project, we shall have the satisfaction of believing that we may possibly have saved to some worthy scholar a hundred, or perchance a few hundred dollars, which otherwise he must have spent to obtain from Europe half a dozen valuable works of reference!

But there are other reasons urged for this appropriation of the Smithsonian fund.

"There is something to point to, if you should be asked to account for it unexpectedly; and something to point to if a traveler should taunt you with the collections which he has seen abroad, and which gild and recommend the absolutisms of Vienna or St. Petersburg." (Senator Choate's speech, as above.)

This purchasing of a reply to some silly traveler's idle taunts, at a cost of a million and a half of dollars, including a fund sacredly pledged to humain inprovement, seems to me a somewhat costly and unscrupulous mole of gratifying national vanity. It is ineffectual, too, unless we are prepared to add a few millions more to buy up-if money could buy-the means of reply to other taunts, quite as just and quite as likely to be cast up to us. There is the Vatican, with its

"Statues but known from shapes of the earth, By being too lovely for mortal birth."

There is the Florence gallery, with its

"Paintings, whose colors of life were caught
From the fairy tints in the rainbow wrought-"

images of beauty, living conceptions of grandeur, refining, cultivating, elevating; worth all the musty manuscripts of Oxford, ten times told. How are we to escape the imputation that our rude land can show no such triumphs of art as these? Are we to follow Bonaparte's plan? Are we to carry war into the land of the olive and the vine, and enrich this city, as the French Emperor did his capital, with the artistical spoils of the world? Unless we adopt some such plan, must not Europe's taunts remain unanswered still?

And let then so remain! I share not the feelings of the learned and eloquent Senator to whose remarks I have taken the liberty to reply, when he says:

"I confess to a pang of envy and grief that there should be one drop or one morsel more of the bread or water of intellectual life tasted by 
the European than by the American mind. Why should not the sonl of this country eat as good food and as much of it as the soul of Europe?"

It grieves me not that the fantastic taste of some epicure in learning may chance to fincl, on the bookshelves of Paris, some literary morsel of choice and ancient flavor, such as our own metropolis supplies not. I feel 110 envy if we republicans are outdone by luxurious Europe in some high-seasoned delicacy of the pampered soul. Inough have we to console ourselves-objects of national ambition, how nuch higher, how infinitely nobler than these; objects of national pride, before which these petty antiquarian trimmplis dwarf down into utter insignificancy! Look abroad over our far-spreading land, then glance across to the monarchies of the Old World, and say if I speak not truth! * * *

And shall we grudge to Europe her antiquarian lore, her cumbrous folios, her illuminated manuscripts, the chaff of learned dullness that encumbers her old library shelves? A "pang of envy and grief " shall we feel? Out upon it! Men have we-a people-a free people; selfrespecting, self-governing; that which gold can not buy; that which kings can not make! Grief! Envy! Theirs let it be who look npon this young land in her freshness, in her strength! Let them feel it who behold, from afar, our people bravely battling their onward way; treading, with liberty at their side, the path of progressive improvement; each step upward and onward-onward to the great goal of public virtue and social equality. ${ }^{x}$

Mr. J. R. Ingersoll agreed with Mr. Owen that a great library, such as was provided for by the Senate bill, was not desirable; and said that the necessary buildings to contain the greatest library in the world would, in its own erection, exhaust the entire suin. This Capitol itself would not be sufficient to contain Soo,ooo rolumes, which wonld be the largest library in the world, so properly arranged as to be accessible.

On the following day George Perkins Marsh, of Vermont, replied to Mr. Owen and advocated the library plan in the following speech:

Books [he said], Mr. Smithson did not collect, as we propose to do, because to one who had no fixed habitation a library would have been but an incumbrance; and he lived in the great cities of Europe, where public and private munificence has collected and deroted to general use such ample repositories of the records of knowledge, that indiviclual accumulation of such stores is almost superfluous. But though he gathered no library his writings show him to have been a 
man of somewhat multifarious reading; and it is quite a gratuitous assumption of those narrow minds, who think no path worth traveling but that which they have trodkten, no freld worth cultivating whose fruits they have never plucked. Apart, then, from the liberty which the broad words of the will give us, we are entitled to believe that the purposes of the testator were as comprehensive as the language he usedthat he aimed at promoting all kwowledge for the common benefit of all men. ${ }^{\mathrm{x}} * *^{*} *$

A library, continued Mr. Marsh, is one of the most efficient means of increasing and diffusing knowlectge, and the provision in the bill before the House for a library, though too limited, constitutes its most valuable feature.

I had originally purposed to examine the subject from quite a different point of view, but the eloquent remarks of the chairman of the special committee [Mr. Owen], which seem to be intencled as an argument rather against this provision than in favor of the bill; and as a reply to the able ancl brilliant speech of a distinguished member of another branch of Congress, upon a former occasion [Mr. Clioate], has induced me to take a somewhat narrower range than I should otherwise have done. I wish, sir, that Senator was here to rejoin, in his own proper person, to the beantiful speech of the gentleman from Indiana, who seems rather to admire the rhetoric than to be convinced by the logic of the eloquent orator to whom I refer. In that case, sir, I think my friend from Indiana, trenchant as are his own weapons, would feel, as many have felt before, that the polished blade of the gentleman who lately did such honor to Massachusetts in the Senate of the United States, is not the less keen because, like Harmodius and Aristogiton, he wraps it in sprays of myrtle.

It has been objected by some that the appropriation is too large for the purpose expressed- "the gractual formation of a library composed of valuable works pertaining to all departments of human knowledge." But if we consider how much is embraced in these comprehensive words we shall arrive at a very different conclusion. The great libraries of Europe range from 200,000 to half a million, or perhaps even 750,000 volumes. That of the University of Göttingen, the most useful of all for the purposes of general scliolarship, contains about 300,000. How long would it require to collect a library like this with an annual expenditure of $\$ 10,000$ ? The Library of Congress is said to have cost about $\$ 3.50$ per volume; but, as a whole, it has not been economically purchased, and though composed chiefly of works which do not maintain a permanently high price, yet as a large proportion of the annual purchases consists of new books fron the press in Jondon, the dearest book market in the world, its cost has been much higher than that of a great nissellaneous library ought to be. The best public library in America, 


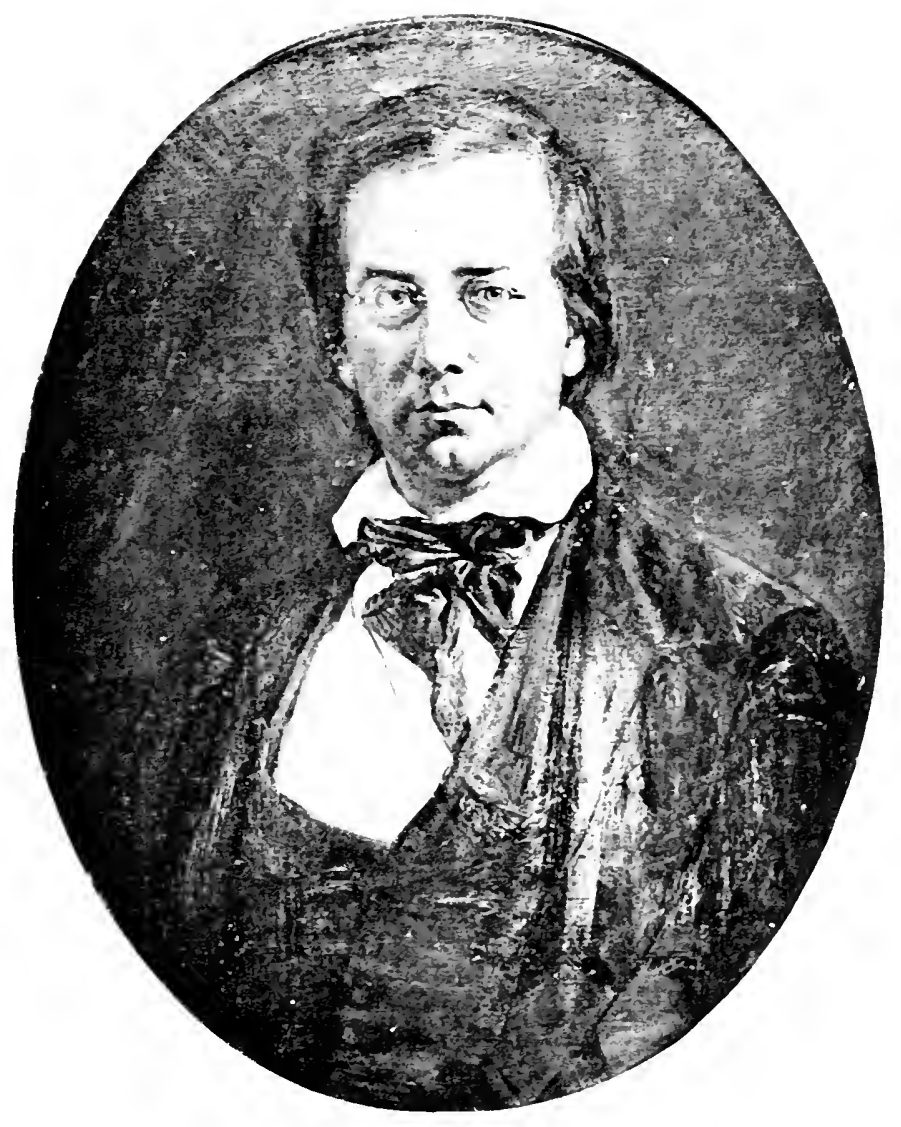

GEORGE PERKINS MARSH 

for its extent (10,000 volumes), which I am happy to say is that of the University of ny native State, Vermont, cost but $\$ 1.50$ per volume. It can hardly be expected that the Government, which always pays the highest price, will be so favorably dealt witli; and it is scarcely to be hoped that it will succeed in securing the services of so faithful and so competent an agent as was employed by the University of Vermont.

I have myself been, infortunately for my purse, a book buyer, and have had occasion to procure books, not only in this country, but from all the principal book marts in western Europe. From my own experience, and some inquiry, I an satisfied that the whole cost of such books as a national library ought to consist of, including binding and all other charges, except the compensation and traveling expenses of an agent, should not exceed $\$ 2$ per volume. If you allow $\$ 2$, ooo for the compensation and expenses of an agent (which would not be increased upon a considerably larger expenditure) you have $\$ \$, 000$ remaining, which, at the average cost, I have supposed, would purchase 4,000 volumes a year. How long, I repeat, would it require at this rate to accumulate a library equal in extent to that of Göttingen? More than seventy years. In some serenty years, then, in three score years and ten, when you, sir, and $\mathrm{I}$, and all who hear my roice, and all the present actors in this busy world shall be numbered with the dead, we may hope that free, enlightened America, by the too sparing use of the generous bounty of a stranger, will possess a collection of the recorded workings of the human mind not inferior to that now enjoyed by a single school in the miniature kingdom of Hanorer. And what provision is made for the increase of books meanwhile? Look at the activity of the presses of London and Paris, at the vastly prolific literature of Germany, at the increasing productions of our own country, to omit the smaller but still valuable contributions to the store of human knowledge in the languages of other countries, and you will perceive that this appropriation, so far from being extravagantly large, will scarcely even suffice for keeping up with the current literature of the day. Göttingen will, meantime, go on. Her 300,000 rolumes will increase in serenty years to half a million, and we will still lag 200,000 rolumes belind.

The utility of great libraries has been questioned, and it has been confidently asserted that all truly valuable knowledge is comprised in a conparatively sniall number of volumes. It is said that the vast collections of the Vatican, of Paris, of Munich, and of Copenliagen are in a great measure composed of works originally worthless or now obsolete, or superseded by new editions, or surpassed by later treatises. That there is some foundation for this opinion I shall not deny; but after every deduction is made upon these acconnts, there will still renain in any of these libraries a great number of works which, having originally had intrinsic worth, have yet their pernanent value. Because a newer, or better, or truer book upon a given subject now exists, it does not neces- 
sarily follow that the older and inferior is to be rejected. It may contain important truths or interesting views that later, and, upon the whole, better authors have overlooked; it may embody curious anecdotes of forgotten times; it may be valuable as an illustration of the history of opinion or as a model of composition; or, if of great antiquity, it may possess much iuterest as a specimen of early typography.

Again, because any one indiridual, even the most learned, can not, in this short life, exhaust all art, because he can not thoronghly master but a few hundred volumes, read, or even have occasion to consult, but a few thousands, we are not therefore authorized to conclude that all beyond these are superfluous. Each of the huudred authors who have produced those thousands of volumes had read also his thousands. The scholar is formed, not by the books alone he has read, but he receives, at second hand, the essence of multitudes of others, for every good book supposes and implies the previous existence of numerous other good books.

An individual even of moderate means and who is content to confine his studies within somewhat narrow bounds may select and acquire for himself a library adequate to his own intellectual wants and tastes, though entirely unsuited to the purposes of one of different or larger aims, and by the diligent use of this, he may attain a high degree of mental culture, but a national library can be accommodated to no narrow or arbitrary standard. It must embrace all science-all history-all languages. It must be extensive enough to furnish aliment enough for the cravings of every appetite. We need some great establishiment that shall not hoard its treasures with the jealous niggardliness which locks up the libraries of Britain, but shall enulate the generous munificence which throws open to the world the boundless stores of literary wealth of Germany and France-some exhaustless fountain where the poorest and humblest aspirant may slake his thirst for knowledge without money and without price.

Of all places in our territory this central heart of the nation is the fittest for such an establishment. It is situated in the middle zone of our system-easily and cheaply accessible from every quarter of the Union-blessed with a mild, a salubrious, and an equable climateabundant in the necessaries and comforts of physical life-far removed from the din of commerce and free from sectional influences.

Let us here erect such a temple to the muses, served and giarded by no exclusive priesthood, but with its hundred gates thrown open, that every votary may enter mquestioned, and you will find it thronged with ardent worshipers, who, though porerty may compel them to subsist, like Heyne, on the pods of pulse and the parings of routs, shall yet forget the hunger of the body in the more craving wants of the soul.

From the limited powers of our National Goverment, and the jealous care with which their exercise is watched and resisted, in cases where 
the interests of mere humanity-not party-are concerned it can do little for the general promotion of literature and science. 'The present is a rare opportunity, the only one yet offered, and never, perliaps, to be repeated, for taking our proper place anong the nations of the earth, not merely as a political society, but as patrons of knowledge and the liberal arts. The treasures of our national wealth are, perhaps, not at our command for this purpose, and it is only by the discreet use of this bequest, and of the funds which private liberality will assuredly contribute to extend the means of the institution, that we can hope to kindle a luninary whose light shall encompass the earth and repay to Europe the illumination we have borrowed from her.

The library of Göttingen, of which I have spoken, contains six times as many volumes as the largest American collections; it has been accumulated within a comparatively short period-scarcely a century-and, having been selected upon a fixed plan by the ablest scholars in the world, it contains few books originally without merit, few duplicates, and few which the progress of science and literature have rendered worthless. And yet, though upon the whole the best existing library, it, in many departments, does not approach to completeness, and the scholars who resort to it are often obliged to seek elsewhere sources of knowledge which Göttingen does not afford.

Here the speaker entered upon a comparison of the resources of the Library of Congress with those of the great libraries of Europe which we have quoted above. He then continued:

Let it not be said that our own brief history proves that great libraries are superfluous, because without them we have produced statesmen, civilians, orators, and jurisprudents no wise inferior to the ablest of their Enropean contemporaries. Without dwelling upon the stimulus of popular institutions and the stirring excitement of our revolutionary and later history, which have tended to encourage the development of this species of talent, the objection is sufficiently answered by saying that in the case of the American statesmen of the Rerolution as well as of many of later date, private wealth has supplied the place of public provisions for the attainment of knowledge. In the period of our colonial history the sons of wealthy fanilies were often educated in the best schools of Europe, and the franers of our Constitution were chiefly men of high edtacation and elegant attainments. Jefferson, wlose writings are canonical with the Democracy, had the best private library in America, and was a man of multifarious if not of profound learning. The State papers of that remarkable era are, with a few exceptions, obviously productions of men not merely of inspired genius or of patient thought,

$$
\text { 'Congressional Globe 16: } 851-\$_{52} \text {. }
$$


but of laborious acquisition, and they are full not of that cheap learning which is proved by pedantic quotation, but of that sound discipline which is the unequivocal result of extensive reading and diligent research. Who have been the men in all ages that have exercised the wisest and most permanent influence both on the moral and physical well-being of man? 'The spirit of the crusades was roused by the preaching of a thoughtful solitary; Columbus was a learned scholar and Luther but a studious monk. Watt, the great improver of the steam engine, was a man of curious and recondite learning. Bonaparte was carefully educated at the school of Brienne and was through life a liberal patron of learning and the arts. The glorious rebellion of 1649 was the work of men of the closet, and Mitton, who to our shane is less known among us by his prose than by his poetry, was its apostle. Our ow1 independence was declared and maintained by scholars, and all men know that the French Rerolution had its germ in the writings of the encyclopedists. All men, in fact, who have acted upon opinion, who have contributed to establish principles that have left their impress for ages, have spent some part of their lives in scholastic retirement. It is this very point-the maintenance of principles discovered and defended by men prepared for that serrice by severe discipline and laborious study-that so strikingly distinguishes the English rebellion of $16+9$ and our own Revolution from most other insurrectionary movements, and particularly from the French Revolution. The English and American statesmen of those two periods were contending for truths, the French atheists and philosophers for interests; the former songht to learn their duties, the latter concerned themselves only about their rights; the Anglo-Saxon was inspired by principle, the Gaul was instigated by passion.

The principles of American liberty, which education and habit have rendered so familiar to us that we fancy them intuitive or even instinctive, are in truth no more obvious than the physical theory of the universe, and the study of the philosophical and political history of the last three centuries will convince every inquirer that their development from their germs, as involved in the fundanental doctrines of the Reformation, has been the work not of unconscions time only, but has required the labor of successive generations of philosophers and statesnlen.

I look upon a great and well-selected library, composed of the montuments of all knowledge, in all tongues, as the most effective means of releasing us from the slavish deference which, in spite of our lond and vaporing protestations of independence, we habitually pay to English precedents and authorities in all matters of opinion. Our history and our political experience are so brief that in the multitude of new cases which are perpetually arising we are often at a loss for clomestic parallels and find it cheaper to cite an English clictum than to investigate a question 
upon more independent grounds. Not only are our parliamentary law, our legislative action, our judicial proceedings to a great extent fashioned after those of the mother conntry, but the fundamental principles of our Gorernment, our theory of the political rights of man, are often distorted in order that they nay be accommodated to rules and defmitions drawn from English constitutional law. Even the most sacred of political rights, the right of petition, I have heard both attacked and defended upon this floor by very sufficient Democrats entirely upon precedents drawn from the practice of the British Parliament. Our community of origin, language, and law exposes the younger nation to the constant danger of being overshadowed by the authority of the elder. It is a great evil to a young and growing people, as well as to a yonthful and aspiring spirit, to have its energies cramped and its originality smothered by a servile spirit of conformity to any one model, however excellent, and it is quite time for us to learn that there are other sources of instruction than the counsels and examples of our ancient mother.

Sir, I make these remarks in no narrow feeling of jealous hostility to England; still less at this crisis, when some are seeking to raise a whirlwind of poptular indignation against that country, upon which they themselves may float to power, would I join in any vulgar denunciations of a people from whom we have borrowed so much. We owe to England much of our political principles, many of the foundations of our civil and religious liberties, many of the most valuable features of our jurisprudence. Something, indeed, we have repaid. England, in common with all Europe, has profited by our experience. The grasp of feudal oppression has been relaxed, the atrocious sererity of the criminal law has been mitigated, judicial proceedings have been simplified, the subject lias been admitted to a larger participation in the concerns of government, monoplies are becoming obsolete, and the responsibilities of rulers are felt to be more stringent. To the credit of many of these aneliorations we may fairly lay claim; while in science and its application to the arts we have sustained no disgraceful rivalry with our transatlantic brethern. But no generous man thinks his debt of gratitude canceled till it is thrice repaid, and we have therefore yet much to do before we can say that America is no longer the debtor of England. Let us then seize this one opportunity which a son of her own has offered us, and build with it a pharos, whose light shall serre as well to guide the mariner in the distant horizon, as to illuminate lim who casts anchor at its foot. $* * *$

Mr. Chairman, at present I neither propose nor expect any nodification of this bill. I am content with it as an experinent, thongh I should prefer the appropriation of the entire incone of the fund for one generation-three times only as long as it has now lain iclle-to the purpose of fonnding such a library as the workl has not yet seen. If I snpport the bill, I shall support it, I repeat, as an experinent, but in the cunficlent 
hope that the plan will soon be so changed as to make the Smithsonian Institution a fitter representative of a charity which embraces all knowledge as its object and appoints the whole human race its beneficiaries. ${ }^{x}$

In reply Mr. Owen said:

This bill had been franed in a spirit of compromise. The original Senate bill of the last session appropriated $\$ 5,000$ for this object. The gentleman from Vermont, Mr. O. believed, proposed twenty thousand. The bill proposed a medium - a sim not exceeding \$io,ooo. He hoped the House would not go further. A gentleman who had formerly been Librarian of Congress, in conversation with him, had said that he thought it was impracticable to purchase with advantage more than $\$ 10,000$ worth of books. The duty must be intrusted to one agent to prevent the purchase of duplicates, and no one agent could purchase advantageously more than this amount, so that there was a practical difficulty in the way. ${ }^{2}$

On the 2Stl of April, the discussion of the Smithsonian bill being resumed, Mr. Thurman said:

He was rather inclined to believe that the best disposition of the fund that could be made would be to invest the interest arising from it in a library. There were great objections to this plan, to be sure. They had been forcibly stated by the chairman of the select committee (Mr. Oren). But there was one great recommendation it possessed that strongly influenced Mr. T. That was that though it might not effect the greatest amount of benefit that could be produced by the fund, it was not liable to the abuses to which the other plans would probably give rise. It would create no large body of officeholders, no patronage, no faroritism, no partial, sectional advantages.

So, with an amendment moved by Mr. Marsh (April 29) increasing the annual appropriation for the Library to $\$ 25,000$, the bill passed the House April 29, the Senate, August 7, and was approved August IO, I 446 , section 8 providing for an appropriation not exceeding an average of $\$ 25,000$ annually for the gradual formation of a library composed of raluable works pertaining to all departments of human knowledge.

'The question of a national library thus passed from Congress to the Board of Regrents of the Smithsonian Institution. At a meeting of the Board of Regents, September S, I846,

\footnotetext{
${ }^{2}$ Congressional Clobe, $16: 853-854$.

${ }^{2}$ Congressional Globe 15: 719 .
} 
accordingly, the following preamble and resolution were offered and agreed to:

Whereas the act to establish the Suithsonian Institution prescribes an appropriation, not exceeding an average of twenty-five thousand dollars annually, for the gradual formation of a library composed of valuable books pertaining to all departments of limman knowledge: Therefore,

Resolved, That a committee of three be appointed to prepare a report upon the subject of the formation of such a library, indicating its general character and the modes of proceeding to accumulate it, and to present such report at the next regular meeting of the board. ${ }^{2}$

Whereupon the chancellor appointed Mr. Choate, Mr. Hawley, and Mr. Rush said committee.

On the $3 \mathrm{~d}$ of December this committee made report, and on the 4th the Board of Regents-

Resolved, That for the present, out of the interest accruing to the Institution, the sum of twenty thousand dollars be, and the same is hereby, appropriated for the purchase of books and the gradual fitting up of a library, and all other incidental expenses relating to the library, except the salaries of the librarian or librarians, the said appropriation to commence from the first of January, eighteen hundred and forty-eight.

Resolved, That the portion of the building to be for the present set apart for a library be of sufficient capacity to contain not less than one lundred thousand volumes; and that it is desirable that the plan should be such as to render an extension practicable if hereafter desired.

Resolved, That it be recommended to the Secretary of the Smithsonian Institution forthwith to employ, subject to the approval of the Board of Regents, an assistant secretary, well qualified to discharge the duties of librarian.

Resolved, That a committee be appointed, in conjunction with the Secretary, to prepare and submit to this board extended lists of books, in the different departments of learning, proper to be first purchased, according to the general principles of this report; and, for this purpose, that they be authorized to request the aid of the librarian, and of other persons competent to afford it, and to engage to such persons the honor of the board for discretionary remuneration of such aid. ${ }^{2}$

Mr. Choate, Mr. Hilliard, and Mr. Rush were appointed the said committee.

On the 25th of January, IS47, the complete plan of the Smithsonian Institution was presented by the comninittee on

\footnotetext{
${ }^{1}$ Smithsonian Institution report, March 3, I $S_{47}$, p. 4. Twenty-ninth Congress, second session, Senate document No. 211.

'Smithsonian Institution report, March 3, 1847, pp. 12, 13.
} 
organization, Messrs. Owen, Hilliard, and Bache. It provided for the library as follows:

In proposing that, in the building about to be erected, there should be provicled library room sufficient to receive a hundred thousand volumes, your committee yielded rather to what seemed a fair concession to the spirit of the eighth section of our charter, than to their own deliberate conviction that a library of more than half that size conld not, with the present means of our Institution, advantageously be purchased.

But, without a vast accumulation of books in this metropolis, your committee conceive that a librarian of the Smithsonian Institution may, under proper system, become a center of literary and bibliographical reference for our entire country. Your committee recommend that the librarian be instructed to procure catalogues, written or printed, of all important public libraries in the United States; and also in proportion as they can be obtained, printed catalogues of the principal libraries in Europe, and the more important works on bibliography. With these beside him, he may be consulted by the scholar, the author, the historian, from erery section of the Union, and will be prepared to inform them whether any works they may desire to examine are to be found in the United States; and if so, in what library; or if in Europe only, in what country of Europe they must be sought.

Informed by these catalogues it will be easy and your committee think desirable for those who may be charged with the selection of books to make the Smithsonian library chiefly a supplementary one; to purchase for the most part valuable works which are not to be found elsewhere in the Union, thus carrying out the principle to which your committee has already alluded as influencing all their recommendations-that it is expedient, as far as may be, to occupy untenanted ground.

Exceptions to this rule nust here of course be made, as in the case of standard works of reference required for the immediate use of the Institution, and also of the very numerous works, many of current science, which, by a proper system of exchange, we may procure without purchasing. In this latter comnexion the transactions and reports of the Institution will obtain for us valuable returns.

In following out this mode of collecting a library for the Institution, whenever a particular class of works of importance is found to be especially deficient in the libraries of our country, the vacancy may be filled. The librarian night also procure, by entering into correspondence with the librarians of other conntries, any special extracts or itenss of information required by students.

Vour committee consider it inexpedient to commence the regular purchase of books until about a year before the time when the building is prepared to receive them. Meanwlile lists and catalogues should be procured.'

'Smithsonian Institution report, March 3, r8.47, pp. 24-25. 


\section{On Jannary 26, IS47, Professor Jewett was appointed} librarian, and on the 2 ist of December, I 847 , Secretary Henry presented the following letter from Professor Jewett containing suggestions as to the formation of the library:

MY DeAr Sir: As I do not expect to have the pleasture of seeing you again before the nneeting of the Regents, I will, with your indulgence, refer to some of the principal matters which will require attention in commencing the library. They would no doubt all occur to you in their order, but I thought you might find it convenient to have this part of the business in some degree prepared to your hands. A great deal of preparatory work is to be gone through with before any books can be placed on the shelves.

I. On the plan proposed for the library, it seems to nte that the first thing to be done is to make arrangements for obtaining catalogucs, printed or in manuscript, of the principal libraries of the United States; to examine these libraries, as far as can be done personally, in order to know their general character, the statistics of their increase, etc.; and to form such alliances with the librarians as will be indispensable in making the library of the institution, in conformity with the suggestion of Doctor Bache, a supplementary one, and a center of bibliographical reference. Some of the libraries possess printed catalogues complete nearly down to the present time; others are several years behind hand. It will be necessary to procure manuscript catalogues in continuation of those which have been printed, and to make arrangements for receiving, from month to month, or from year to year, lists of all future accessions. These supplementary catalogues should all be prepared on a uniform plan. The titles should be written on cards of the same size, so that they may be placed together in one alphabetical arrangement in order to facilitate research. A mark placed on the back of each card will designate the library from which it came. Now, in every library with which we are in correspondence some one must be employed to do this. It would be merely clerk's labor, where the catalogues are properly kept, and no doubt the librarian or assistant night in every case be induced to undertake it for a small compensation.

2. The next thing to be done will be to make arrangements for procuring the books to which we are entitled by the tenth section of the charter of the institution. Unless something be done, this provision in course of time will bring in comparatively few books in a year. I have 110 doutbt that publishers generally would readily send their books if the subject were properly presented to them and arrangements made by which they could transmit them to Washington without subjecting the institution or thenselves to expenses altogether disproportioned to the value of the books. It has occured to me that perlinps the sereral district. clerks might be induced to attend to the business; it is perhaps 
legally their duty to do so, but I suppose it would be unsafe to rely upon their performing such an unexpected duty unless they received for it some additional conpensation. Besides this, a circular might be printed and sent to publishers, setting forth the advantages which result directly to the cause of letters and indirectly to themselves from compliance with this requirement. By these means I think we shonld obtain nearly all the publications of importance issued from the American press.

3. The selection of books for the first purchase must be made. This will, I suppose, comprise three classes of works: I. Those which may be immediately needed in the scientific department; 2. Bibliographical works and descriptions, histories, and catalogues of similar institutions, and 3. The general collection, consisting of the memoirs, transactions, and jonrnals of the learned societies of Europe and America. These three classes of books will form a library quite unique and one of great utility. The catalogue, if it be made with fullness and accuracy, will be a valuable publication. I think, further, that a somewhat extended list of books should be made out for future purchases. These lists should be entrusted to honest and faithful men in some of the principal book marts in Europe, with orders to buy the books whenever they can find them, at say one-half the ordinary prices. In this way we should obtain at very low prices great numbers of the books which we shall want. Of conrse the same list shonld not be left with different men. The work should be done with care and by consultation with the best scholars in the country. It will be difficult to find the necessary bibliographical helps. The best collection of them in the country is in the library of Brown University, but this is very imperfect.

4. The first purchases are to be made and the arrangements for future purchases. These, of course, should not be commenced until the lists are as far completed as they can judiciously be in this country. ****

I have thus stated quite in detail the work which must be done before the library can be ready for use, or rather before any part of it can be placed upon the shelves. Before it can be ready for use muclu more is to be done in arranging and cataloguing. To lay properly the fonndation of a large library is a slow work, and much time numst necessarily be consumed in producing but small visible results.

I am, my dear sir, very truly, your friend and servant,

C. C. JEWETT

Professor Hinky, LL. D., Secretary Smithsonian Institution.'

The resolutions of the Board of Regents, the report of the committee on organization, and the plan proposed by Librarian Jewett, were in practical agreement, and were summed

\footnotetext{
'Smithsonian Institution report, Thirtieth Congress, first session, Senate miscellaneous document No. 23, pp. 191-193.
} 
up in the following progranme for the Snithisonian library, presented by the secretary of the Institution to the Board of Regents, December S, is 47 :

A library will be required, consisting, first, of a complete collection of the transactions and proceedings of all the learned societies in the world; second, of the more important current periodical publications and other works necessary in preparing the periodical reports. $* * *$ With reference to the collection of books other than those nentioned abore, catalogues of all the different libraries in the United States should be procured in order that the valuable books first purchased may be such as are not to be fomd in the United States. Also catalogues of memoirs and of books in foreign libraries and other materials should be collected for rendering the Institution a center of bibliographical knowledge, whence the student may be directed to any work which he may require. $* * * *$

The duty of the assistant secretary, acting as librarian, will be for the present to assist in taking charge of the collections; to select and purchase under the direction of the Secretary aind a connuittee of the board books and catalognes, and to procure the information before mentioned; to give information on plans of libraries and to assist the Secretary in editing the publications of the Institution, and in the other duties of his office. ${ }^{\mathrm{T}}$

On the inth of December the executive committee made report embodying a proposed scale of expenditures for four years from the igth of Miarch, i $S_{47}$, being the remainder of the term of the contract for the erection of the Institution building:

If [said they] any considerable amount of books, beyond those required for present reference, be purchased at this time, they will lie in boxes with nunch risk of injury and no possibility of being accessible to the public; nor, the commintee think, will it be prudent or desirable whilst the main builcing is in progress, and while temporary arrangements must be made in one of the wings for the reception of such works as by purchase, by exchange, and from other sources, shall have accumulated in the library, to open that provisional library to the public. Few would be likely to resort to it as a place of study anid the noise and confusion incident to the erection of an extensive building.

Again, thougl no large sums be spent directly for books for the present, every appropriation made for the publication of transactions or other works to be distributed to learned and scientific societies throughout the world is a virtual contribution to the library. It can

ISmithsonian Institution report, Jantuary 6, 1848, pp. 176-177; 'Thirtieth congress, first session, Senate miscellancons documents, No. 23.

$$
23399-04-2 S
$$


not be doubted that the exchanges to which, by such extended distribution, the institution will be entitled, will in many cases overpay, in the shape of additions to the library, the cost of the works distributed.

And, finally, it should be remarked that under the scale of expenditures herein proposed the sum of $\$ 140,000$ will be added to the original capital of the Institution, making an addition to its income of $\$ 8,400$ annually forever; one-half of which, by the resolntions hereinafter recited, commonly called the compronise resolutions, will inure to the benefit of the library. It was doubted at the time of the passage of these resolutions whether, under their operation, and supposing the entire income of the institution to be the interest from its original capital, the permanent annual appropriation for the purchase of books could exceed from $\$ 4$, ooo to $\$ 5$, ooo.

By the operation of the present plan it may, therefore, be considered as doubled, or nearly so. The additional $\$ 4,200$ added by that plan annually forever to the library appropriation is far more than an equivalent for the delay it presupposes in the accumulation of works not wanted for immediate reference or present purposes, a delay extending only to the period when suitable permanent arrangements can be made for their reception.",

In accordance with these views the committee appended the following resolution:

Resolved, That for the present the resolution of the Board passed on the fourth of December last and authorizing an appropriation of twenty thousand dollars for the purchase of books, and which said appropriation is to commence from the Ist of Jantary next, shall be strictly construed to anthorize only the purchase of such valuable works of reference as the Secretary or the building or executive commintee may consider useful for present purposes or otherwise likely to be immediately demanded in the prosecutions of the plan of the Institution: Provided, howezer, That nothing in this nor in the preceding series of resolntions contained shall be construed to rescind or in any way impair the force of certain resolutions passed by the Board on the twenty-sixth and twenty-eighth of Jannary last. ${ }^{2} * * *$

And on the 27 th of December, IS47, Mr. Choate, from the committee appointed on the $23 \mathrm{~d}$, relative to the disty of the assistant secretary, made the following report, with acconlpanying resolutions:

The conninittee appointed at a meeting of the Board of Regents on the 23 d instant, to inquire and report in what manner the assistant

'Smithsonian Institution report, Thirtieth Congress, first session, Senate miscellaneous doemuents, No. 23 , p. 168.

altid.. No, 23, p. 17u. 
secretary, as librarian, may be employed (if at all) with advantage to the Snithsonian Institution, between the present time and the igth of March, is 49, respectfully present for the consicleration of the Board the following resolutions, enbracing the nuatter of their inquiries, together witl a report from the assistant secretary.

Respectfully submitted by

\section{R. CHOATE, \\ A. D. ВАCHF, \\ R. MCCLEI,I,ANI,}

Committee.

The resolutions accompanying the report of the committee were as follows:

Resolved, That the assistant secretary, acting as librarian, may be employed with advantage to the Smithsonian Institution chring a portion of the time between this date and the I9th of March, 1849, in the following duties, to wit:

I. The preparation of catalognes of books suitable for the connuencement of the library, in accordance with the plan of organization heretofore adopted by the Board of Regents.

2. The purchase of the more necessary books on bibliography.

3. The collection and systematic arrangement, for purposes of con1parison, of the printed catalognes of the principal libraries thronghont the United States, together with information in regard to the expenditures, plans of increase, and other particulars relating to the said libraries.

4. The collection of works to which the Institution may be entitled under the tenth section of the act organizing the Institution.

Resolved, That the assistant secretary, acting as librarian, be employed for the purposes specified in the foregoing resolution under the direction of a committee of three members of the board, to be appointed by the Chancellor, and to act in conjunction with the Secretary, at a compensation fixed by the execntive committee, but not to exceed one thousand dollars, for any services he nilay render between this date and the time fixed for the commencement of his regular duties as assistant secretary.

The said resolutions coming up for consideration, they were adopted.

Wherenpon the Chancellor appointed Mr. Choate, Mr. Marsh, and Mr. Bache the said committee.

${ }^{2}$ Smithsonian Institution report, Thirtieth comgress, first session, Senate miscellaneous documents, No. 23, pp. 161-162. 
FARII UNDER'IAKINGS OF 'THE, SMITHSONIAN LIBRARYCOL,LEC'TIONS.

The two proposals regarding the Smitlisonian library were thus, first, that it should be made a national reference library; and, second, that it should be made a national bibliograplical burean.

The objections to the first proposal were that it would require the expenditure of the larger part of the income of the Smithson f1111; that if $\$ 25,000$ were deroted each year to the purchase of books, no man or set of men conld be found sufficiently skilled in bibliography to expend this sum judicionsly; that even should this sum be laid ont wisely in the purchase of books and manuscripts of a valuable character, such a collection would be of no use in Washington; scarcely half a dozen readers would be found in the city with leisure enough to visit the library, and the few literary and scientific nen who ninght come from a distance to consult the library would have difficulty in finding it and getting to it." "The building is removed from all habitable parts of the city," said the correspondent of the New York Courier and Enquirer, "and can be reached only after one-half mile of muldy walking from Pennsylvania avenue, so that the probability is that the Institution will have few visitors except those who go from mere curiosity and are able to pay two dollars hack hire."

These objections did not, however, apply to the collection of such books as were necessary to the operation of the Institution, authoritative scientific treatises, especially bibliographical works, publications secured by exchange with institutions of similar character, and publications to which the Institution was entitled under the copyright section of the organic act.

With reference to the collection of books on bibliography, a class of books which was necessary to make the Institution a center of bibliographical knowledge, Librarian Jewett said in his first report, December I 3,1848 :

I have the honor to present herewith a list of about 3 ,ooo bibliographical works. 'The work of Nanur, publisherl in 1837 , purporting 
to be a complete catalogue of bibliographical works, contains Io, 236 titles. A complete bibliographical library would contain nearly 20,000 volumes. The 3,000 volumes of the list now presented are not, therefore, to be considered as constituting a complete catalogue of books in this department, but merely as a selection of those most immediately inportant.

Fvery list of this kind shonld include not only works professedly bibliographical, but also histories of literature, of science, and of art, as well as many biographical and critical works.

It is impossible to estimate too highly the value of such a collection. In a large library these works are the guides to research, showing what to read, study, or consult. In the absence of such a library they supply to some extent the deficiency by describing books in such a way as oftentimes to enable us to dispense with the books themselves.

And yet the importance of bibliographical studies is in this country but too little appreciated. In truth, the neglect of them is the most fruitful source of superficial, conceited, and rash authorship. On the continent of Europe, however, they are held in the highest esteem. This is doubtless one principal cause of the acknowledged superiority of the Germans in all matters requiring wide research.

Every student worthy of the name when about to investigate a subject wishes to know first what has been done by others in the same field.

Now, on alnost every important brancl of learning some diligent scholar has collected from the whole clomain of literature the books pertaining thereto, arranged then for convenience of reference, analyzed their contents, and described their absolute and relative merit, with their external peculiarities and history. He has thus given a bibliography' of that branch of knowledge. Such a work should manifestly be the first to be taken up and among the last to be laid down by anyone who would intelligently study that subject. A collection of such works, pertaining to all departments of knowledge, ought to be the first purchase for every general library.

Yet there is no respectable collection of then in any of our public libraries. The best is, I believe, that of Brown University, which contains but a few hundred volumes. Without question, therefore, by procuring the books necessary for carrying out the plan of making the library a center of bibliographical reference we shall furuish one class of books most immediately important to American scholars, as well as one most needed in making judicions selections for the future and in aiding other libraries in the conntry in their choice of books.

The selection here offered is intended to cover nearly the whole ground of bibliography, and is arranged under the following divisions:

1. Bibliothece bibliographice, or catalogne of bibliographical works.

2. Elementary bibliograpley, including treatises of tle origin and progress of writing; of ancient manuscripts, their materials, form, ornaments, 
preservation, and the method of deciphering them; of printing, its 11istory, and practice; of the arts of engraving, binding, paper making, etc.; of the forms of books; of the rights of authors, publishers, and readers; of the book trade; of the use and abuse of books; of libraries, their history, statistics, selection, arrangement, preservation, and use.

3. Practical bibiigrraphy.-Works designed to be used in the selection and purchase of books. These may be-

( I) Universal, comprising books in all languages, on all subjects, and of all periods.

\section{(2) Limited-}

a. To particular countries or languages.

b. To particular periods of time.

c. To particular branches of knowledge.

d. To works classed according to some accidental peculiarity, as rare, anonymous, pseudonymous, polyonomous works, books privately printed, books prohibited, books condemned to be burned, etc.

c. To particular kinds of composition, as poetry, proverbs, etc.

Under most of these heads are comprised works of several kinds, viz: I. The history of the subject. 2. The bibliography, properly so called, i. e., the catalogue raisonne of all books relating to it. 3. The biograplyy of its cultivators. 4. The journals which contain the record of its progress. Thus, in the department of natural history wonld be included Cuvier's History of the natural sciences, Engelmann's Bibliograplyy of natural history, Callisen's Biographical dictionary of naturalists, and the Annals of the natural sciences; and inasmuch as neither of these is perfect of its kind there must be many others of eacli description.

The result of these recommendations of Professor Jewett was that by ${ }_{1} 86$ the Smithsonian library possessed the most complete collection of library catalogues in the country, and one of the best and most complete collections of bibliographical works.

With reference to the publications of learned societies the librarian reported at the same time, as follows:

I have made and herewith present a list, which I believe to be nearly complete, of all the publications of learned societies in actual operation throughout the world. Doubtless these publications possess various grades of nuerit. But it is difficult, and I think undesirable, to reject any of them. Papers of the greatest importance are sometinies published in the most provincial academies.

The department of public instruction of the Frencl Government published in the year $18+7$ the first volume of a work intended to be continued anuually, entitled "Annuaire des Sociétés savantes de la 
France et de l'Etranger." 'The rolume for the first year, an octavo of more than 1, ooo pages, contains historical sketches of all the learned societies in France, the regulations of the institutions, an account of their various publications, and other works, and the names of their members. A similar account of the academies of other countries was pronised for the second year, but I can not learn that it has yet appeared. The labor upon it was probably interrupted by the revolution of February, and has not yet been resumed.

The lists which I now present are made from the Reverend Doctor Hume's Learned societies and printing clubs of the United Kingdom for Great Britain, the Annuaire for France, and from varions other sources, principally from the first volume of the catalogue of printed books in the British Iuseum for other countries.

This report was the basis of the Swithsonian excliange system. By the year 1853 the Smithsonian collection of the later publications of the learned societies of the world was reckoned the most extensive in the conntry.

Many of the earlier publications, however, were wanting. In his report, dated December 3I, I 853 , Librarian Jewett called attention to this. "Very few of our sets," said he, "are complete. Inquiries are daily made for back numbers which are wanting. As it is probable that we have received all, or nearly all, of the earlier publications of societies which they [the societies] are able to supply, it seems advisable to furnish our agents in Enrope with lists of the volunes which we possess, and authorize them to purchase, as opportunities may occur, the volumes that are wanting." So in the following year an assistant was employed to make a catalogne of all the books received by exchange, and in. I 855 and $I \delta_{5} 6$ a list of "Publications of learned societies and periodicals in the library of the Smithsonian Institution" was published. Such was the beginning of the Smitlisonian collection of society publications.

With reference to the copyright literature to which the institution was entitled under the tenth section of the act of August 10, I846, Librarian Jewett made the following recon1mendation: "That it be always kept in the library, apart fron the other collections, and arranged in chronological order; that publishers be allowed by the postal authorities to

'December 3 I, IS54, 40 pp., $4^{\circ}$; pt. 2, May, 1856, 38 pp., $4^{\circ}$. 
forwari their works withont expense, and that notice of all works copyrighted be published by the Institution in a monthly bibliograplical bulletin." "

And Norton's Literary" Gazctte (July I 5, I852) said: "We are surprised at the apathy shown by some of our leading publishers in complying with the law in relation to copyrights, which directs that a copy of every book copyrighted shall be placed in the Library of Congress, and also in that of the Snithsonian Institution. If publishers would look merely to their own advantage, they wonld see that there conld be no better advertisement to their publications than a position where they can be seen and judged npon by the first men in the nation. Books intended for these libraries, if sent to the office of this paper, properly directed, will be always promptly forwarded." Publishers did not, lowever, see the value of the copyright deposit, hence the following important reports upon the copyright office, the first in the sixth annual report of the Sunithsonian Institution, August 2O, IS 52 , as follows:

The copyright laws of most nations require the delivery to the government, or to libraries designated by it, of a copy, or of several copies, of every work for which copyright is claimed. As far as I have been able to ascertain, in Saxony and in Portngal only one copy is demanded; in France, Austria, Russia, Bararia, Demmark, and Prussia two copies are required; in the Italian States generally, Holland, Belgium, and the United States three copies; in Lingland five copies; in Sweden four or five copies. The number in several of these countries has varied at different periods.

This requirement had its origin in France as far back as 1537 . Its object is twofold:

First, the deposit is considered necessary to the complete protection of the anthor. If lis copyright be infringed, it may be important for him to be able to produce a certified copy of his work in order that it may be compared with the alleged counterfeit. In no other way can he be sure of funding such a copy than by making the deposit a condition of the copyright laws. It is like the model of a machine deposited in the Patent Office. Judge McLean, in delivering the opinion of the Supreme

\footnotetext{
${ }^{2}$ Fourth annual report of the Smithsonian Institntion, July 29, 1850, p. 35; thirtyfirst Congress, first session, Senate niscellaneous docunnent No. I20. In the Fifth aninual report of the Smithsonian Institution, March 1, 185I, pp. I.46-320, the librarian publisherl a list of copyright pulblications deposited in the Smithsonian library between August 10, 1846, and December 31, I849.
} 
Court of the United States in the case of Wheaton versus Peters, says: "The deposit of the book in the Department of State may be inportant to identify it at any future period, should the copyright be disputed, or an unfounded clain of authorship asserted."

The second reason for the requirenent is the public bencfit. 'The right of the Government to demand copies of the work for this purpose is a necessary consequence of the established theory of the copyright law.

The English and American courts agree in resting the right of an author to the exclusive privilege of printing and selling his book upon the statnte and upon the common law. "Congress," says Judge McI.ean, in delivering the opinion of the Supreme Court in the case of Wheaton rersus Peters, "instead of sanctioning an existing right, created it." He says, further, with respect to the right of the Govermment to demand copies: "No one can deny that when the legislature are about to vest an exclusive right in the author or inventor, they have the porrer to prescribe the condition on which such right should be enjoyed."

It is manifest, howerer, that inasmuch as the law is intended to enconrage the production of books, 110 conditions should be annexed to it which would be onerous to publishers, for such conditions would tend to defeat the very end proposed to be answered by the statute. Too many copies should not, therefore, be required. In England at one time eleven copies were demanded. It was made to appear that the law, with such conditions, operated as a discouragement to the publication of expensive works; it was in consequence changed. Five copies are now required, and a sum of money amounting to $£ 2$, So a year paid by the Government to the other six libraries in compensation for the loss of the privilege which they previously enjoyed.

The benefit of the deposit to the public is very great. It is universally allowed to be important for the interests of learning that in every country there should at least be one library where every book, pamphlet, or literary production of any kind issued in the country should be carefully preserved. Now it is utterly impossible to collect the whole in any other way thain by making the deposit a condition to the resting of the right of copy.

The advantage of the cleposit to learning seens to have been the sole motive for its first introduction, and not, as is sometimes supposed, the censorship. Francis the First, of France, in 1537, gives as the ground for repuiring a copy for the royal library at Blois that these books "will be veritable proofs of that praiserrorthy restoration of letters occurring in our time through our diligence, care, and labor, $* * * *$ and that recourse may be had to them if perchance the books should perish from the memory of man or be varied from the true and original publication." (See Renouard, Traité des droits d'auteurs, t. i, p. 42.) No mention is made of their use for the purposes of the censorship, which, indeed, must be exercised before the printing of the book and not afterwards. 
In another ordinance of the sane year, explanatcry to the one above cited, the King expressly declares that it was not intended to affect the censorship in any way; and again, in an ordinance of 1538 , appointing Nicobar Greek printer, it is ordered that "a copy of every book printed shall be deposited in the royal library, to the end that should any calamities befall literature, posterity might there find a resource for repairing in part the loss of books." (Renouard ut sup.) The legal deposit, it is manifest, had its origin in an enlightened regard for learning and not in any odious restrictions upon the liberty of the press.

It follows, then, from the facts and considerations which have been presented, that one copy of every book should be demanded of its author, to be preserved in some public national library, both for his own sake and for that of the public. The legislature have the undoubted right to demand several copies as a condition to the granting of an exclusive right to the publication and sale of the book, provided that they do not demand so many as to impose a burden on the publisher, and thus discourage instead of encourage the publication of books. The interest of the author and of the public (which rightly understood can never be at variance) may alike require that more than one copy should be thus deposited; for if but one be deposited, and that be destroyed by fire or other casualty, the benefit of the deposit would be lost.

It ought to be remarked further that the exacting of copies by the Government implies an obligation to preserve them carefully, and to make them subservient to the purposes, both public and private, for which the deposit is made.

In this respect our own copyright law is defective. It requires the book to be deposited, within three months after its publication, in the office of the clerk of the district in which the author resides. It also directs the clerk to transmit the copy to the State Department at Washington. It makes, however, no provision for the transmission and it establishes no supervision. The consequence is that not more than onelalf of the books for which copyrights are secured in the country ever reach the State Department, and no record is transmitted when the books are not sent.

These books which are received are now kept in a room by themselves. They are, however, lent ont to persons connected with the Department; they are not properly recorded; no stamp is placed upon them for their identification; no catalogue is kept of them; they are not accessible for general use. Thus the benefit to the public is almost entirely lost.

The Supreme Court has decided that the deposit of the copy in the State Department is essential to a valid title; but in case of the loss of the certificate the author has no certain means of establishing his claims. The benefit to the anthor is therefore lost (as in the case of Wheaton) or liable to be lost, though he may have fulfilled all the conditions of the law. 
The requirement of a copy of every book and other article for which a copyright is secured for the Snithsonian Institution, and also for the Library of Congress, is made in the tenth section of the act of Congress establishing the Suithsonian Institution. No penalty is attached to a neglect of the requirement. It has therefore been generally held to be nilerely directory. In the case of Jollie i'. Jacques (southcril district, New York), it was held that the delivery of copies to the two libraries was not a prerequisite to a title to copyright. By many also it is doubted whether, inasmuch as this enactment does not purport to be an amendment to the copyright law, a demand for the copy, in case it were refused, would be enforced by the courts.

Many publishers are not aware of the law; others regard it as unjust and refuse to comply with it on that account; others again find a conpliance inconvenient, and, not considering it essential, neglect it. The consequence is that not half the books to which we are entitled are received by us. Music being issued by fewer publishers, and being more easily sent, has generally been deposited, as also have labels of patent medicines. The labor of issuing certificates for these and recording them is as great as for the books, whilst they have scarcely any appreciable and permanent value.

The books are frequently sent by mail, sometimes sealed, thus subjecting the Institution to letter postage upon them. The postmaster is directed to open such packages; but not unfrequently sealed letters are found within them, and thus the whole package is chargeable with letter rates. This incleed is the case not only with respect to books received under the copyright law, but also with respect to those received by donation. We lave taken every means to make known the fact that we do not possess the franking privilege. We have invariably written to the publishers or donors of works who have made to us these expensive presents, and have several times received for reply that they were misinformed by the local postmaster, who had stated to them that the Smithsonian Institution was entitled to receive letters and packages without the payment of postage. It seems to be inferred, from the connection of the Snithsonian Institution with the Govermment, that it of necessity possesses the franking privilege. We are thus subjected to great expense which it is impossible for us to avoid or materially to diminish.

The whole value of the books received during the year i 85 I by the copyright clause of our charter has been estimated at four hundred and fifty dollars, which is perhaps a low estimate, taking no account of maps, music, and other articles. The expenditure for postage and transportation of these, together with the time and labor spent in issuing certificates, may be estimated at two hundred and twenty-five dollars. It will thus be seen that the privilege is, in its present condition, far from being so important as it was intended and supposed to be. 
The same remarks apply probably with equal force to the subject as it concerns the Library of Congress. It would seem, therefore, from this statenent, that the law is not satisfactory to any of the parties affected by it. A thorough change of system, so far as the deposit of copies is concerned, seems to be required in order to give the security promised to anthors, to relieve publishers from the trouble, expense, and nncertainty attending their efforts to comply with the conditions of the present law, and to provide for the public benefit and the transmission to posterity of materials for the history of our own times.

The interests of all parties may be secured by a much simpler method than the present. After much consultation with those more particularly concerned, I have been led to believe that the following plan would prove generally acceptable:

I. To require a clain of eopyright under the name of the proprietor (to which should be subjoined his residence), with the date of the commencement of such claim, to be printed upon the title-page or the reverse of the title of every eopy of his work, as follows:

"Copyright in this work is elaimed from and after the 6th of August, I 852 , by me, as author [or proprietor].

$$
\text { Of Boston, Massachusetts.", }
$$

2. 'To require the deposit of one or more eopies of the book within one month after the date of the claim, if the book be published in any of the States east of the Mississippi River, and within three months if published west of the same. The books to be transmitted by mail or otherwise, at the risk and cost of the elainant of the copyright.

The person depositing the book should be entitled to a certifieate of deposit, on the payment of a small fee, which certificate should be made receivable in all courts of justice as prima facic evidence of compliance with the conditions of the law.

The omission to deposit within the time specified should not invalidate the copyright, but every proprietor of copyright should be allowed to deposit the copy, or copics, at any time afterwards, and previous to the commencement of an action for infringement of copyriglit, by paying the value of the book and - dollars. But if the book be demanded and refused the copyriglit should be thereby forfeited.

It should be obligatory that record be kept in the place of deposit; that the books be stamper so as to be easily and with certainty identified, and that they be restricted to the depository, unless required by a court of law.

The law would apply not only to books, but to maps and charts, 111usic, engravings, cte., and should require that every copy so sent for security of copyright should be perfect, and, if a book, well bound.

A montlily list of hooks thus deposited shonld be printed and distributed to booksellers and others. There are other details which would 
be necessary to be considered in preparing such a law, but they are easily adjusted after establishing the principles npon which the enactment is to be founded.

A law witls the provisions above stated wonld be much more satisfactory to the publishers, because it would require less of them and subject then to much less expense, and, more than all, wonld effect what the present law does not, security of copyright.

The question next arises, "Where shall the deposit of the book be made?" If but one copy be required, I begr leave to suggest that it could be most properly placed in the library of the Smithsonian Institution. The comnection of this establishment with the Government is such as to render the deposit here peculiarly appropriate. We believe that it would be permanently more useful here, and better protected than in any other establishment. The rooms in the State Department appropriated to the purpose are now crowded to excess, and are besides needed for other purposes. The care of them occupies much of the time of a clerk, whose services can ill be spared. The clerks are continnally changing, and hence it is impossible that any proper system for the care and usefulness of the books can be carried ont. The business is entirely foreign to the Department, and has, I have been told, generally been considered as an incumbrance. It belongs more properly to a public library, and to one maintaining just the relation to the General Government which the Smithsonian Institution does. This is the view taken of the matter in other countries. In England the copy is required for the British Museum (which sustains a relation to the British Government similar to that which the Smithsonian Institution does to our own) and not for the library of the House of Commons or any library of the executive departments.

I am unable to say whether or not the deposit is desired by the guardians of the Library of Congress. There is no doubt, however, that two or even three copies would be cheerfully granted by all publishers in this country, if they were sure that the purposes of the deposit would be ansacred. The dissatisfaction which has hitherto been expressed has arisen entirely from the indefiniteness of the law, the difficulty of conplying with it, and the doubt whether the deposit wonld be safely guarded, and rendered available for the object for which it is made.

In the report presented January, I $S_{53}$, Professor Jewett said, with regard to this part of the work of the library:

Every book which has been received has been inmediately and carefully recorded, and a certificate of cheposit sent (generally by return mail) to the depositor. The same care has been exercised for the most insignificant as for the most important, and has been dictated by a sense

rSixth Annual Report of the Smithsonian Institution, Thirty-second Congress, first session, Senate miscellaneous docmnent No. 105, plp. 31-37. 
of justice to the publishers, inasmuch as the deposit was supposed to be essential to the perfection of their title. Had the articles thus sent been regarded merely as donations to the library, many of them might have been differently treated. Loose sheets of music, schoolbooks, and many cheap publications might merely have been placed together in some spot where they would long have remained undisturbed. For themselves, and as parts of an imperfect collection, they were hardly worth recording. It should be particularly observed that any article, however apparently worthless, acquires ralue and importance as an integral part of a complete collection. A collection of all the productions of the American press would, if perfect and entire, teach lessons which wonld not be gleaned from its parts.

It would show the extent of the literary labors of the time.

It would show the proportionate attention to the various departments of learning.

It would show from year to year the increase or decrease of interest in particular pursuits.

It would show the comparative literary fertility and wealth of different portions of the country.

It would show the progressive improvements in the subsidiary arts of papermaking, binding, engraving, and so forth.

All these points possess interest to different classes of inquirers. The wants of all literary investigators should be respected, and, as far as possible supplied. The historian is not less to be provided for than the philosopher, the artist than the statesman. If we had the means, we would reject nothing, not even that which night to ourselves appear utterly trivial and unwortly of preservation, for the article which one would reject might, in coming times, for some reason which could not possibly have been foreseen, possess more interest than any other in the collection.

It is impossible for any man to judge competently of the wants of future generations. It is unsafe to intrust to anyone the power of rejecting works as worthless. Many enlightened contemporaries of Milton and Newton would have rejected, as worthless, the Paradise Lost and the Principia. Sir Thomas Bodley, the founder of the great library which bears his name-a contemporary of Shakespeare-insisted, contrary to the adrice of his librarian, Dr. James, in excluding plays and almanacs, and most pamphlets, which lie was accustomed to call "riffraff" and "baggage-books." The Bodleian Library is now paying very high prices for those books which then might have been procured almost without cost.

It is stated that one of the libraries in England, to which books were scnt by copyright, and which was allowed to select such as were worthy to be retained, rejected, in a single year, The Antiquary; Mrs. Opie's novels; one of Wordsworth's odes, and his letter to a friend of 
Burns; Cobbett's publications; Jameson on Minerals (second edition), and the Edinburgh Mcdical and Surgical Journal; The Siege of Corinth, and Shelley's Alastor; Lord Brougham's Speech on agricultural distress, and McCulloch's Essay on the national debt; Conparative tables of commercial weights; Becthoven's musical compositions, and many other similar works. (See "Copy of a representation from the trustees of the British Museum to the treasury," March 27, 1846, p. 35.)

There ought therefore to be in every country one complete collection of everything published-one library where everything printed should be garnered up and treated as of some importance; for, althongh in the multitude of libraries everything may be preserved somewhere, yet, from being scattered about, and from there being no one place where the student would be sure of finding all that he might seek, many books would be practically lost.

The investigator of the last half century of American history is now obliged to travel the country through to collect books and papers for his work. Suppose that everything published in the country for the last hundred years had been preserved in one library, had that library been in town or country, in the remote East or farthest South, it would have been the great place of resort for students of American history.

How many would already have gained among its alcores the means of presenting to the world, in new and fresh pictures, the eventful history of our country. How many disputed and doubtful points would have been settled. How many errors would have been avoided. How much injustice to private character would have been silenced. How many bright examples of patriotism and devotion, now lost, would have been held up to the emulation of youth and the admiration of all.

Although these remarks go to show the importance of a complete collection somewhere, they do not show that the same rule of accepting or rejecting should be followed where it is known that the collection can never be made complete.

Every partial collection is supposed to be a selection made for some specific purpose; and although many works, apparently very remote in their character from those chosen, may be desirable, yet, when means of procuring and preserving are limited, it may be best, it may be necessary to confine the selection to such as are most intimately connected with the main purpose of the library.

It might further be a question whether, adnitting the importance of a complete collection of copyright books, it should be made here.

I endearor to show, in my last report, that it would not be practicable to collect these books in any other way than by a condition of the copyright law, enforcing the deposit somewhere.

It seems appropriate, if not necessary, that the place of deposit designated by Government should be at Washington. Fixperience has slown that the selection of the State Departnent for this purpose is incon- 
venient. The President of the United States, in his last message to Congress, has expressed the opinion that it would be a benefit to the public service to transfer the execution of the copyright law from the State Department. The other places of deposit would be the Library of Congress and the Smithsonian Institution. Whether the deposit be made here or in the Library of Congress, it certainly is the duty of the Government to defray all expenses connected with it. It pertains to the Government, is a necessary condition of the protection which the Government promises to anthors, and is precisely analogous to the case of the deposit of models in the Patent Office. 'This Institution can not afford, at its own cost, to receive and take care of everything that is deposited. At the same time it is bound, by its position, to urge the necessity of the deposit, to show how it should be regulated, and to do all that it can, without prejudice to its other interests, to secure to authors and to publishers, as well as to students and literary men, the full advantages which the law contemplates. I accordingly proposed last year a plan which seemed to me to meet all the necessities of the case.

The general features of this plan were-

I. To dispense with the registration of titie, rendering the publication of the claim of copyright the only preliminary to the vesting of the right previous to the depositing of a copy.

2. To reduce the number of copies required for deposit from three to one.

3. To require the deposit of one copy, at the risk and expense of the proprietor of the copyright, within a reasonable time after publication.

t. To require a small fee from the proprietor sufficient to defray the expense of furnishing certificates, keeping records, and preserving the books. This fee might be made considerably less than that now required of publisher and still meet all those purposes.

Thuts the trouble and expense to pubiishers wot1d be greatly diminished without involving any burden either upon Government or the Institution receiving the deposits.

The deposit in the library of this Institution might be made of great incilental benefit to publishers and authors.

It has been proposed to issue a monthly bulletin to contain the list of all books deposited during the preceding month. This work night, under the operation of such a law as proposed, be commenced immediately. It would be widely circulated in this country and anong reading and studious men in all parts of the world. Publishers would generally be willing to pay a large price for such a medium of advertising. But in the case strpposed the advertisenent would be incidental to the deposit and woukt cost then 1rotling. By our systen of stereotyping the titles separately they woukd not only fill their place in the bulletin, but would serve for the catalogue of our own library and of every other possessing the books and receiving from us its printed catalogue. 


$$
2
$$



Various attempts have been made to make complete lists of American publications, but although some have been quite full none have ever been complete. The best is that of Mr. Norton, in the Litcrary Gazette.

It would be matter of surprise to many, and of patriotic pride to all, to know the interest with which this list is received in Europe. But a few years have elapsed since an English review arrogantly asked, "In the four quarters of the world, who reads an American book?" It would not now be more arrogant in us to demand, what citizen of the great republic of letters does not read American books?

On the presentation of my last report, I hoped that it would be printed and distributed early in the year among publishers and anthors, that we might be able ere this time to ascertain fully their views on the subject. They are more inmediately interested in the matter, and nothing should be done which would be unsatisfactory to them.

There is in this connexion another idea, which long ago occurred to me, but which I have not ventured to suggest openly lest it should seem extravagant, and because I could see no immediate means for accomplishing the object; I mean an international copyright exchange.

If, for example, a duplicate collection of all works for which copyrights are secured in this country could be made, it might be offered to England in exchange for a like collection of its own publications; and this exchange, if prosperous between two countries might be extended to all the principal nations of the book-making world. I do not propose any plan for effecting this end, nor do I know that it could ever be realized; but in view of what has been done by this Institution during the last year in the way of literary exchanges, such anidea is not altogether chimerical. The advantages which would result from such an interchange would be immense. The literary and scientific labors of each country would be known in their full extent, and almost simultaneously in all other countries. Would not science advance more rapidly? Would not better justice be done to American genius?

Nothing, it seems to me, conkl more effectually conduce to the rapid progress of science and humanity than a system which should make the literary and scientific labors in each country known immediately in all others.

The books gathered would, it is true, be in but one library; but books in a large public library, though clained to the slelves, are not to be shut ont fron the world. They contain ideas which entering the minds of those who have access to them fructify and the fruit is scattered far and wicle. Books, it is true are silent and motionless, they seem to produce no results. But within them is the spring of all progress, the spirit which stimulates and sustains all the activity that the world of letters, of science, of politics, and of religion, manifests. ${ }^{t}$

'Smithsonian Institution report, March I, 1853 ; Thirty-secont Congress, second session, Senate miscellaneous document No. 53, pp. 36-4\%.

$23399-0.4-29$ 
The result of these reports was the passage of an act, Narch, 3, I 855 , authorizing the transmission free of postage of articles entered for copyright. The effect of this law was to diminish considerably the expense to which the Institution had been subjected in receiving books of this kind. On the whole, however, the law relative to the deposit of works intended for copyriglit was not a benefit to the library, as a scientific library merely. The expense of certificates, shelf roonl, and clerk hire, much exceeded the value of all the books received in this way. Secretary Henry said that all the books published in the United States required for the Smithsonian library might have been purchased for onetenth part of what had been expended on those obtained by the copyright law. Schoolbooks, works intended for children, and the lighter and more worthless publications of the day were forwarded to the library, but the larger and more valuable productions of the American press were often withheld. The principal office of these copyright accessions, therefore, was to swell the number of volumes contained in the library and so satisfy those who desired to see there a large number of books rather than a choice collection. They also increased the cost of the reading-room service, the class of literature which was copyrighted being in great demand, especially among young people. ${ }^{\mathrm{t}}$

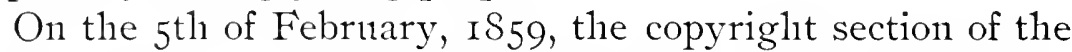
act of August IO, IS46, was repealed and the copyright business of the Department of State, Library of Congress, and Smithsonian library transferred to the Department of the Interior.

BIBLIOGRAPHICAL ENTERPRISES, GENERAL CATALOGUE OF AMERICAN IIBRARIES, COOPERATIVE CATALOGUING, ETC.

In the original programme of organization a proposition was introduced by Professor Bache to render the Institution a center of bibliographical knowledge to which students in every part of the conntry conld apply by letter or otherwise for information as to what books existed on a particular subject and in what libraries they could be found.

\footnotetext{
'Tenth annual report of the Snithsonian Institution, p. 30.
} 
In establishing this bibliographical burean it was of primary inportance to make a survey of Annerican libraries in order to learn their condition and prospects and to establish with them relations indispensable to success in any general system of operations. Accordingly, in the year i $S_{4} 8$, Librarian Jewett began the collection of statistical and historical notes on the libraries of the United States by sending to the varions libraries a circular letter containing the following questions:

I. By what name is the library legally designated? 2. When was it founded? 3. What number of volumes does it contain? 4. Has it collections of mannscripts, maps and charts, 1n11sic, engravings, medals, coins, etc.? If so, please to state the number of each article of each description. 5. Are the numbers given in reply to the last two questions ascertained by actually counting the volumes and articles, or are they from a conjectural estimate? 6 . What has been the yearly average number of volumes added to the library for the last ten years? 7 . What has been the yearly arcrage expenditure for the purchase of books? 8. Is there a permanent fund for the increase of the library? If so, how large is it, and what sum does it yield annually? 9. How many and what officers are employed? What are the names and addresses of the present officers? Io. Has a building been erected expressly for the library? If so, when, of what material, and at what expense? II. What are the dimensions, and what is the ground plan of the library building or rooms? 12. Are the books arranged on the shelves according to subjects or on some other system? I3. Is there a printed catalogne of the library? If so, when was it printed, and what is its size and the number of pages? If more than one, what is the date of each? I4. How is the library opened, and how long is it kept open each time? I5. Who are entitled to the use of the library and on what terms? i6. Are books lent out to read? If so, how many are taken ont annutally? 17. What is the yearly average number of persons consulting the library without taking anay books? IS. Have the books been injured at any time by insects? 19. Is there any regulation by which books may be lent by courtesy to persons at a distance? If so, what is it?

By the end of the year i $84 S$ answers had been received from some of these letters and Librarian Jewett had visited and examined many of the principal libraries. By the end of the year i 849 many more answers had been received and Professor Jewett had collected from various otler sources information respecting most of the public libraries of the

'Thirty-first Congress, first session, Se nate miscellaneous rlocuments, No. I20, I'p. 4-5. 
United States. In the following year the results of this investigation were published as an "Appendix to the report of the Board of Regents of the Smithsonian Institution, containing a report on the public libraries of the United States of America, January I, I 850. By Charles C. Jewett, librarian of the Smithsonian Institution." This was a prelinininary edition only, and those who received copies of the work were requested to furnish corrections, additions, and suggestions for a second edition, so that within a few years materials might be obtained for accurate accounts, embracing all historical facts of importance with reference to every library and every institution possessing a library in the country, and including the history and statistics, with description of the bibliographical and scientific treasures of each. December $3 \mathrm{I}, \mathrm{I} \mathrm{S}_{53}$, Librarian Jewett reported that the first edition of the "Notices of public libraries" being almost exhausted and a large amount of additional information regarding American libraries having been received, it seemed desirable to issue a new and enlarged edition of that work. In the following year, accordingly, the task of preparing a new edition of this work was intrusted to William J. Rhees. The results were published under the title "Manual of public libraries, institutions, and societies in the United States and British provinces of North America. By William J. Rhees, chief clerk of the Smithsonian Institution. Philadelphia: J. B. Lippincott \& Co., IS 59." With the information afforded by these publications, cooperation among American libraries and the activity of the Smithsonian Institution as a bibliograplical burean was made possible.

In order, however, that the Institution as a bibliographical burean might inform students what books there were on any subject and where they might be found, it was necessary for the librarian to obtain all the inportant works on bibliography and to secure copies of the catalogues of all the important libraries in the conntry. Three copies of each catalogue it was thought should be secured, one to be preserved in its original form and the other two to be cut $11 \mathrm{p}$ in order that the titles on each side of a leaf could be pasted on cards

${ }^{r}$ Thirty-first Congress, first session, Senate miscellaneous documents, No. I 20. 
and the whole arranged in drawers so as to form a general catalogue. With regard to the preparation of this general catalogue of Anerican libraries, Professor Jewett reported, December i 3, i 348 , as follows:

I have commenced the work in the following manner: Taking the printed catalogue of the library of Harvard University, I separate the titles and paste each one upon a card about 6 inches long by 4 wide. This size card was selected in order to allow room for long titles with the annotations which may be necessary. The letters "H. U." are to be stamped upon the card to denote that the book belongs to Harvard University. When the titles of the Harvard University catalogue are finished it is proposed to begin upon the catalogue of the Philadelphia library. Whenever the titles are the same it will be sufficient to stamp upon the card in addition to the letters "H. U." the letters "P. L. C.," thus denoting that the book belongs also to the Philadelphia Library Company. When new titles are found they should be placed upon the cards like the others. The catalogues of all the other libraries are to be treated in like manner. When the arrangement of the printert catalogues is completed it will be necessary to obtain manuscript continuations. These must be copied on the same kind of cards. It will then be easy to arrange the titles in alphabetical or other order and to preserve them in such order, however frequent and numerous the accessions which may be made.

It is hardly necessary to enlarge upon the great value of such a catalogue. From it we could readily ascertain what books there are in the various public libraries and how well each department of learning is provided for. We should thus be enabled to fill up our own library with a more intelligent reference to the actual wants of the country.

Such a catalogue will also enable us to direct a student to the books which he may want, if they are to be found in any of our libraries.

There will be also an incidental advantage gained by it of great importance to the department of American history and bibliography. The Institution proposes to publish anong its "contributions" a complete bibliography of the materials of American history prior to A. D. I700. This will be one of the most valuable contributions ever offered to the facilities for studying the early history of our country. But it is only a commencement. The books relating to and printed in Anerica after 1700 are vastly more numberous and certainly of great importance. They relate to the period of our early struggles, to the achievement of our independence, to the formation and consolidation of our Government. No proper bibliographical survey of this field has ever yet been made. The books and pamphlets relating to it were pulblished, the larger part, perhaps, in America, but many of them in liurope, and they are now scattered far and wide. Some very valuable collections 
have been made of them, the best of which is due to the diligence, learning, and devotion of a distinguished gentleman of this city. No collection, howerer, that has yet been made can be considered complete. Still we may safely say that a large proportion of the books extant relating to this period are to be found among the libraries of the United States. One great difficulty heretofore encountered by our bibliographers has been to ascertain where they are preserved. Many libraries have no printed catalogues, of others the catalogues are far in arrears. From our supposed general catalogue it will be easy to find every book of this description which is preserved in any of our collections and to ascertain at a glance the place of its deposit.

I have made, of course, but a commencement on this work. To bring it to completion will be the labor of more than another year. ${ }^{\mathrm{*}} * * *$

During the year I $\$ 49$ considerable progress upon this general catalogue of American libraries was made. Fifty-five thousand titles were prepared from printed catalognes, and 4,000 titles had been transcribed. The work thins far compreheided a catalogne in one alphabet of the sereral libraries of Cambridge and Washington.

This general catalogue was of use, however, only to students resident in Washington or correspondents of the Sinithsonian Institution. It was manifest, therefore, that its benefits would be vastly increased if copies of the catalogue could be 11n1tiplied. But the catalognes of the different libraries were constructed on plans so various and, in most cases, so faulty that it was unadvisable to print any catalogne formed from them. It therefore occurred to Professor Jewett that the formulation of a set of rules for preparing catalogues would promote uniformity in cataloguing, at least. The result was the "Sinithsonian report. On the construction of catalogues of libraries, and of a general catalogue; and their publication by mea1s of separate stereotyped titles. With rules and examples. By Charles C. Jewett, librarian of the Smithsonian Institution.."

\footnotetext{
${ }^{2}$ Third annual report of the Smithsonian Institution, Thirtieth Congress, second session, Miscellaneous document No. 4S, pp. 45-47.

${ }^{2}$ Waslington: Published by the Sunithsonian Institution, IS52. vi, 78 pp. $S^{\circ}$. 2d ed. 1853. xii, $96 \mathrm{pp}$. $\mathrm{S}^{\circ}$. Translater in the "Biblioteca rli bibliografia e paleografia," with the title "Della compilazione dei cataloghi per biblioteche e del modo di publolicarli per 111czzo di titoli separati stereotipati. Regole ed esempi di Charles C. Jewctt. I'rinla versione dall' inglese a cura del Dr. Guido Biagi, bibliotecario della R. Marucelliana di Firenze. In lirenze: G. C. Sansoni, editore, ISSS." ix, $120 \mathrm{pl}$. $\mathrm{s}^{\circ}$.
} 
But this was not enough. Library trustees, from false notions of econony, often employed incompetent librarians because they would work cheaply, or required competent librarians to perform so many other duties that they had not time to derote to the catalogue, or, finally, crippled and tranmeled them by prescribing absurd and nusuitable systems. A set of rules intended to promote uniformity in cataloguing would not be sufficient; there must be cooperation in cataloguing, and the end of that cooperation munst be accuracy and cheapness. The cataloguing of American libraries might be done by Smithsonian or other experts according to the rules for preparing catalognes above mentioned, and the catalogues thus prepared printed at the Suithsonian or other central office, each title being stereotyped separately and used in printing every subsequent catalogue of the same libraries or other libraries. In this way, Professor Jewett conceived, a book once catalogned would never have to be catalogued again; what was spent on the first catalogue of a library wonld never have to be spent again, either by that library or by any other.

This plan for stereotyped catalogues was presented to the Board of Regents of the Smithsonian Institution July 5, I S 50. By them it was referred to the Secretary and executive committee, who in turn referred it to a commission of literary gentlemen for examination. This plan provided for stereotyping or electrotyping catalogues of libraries in a uniform style, and forming a general stereotype catalogue of the public libraries of the United States. It was to work as follows: Titles of books were to be stereotyped on separate movable blocks. These blocks were to be kept at the Sinithsonian Institution, and used for the printing of new editions of the catalognes for which they were originally made, allowing the interposition of additional titles in the proper order; they were to be used also for the printing of all other catalogues containing the same titles, in the printing of bibliographies of particular branches of knowledge-alphabetically; chronologically, or classed-and in the printing of a general catalogne of the public libraries of the United States. If successfully carried ont it would, it was thonght, make more available the 
aids to literary labor already in the country and secure the construction of better and less expensive catalogues. The plan of this undertaking was discussed by its author in his report as librarian of the Smithsonian Institution for $\mathrm{I}_{5} \mathrm{O}$ :

It would not be possible for me [said le], within the customary limits of a report like this, to present all the details of a scheme so extensive; yet it is proper that I should dwell somewhat at length upon the exigencies in which it originated, its principal features, its practicability, and the benefits which it promises to our public libraries and to the cause of knowledge.

We can but glance at the nature and extent of the difficulties which have hitherto been encountered in attempting to furnish suitable printed catalogues of growing libraries and which have led or are leading to a common abandonment of the hope of affording guides so important to the literary accumulations of the larger libraries of Europe.

It is, of course, entirely practicable to publish a complete and satisfactory catalogue of a library which is stationary. But most public libraries are constantly and rapidly increasing. This circumstance, so gratifying on every other account, is the cause of the difficulties to which I have alluded.

While the catalogue of such a collection is passing through the press new books are received, the titles of which it is inpossible in the ordinary manner of printing to incorporate with the body of the work. Recourse must then be had to a supplement. In no other way can the acquisitions of the library be made known to the public. If, as in the Library of Congress, the number of supplenents be increased to nine the student may be obliged to grope his weary way through ten catalogues instead of one in order to ascertain whether any book which he seeks is in the library. He can not be certain even then that the book is not in the collection, for it may have been received since the last appendix was printed. Supplements soon becone intolerable. The whole catalogue must then be rearranged and reprinted. The expense of this process may be borne so long as the library is small, but it soon becones burdensone, and cre long insupportable even to national establishments.

There is but one course left - not to print at all. To this no sclolar consents except frown necessity.

But to this alternative, grievous as it is, nearly all the large libraries of Iinrope lave been reluctantly driven. More than a century has passed since the printing of the catalogue of the Royal Library of Paris was connmencel. It is not yet finished. No one feels in it the interest which lie would, if he could hope to have it kept up complete, if once it were brought up to a given date.

Doctor Pert\%, chief librarian of the Royal Library of Berlin, declares that to print the catalogue of a large library, which is constantly 
increasing, is to throw money away. His opinion is founded upon the supposed inpossibility of keeping up the catalogue so as continually to represent the actual possessions of the library.

The first volune of the new catilogne of printed books in the British Nusemm was publisled in $1 S_{f}$. It is a folio of four hundred and fiftyseren pages, and contains all the titles, under the letter $A$, of books in the library at the end of the year 1838. Mr. Panizzi, from the first, strongly opposed the printing of any part of the catalogue before the whole, up to the prescribed limit ( 1838 ), should be completed in manuscript. Time las shown the justness of his views. The commissioners lately appointed by the Queen to inquire into the constitution and management of the Museun, have, in their report, expressed an opinion decidedly against the printing of the catalogue at all, and principally on the ground that it must ever remain imperfect.

One of the witnesses (the Right Honorable J. WT. Croker) examined before the commissioners thus strongly states the case with respect to printing:

"You receive, I suppose, into your library every year some twenty thousand volumes, or something like that. Why, if you had a printed catalogue dropped down from Heaven to you at this moment perfect, this day twelve-month your twenty thousand interlineations would spoil the simplicity of that catalogne; again the next year twenty thousand more; and the next year twenty thousand more; so that at the end of four or five years you would have your catalogue just in the condition that your new catalogue is now (the manuscript part greater than the printed part). With that new catalogue before your eyes, I an astonished there should be any discussion about it, for there is the experinent; the experiment has been made and failed.'

Not one European library of the first class has a complete printed catalogue in a single work. The Bodleian library issued in $1 \$+3$ a catalogue in three large volumes, folio, which is generally but erroneously supposed to contain the titles of all books in the collection: but all books of which special catalogues had previously been printed are onitted in it. For a complete catalogue of the Bodleian library it is necessary to procure not only the three volumes (folio) printed in $1 s_{43}$, but also four other rolunes containing the catalogues of collection helonging to the library. Therefore one may be olsliged to search five catalogues before he can ascertain whether any particular book was in that library up to the end of the year $1 s_{34}$.

The catalogue of $18_{43}$ is only brouglit down to 1835 . None, therefore, of the literature of the last fifteen years and none of the acquisitions of the library during that period are contained in it. A supplement is in press, or perhaps already published, which contains the additions to the library from i 835 to 1847 . When this is publisled it will be possible to ascertain whether any given book was or was not in the library to to the 
end of the year $1 S_{4} 7$, but it may be necessary to search six catalogues for the purpose.

In riew of these facts it is not surprising that the commissioners upon the British Musenm should come to the opinion that it is unwise to print the catalogue of that library and should advise that nothing more be attempted than to prepare and keep up a manuscript catalogue.

But in this opinion the British public, who look to the end without considering the difficulties of the way, do not seem cordially to acquiesce, and it will perhaps be found necessary to print, even at the estimated cost of $\mathcal{L}+0,000$ sterling and with the certainty that almost as soon as the catalogue comes from the press the republication of it will be as loudly demanded.

This is certainly a disheartening state of things. It applies with equal force to catalogues of all forms-a ${ }^{1}$ phabetical, chronological, and classed. It has been felt and lamented by everyone who has had the care of an increasing library.

In seeking a remedy for this evil, the idea occurred to me several years ago to stcrotype the titles separately' and to preserve the plates or blocks in alphabetical order of the titles, so as to be able readily to insert additional titles in their proper places and then to reprint the whole catalogue. By these means the clief cost of republication, that of composition, together with the trouble of revision and correction of the press, would, except for the new titles, be avoided. The great difficulty which had so long oppressed and discouraged librarians and involved libraries in expenses so enormots would thus be overcome.

This idea had occurred to me before my appointment as librarian of the Smithsonian Institution, and assumed, in my mind, new importance in connection with the plan of forming a general catalogue of American libraries.

My action in the matter was checked by the discouraging opinions of several stereotypers whom I consulted. I did not, indeed, believe the difficulties which they suggested to be insuperable, but I was so situated that it was impossible for me at once to institute the experiments neces sary to show the practicability of stereotyping titles separately.

In the meantime the librarian and directors of the American Antiquarian Society, having heard of the plan, opened a correspondence with me on the subject, with a view of employing it in the republication of their own cataloguc. The energetic aid and ingenious suggestions of one of the directors, the Rev. Fidward F. Hale, of Worcester, gave a new impulse to the scheme, and induced me to propose its adoption by the Sullithonian Institution sooner than I had anticipated.

'The suggestions of Mr. Hale were seconded by the practical skill of Mr. Wilcox, an ingenions electrotypist of Boston, who made the electrotyped pase of separate novable titles which I have already submitted to your inspection. It is a beatutiful piece of work. It clen- 
onstrated to the conviction of the most incredulous the practicability of this nuetlod of printing catalognes.

After the plan had been made public by a paper which I presented in August last to the Anterican Association for the Advancement of Science, Mr. John K. Rogers, agent of the Boston Type and Stereotype Foundry, devised a method of accomplishing the purpose by means of the common process of stereotyping. He caused a page to be made for exhibition at the mechanics' fair in Boston. He has since been at the expense of another page, very handsomely executed and with several improvements, which I liave now the pleasure of submitting to your examination. This page establishes the applicability of the common stereotype process to our purpose. The company which Mr. Rogers represents is ready to enter into a contract to do the work at a very sulll advance upon the usual price of stereotyping. Whaterer the result may be, our thanks are clue to Mr. Rogers for his intelligent and liberal efforts.

Meanwhile my attention was directed to a new process of stereotyping which promises to form an era in the art. A gentleman from Indiana, Mr. Josiah Warren, is the inventor. The material which he uses for stereotyping costs not more than 3 cents an octaro page. The process is so simple that any man of average ingenuity could learn to practice it successfully by tro or three day's' instruction. The cost of apparatus for carrying on the work is very small. The rapidity of execution is stch that one man can produce at least twenty-five octaro pages a day, all finished and ready for use. The plates give a beautiful impression. They seem as durable as common stereotype plates, and, so far as now known, they are not in any great degree nore liable to injury.

If this invention bears successfully the severe tests of practical men, it will have been brought forward at a most favorable period for this project. It will be seen by the specimens which I hereby present that it offers extraordinary facilities for the kind of work which we require, and it will reduce the expense very greatly.

This prelininary point of the practicability of stereotyping by titles nay therefore be considered as established. That it can be done by the electrotspe procesis, as well as by the ordinary mode of stereotyping, is placed beyond dispute. It seems equally certain that it can be done by Mr. Warren's method. The choice anong these three ways must be deternined by their comparative conomy, convenience, and elegance. We have not yet had the opportunity to bring this point to a final decision. It is certain, however, that the work can be done. I proceed therefore to state the proposed manner of applying this plan to the printing of catalogues of particular libraries, and to the formation of a general catalogne of all the libraries in this conntry. It is as follows:

I. The Smithsonian Institution to publish rules for the preparation of catalogues. 
2. To request other institutions intending to publish catalogues of their books to prepare them according to these rules, with a view to their being stereotyped under the direction of the Smithsonian Institution.

3. The Smithsonian Institution to pay the whole extra expense of stereotyping, or such part thereof as may be agreed on.

4. The stereotyped titles to remain the property of the Smithsonian Institution.

5. Every library 11niting in this plan to have the right of using all the titles in the possession of the, Institution as often as desired for the printing of its own catalogue by the Smithsonian Institution, paying only the expense of making up the pages, of the presswork, and of distributing the titles to their proper places.

6. The Smithsonian Institution to publish, as soon as possible and at stated intervals, general catalognes of all libraries coming into this systenl.

It is believed there is nothing impracticable in any part of this plan, provided that the benefits to be derived from it be such as to secure the cooperation of the various libraries in the country. To these benefits, therefore, it is necessary to direct particular attention.

And first, let us consider its advantages in an economical point of view to the first institution adopting it.

We will suppose, for example, that the American Antiquarian Society proposes to publish a new catalogue of its library. This institution printed, in 1837 , a handsome and valuable catalogue, in five hundred and sixty-two large octaro pages, in fine type. The composition cost, we will suppose, one dollar a page. All this must now be reprinted, in order to add the titles of books received since I $_{37} 7$, the number of which is almost equal to that of the former catalogue. If a new catalogue be now printed, in ten or twelve years it will be necessary to reprint the whole, and this process will go on, till the expense of reprinting will be quite appalling. Now, had the titles of the original catalogue been stereotyped, the catalogne, instead of costing for the composition five hundred dollars, night have cost, for composition and stereotyping, seven hundred and fifty dollars, counting the extra cost of stereotyping in titles 50 per cent above that of composition.

But the necessity of recomposing the first part would no longer exist. five hundred clollars would therefore be saved in the first reprint, whilst the extra expense of stereotyping was only two hundred and fifty dollars. 'Thus the net gain would be two hundred and fifty dollars, minus the cost of newly making up and composing the old matter, which would be very inconsiderable. But there would be still further gains. It would not be thought necessary to print so large editions if the work conld be reproduced at a trifling expense. 'The rearrangenent, too, passes from the hands of the librarian to those of the printer; and the proof reading has been done, once for all. 
The time for applying this system to the first erlition is indeed past, but the same reasoning, at the present moment, applies to the second. If the whole be now stereotyped, and two hundred copies struck off, the accessions for the first year may be stereotyped and printed separately, and in the second or third year a new catalogue may be issued, with the additions incorporated. In the meantime, it is probable that many of the supplementary litles would have been stereotyped for other libraries, and thus the cost of writing them out and of stereotyping them be spared to the Antiquarian Society. If the cost of composition for the catalogue about to be published (containing thirty thousand titles or more) be stated at one thousand dollars, for an additional sum of five lundred dollars the necessity of recomposing would be forever obviated, and the great advantage secured of being able to print every two or three years, at small expense, new editions, each complete to the time of its publication.

It is thus, I think, demonstrable that, even for the use of a single library, this plan would be economical.

Let us next consider the advantages which the second library, adopting the plan, may hope from it in an economical point of view.

We will suppose, for the sake of example, that after the catalogue of the Antiquarian Society's library has been stereotyped, and the titles placed under the care of the Smithsonian Institution, it is proposed to issue a new edition of the catalogue of the Library of Congress. What inducements would there be for adopting this plan?

It has been the practice in this library to print a new edition of the catalogue every ten years, and to isste annual supplements. About one-fifth of the catalogue has been printed five times; two-fifths four times, etc. Now, from what has already been said, it will be manifest how great the saving would have been had this plan been known and followed from the first, eren if the first cost of stereotyping by titles had been twice or three times that of ordinary printing; and consequently how great the prospective advantage of adopting the plan, even independently of any general system.

But I now suppose that, when the plan is adopted for the Library of Congress, the catalogue of the Antiquarian library has already becn stereotyped, and that the titles are in possession of the Smithsonian Institution, for the use of other libraries entering into the general arrangement. Here is a new and very important element in the calculation.

We suppose the number of titles of the Antiquarian library, already stereotyped, to be thirty thousand. Some of these would doubtless be the same in both collections. For all that is common to the two, the expense of the preparation of titles, of composition, and of resision would be saved to the Library of Congress. It is inpossible to say, with exactness, how much the saving would be from these sources, because these two catalogues are not uniform nor complete. If the Library of Congress was properly catalogued it would give, perhaps, seventy thou- 
sand titles. Of these I presume not less than fifteen thousand would be identical with the same number of the Antiquarian library. At this rate, more than one-fifth of the labor and cost of preparation wonld be saved by the use of titles prepared and stereotyped by others, over and above the savings already enumerated.

After the stereotyping of the Antiquarian Library and the Library of Congress we should have perhaps eighty-five thousand stereotyped titles. Of course the third institution adopting the plan would be likely to find a very large number of its titles identical with those already stereotyped. The amount saved by the use of titles already stereotyped would soon (perliaps in the third library) be sufficient to counterbalance the extra expenditure for stereotyping for that library. At any rate, the extra expense would be a quantity constantly and rapidly diminishing, and it would soon (certainly after the fourth or fifth library) vanish entirely. The Smithsonian Institution would not therefore be required to assume the charge of an enterprise which might involve it in great and increasing expense, but rather and solely to lielp put into operation and to guide a system which will almost immediately pay its own way and will soon save enormous sunus of money to our public libraries.

That the aggregate conomy' of this plan would be very great may be seen from the following statenent:

We have in our library fifteen thousand pages, mostly in octavo, of catalogues of public libraries in the United States. These contain at least four hundred and fifty thousand titles. But according to the best estimate which I can make from a comparison of these catalogues, there are among them not more than one hundred and fifty thousand different titles. Two-thirds, then, of the whole cost of printing the catalogues the first time might have been saved by assuming the extra expense of stereotyping the remaining third.

I have put thus prominently forward the economy to be expected from the proposed enterprise, not because this in ny estination is the most powerful argument in favor of it, nor because I should entirely despair of its acloption were it not advantageous in a pecuniary point of view, but becanse, even if there were no other reasons for it (provided there were none against it), the fact of its great econony wonld be decisive, and because in the present poverty of onr institutions of learning, and in the vast number of plans for the extension of their 11sefulness, which present thenselves for consideration and claim approval this might stand a much smaller chance of success if it rested entirely upon other grounds than the saving of money.

Having now, however, shown its economy when employed by a single library and its great economy in connection with a general system, I proceed to suggest a few anong the many benefits to the cause of knowledge which this plan promises if generally adopted. 
It can hardly be necessary for me to dwell at length upon the benefits to be expected from a general printed catalogue of all books in the public libraries of Anerica. By means of it every student in America would have the means of knowing the full extent of his resources for investigation. The places where the book conld be found wonld be indicated in the catalogue. A correspondence would be kept up between this Institntion and every other library in the country. A systen of exchange and of general loans might, with ceriain stringent conditions, he established, so that all the literary treasures of the country would be measurably accessible to every scholar. When the loan of a book wonld be impossible, extracts could be copied, quotations verified, and researches made through the intervention of this Institution, which wonld in many cases be nearly as valuable to the student as the personal examination of the book.

In connection with this topic I would add: By law a copy of every book for which a copyright shall be secured in this country is required to be delivered to the Smithsonian Institution and to be preserved therein. It is hoped that additional legislation on this subject will, while it lightens the burdens of publishers, secure the observance of this law with respect to the Smithsonian Institution in all cases. If, then, the books thus obtained be all preserved, they will constitute the complete monumental history of American literature during the existence of the law. It is useless to enlarge upon the value of such a collection.

If, now, a list of these publications, as they come into the library, should month by month be published in the proposed Bulletin and the titles immediately stereotyped, the expense would be trifling of publishing every year a catalogue of the books copyrighted in America during the year, and to print every five years a general catalogue of American publications up to that limit. Thus the monthly bulletins, the annual lists, and the quinquennial catalogues would furnish full and satisfactory records of American publications.

Again, this general catalogue would enable purchasers of books for public libraries to consult judicionsly for the wants of the country. So poor are we in the books which scholars need; so long, at best, minst we remain in a condition of provincial dependence in literary matters, that a responsibility to the whole conntry rests upon the man who selects the books for any public library.

Another important benefit of this system is that it allows us to vary the form of the catalogue at will from the alphabetical to the classed and to modify the classification as we please. The titles, separately stereotyped, may change their order at command. If, for example, it were required to print a separate list of all books in the conntry on the subject of meteorology, it wonld be necessary merely to check off in the general catalogue the titles to be used and to hand it to the printer to do the rest of the work. 
Another great benefit of this project would be to secure uniformity in catalogues. A good degree of uniformity would be absolutely indispensable to the success of the plan. Entire uniformity is not, indeed, to be expected. Perfection is not an attribute of the works of man. But a much ligher degree of uniformity would result from this plan than could otherwise be hoped for. The rules for cataloguing must be stringent, and should meet as far as possible all difficulties of detair. Nothing, so far as can be avoided, should be left to the individual taste or judgment of the eatalogner. He should be a man of sufficient learning, accuracy, and fidelity to apply the rules. In cases of doubt reference should be made to the central establishment, to which the whole work should be submitted page by page for examination and revision. Thus we should have all our catalogues formed substantially on one plan. Now, even if the plan adopted were that of the worst of our catalogues, if all were made on the same plan this uniformity would render catalogues thus made far more useful than the present chaos of irregularities. But we hope that the best possible system may be adopted.

Another general consideration is that this project looks toward the accomplishment of that cherisherl drean of scholars-a unicrsal catalogue. If the system slould be successful in this conntry it may eventnally be so in every country of Europe. When all shall have adopted and carriech out the plan each for itself, the aggregate of the general catalogues thus formed, few in number, will embrace the whole body of literature extant, and from them it will be no impossible task to cligest and publish a universal bibliography. How nuch this would promote the progress of knowledge by showing more distinctly what has been attempted and accomplished and what yet remains to be achieved, and by thus directing the outlay of intellect aright; how much, by rebuking the rashness which rushes into authorship ignorant of what others have written and adding to the mass of books without adding to the sum of knowledge; how much by giving confidence to the true and heroic student, who fears no labor, so that it bring hin to the commanding leight at which he aims-the summit of learning in the branch to which he devotes himself; how much such a work would, in these and other ways, promote the great object we have in riew is well deserving the attention of every thoughtful mind. Upon it I may not at present longer dwell.

In Anerica alone can this systen be put into immediate operation. In every large country in Europe the arrears in cataloguing, or the mass of titles accumulated in the libraries, would rencler the first expenses of the enterprise quite startling. But here all things conspire in our favor; onr libraries are all small and mostly repetitions one of another. But they are prosperous and will rapidly increase. Their supporters are all desirous of having printed catalogues. A central adninis- 
tration is necessary. 'This can be accepted by the Smithsonian Institution, whose position is peculiarly farorable and whose funds are consecrated to such purposes. The enterprise requires no great ontlay of money, no gigantic effort. It may go noiselessly but rapidly into operation. There is nothing to prevent its inmediate usefulness.

The commissioners appointed to cxamine and report upon the project considered not only its general features bnt also its minute details. To them were submitted the rules proposed for cataloguing, which were separately discussed, and after having been varionsly annended and modified were recommended for adoption. It is not supposed that this code provides for every case that will occur. The peculiarities of books are, like the idiosyncracies of authors, innumerable. They baffle the best efforts of classification, except under general heads. The most elaborately formed laws for recording their titles would be inadequate to provide for entire uniformity or consistency. Doubts and difficulties would inevitably arise as to the application of the laws. These must, to prevent varying decisions, be submitted to one person. Hence it is important that the first part of the work, which will furnish examples for the rest, shonld be done nuder the immediate eye of the superintendent.

Easy as the operation may seem to those who have never attempted it, there is no species of literary labor so difficult or that requires linowledge so extensive and various as the cataloguing of a large library. It demands peculiar qualifications of patience and accuracy and a special education-a professional training. Eren those most expert must work slowly if they would avoid mistakes. It is therefore a great consicleration that on this plan each title once prepared is prepared for all the hbraries in which the book occurs; whereas on any other, time and thought and labor are repeated for every copy of the book.

From the favor with which the plan has been met, it can hardly be doubted that it will receive the hearty and rigorons cooperation of all the libraries in the conntry. Several are ready to begin npon their catalogues at once. For the reasons already stated, however, it is desirable to begin here. At first the work can not proceed rapidly. After the accumulation of a considerable number of titles, progress will be mucl more accelerated.

Great as this enterprise is, it will not require the ontlay of much noney on the part of the Smithsonian Institution to put it in operation, which being once done it will take care of itself. It will not be a constant drain upon our funds, but on the contrary it will ere long far more than repay in the facilities for making our own catalogne all that may at first be expended 11pon it.

Respectfully submitted.

DECEMBER $3 \mathrm{I}, 185^{\circ}$

CHAK1,AS C. JHWETT'

"Smithsonian Institution report, Thirty-first Congress, special session, March I, I85I, Senate Miscellaneous document No. I, pp. 32-4I.

$23399-04-30$ 
At the library convention, September I 5, I 853 , other points in relation to this method of cataloguing were discussed by Professor Jewett. He said:

It nuay not be aniss for me to notice one or two objections which may occur to the minds of practical printers against the use of these stereotype plates. One is that the plates, being used so of ten, will become worn; and that when new plates are inserted the difference between the new and old plates will be observable on the printed sheets.

To this objection I can say in reply, first, the number of copies required for each catalogue would be so small that it would be many years before there would be any noticeable difference between the old and new plates were they made fron common type metal; but, secondly, the material which we employ is harder than type netal and resists much longer the wear of the press. I presume that a run of 100,000 copies would not make any observable difference between the old plates and the new.

Another difficulty which may suggest itself to some is in keeping the register and preserving a uniform length of pages. The register, so far as the top and sides of the page are concerned, can be kept n1ost perfectly. Tariations in the length of the pages can not be entirely avoided. But if some pages be longer or shorter by three or four lines it is not a very serious matter. It may offend a printer's eye, but would not be noticed by the general reader. I may remark, however, that there are several ways of reducing the inequalities. Very long titles may be stereotyped in two or three pieces. The titles on a short page may be spread apart, making the matter a little more open, and thus elongating the parge. The catalogue may be printed in double-column folio. This size is preferable for a catalogue on other accounts. It presents more titles to the eye at once, and it also saves paper.

I would not be understood as insisting upon the catalogue being in folio, nor, indeed, upon its being alphabetical. These are natters not essential to the system. Each librarian can choose for himself, the system possessing this great advantage, that it is equally applicable to the folio, quarto, or octaro size, to alphabetical and to classed catalogues.

'There is one other point which n11ay be noticed. This kind of catalogne is not reconmended for all purposes for whicl a catalogue or list of hooks may be desirable. It is proposed as the standard catalogue for reference in every library containing works of permanent value. It is proposed as the basis for all other apparatus, sucl as indexes, shelf lists, "finding catalogues," or short title catalogues, which it may be thourht that the pectiliar circumstances of any library or every library require. From this catalogne all others nua casily be made. This is supposed to be in general the first and most important of all the means 
for rendering a library serviceable to all classes of persons who may consult it. ${ }^{x}$

By this process the "Snithsonian report on the construction of catalogues of libraries," i 853 , and the "Catalogue of the Library of Congress. Chapter I, Ancient listory," I 854 , were printed, as we have described above. Pending a further appropriation for the completion of the Catalogne of the Library of Congress, the workmen engaged on these two publications were employed to apply the system to the printing of the Congressional Globe. Eventually, however, this method of stereotyping proved a failure, owing to the shrinkage and warping of the material which formed the plates. ${ }^{2}$ Other methods of stereotyping might be employed, but this could be employed only in cases where the plates could be used within a limited period in the printing of different catalogues or bibliographies.

The plan of stereotyping titles separately was the basis not only of the plan of cooperative catalogning, but of all the bibliograplical plans of the Institution. The stereotyped titles which were used in printing the catalogues of different libraries night as well be nsed also in printing the bibliographies of different subjects. So a series of bibliographical works was projected and commenced by the Institution.

In the report of the Secretary of the Institution, December I3, I 849 , the plan of a Bibliographia anericana, to be con1piled by Henry Stevens, at that time America's greatest bibliographer, and published by the Sunithsonian Institution, was set forth. This was the first of the great bibliographical nudertakings of the Institution; nndertakings the failure of which caused Henry Stevens to refer to that Institution in later years as "that mighty linbo of expensive ventures."

Professor Henry said:

* * * The Sinitlisonian Institution has been the means of starting an important literary enterprise, intended to facilitate the study of the history and hiterature of onr conntry. Mr. Henry Stevens, who has been engaged for a number of years as the agent $i_{i 1}$ this conntry of the

'Norlon's Lilerary' and Educalional hegisler for 1854,1 1. 67 .

"W. IF. Poole, in Library Journal, ir: 200. 
British Museum and other European libraries, has commenced the preparation of a bibliographical work, comprising a description of all books relative to or published in America prior to the year I700, and indicating not only the contents and value of the books, but also the principal libraries in this and other countries where they are to be found. The preparation of a work of this kind will be in accordance with that part of our plan which contenplates rendering the Institution a center of bibliographical knowledge, and will have a direct influence in promoting the objects of the various historical societies which are now established in almost every State of the Union, and in bringing the Institution into friendly relations with them. A certificate has been given to Mr. Stevens to the effect that this work, if found, by a conlmission to whom it shall be referred, properly executed, will be accepted for publication as part of the Smithsonian Contributions to knowledge. Assured by this certificate that the work will be properly executed, a number of gentlemen and institutions, whose libraries will be examined and referred to, have liberally subscribed to defray the necessary expense of its preparation. With this enconragenent, Mr. Stevens has started for Europe to commence investigations in foreign libraries. ${ }^{\mathrm{r}}$

The prospectus of this work was as follows:

BIBLIOGRAPHIA AHERICANA.

A bibliographical account of the sources of early American history; comprising a description of books relating to America printed prior to the year 1700 , and of all books printed in America from 1543 to 1700 , together with notices of many of the more important unpublished manuscripts. Prepared by Henry Stevens, and published under the direction of the Smithsonian Institution at Washington.

PLAN OF' 'THE WORK.

I. It will contain a descriptive list of all books relating to America and of all books printed in America prior to the year I 700 which may be found in the principal and private libraries of Europe and America, or which are described in other works; together witl notices of many of the more inportant ninpublished manuseripts.

2. The descriptions will be nuade, as far as possible, from an examination of the books themselves. If any be taken from other sources of information they will be distinguished by some peculiar mark.

3. The titles, including the inprint or colophon, will in all cases be given in finl, word for word, and letter for letter.

4. 'The collation of each book will be given; that is, such a descripLion as will indicate a perfect copy.

'Third ammal report of the Smithsonian Institution, Thirtieth Congress, second session, Miscellaneous documents, No. $45, \Gamma .17$. 
5. The market value of the books, with the prices at which they have been sold at public sales, will, whenever possible, be givun.

6. Different editions and varions translations of the principal works will be diligently compared with each other, and their variations and relative merits pointed ont, especially of sucl works as the collections of royages and travels by De Bry, Hulsius, Ramusius, Hakluyt, Purchas, Thévenot, etc.; the corresponding parts of which will be compared, not only with each other, but with the editions of the works from which they were translated, abridged, or reprinted.

7. Bibliograplical notes will be appended when deemed necessary, containing abstracts of the contents of the works when the titles fail to give a proper idea of then; aneclotes of authors, printers, engravers, etc.; important items of historical and geographical information; notices of peculiarities of copies, as large paper, vellum, cancelled leaves, etc.; the number of copies printed, together with the comparative rarity and intrinsic value of the works.

8. The notes upon the books printed in America will comprise a full history of the origin and progress of printing in North and South America from the year 1543 to 1700 .

9. Under the title of every work will be designated one or more libraries in which it may be found.

IO. The titles will be arranged alphabetically under the names of the atithors or the leading word of the title.

I . The work will contain a full introductory memoir upon the materials of early American history, together with an account of the principal collections of them which have been made in Europe and Anerica.

I2. Three indexes to the contents of the work will be griven, viz: I, a chronological index, in which the titles will be arranged according to the years in which the works were printed; 2, an inclex of the subjects treated in the books; 3, an alphabetical index of the persons and subjects mentioned in the notes and introductory nenoir.

PREPARATION OF THF, WORK FOR 'THE, PRESS.

I. The expense of preparing the work for the press will be defrayed by subscription.

2. It is estimated that the work will contain not less than five thousand titles, which are to be obtained fronl the public and private libraries of Iingland, Ireland, Scotland, France, Cermany, Denmark, Sweden, IIolland, Belginm, Italy, Anerica, Spain, etc. It is obvious that if any single individual possessed the reguisite knowledge of languages and bibliography for this task it would recuire of him several years of muremitting toil. In order, therefore, to accomplish the labor within a reasonable period it will be necessiry to employ upon it several persons. These should be learned and responsible men. Such men can not be enployed unless their services be well reduited. Besides this, the whole work 
must be superintended and revised by Mr. Stevens himself, who, for this purpose will be subjected to heavy traveling and other expenses. It is estinlated that the necessary expenses attending the preparation of the work for the press, to say nothing of Mr. Sterens's own time and services, will amount to $\$ 5$, ooo (or $£ \mathrm{I}, 000$ ). The work will not therefore be commenced until this sum is subscribed.

3. Any public institution or any individual possessing books of this class may join in the subscription on the following conditions, viz:

(I) That all the books of this class belonging to each subscriber be submitted to the inspection of Mr. Stevens and all reasonable facilities and assistance be afforded him in his work.

(2) That the name of the subscriber be indicated under the title of every book which he contributes, so that when the work is completed it will show not only the treasures but also the deficiencies in this department of the library of each subscriber and enable hin by marginal marks against the titles of books which he may subsequently procure to preserve a perpetual record of his collection and of its deficiencies.

(3) That each subscriber be entitled to contribute not only the title of every book of this class which he may possess at the tine of subscribing, but also of all other books of this class which he may procure for his own library previously to January, 1850 , or before the work shall go to the press.

(4) That the sum subscribed by each be in proportion to the number of titles contributed, or be such as Mr. Stevens may accept.

(5) That this sum be paid to Mr. Stevens on the acceptance of the manuscript for publication by the Smithsonian Institution.

(6) That each stusscriber be entitled to receive from the Sulithsonian Institution ten copies of the work for every $\$ 500$ (or $\mathcal{E} \mathrm{I} 00$ ) subscribed, and in the same proportion for a larger or smaller subscription.

4. Inasmuch as the library of the British Museum contains a larger number of this class of books than any other library in the world, and at the same time affords extraordinary facilities for bibliographical research, it is proposed to commence the work there. All the titles which this library can furnish will be written ont upon cards made for the purpose, measuring about 8 inches by 6 . When these have been carefully revised and copied they will, if it be desired, be sent in small parcels to each of the subscribers for their inspection and remarks. When the work is completed, so far as the library of the British Musenm can furnish the materials, Mr. Stevens will himself visit each of the other libraries for which he will have received subscriptions, comparing and revising the titles, and adding such other books as he may find which lad not been previously described.

5. It is hoped that sufficient force can be arlvantageously employed upon the work to prepare it for the press in eighteen months. 

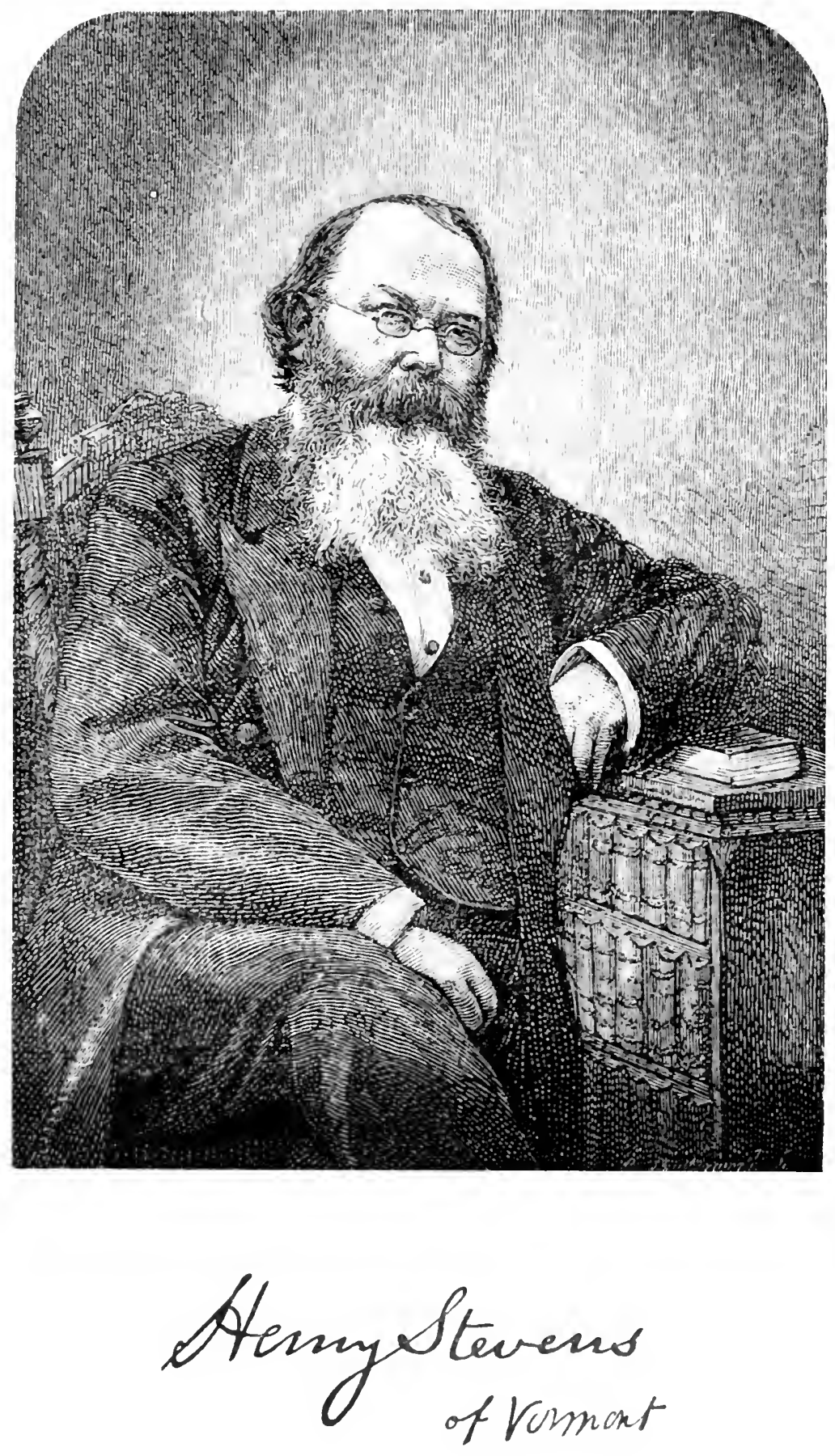


\section{•}


When the manuscript of the work shall have been completed, according to the plan detailed above, it is to be delivered to the Secretary of the Snithsonian Institution at Washington, who will, in accordance with the rules of the Institution, as published in the Programme of Organization of December sth, I $8+7$, submit it to a commission of competent judges. If the commission report favorably as to the faithful execution of the work, it is to be published and distributed at the sole expense of the Smithsonian Institution, constituting one or more volumes of the quarto series of Smithsonian Contributions to knowledge, similar in form and style of execution to the first volume about to be published. It will be uniform with the quarto edition of the United States Iixploring expedition. ${ }^{x}$

In the preparation of this work Henry Stevens worked along two lines; first, the description of the Anericana which passed through his hands as a bookseller, and, second, the description of the Americana in the British Musenm. In connection with the first he undertook the publication of a monthly periodical entitled Stevens's American Bibliographer, the purpose of which he explained as follow's: " $\mathrm{My}$ object in issuing this periodical is to 'book' materials for my Bibliographia americana, and to receive the cooperation of librarians and bibliographers in the examination and collation of rare books relating to America. I have advanced sufficiently far in my Bibliographia anericana to know that it is perfectly impossible to prepare the copy in manuscript with sufficient accuracy to print from at a time and place when and where the rare book described can not be referred to. I therefore in this periodical shall print the titles of each work in full, and correct the proofs from the books theniselves as they pass through my hands or are found in the library of the British Museun or elsewhere. Brief collations of each work will be given, with notes, illustrations, ete. Wishing not to interfere with the Bibliographia americana, I limit the number of subscribers positively to 75 , and hope that I may be fortunate enough to secure as subscribers in the United States 50 librarians and bibliographers who will be kind enough to point out to me such

\footnotetext{
'Third anntual report of the Board of Regents, Snithsonian Institution, 'Phirtieth Congress, second session, Miscellancous No. 4S, 1'1. 55-57.
} 
inaccuracies and variations as they may detect in comparing n11y titles and observations with their own. Price $3 \mathrm{~s}$. 6d. per number, or \$IO a year." "

The first numuber of this periodical was issued January 5, I 854 , but only two numbers seem to have been published.

After abandoning the periodical Henry Stevens planned to print the bibliograplical notes which he collected in a series of contributions to the Bibliograplia anericana, to be entitled "Historical nuggets." In this preliminary work he planned to include nothing which could be as well printed for the first time in the larger work; in other words, it was to embrace only such book rarities as it would be difficult to describe with exactness from any single copy. The series was to be conlpleted in ten volumes, volume ro to contain the index. In I 857 the first two volumes, including 3,000 titles, were printed, ${ }^{2}$ and by 1862 considerable progress had been made with three more volumes, including 4,500 titles, but no more volunes were published, and as the periodical ended with the second number, so the series ended with the second volune.

In his second and less onerous line of investigation, his examination and description of the Americana in the British Museum, Mr. Stevens was hardly more successful.

In I 856 he published a "Catalogne of American books in the library of the British Museu111." This was complete at the date of its publication, and Stevens intended to keep it complete and reissue it from time to time, but was nnable to do so.

The "Nuggets" and the "Catalogue," which were thus to supplenent each other and together form a collection of material for the Bibliographia americana, having failed, the project of the Bibliographia americana itself was given up.

The history of the other bibliographical undertakings of the Institntion was sinilar.

In Decenber, I 852, a "Bibliographia americana historiconaturalis, or Bibliography of American natural history for the year I $8_{5}$ I," by Charles Girard ( 64 pp., $8^{\circ}$ ), was published, but the publication was not continned. In January,

'Vorton's Lilerary' Cazctte 3: 214, December 15, 1953.

"They were not published until 1862 . 
I 853 , the librarian reported that the catalogue of bibliographical works in the library would shortly be put to press, that the list of periodical publications received by the library was nearly finished, and that a bibliography of education was expected to be finished during the year i 853 . But of these only the second was published, the failure of the bibliograplical undertakings of the Institution being consequent upon the defeat of the library plan.

I)EFEA'T OF THE, I,IHRARY PI,AN.

The modus atiendi established by the compromise resolutions adopted Jannary 26, IS47, was nusatisfactory to both parties, and both recognized that they had effected a temporary solution of the problem only. It was, therefore, necessary for Librarian Jewett to carry on within the Snithsonian Institution the library propaganda which Senator Choate and Representative Marsh had undertaken in the halls of Congress, and keep the library pian to the front by extended dissertations in his annual reports upon the value and necessity of a national library.

In his first report, presented December I3, I $S_{4} S$, Librarian Jeweet, in describing the work preparatory for his "Notices of public libraries in the United States of America," dwelt upon this subject at length. He said:

I regret that the answers to the queries have not all been received, so that I an unable at present to ofier a full report respecting them. 'The most important statistics have, however, been obtained. 'These are presented in an accomparying document. I beg leave here to offer some important deductions from the facts contained in this paper.

The aggregate number of volumes in the public libraries of the United States is about 1,294,000. These are distributed anong 182 libraries. Forty-three of these libraries contain over 10,000 volumes eacli; nine over 20,000 cach, and only two 50,000. The library of Harvard University, the largest this side the Atlantic, contains, together with the libraries of the law school and the divinity school, nipward of zo,000 volumes.

These statenents enable us to institute an instructive conparison between our libraries and those of the principal 11ations of Isurope. It slould be prenised, however, that it is a very dificult thing to procure exact statistics of libraries. With reference to I'rance, (iermany, Isetgium, Russia, and spain we are in posiession of conparatively aceurate 
returns. Witl respect to Great Britain, Holland, Sweden, Denmark, and Norway those which I give below are as accurate as I could procure, though certainly not very satisfactory. I an1 not acquainted with any book which gives a good account of the present condition of libraries in several of these conntries, except one, to which I have not had access. For greater convenience of reference and comparison, I present these statistics in a tabular form.

The first column of the table gives the name of the conntry.

The second, the year to which the statistics relate.

The third, the number of public libraries. By public libraries are not meant those exclusively which are opened to the public without restriction, but rather those belonging to public institutions, and which are accessible under proper regulations to persons who wish to consult them for literary purposes.

The fourth column contains the aggregate number of volumes in the libraries.

The fifth gives the number of libraries containing over io, ooo volumes each.

The sixth, the average number of volumes in libraries containing over Io, ooo volumes each.

The seventh, the number of volumes in the largest library of each country.

The eighth, the number of volumes to every million of inhabitants.

Comparative statistics of libraries in Germany, France, Great Britain, Russia, United States of America, Denmark, Belgium, Szeden, Spain, and Norway.

\begin{tabular}{|c|c|c|c|c|c|c|c|c|c|c|}
\hline & & & & 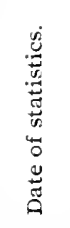 & 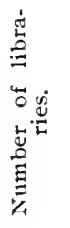 & 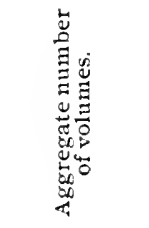 & 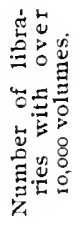 & 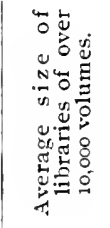 & 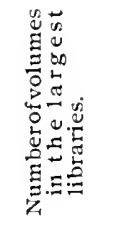 & 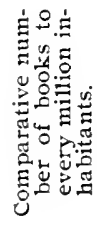 \\
\hline \multicolumn{11}{|c|}{$\begin{array}{l}\text { Germany, including } \\
\text { Austria and Switzer- }\end{array}$} \\
\hline land & & . & . & 1845 & 103 & $5,578,980$ & 68 & So,, 00 & 600,000 & 136,072 \\
\hline France & & & & 1844 & $24 \mathrm{I}$ & $4,771,000$ & I $2 \mathrm{I}$ & 35,000 & Soo, 000 & 145,000 \\
\hline Great Bri & ain & & ${ }^{\circ}$ & 1840 & $3 I$ & $2,001,000$ & 23 & 85,000 & 420,000 & $8_{3}, 000$ \\
\hline Russia & & & . & 1843 & 120 & $I, 321$, I I 5 & 16 & 69,000 & 464,000 & $2 S, 000$ \\
\hline UnitedSt & iteso & $\mathrm{f}_{\mathrm{I}}$ & nerica & I 847 & 182 & I, 294, 000 & 43 & 17,000 & 70,000 & 64,000 \\
\hline Demlnark & 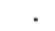 & . & . . & IS40 & 13 & 660,000 & 5 & 123,000 & 400,000 & 330,000 \\
\hline Belginn & . & . & . . & $184 \mathrm{I}$ & 31 & 614,722 & 16 & 35,000 & 100,000 & 153,000 \\
\hline Sweden & . & . & . . & $184 \mathrm{I}$ & 16 & 358 , o00 & 7 & 43 , o00 & I50, 000 & I 20,000 \\
\hline Spain. & 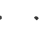 & . & . . & 1835 & 21 & 354,557 & 5 & 57,000 & 200,000 & 30,000 \\
\hline Norway & 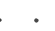 & . & 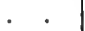 & I 842 & 14 & $\therefore 57,783$ & 2 & 74,000 & I 26,000 & I 50,000 \\
\hline
\end{tabular}

This table enables us to estimate at a glance, and witl a good degree of accuracy, the relative value of the public provisions made in Europe and Anerica for general intellectual culture, as well as of those for the most extensive scientific and literary research. 
It will be seen that in the number of public libraries France is the only country in the world that excels us. It should be observed that the returns respecting France are official and minute, inclucling libraries of not more than 500 volumes. Many of our public schools, however, possess libraries larger than these, but they are not enumerated in our lists. If they were, they would swell the number of American libraries far beyond that of any other cominty in the world.

In the aggregate number of volumes in the public libraries Germany, France, Great Britain, and Russia are before us. Were all the districtschool libraries and village collections in the United States included in the estinnate, we should probably take fourth rank.

In the aierage size of libraries containing over ten thousand aolumes we are the last of all.

In the size of the largest library' we also stand last of all.

In the number of columes, compared with the population, we rank below all but Russia and Spain.

These results show that in public provisions for the general diffusion of knowledge by means of libraries, we stand in the rery first rank among the nations; and when we consider the cheapness of our publications and the vast number of them scattered over the land, with the extent of our periodical literature, we may justly and prondly challenge a comparison with any nation in the world for the means of general culture. This, certaiuly, is much for a country so new, whose clief energies have, as a matter of necessity, beeu directed to the felling of forests, the clearing of lands, and the support of plyysical life. It shows, as well remarked by a foreign writer, "that the man who, with steady and rigorous hand, have known how to rule themselves and be completely free, have well discerned the fonndations upon which alone the weal of a free State can safely repose."

But this cleduction, so full of encouragement, so fraught with matter for gratulation and pride, must be followed by others of a different character.

The statistics given indicate that while no conntry in the world lias done so much for diffusing knowledge, none has done so little toward furnishing the means which public libraries can supply for its increase. It was cloubtless the first duty of the infant republic to provide that all should know something, that the mass of the people should be elevated and enlightened. It lias now become her duty to see to it that no bounds are placed to the culture that each may obtain if he chooses. Now, in the lour of her strength, she onght to provide for her citizens the means of as high eulture, of as profonnd research, of as noble advances in science, literature, and art as are enjoyed by the eitizens of any other nation in the world. Slue should take care that while the poor man's son may obtain that clementary education which will enable him to perform the duties of a good and intelligent citizen, he be not, by his porerty, debarred from the higher walks of seience and 
literature; that there be no monopoly of learning by the rich-by those who are able to study at the institutions of Europe, or to surround themselres by the books which they need at home. Our condition in these respects has been deeply lanented by our scholars. At various times strong efforts have been made for its improvement. At length the munificent bequest of a foreigner, placed at the disposal of Congress, furnished the means of meeting this, among other demands of science and letters. In the act of Congress establishing the Smithsonian Institution, and in the acts of the Board of Regents for the organization of the same, a large public library forms a prominent feature.

It has been supposed by some, not acquainted with researches requiring many books, that very large libraries are superfluous. They calculate, perliaps, how many books a man can read in a long life, and ask what can be the use of more. Nay, even many men fond of reading feel like an English writer of some note who describes his pain as amounting to "midsummer madness" when he entered a large library and reflected how snall a number of all the books it contained he could read through.

"In my yonthful days," says De Quincey, "I never entered a great library, say of 100,000 volumes, but my predominant feeling was one of pain and distmrbance of mind, not much unlike that which drew tears from Xerxes, on reviewing his immense army, and reflecting that in one hundred years no one soul would remain alive. To me, with respect to the books, the same effect would be brought about by my death. Here, said I, are 100,000 books, the worst of them capable of giving me some pleasure and instruction, and before I can have time to extract the honey from one-twentieth of this hive, in all likelihood I shall be summoned away.

"Now I have been told by an eminent English author, that with respect to one single work, viz, the History of Thuanus, a calculation has been made by a Portuguese monk, which showed that barely to read over the works, and allowing no time for reflection, would require three years labor at the rate of, I think, three hours a day. Further, I had myself ascertained that to read a duodecimo volume in prose of too pages, all skipping being barred, and the rapid reading which belongs to the vulgar interest of a novel, was a very sufficient work for one day. Consequently 365 per anmum, that is with a very small allowance for the claims of life on one's own account and on that of one's friends, I, ooo for every triennium, that is 10,000 in thirty years, will be as much as a man who lives for that only can hope to accomplish. From the age of 20 to 80 , the utmost he could hope to travel through would be 20,000 volumes, a number not, perliaps, above 5 per cent of what the mere current literature of linrope would accumulate in that period of years."

Now, supposing for a moment that there were no other use to be made of books but the reading of them through at so many pages the hour, one would think it might have occurred to this writer that there are 
among the frequenters of a large library a great variety of 111en, with a wide diversity of interests, tastes, and pursuits; that thongh each might not be able to read through more than 2,000 books-one-tenth of the supposed number-still 50 men, whose reading was in different directions, might call for 100,000 .

But apart from this consideration and above it is another of far more importance to the scholar. It is that this view of the use to be made of a large collection of books is fonncled upon an utter misapprehension of the relation of books and libraries to learning.

There are three uses to be made of books by those who understand their value.

The first is for reading. This, paradoxical as the assertion may somnd, is the least important of their uses. By reading. I mean cursory perusal, such as the writer above quoted describes. Reading as a pastime, reading for the acquiring of general information, reading as a means of refining and cultivating the tastes is, indeed, indispensable to every welleducated man. And the means of such reading in this country are largely supplied by our circulating libraries, athenæums, book auctions, and cheap publications. But the scholar has need of books for other and ligher purposes.

A second important use of books is for study. By study, I mean that vigorous mental application which is necessary in order to fully comprehend, weigl, analyze, and appropriate the thoughts, facts, and arguments of an author. It is study which disciplines the mind, which trains the intellect for the rapid accumulation and appropriate use of knowledge. It is study which gives education, which derelops the faculties. But it is evident that for study one needs even fewer books, if they be rightly chosen, than for reading.

The third 11se to be made of books is for reference.

Every man has occasion to refer to a dictionary or an encyclopedia. Yet who ever undertakes to read one through? Everyone accustomed to composition sometimes has occasion to trace the history and meaning of a word. "There are cases," says Coleridge, "in whicl more knowledge of more value may be conveyed by the history of a word than the history of a campaign." Bnt to learn the history or usage of a single word we may be compelled to look into five, twenty, or fifty dictionaries in different languages.

Now, the use of books by sclolars is in general analogous to the wise of a dictionary by any intelligent man. There are sone sciences which scem to require less the aid of libraries than others. It may eren be true that some important discoveries have been the result of mere accident. But such is not the general rule. The progress of science is not fortuitons. Natnre does not often disclose her treasnres upon a blundering invitation. She must be diligently sought. ile who would make valuable discoveries must, as a general thing, prepare himself by a thorough 
acquaintance with the present condition and tendencies of the science which he cultivates.

He must do more, much more. "Of every branch of the two great stibdivisions of human learuing" (viz, science and literature), says an able writer, "its history is a constituent part, absolutaly necessary to all who would be competent to form just opinions on its present state.' He must know the past in order to appreciate the present, and in order to lieip shape the future. He must not only be able to place himself on the line of demarcation between the nnknown and the known, but if he wonld penetrate the darkness of the former, he must have gained his direction by a careful tracing ont of the analogies of the latter. Consequently he must give himself to long-continued, patient, laborious study of the history of science.

Moreover it is not only necessary to study that science which one wishes to eularge by his discoveries; he must be familiar with the subjects which are allied to it. But where can we find the limits of any science? All knowledge is bound together by an indissoluble, though sometimes an invisible bond. He who is versed in but one department of science, and is entirely ignorant of others, can not be said to be thoroughly acquainted with any. In the words of the writer already quoted, "If the books could be arranged in order of relevancy, witl respect, say, to natural science, from the one which is most essential to it down to the one which is least essential to it, there would be no perceptible break anywhere, no point at which natural history ends and other knowledge begins." What, then, must he who would clevote himself to the enlargement of one department of knowledge wait ere he commences till he has mastered all? By no means; such is not the inference. The legitimate conclusion from the argument is that no thorough student in any one department of knowledge can safely say that he nnay not need io,ooo or even 50,000 books, and many of them of a character at first sight most remote from his path, not indeed for the purpose of reading or of studying them, but in order to settle, by momentary references, questions which may arise, the settling of which may be of the greatest importance to his progress.

If this be true with respect to those sciences where there is the least apparent want of books, mucl more so is it of those whose deductions are drawn from researches among the records of the past. 'The demands of the statesman, the jurist, the political economist, the historian, can not be met without furnishing the naterials for the widest investigation, nor always, indeed, those of the novelist or the poet. I lave sometines heard it said that the knowledge of the middle ages to be gained from one of the novels of Sir Walter Scott is far more valuable than that to be acquired from the perusal of a library of dusty tontes. But who that has ever lived was a more constant delver anidst the dusty lore of the past, in old libraries, among worm-eaten books, than the illustrious 
author of these volumes. He could not otherwise have produced thenn. Without the large libraries we conld not have had the enchanting romance.

If it be asked whether the libraries which we already possess are not sufficient to meet this demand, we reply, in the first place, that the large libraries of Europe, containing from 200,000 to 800,000 volumes, some of then selected with great care, have not been found large enough to meet the wants of her scholars, and we nay not allow that our conntrynnen are less fond of learning, less thorough and profound in their investigations, when they have the means of pursuing them, than their transatlantic brethren.

It may, however, justly be supposed that the number of volumes is a very inadequate criterion of the value of a library; that a judicious selection nua do much to compensate for numerical inferiority, and, consequently, that our libraries, although smaller, may be more useful to learning than the larger collections of Europe. This may be sufficiently answered by applying another and the most satisfactory method of testing the real value of our libraries, which is to take some works of acknowledged learning and importance and inquire what books were necessary for their composition, and how many of them our public libraries can furnish? 'This process, it will be seen, is a tedious one. I have, however, pursued it in reference to a considerable number of books on a variety of subjects. Some of the results thus obtained nuy be stated in a few words, and they are fair specimens of all the others.

In Mr. Wheaton's History of international law-a production which reflects great credit upon American talent and scholarship, and which procured for its lamented author the honor of election to the French Institute-i 39 works are referred to in the notes. A nuch larger number were, of course, consulted, many of which are mentioned in the body of the work. Thirty-nine among the most important and expensive of those which are formally cited, are not to be fonnd in the largest law libraries in the United States. More than one-half of the renainder are common books, to be found in any well-selected general library of 5,000 volumes. This work was written in Europe. It could not have been written in this country from the materials contained in our public libraries.

If we take a book of a different kind, demanding for its connosition a thorough knowledge of the history of one of the physical sciences, and, consequently, requiring the assistance of authorities less accessible and of less general importance, the result will be all the more striking.

In the first rolume of Hoefer's History of chenistry, 251 works are referred to. Of these, about 50 are common books, to be fomd in almost any library of 5,000 volumes. Of the remaining 191 I can not find 75 in all of our public libraries.

The plan of our institution contemplates the publication of a series of 
reports on the condition and progress of various branches of knowledge, prepared by collaborators who are to be furnished with all the journals, domestic and foreign, necessary to aid them in their labors. Such reports, if properly prepared, will be very useful. We need merely refer, for illustration, to those published by the Swedish Acadeny. But the preparation of them will require the purchase of a great number of books which are not at present to be found in our public libraries. This will be made manifest by a few facts. Of $3^{3}$ publications, mostly periodica! , referred to in a late report of Berzelius on the progress of chemistry, I can find but 13 in our public libraries.

Mr. J. R. Bartlett informs me that of 204 works which he refers to in his report on the progress of ethnology, 129 are not to be found in the public libraries of New York, nor in any others probably in the United States. The cost of the books which, in order to prepare his work, he had to procure at his own expense was $\$ \mathrm{I}, 000$. And yet this report is only a pamphlet of I 5 I pages.

From these facts it is manifest that there is no exagreration in the language of one of the members of our Board of Regents from South Carolina, who, in a report to the Senlate in I $8_{3} 6$, stated that "our whole body of literature, if collected in one place, would not afford the means of investigating one point of science or literature through all, or even a considerable portion, of what has been written on it." "Here," he adds, "where the foundations of govermment repose on the aggregate intelligence of the citizens, the assistance afforded by public institutions to the exertions of intellect is but one-tenth of that within the reach of the mind of civilized Europe."

The complaints of our scholars testify to our deficiency. Their wants have weighed heavily upon them. They have repressed genius. They have condemned to oblivion names that would have rivalled the brightest in the history of science and letters. I might mention, it is true, Americans who have ranked among the most learned of the world. But they, like others less renowned, have had sorrowful experiences of the deficiency of which we complain. They, however, in nost instances, have, from their own private wealth, supplied the clefects of public provisions. Had they been poor, they would not generally lave been the anthors they were. 'They could not have had access to the necessary books had they not possessed the wealth for buying them or for crossing the Atlantic to consult them where they were already accumulated. The pages of our literary journals, the cloquent speeches elicited in Congress by the bills to establish the Snithsonian Institution, and the united voices of the friends of good letters throughout the land bear sad and nnvarying testinony to our deficiencies.

Now, to supply these wants, or, in other words, to place American students on a footing with those of the most farored country of Finrope, is the design of the Smithsonian library. 
In his second report, presented July 29, I850, Professor Jewett returned to the subject:

Our institutions [said he] are founded upon the intelligence of the many; not upon the power or wealth or learning of the fcw. The diffusion of knowledge is our safeguard. The common school, the village library, the cheap free press are the supports, the guaranties, the champions of liberty. We shall never be found pleading for anything that interferes with these or abridges their usefulness. It is rather in their interest that we ask for the means of the highest literary acquisitions. The stream can not rise higher than the fountain; if the source be not well supplied, the river fails. Teachers must have the facilities for learning; and as the standard of education is raised, higher attaimments are demanded from teachers-attainments which can not at present be made in this country by the aid of our public institutions. I use the word "teachers" in its widest acceptation, including all who attempt to instruct the public. It is in the appliances for thorough study, for original research, for independent investigation, that we are deficient. If a studious and reflecting American desires to review the history of the world, or some portion of it, from his American position, unless he be able to expend thousands of dollars in the purchase of books, he must abandon his design, for he can not procure them from our public collections.

There has recently appeared from the American press, written by an American scholar, one of the most comprehensive, profound, and elegant works which has ever been published in the department of literary. history. We receive it with patriotic pride. But this work could be written in this country only by one who was able to procure for himself the necessary literary apparatus. The library of the author contains some 13,000 volumes, and in the department of Spanish literature is one of the richest in the world. Our object is to provide that cvery man in America, though he be poor, whose mind kindles witl a great theme, may be able to pursue it and enrich our national literature with the results of original investigations. It is sometimes said in reply that if anyone desires books not already to be found he may order them from Europe and receive them in six weeks or two months. But the scholar may be, and gencrally is, poor. If not, he can not from the outset foresee the extent of the field over which he nust range, the side paths which he must trace out in order to settle the true route; he will thus be subject to great delay in ascertaining and collecting his materials. But the ordering of books is a very different matter from what is generally supposed. If the book be a new one, still in the market, it may be received within a few weeks; but if, as is the case with two-thirds or perhaps nine-tenths of the books which may be needed, it be an old work, and only to be fonnd at long intervals and by diligent search, the 
case is very different. His order will be answered only by the plirase, "out of print." He may order again and receive for reply, "can not be obtained." This will be his experience till he devotes years to gathering his materials, or till, discouraged by his ill success, he abandons his desimn and sinks down to be a mere copyist and compiler; to take his opinions at secondhand, from perhaps superficial and prejudiced writers, the only ones to whom he can gain access. We are thus, as a nation, conclemned to literary dependence if not imbecility.

The Government and the educated men of every State in Europe have felt the importance of having at least one library in each country where the materials for thorough scholarship should be garnered and opened to the studious, yet no nation in Europe is in a situation so much demanding such a collection as ourselves. If Roscoe could not obtain, as has been stated, in England the books which he wanted for writing the history of Leo $\mathrm{X}$, it was comparatively easy for him to cross the cliannel and consult larger collections on the Continent; but for our authors a voyage of sereral thousand miles and the expense of a residence abroad are almost insurmountable barriers to literary exertion.

* * * Books, as Voltaire has well said, rule the whole civilized world. But so rapid has been of late years the multiplication of them that few scholars indeed can procure, by their own private resources, all that they need for their investigations. Yet, with the multiplication of books, has increased the number which it is necessary for everyone to consult who would not be behind the age in his learning. Hence public libraries have become an indispensable requisite to the attainment of liberal scholarship. ${ }^{x}$

And at the library convention in New York, September I6, I 853 , Professor Jewett said: "A great central library is an important national object; as necessary to secure the literary independence of this people as was the war of the Revolution to secure its political independence. It is an object which, besides attracting donations and bequests from the rich, will receive appropriations from our national Treasury."

In these views Professor Jewett was supported by students and librarians throughout the country. Norton's Literary Gasette (February I 5, I 852), said: "The Smithsonian library is destined, we hope, to meet that great want of American scholarship, a national library for reference and research." The national convention of librarians and bibliographers, which met in New York, September I 5-I 7, i $853-$

'Smithsonian Institution report, July 29, 1S50, pp. 40-42; Thirty-first Congress, first session, Senate miscellaneous documents, No, r 20. 
Resolicd, That the thanks of this convention be presented to the Board of Regrents and officers of the Snithsonian Institution for their steady and cffective efforts for the increase and diffusion of knowledge among men, and particularly for the measures which they have adopted for the encouragement and promotion of the public libraries of our cotuntry, and we have great pleasure in looking to that Institntion as the central establishment of the United States for the furtherance of all such object.. $* * *$

Risolicd, That the establishment of a great central library for reference and research, while it is demanded by the condition of the United States as to general civilization and intellectual advancement, is especially interesting to this convention from the learing it would have upon libraries throughout the country.

Resolicd, That we deem such an establishment as being eninently worthy of support from the national Treasury, and that in no way can the Government better promote the progress of learning through the whole country than by placing a central national library under the administration of the Smithsonian Institution. ${ }^{1}$

And George Livermore, in the North Amcrican Review for July, I 850 , said:

Alluding to our attainments in literature and science in comparison with those of other nations of our age, Mr. Justice Story, in an address before the Phi Beta Kappa Society at Cambridge, a few years since. made the following remarks:

"We have no reason to blush for what we have been or what we are. But we shall have much to blush for if, when the highest attainments of the human intellect are within our reach, we surrender ourselves to an obstinate indifference or shallow mediocrity; if, in our literary career, we are content to rank behind the meanest principality of Europe. Let us not waste our time in secking for apologies for our ignorance where it exists or in framing excuses to conceal it. I, et our short reply to all such suggestions be, like the answer of a noble youth on another occasion, that we know the fact and are every day getting the better of it."

The orator then ventures to mention one of our greatest national deficiencies and says: "There is not, pcrha,s, a single library in America sufficiently copious to have enabled Gibbon to have verified the authorities for his immortal History of the decline and fall of the Roman Eimpire."

Notwithstanding his prefatory remarks and the qualifying terms in which he stated this fact, it was received with surprise and some doubt by a large portion of his audience. Nearly all his learers thought it a bold statement to be made so near to the vast bibliographical treasures of

\footnotetext{
'Smithsonian Institution report, August 1, 1854, p. 29; Thirty-thind congress, first session, House Miscellaneous Locument No. 97.
} 
Harrard College. It was even hinted that the orator had been probably seeking in vain for sonne ancient black-letter law book from the press of Richard Pynson, and drawn his general conclusions from his particular disappointment. But had the distingnished jurist been as learned in bibliothecal as in legal lore, had he and his andience been as thoroughly faniliar with the actual condition and wants of our public libraries as they were in general inpressed with the importance of stren110ns efforts on the part of men of literature and science to raise our relative rank with other nations in these respects, he would have presented a much stronger case without danger of exciting surprise or doubt. It would not have been necessary to have cited so distinguished an author as Gibbon nor so claborate and learned a work as his matchless history. Onr own neigliborhood wonkl furnish many instances where research has been abandoned in despair on account of the meagerness of materials for pursuing the necessary investigations. We do not hesitate to say that not one, nor all the libraries in this conntry combined, wonld furnish sufficient materials for writing a complete history of that little book of three or four score pages which has had such a mighty influence in molding the character and creed of former generations, "The New England primer."

With respect to Gibbon, it might have been said with equal truth that probably not all the libraries in Great Britain, and perhaps no single library in the world, was sufficiently copious to have supplied lim with the anthorities for his work. According to his own published statement he was obliged to collect and purchase for his own use the extensive and valuable works which form the basis of his history. So in our own conntry, such writers as Irving, Sparks. Prescott, and Bancroft have been obliged to visit Europe to collect materials for their histories, or at a great expense to import the works which ought to have been freely furnished to them from our public libraries. It was only by visiting Spain and collecting at his own cost one of the best libraries of Spanish literature anywhere to be found that Mr. Ticknor was enabled to avail himself of the materials necessary for writing his invaluable work. If either of the above-named distinguished authors had been less favorcd in their means the world would not have enjoyed the results of their studies. Is it strange, then, that our country has not produced a larger number of eminent and thorongh scholars? The pursuits of literature are at present too expensive for any but fortune's favorites to engage in them with success.

It would be difficult to name a subject of equal importance that has heretofore received so little attention, or a want equally pressing which has been so inadequately supplied, as that of large and well-selected libraries. We wonld not be understood as intimating that there has been a designed neglect or unwillingness to furnish the means for the highest intellectual culture and for the most thorough literary and scientific investigations. On the contrary, we have the fullest faith that 
it is only necessary to have the deficiencies in these respects made known in order that they may be soon supplied. Indeed, the paramount importance of large, well-furnished libraries, easily accessible to students and others, has never been denied. The reason why we have to lanent their present great deficiencies is the mistaken notion as to what may properly he said to constitute a satisfactory collection.

We suppose that the opinion pretty extensively prevails that, as far as this country and Europe are concerned, the present condition of these institutions may be regarded with unalloyed satisfaction. We often hear the libraries of Harvard, Yale, and Brown universities, with those in the cities of Boston, New York, and Philadelphia, allnded to in terms which show very evidently that, in the estimate of the public, there is no cause for complaint on account of their present condition. According to the common belief, these larger collections contain nearly every worl worth preserving in the various departments of literature and science. If a scliolar desires thoroughly to investigate any subject, he has only to resort thither to find all that has ever been published by his predecessors in the same departments, and all that is necessary to aid him in his purstits. Certainly these large collections-from 30,000 to 60,000 volumes-must contain all that any scholar can ever need. But if, perchance, a case should arise in which a rare work is needed for reference, and is not to be fonnd in the comntry, a visit to the British Musenm, where there are nearly half a miflion of volumes, or to the national library at Paris, with twice that number, will supply all deficiencies.

A single fact, selected from a multitude of a similar character which have come to our knowledge, will be sufficient to show the error of such a conclusion. Within a few months an English writer has published the following statement in the London Athencum: "In the progress of a late historical inquiry I covered a sheet of paper with notes and questions that could be solved only by reference to contemporary tracts and pamphlets. On risiting the Museum it was found that not 5 per cent of what I wanted were contained in that great national collection." Now, it must be acknowledged that the library of the British Museum contains one of the most complete collections of historical works to be found in any country, and it is known to be particularly rich in books and pamphlets relative to the history of Great Britain. Yet the writer whon we have quoted fincls cause to regret its great incompleteness in that department. We presmue a similar, perhaps a greater, deficiency would be fonnd in nearly every other department. Nor is this the fault of those to whom the duty of purchasing the books is intrusted. Considering the multiplicity and variety of objects that claim their attention, and the inadequate means afforded them, it is wonderful that so muel has been accomplished in stuplying the wants of different classes of readers and scholars. 
The popular error that only the best books and on the most important subjects are worth preserving has done much to retard the establishment and growtl of large libraries in this country. When a person unaccustomed to the use or sight of many books enters for the first time a large library, he is very likely to utter an exclanation of astonishment at the vastness - the unnecessary extent-of the collection, and to make the wondering inquiry whether anybody is expected to read all the volumes, as if all books that are worth preserving are therefore to be read through! It has been weil said that a national library should contain all those works which are too costly, too voluminous, or of too little value in the common estimation to be found elsewhere, down even to the smallest tracts. An old almanac or a forgotten pamphlet has sometimes enabled the historian to verify or correct some important point which would otherwise have remained in dispute. ${ }^{\mathrm{T}}$

Secretary Henry and his followers, however, felt that there could be a bibliographical bureau at the Institution without a library. In lis report for $I_{5} I$ he said:

With reference to the library, the idea ought never be entertained that the portion of the limited income of the Smithsonian fund which can be deroted to the purchase of books will ever be sufficient to meet the wants of the American scholar. On the contrary, it is the duty of this Institution to increase those wants by pointing out new fields for exploration, and by stimulating other researches than those which are now cultivated. It is a part of that duty to make the value of libraries more generally known and their wants in this conntry more generally felt; to show in what branches of knowledge our libraries are most deficient; to point out the means by which those deficiencies can be supplied; to instruct the public in the best methods of procuring, arranging, cataloguing, and preserving books; to give information as to the best form and construction of library buildings; in short, to do all which was originally intended in the plan of rendering the Institution a center of bibliographical knowledge, to which the Anerican scholar can refer for all information relative to books in general, and particularly to those in our own country. The libraries of the country must be supplied by the country itself; by the General Government; by the State governments; by cities, towns, and villages, and by wealthy and liberal individuals. It is to be hoped that in the restoration of the Library of Congress a foundation will be laid for a collection of books worthy of a Government whose perpetuity principally depends on the intelligence of the people.

The proper management of books and general instruction as to their use are matters perlaps of more importance than their accumulation in any one place. It is estinated that about twenty thousand rolumes, 
including panphlets, purporting to be additions to the stums of human knowledge, are published annually; and unless this mass be properly arranged, and the means furnished by which its contents may be ascertained, literature and science will be overwhelned by their own unwieldy bulk. The pile will begin to totter under its own weight, and all the additions we may heap upon it will tend to add to the extension of the base without increasing the elevation and dignity of the edifice.

One of the most important means of facilitating the use of libraries, particularly with reference to science, is well digested indexes of subjects, not merely referring to rolumes of books, but to memoirs, papers, and parts of scientific transactions and systematic works. As an example of this, I would refer to the admirably arranged and valuable inclex to watural philosophy and the mechanical arts by Doctor Young. "If my library were on fire," said a celebrated author, "and I could save but one scientific book, it would be Doctor Yonng's index." 'This work comes down to I 807 , and I know of no richer gift which could be bestowed upon the science of our own day than the continuation of this index to the present time. Every one who is desirous of enlarging the bounds of luman knowledge should, in justice to himself, as well as to the public, be acquainted with what has previously been done in the same line, and this he will only be enabled to accomplish by the use of indexes of the kind above mentioned. ${ }^{\mathrm{T}}$

In the spring of ${ }^{8} 8_{54}$ matters reached a crisis. In April, Librarian Jewett was called upon by a special committee of the Board of Regents, appointed to report whether it was desirable to make any changes in the distribution of the income of the Institution, to submit in writing, through the Secretary, any statements which he might wish to make. In reply he said in criticism of the policy of the Institution regarding the Library:

*** The active operations have procured books for the Library, but not one quarter of what the money expended on them would have procured by direct purchase.

I will not here take into account the consicleration that undoubtedly many of these books received would have been sent to a large library of this kind as donations, nor the fact that the gifts which have produced these returns are not solely of the publications of the Institution, lut of a large number of other books gratuitously furnished to the Institution for the purpose of distribution.

Sixth annual report of the Smithsonian Institution, Augnst 20, IS52, p. 22; Thirty-second Congress, first session, Senate miscellaneons docmuent No. 1 s. 
The library has not been favored with complete sets of the transactions of many of the oldest societies in exchange, nor indeed of any of the oldest. The full sets of the transactions of many of the oldest societies which we possess-as those of the Royal Society, the French Institute, the Royal Swedish Academy, etc. - have been procured by purchase, excepting the late volumes of them.

The Secretary says it must never be supposed that a great library can be collected with the part of the income that will come to the library under the compromise.

But are we not bound in good faith to try? Are we not bound to make the best use, and to allow the best use in every way to be made of what does, without doubt, under the compromise, belong to the library for this purpose. If we say to the world that we never expected to form a library, and particularly if we argue against a library, and more particularly still, if we say we would not take a library of 100,000 volumes as a gift, if we must provide for it room and custody, we can not, of course, expect to get a library with the part of the fund under the compromise devoted to that purpose, nor could we with the whole incone.

It has never been supposed that by direct purchases with this part of the fund we can form the library which is wanted in this country. But, by showing a wish for such a collection, a liberal and enlightened appreciation of it, a sympathy with those who say they want it, rather than with those who do not feel the need of it, if we buy judiciously with the means which, under the compromise, we have, and accept the means that are offered to us, we shall with astonishing rapidity collect a magnificent library here. Such a library, when fairly started in such a position, is sure to increase rapidly. There is now a library of 25,000 volumes, the best in the world in its speciality, and that speciality the most important of all to this country, which could be had on terms entirely within our means. I met, the last week, a gentleman who had a special collection of autograph letters, which might well be coveted by any library in the world, and which it would cost next to nothing to keep for centuries, and be worth thousands of dollars. He stated that he had made his will, and given this collection to Harvard University; that he had desired to give it to the Smithonian Institution, but his intentions had been repelled by remarks such as I have alluded to.

With the whole or the half of the available income the main hope of the library would be on public and private liberality. And such a hope was never known to be deceived, and will not here be deceived if we are true to ourselves and make an honest and diligent use of our adrantages. ${ }^{x}$

"Thirty-third Congress, second session, IIonse report No. 141, pp. I 29-130, I3 I, I36. 
These statements seem to have been without effect upon the majority of the conmittee, for on the 2 oth of May they reported upon the library as follows:

The "increase and diffusion of knowledge among men" are the great purposes of this munificent trust. To increase knowledge implies research or new and active investigation in some one or more of the departments of learning. To diffuse knowledge among men implies active measures for its distribution so far as may be anong mankind.

Neither of these purposes could be accomplished or materially advanced by the accumulation of a great library at the city of Washington. This would be to gather within the walls of a building here those fruits of learning which had been reaped elsewhere. It would be the hizing of knowledge, not its increase and diffusion. It would be the collection of what philosophical inquirers, men of research, of observation, and of original thought had ascertained, conceived, or invented, and already published to the world. But it would not of itself add to the sum of human knowledge, it would not increase the stores of learning, but only bring them together. It would develop no new truths, reveal no hidden laws of nature, but only contain the record of what might be already known, so that in no proper sense could it be said to increase knowledge. Neither would it diffuse knowledge except within a limited sphere. The Institution would necessarily be local, for although it might aid the few men of research residing in Washington, and such students and investigators as occasionally visited the city, it would fail to accomplish the more extensive purpose of the testator and of the law, since it could not be expected to draw hither the great body of such men. These nuust always be scattered over the country engaged in pursuits which require their residence elsewhere, and with only occasional opportmities of aiding their inquiries by resort to the library of the Suithsonian Institution. While, therefore, a well-selected library of valuable books pertaining to all departments of learning may well be one of the means employed by the Institution, its purpose requires other instrumentalities by which knowledge may be increased and diffused among men. We must never forget that both the will of Smithson and the act of Congress recognize that, as a nation is appointed the great dispenser of the fruits of his munificence, so these benefits are to be universal, and the recipients to be men everywhere and in all time.

If the language of the will hat been " to increase and diffuse knowledge among the people of the United States," a library would be but a feeble and inperfect instrument as an active agent even for that linited purpose. The accumulation of books in the political center of a great country, or even in the center of population of a nunnerous people, would no doubt gratify the pride of the nation and be attencled with some profitable results. But such a library would not insure nuental 
activity to inquirers who slonld live remote from its locality, and its relation to all increase of knowledge would be merely incidental. It would have no effective operation in the thirty-one States which constitute the nation or people of the Union, and instead of being diffusive in its nature would be centralizing in its influence and passive in its character.

$* \quad * \quad * \quad * \quad * \quad * \quad * \quad * \quad * \quad *$

It is not beliered to be advisable to accumulate in the Smithsonian Institution great masses of books, without reference to their peculiar character and value. What we want, and what the act of Congress contemplates, is not a collection of everything which learned dullness and literary folly as well as real wisdon and sound science have put into print-a vast and nnwieldy repertory, in which the trash as well as the precious may be found-but a library of valuable books pertaining to all departments of human knowledge. The exchanges will gradually furnish us with much that answers to this description, and moderate appropriations will supply, quite as rapidly as necessary, whatever besides may be requisite to constitute a valuable library of research in all departments of human knowledge. ${ }^{\mathrm{r}}$

The committee which presented this report consisted of Hon. J. A. Pearce, Hon. J. M. Mason, Hon. Richard Rush, Hon. John W. Maury, Gen. J. G. Totten, Prof. A. D. Bache, and Hon. J. Meachanı.

The last named did not, however, concur in the above report, but presented a minority report, in which he rehearsed the history of the Sulthsonian fund at length. Referring to Mr. Choate, the author of the library plan, he said:

Mr. Choate wished for twenty-five years to devote $\$ 20$, ooo a year to the library. In that time a magnificent library would be collected. A few years of the interest devoted to the accumulation of a subsidiary fund would provide for its perpetual support. The great object would then be so far accomplished that it would take care of itself, or 1niglit safely be intrusted to the liberality of the public; and the whole fund wonld be left unimpaired, yielding its income forever for new and ever varying applications. He slowed that a large library was the particular instrunentality which was first and most needed in this country for the increase of knowledge; that it would be at the same time preeminently diffusive; that it would be consulted for all branches of knowledge; that it was less liable to abuse than alnost any other mode of applying the fund; that neither the I,ibrary of Congress nor any other library of the conntry conld ever meet the demand; that in no other way, so far as could le seen, could this greatest of all the wants of Anerican science and 
learning be met, and that, while it was met in this way, there would be not only real progress toward the increase and diffusion of knowledge, but also visible and palpable progress. The public could see all the while where the money went, and conld know that its representative in property was ever in possession of the Institution.

\section{Continuing, Mr. Meacham said:}

It will never be possible to convince a large number of intelligent and educated men that a library is not an institution for the increase and diffusion of knowledge; that it is the mere "hining" of knowledge for the gratification of national pride, or even for "some profitable results."

They would see every civilized and enlightened nation of the face of the earth using liberally the public means for the purpose of forming such institutions. They would find the wisest statesmen, the most learned scholars of all classes, uniting in support of public libraries. They would hear regrets, after these libraries had reached a quarier or a half a million of rolumes, that they were not large enough to meet the wants of investigators. They would see that these libraries in London, Paris, Berlin, Copenhagen, Göttingen, and other cities were great centers of activity in the increase and diffusion of knowledge. Entering the reading room of the British Insemm, among its 200 or 300 daily readers they would find earnest investigators, real promoters of knowledge-men who bring out of their treasures things nea' as well as things old, who increase as well as diffuse knowledge, and who have gone thither for help in their work. They would there, and in other great storehouses of knowledge, find scholars from all parts of the world pursuing their various courses of investigation.

But it is not necessary to rest in faith upon the settled conviction of every civilized people. It is easy to demonstrate that this concurrent testimony of all the learned rests upon solid grounds, and to show hou' it is that libraries are for the increase of knowledge.

To increase knowledge in any department one must have possessed himself of the knowledge extant in that department. It is possible that a man not knowing all that had been discovered in the direction of his researches may yet discover something not known; some steps he may overleap. But such is a rare exception to a general rule. Alnost universally what is known to the ntmost limit is used as the steppingstone to what is beyond. Knowledge grows by small accretions. I:ach addition is procured at the expense of toil and time. It is small, perlaps; but no man hereafter can overlook it, as he presses on for greater advancement in that direction. It is not indeed said that he who would increase knowledge in one department 11 ust know all that is knowable in all departments, but only that he must know all that is known in the direction of his researches. There are many directions in which knowl- 
edge is ever expanding. It may be but a small thing to a man whose researches are restricted to one particular department (say electricity) to learn all that is known on that subject. All the books needed may be but a few volumes to prepare him for a course of researches for increasing that kind of knowledge; and the opposition to large libraries generally comes from those who can thus easily acquire the means of commencing and continuing original researches. But let such an one be reminded that electricity is not all of knowledge; that chemistry is not all; that all the natural sciences and all the physical sciences do not comprehend all of knowledge which is to be increased and diffused. There is mathematical knowledge, there is historical knowledge, there is legal knowledge, there is knowledge of government, knowledge of statistics, knowledge of geography, knowledge of medicine, knowledge of man in his intellectual and moral character and relations, knowledge of languages, knowledge of art, knowledge of the practical applications of science, of agriculture, commerce, and mechanical arts, and knowledge in infinite varieties of form and name. In all these knowledge may be increased.

We are prone to draw our analogies too much from the physical sciences when we think of the increase of knowledge. So great has of late been the progress of physical science, and so beneficial have been its results upon the material conclition and indirectly upon the moral and intellectual condition of the human race, that it is ever present in the thoughts. It is visible and palpable. Progress in it is readily recognized. It seems, therefore, more real than progress in other directions, but it is not more real than any other knowledge not merely speculative.

All knowledge is worthy of support. All knowledge is to be increased. And although one increaser may need in his efforts but few books, yet the aggregate of those needed by all must necessarily be large.

One very important branch of knowledge, for instance, is that of American history. The man who, tracing it from the earliest discoveries through all the colonizations and all the peopling and all the events which have developed our institutions, might deduce with certainty laws and principles new to the world and which would greatly promote its progress in civilization, would be increasing knowledge in that department. But to do this it would be necessary for him to have access to at least 25,000 books in that clepartment of research. He could not find these books in all the public libraries of America combined. They would not enable hinn to make this contribution to knowlelge. For a thorough investigation of English history with a like purpose there miglit be required three or four times as many books; so, too, of French, of German, and of other histories.

To 11:s history is of peculiar importance. A new people, working 
out the greatest problem of time-the true theory and practice of selfgovermment - we wish to examine history for onrselves. We know that it has heen tortured to teach doctrines which we have disavowed and rejected. We wish for access to the sources of history that we may form our own independent judgment. We wish to rewrite it from our own standpoint. Our children and the waiting world are to be taught to read history aright. Our free institutions are not the offspring of ignorant blundering and sciolistic rashness. Our fathers-the Jeffersons, the Adamses-were men of stndy and thought. They had passed portions of their lives like recluses among books. And so, earlier, the first colonists were men of education and study and they brought libraries with them to this far off Westem world. The doctrines cleveloped here are destined to spread, not by sudden ontbursts of enthusiasm, not in the wild tramp of revolutions so much as by the silent influence of what thinking and studions men will write and speak. Ve need the books to aid our students in this noble work.

History is indeed a large department, and he who cultivates it must have many books. Other branches, too, require each its quota; one may be satisfied with a few, another require many thousands. If we suppose ourselves providing a library for a hundred investigators in different directions, the average number of books for each, different from those which others might need (not to read through, but to constilt), might be 5, 000 ; the whole number of books necessary to meet the wants of these hundred investigators wonld then be 500,000; and thus we should require the large library.

But, again, knowledge acquired is essential to the increase of knowledge, not only as the necessary stepping-stone or point of support, but also in furnishing analogies, and indicating the direction in which new knowledge is to be sought. Efforts must not be projected at random into the unknown. They must, to be successful, be directed by' a previons acquaintance with what has been discovered, and the mamer of its discovery. The greatest discoveries are made by men whose minds have been trained to the work, by studying the analogies of past discovery.

To say that a library is not for the increase of knowledge is to say that the existence of knowledge is not essential to its increase; that the past is nothing to the future; that all now known may be blottert out, and yet the progress of knowledge continuc. The mere statement of such a proposition is its refutation.

As to the relation of a library to the diffusion of knowledge, little need be saicl. To it would be attracted those who wish to learn for themselves, and especially those who wish to learn that they may teach. The lights, as has been said, kindled here would shine upon a thousand hills. The bookmakers, the lecturers, the teachers would come here to spend their studious weeks, and gather that they might distribute. 
For diffusiveness, what other instrunentality can compare with this?

There is a fallacy lurking in the language of the committee when they say of the library, "It would not, of itself, add to the sum of human knowledge." Of itself, neither would it diffuse knowledge. Of itself, it could do nothing. Neither could any institution, corporation, or establishment, of itsclf, either increase or diffuse knowledge. Corporations, institutions, libraries are mere means, instrumentalities, facilities, incitements to individuals who, as individuals, in the exercise of individual intellect, increase knowledge. In this regard, therefore, a library stands in precisely the relation to knowledge that a learned society does. Both are means. Neither is capable of effecting the end, of itsclf. The observation of the connuittee, in the same sense and in a like degree, is applicable to the plan which the report proposes to establish.

But among the means, the most important of all and most wanted in this country and at this time is a great library. We have the means of education, of discipline in schools and colleges; we have active minds and active presses, and far greater facilities for spreading among men whatever we can do to promote knowledge than are enjoyed in any otıe country. But we have not books. 'The public libraries of this country do not furnish neans for extensive study in any department. Not one of the truly learned works which have been produced by our countrymen has been, or could have bee1, written by the aid of our public libraries alone. Works like Irring's Columbus, Wheaton's History of international law, Prescott's works, Ticknor's History of Spanish literature-even works relating to our own history, as Bancroft's History-can not be written from the collections in our public libraries. The "Anerican Archives" conld only be compiled from a library of some 25 , Ooo volumes, collected at his own expense by a private individual, and which yet remains private property. There is, perhaps, no one subject that can be fully and satisfactorily investigated in our public libraries. We need one large library, at a central and conrenient point, accessible freely to all who wish to consult it, and supplied with the amplest materials for research.

Such a library would afford to the poor as well as to the rich the facilities of learning. It would be eninently democratic.

The rich for the most part are now our learned men-those who can go to Europe to consult the libraries of the Old World. Had we our library here the citizen of the most distant of the thirty-one States could come here more easily than he could go to Germany. The question with him now is, Shall I go to Europe or give up nyy investigation? The question then would be, Shall I give it up or go to Washington?

A large library must have a local habitation somewhere. Wherever it might be it would be visited by the studious. But there is no place in this country so farorable for its location as Washington. 'The facil- 
ities of connnnunication with erery part of the Union are greater than for any other place. This is the only place in the Enion with which every citizen wonld lave at all times the means of free connmunication. A citizen of a distant State, desirons of ascertaining facts to be learned only in a large library, might know of no perion in New York or Boston to whom he wonld feel at liberty to write. But in Washington there is, for a great part of the year, the representative from his district, of whom he could readily seek assistance, although not personally known to hin, in procuring the information he might need to any reasonable extent.

There are other reasons why such a library should be in Washington. It must be comnected with the Government. The publications of the Government wonld constitute a most important portion of such a collection. These conld not so well, if at all, be gathered elsewhere. A large proportion of researches to be made connect themselves with the Gorermment archives, and these archives can not, of course, be removed from the capital. Again, the collection of American publications, which will hereafter be so much desired by investigators, can not possibly be made except by the aid of the Govermment through the copyright law; and it is manifest that this collection should be preserved at the capital. Besicles all this, the fact of this institution being metropolitan, and connected with the Government, makes it so far a national establishment. To stich an establishment would be attracted more of the donations and bequests of private collectors, of books, specimens, and works of art, than to any other. From this source it is to be expected that the library, if once placed in the prominent position which Congress intended it should hold, would rapidly rise to the first rank among the literary storehouses of the world. Had the whole sum which Congress allowed and intended for the libraty been expended, we should have had at this moment a library of nearly or quite 200,000 volumes. The money for the building was specifically appropriated for it by Congress, and might have been used at once for the purpose. A building expeditiously finished and filled with the stores of learning produces an impression upon our rapidly moring countrymen. There is something to see. If money has been expended, there is something to show for it; there is property. It is but an investnent, and one would easily be convinced that it is convertible property, which conld be changed back again into gold. It would not seem like water spilled upon the ground, which can not be gathered ip.

It is desirable in the management of a public institution, not only to make progress but to shou progress. Popularity depends upon it. and popularity, though not to be sought in dereliction of principle, or neglect of other means of ntility, is not in this comntry to be despised.

Again, it may be truly said, that whatever might be the future contse of the Institution, the library wonld be essential to its greatest sncesen. Should we make it the seat of a learned society-such a society 11eeds a 
library, and a very large one, for its efficiency. Should it be devoted in turns to varying specialties, each would find in the general library one of the principal instrumentalities for effecting its purposes. It would find in this a part of its plans provided for. ${ }^{\mathrm{x}}$

Mr. Meacham's report was not presented nutil after the adjournment of the Board of Regents. But even had it been presented before their adjournment it is improbable that it would have affected their action. On the Sth of July, i 854 , the Regents adopted the following resolution:

The Secretary of the Institution and of this Board is, by the seventh section of the act " to establish the Smithsonian Institution," required to discharge the duties of "librarian and keeper of the museum," having, with the consent of the Board of Regents, power to employ assistants, the better to enable lim to discharge those duties; for a better construction whereof,

Be it resolied, That whilst power is reserved in the said section to the Board of Regents to remove both the Secretary and his assistants, in the opinion of the Board power nevertheless remains with the Secretary to remove his said assistants. ${ }^{2}$

Yeas.-Messrs. Bache, Hawley, Mason, Pearce, Rush, Totten-6.

Nays.-Messrs. Douglas, Englisl, Stuart, Towers-4.

So the library plan was finally defeated, and its representative in the Institution, Professor Jewett, was removed from office, July Io, IS 54 .

July i9 Rufus Choate wrote to his son, "Yesterday I ought to have been at Washington. What they have done I know not. If $m y$ friends carried an adjournment it is well. If not, the library fuit, as the expressive perfect tense has it." ${ }^{3}$

In consequence of the resolutions passed by the Board of Regents, July 8, is 54 , which led to the removal of Professor Jewett from the office of librarian of the Smithsonian Institution, Rufus Choate resigned his office as Regent of the Smithsonian Institution, January I 3, I 855 . This resignation being communicated to the Senate January I 7 , Mr. Pearce, in justification of the action of the Board of Regents, said:

It is singular that in the act of Congress there is a limitation upon the appropriations for a library and no limit to the appropriations which may be made for any other of the designated objects. The limitation in

${ }^{x}$ Smithsonian report, Angust I, 1854 , pp. 28.4-288.

${ }^{2}$ lbirl., p. 96.

${ }^{3}$ Samuel G. Brown, Life of Rufus Choate (i87o), p. 275. 
the library expenditure was rather inappropriately added to one of the sections of the bill to which it was not germane. It forbids the applicatiou of more than $\$ 25$, O00 per annum to that purpose, but the act does not anywhere require the Regents to expend annually that amount. It establishes no minimum below which they shall not fall in their appropriations, but it simply establishes a maximum beyond which they shall not go. That has been done by Congress in regard to the library, but in regard to no other object of expenditure. Well, sir, the Regents, in their discretion, have not thought it necessary or expedient to expend the whole amount of the sum to which they were limited by that provision of the act, and hence. I think, all the difficulties in regard to this matter. They could not understand the words " not exceeding $\$ 25,000$ " to mean not less than $\$ 25,000$, or to mean nearly $\$ 25,000$, or to signify anything else than that such was the utmost limit of expenditure authorized by the act for this purpose. The words necessarily imply that the Regents might expend less than that sum, and the question how much less was one purely for their discretion. ${ }^{x}$

Mr. Mason, another member of the Board of Regents, said:

Suppose this fund of $\$ 30,000$ or $\$ 40,000$ is deroted to the purchase of books, which are to be stored here on shclves, in the city of Washington, who is to read them? Why, sir, the members of Congress hare little time to read the books which accumulate here in the public Library. The citizens of Washington form a very small proportion of the people of these United States, and thus this great trust, which was intended for mankind, would be limited to the walls of Washington.

There is another great objection to it. Books are derived from booksellers. Booksellers are connected with bookmakers, and bookmakers and booksellers with that hungry legion who all live, and of whom some grow rich, on the spoils of genius and industry. Then, there are the paper makers, and the book printers and publishers and the stereotypists, all, all would be hovering around this fund, to say nothing of factorage, commission, foreign travel to pick up rare works and the ten thousand jobs that follow in such a train, where money is to be spent by law in large annual stated sums to buy books; and, at last, what would you have done? Why, you would have taken this great, noble, beneficent donation to mankind and converted it into a fruitful job for every race of needy and artful adrenturers. ${ }^{2}$

Mr. Douglas, a third member of the Board of Regents, said, on the other hand:

When all the various plans for the organization of the Institution were presented in the House of Representatives, and especially the library plan, as a principal feature, not an exclusive one, in antagonisn to a

'Congressional Globe, $36:$ p. 302, 303 .

Ibicl., 36: p. 30.4.

$23399 \cdot 4-32$ 
plan that the library should be a subordinate feature, or that there should be no library at all, it is my firm conviction that Congress, by its action, did sanction the policy of a library as a principal, but not an exclusire feature in the Institution. In other words, the plan proposed by Mr. Marsh, of Vermont, in opposition to that of Mr. Hough, of New York, did prevail, and the main features of Mr. Marsh's plan tended to the establishment of a library. The library plan, as it was called, having prevailed, there was a limitation on the amount of funds to be devoted to that plan inserted in the law, which was that out of the $\$ 30$, ooo of income of the Institution not exceeding $\$ 25$, o00 should be appropriated to the library.

I do not hold that the Regents are compelled to appropriate to a library the sum of $\$ 25,000$ each year, but I do hold that the law in its terms, when carefully examined, contemplates the library as a prominent object in the Institution, and that at least a majority of the funds should be expended in the building up of the library. ${ }^{\mathrm{x}}$

So it was "Resolved, That the Committee on the Judiciary inquire whether any, and, if any, what action of the Senate is necessary and proper in regard to the Smithsonian Institution." 2

The Judiciary Committee reported by Judge Butler, February 6 , I 855 , with the following comment upon the eighth section of the act of August Io, I846, providing a sum, not exceeding an average of $\$ 25,000$ annually, for the formation of a library, and upon the measures of the Smithsonian anthorities:

This section can not, by any fair construction of its language, be deemed to imply that any appropriation to that amount, or nearly so, was intended to be required. It is not a direction to the Regents to apply that sum, but a prohibition to apply more; and it leaves it to the Regents to decide what amount within the sum limited can be advantageously applied to the library, having a due regard to the other objects entumerated in the law.

Indeed, the eighth section would seem to be intended to prevent the absorption of the funds of the Institution in the purchase of books. Anct there would seem to be sound reason for giving it that construction, for such an application of the funds could hardly be regarded as a faithful execution of the trust, for the collection of an inmense library at Washington would certainly not tend " to increase or diffuse knowledge", in any other conntry, not even among the conntrymen of the testator; very few even of the citizens of the United States would receive any

$$
{ }^{2} \text { Congressional Globe 36: 305. } \quad \text { Ibid., 36: } 307 .
$$


benefit from it. And if the money was to be so appropriated, it would have been far better to buy the books and place them at once in the Congress Library. They would be more acceptable to the public there, and it would have saved the expense of a costly building and the salaries of the officers; yet nobody would have listened to such a proposition or consented that the United States should take to itself and for its own use the money which they accepted as a trust for "the increase and diffusion of knowledge among men." r

On the other hand [said the committee], a library formed upon the exchange systen "will contain books suitable to the present state of scientific knowledge, and will keep pace with its advance, and it is certainly far superior to a vast collection of expensive books, most of which may be found in any public library, and many of which are mere objects of curiosity or amusement, and seldom, if ever, opened by anyone engaged in the pursuits of science.",

The resignation of Rufus Choate as Regent of the Smithsonian Institution was communicated to the House of Representatives January $\mathrm{I} 7, \mathrm{I} \mathrm{S}_{55}$, and by them referred to a select committee who were directed to inquire and report whether the Smithsonian Institution had been managed, and its funds expended, in accordance with the law establishing the Institution. On the $3 \mathrm{~d}$ of March this committee made report by Mr. Upham, of Massachusetts. Commenting upon the text of the Smithson will, they said:

The word "increase" is held by some of the zealous combatants in the Smithsonian controversy to be identical with "discovery." The idea seems to be that knowledge can only be increased by the disco'cry' of a ncw truth. This is an arbitrary and untenable position. A mind experiences an increase of knowledge if it knows more than it did before, althougl the ideas which it has received may be in the commonest text-books. There has been an increase of knowledge in the school, in the congregation, in the lecture room, if ideas not before known to them have been received into the minds of the hearers; even, indeed, it matters not if those ideas have been recorded for thousands of years in languages, classical or sacred, that have been dead long ago. Knowledge has bcen increased, if one mind has received more, whether it be new or old truth. The language of Sunthson is perfectly simple, and in its natural sense covers the whole ground; it includes, but does not require nea' truth. Truth discovered a thousand years ago is as good as truth discorered yesterday. Knowledge embraces it all alike,

'Tenth annual Smithsonian report, Thirly-fourth Congress, first session, Senate miscellaneous documents, No. 73, p. 84 .

2Ibid., p. 85 . 
and Smithson's object was to carry knowledge where it was not before, and to increase it where it was; to spread it over a wider area and to a greater depth.

In like manner a particular meaning has been crowded upon the word "knowledge" -not its ordinary meaning in common usage, but a narrow, technical, and special meaning. This has been done by confounding it witl "science." It is true that, in their primitive origin, or roots, in the languages from which they are derived, these words may be identical in their meaning, but not so as actually used in common conversation and familiar and general literature. "Knowledge" is allcomprehensive, embracing science, art, literature, politics, business, the whole world of nature and culture, the entire realm of facts and reality, all ages and all that they have contained. "Science" is almost universally employed to denote those branches of knowledge which are systemized into a distinct organization or arrangement, based upon definite principles, and reduced to particular rules. In the progress of knowledge new sciences are added to the list, and in the establishment of new classifications the boundary lines are altered. There is a vast amount of knowledge not included in any science. Further, the word science is sometimes used to embrace only a part of what, in a broader sense, is included in the sciences. It is getting to become quite generally used to denote what are called the physical sciences, excluding political, moral, and intellectual science-excluding history, the arts, and all general literature. Surely, it can not be maintained that "knowledge" 'was used by Smithson as merely identical with "science" in this last-mentioned and most limited sense.

The words "among men" were used merely to corroborate the idea expressed by the word "diffusion." They do not necessarily imply that the Institution should confine itself to world-wide operations. The word is not, as some seem to suppose, "mankind," but " men;", and he diffuses knowledge "among men", as truly, and in as full a sense, when he enlightens the minds of his neighbors, as of persons at the farthest pole. He best fulfills the idea of Smithson who increases human intelligence, whenever and wherever he has an opportunity, in every circle of influence, however near or however remote.

Commenting upon the eighth section of the act of August ro, 1846 , which provided for an appropriation not exceeding an average of $\$ 25,000$ annually for the formation of a library, they said:

Thle expression " not exceeding" is in constant use in the legislation of Congress and in all legislation everywhere in which appropriations are made, and it will not be disputed that, in all instances, the expecta-

'Smitlisonian report, Thirty-third Congress, second session, House report No. I4I, pp. $15^{-16}$. 
tion and the general understanding of the Legislature is that about the amount thus specified will be expended. The word "average" can only be cousidered as indicating the expectation of the Legislature that the sum expended in sonne years miglit exceed $\$ 25,000$. Tlue word was used in order to give the managers authority, in case a sum less than \$25,000 were expended one year, to expend just so much more the next, and aice i'ersa. No doubt, we think, can be cntertained that the framers and enactors of the law expected that about $\$ 200,000$ would be expended " for the gradual formation of a library, composed of valuable works pertaining to all departments of human knowledge, " in eight years. If the law does not contemplate that the annual expenditure for the formation of a library shall be something like $\$ 25,000$, any other figures might as well have been used. If the administrators of the law are at liberty to spend as little as they may please for a library, in the face of the sum thus indicated in the law, they would have been equally at liberty whatever sum might have been named, whether $\$ 30,000$ or $\$ 40,000$. In other words, if the clause of the act under consideration can be construed as justifying an annual average expenditure for the gradual formation of a library of less than $\$ 20,000$, any intermediate sum between that and the entire income of the fund would have been of equal authority and significance as indicating the intention of the Legislature, whicherer of the said intermediate sums might have been inserted in the act. That is to say, those who maintain that the language and design of the act are carried out by expending less than $\$ 2,000$ annually for books, assume and assert that it would not have altered the sense of the act had \$2,000, or $\$ 10,000$, or $\$ 40,000$ been the sum actually named in it instead of $\$ 25,000$. $^{\mathrm{s}}$

\section{In conclusion, they said:}

But a few words are needed to do justice to the value of a great universal library at the metropolis of the Union. Every person who undertakes to prepare and publish a book on any subject will be found to bear testimony to the need of such a library. The great historians and classical writers of the country have to send abroad, of ten to go abroad in person, in order to obtain materials for their works. A1l literary men are eager to inspect catalogues and explore alcoves in the prosecution of their favorite departments, and there is no direction in which they are more tempter to drain their generally quite moderate resources than in the purchase of books. Such a library as would be accumulated by an appropriation of $\$ 20,000$ annually for twenty years, judiciously expended, would be frequented by scholars and anthors in much larger numbers than persons not acquainted with their wants will be likely to suppose. In half a century it would give to America a library unequaled in value, and probably in size, in the world.

\footnotetext{
Smithsonian reporl, Thirty-third Congress, second session, House report No. I4I, p. I7.
} 
There is a special reason why such a library should be provided at this seat of the Federal Government. The annals of all other countries, rumning back into the past, are soon shrouded in fable or lost in total darkness, but ours, during their whole duration, are within the range of unclouded history. The great social, moral, and political experiment here going on to test the last hope of humanity is capable of being described in clear and certain records. The history of each State and Territory can be written on the solid basis of ascertained facts. In each State and Territory there are, and from the first have been, many persons who are preparing and have published works illustrative of the entire progress of those respective communities. In local history, commemorative addresses, and the vast variety of production of this sort our literature is rich and auple beyond that of any other people. There is no way in which the patriotism and virtue of a people can be so effectually fostered and strengthened as by cherishing in their breasts an interest in their ancestry, in the incidents that have marked the fortunes of their States, their towns, and the scenes of their residence, the transmitted reminiscences of their homes and firesides. It would be a great and good thing could there be collected in a national library in distinct alcoves all valuable publications illustrating the history of the several States of this Union. Different processes of legislation and various social and political influences have operated upon them severally, and the records of the results ought to be here for the inspection and instruction of the representatives of the people, of the people themselves, and of the whole world.

But if every other description of books is avoided or crowded out, there is one which surely ought not to be. If the resources of the Institution are to be exclusively or mainly devoted to science rather than to general literature and knowledge, it ought at any rate to have within its walls a perfect and universal library of science and art, not merely modern science and recent researclies, but all the publications of all ages and all countries, that illustrate the progress of science as such. If we can not have a universal library, give us ct least a scientific library such as no other nation can boast. ${ }^{x}$

This report was signed by Mr. Upham alone.

The committee also reported the following brief for the library plan submitted by Mr. Meacham:

Congress established the Smithsonian Institution for the faithful execution of Smithson's trust, "according to the will of the donor," by a certain act approved August Io, I 846.

In this act Congress directed a manner (as in the act of July I, I836, it had promised to do) in which the funds should be applied.

'Suithsonian report, Thirty-third Congress, second session, House report No. I4I, PP. 25, 26. 
By this act a majority of the funds were to be appropriated to the library. This is proved-

By the erident design of the Congress that passed the law they refused to linit the maximum sum to be deroted to that olject at a less sum than \$25,000, though repeated efforts were made for a less sum.

By the terms of the law itself, that fixes the sum at an average of $\$ 25,000$, and shows that such, or near that sum, should be expended on the library. They certainly were not sporting with an imaginary sum.

By the decision of the Board of Regents, who on December 4, 1846, roted that $\$ 20,000$ be appropriated for the library "for the present." This showed their understanding of the act.

By the compromise which divided the incone equally between the library and the Musenm on the one hand and publications and researches on the other, the friends of the library felt as if they had lost, and the friends of the publications felt as if they had gained by the compromise. The opinions of both go to show the general understanding that the sum to be given to the library was more than half of the whole at the time of the compromise. $* * * *$

The library is the only one of the "purposes provided" for which Congress clirects the Regents "shall make an appropriation."

The library is required to be on a liberal scale for the accommodation of this and the other purposes provided.

The act anthorizes an annual expenditure of nearly five-sixths of the whole income upon it-guarding all other purposes only to the extent of about one-sixth of the income.

The appropriations which the Regents are commancled to make for the library are for a particular kind or class of library-one "composed of valuable works pertaining to all departments of human knowledge." It is not a scientific library; it is not a library as an auxiliary to some other purpose, but a universal library of valuable books in all departments. A library answering this description must necessarily be large. Its formation would be "gradual" under the whole sum indicated; for libraries answering, in the judgment of those who most use them, this description, must contain, in the present age, from 200,000 to 500,000 volu1nes. ${ }^{\mathrm{x}}$

On the same day Mr. Meacham spoke in explanation of his position, as follows:

On the $4^{\text {th }}$ clay of December, 1846 , the Board of Regents of the Suithsonian Institution appropriated $\$ 20,000$ annually to the library, inclependent of salaries. If this resolution had been carried out, we slould, even now, have much the largest library in this country. It would be something to have, to see, to use, to grow. And I ask you to place

'Smithsonian report, Thirty-third Congress, second session, Honse report No. I4I, pp. 48, 49. 
beside this the half dozen quarto and the half dozen octavo volumes published by the Institution, and tell me which you would preferwhich would tend most for the increase and diffusion of knowledge.

Then, referring to the compromise resolutions of January 26, I 847 , he said:

The friends of the library reconciled their course with the law thus: If $\$ 2 \mathrm{c}$, 000 a year be expended for books during the four or five years while the building is in progress, we shall gather a considerable library, and then we may be justified in believing that, for the future, the share that will come to the library under the compromise, may be considered as meeting the requirements of the law; the friends of the scientific scheme will be propitiated, and perpetual harmony secured.

I think, sir, that they strained their discretion; but they acted in a spirit of conciliation worthy of a fairer requital than it has met. ****

I have not sought letters of recommendation for the library plan, nor have others for me. I doubt not I could have obtained thousands. To show them on either side seems to me idle parade. We doubt not that librarians in Athens and Paris are glad to get handsome books from America, and are ready to praise them before our traveling countrymen. 'Tis polite to do so. We doubt not that scientific men like to have means of publisling their works, too heavy for booksellers. We need not here doubt that it may sometimes be usef ul to publish, gratuitously, books that people do not care enough about to buy. But the question here is, Can the Smithsonian Institution laz'fully' derote itself to such a purpose exclusively or principally? ${ }^{\mathrm{I}}$

The divided opinions of Congressmen regarding the administration of the Snithsonian Institution were representative of public opinion in the country at large. The Southern Literary' Messenger (August, I 855), said:

We are ourselves devoted lovers of books, and despite of Hobbes, should fear no infection of learned ignorance from the presence of a Bodleian or Ambrosian in the city of Washington; but the will does not seem to provide for any such foundation. The language of Mr. Choate in opposing the conversion of the fund to purposes of education, might be applied with equal force to the establishment of a library. "It would hardly appear to be an instrumentality coming up to the sonorous promise of increasing and diffusing knowledge among men. Who would the readers be? Who could afford to conie all the way to Washington from the Soutl, West, and North to learn." An expensive and tedious pilgrimage to the shrine could, of course, be only the privilege of a few; but for any purpose of wide ntility the library would be no more felt than so much sunshine on the poles. 
The North American Reriea (October, IS54), on the other hand, referred to the fact, that the act of August Io, i 846 , had directed an appropriation of not more than $\$ 25,000$ annually for the library, and said:

Had an average amnual appropriation of $\$ 25,000$ been actually made for the library in eiglit years, the sum of $\$ 200,000$ would have been so expended, and there would be at Washington a magnificent library containing 200,000 volnmes. ${ }^{\circ}$

The Review then detailed the history of the Institution, and concluded as follows:

We suggest but a single one of the advantages of the library plan, which should especially recommend it. The collection of a great library is almost the only object which is not likely to be attained in any other way. The available fund of the Smithsonian Institution will be about $\$ 700,000$. Now, it is manifestly better to spend this chiefly for some one thing that can not be done so well with a less fund than to separate it into portions for several objects. A library of 200,000 volumes is a great deal more than twice as good as a library of too,000 volumes, but however many publications the Institution may issue, the benefits of printing them will increase only in the same proportion as the number. A dozen separate institutions, each with a fund of $\$ 50,000$, can do much, probably more, in the way of publications and researches as the Smithsonian with $\$ 600,000$; but if each should collect the best library it could, the result would be far inferior to what the Smithsonian may have and ought to have already. We may safely leave to the numerous respectable societies and other organizations the work of publications and researches, but there is no way in which the loss of the Smithsonian library, as it should be, can be replaced. ${ }^{2}$

\section{Norton's Literary' Gazette took still a third view:}

Whatever decision is arrived at [it said], and we apprehend it can be but in accordance with those previously attained, it can not but affect farorably the question of establishing a national library, and that on a far more secure and extended basis than that of the Smithsonian endowment. For eren if a large library had been established on that foundation future legislation might have diverted the funds from its support. But a fact of still greater moment is that Smithson's bequest, munificent though it was, would not be more than sufficient to lay the foundation of the library that our country should now have, and the original fund being thus entirely invested the ammual expenditures would have to be dependent upon extraneous support, a contingency which, like the other, might destroy its future usefulness. ${ }^{3}$

'North American lieàca', 79: 454

Ibid., pp. $462-463$.

${ }^{3}$ Norton's Literary' Gasetle, n. S., 2: 67, February 15, IS55. 
Is not such an establishment needed? What would be its effects upon our country? With an ample depot of maps and charts on the one hand, and a repository for American archives and State papers on the other, it would need no collection of beasts, birds, or fossils to make its influence felt in every corner of onr land. Its plan of operation should be upon the most liberal scale. If any responsible person wishes to consult a work on its shelves let it be loaned or forwarded to him under such necessary restrictions as are found sufficient by the Royal Library of Berlin and other European institutions. If this is found to interfere with that certainty of consulting works which should ever attach to a reference library, then let such a corps of assistants be organized that extracts can be copied, tracings be made, and naps copied, so that the library shall remain not a mere local institution but one of the greatest usefulness.

No one can well doubt the willingness of our Government to foster such an enterprise, when he looks at the sums expended upon exploring expeditions and for the publication of their results. Let the matter be properly brought before our National Legislature, and the same liberality will be evinced that has ever been so freely displayed for the encouragement of scientific and geographical explorations. A happy exemplification of this truth is contained in the address made before the national convention of librarians, by its distinguished president. He says: "Congress, liaving the control of the Treasury of this rich, ninghty, and intelligent nation, will not, I believe, be backward in making appropriations for this object, whenever it shall be suitably presented to them. Congress may be regarded as liberal in matters of science and of learning, whenever they are sure that the money will be honestly and properly expended. Many men do not believe this, but look at the action for replenishing the desolated hall of the Library of Congress. Most persons were of the opinion that Congress could not be brought to make an appropriation exceeding $\$ 30$, ooo for this purpose; but when Mr. Chandler proposed $\$ 75,000$, it was readily granted. It would have been, had he asked $\$ 200,000$, if they had thought that sum necessary, and believed that it would be honestly and judiciously devoted to the gathering of a good library.",

No tine can be more auspicious for sucl an undertaking than the present, and while we already behold the Suithsonian Institution rivaling, in the importance of its original researches, the Royal Society of Great Britain and the Acadénie des Sciences of France, we hope soon to see a national library arising by its sicle, vieing, in the completeness of its collections, with the Bibliothèque Impériale, the Royal Library of Berlin, and the library of the British Museum. ${ }^{x}$

With these prophetic words we may close the early history of the national library, a history full of interesting plans and not without interesting achievenents. 
Aprendizes 



\section{Appendix I.}

Officers of the Library. ISOz-IS67.

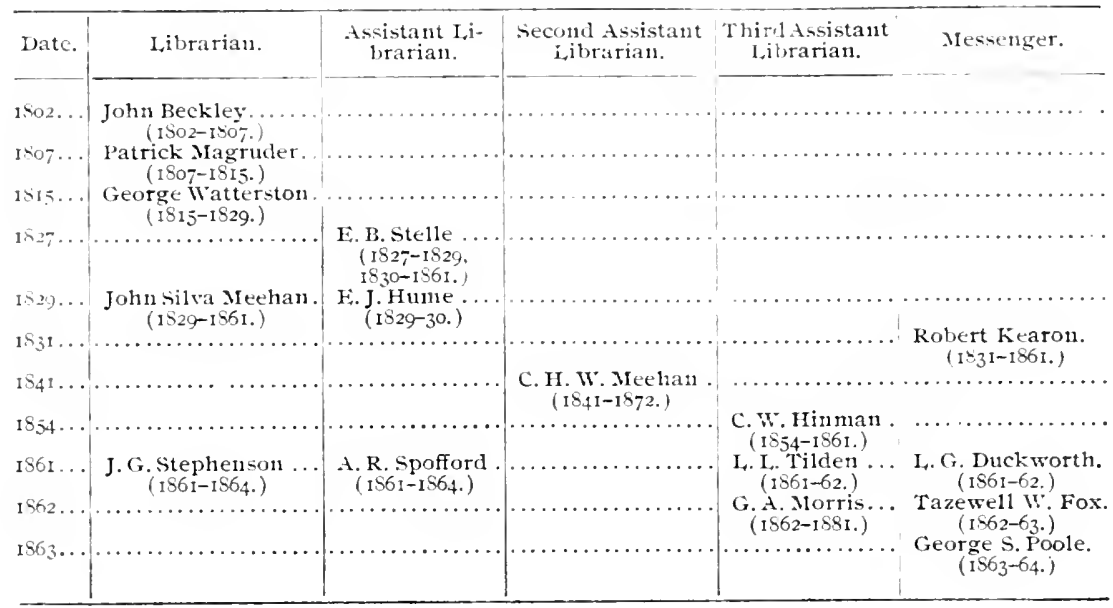

\section{APPENDIX II.}

Members of the Library Committee.

Ninth Congress, first session:

Senate . . . Samuel Latham Mitchill, Abrahan Baldwin, John Quincy Adams.

House . . . Joseph Clay, Thomas M. Randolph, Samuel WW. Dana.

Ninth Congress, second session:

Senate . . . S. L. Mitchill, A. Baldwin, J. Q. Adans.

House . . . J. Clay, T. M. Randolph, S. IV. Dana.

Tenth Congress, first session:

Senate . . S. L. Mitchill, J. Q. Adanı, William Branch Giles.

House . . . S. W. Dana, J. Clay, W. C. Nicholas.

Tenth Congress, second session:

Senate . . . W. B. Giles, Buckner 'Thruston, Andrew Gregg.

House . . . W. C. Nicholas, Benjamin Say, S. W. Dana.

Eileventh Congress, first session:

Senate . . . W. B. Ciles, B. Thruston, A. Gregg.

House . . . W. C. Niclolas, B. Say, S. W. Dana. 
Eileventh Congress, second session:

Senate . . . James Lloyd, Michael Leib, Samuel Smith of Maryland.

House . . . S. W. Dana, Thomas Newton, Adam Seybert. Eleventh Congress, third session:

Senate . . . M. Leib, S. Smith of Maryland, John Condit.

House . . . . A. Seybert, 'Timothy Pitkin, Alexander M'Kim.

Twelfth Congress, first session:

Senate . . . M. Leib, S. Smith of Maryland, J. Condit.

House . . . Adam Seybert, William Lowndes, Josialı Quincy.

Twelfth Congress, second session:

Senate . . . M. Leib, Charles Tait, George W. Campbell.

House . . . . S. L. Mitchill, A. Seybert, James Emott.

Thirteenth Congress, first session:

Senate . . . M. Leib, David Stone, C. Tait.

House . . . A. Seybert, Joln1 Robertson, Lewis Burr Sturges.

Thirteenth Congress, second session:

Senate . . . M. Leib, Robert Henry Goldsborough, Jeremiah Mason.

House . . . . A. Seybert, Langdon Cheves, William Gaston.

Thirteenth Congress, third session:

Senate . . . R. H. Goldsborough, Eligius Fromentin, C. Tait.

House . . . A. Seybert, W. Lowndes, W. Gaston.

Fourteenth Congress, first session:

Senate . . . E. Fromentin, William Hunter, R. H. Goldsborough.

House . . . Joln W. Taylor, Joseph Hopkinson, Henry St.

G. Tucker.

Fourteenth Congress, second session:

Senate . . . . E. Fromentin, R. H. Goldsborough, W. Hunter.

House . . . . J. W. Taylor, J. Hopkinson, H. St. G. Tucker.

Fifteenth Congress, first session:

Senate . . . . Mahlon Dickerson, Rufus King, C. Tait.

House . . . . A. Seybert, Ezekiel Whitman, Henry Middleton.

Fifteenth Congress, second session:

Senate . . . M. Dickerson, R. King, E. Fionentin.

House . . . A. Seybert, Jonathan Mason, William Irving.

Sixteenth Congress, first session:

Senate . . . M. Dickerson, W. Hunter, S. W. Dana.

House . . . Cliarles Pinckney, Silas Wood, Henry Meigs. 
Sixteenth Congress, second session:

Senate . . . M. Dickurson, S. MV. Dana, WV. Inunter.

House . . . Rollin C. Nallary, Severn Ii. Parker, Robert Allen.

Serenteenth Congress, first session:

Senate. . . M. Dickerson, John W. Walker, John Eilliot.

House . . . . Joel R. Poinsett, A. Snyth, Thomas Whipple.

Seventeenth Congress, second session:

Senate . . . M. Dickerson, J. Elliot, Elijah H. Mills.

House . . . A. Snyth, 'T. Whipple, Alfred Cuthbert.

Iighteentli Congress, first session:

Senate . . . M. Dickerson, J. Elliot, Thomas H. Williams.

House . . . . A. Smyth, William C. Bradley, J. R. Poinsett.

Eighteenth Congress, second sessiou:

Senate . . . . M. Dickerson, J. Elliot, T. H. Williams.

House . . . William C. Rives, W. C. Bradley, J. R. Poinsett.

Nineteenth Congress, first session:

Senate . . . M. Dickerson, John Gaillard, Ashur Robbins,

Nathan Sanford (vice Gaillard, deceased).

House . . . Edward Eiverett, W. C. Bradley, Silas Wood.

Nineteenth Congress, second session:

Senate . . . M. Dickerson, A. Robbins, N. Sanford.

House . . . E. Everett, W. C. Bradley, S. Wood.

Twentieth Congress, first session:

Senate . . . M. Dickerson, N. Sanford, A. Robbins.

House . . . E. Everett, S. Wood, Charles Miner.

Twentieth Congress, second session:

Senate . . . N. Sanford, A. Robbins, Levi Woodbury.

House . . . . E. Everett, S. Wood, Charles Miner.

Twenty-first Congress, first session:

Senate . . . A. Robbins, L. Woodbury, Felix Grundy.

House . . . E. Eiverett, Gulian C. Verplanck, James M. Wayne.

Twenty-first Congress, second session:

Senate . . . A. Robbins, I. Woodbury, Theodore Frelinghuysen.

House . . . E. Iiverett, G. C. Verplanck, J. M. Wayne.

Twenty-second Congress, first session:

Senate . . . A. Robbins, T. Frelinghuysen, George Poindexter.

House . . . E. Iiverett, G. C. Verplanek, J. M. Wayre.

Twenty-second Congress, second session:

Senate . . . A. Robbins, G. Poindexter, George M. Bibb.

House . . . E. Everett, G. C. Verplanck, J. N. Wayne. 
Twenty-third Congress, first session:

Senate . . . A. Robbins, G. Poindexter, G. M. Bibb.

House . . . . E. Everett, J. N. Wayne, George Loyall.

Twenty-third Congress, second session:

Senate . . . A. Robbins, G. Poindexter, G. M. Bibb, Wm.

C. Preston (vice Poindexter).

House . . . E. Everett, J. N. Wayne, G. Loyall, Horace Binney (vice Wayne)

Twenty-fourth Congress, first session:

Senate . . . W. C. Preston, Alexander Porter, A. Robbins.

House . . . . G. Loyall, John MicKeon, Waddy Thompson.

Twenty-fourth Congress, second session:

Senate . . . A. Robbins, W. C. Preston, Garret D. Wall.

House . . . John M. Patton, J. McKeon, Henry L. Pinckney.

Twenty-fifth Congress, first session:

Senate . . . A. Robbins, W. C. Preston, G. D. Wall.

House . . . J. M. Patton, Isaac E. Crary, Levi Lincoln.

Twenty-fifth Congress, second session:

Senate . . . A. Robbins, William Allen, G. D. Wall.

House . . . . J. M. Patton, John Pope, Charles McClure.

Twenty-fifth Congress, third session:

Senate . . . A. Robbins, G. D. Wall, Wm. Allen.

House . . . . J. Pope, C. McClure, Jesse F. Cleveland.

Twenty-sixth Congress, first session:

Senate . . . Benjamin 'Tappan, W. C. Preston, G. D. Wall.

House . . . Dixon H. Lewis, Joseph I. 'Tillinghast, Charles

Naylor.

Twenty-sixth Congress, second session:

Senate . . . G. D. Wall, W. C. Preston, B. Tappan.

House . . . J. L. Tillinghast, Caleb Cushing, George M. Keim.

Twenty-seventh Congress, first session:

Senate . . . Thomas Clayton, IT. C. Preston, B. Tappan.

House . . . J. I. 'Tillinghast, John B. Aycrigg, T. D. Sumter.

Twenty-seventl Congress, second session:

Senate . . W. C. Preston, B. 'Tappan, Rufus Choate.

House . . . J. L. 'Tillinghast, J. B. Aycrigg, T. D. Sumter.

Twenty-seventh Congress, third session:

Senate . . . William Moodbridge, B. 'Tappan, R. Choate.

House . . . . J. L. 'Tillinghast, J. B. Aycrigg, 'I. D. Sumter.

Twenty-eighth Congress, first session:

Senate . . R. Choate, B. 'I'appan, John McP. Berrien.

House . . . . Fdunund Burke, George P. Marsh, William B.

Iaclay. 
Twenty-eighth Congress, second session:

Senate . . . R. Choate, B. Tappan, James A. Pearce.

House . . . E. Burke, G. P. Marsh, Lucius Lyon.

Twenty-ninth Congress, first session:

Senate . . . J. A. Pearce, Josepl W. Chalmers, Dixon H. Lewis.

House . . . Richard Brolhear, W. W. Campbell, E. WW. Hubard.

Twenty-ninth Congress, second session:

Senate . . . J. A. Pearce, J. W. Chalmers, D. H. Lewis.

House . . . R. Brodhead, W. W. Campbell, James McDorrell.

Thirtieth Congress, first session:

Senate . . . J. A. Pearce, Jefferson Daris, James M. Mason.

House . . . J. Q. Adams, William B. Preston, Henry C.

Murphy, John C. Palfrey (vice Adams, deceased).

Thirtieth Congress, second session:

Senate . . . . J. A. Pearce, J. Davis, J. M. Mason.

House . . . . W. B. Preston, H. C. Murphy, J. C. Palfrey.

Thirty-first Congress, first session:

Senate . . . . J. A. Pearce, J. M. Mason, J. Davis.

House . . . Isaac E. Holmes, Horace Mann, Alfred Gilmore.

Thirty-first Congress, second session:

Senate . . . J. A. Pearce, J. M. Mason, J. Davis.

House . . . . I. E. Holmes, H. Mann, William Duer.

Thirty-second Congress, first session:

Senate . . . J. A. Pearce, Jeremiah Clemens, Augustus C. Dodge, James A. Bayard (rice Dodge).

House . . . Joseph R. Chandler, Joseph A. Woodward, H. Mann.

Thirty-second Congress, second session:

Senate . . . J. A. Pearce, J. Clemens, A. C. Dodge.

House . . . . J. R. Chandler, J. A. Woodwarl, H. Manu.

Thirty-third Congress, first session:

Senate . . . J. A. Pearce, Lewis Cass, J. A. Bayard.

House . . . J. R. Chandler, Thomas H. Benton, Chas. J. Faulkner.

Thirty-third Congress, second session:

Senate . . . J. A. Pearce, L. Cass, J. A. Bayard.

House . . . J. R. Chandler, 'T. H. Benton, C. J. Faulkner.

Thirty-fourth Congress, first session:

Senate . . . J. A. Pearce, L. Cass, J. A. Bayard.

House . . . William Aiken, Job R. Ty'son, John U. Pettit.

$23399-44-33$ 
Thirty-fourtl Congress, stecond session:

Senate . . . J. A. Pearce, L. Cass, J. A. Bayard.

House . . . W. Aiken, J. R. Tyson, J. U. Pettit.

Thirty-fourth Congress, third session:

Senate . . . J. A. Pearce, L. Cass, J. A. Bayard.

House . . . IV. Aiken, J. R. Tyson, J. U. Pettit.

Thirty-fifth Congress, first session:

Senate . . . J. E. Pearce, J. A. Bayard, R. M. T. Hunter, William P. Fessenden (vice Hunter).

House . . . William H. Dinnnick, Warren Winslow, J. U. Pettit.

Thirty-fifth Congress, second session:

Senate . . . J. A. Pearce, J. A. Bayard, W. P. Fessenden.

House . . . W. H. Dimmick, W. Winslow, J. U. Pettit.

Thirty-sixtl Congress, first session:

Senate . . . J. A. Pearce, J. A. Bayard, Jacob Collamer.

House . . . J. U. Pettit, Charles F. LCans, Janes L. Pugh.

Thirty-sixth Congress, second session:

Senate . . . J. A. Pearce, J. A. Bayard, J. Collamer.

House . . . J. U. Pettit, C. F. Adans, J. L. Pugh.

Thirty-serenth Congress, first session:

Senate . . . J. A. Pearce, J. Collamer, II. P. Fessenden.

House . . . Edward McPherson, Augustus Frank, Jolni

Law.

Thirty-seventl Congress, second session:

Senate . . . J. A. Pearce, J. Collamer, Wr. P. Fessenden.

House . . . E. MicPherson, A. Frank, J. Law.

Thirty-serenth Congress, third session:

Senate . . . J. A. Pearce, J. Collanner, IV. P. Fessenden.

House . . . E. MicPherson, A. Frank, J. Law.

Thirty-eighth Congress, first session:

Senate . . . J.Collanner, Wr. P. Tessenclen, Reverdy Johnson.

House . . . A. Frank, Elihı B. Waslıburne, William F.

Wadsworth.

Thirty-eighth Congress, second session:

Senate . . . J. Collaner, R. Johnson, Jacoh M. Howard.

House . . . A. Frank, I. B. Washburne, W. H. Wadsworth. 
APPENDIX III.

Number of volumes in the Library.

\begin{tabular}{|c|c|c|c|}
\hline Date. & $\begin{array}{l}\text { Number of } \\
\text { volumes. }\end{array}$ & Date. & $\begin{array}{l}\text { Number of } \\
\text { volumes. }\end{array}$ \\
\hline ISO0 $\ldots \ldots \ldots \ldots \ldots . . . . .$. & 243 & $I 8_{4} 7 \ldots \ldots \ldots \ldots \ldots$ & 42,000 \\
\hline I $S_{1} 4 \ldots \ldots \ldots$ & 3,000 & $1849 \ldots \ldots \ldots \ldots \ldots \ldots \ldots \ldots \ldots \ldots$ & 45,000 \\
\hline I $S_{1} 5 \ldots \ldots \ldots \ldots \ldots$ & 6,487 & $1851 \ldots \ldots \ldots \ldots \ldots \ldots$ & 55,000 \\
\hline $1822 \ldots \ldots \ldots \ldots \ldots$ & 12,000 & 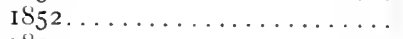 & 20,000 \\
\hline $1830 \ldots$ & I6,, 00 & $1853 \ldots \ldots \ldots \ldots \ldots \ldots$ & 35,000 \\
\hline $1836 \ldots \ldots$ & 24,000 & $I S_{54} \ldots \ldots \ldots \ldots \ldots \ldots \ldots$ & 40,000 \\
\hline $1840 \ldots \ldots \ldots \ldots \ldots$ & 30,000 & $1860 \ldots \ldots \ldots \ldots \ldots \ldots$ & 63,000 \\
\hline I $845 \ldots \ldots \ldots \ldots$ & 40,000 & $186_{4} \ldots \ldots \ldots \ldots \ldots \ldots$ & 82,000 \\
\hline
\end{tabular}

\section{Appendix IV.}

Legislative appropriations for the Library of Congress. ${ }^{x}$

\begin{tabular}{|c|c|c|c|c|c|c|c|c|}
\hline Date. & Salaries. & Books. & $\begin{array}{l}\text { Law } \\
\text { books. }\end{array}$ & $\begin{array}{l}\text { Contin- } \\
\text { gent ex- } \\
\text { penses. }\end{array}$ & $\begin{array}{c}\text { Publica- } \\
\text { tion } \\
\text { of cata- } \\
\text { logue. }\end{array}$ & Repairs. & $\begin{array}{c}\text { Ex- } \\
\text { changes. }\end{array}$ & $\begin{array}{l}\text { Furni- } \\
\text { ture. }\end{array}$ \\
\hline $1900 \ldots \ldots \ldots \ldots$ & $\cdots \cdots$ & $\$ 5, \infty 00.00$ & & & & & & \\
\hline I $905 \ldots \ldots \ldots \ldots$ & & & & $2 \$ 900.00$ & & $\$ 700.00$ & & \\
\hline $05 \ldots \ldots \ldots \ldots$ & & $5,000.00$ & $\ldots$ & 2450.00 & & $\ldots \ldots \ldots$ & & \\
\hline $\begin{array}{r}\ldots \ldots \ldots \\
\ldots \ldots \ldots \ldots\end{array}$ & & & $\cdots$ & $\begin{array}{l}2500.00 \\
2500.00\end{array}$ & .. & $\ldots \ldots$ & & \\
\hline $\begin{array}{l}1 \text { sas } \ldots \ldots \ldots \ldots \ldots \\
\text { ison, } \ldots \ldots \ldots \ldots \ldots\end{array}$ & & $\cdots$ & …… & $=800.00$ & a.......... & $5,000.00$ & & \\
\hline $\begin{array}{l}1 \text { 1 } \\
1,10, \ldots \ldots \ldots \ldots \ldots\end{array}$ & & & (n........ & 2800.00 & & & $\cdots \cdot \cdot$ & \\
\hline Is $11 \ldots \ldots \ldots \ldots$ & $\ldots \ldots \ldots \ldots$ & $5,000.00$ & $\ldots \ldots \ldots$ & 2.500 .00 & $\ldots \ldots$ & 000.00 & $\ldots \ldots \ldots$ & $\cdots$ \\
\hline $1812 \ldots \ldots \ldots \ldots$ & & $\cdots \cdots$ & $\ldots \ldots \ldots$ & 2500.00 & $\cdots \cdots \cdots$ & $\cdots \cdots$ & 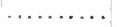 & \\
\hline $1 \$: 3 \ldots \ldots \ldots \ldots \ldots$ & & & $\cdots \cdots$ & 2800.00 & $\ldots \ldots \ldots$ & & & \\
\hline $1814 \ldots \ldots \ldots \ldots \ldots$ & & $\cdots$ & $\ldots \ldots \ldots$ & 2800.00 & 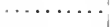 & & & \\
\hline $\begin{array}{l}\text { Isis } \ldots \ldots \ldots \ldots \\
\text { isio } \ldots \ldots \ldots \ldots \ldots\end{array}$ & an. & $\begin{array}{l}23,950.00 \\
\ldots \ldots \ldots \ldots\end{array}$ & $\ldots$ & 2500.00 & $\cdots \cdots$ & & $\cdots$ & $\$ 972.37$ \\
\hline $1916 \ldots \ldots \ldots \ldots \ldots$ & $\$ 900.00$ & 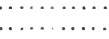 & 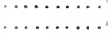 & $6,262.56$ & $\ldots \ldots$ & & & $1,520.87$ \\
\hline $1517 \ldots \ldots \ldots \ldots \ldots \ldots$ & I, 500.00 & $2,000.00$ & $\ldots \ldots \ldots \ldots$ & $\begin{array}{l}450.00 \\
.450 .00\end{array}$ & …...... &. & $\begin{array}{l}\cdots \ldots \ldots \\
\ldots \ldots \ldots\end{array}$ & $537-70+2$ \\
\hline 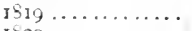 & $1,500.00$ & . $\ldots \ldots \ldots$ & ....... & 450.00 & $\ldots \ldots$ & & $\ldots$ & $\begin{array}{l}537 \\
375\end{array}$ \\
\hline $1520 \ldots \ldots \ldots \ldots$ & $1,500.00$ & $2,000.00$ & $\ldots \ldots \ldots$ & $45^{\circ} .00$ & & & & $3 / 5.00$ \\
\hline $1521 \ldots \ldots \ldots \ldots$ & $1,500, \infty$ & $1,000,00$ & $\cdots$ & $450 . \infty 0$ & $\cdots \ldots$ & - & ........ & $\cdots$ \\
\hline $1522 \ldots \ldots \ldots \ldots$ & I, 500.00 & $1,000.00$ & $\ldots \ldots \ldots \ldots$ & 450.00 & ...... & $\cdots$ & & \\
\hline $1523 \ldots \ldots \ldots \ldots \ldots$ & $I, 500.00$ & $2,000,00$ & $\ldots \ldots \ldots \ldots$ & $45^{\circ} . \infty$ & $\ldots \ldots \ldots$ & $\cdots$ & $\cdots$ & \\
\hline $1524 \ldots \ldots \ldots \ldots \ldots$ & $1,500.00$ & $5,000,00$ & $\ldots \ldots \ldots \ldots$ & 450.00 & $\ldots \ldots \ldots$ & . & $\cdots \cdots$ & $1,5+5,00$ \\
\hline $1,825 \ldots \ldots \ldots \ldots$ & $1,500.00$ & $5,000,00$ & $\ldots \ldots$ & 450.00 & $\ldots \ldots \ldots$ & $\cdots \cdots \cdots$ & …..... & 339.00 \\
\hline $1825 \ldots \ldots \ldots \ldots \ldots$ & $1,500.00$ & $5,000,00$ & $\cdots \ldots \ldots \ldots$ & 450.00 & $\ldots \ldots \ldots$ & & .. & 295.25 \\
\hline $\begin{array}{l}1527 \ldots \ldots \ldots \ldots \\
1524 \ldots \ldots \ldots \ldots \ldots\end{array}$ & $\left|\begin{array}{l}2,300.00 \\
2,950.50\end{array}\right|$ & $\begin{array}{l}3,000.00 \\
5.000 .00\end{array}$ & $\begin{array}{l}\cdots \ldots \ldots \ldots \\
\ldots \ldots \ldots \ldots\end{array}$ & $\begin{array}{l}450.00 \\
\ldots \ldots\end{array}$ & $\begin{array}{l}\cdots \ldots \ldots \ldots \\
\ldots \ldots \ldots \ldots\end{array}$ & $\cdots$ & $\begin{array}{l}\cdots \cdots \\
\cdots \cdots\end{array}$ & $\cdots \cdots \cdots$ \\
\hline I $920 \ldots \ldots \ldots \ldots$ & $2,300.00$ & 5,00 & $\cdots \cdots \cdot$ & 450.00 & $\ldots \ldots \ldots$ & & $\cdots$ & $\ldots \ldots$ \\
\hline $193^{0} \ldots \ldots \ldots \ldots$ & $2,300.00$ & 5,00 & $\ldots \ldots \ldots$ & 450.00 & $\ldots \ldots \ldots$ & $\cdots$ & $\cdots$ & 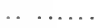 \\
\hline $18_{3} 1 \ldots \ldots \ldots \ldots$ & $2,300,00$ & $5,000.00$ & ….... & $\$ 00.00$ & $\cdots \cdots$ & $\ldots$ & $\ldots \ldots \ldots \ldots$ & $\ldots \ldots$ \\
\hline $1532 \ldots \ldots \ldots \ldots$ & $2,300.00$ & $5,000.00$ & $\because 7,000,00$ & 500.00 & . $\cdot$ & $\cdots \cdots$ & ........ & $3,000.00$ \\
\hline $1833 \ldots \ldots \ldots \ldots \ldots$ & $2,650.00$ & 5.000 .00 & $1, \infty 00 . \infty$ & 900.00 & $\cdots \cdots$ & & & . \\
\hline $19,34 \ldots \ldots \ldots \ldots$ & $2,650.00$ & $5,000,00$ & $1, \infty 0, \infty$ & I, 100.00 & .. & $\cdots$ & & \\
\hline $1535 \ldots \ldots \ldots \ldots \ldots$ & $2,650.00$ & $5,000.00$ & $1, \infty \infty, \infty$ & $1,100.00$ & & & $\cdots \cdots$ & $1,500.00$ \\
\hline $1, y, \ldots \ldots \ldots \ldots$ & $3,043.00$ & $5,000.00$ & $1,000.00$ & $1,200.00$ & $\cdots \cdots$ & & * & $\cdots \cdots$ \\
\hline $1927 \ldots \ldots \ldots \ldots$ & $4,145.00$ & $5,000,00$ & $5,000.00$ & 500.00 & on. & & & $\cdots \cdots$ \\
\hline $14 y_{n} \ldots \ldots \ldots \ldots$ & $3,922.40$ & $5,000.00$ & $\cdots \cdot \ldots$ & 500.00 & $p 1,400,00$ & & $\cdots$ & \\
\hline $1330 \ldots \ldots \ldots \ldots$ & 3.350 .00 & 5 & & $\begin{array}{l}600.00 \\
600,00\end{array}$ & $\cdots$. & $\cdots$ & . & \\
\hline 1 & $\begin{array}{l}3,73 \% \cdot 50 \\
4,579.37\end{array}$ & $\begin{array}{l}5,000.00 \\
5,000.00\end{array}$ & $\ldots \ldots \ldots$ & 600.00 & 273.00 & & & . \\
\hline $\sin 1 \geq \ldots \ldots \ldots \ldots$ & 5.300 .00 & $5,000,00$ & $1, \infty \infty, \infty$ & $1,800,00$ & $\ldots \ldots \ldots$ & & . & . \\
\hline $14+33 \ldots \ldots \ldots \ldots$ & $2,250.00$ & $2,500,00$ & 500.00 & 400.00 & & & & \\
\hline $1313-\ldots+\ldots \ldots \ldots$ & $4,500.00$ & $5,000,00$ & $\mathrm{I}, 000.00$ & $1,025.00$ & & & & 225.00 \\
\hline $14:-15 \ldots \ldots \ldots$ & $4,500.00$ & $2,500.00$ & $1,000,00$ & 600.00 & & & & \\
\hline $1,-4, \ldots \ldots \ldots$ & 4.500 .00 & $5,000,00$ & $1,000.00$ & 600.00 & & $\cdots \cdots$ & & \\
\hline $1+y^{+}-4 \ldots \ldots \ldots$ & $\begin{array}{l}4.500 .00 \\
4.500 .00\end{array}$ & $\begin{array}{l}5,000.00 \\
5,000,00\end{array}$ & $1, \infty 00.00$ & $\begin{array}{r}500.00 \\
\end{array}$ & & $2,412.00$ & $\$ 500,00$ & \\
\hline $14 y-4, \ldots \ldots \ldots \ldots$ & 4.500 .00 & 5.000 .00 & $1,000.00$ & $1,400.00$ & $\ldots \ldots \ldots$ & & $2,000.00$ & \\
\hline $14-50 \ldots \ldots \ldots$ & $4,500.00$ & 5.060 .00 & $1,000,00$ & $\$ 00.00$ & $2,000.00$ & & & \\
\hline
\end{tabular}


Legislative appropriations for the Library of Congress-Continued.

\begin{tabular}{|c|c|c|c|c|c|c|c|c|}
\hline Date. & Salaries. & Books. & $\begin{array}{c}\text { Law } \\
\text { books. }\end{array}$ & $\begin{array}{l}\text { Contin- } \\
\text { gent ex- } \\
\text { penses. }\end{array}$ & $\begin{array}{l}\text { Publica- } \\
\text { tion } \\
\text { of cata- } \\
\text { logue. }\end{array}$ & Repairs. & $\begin{array}{c}\text { Ex- } \\
\text { changes. }\end{array}$ & $\begin{array}{l}\text { Furni- } \\
\text { ture. }\end{array}$ \\
\hline $1850-51$. & $\$ 4,500.00$ & $\$ 5,000,00$ & $\$ 2,000,00$ & $\$ 1,800,00$ & & & $\$ 2,000.00$ & \\
\hline $1851-52 \ldots \ldots \ldots \ldots$ & $4,500,00$ & $5,000.00$ & $2,000,00$ & Soo. 00 & & & & \\
\hline $1552-53 \ldots \ldots \ldots$ & $5,273.00$ & $85,000.00$ & $2,000.00$ & 800.00 & $\cdots$ & $5-5,700.00$ & I, 000.00 & \\
\hline $1853-5+\ldots \ldots \ldots$ & 4.500 .00 & $5,000.00$ & $3,700.00$ & $1,000,00$ & $\$ 3,000.00$ & $20,500.00$ & $\ldots \ldots \ldots$ & . \\
\hline $155.4-55 \ldots \ldots \ldots$ & $6,714.18$ & $5,000,00$ & $2,000.00$ & $1,000,00$ & $5,000.00$ & $3,500.00$ & & \\
\hline $1855-56 \ldots$ & $10,416.6 S$ & $5,000.00$ & $2,000.00$ & $1,000.00$ & I......... & $\ldots \ldots \ldots$ & & \\
\hline $1856-57$. & $9,000.00$ & 5.000 .00 & $2,000.00$ & I, $, 000,00$ & & & & $\$ 400.00$ \\
\hline $1 \div 5 ;-5 k$. & $9,000.00$ & $5,000.00$ & $2,000,00$ & $1,000.00$ & $4,000,00$ & & & 270.00 \\
\hline $1855-59 \ldots \ldots \ldots$ & $9,000.00$ & 5.000 .00 & $2,000.00$ & $1,000.00$ & $\ldots \ldots \ldots$ & $\ldots$ & $\cdots$ & $\ldots \ldots \ldots$ \\
\hline Is $59-60 \ldots \ldots \ldots$. & 9.000 .00 & $5,000.00$ & $2,000,00$ & $1,000,00$ & & & & \\
\hline $1560-61 \ldots \ldots \ldots$ & 9.000 .00 & $5,000,00$ & $2,000.00$ & $1,000.00$ & & & & \\
\hline $1501-62 \ldots \ldots \ldots$ & $9,000,00$ & $5,000.00$ & $2,000.00$ & $1,000.00$ & & & & \\
\hline $1862-63 \ldots \ldots \ldots$ & $10,000.00$ & $5,000.00$ & $2,000.00$ & $I, 000.00$ & & $\ldots$ & & $\cdots$ \\
\hline $1863-64 \ldots \ldots \ldots$ & $10,209.00$ & $5,000.00$ & $\therefore, 000.00$ & $\mathrm{I}, 000.00$ & $\ldots \ldots \ldots$ & $7,500.00$ & & $I_{4}, 000.00$ \\
\hline \multirow[t]{2}{*}{$1864-65 \ldots \ldots \ldots$} & \multirow[t]{2}{*}{$10,500,00$} & 5.000 .00 & $2,000.00$ & \multirow[t]{2}{*}{$2,000.00$} & \multirow[t]{2}{*}{ 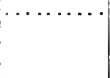 } & \multirow[t]{2}{*}{$1,700.00$} & & \\
\hline & & $329,950.00$ & $53,700.00$ & & & & & \\
\hline
\end{tabular}

1 Fot civil war papers.

\section{Appendix V.}

Catalogues of the Library of Congress, r8oo-1867.

[List of books purcliased by Caddell and Daris for the library of Congress.]

[Washington, rsor.] $s p . \mathcal{S}^{\circ}$.

Letter from Cadkell and Davis, dated London, December II, ISoo, to W. Bingham and Robert Waln, including an invoice of the books sent. This is bound in a volume lettered "State Papers, ISoI, December, ISo2, January" in the Library of Congress.

I. Catalogue | of | Books, Maps, and Charts, | Belonging to | the library | of the | two Houses of Congress. | - I April, I 802. $1-1$

Washington City': Printed by William Inuane. |. . . . I [r8o2.] Io p. $\mathrm{s}^{\circ}$.

Books arranger by size; estimated value of each book is afixed.

Supplemental catalogue of books, maps, and charts, belonging to the library of the two Houses of Congress. October, 1803 .

Washington City: Printed by James D. Westcott [1803]. 2 p.l., [3] p. s $^{\circ}$.

II. Catalogne of books, maps, and clarts, belonging to the library of the two Houses of Congress. I $\mathrm{SO}_{4}$.

[Washington, rsot.] I $_{3} \mathrm{p} . \mathcal{S}^{\circ}$.

III. Catalogue of the books, maps and charts belonging to the library established in the Capitol at the city of Washington, for the two houses of Congress: to which are prefixed the statutes and bye-laws relative to that institution.

City of Washington: A. \& G. Way, printers, Isos. to p. so. 
IV. Catalogue of the books, maps and charts, belonging to the library established in the Capitol at the city of Washington, for the two houses of Congress: to which are annexed the statutes and bye-laws relative to that institution.

Il'ashington City: Printed by Roger C. Ilcightman, I812. IOI p. $8^{\circ}$.

First classified catalogue of the library, and last one issued before its destruction in I $S_{14}$. Represents 3,076 volumes (in 18 classes, sub)arranged by size), 53 maps, charts, and plans.

V. Catalogue of the Library of the United States. To which is annexed, a copious index, alphabetically arranged.

IVashington: Printed by Jonathan Elliot, I815. 5 p.l., [3]-I7o, xxxiip. $t^{\circ}$.

Pp. iii-xxi at the end are taken up with the index; pp. xxiii-xxviii contain the "Rules and regulations to be observed in the Library of Congress;" pp. xxix-xxxii "Abstract of laws concerning the Library of Congress."

This Catalogue comprises exclusively the books purchased from Thomas Jefferson in $18_{15}$. The titles are arranged in alphabetical order under 44 divisions based upon Bacon's classification of buman knowledge which was the basic scheme of the arrangement of the Library until the enil of the century.

A supplement to the Catalogue of the Library of Congress.

W'ashington City': Printed by' Daniel Rapine (agent), Capitol Hill, I820. $28 \mathrm{p} .4^{\circ}$.

Alphabetical by authors.

A supplement to the Catalogue of the Library of Congress.

Washington: Printed by Davis \& Foree (Franklin's head), Pennsyliania aremue, I825. to p. $8^{\circ}$.

Includes titles contained in $1 \$ 20$ supplement.

A supplement to the Catalogue of the Library of Congress.

Il'ashington: Printed by Peter Foree, comer of Eleventh street and Pennsyliania arenue, I827. I09 p. $8^{\circ}$.

Classified, with author index. Cumulative, including litles contained in supplements of 1820 aud 1825 .

An additional supplenent to the Catalogue of the Library of Congress. l'ashington: Printed by Rothwell of Ustick, 1828 . I6 p. $8^{\circ}$.

VI. Catalogue of the I,ibrary of Congress, December, is 30.

H'ashington: Irinted by Duff Green, $1830 . \quad$ i'i, [9]-258 p. $8^{\circ}$.

VII. Catalogute of the I,ibrary of Congress, in December, I 830 ; a supplement of the additions in December, I $_{3} \mathrm{I}$; and an index to the names of anthors and annotators, and to the publications of learned societies, to encyclopedias, newspapers, reviews, magazines, \&c.

Washington: Printed by Duff Green, I83I. vii, [q]-362 p. $8^{\circ}$. A reissue of the catalogue of ${ }_{1} S_{3} \mathrm{O}$, with supplement, p. 259-320, and author index p. $321-362$. 
Supplement to the catalogue of the Library of Congress, December, I 83 I.

[Washington: Printed by D. Green, $\left.I 8_{3} I.\right]$ I p. I., [26I]-320 p. $8^{\circ}$.

Supplement to the catalogue of the Library of Congress, December, 1833 .

[Washington: F. W. De Krafft, printer, 1833.] 92 p. $8^{\circ}$.

Cataiogue of additions to the Library of Congress since December, I 833 .

[IVashington, 1834]. 13 p. $8^{\circ}$. Half title.

Catalogue of additions to the Library of Congress since December, 1834 .

[Washington, 1835]. 22 p. $8^{\circ}$. Half title.

Catalogue of additions to the Library of Congress since December, 1835 .

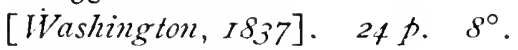
Half title.

Catalogue of books in the law department of the Library of Congress, January I, 1839.

[Washington, 1839]. 98 p. $8^{\circ}$.

$4,17+$ vols. Advance issue of chapters $18-23$ of the following:

VIII. Catalogue of the Library of Congress, in the Capitol of the United States of America, December, I 839.

City of Washington: Printed by order of Congress, (By' Langtree and O'Sullivan) 1840 . vii, (9) 747 p. $8^{\circ}$.

Supplement to the Catalogue of the Library of Congress, December, I 840 .

[Washington, I8fo]. (I p. l. $), 28$ p. $s^{\circ}$. Half title.

Supplement to the Catalogue of the Library of Congress, December, I 842 .

[Washington, I842]. (I p. I. ), 29 p. $\mathcal{S}^{\circ}$. Half title.

Supplement to the Catalogue of the Library of Congress, December, I 843 .

[Washington, 1843]. (I p.l.), 33 t. $8^{\circ}$. Half title.

Supplement to the Catalogue of the Library of Congress, December I, 1844.

[Washington, 1844]. 20 p. $8^{\circ}$. Caption title. 
Supplement to the Catalogue of the Library of Congress, December I, $1 S+5$.

[Washington, 1875]. I9 p. $8^{\circ}$.

Caption title.

Supplement to the Catalogue of the Library of Congress, December I, $18+6$.

[Washington, $18, f 6] .12 p . \quad 8^{\circ}$.

Caption title. Contains the first list of copyright books "received in compliance with the roth section of the "act to establish the Smithsonian Institution." " (Section repealed IS59.)

Supplement to the Catalogue of the Library of Congress, December $6,18+7$.

[Washington, 1847]. 23 p. $8^{\circ}$. Caption title.

Supplement to the Catalogue of the Library of Congress, December, I848.

[Washington, 1848 ]. $4^{6}$ p. $8^{\circ}$.

Caption title.

IX. Catalogue of the Library of Congress, June 30, I 849.

[Washington, 1879]. ro22 p. $8^{\circ}$.

No t. p. Title taken from binder's label. Chapters $18-23$ were reissued as follows:

Catalogue of books in the law department of the Library of Congress, December, is 49 .

City of Washington: Printed by order of Congress [by' Towers], 1879. is', 139p. s $^{\circ}$.

Supplement to the Catalogue of the Library of Congress, December, I 850 .

[IVashington, 1850 ]. 36 p. $8^{\circ}$.

Caption title. Lists of books reccived by international excliange, "Agency of A. Vattemare," p. 32-36.

Supplement to the Catalogue of the Library of Congress. Decemleer, 1851. [Hashington, 1851 ]. $33 \mathrm{p} . \mathrm{S}^{\circ}$.

Caption title.

Additions nade to the Library of Congress since the first day of December, 1851. November 1, 1852.

IVashington: Printed by Lemuel Towers, $1852.129 p .8^{\circ}$.

Additions made to the Library of Congress since the first day of

November, 1852 . November I, 1853.

Washington: Printed by Lemuel Towers, 1853 . 21I p. $8^{\circ}$. 
Additions made to the Library of Congress since the first day of November, 1853 . November I, I 854.

IVashington: Printed by John T. and Lem. Towers, 1854. 295 p. $8^{\circ}$.

Catalogue of the Library of Congress. Chapter I. Ancient history. Complete to January, i 854 .

Washington: Stereotyped and printed at the Smithsonian Institition, 1854.77 p. $8^{\circ}$.

Prepared upon the plan recommended by Professor Jewett, of the Smithsonian Institution..

Catalogue of the Library of Congress. Chapter I. Ancient history. Complete to January, I 854 .

Washington: Stereotyped and printed at the Smithsonian Institution, r854. (r p.l.), rq. ( $r$ ) p. Folio.

Additions made to the Library of Congress since the first day of Norember, I 854 . Norember I, 1855.

Washington: Printed by John T. and Lem. Towers, I855. 249 p. $s^{\circ}$.

Additions made to the Library of Congress since the first day of November, i 855 . November I, I856.

Hashington: Printed by John T. \& Lem. Towers, 1856. 125 p. $8^{\circ}$.

Additions made to the Library of Congress since the first day of November, 1856 . November I, 1857.

Washington: Printed by Lemuel Towers, 1857. 93 p. $8^{\circ}$.

Additions made to the Library of Congress since the first day of November, 1857. November I, I 858.

Washington: Printed by Lemuel Towers, $1858.7 x p . \quad 8^{\circ}$.

Additions made to the Library of Congress since the first day of July, 1859 . November I6, I 859.

Washington: Printed by Lemul Towers, 1859 . to p. $8^{\circ}$.

Additions made to the Library of Congress since the sixteenth day of November, i 859. November I, 1860.

Washington: Printed by I.cmuel Toaers, I860. $37 \mathrm{p} . \quad 8^{\circ}$.

Catalogue of the Library of Congress. Chapters XVIII-XXIII. Jurisprudence.

IVashington: Printed by order of Congress [by Towers], is6o. viii, 225 p. $8^{\circ}$.

Added t. p. Catalogue of the law department of the Library of Congress. By Charles II. W. Mreeha11.

I5939 vols. Advance issue of portion of following: 
X. Catalogue of the Library of Congress. Printed by order of Congress.

City of II ashington: Lemuel Towers, printer, rS6r. aiii, $1398 \mathrm{p}$. $S^{\circ}$.

Additions made to the Library of Congress since the first day of November, 1860. With omissions from the last general catalogue. December I, I86 I.

Washington: Government printing office, 1862. So p. $8^{\circ}$.

Catalogue of additions made to the Library of Congress from December 1, 1861, to December 1, 1862.

Washington: Government printing offcc, 1862. 151,33p. $8^{\circ}$.

The 33 pages at end contain list of law books.

Catalogue of additions made to the Library of Congress from December 1, 1862, to December 1, 1863.

Washington: Govemment printing office, $1863 . \quad 11+p . \quad 8^{\circ}$.

Catalogue of additions made to the Library of Congress from December 1, I 86.3 , to December I, i 864.

I'ashington: Govrmment printing office, 1867. 113 p. $8^{\circ}$.

XI. Alphabetical catalogue of the Library of Congress. Authors. Washington: Government printing officc, 1867.1236 p. $7^{\circ}$.

\section{APPENDIX VI.}

\section{Classification of ihe Library}

In this table the earlier schemes of classification are indicated in detail; the Spofford scheme is printed in a fragmentary form, and only with a view to illustrating the evolution of the schene originated by Jefferson. It may be observed, however, that the principal modifications introduced during the Spofford administration, besides those here noted, consisted in additions of form classes, geographical subdivisions, and subdivisions by subject arranged alphabetically. The classes in the schemes of 1815 and of 1861 which Librarian Spofford retained, with such subdivisions as were necessary, are indicated in this table in SMALL CAPITALS; the new classes introduced into the schemes of Librarian Meehan and Librarian Spofford (the latter in part only) are indicated in italic. Of other changes of location, of name, or by subdivision, the first are indicated by numbers in parentheses following the nane of the class and showing the number of the class to which the section was transferred. 



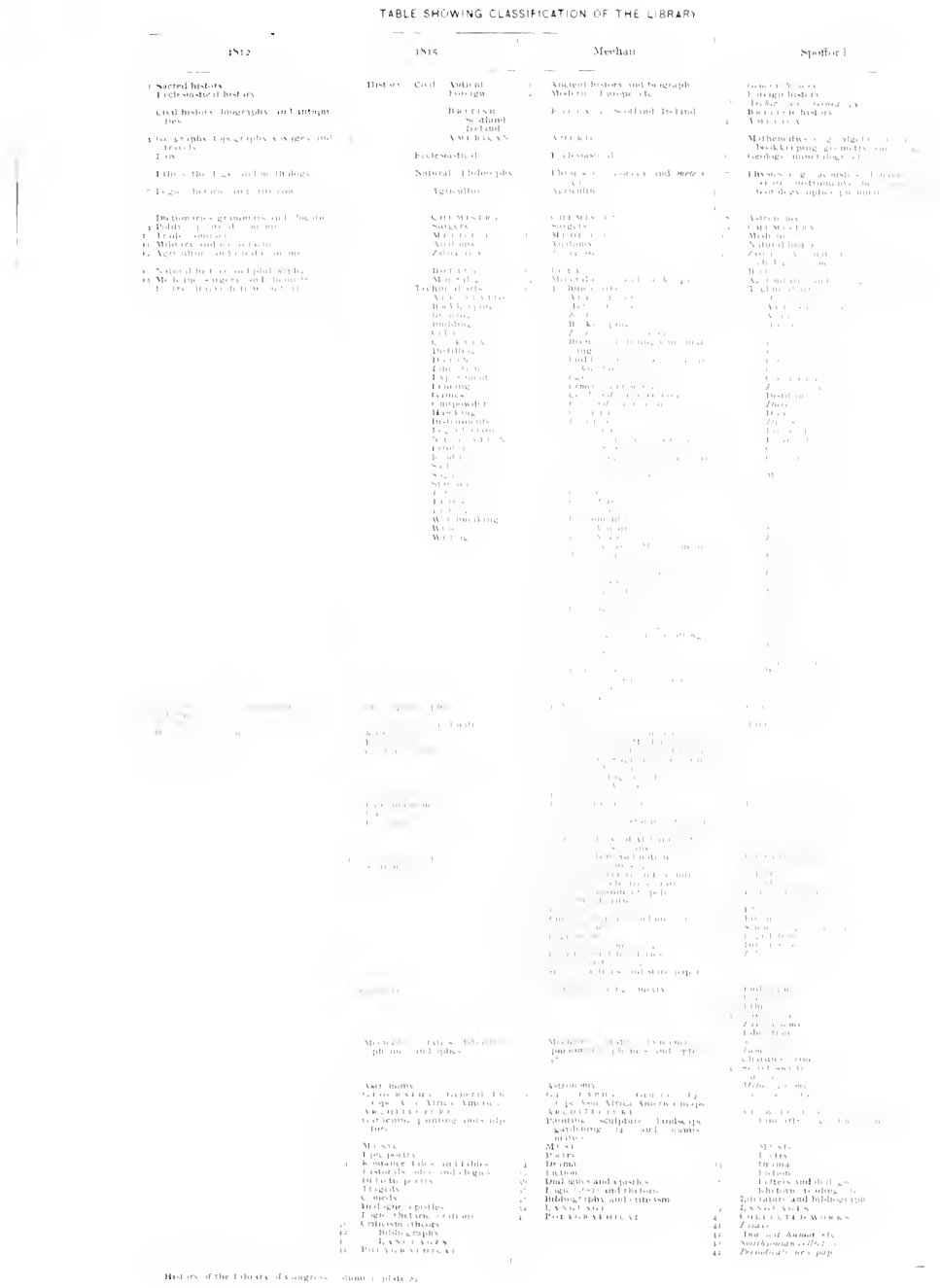




\section{INDEX}

Access to shelves, 216,380 .

Accession book, 35, I8o.

Adams, John Quincy, on the work of the Library Committec, $47,48$.

Adams \& Co.'s express, damage for i11jured books, 352 .

Admission to the Library, $185,376$.

Agent of the Joint Library Committee to have library privileges, 57 .

Alexander VI, Pope, bull on dirision of the New World, acquired, 3 Io.

Allen, Edward, London agent of the Library, $35 \mathrm{I}$.

American Association for the Advancement of Science, commitiee on geographical department in Library, 3.40.

American Athenæun in Paris, proposed as agency for exchanges, $25^{\mathrm{S}}$.

American Bibliographer, Stevens's, 47 I.

American history, collections for, I69; lack of materials, 447 ; relation of $\mathrm{Li}$ brary to, 50, 234, 492; transcripts of colonial documents, 166, 3 I5. See also Civil war.

American libraries, I68, 233; Jewett's report o11, 452; Rhees's manual of, 452; union catalogne of, 452 ; compared with Europea11, 240, 473.

Anerican natural history, bibliography of, 473 .

American Register. See Walsh's American Register.

American scliolars, need of large libraries for, $479,481,483$.

American topograplys, Tatham's collection, $5 \%$.

Americana, 446; Iarrard collection of, 168; Obadiah Rich's collection of, 167 ; to be collected for the Library, 165,246 ; collection in the Library, $3 \mathrm{II}$; bibliography of, proposerl, 453; to be compiled by Stevens, 467 ; prospectus of, 468 ; in the British Museum, 470; catalogue of, 472 .
Anderson, Charles F., plan for extension of Capitol, 218.

Anderson \& Meehan, publishers, 213.

Anonymous works, cataloguing of, 356 , 357,365 .

Appropriations, I9, $41,152,159,163$; table of, 5 I5.

Archives to be removed to Library, I6o. Assistant librarian, 348; office established, I 79.

Astor Library, 243.

Attorney-General, I,ibrary privilege for, $29,56,154,183$.

Atwater, Caleb, on tle Library, $353,382$. Bache, plaus a bibliographical bureau, 450.

Bacon, Joln1, on appropriation for the Library, 29.

Baconian classification, i.t2.

Baldwin, Abraluam, chairman of Lilorary Committee, 35, 36 .

Barlow, Joel, private library of, 36 .

Bartlett, Richard, on danger of nonfireproof room, ${ }_{3} 8$.

Bavaria, proposes exchange of public documents, 264.

Bayard, Janies A., nember of Committee on Library Organization, 26; on appropriation, 29; on extension of I, ibrary privilege, $3 \mathrm{I}$.

Beckley, John, appointed Librarian, 34.

Belgitum, proposes excliange of pulblic docunients, 257 .

Benton, his use of the Library, 380 .

Bequests. Sie Donations.

Bibliograplia Anericana, to be conpiled by Stevens, 467; prospectus of, 468 .

"Bibliograplia Americana historico-naturalis," 472.

Bibliographical bulletin, proposed by Jewett, 440,463 .

Bibliograplical bureau, proposed by Bacle in connection with the Snithsonian Institution, 450; by Henry, $4 \$ 6$. 
Bibliographical policy of Library, 226, 302.

Bibliographical works, value of, 437 ; Smithsonian collection of, 436 ; to be published by Smithsonian, 467; Smithsonian catalogue of, 473 .

Bibliography, of Americana, 453; of education, 473; of natural history, 472; of Rebellion literature, 373; universal, 464.

Bibliothèque Nationale, Paris, design for, described, I24.

Bigger, Finley, appointed disbursing officer, $35 \circ$.

Bills, preservation of, 398 .

Binding of books, 353 .

Bingham, William, member of Joint Library Committee, 24.

Blodget, Samuel, suggests law to augment National Library, 46, note.

Blodget's Hotel, occupied by Library, r 20.

Bond, given by Librarian, 33, I9o, I9I, 192, 193, 195 .

Book agents appointed, 350; commission of, $35 \mathrm{I}$.

Books, prices of, 37, 90, 239, 309, 423.

Books, time required for reading, 476 ; uses of, 477 .

Borland, on purchase of MS. of Washington's Farewell Address, $33^{\circ}$.

Borrowing books, 5 , IS1, 182, 375, 506 .

Bossange, Hector, offers to supply books for Library, $35 \mathrm{I}$.

Boston Athenæum, acquires Washington's library, 248.

Bosion Daily Ad'ertiser, December 23, I 825 , on Library fire, 132.

Botanical muscum, Watterston on, I 12.

Bradley, bibliographical plan of, 225, 226.

British Inseum, cataloguing in, 356; copyright privilege in, 445; collection of Americana in, 246, 470; catalogue of Americana in (Sterens), 472; deficiencies in, 485; example of, 160 .

Brodhead, on expenditures for the repair of the Library room, 296.

Brow11, on purchase of MS. of Washington's Farewell Address, 332.

Brown University Library, bibliograplical collection in, 437 .

Buchanan, on the organization of the Smithsonian Institution, 4I5.

Suckingham, James Silk, on the Library, 379.
Building suggested for Library, I 23.

Bulfinch, Charles, plan for Library rooms, I28; on rendering Library fireproof, 136.

Buturlin library, offered to Congress, 229; opinion of the press on, 230; G. W. Greene on, 236; discussed in Senate, 238 ; planned as nucleus of Astor L ibrary, 243.

Buying, 428 ; in Europe, 152, 162 ; in $\mathrm{IS}_{52}$, 3or; bids, 308. See also Book agents, prices.

Cadell \& Davies, London booksellers, 24. Calendaring of MSS., 314.

Canada, proposes exchange of public documents, 264.

Carey \& Co., Plinladelphia booksellers, 164.

Carter, on purchase of MIS. of Washington's Farewell Address, 332.

Cartographical depot, proposed, 346.

Casey, on purchase of MS. of Washington's Farewell Address, 331.

Cass, Lewis, on need for national library, 228; subunits resolution on inquiry into the origin of the fire, 2S.4 on expense of the fire, $2 S_{5}$; his use of the Library, 38 .

Catalogue, scrapbook, 356; union, 398, 431, 452, 463; universal (Jewctt), 46.4.

Catalogues of Library, 147,354 ; criticism of, 148,355 ; cost of, $149,355,362$; distribution of, 367 ; format of, 466 ; list of, 516; of documents, 25I; of rebellion literature, 373 .

Cataloguing, cooperative, $358,360,455$; conditions necessary in, 465 ; rules for, 454; of anonymous works, 356, 357, 365 .

Champagne Club (January 3, I $S_{35}$ ), describes the reading room, $3 \mathrm{So}, 3^{S} \mathrm{I}$.

Chandler, on purchase of MS. of Washington's Farewell Address, 332, 338 .

Chaplains of Congress, Library privilege for, $18_{3}, 373$.

Charging system, 5S, IS1, IS2, 505.

Clioate, Rufus, on the Library, I 86,409 ; on the organization of the Smithsonian Institution, 404; on the Smithsonian library, 434; resigns as Regent of, 496.

Civil war, literature on, 247.

Cliarts in Library, 60.

Chittenden, Lucius E., appointed disbursing officer, $35^{\circ}$.

Clarke, on purcliase of MISS., 325. 
Classification, by size, 4S, 49; by subject (Jefferson), I41; morlifications, 36\%; table exhibiting development of, $52 \mathrm{r}$; of Senate library, 399.

Clay, Henry, letter to Watterston on his removal, 199; on Buturlin library, 2.43; on purchase of MS. of Washington's Farewell Address, 327.

Clayton, on transcription of documents on American history, 316.

Clerk of the Ilouse, to take charge of the Library, 27; Library privilege for, $1 S_{4}$, 373 .

Clingman, on repairing the Library room, 291.

Closing of the Library, $28,5 \$, \mathbf{S} 5,36 \mathrm{~S}$, 376.

Cluskey. C. B., on lighting the Library, 217.

Coale \& Maxwell, Baltimore booksellers, I55.

Collamer, on Senate library, 400.

Collections (IS14), 4 S; (1S29), I68; ( IS51), 269; (IS64), 310. See also Documents, manuscripts, etc.

College libraries, 233.

Columbian Institnte, supported by Watterston, iss.

Committee on Library, duties of, 177 , 225,308 ; members of, 509; organization of, 222; power of, 32S; rccords of, 222.

Committee on Library reports (December IS, ISo1), on organization, 32; (January 20, isu6), on increased appropriations, 45; administrative reports (February II, 1So7), 47; (April II, ISOS), 4S; (Januzry 27, iso9), 4\$; on Jefferson library (October 7, 1814), 72; (November $28,1 S_{4}$ ), $84 ;$ (February 2O, ISI5), Ioo; administrative reports (January 26, 1316$), 151$; (January 6, $1 S_{17}$ ), 156 ; on Library building, February $1 \$, 1 \$ 17$, 123; administrative reports (Vecember I9, 1S20), 127; ( Nay 16, IS26), 164; (May 17, IS28), 164; on Buturlin collection (Narch 15, 1836), 239; on Vatteniare exchange ( $J$ une $5,18_{4}$ ) ), 255; on Durazzo collection ( June 7, 1944), 245; on Vattenare exchange (May 4, 1S48), 259; on extension of privilege to Court of Clains ( June 12, $1 S_{58}$ ), 374 .

Conferleracy, a library for, 339.

Continental Congress, 17.
Converse, S., on transcription of drecuments on American history, 315.

Cooperative cataloguing, $358,360,455$.

Copsright, in England, 150 , 445; the Library as place for deposit, $158,247,257$; law to be amended, 259, 260; Filliot's index to copyright books, 372; Snithsonian Institution as place for deposit, 43 I, 439; copyright, object of reposit, 440 ; list of copyright publications issuer, 440, 4.4; publications received by State Department, $4+2$; of music, 443 ; international copyright exchange, 449; franking privilege, 450 ; business transferred to Department of the Interior, $45^{\circ}$.

Coues, Samuel E., mentioned as Jeehan's successor, 347 .

Court of Claims, Library privilege for, 374 .

Cuba, literature on, 247 .

Current events, books on, 247.

Custom-house agents, 351 .

Dana, member of Select Committee on Library, 30; on Sellator Mitcliill, 45 .

D'Arusmont, Frances Wright, on Jefferson library, $9^{6 .}$

Davis, on purchase of MS. of Yiashington's Farewell Adldress, 329.

Days and hours of opening, $2 \mathrm{~S}, 5 \mathrm{~S}, \mathrm{I} \mathrm{S}_{5}$, 368 ; evening, 376 .

De Brahme's MISS. to be bought by the Library, 313.

Decorations, 294.

Dennis, moves a joint library committee be appointed, 23; on I,ibrary privilege for judges of the District, $3 \mathrm{r}$.

Departments, heads of, Library privilege for, $31,56,157,1 \$_{3}, 373$.

De Quincey, on the use of large libraries, 476.

Desiderata, lists of, $157,165,30 \mathrm{~S}$.

Dexter, Samuel, chairman of the first Joint Library Connuittee, 2.4.

I)ickerson, Mahlon, interest in the Library, $159,223,227$.

Ibiplomatic corps, library privilege for, $31,56,154,183$.

Disbursing officet appointed, 350 .

Distribution of catalogues, 367 ; of public documents, 174, 253, 266.

Documents, collection in Library, 54, 59, 173, 251, 253; in Ilonse library, 33\$; distribution of, 174, 253, 266; exchange of, $25 \%$; index of, 368 ; preservation of, 39S; municipal, 263; State, 25i, 262. 
Donations, 4S; solicited, 150; acknow1edgnients of, 352 ; to the Smithsonian Institution, 485 .

Dougherty, Joseph, letter to S. H. Smith, 102.

Douglas, on the abandonnent of the Library plan for the Smithsonian Institution, 497.

Draper, I., proposes the American Athenaeunl in Paris as agency for exchanges, 258 .

Duans, Williant, letter to Madison, 25.

Dufief, bookseller of Philalelphia, 37 .

Duncanson, Villiam Mayne, proposed as Librarian, 44.

Duplicates, 65 ; exchange of, 358 .

Duponte's collection, I68.

Durazzo collection, offered to Congress, 243; connmittee report on, 245 .

Duties on books, etc., imported for the Library, 163,268 ; on international exchanges, 259, 260, 261; custom-liouse agents, 351 .

Dwight, Henry F., on a national library, I I I.

Easby, Willian, on expenses occasioned by the fire, $2 S 0$.

Eastburn\& Co., New Torkbooksellers, 164.

Ebeling's collection of n11aps, 344 .

Education, bibiograply of, 473.

Electrotyping catalogues, 458 .

Erlet, Mrs. F. F., on panplinets in the Library, $1 \$ 6$.

Elliot, William, list of copyright hooks, 372.

Eiliptic room, $4 \mathrm{I}$.

Elmer, Libenezer, on appropriation for the I,1brary, 30 .

Engravings in Library, 60 .

Erving, George VI., 37, $3 \mathrm{~s}$; presents collection of lromze nerlals, 131, 132.

European libraries, compared with Anerican, $4: 3$.

Iinstis, menulur of Select Committee on Library, $\hat{3}^{(1)}$

Livins, Thomas, nember of the first Joint Library Committee, 23.

Fivenusg opening, 376.

Everett, Filward, on the fire of $1 \$ 25,132$; lettersto Watterston, 164,165 ; to Josepli Story, 165; services of, 224, 227; 011 transeription of flocunents on Ancrican listory, 317; on a geographical repartment, 346 .
Exchange of documents, domestic, 253 263; international, 254, 257; municipal, 263 ; reports to be issued, 258 ; of duplicates, 358 ; international copyright, 449 ; between libraries, 358,463 ; of society publications, 488 .

Ex-Presidents, Library privilege for, 373 .

Faden, William, collection of maps, 340 , note.

Financial agents of the Library Conmittee, 350 .

Fincs, 58, 60, 61, 176, 1SI.

Fires in the Library (18I4), 66; (I 25 ), ${ }_{132}$; ( $\left.\mathrm{IS}_{5} \mathrm{I}\right)$, 275; causes of, $2 \mathrm{So}, 2 \mathrm{~S}_{4}$; appropriation to meet expenses incurred, 256.

Fireproof room, question of, 136; Jewett on, 283.

Fixtures and furniture, 60, 12I, 130, 215.

Floor, 216, 2S9, 290, 300.

Florida, De Bralnme's collection on, 3 r 3 .

Foot, Solomon, on Senate library, 393.

Force, Peter, accuired part of Tatham collection, 53, note.

Foreign ministers, Library privilege for, $3 \mathrm{I}, 56,154,18_{3}$.

France, excliange of documents, 257, 264.

Frankliı's library, 37.

Fromentin, Eiligius, member of Library Committec, 122; letter to the Register of the Treasury, 155 .

Frost, J. T., Assistant Librarian, 45; on the destruction of the Library, 67 .

Furniture and fixtures, 60, 12I, 130, 215.

Geograplical department, proposed by F. B. Hunt, 340 ; nienorial on, 344 ; qualifications of the superintendent, 345; Fiverett on, 346.

Georgetou'n Daily' Federat L'epublican, quoted, 91.

Germany, literature on, 247.

Gerry, Flloridge, subunits plan for I,ibrary, IS, 26.

Gifts. Sce Donations.

Gillett, R. II., appointed disbursing officer, 350 .

Girard, Charles, bibliograpliy of Anerican :latural history, 472 .

Girarlin, recommended for librariansliip, I79.

Gleig, George R., account of the Capitol, refcrred to, 43 , wote.

Corlelarel, Calvin, on appropriation for the I,ilorary, 30 . 
Göttingen University library, eximulle of, $1.41,405,425$.

Gordon, Thomas I`, wants Congressional patronage for index to docments, 369 .

Great Britain proposes exchange of public documents, 257 .

Greene, George Washington, on a national library, 236 , note.

Gueullette, Simon, "Method of I,earning Roman Itistory," translated by Watterston, 114.

Hale, Edward Iiverett, collection of maps, 3.10 ; suggestions on stereotyping catalogue titles, $45 \mathrm{~S}$.

Hamilton MSS., bouglit, 321.

Hartley correspondence, offered to the Library, 313 .

IIarvard College, president of, on need for a national library, I40.

Harvard University Library, collection of Americana, I68; De Brahme collection, 313; maps in, 343; catalogne of, entered in union catalogue, 45.3 ; $11 m$ mber of volumes in, 473 .

Heating, 13०, 289, 299; Jewett on, 283.

Henry, Joseph, on formation of the Smithsonian I.ibrary, 433; on Stevens's plan for a Bibliograplia Americana, 467; on a bibliograplitical bureau, 4s6.

Hickey, W., on Senate library, 394.

Hinman, Charles W., assistant in the Library, 349.

Historical Nuggets, published by Stevens, 472 .

Iistory, importance of materials for, 492 . See also American history.

Hoban, James, report on the Capitol, 34.

IIolmes, Isaac E., on purchase of MS. of Washington's I'arewell Arldress, 333.

Hohnes, John, speech on Watterston's removal, 199.

Ilours and days of openiner, $28,5 S, 185$, 368; evening, 376 .

IIouse library, $3 \mathrm{~S}_{7}$; room, $3 \mathrm{SS}$.

Inouston, Sim, letter to the Librarian, IS2.

Inme, I\% J., assistant librarian, IS9, 34.

Inngary, literature on, 2.47 .

IIurt, Folward I3., plan for a geograplical department, 3.40 .

IInnter, on temporary quarters for the Library, 285; on repairing the J,iluary room, $288,296$.

Importerl hooks, duties on. Set Duties.
Index, of documents, 314, 368; of $\Lambda a$ tional Intelligencer, 372 .

Inlexes, importance of, 457 .

Inge, on purehase of MS. of Washington's larewell Address, 336 .

Ingersoll, J. R., on purchase of IISS., 326; on library plan for Smithsonian Institution, 42 I.

Interior Department, copyright husiness trausferred to, $45^{\circ}$.

Intermational copyright exclange, 4.49.

International excliange, 254, 257; reports to be issued, 25 $\%$. . Ser also Vattemare.

Janes, Beehe \& Co., awarded contract for construction of I,ibrary room, 292.

Janitor, $203,349$.

Jefferson, Thomas, appoints Beekley as librarian, $3 \%$; on selection of books, 36 ; on Franklin's library, 37; on the appointment of Librarian, 4.4 ; letters to S. II. Smith, 69, S2, 9 ; ; to Milligan, $\mathrm{SI}$, IO3; to Dougherty, IoI; to Watterston on classification, 143; to Woodward on classification, I 47 ; to Watterston on catalogue of Library, 1.45; continned interest in the Iibrary; I5y; recommends Girardin for librarianship, 179; on MSS. of Virginia records, 170 ; MIS. of his "Notes on Virginia," presented to the Ifibrary, 3 I2; his MISS. bonglit, $32 \mathrm{I}$.

Jefferson library, offered to Congress, 68 ; committee report on, 72 ; purchase of, 72, 8.4; objections to, 74, So; press con1ment on, S9; evaluation of, So, 8.4, 89 ; price per volume, $S_{2}, S_{.4}$; removal to Washington, 97; dannaged loy fire, 278 . Jeweth, Charles Coffin, on construction of Iibrary builling, $2 \mathrm{~S}_{2}$; on bibliographieal plans for the Library, 302; on a catalogue for the Library, $35 \mathrm{~S}$; plan for catalogning, 359; on cost of cataloguing, 362 ; on formation of the smithsomian library, 431; proposes a bibliographical bulletin, ffo; collects library statistics, 451 ; issues report on libraties, 452; plan for a union catalogue of American libraries, 453; formulates rules for catalogning, 45\%; plan for stereotyping catalogue titles, 456; on the importane of large hibraries fer the American scholar, 481 ; on the lihrary policy of the Smithsonian Institution, 4s 7 removed from office, $49^{\circ}$. 
Jillson continues Jewett's work, 363 .

Johnson on purchase of MS. of Washington's Farewell Address, 332, 335.

Judges of the District, Library privilege for, 3 I, 375 .

Judiciary Committee report on library plan for the Smithsonian Institution, 498.

Kearney, James, assistant librarian, 44.

Kearon, Robert, Atwater on, 353 .

King, Cyrus, on purchase of Jefferson library, 74, 85,86 .

King, Josias Wilson, assistant librarian, 35.

King, Willian R., on anthority of Library Committee, 328, 329.

Kirkland, John T., on need for national library, 140.

Knapp, Samuel L., on character of the Library, 49; bibliograplical plan of, 226.

"Knowledge," meaning of term in Smithson's will, 500.

Koh1, J. G., proposes a cartographical depot in the Library, 346.

Lanman, Charles, candidate for librarianship, $3_{4}$.

Latrobe's plan for Library rooms, I2S.

Law collection, condition of, 157, I71, $24 \mathrm{~S}$; Joseph Story on, 165; to be under control of Supreme Court, I73; rooms for, 216, 250; appropriations for, 217; privileges of, 374 .

Iraws (April 24, ISoo), removal and accommodation of the Government, 23; (January 26, 1802), establishing the Library, 32; (January 2, r805), disposal of public documents, 54, 55; (February 2 I, ISo6), appropriation for the support of Library, 46; (May 1, I810), privilege for agent of committee, 56; (January 30, IS15), purchase of Jefferson library, S9: (March 3, 1S15), Library room and transportation of Library, roI; (December $3,181 S)$, removal of Library to north wing of Capitol, r26; (May 26, I824), appropriation and rooms, 163; (February II, IS25), dinties on books, etc., imported for Library, 163; (July 14, 1832), law department, 249; (March $29,1848)$, to remit duties on books, etc., for the I-ibrary, 268; (June 26, I8.48), cxchange of public documents, 260; (December 26, I 951 ), expenses occasioned by fire, 279; (January 15 , I852), providing room for Library, $28_{7}$; (March 19, 1S52), repairs of Library room, 29I; (Jannary I3, IS52), appropriation to meet expenses incurred by fire, 286. See also Resolutions.

Law, William, on transcripts of documents on American history, 315 .

"The Lawyer," novel by Watterston, Iog. Learning, relation of libraries to, 478 , $479,48 \mathrm{I}, 483$.

I enox, James, purchases MS. of Washington's Farewell Address, 340.

Lester, C. Edwards, letter on Durazzo collection, 243.

Liberia, proposes exchange of public documents, 264 .

Librarian, appointment by President of Senate and Speaker of House suggested, 30 ; by Joint Library Committee suggested, 153; by President, 29, 30, 32, 33; discussed, I99; bond of, 33, I90, I9I, 192, I93, 195; duties of, $58,60,61$, ISo; removal of, I99; salary of, $33,153,17 S$, 348.

Librarians appointed (Beckley), 34; (Magruder), 44; (Watterston), Io7; (Meehan ), 189; (Stephenson), 383; (Spofford), 384 .

Libraries, large, importance of, 476 ; importance to scholars, 49I, 493.

Library buildings, Jewett on, $2 S_{2}$.

Library Company of Philadelphia offers use of its books to Congress, 17 ; catalogue of, entered in union catalogne, 453.

Library couvention, New York (I853), on the stereotyping of catalogue titles, 361 ; on the Smithsonian as a national library, 482 .

I,ibrary of Congress (before I 800 ), I7; (I800-1805), 23; (1SO5-I814), 4I; (I8I5-ISI7), I50; (I 8 I7-I824), I58; (I824-1829), I60; (I $829-185$ I ), 2 I3 ; (1852-1864), 275; intended for use of Congress, 306; as nucleus of national library, 234, 304, 506; relations with other Washington libraries, 400.

I,ibrary statistics, collected by Jewett, 45I. Jieber, Irancis, on national library, 227. I,ighting of the Library, I30, 136, 217 , 289; Jewett on, 284 .

I.ivermore, George, on need for large libraries for American scliolars, $4 S_{3}$. 
Livermore, Samuel, moves establishment of Congressional Library, 23.

Livingston, E. R., proposes to index pulblic documents, 372 .

Loan system, 5S, IS 1, i $2,375,505$; loans between libraries, 463 .

Loans, time of, $2 \mathrm{~S}, 5 \mathrm{~S}$.

London Gazctte, file of, in the Library, $3+7$.

Loss of books, I77.

Loss of MS., $\mathrm{IS}_{3}$.

Lounging in the Library, I2S, IS6, 2 IS, 3 So.

McDonald, John, applies for librarianship, 25, 34 .

McDuffie, proposes transcription of documents on American history, 315.

Mackintosh, James, Library of, 235.

Maclane, Mary, on the library, $3 S_{2}$.

Macleod, Donald, applies for the librarianship, $3 \dot{4} 8$.

IcIIullin, on the Architect of the Capitol, 296.

Madison, to Jefferson, 72 .

Madison MSS., bought, 321 .

Madison's Administration, Watterston on, 113 .

Magruder, Patrick, appointed Librarian, 4 ; resigns, 6S, 107.

Mallory, on Senate library, 393.

Manuscripts, collection of, 169, 234. 312; lost, $1 S_{3}$; calendaring of, $3^{1} 14$; transcripts of, $166,315$.

Maps, in Library, 60, 160,340 ; of the States, 340; collections of (Ebeling), 344, (Faden), 340, (Hale), 340, (Harvard), 343 .

Marsh, George Perkins, on Durazzo collection, 245; on Library of Congress, 270; on library plan for Smithsonian Institution, 421,428 .

Marshall, John, anecdote of, 57 .

Martineau, Harriet, on collection of inedals, $13 \mathrm{I}$.

Mason, on abandonment of library plan for Smithsonian Institution, 497.

Meachan, J., on library plan for the Smithsonian Institution, 490; criticised by the committee, 502 ; rejoinder, 503.

Medals, collection of, 131, 132, 221 ; destroyed by fire, 277 .

Meehan, C. H. W., assistant in the $\mathrm{L}$ ibrary, 25I, 348; Atwater on, 353.
Meehan, John Silva, appointed Librarian, IS9; biography, 213; as journalist, 2 I4 as Librarian, 2I4, 215 ; death of, 215; on effects of the fire, 277 ; Atwater on, 353 .

Messenger, salary of, 349 .

Mexico, literature on, 247 .

Miller, on purchase of MSS., 324.

Milligan, Joseph, letters to Jefferson, 78 , $S_{4}, 102,104$.

Mills, Robert, plan for extension of Capitol, 217.

Ministers, foreign, Library privilege for, $31,56,154, I_{3}$.

Minute book of the Library Committee, 222.

Mitchill, Samuel Latham, chairnan of Library Committee, 45.

IIonticello library. See Jefferson library.

Montresor collection, $5 \mathrm{I}$.

Morfit, H., index to National Intclligencer, 372 .

Morris, George A., assistant in the Library, 349 .

Municipal publications, exchange of, 263. Iurphy, reports on international exchange, 259.

Music, copyright of, $4+3$.

National Intelligencer (July 3I, ISI5), on need for national library, 13S; (August 28, I823), on need for national library, I60; (January I, IS25), on Library room, I 29; (December 24, I 825), on Library fire, 134; (June 16, IS29), on Watterston's removal, I97; (November $\left.13,17,24,18_{37}\right)$, on cataloguing, 355; (January 3, 1 $S_{44}$, May 25, IS53), on evening opening, 376; (April It, $\left.185_{2}\right)$, on bibliographical policy of Library, 303; (June 21, IS60), on colonial documents, 318 ; Morfit's index to, 372 .

National Institute, 4 I 5.

Vational Journal, on rewnoval of Watterston, 190, 191, 194, 197.

National library, need for, discussed, 5o, I3S, 161, 304, 476, 49ז, 493, 505; (Kirkland), Ifo; (I)wight), If 1 ; (Tyson), 236; (Jewett), 473; must be established by Congress, 22S, 306; New York library conference ( $1 S_{53}$ ), resolutions on, $4 \delta_{2}$; location of, 49.4 ; scope of, $4 S 6$; value of, 501 .

National Kegister, elited by Watterston, I 12.

$$
23399-04-34
$$


Natural listory, bibliography of, 472.

Nca' York Ez'ening Post, correspondence on purcliase of Jefferson library, 87 .

New York library conference ( 1853 ), 36 r, 482.

New York Society library, I 7 .

Newspapers, collection of, 6o, 346; Washington, 388 .

North American Review (December, ISI8), on need for national library, I4o; (July, I 837 ), on a national library, 23I; (July, I $\left.5_{50}\right)$, on need of large libraries for American scholars, $4 \delta_{3}$; (October, I854), on the library plan of the Smithsonian Institution, 505 .

Norton, Charles B., offers his collection of MISS., 313.

Norton's Literary Gazette (February 15, I 852 ), on Smithsonian library, $4 S_{2}$; ( July I 5, I 852 ), on selection of books for Library, 3o8; (July I5, 1852), on copyright law, 440; (February I5, I855), on library plan for Smithsonian Institution, 505 .

Notation, sclieme of, 367 .

Nourse, Michael, appointed disbursing officer, 350 .

Oakley, on purchase of Jefferson library, 73,77 .

Officers, $17 S, 347,348$; list of, 509. See also Librarian, Assistant librarian.

Opening, hours and days of, 2S, 58, 185 , 368 ; evening, 376 .

Otis, Samuel, letter to Jefferson, 24; applies for librarianslip, 34.

Ove1 or elliptic room, 4I.

Owen, Robert Dale, on the library plan for the Smithsonian Institution, $417,42 S$.

Paintings in Library, 220; destroyed by fire, 276.

Palfrey, J. G., on Dr. Priestley's library, 155; on purchase of Jefferson's MSS. 332.

Pamplilets in Library, is6.

Patent Office, library of, 400.

Patents, Conmissioner of, I,ibrary privilege for, 184,375 .

Paulding, J. K., letter to Watterston, 117.

Pearce, James Alfred, services of, 223; on repairing the Library room, 287 ; on the authority of the Library Committee, 328 ; on organization of the Smithsonian Institution, 4II; on the abandonment of the library plan for the Smithsonian Institution, $49^{6 .}$
Penalty, 58, 6o, 6r, 176, ISr.

Periodicals in Library, 20; ordered, 156; difficulty in getting, 347; displayed on tables, 353 .

Philadelphia Library Company offers use of its books to Congress, 17; catalogue of, entered in union catalogue, 453.

Pickering, on purchase of Jefferson's library, 76 .

Poinsett, Joel, interest in the Library, I 59, 224.

Politics in Library, causes injury, 187 , 209.

Portugal, proposes exchange of public documents, 257 .

Post-office building, library i11, 120.

President, Library privilege for, 56 ; power of appointment, 29, 30, 32, 33, 153 ; of removal, 199 .

Preston, on Buturlin library,23S, 239; on Vattemare's plan for international exchange, 255 .

Prices of books, 37, 90, 239, 423; raised by demand in America, 309.

Priestley's library, 155.

Private libraries in America, 36.

Privileges of the I,ibrary, extension of, 55, I 54, I $S_{3}, 373$; objections to, $18_{4}$.

Quincy, Josiah, on John Randolph, 26.

Randolph, John, member of Committee on Library Organization, 26; on appropriation for the Library, 30; on Library privilege, 3I; on Senator Mitchill, 45.

Receipt for books, $2 S$.

Reading, time required for, 476 .

Rebellion publications, catalogue of, 373 .

Reed, John, on purchase of Jefferson library, 75 .

Regulations, $27,33,58$, 171 ; relating to documents, 59 .

Reibelt, J. P., asks to le appointed Librarian, 44.

Reports. Sce Committee on library rereports.

Resolution, on privilege for Suprene Court (March 2, 1812), 57; for heads of lepartments, etc. (Jannary I3, I830), 373; on interuational excluange, (June 20, 1840), 256; on distribution of catalogue, (January 20, 1843), 367; on purchase of MS. of Washington's Farewell Address (February 12, 1850), 340; on distribution of public documents, (January 28, $\mathbf{1} 857,266$ ). See also Laws. 
Revillagigedo's instructions, IIS. presented to Library, 3I2.

Revolution of I $\$ 4 \$$, literature on, 247.

Rich, Obadiali, collection of Antericana, 167; I ondon agent of the I,ibrary, 226 , 246,35 ,; deatli of, 351 .

Rich Brothers, Lomlon agents, 309, $35 \mathrm{r}$.

Richards \& Mallory, (ieorgetown booksellers, offer use of their books to Senate, 6.5.

Rives, on the organization of the smithsonian Institution, 413 .

Rogers, Joln K., method of stereotyping, 459.

Roon for Library (ISo2), 33; (ISO5), 4I; (ISI5), I20; (IS24), 129; (IS29-5I), $215 ;\left(1 S_{52-64}\right), 287$.

Ross, General, on the destruction of the Library, 68.

Royall, Anne, on Watterston, I07, II9; on useless books in the Library, 169.

Rules and regulations, $27,33,58$, I 7 ; as to use of documents, 59 .

Rush, Richard, asks for relaxation of rules, 184 .

Sainsbury, W. Noël, letter regarding calendar of colonial papers, 3 IS.

Salaries, 33, I78, $3 \downarrow 8$.

Sardinia, donation of public documents, 264.

Sargent, Nathan, on Randolple's library, 26 , note.

Science, relation of libraries to, $47 \mathrm{~S}, 479$, $4 \mathrm{SI}_{1} 48_{3}$.

Secretary of the Senate to take charge of the Library, 27; Library privilege for, I 84,373 .

Selection of books, 223, 226, 229; on current events, 247; duty of, delegated to the Librarian, 308; Jefferson on, 36; Jewett on,4.46; policy regarding, 226,302.

Senate library, 392.

Shelving, 2i9; Jewett on, 283; heiglit of, 298.

Skirving, Joln, appointed superintendent of constrution of Lilnary room, 292.

Switl, Samuel Harrison, letters to Jefferson, 7I, 80, 97.

Sinith, Thomas $I_{1}$, appointed disbursing officer, $35^{\circ}$.

Smithson, Janes, meaning of luis will discussed, 499.

Snithsonian Institution, organization of, 404; Regents' resolutions, 429; apjero- priations for the library, 429; committee on library appointerl, 429; committee on organization, 430; executive committee's report on library, 433; report of library committee, 434, 499; duties of librarian, 435; collections in, 436; bibliograplical publications, 467; library plan defeated, 473, 496; Ilenry's plan for bibliographical bureau, 4s6; exelange of socicty publications, 48s; Regents' resolution on power of Seeretary, 496; Juliciary Con1mittee on library plan, 495; neaning of Smithson's will, 499; Iouse con1nittee on managenent of, 499; phrase "not exceeding" in law establishing, 500; Meachan's eriticisms, 502.

Society publications, ordered, 156,438 ; exchange of, $4 S S$.

Solicitor of the Treasury granted I ibrary privilege, 374 .

Somerby, H. G., on transeripts of hocuments on American listory, 316.

Southem Literary Messenger on administration of Smithsonian Institution, 504.

Spain proposes exchange of public locuments, 264.

Sparks, Jared, on value of Jefferson collection, 95; on the collection of American history, I69; on transcription of documents on American listory, 315.

Spofford, Ainsworth R., appointed assistant librarian, 348 ; refornus in cataloguing, 365; appointed Librarian, 394.

sprigg on Library privilege for julges of the $]$ istrict, 34 .

Staff, $178,347,348,509$. Ser also I,ibrarian, Assistant librarian.

Stanton on expenses occasioned by the fire, 279.

State Department receives copyright works, $4+2$.

State documents, 25 I wanted by Vattenure, 262.

State laws, to be procured for the I, ibrary, $165,171,250$.

Statistics of American libraries (Jewett), 451; of European libraries, 47.4 .

Statues in Jibrary, 220.

Stelle, Iidwarl I3, appointed assistant librarian, tso; renoved, 1S9; Watterston on, 201; restored, 345 ; Atwater on, 353 . 
Stephens on purchase of MS. of Washington's Farewell Address, 336, 337.

Stephenson, John G., biography of, $3{ }_{3}$. Stereotyping of catalogues, titles recommended by the Smithsonian Institution, 360 ; adopted by the Library Committee, $36 \mathrm{I}$; manner of applying, 459; economy of, 455, 460; objections to, 466.

Stevens, Ifenry, offers his collection of Vermont laws, 247; proposes calendar of colonial papers, 317 ; to compile Bibliographia Americana, 467; publishes "Sterens's American bibliographer," $47 \mathrm{I}$; "Historical nuggets," 472; "Catalogue of American books in the library of the British Museum," 472.

Ster'ens's American bibliographer, $47 \mathrm{I}$.

Story, Joseph, on law collection, I65.

Sumner, Charles, on Buturlin library, 243.

Supreme Court, Library privilege for, $29,31,56,18_{3}$; to control law collection, I73.

Supreme court of the District, Library privilege for, 3I, 375 .

Switzerland, donation of public docu111ents, 264.

Tappan, on the Smithsonian Institution, $404,410$.

Tariff. See Duties on books.

Tatham, Willian, collection of American topography and of American history, 50.

Taylor, Franck, book agent of the I,ibrary, 35 I.

Thefts of books, 177 .

Thompson, Pishey, book agent of the Library, I64, 226, 35 o.

Thornton, William, letter to Jefferson, 79.

Thurman, on library plan for the Smithsonian Institution, $42 S$.

Tickuor, George, on valne of Jefferson library, 95.

Time of I,ibrary loans, $2 \mathrm{~S}, 5 \mathrm{~S}$.

Time required for reading, 476 .

To-day, Boston, cited on character of Library, 269.

Topograplyy, Anerican, Tathan's collection, 5 o.

Tornel, Jose María, presents MS. to the Library, 312.

Transcription of documents for Anerican listory, 166,315 .
Translations of foreign books, 162 .

Tutt, offered librarianship, $2 I_{3}$, note.

Tyson, Job R., on need for a national library, 236.

Union, correspondence on Americana, 3 II.

Union catalogue of American libraries, 43 I, 452, 463; value of, 453 ; of Washington libraries, 398 .

United States Congress, documents cited:

Serentli Congress, first session, Senate report, 32 .

Ninth Congress, first session, Senate report, 45 .

Ninth Congress, second session, Senate report, 47 .

Thirteenth Congress, third session, Senate report, 73, I00.

Thirteenth Congress, third session, House locument No. 2, 66.

Sixteenth Congress, second session, Senate report No. 25, 127.

Seventeenth Congress, first session, House document No. 26, I 29.

Seventeenth Congress, second session, Senate document No. 9, I 29.

Eighteenth Congress, first session, House report No. 69, I6I.

Nineteentli Congress, first session, Senate report No. 9S, I6.4.

Nineteenth Congress, first session, House report No. 66, 137.

'Twentieth Congress, first session, Senate report No. 19S, I64.

Twenty-fourth Congress, first session, Senate report No. II, 164.

Twenty-fourth Congress, first session, Senate report No. 242, 243.

Twenty-sixth Congress, first session, Senate document No. 52I, 256.

Twenty-sixth Congress, first session, Senate document No. 529, 256.

'Twenty-sixth Congress, first session, Senate report, No. 52 I, 255; report, No. I6, 252; Honse document, No. 50, 255; House report, No. 5\$6, 255.

'Twenty-seventh Congress, third session, House report, No. 4I, 372.

Twenty-eightl Congress, first session, House report, No. 516, 217; $553,246$.

'Thirtieth Congress, first session, Senate miscellaneons document, No. 46, 259. 
United States Congress, documents cited-Continued.

Thirtieth Congress, first session, Senate miscellaneous document, No. $126,262$.

Thirtieth Congress, first session, House miscellaneous document, No. 99, 261 .

Thirtieth Congress, first session, House report, No. 90, 217.

Thirty-first Congress, first session, Senate miscellaneous document, No. $126,263$.

Thirty-first Congress, first session, Senate report, No. I45, 2 IS.

Thirty-second Congress, first session, Senate report, No. 63,291 .

Thirty-second Congress, second session, Senate miscellaneous document, No. 53,361 .

Thirty-second Congress, second session, House document, No. 1, 293.

Thirty-second Congress, second session, House document, No. IS, 293.

Thirty-fourth Congress, third session, House executive document, No. I, 300 .

Thirty-fifth Congress, first session, Senate report, No. 328, 375 .

Thirty-fifth Congress, first session, House miscellaneous document, No. 129,267 .

Thirty-seventh Congress, third session, Senate report, No. 73,264 .

'Thirty-eighth Congress, first session, Senate miscellaneous documents, No. $3,399$.

Thirty-eighth Congress, first session, House executive documents, No. I, 300 .

Fifty-third Congress, second session, Senate report, No. $178,292$.

United States Tilegraph, on Watterston's removal, 191, 192, 195.

Universal catalogue, 464 .

Upcott, William, MSS., collection refused, 313 .

Lse of the Library, 379; during the War, $3 s_{3}$.

Vattemare, Alexandre, establishes system of international excluanges, 254; appointerl agent of I,ibrary Committee,
261; granted franking privilege, 262 : informed of discontinuance of agency, 264.

Venable, on purchase of MSS., 324.

Ventilation, 290.

Vermont, Stevens's collection of laws of, 247.

Verplanck, G. C., services of, 224.

Vice-Presilent, Library privilege for, 56 . Virginia records, acquired hy I,ibrary, $170,171,312$.

Volumes in I,ibrary, n11111)er of, 515 .

"'Vonderpuff, Johannes," ironical letter to Jefferson, $9 \mathrm{r}$.

Walsh's American register, on purchase of Jefferson Library; S9; on need for national library, 139.

Walter, Thomas U., on causes of fire ( $1 S_{5} \mathrm{I}$ ), $2 S \mathrm{I}$; on repairing Library, $2 \mathrm{SS}$; arcli $\mathrm{i}$ tect of new Library room, 292: on progress of the work, 293.

Warden, David B., on L,ibrary quarters, 42.

Warren, Josiah, method of stereotyping, 459.

Washington, George, returns thanks to Philadelphia Library Company, 17.

Washington MSS. bought, $32 \mathrm{I}$.

Washington's Farewell Address, MS. of, Senate discussion on, 326; House discussion on, $33^{1}$; vote on, 334, 339; bought by Lenox, 340.

Washington's Library, offered for sale, 247.

Washington Botanical Societr, established, IrS.

Washington City Chronicle, edited by Watterston, II2; on system of classification, 146.

IV ashington City Gazette, edited by Watterston, III.

Washington City Library, 347, 400; use of, offered to Congress, 68 .

M'ashington Republic, corresponlence on causes of fire $\left(\mathrm{I} 8_{5} \mathrm{r}\right), 2 \mathrm{~S}$.

Watson, Josepl, presents MS. to Library, 312.

Watterston, George, appointel librarian, 107; biography of, 10S; as author, rog; as journalist, III, I I2; on botanical 111useun1, I12; on Malison's administration, 113; interest in ealucation, Ir4; in Washington City, i 15; in statistics, i16; in politics, I 18 ; in social life, 119; views on slavery, Ing; letter to Malison, ac- 
cepting appointment, I2I; to Jefferson, on catalogue of Iibrary, I47, I49; to Jefferson, on classification, I 4 I ; to Brent, O11 returning books, $\mathrm{IS}_{2}$; to Library Comnittee, on condition of Library, I76; removal of, journalistic controversy, I 89 ; Watterston on his removal, 194; its effect on the Library, 199; on Meehan's appointment as assistant librarian, 2oI; letter to Clayton on reinstaten1ent, 203, 204; to Clay, on same, 205; to Fillnore, on same, 207; applying for office of Commissioner of Public Buildings, 20S; death of, 209; on Buturlin library, 23S; on index to public documents, 369; on purchase of books, $42 S$.
Weller, on Senate Library, 393.

Wheatley, on the catalogue of 1840,354 . Wheaton, Henry, proposes the American Athenzum in Paris as agency for exchanges, 25 S.

Wilcox, method of electrotyping, $45^{8}$.

Wilde, Richard Henry, on Buturlin lihrary, 229.

Wiley \& Putnam, offers to supply books for Library, 350 .

Wirt, William, asks to have lis Library privilege extended to a friend, I 84 .

Woodbury, Levi, services of, 224.

Woodward, Angustus Brevoort, system of classification, 142.

Wiirttemberg, proposes exchange of public documents, 257. 


\section{ADDENDUM.}

In the Continental Congress, January $23, \quad$ I $7 S_{3}$, a committee, consisting of Mr. Madison, Mr. Mifflin, and Mr. Williamson, reported, in consequence of a motion of Mr. Bland, a list of books proper for the use of Congress, and proposed that the Secretary should be instructed to procure the same. In favor of the report it was urged as indispensable that Congress should have at all times at command such authors on the law of nations, treaties, negotiations, etc., as would render their proceedings in such cases conformable to propriety; and it was observed that the want of this information was manifest in several important acts of Congress. It was further observed that no time ought to be lost in collecting every book and tract which related to American antiquities and the affairs of the United States, since many of the most valuable of these were every day becoming extinct; and they were necessary, not only as materials for a history of the United States, but might be rendered still more so by future pretensions against their rights from Spain, or other powers which had shared in the discoveries and possessions of the New World. Against the report were urged, first, the inconvenience of advancing even a few hnindred pounds at this crisis; secondly, the difference of expense between procuring the books during the war and after a peace. These objections prevailed by a considerable najority. A notion was then made by Mr. Wilson, seconded by Mr. Madison, to confine the purchase, for the present, to the most essential part of the books. This also was negatived. 



University of California

SOUTHERN REGIONAL LIBRARY FACILITY

305 De Neve Drive - Parking Lot 17 • Box 951388

LOS ANGELES, CALIFORNIA 90095-1388

Return this material to the library from which it was borrowed.

LD 21-20m-8,'52

$(\mathrm{A} 2854 \mathrm{~s} 4) 476$ 


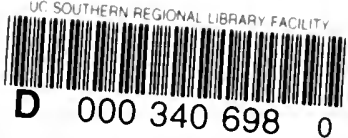


